$$
\begin{gathered}
\text { Universidade de São Paulo } \\
\text { Instituto de Química de São Carlos } \\
\text { Química Orgânica e Biológica }
\end{gathered}
$$

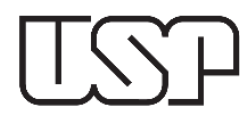

IQSC

Uso da biomassa como bloco de construção na síntese de moléculas com alto valor agregado

São Carlos 


\section{Uso da biomassa como bloco de construção na síntese de moléculas com alto valor agregado}

Tese apresentada ao Instituto de Química de São Carlos da Universidade de São Paulo como parte dos requisitos para a obtenção do título de Doutora em ciências. Área de concentração: Química Orgânica e Biológica.

Orientador: Prof. Dr. Antonio Carlos Bender Burtoloso.

São Carlos-SP 2021 
Ficha Catalográfica elaborada pela Seção de Referência e Atendimento ao Usuário do SBI/IQSC

\section{Santos, Camila Souza}

Uso da biomassa como bloco de construção na síntese de moléculas com alto valor agregado / Camila Souza Santos. - São Carlos, 2021.

$335 \mathrm{f}$.

Tese (Doutorado em Química Orgânica e Biológica) - Instituto de Química de São Carlos / Universidade de São Paulo, 2021.

Orientador: Prof. Dr. Antonio Carlos Bender Burtoloso

1. Biomassa. 2. Poliol. 3. Ciclopentadieno. 4. Gama-valerolactona. 5. Levulinato de etila. I. Título.

Sonia Alves - CRB: 4280/8

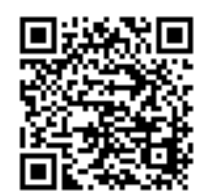




\section{Agradecimentos}

Primeiramente, agradeço a minha Mãe Luci e a minha irmã Geruza por todo sacrifício que vocês fizeram para que eu pudesse chegar até aqui. Agradeço ao grande criador pelas boas energias, saúde e pela pitada de determinação e coragem que foram acrescidas a minha modulação.

Aos meus professores do ensino médio, Valderez Tedesco por incentivar meu potencial e a Antonioni por apresentar minha grande paixão: A química orgânica. Motivo que me levou a fazer graduação em Química.

À Universidade Estadual do Sudoeste da Bahia (UESB), por todo apoio durante a graduação e pelos bons professores que fazem parte do corpo docente desta instituição. Em especial, a minha orientadora e mãe científica da graduação Vanderlúcia Fonseca de Paula (UESB) pelos conselhos, ajuda e inspiração. Agradeço ainda, a professora Marina Menezes Filha (UESB) pela amizade e apoio. A minha irmã científica Jamille Reis agradeço por todos os ensinamentos e amizade durante a iniciação científica. Agradeço ao professor Dennis Russowsky (UFRGS) e a toda comunidade da UFRGS pela oportunidade de estagiar durante a graduação. Com toda certeza seus ensinamentos foram valiosos.

À Dulce Helena (UNESP) agradeço pela orientação e acolhimento durante o mestrado.

À Universidade de São Paulo agradeço pela infraestrutura e pelo programa de pós-graduação. Tenho grande orgulho em falar que estudei na melhor universidade do Brasil!!!! Agradeço ao professor Antonio Burtoloso por me aceitar em seu grupo de pesquisa e me orientar ao longo desses anos. Aos meus colegas do Laboratório Warner Bruce Kover e companheiros de luta: Rafael Mafra, Anees, Gustavo, Alexander, Edson, João Victor, João Henrique, Nikolas, Rafael Gallo, Lucas, Evandro, Clarice, Orlando, Larissa, Eduardo, Tharik, Matheus, David, Jorge, Raddel e aos técnicos João Pedro e Marilia deixo minha gratidão. Agradeço, em especial, a minha irmã de alma Paty, Paty, Paty... Pela amizade e carinho.

Aos colegas do laboratório de Biocatálise e ao professor André, em especial ao Lucas, agradeço pelas ajudas quando foram necessárias.

À Central de Análises Químicas e Instrumentais (CAQI) do IQSC, e ao professor Gilberto do laboratório de Ressonância Magnética Nuclear da UFSCAR, agradeço pelo apoio técnico e instrumental.

À CAPES pela concessão da bolsa de doutorado e a FAPESP pelo suporte ao grupo.

Minha trajetória seria impossivel sem a ajuda de vocês. Deixo meu carinho, um grande abraço e meus sinceros agradecimentos!!! Bjsss de Luz!! 


\section{RESUMO}

A tese apresentada tem como objetivo principal usar moléculas oriundas da biomassa para construção de produtos com alto valor agregado. No capítulo I, é apresentado o desenvolvimento de uma rota sintética, na qual utilizou-se levulinato de etila (LE) como material de partida, para obtenção de ciclopentadienos e ciclopentanos 1,2,4-trissubstituídos em condições brandas e ambientalmente amigáveis. Nesta estratégia, os produtos de interesse foram alcançados por meio da formação de um intermediário obtido pela autocondensação entre duas moléculas de (LE). A aquisição deste intermediário aborda a formação de enaminas geradas no meio reacional. O ciclopentadieno 1,2,4-trissubstituído foi obtido pela reação do intermediário, em meio básico, com rendimento global de aproximadamente $40 \%$. Aplicações sintéticas para este ciclopentadieno foram exploradas como, por exemplo, produtos da reação de Diels-Alder (82-90\% de rendimento) e reação de hidrogenação para formação de ciclopentanos (91\% de rendimento). Outras séries de aplicações para formação de variados compostos também foram exploradas, na qual obteve-se a formação de produtos com rendimentos entre $60-88 \%$. No capítulo II, é descrito um novo método, direto, para produção de polióis com cadeias longas a partir da $\gamma$-valerolactona (GVL). A etapa principal envolve uma condensação de Claisen entre duas moléculas da GVL para fornecer um hemiacetal cíclico com $85 \%$ de rendimento, sob condições simples e ambientalmente amigáveis. Após alquilação e/ou redução, esse hemiacetal serve como uma nova plataforma para produzir várias moléculas, com cadeia ramificada e de alto valor agregado, com carbonos que variam de $\mathrm{C} 10$ a C21. No capítulo III, os resultados parciais demostram o potencial da $\beta$-angélica lactona ( $\beta-A L)$ como material de partida para síntese de pirrolidonas diidroxiladas que, futuramente, poderão ser convertidas em alcaloides pirrolidínicos trissubstituídos e/ou tetrassubstituídos. A estratégia empregada para a construção das pirrolidonas tem como etapa principal a abertura da $\beta-A L$ diidroxiladas protegidas, frente a variadas aminas, para produzir amidas com rendimentos $>90 \%$. 


\section{ABSTRACT}

The main objective of this thesis is the use of molecules from biomass to construct high added value compounds. In chapter I, ethyl levulinate (EL) is employed as starting material to obtain 1,2,4-tri-substituted cyclopentadienes and cyclopentanes from a new synthetic route, under mild and environmentally friendly conditions. In this strategy, the desired products were achieved through the intermediacy of a key intermediate, obtained by the self-condensation between two molecules of (EL) via enamine chemistry. The 1,2,4-trisubstituted cyclopentadiene was obtained by the reaction of this intermediate, in a basic medium, with an overall yield of approximately 40\%. Synthetic applications for this cyclopentadiene have also been explored. Adducts from a Diels-Alder reaction (82-90\% yield) and hydrogenation reactions to provide cyclopentanes (91\% yield) are two examples. Other applications were also explored. In chapter II, a new anddirect method is described for the production of long chain polyols from $\gamma$-valerolactone (GVL). The main step involves a Claisen condensation between two GVL molecules to give a cyclic hemiacetal with $85 \%$ yield, under simple and environmentally friendly conditions. After alkylation and/or reduction, this hemiacetal serves as a new platform to produce several interesting, branched chain, molecules with carbons ranging from C10 to C21. In chapter III, the partial results demonstrate the potential of $\beta$-angelic lactone $(\beta-A L)$, another platform from biomass, as a starting material for the synthesis of dihydroxylated pyrrolidones that, in the future, may be converted into tri-substituted and/or tetrasubstituted pyrrolidinic alkaloids. The strategy used for the construction of the pyrrolidones is based on dihydroxylation and aminolysis reactions. 


\section{LISTAS DE ESQUEMAS}

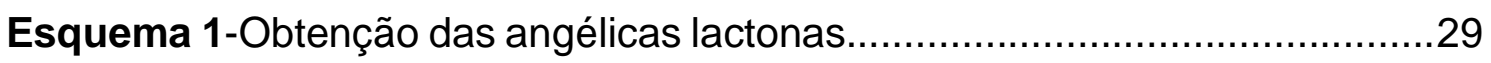

Esquema 2-Reação de isomerização enantiosseletiva da $\alpha-A L$.........................30

Esquema 3- Formação de hidrocarbonetos a partir das angélicas lactonas......31

Esquema 4- Síntese da cis-jasmona e diidrojasmoa a partir da $\alpha-A L$.................32

Esquema 5-Uso da $\beta$-AL no preparo da ( \pm )-blastmicinona..................................33

Esquema 6- Pirrolidonas com atividades farmacológicas..................................33

Esquema 7- Formação de 5-metilpirrolidinona desenvolvida por Fischmeister et

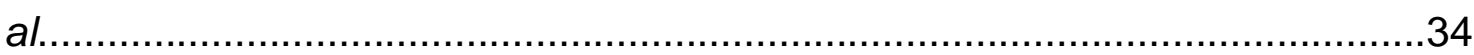

Esquema 8-Síntese de pirrolidona partindo da glicose.....................................34

Esquema 9-Formação de 5-metilpirrolidinona desenvolvida por Burtoloso et

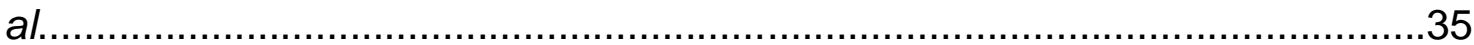

Esquema 10-Síntese de vários ciclopentadienos realizada por Gleiter et al.... 36 Esquema 11- Síntese de vários ciclopentadienos realizada por Kotora et al.... 36 Esquema 12- Síntese de vários ciclopentadienos realizada por Trofimov et

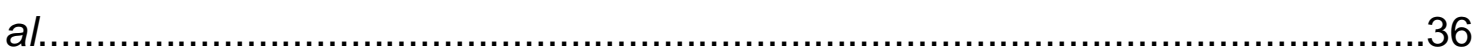

Esquema 13- Síntese de vários ciclopentadienos realizada por Ueda et al...... 37

Esquema 14- Representação para formação de diversos ciclopentanos............39

Esquema 15- Síntese de diversos ciclopentanos..........................................39

Esquema 16- Reação de isomerização da $\alpha$-angélica lactona ( $\alpha-A L)$................40

Esquema 17- Possível produto formado a partir de 2a-2b...............................57

Esquema 18- Reação de hidrólise do dieno 4............................................60

Esquema 19- Reação de esterificação com solução de diazometano ................61

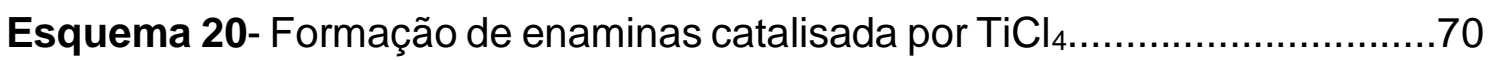

Esquema 21- Conversão da biomassa em GVL..........................................

Esquema 22-Formação da GVL catalisada por Ru/C.....................................76

Esquema 23- Representação da reação Meerwein-Ponndorf-Verley...............77

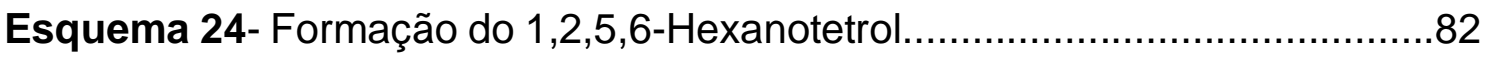

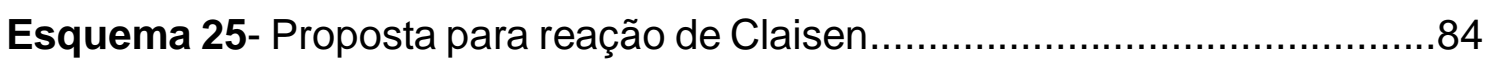

Esquema 26- Alguns compostos preparados a partir de 18............................89

Esquema 27-Reação de oxidação com IBX do composto 21...........................92

Esquema 28-Reação de oxidação com IBX do composto 22...........................93

Esquema 29- Proposta para reação de alquilação one-pot...............................94 
Esquema 30- Formação do produto 29

Esquema 31- Síntese da (+)-codonopsinina realizada por Yoda et al.(1996)...107 Esquema 32- Síntese da (-)-Codonopsinina realizada por Correia et al.(2000) 108

Esquema 33- Síntese da (-)-Codonopsina realizada por Roa et al.(2007).......108 Esquema 34- Síntese da 4-epi-(+)-Codonopsinina realizada por Behr et al. (2011) 109

Esquema 35- Proposta para síntese da codonopsinina e análogos 111

Esquema 36- Síntese das pirrolidonas 112

Esquema 37- Reação de eliminação do sulfóxido 115

Esquema 38- Reação de eliminação do Selenóxido......................................116

Esquema 39- Proposta reacional partindo da $\alpha$-angélica lactona....................118

Esquema 40- Proposta reacional partindo da $\beta$-angélica lactona....................118

Esquema 41- Reação de diidroxilação da $\beta$-angélica lactona..........................119

Esquema 42- Reação de proteção do diol 43...........................................120

Esquema 43- Representação das próximas etapas para obtenção dos alcaloides. 


\section{LISTA DE FIGURAS}

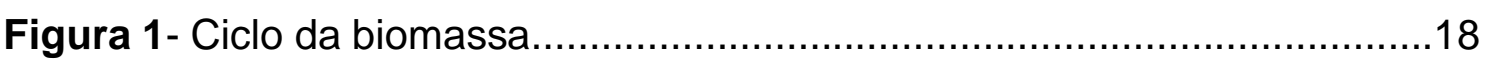

Figura 2- Distribuição da celulose, hemicelulose e lignina na cana-de-açúcar...20

Figura 3- Produtos gerados pela despolimerização da lignina..........................21

Figura 4-Processamento da biomassa para geração das plataformas

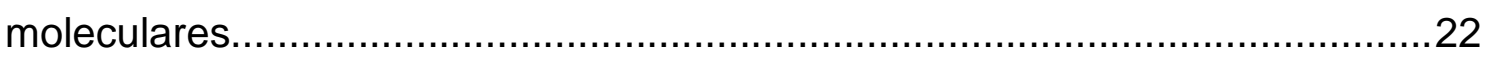

Figura 5- Plataformas moleculares derivadas da biomassa lignocelulósica.......23

Figura 6- Produção de ácido levulínico pelo processo biofine ............................24

Figura 7- Mecanismo para formação do ácido levulínico a partir da celulose.....26

Figura 8- Obtenção de variados compostos a partir do AL...............................27

Figura 9- Aplicações para os ésteres levulinatos...........................................28

Figura 10- Proposta mecanística para formação do intermediário 1.................42

Figura 11- Valores de deslocamentos químicos esperados para formação das

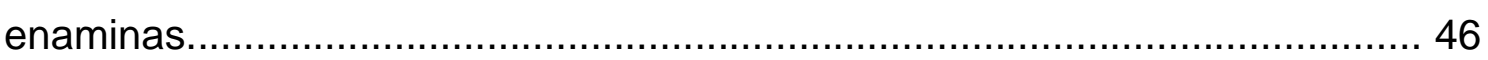

Figura 12- Alguns valores de deslocamentos químicos para 1a e 1b................47

Figura 13- Espectro de RMN de ${ }^{1} \mathrm{H}$ contendo os compostos 1a e 1b................47

Figura 14- Mecanismo para formação da enamina.........................................48

Figura 15- Proposta mecanística via ataque ao íon oxônio...............................48

Figura 16- Proposta mecanística via ataque ao íon imínio.................................49

Figura 17- Análise qualitativa por CG-EM do bruto reacional...........................52

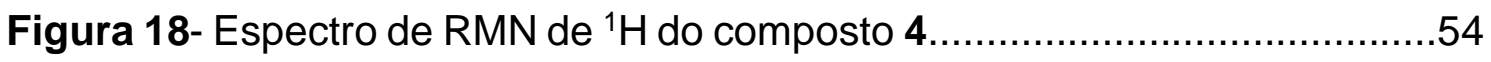

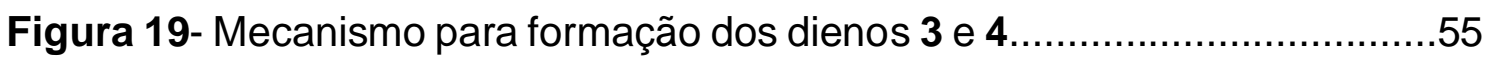

Figura 20- Proposta mecanística para formação de $2(E+Z) \ldots \ldots \ldots \ldots \ldots \ldots \ldots \ldots \ldots \ldots . . . . .55$

Figura 21- Espectro de RMN de ${ }^{13} \mathrm{C}$ da mistura 1a-1b e 2a-2b........................56

Figura 22- Estruturas 3D dos compostos 1a, 1b, 2a e 2b..............................56

Figura 23- Alguns compostos preparados a partir do ciclopentadieno 4.......... 59

Figura 24- Formação de grupo protetor na função ácido carboxílico...................62

Figura 25- Proposta mecanística para formação dos compostos 9 e 10..........62

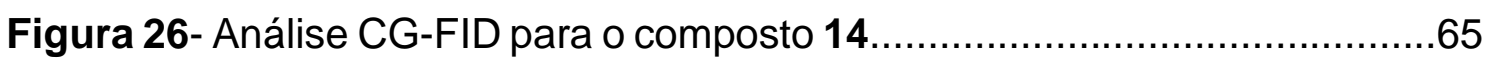

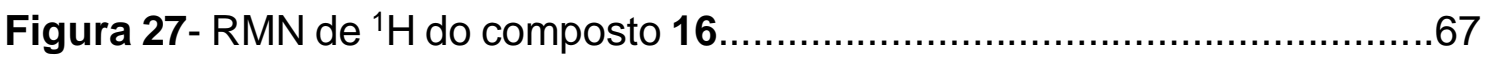

Figura 28- Estruturas de ressonância que contribuem para formação de 17a$17 \mathrm{~b}$ 
Figura 29- Espectro de IV da mistura dos isômeros 17a-17b. 69

Figura 30- Espectro de $\mathrm{RMN}$ de ${ }^{1} \mathrm{H}$ do bruto reacional para formação da

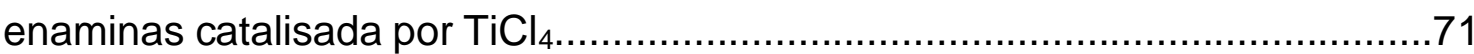

Figura 31- Algumas aplicações da GVL.........................................

Figura 32- Rearranjo de Achmatowicz para formação do 1,2,5-pentanotriol...81 Figura 33- A) Adição $t$-butóxido de potássio à $0^{\circ} \mathrm{C}$; B) Agitação mecânica por

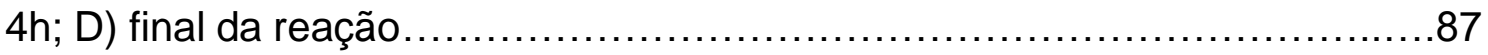

Figura 34- Proposta mecanística para formação de 18 e 19............................8

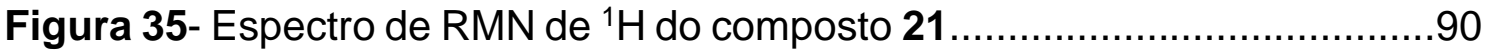

Figura 36-a) Análise por CG-EM da redução parcial de 18. b) Espectros

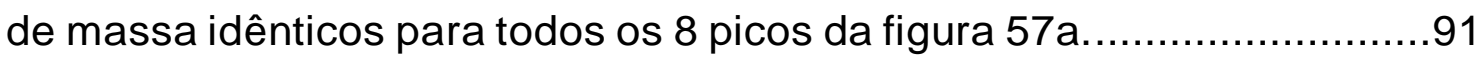

Figura 37-Espectros de RMN de ${ }^{1} \mathrm{He}^{13} \mathrm{C}$ do composto 23...............................

Figura 38- Alcaloides naturais utilizados na medicina...................................103

Figura 39-Exemplos de alcaloides com núcleo pirrolidínicos...........................104

Figura 40- Alcaloides pirrolidínicos di e poli-hidroxilados...............................105

Figura 41- Algumas sínteses totais da (-)-Codonopsinina e dos seus

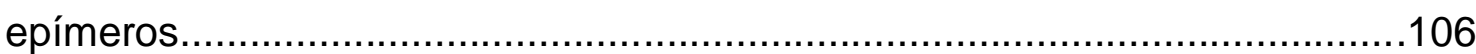

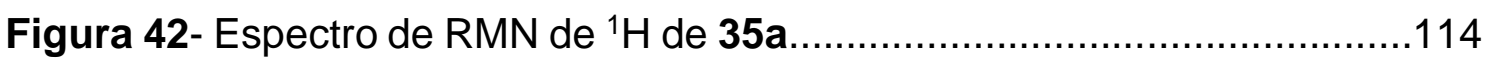

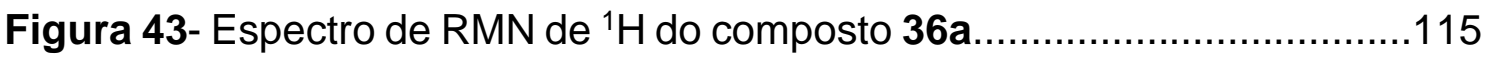

Figura 44- Espectro de RMN de ${ }^{1} \mathrm{H}$ do composto 36a' ...................................116

Figura 45- Mecanismo para diidroxilação da $\beta$-AL......................................120

Figura 46- Análises realizadas por CG-EM............................................. 121

Figura 47- Espectro de RMN do Bruto reacional para formação de 45a..........123

Figura 48-Escopo reacional para formação das amidas 45a-45j....................124

Figura 49- Cromatograma e fragmentações (bruto reacional para formação de

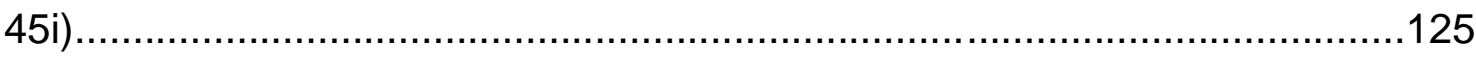

Figura 50- Escopo reacional utilizando $\mathrm{AlCl}_{3}$ como catalisador.......................126

Figura 51 Análise por CG-EM da pirrolidona 46a.....................................128 


\section{LISTA DE TABELAS}

Tabela A-Composição química da biomassa lignocelulósica............................19

Tabela 1- Condições experimentais para formação do intermediário 1.............41

Tabela 2- Condições experimentais para reação de alquilação do LE.................44

Tabela 3- Condições experimentais para formação do silil-enol éter...................45

Tabela 4- Condições experimentais para reações de alquilação a partir das

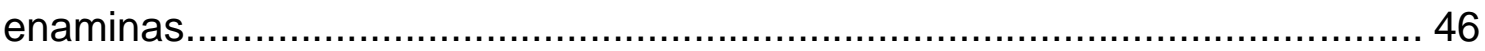

Tabela 5- Condições experimentais para formação dos produtos 1a-1b e 2a2b.

Tabela 6- Condições experimentais para formação do ciclopentadieno 4 partindo da mistura dos isômeros 1 e 2 .53

Tabela 7- Condições experimentais para formação do ciclopentadieno 3 e/ou 4. .58

Tabela 8- Condições experimentais para formação dos ésteres. 61

Tabela 9- Estudo das reações de Diels-Alder. .63

Tabela 10- Condições experimentais para formação do ciclopentano 14..........64

Tabela 11- Condições experimentais para formação do ciclopentano 15...........66

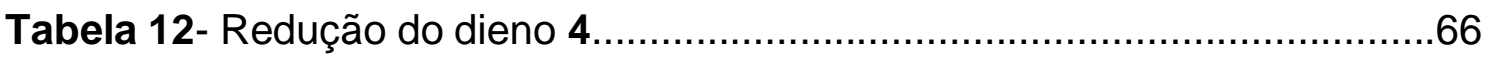

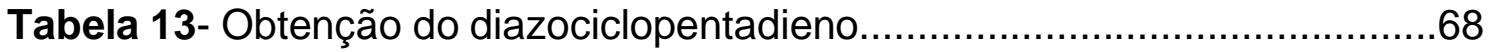

Tabela 14- Otimização das condições reacionais para formação de 18..............86

Tabela 15- Reação sem solvente para formação de 18...................................87

Tabela 16-Otimização das condições para formação do poliol 21 ......................90

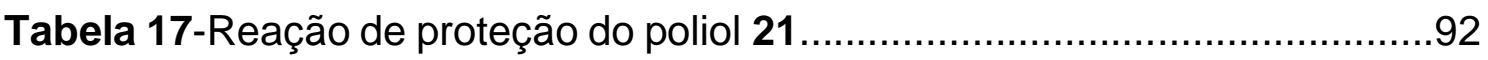

Tabela 18- Otimização das condições reacionais............................................95

Tabela 19- Otimização da quantidade de base e work-up.................................96

Tabela 20-Optimização das condições para reação de alquilação de 18...........98

Tabela 21-Formação de polióis com cadeia longa.......................................100

Tabela 22- Formação dos intermediários de enxofre e selênio........................114

Tabela 23- Reação de epoxidação..............................................................117

Tabela 24- Otimização da reação para abertura da lactona 44......................122

Tabela 25- Condições reacionais para formação da pirrolidona 46b................127 


\section{LISTA DE ABREVIATURAS E SIGLAS}

ACN - acetonitrila

AcOEt - acetato de Etila

Cbz - carbobenzilóxi

CCD - cromatografia de camada delgada

d - dupleto

DABCO - 1,4-diazabicíclo[2.2.2]octano

DBU - 1,8-diazabicíclo[5.4.0]undec-7-eno

dd - duplo dupleto

ddd - duplo duplo dupleto

dddt - duplo duplo duplo tripleto

DMF - dimetilformamida

DMSO - demetilsulfóxido

$\mathrm{dt}$ - duplo tripleto

eqv. - equivalentes

$\mathrm{Hz}-$ hertz

IV - infravermelho

$\mathrm{J}$ - constante de acoplamento

m - multipleto

m/z - razão massa carga

m-CPBA - ácido m-cloroperbenzóico

$\mathrm{MHz}$ - mega-hertz

Ms-mesil

$\mathrm{Ph}$ - fenil

ppm - partes por milhão

q - quarteto 
qd - quartetos de dupleto

quint - quinteto

Rf - fator de retenção

RMN - ressonância magnética nuclear

s - simpleto

sept - septeto

septd - septeto de dupleto

sext - sexteto

$\mathrm{t}$ - tripleto

TBS - t-butildimetilsilil

td- tripleto de dupleto

TEA - trietilamina

TFA - ácido trifluoroacético

TMS - tetrametilsilano

tq - tripletos de quartetos

Ts - tosil

$\mathrm{TsN}_{3}$ - tosil azida

$\mathrm{tt}$ - tripleto de tripletos 


\section{SUMÁRIO}

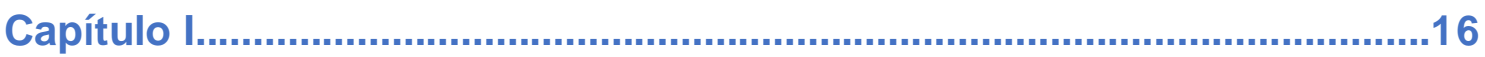

1. INTRODUÇÃO

1.1. História e definição da Biomassa......................................................17

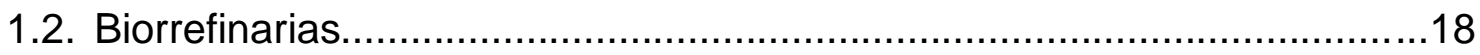

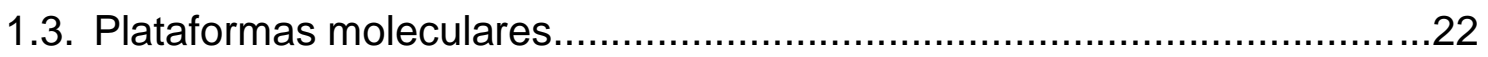

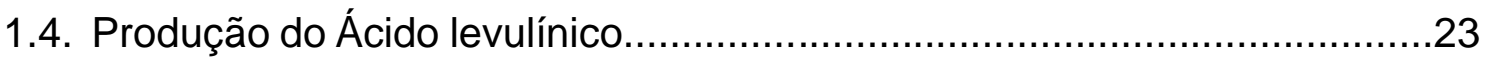

1.4.1. Aplicações do Ácido levulínico........................................................27

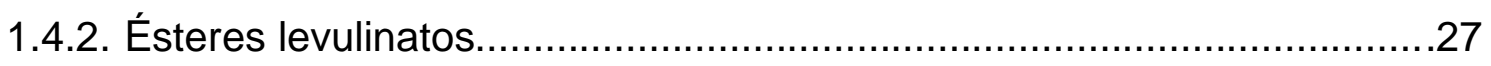

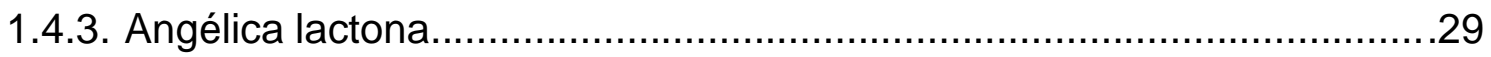

1.4.3.1. Aplicações das Angélicas lactonas...............................................31

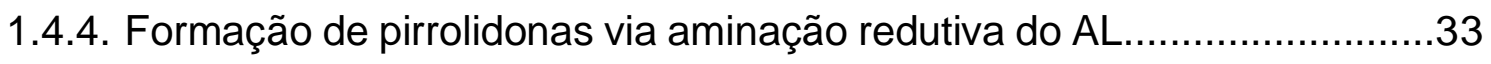

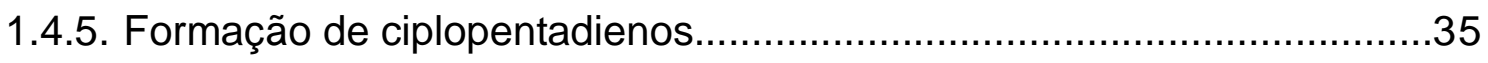

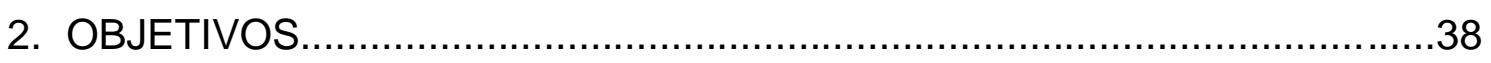

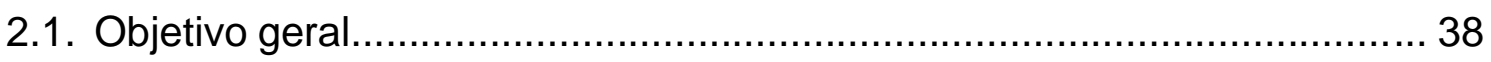

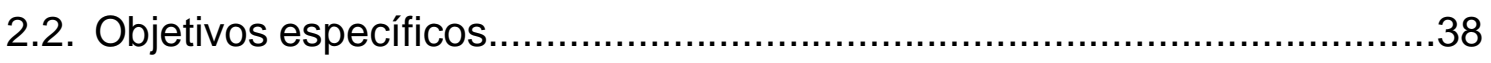

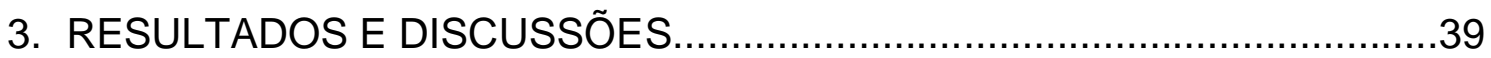

3.1. Reação de adição de Michael entre levulinato de etila e $\beta$-angélica

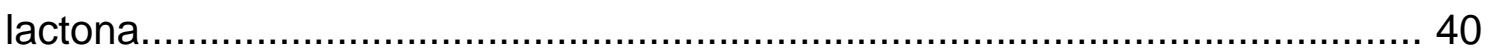

3.2. Reatividade dos hidrogênios e carbonos alfa à carbonila do levulinato de

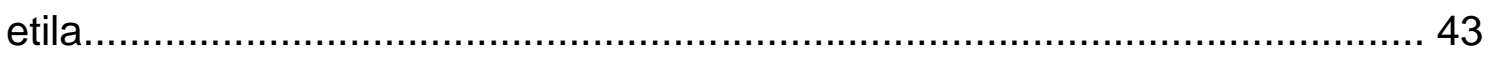

3.3. Desenvolvimento de rota sintética verde para a obtenção de

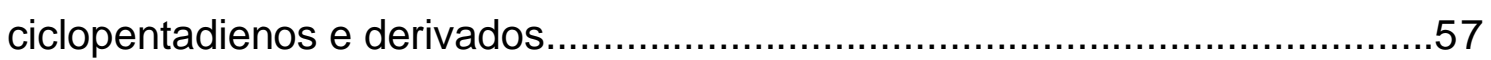

3.4. Aplicações sintéticas para os ciclopentadienos 3 e 4 ................................60

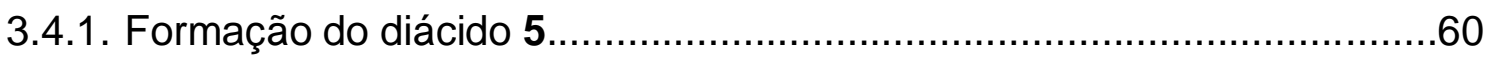

3.4.2. Formação de ésteres: alílico (6), propargílico (7) e metílico (8)................60

3.4.3. Emprego do dieno nas reações de Diels-Alder......................................61

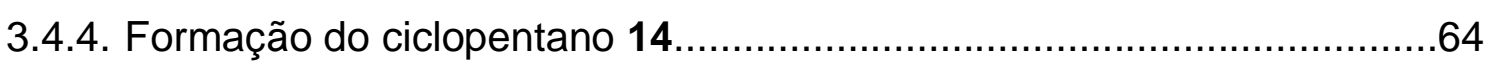

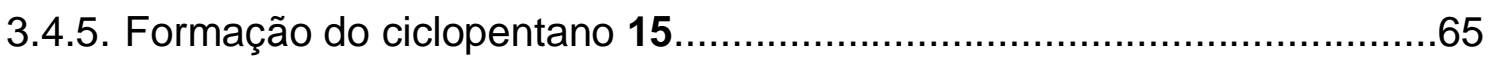

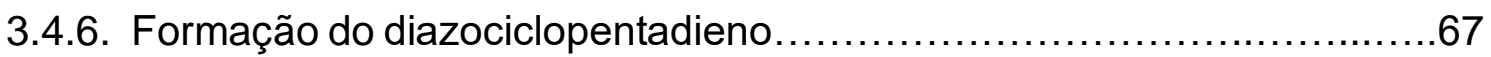

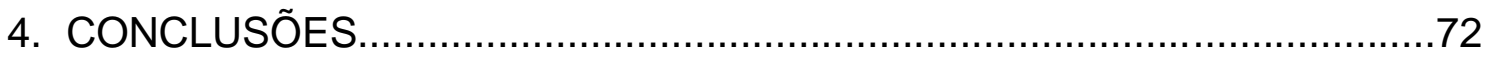

Capítulo II..........................................................................................73 
1. INTRODUÇÃO

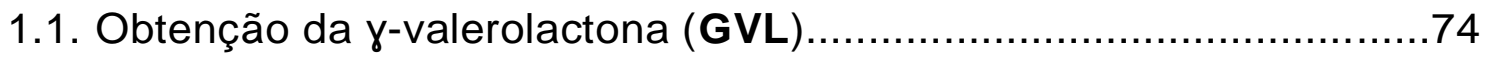

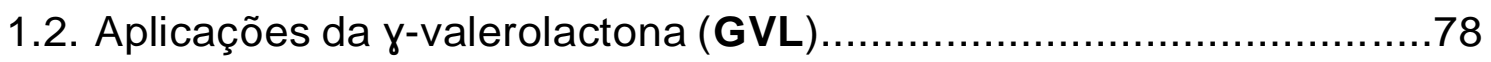

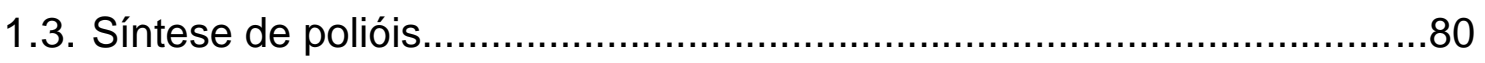

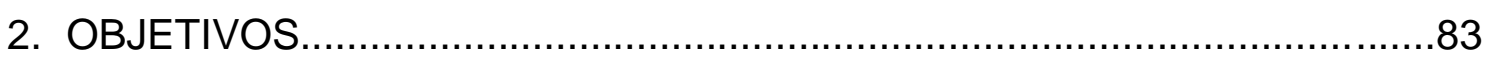

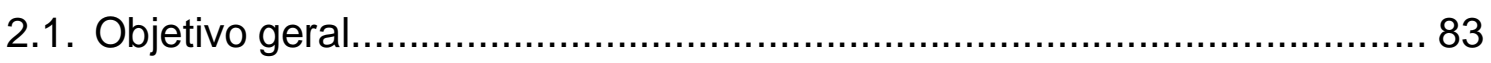

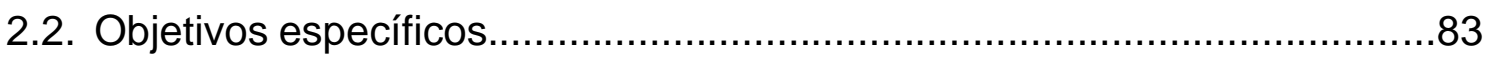

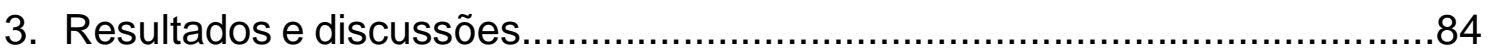

3.1. Estudo de bases para reação de condensação de Claisen entre duas

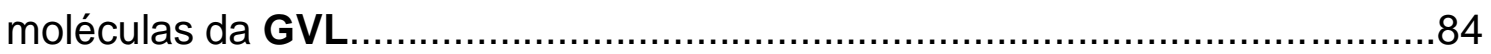

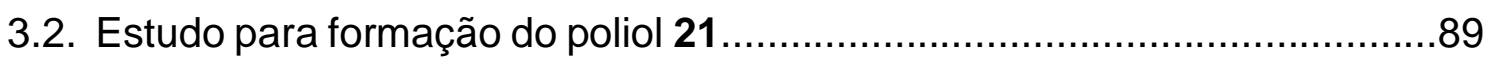

3.3. Reações de alquilação para aumentar a cadeia carbônico do composto

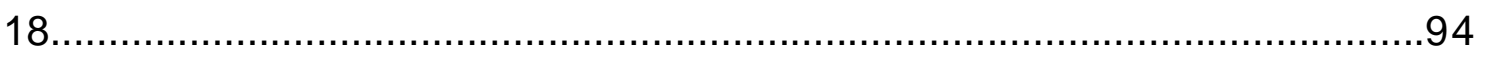

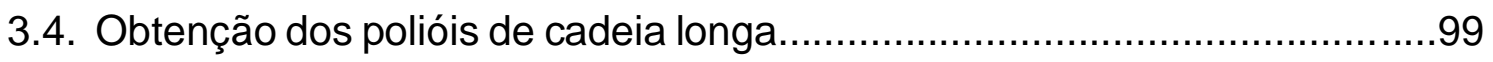

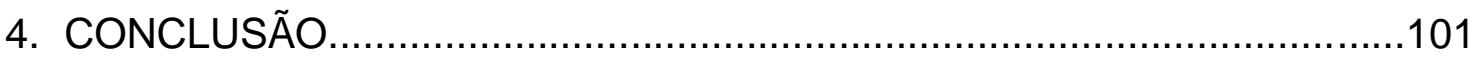

Capítulo III.......................................................................................102

1. INTRODUÇÃO

1.1. Alcaloides pirrolidínicos diidroxilados................................................104

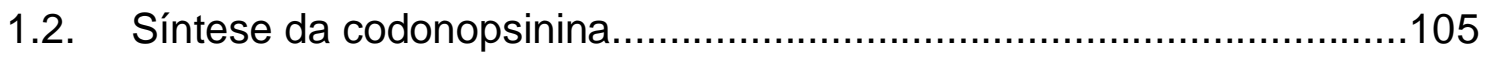

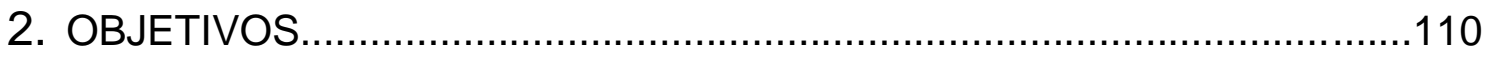

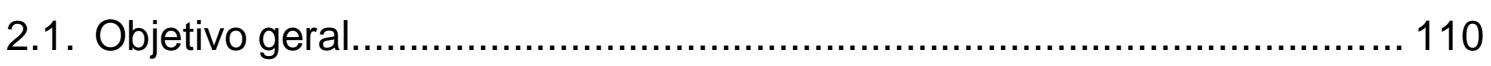

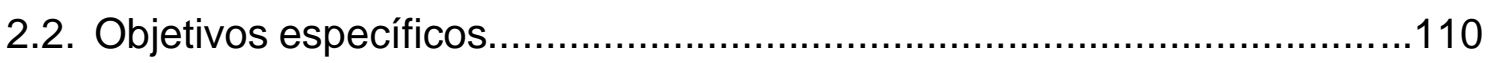

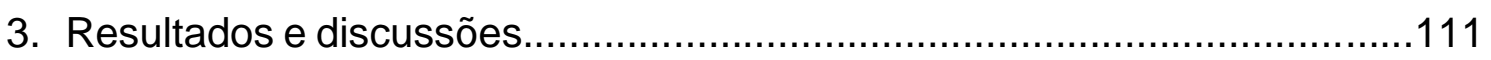

3.1. Proposta sintética da codonopsinina e análogos..................................111

3.2. Rota sintética partindo do ácido levulínico (AL) ....................................112

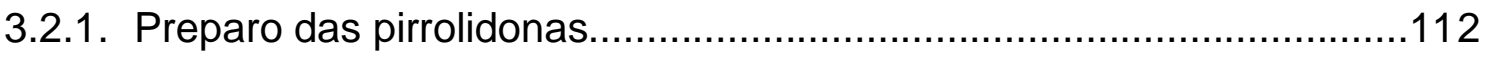

3.2.2. Reação das pirrolidonas frente aos eletrófilos......................................112

3.3. Rota sintética partindo da $\beta$-angélica lactona...........................................119

3.3.1. Estudos das reações de ciclização (amidas 45a-45k)...........................126

4. CONCLUSÕES E PERSPECTIVAS ......................................................130

Capítulo IV....................................................................................... 131

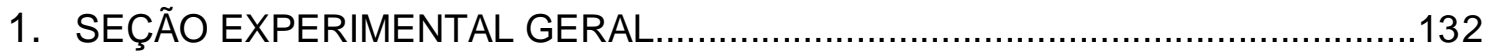

2. Capítulo I: Uso do Levulinato de etila como plataforma química para produção de ciclopentadienos e seus derivados. 
2.1. Auto condensação do levulinato de etila em tolueno. 133

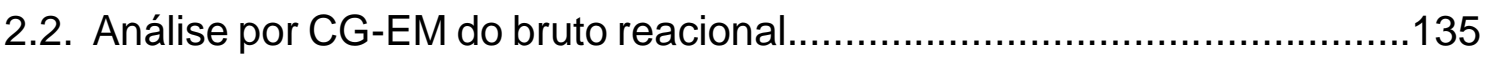

3. Auto condensação do levulinato de etila em anisol...........................138

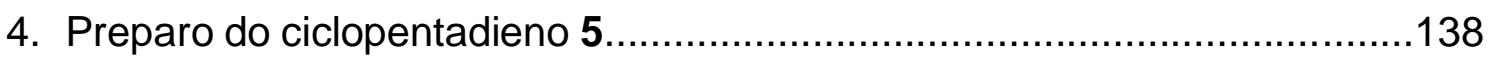

5. Procedimento geral para preparo dos ciclopentadienos 6 e 7 ....................139

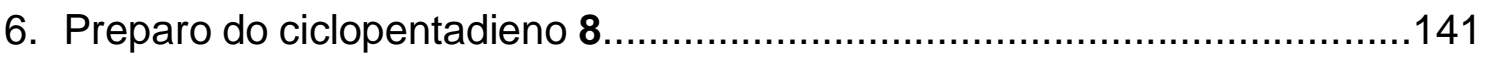

7. Procedimento geral para reação de Diels-Alder........................................142

8. Procedimento geral para síntese de ciclopentanos 14 e 15........................144

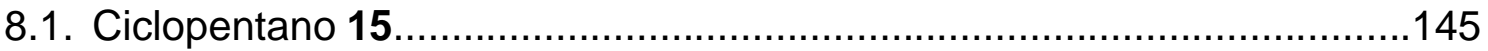

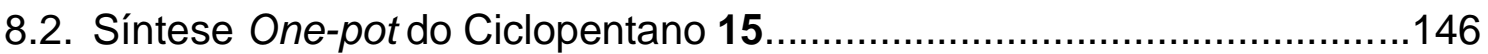

9. Síntese dos diazocompostos Ciclopentadienos 17a e 17b........................147

10.Capitulo II: Um novo método para síntese de polióis de cadeia longa a partir

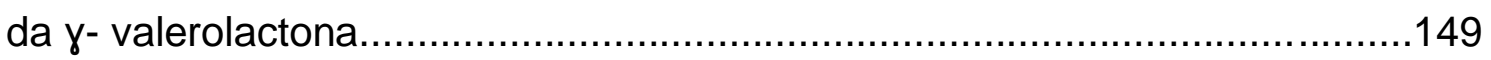

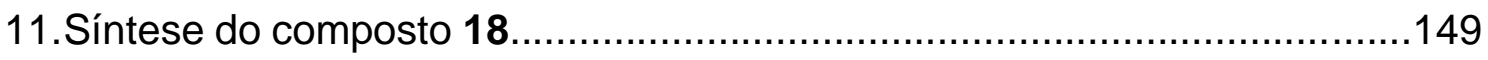

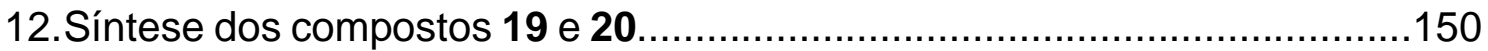

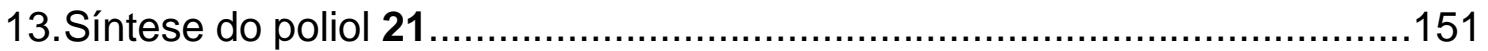

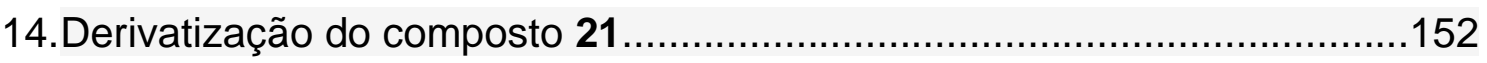

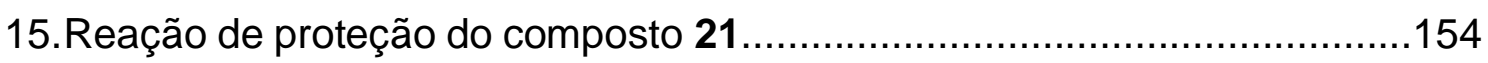

16. Reação de oxidação do composto 22

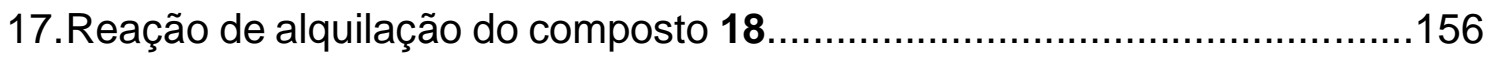

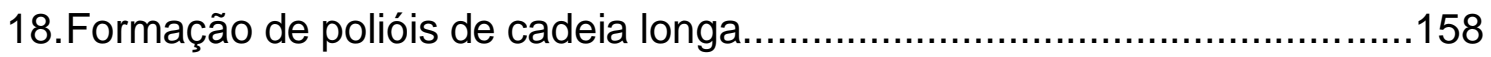

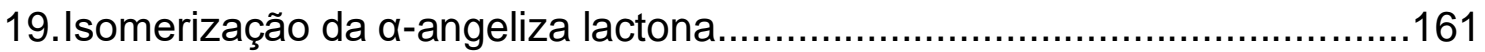

20. Reação de diidroxilação da $\beta$-angélica lactona........................................161

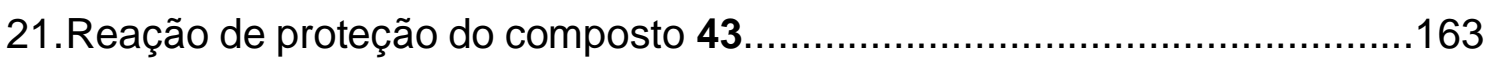

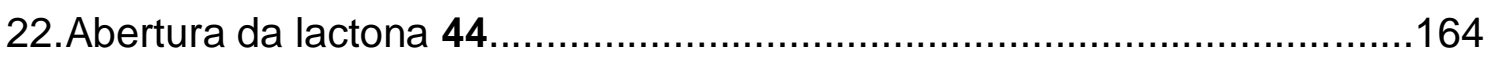

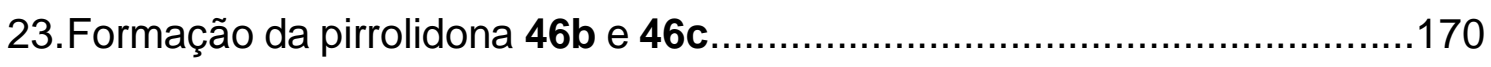

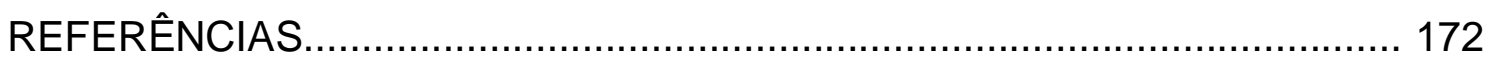

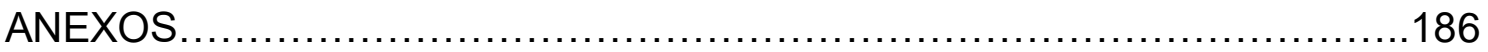




\section{Uso do Levulinato de etila como plataforma química para produção de ciclopentadienos e seus derivados}

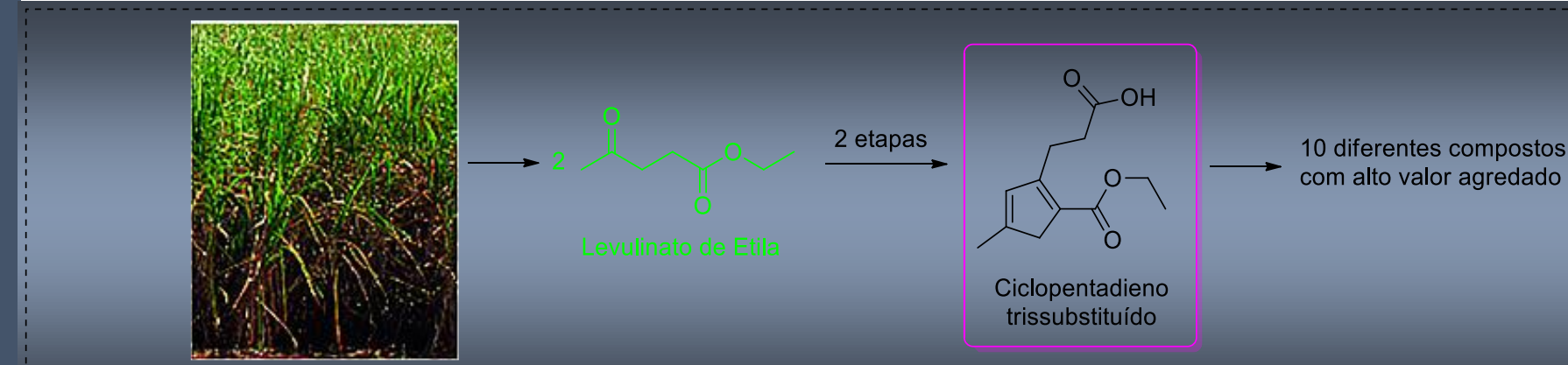

Biomassa

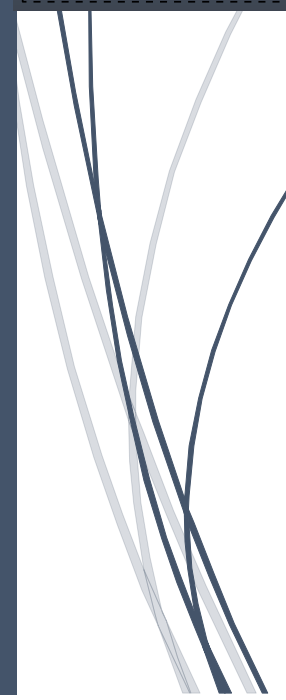




\section{INTRODUÇÃO}

\subsection{História e definição da Biomassa}

Historicamente, o uso inicial da biomassa para geração de energia é relatado desde os primórdios da humanidade e era, praticamente, a única forma de energia utilizada, além da eólica (empregada para navegação), animais (para trabalho no campo) e pequenas quantidades de carvão mineral para aquecimentos de uso doméstico. ${ }^{1,2}$

No século 18 com a Revolução Industrial, que se iniciou com o uso das máquinas a vapor, a importância do carvão mineral, praticamente pequena, cresceu rapidamente para $50 \%$ no fim do século $19 .{ }^{2}$ Deste período para frente, o uso dos combustíveis fósseis petróleo e gás natural tornaram-se fontes predominantes para geração de energia, sendo a biomassa mantida no esquecimento por anos. ${ }^{3}$ Existem duas explicações plausíveis para isso: em primeiro lugar, o transporte do petróleo e do gás era mais facilitado e deram origem a novas formas de utilização como combustíveis. Além disso, o uso da biomassa na forma primitiva, na qual era utilizada, causava desmatamento e degradação do solo e, portanto, desaconselhável. ${ }^{4}$ Contudo, o petróleo e gás natural são fontes consideradas não renováveis e, de acordo com previsões, estima-se sua longevidade entre 80-100 anos, considerando o consumo anual. Além disso, tornou-se evidente uma causalidade entre a queima de combustíveis fósseis e as consequências sobre o clima global. ${ }^{4,5}$

A partir de 1990, houve um aumento significativo na contribuição da biomassa que se encontra, portanto, em plena recuperação. Futuramente, as projeções indicam que a importância da biomassa renovável aumentará bastante e chegará a representar, no fim do século 21 , de $10-20 \%$ de toda a energia usada pelo homem. É considerada, ainda, como uma fonte promissora para geração de combustíveis e intermediários da química fina. ${ }^{2,6,7}$

O termo biomassa é utilizado para designar qualquer tipo de matéria orgânica renovável de origem animal, vegetal ou produtos da sua transformação natural e artificial. As principais fontes renováveis da biomassa são as plantas e algas, geradas anualmente em milhões de toneladas pela fotossíntese. ${ }^{8}$ 
A queima da biomassa, ou de seus derivados, para gerar energia nas indústrias ocasiona a liberação de $\mathrm{CO}_{2}$ na atmosfera. Por outro lado, as plantas apreendem esse $\mathrm{CO}_{2}$, por meio da fotossíntese, fixando-o na matéria orgânica novamente. Assim, através do ciclo de carbono, ocorre a renovação da biomassa. Diferentemente da utilização dos combustíveis fósseis, o uso da biomassa no âmbito industrial, desde que não seja de forma primitiva, não altera a composição da atmosfera (Figura 1). ${ }^{7,8}$

Figura 1- Ciclo da biomassa

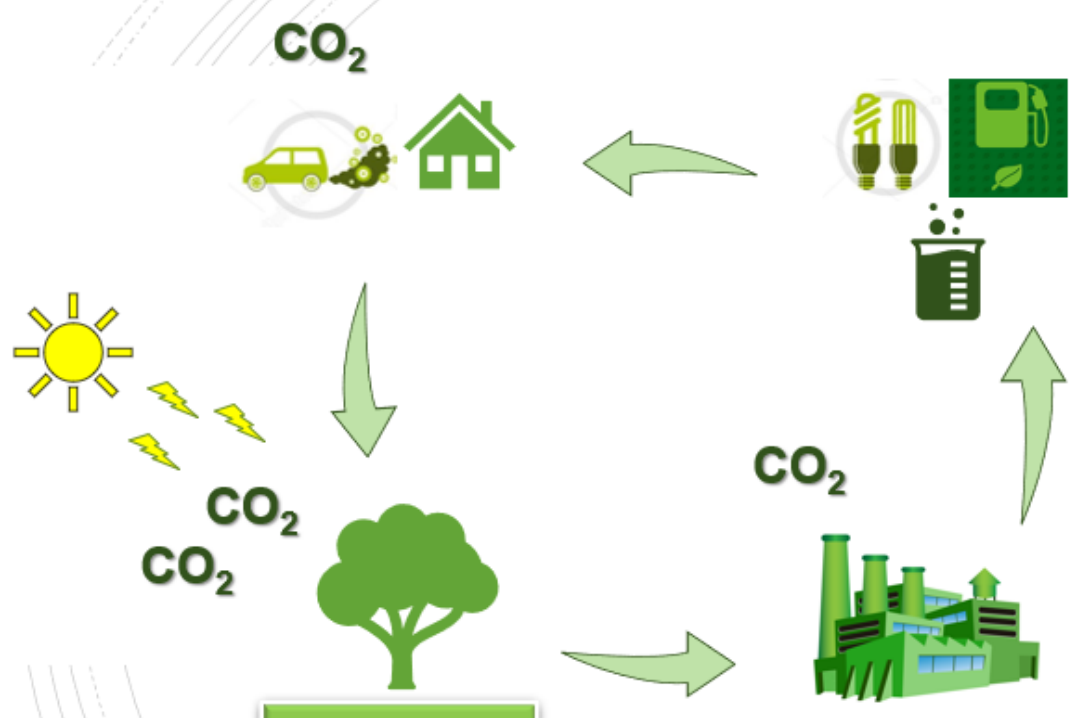

Biomassa

Neste cenário, torna-se evidente a grande necessidade de se desenvolver tecnologias para o aproveitamento da biomassa renovável, que são alternativas economicamente atrativas e ambientalmente amigáveis. Para tanto, um atual investimento consiste no desenvolvimento das biorrefinarias. ${ }^{9}$

\subsection{Biorrefinarias}

Um desenvolvimento sustentável para utilização dos constituintes da biomassa consiste no surgimento das biorrefinarias, uma abordagem similar à refinaria de petróleo, porém, a matéria-prima é uma biomassa renovável que deve ser totalmente aproveitada. A biorrefinaria é uma abordagem industrial considerada um caminho promissor para o desenvolvimento da bioeconomia. $O$ principal objetivo é desenvolver um conjunto de rotas tecnológicas capazes de 
fracionar, extrair, separar e converter a matéria-prima visando à produção de combustíveis, energia e produtos químicos. ${ }^{9-11}$ Os produtos químicos desenvolvidos a partir de coprodutos e resíduos são os que apresentam maior valor agregado na cadeia produtiva, podendo ser aplicados em diversos setores da economia como, por exemplo, petroquímico, farmacêutico, automotivo, construção, agronegócio, cosméticos e muitos outros. ${ }^{12-14}$ Exemplos de matériaprima nas biorrefinarias são: palha e bagaço de cana, espiga de milho, fibra de bananeira, e outros. Os exemplos citados são chamados de biomassa de segunda geração. ${ }^{15}$

Diversos produtos de baixa e alta massa molecular (carboidratos, aminoácidos, lipídeos e biopolímeros como, celulose, hemicelulose, quitina, amido, lignina e proteínas) são constituintes da biomassa. Dentre estes, os mais abundantes são a celulose, hemicelulose e lignina, que são denominadas de biomassa lignocelulósica. Esta composição química varia em função do tipo de biomassa, conforme demostrado na Tabela A. ${ }^{16-17}$

Tabela A- Composição química da biomassa lignocelulósica

\begin{tabular}{cccc}
\hline $\begin{array}{c}\text { Biomassa } \\
\text { Lignocelulósica }\end{array}$ & $\begin{array}{c}\% \\
\text { Celulose }\end{array}$ & $\begin{array}{c}\% \\
\text { Hemicelulose }\end{array}$ & $\begin{array}{c}\% \\
\text { Lignina }\end{array}$ \\
\hline Palha de cana & $40-44$ & $30-32$ & $22-25$ \\
Bagaço de cana & $32-48$ & $19-24$ & $23-32$ \\
Espiga de milho & 45 & 35 & 15 \\
Fibra de coco & $36-43$ & $0,15-0,25$ & $41-45$ \\
Fibra de bananeira & $60-65$ & $06-08$ & $05-10$ \\
Palha de arroz & 43,3 & 26,4 & 16,3 \\
\hline
\end{tabular}

Para que os materiais lignocelulósicos possam ser utilizados como matéria-prima nas biorrefinarias, é necessário que seus constituintes sejam separados. Para tanto, um processo de pré-tratamento é realizado com objetivo de desorganizar a estrutura polimérica da biomassa. Os processos de conversão podem ser bioquímicos (fermentação) ${ }^{18}$, termoquímicos (pirólise e gaseificação) ${ }^{19}$, químicos (hidrólise) ${ }^{20}$ ou mecânicos (pressão) ${ }^{21}$.

No Brasil, a cana-de-açúcar é processada em grande escala para fabricação de etanol e açúcar, gerando milhões de toneladas por ano do bagaço. 
Isso torna seu uso nas biorrefinarias mais atraente, uma vez que o uso do bagaço da cana não compete diretamente com consumo alimentar. A cana-deaçúcar é a biomassa lignocelulósica mais abundante. A composição química presente na parede celular desta espécie vegetal varia entre 40-44\% de celulose, $30-32 \%$ de hemicelulose e $22-25 \%$ de lignina (conforme representado na figura 2). ${ }^{22,23}$

Figura 2- Distribuição da celulose, hemicelulose e lignina na cana-de-açúcar

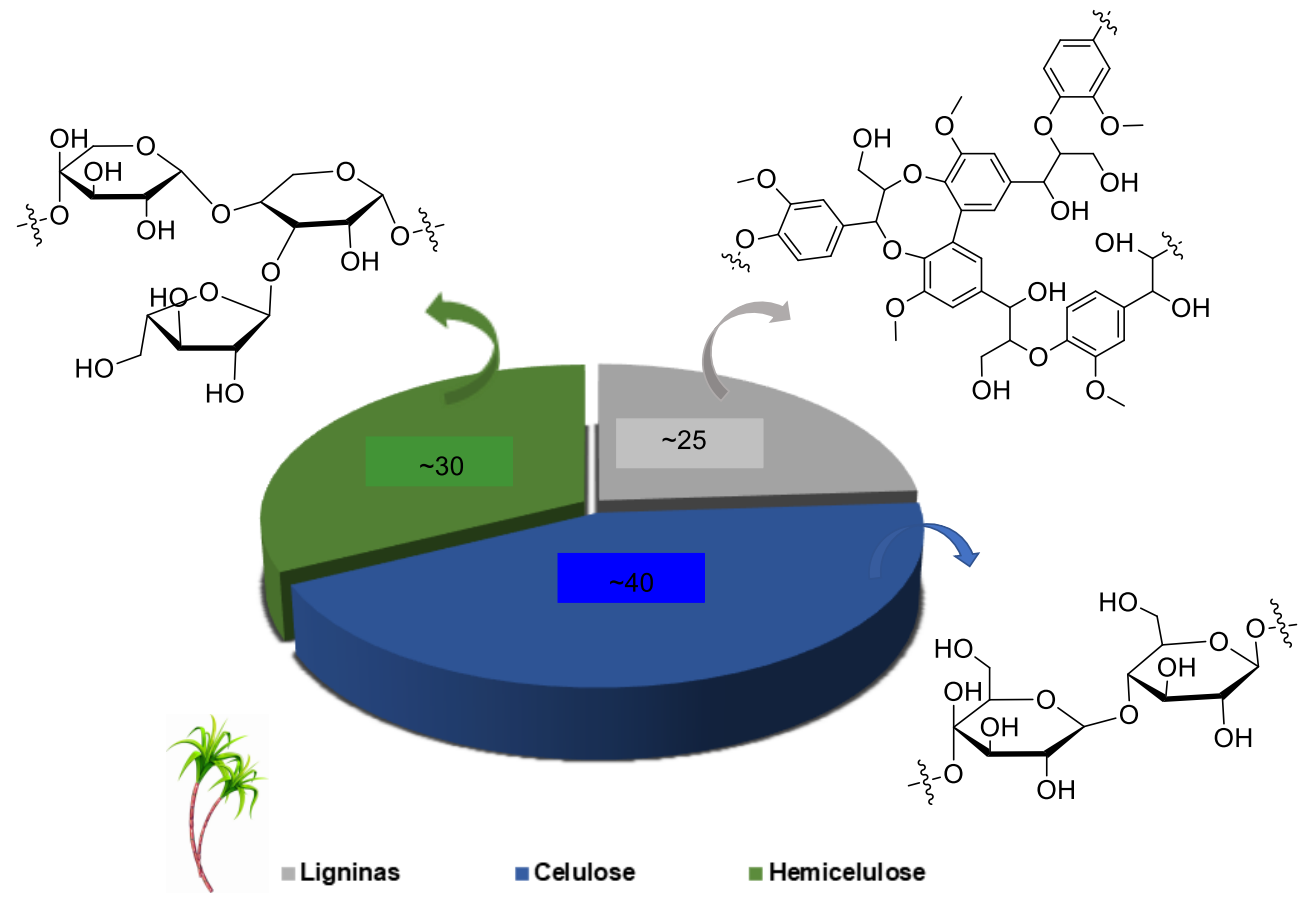

A lignina é uma macromolécula, com estrutura não homogênea, que consiste em três diferentes unidades de fenilpropanoides (álcool p-cumarílico, álcool coferílico e álcool sinapílico). É uma importante fonte para obtenção de substâncias fenólicas. Quase três quartos dos produtos comerciais feitos a partir da lignina aproveitam a estrutura da macromolécula e suas demais propriedades em aplicações como dispersantes, emulsificantes e aglutinantes. ${ }^{24-26} \mathrm{~A}$ partir da degradação química da lignina pode-se obter o cresol, eugenol, vanilina, siringaldeído, coniferaldeído, ácido ferúlico e ácido sinapínico (Figura 3). Estas moléculas estão presentes em grandes proporções no setor industrial, sendo utilizadas principalmente como matéria-prima "verde" para a fabricação de nylons e resinas poliméricas. ${ }^{24-27}$ 
Figura 3- Produtos gerados pela despolimerização da lignina.

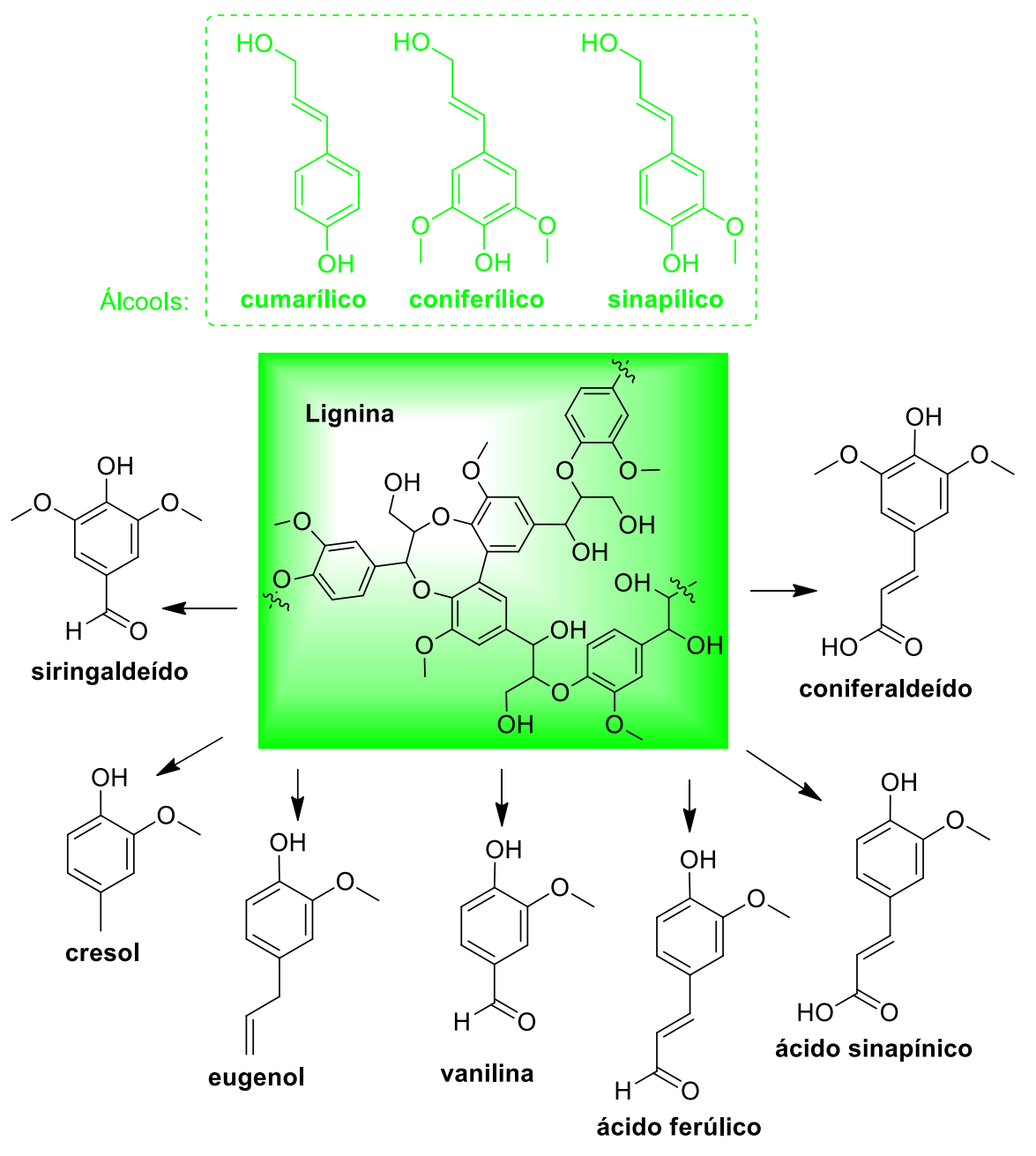

A celulose é um polímero formado por uma longa cadeia de moléculas de glicose unidas por ligações glicosídicas $\beta-1,4$. A reatividade da celulose é determinada tanto pelos grupos funcionais como pelas interações físicoquímicas existentes entre as macromoléculas. Por outro lado, a hemicelulose é constituída por uma mistura de polissacarídeos C6 (galactose e manose) e polissacarídeos C5 (xilose e arabinose). ${ }^{28-29}$

O processo de conversão dos materiais lignocelulósicos mais empregado é o processamento químico. A hidrólise ácida da celulose e hemicelulose leva à formação de hexoses e pentoses. Esses açúcares podem ser convertidos em outros intermediários dando origem à produção de variadas plataformas moleculares. A xilose é o monossacarídeo dentre os demais (arabinose, manose e galactose) gerado em maior quantidade pela hidrólise ácida da fração hemicelulósica. O tratamento com ácido sulfúrico diluído, por exemplo, é capaz 
de hidrolisar com eficiência a fração hemicelulósica sem degradar significativamente a celulose. O uso de um sistema com hidróxido de sódio e peróxido de hidrogênio possibilita a remoção seletiva da lignina por reações de oxidação e hidrólise. ${ }^{30,31}$ As unidades de açúcares (glicose e xilose) são as moléculas que dão alicerce para o surgimento das plataformas moleculares. ${ }^{31}$ $\mathrm{Na}$ figura 4, é apresentado um esquema que representa, de forma resumida, como ocorre o processamento da biomassa para formação das plataformas moleculares.

Figura 4- Processamento da biomassa para geração das plataformas moleculares

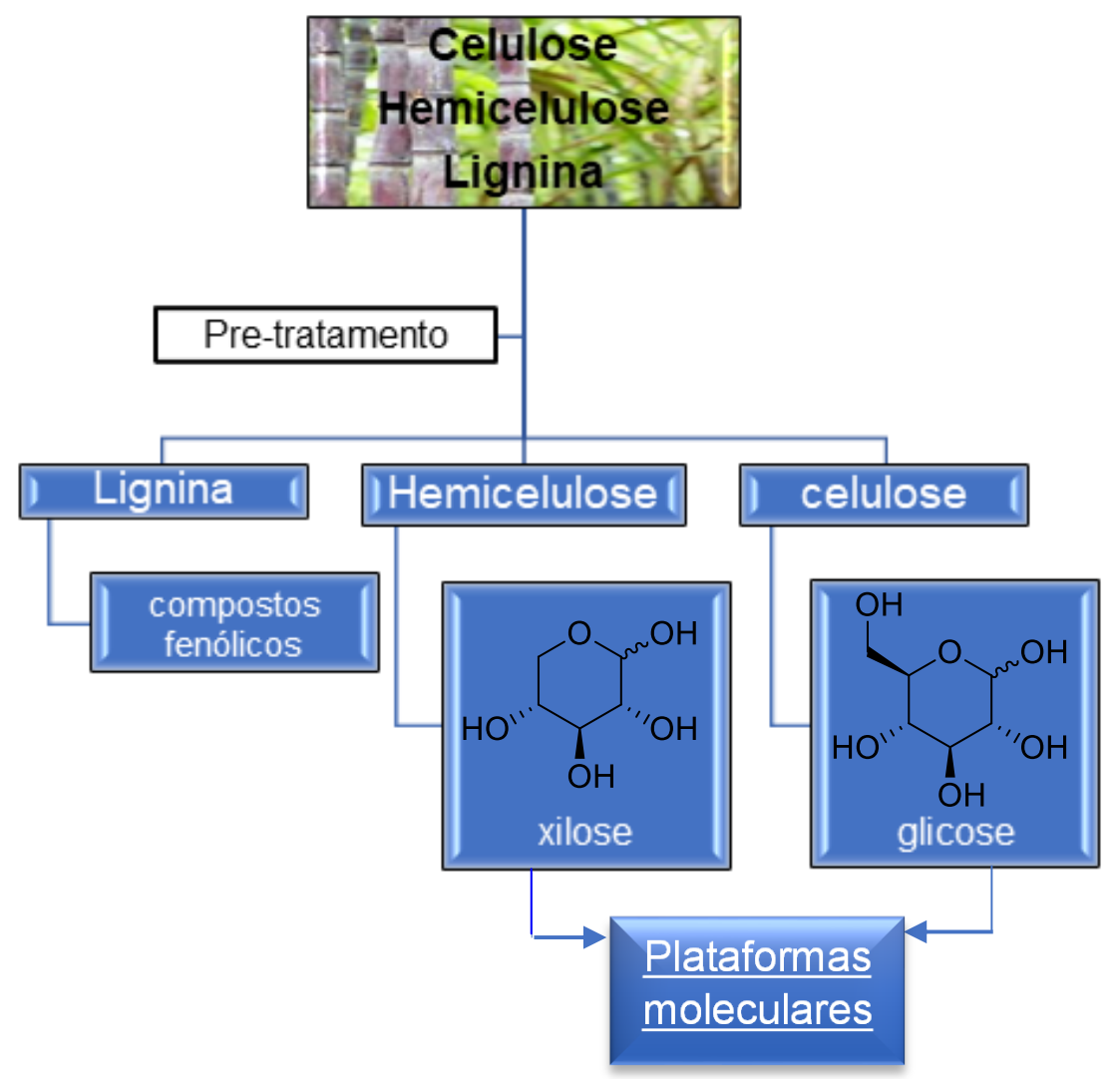

\subsection{Plataformas moleculares}

De acordo com o Departamento de Energia dos EUA, 12 plataformas moleculares, baseadas em derivados da biomassa lignocelulósica, foram selecionadas pelas biorrefinarias. Tais plataformas são constituídas pelos ácidos: succínico, fumárico, málico, 3-hidroxipropiônico, aspártico, glucárico, itacônico, levulínico e glutâmico. Assim como, os álcoois: 3-hidroxibutirolactona, glicerol, sorbitol, xilitol e 5-hidroximetilfurfural ${ }^{32}$ (Figura 5). 
Figura 5- Plataformas moleculares derivadas da biomassa lignocelulósica

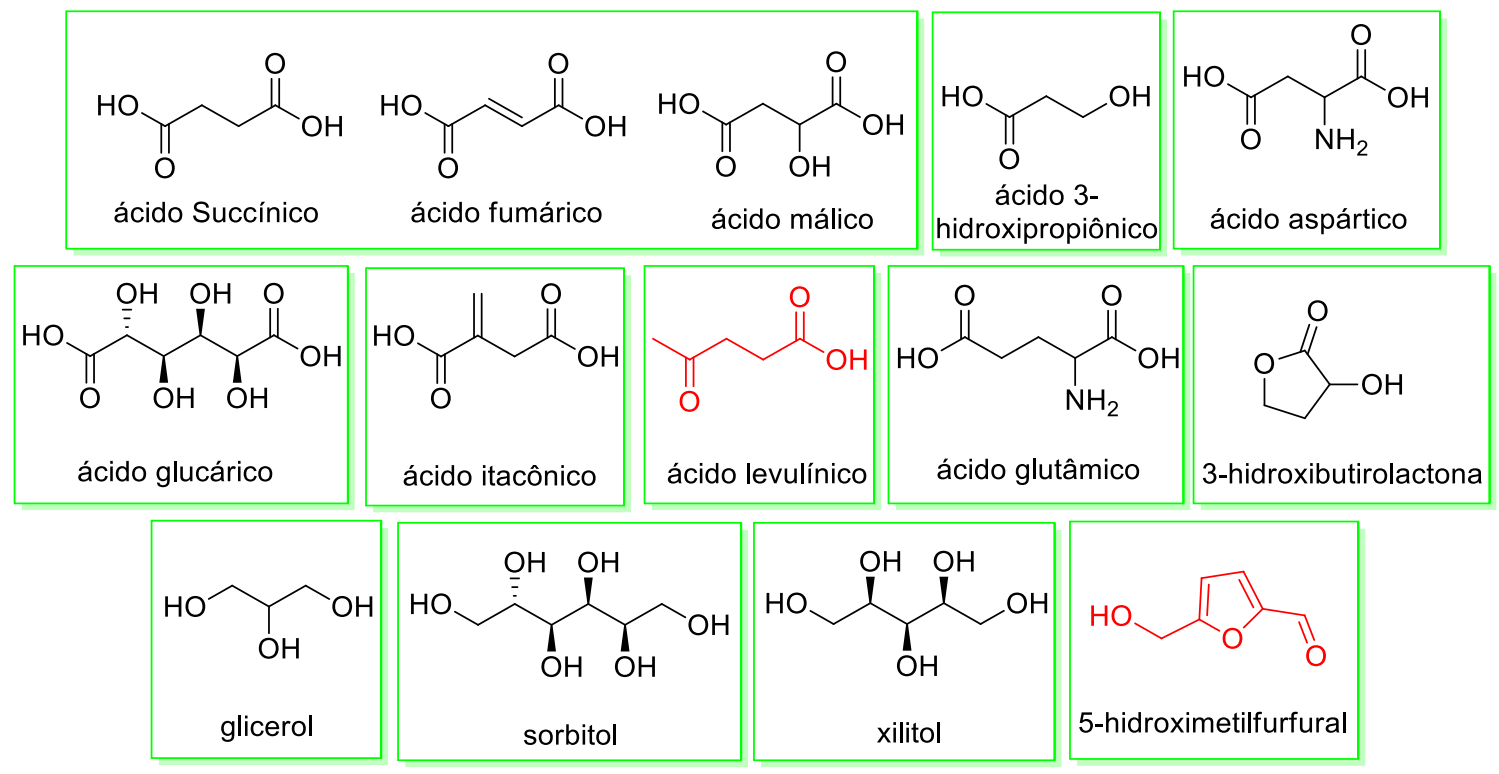

Essas moléculas podem ser utilizadas como blocos de construção versáteis em síntese orgânica e, posteriormente, convertidas em uma variedade de produtos químicos e materiais com elevado valor comercial. ${ }^{33,34}$ Dentre as plataformas moleculares, o ácido levulínico é bastante cobiçado e merece destaque. Sendo assim, serão abordados, sucintamente, nos tópicos a seguir os métodos para produção e algumas aplicações deste importante bloco de construção.

\subsection{Produção do ácido levulínico}

O ácido levulínico $(\mathbf{A L})$ é reconhecido como uma das maiores plataformas químicas oriundas da biomassa. A presença dos grupos funcionais, cetona e ácido carboxílico, na estrutura do AL possibilita o seu uso como um intermediário orgânico promissor para obtenção de variados compostos com amplas aplicações. ${ }^{35}$

Do ponto de vista industrial, a produção do AL nas biorrefinarias, através do processo Biofine patenteado em 1990, ocorre de forma contínua em quatro passos (representado na figura 6). A aparelhagem é composta por dois reatores nos quais ocorrem o processamento de diversos tipos de biomassa. A biomassa lignocelulósica é misturada (no misturador E1) na presença de ácido sulfúrico diluído (1,5-3\% dependendo da matéria-prima). O material é hidrolisado no 
primeiro reator de fluxo em pistão (E2), em tempo de residência curto (12 s), a temperaturas entre $210-220^{\circ} \mathrm{C}$ e à 25 bar de pressão. Nessa etapa, formam-se o 5-hidroximetilfurfural (HMF) e o furfural, que são continuamente removidos e alimentados para um segundo reator. No segundo reator de mistura perfeita (E3), O HMF é submetido a temperaturas variando entre $190-200{ }^{\circ} \mathrm{C}$ e 14 bar de pressão (tempo de residência de 20 minutos). Essas condições, no segundo reator, são cruciais para converter o HMF em AL e, também, para vaporizar o furfural e o ácido fórmico (coproduzidos no processo). As huminas, sólidos formados pela reação de polimerização, e a solução de $\mathbf{A L}$ são separadas por meio de um filtro/prensa (E4), sendo finalizado o processo. As huminas são queimadas para fornecer calor e eletricidade para o processo, enquanto o ácido sulfúrico pode ser reciclado. ${ }^{36}$

Figura 6- Produção de ácido levulínico pelo processo biofine

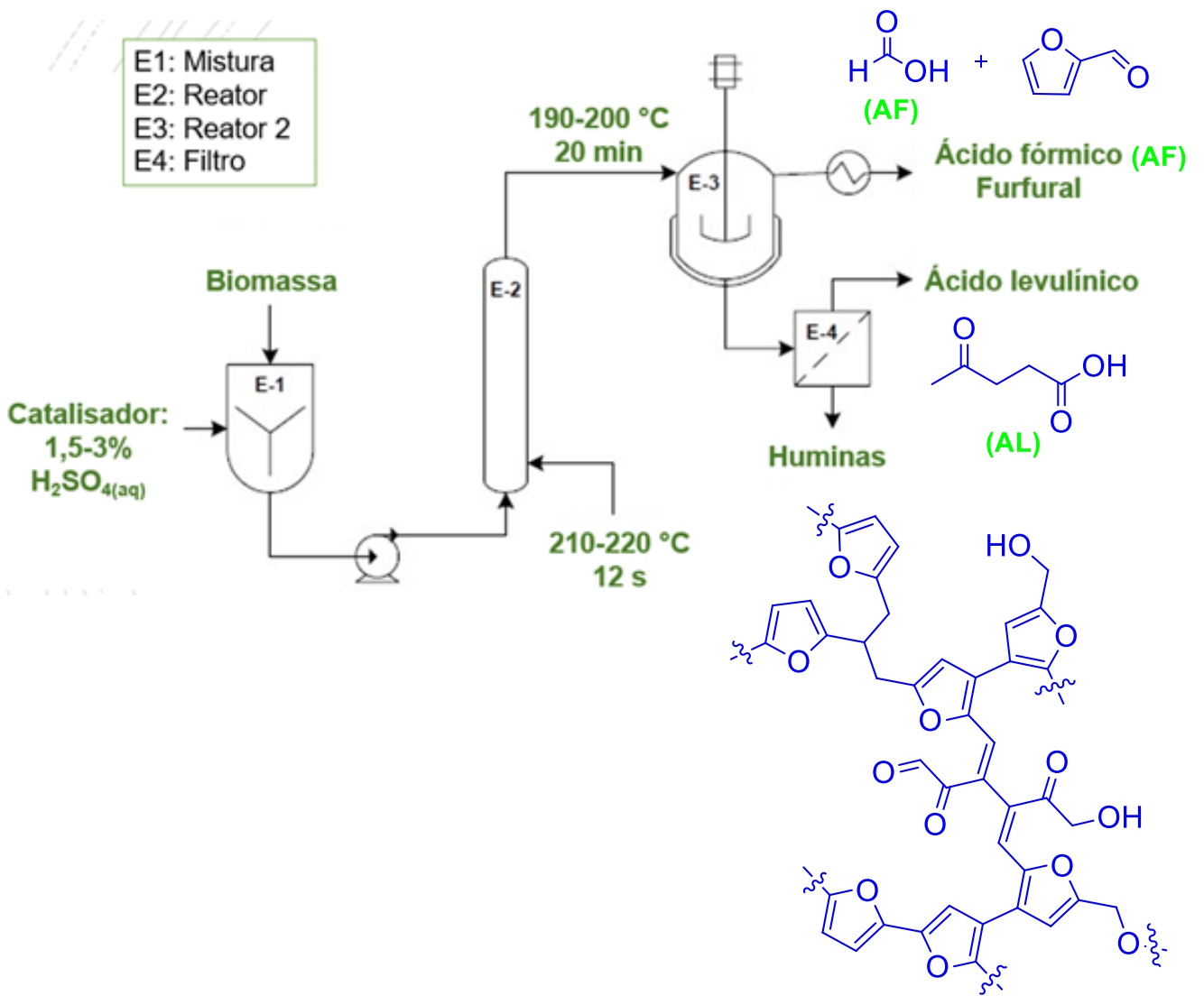

(adaptado de Girisuta (2007) ${ }^{35}$, De Souza et al., $(2014)^{36}$ ). 
O processo biofine, apesar de muito citado como sendo o primeiro processo que viabiliza a biorrefinaria, é limitado ao tipo de matéria prima processada. O AL só é produzido em altos rendimentos quando se utiliza o papel como material prima (celulose/hemicelulose). A utilização da biomassa residual como, por exemplo, resíduos agrícolas leva a baixos valores de rendimento (aproximadamente 50\%). ${ }^{35,36}$

Em 2016, HAYES postulou um novo processo, o Dibanet, que se mostrou mais atraente para a produção de $\mathbf{A L}$ com rendimentos maiores que o biofine (aproximadamente 70\%). Além disso, o processo necessita de uma quantidade inferior de energia para se produzir o AL. Resumidamente, o processo Dibanet envolve um pré-tratamento da biomassa com uma solução de peróxido de hidrogênio e ácido fórmico. Nesta etapa, a lignina presente na biomassa residual é dissolvida e o peróxido de hidrogênio é decomposto, rapidamente, na presença de um catalisador (catalisadores de ferro, por exemplo). Como produtos da reação obtém-se uma polpa rica em celulose e uma porção líquida contendo ácido fórmico, lignina dissolvida e uma pequena quantidade de açúcares que se hidrolisa parcialmente. A polpa rica em celulose é separada e transferida para um reator, no qual adiciona-se um catalisador ácido e, assim, a celulose é convertida em $\mathbf{A L} .{ }^{37}$

Nas últimas décadas, houve um interesse crescente por ampliar a produção do $\mathbf{A L}$ e, com isso, diversos catalisadores heterogêneos, por exemplo, Amberlite IR-120, Resina-Dowex, LZY-Zeolita, e metais suportados em sílica são estudados para converter a celulose em AL. Todavia, muitas pesquisas ainda devem ser realizadas para melhorar o rendimento e a escalabilidade do processo. Além disso, a maioria dos catalisadores heterogêneos são empregados para converter apenas as unidades de poli e/ou monossacarídeo (celulose, frutose, glicose) e não a matéria-prima bruta (bagaço-de-cana, por exemplo). ${ }^{38-40}$

Do ponto de vista mecanístico (Figura 7), a primeira etapa do processo para formação do AL é a hidrólise da celulose em unidades de glicose. A glicose isomeriza-se em frutose, apoiado pelo rearranjo de Lobry de Bruyn-Alberda van Ekstein $^{41}$ (representado na cor preta) e, em seguida, após a desidratação da frutose, forma-se o HMF (representado em azul). A partir do HMF, o ácido levulínico é produzido através de várias etapas de hidratação e desidratação, 
sob condições ácidas (representado em vermelho), cujo mecanismo não é totalmente descrito na literatura. Na conversão, o ácido fórmico é produzido em quantidade equimolar ao $\mathbf{A L} .^{42}$

Figura 7- Mecanismo para formação do ácido levulínico a partir da celulose

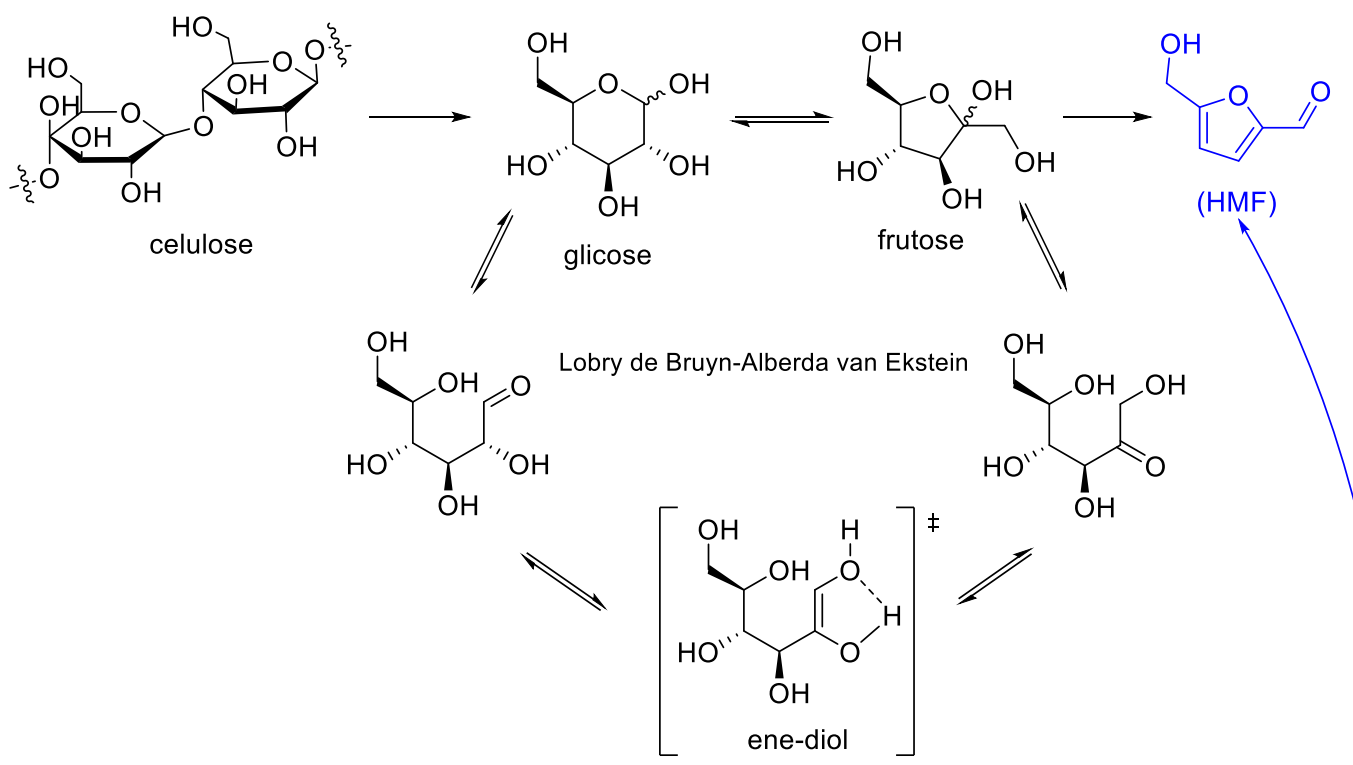<smiles>C=CCO[C@H]1O[C@@H](CO)C(O)C1O</smiles>

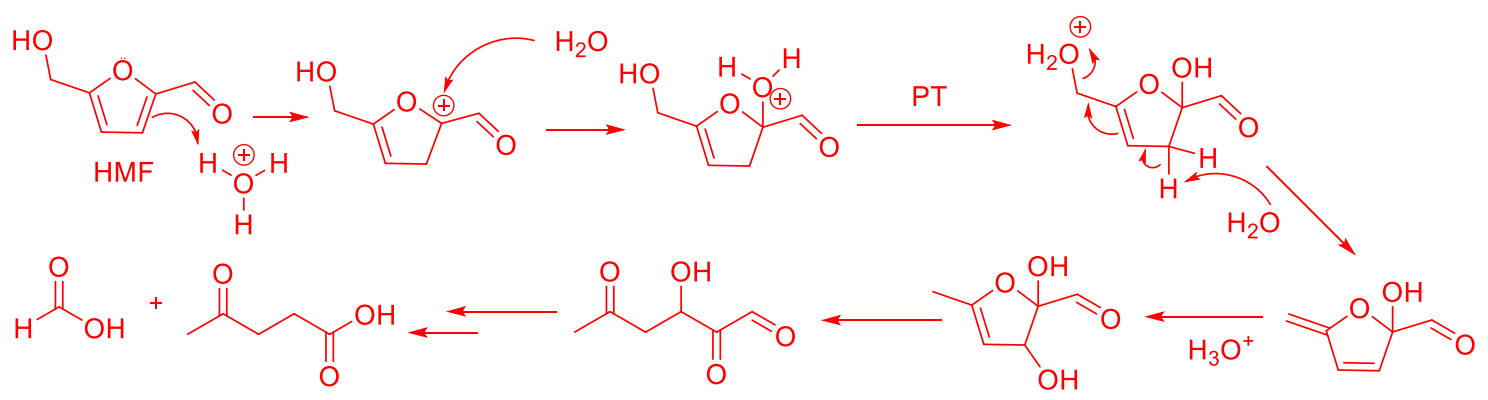




\subsubsection{Aplicações do Ácido levulínico}

Como já mencionado, o AL é uma promissora plataforma molecular aplicada na produção de variados compostos. ${ }^{43}$ Por exemplo, obtém-se a partir do AL 0 2-metiltetraidrofurano, um biocombustível que pode ser misturado à gasolina e, ainda, pode ser utilizado com solvente. ${ }^{44} \mathrm{O}$ Ácido 5 -aminolevulínico pode ser empregado como herbicida e na terapia fotodinâmica. ${ }^{45} \mathrm{~A} \gamma$-valerolactona, que é considerada como outro importante bloco de construção para a síntese orgânica, pode ser aplicada como aditivo alimentar e de combustível, bem como solvente. ${ }^{46}$ Os ésteres levulinatos são utilizados como um aditivo para o diesel e, novamente, como bloco de construção na síntese orgânica. ${ }^{47,48}$ Além dessas substâncias, obtêm-se ainda o ácido acetilacrílico, 1,4-pentanodiol, a-angélica lactona e ácido acrílico. ${ }^{49}$ Vide Figura 8 para verificar as substâncias citadas.

Figura 8- Obtenção de variados compostos a partir do AL

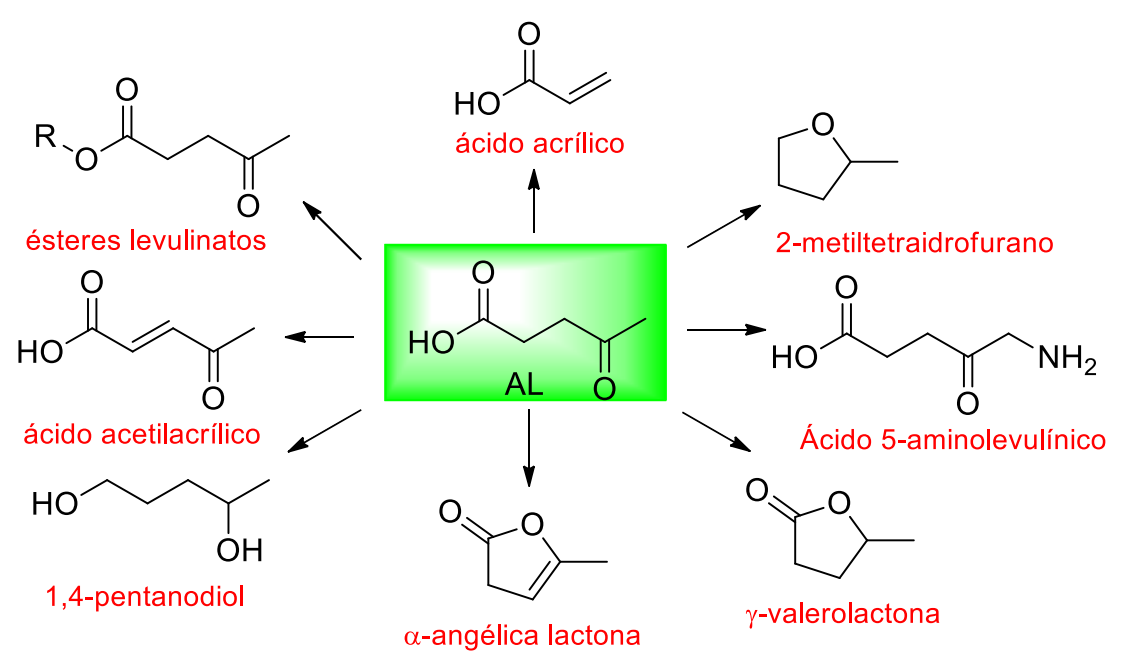

Dentre as plataformas moleculares geradas pelas transformações do $\mathbf{A L}$, os ésteres levulinatos ${ }^{46}$ e a $\alpha$-angélica lactona merecem destaque, pois apresentam uma ampla aplicabilidade. ${ }^{50}$

\subsection{2. Ésteres levulinatos}

Com relação aos ésteres do ácido levulínico, os levulinatos de alquila como, por exemplo, levulinato de etila ou metila, são produtos químicos com forte 
potencial para uso em diversas aplicações, substituindo os atuais produtos produzidos a partir de rotas petroquímicas. ${ }^{51}$

O método mais aplicado para formação dos levulinatos é a catálise ácida (homogênea ou heterogênea) na reação de esterificação do AL frente a diversos álcoois. Reações não catalisadas foram relatadas como uma forma possível de produzir os ésteres, mas de forma muito lenta, pois o processo é autocatalítico (envolvendo o próprio ácido carboxílico). Bankole et al.(2001) relataram a esterificação autocatalítica do ácido levulínico em levulinato de etila (ácido levulínico/etanol 1:1), a temperaturas de $25-250{ }^{\circ} \mathrm{C}$. A maior conversão foi alcançada à $250{ }^{\circ} \mathrm{C}$ após $60 \mathrm{~min}\left(60 \%\right.$ de rendimento) ${ }^{52}$ Catalisadores heterogêneos são, geralmente, os preferidos, pois podem ser facilmente separados da mistura reacional e reciclados. Além disso, dão maiores rendimentos. Os catalisadores de Brønsted são frequentemente usados, dentre eles, os ácidos heteropoliácidos (HPAs) e zeólitas. ${ }^{53}$

Não há relatos na literatura para o uso dos ésteres levulinatos como bloco de construção na síntese de moléculas complexas. Apenas existem estudos sobre seu uso para o preparo de lactamas $^{54}$, ciclopentadienos ${ }^{55,56}$ e, ainda, 1,4pentanodiol e a $\gamma$-valerolactona (GVL). As duas últimas também podem ser obtidas a partir do ácido levulínico, sendo a transformação mais interessante do ponto de vista econômico. ${ }^{57} \mathrm{Na}$ maioria dos trabalhos, o uso dos levulinatos é aplicado como biodiesel, uma vez que esses possuem propriedades físicas adequadas para servir como biocombustível. ${ }^{58} \mathrm{Na}$ figura 9, encontram-se algumas transformações para os levulinatos.

Figura 9- Aplicações para os ésteres levulinato

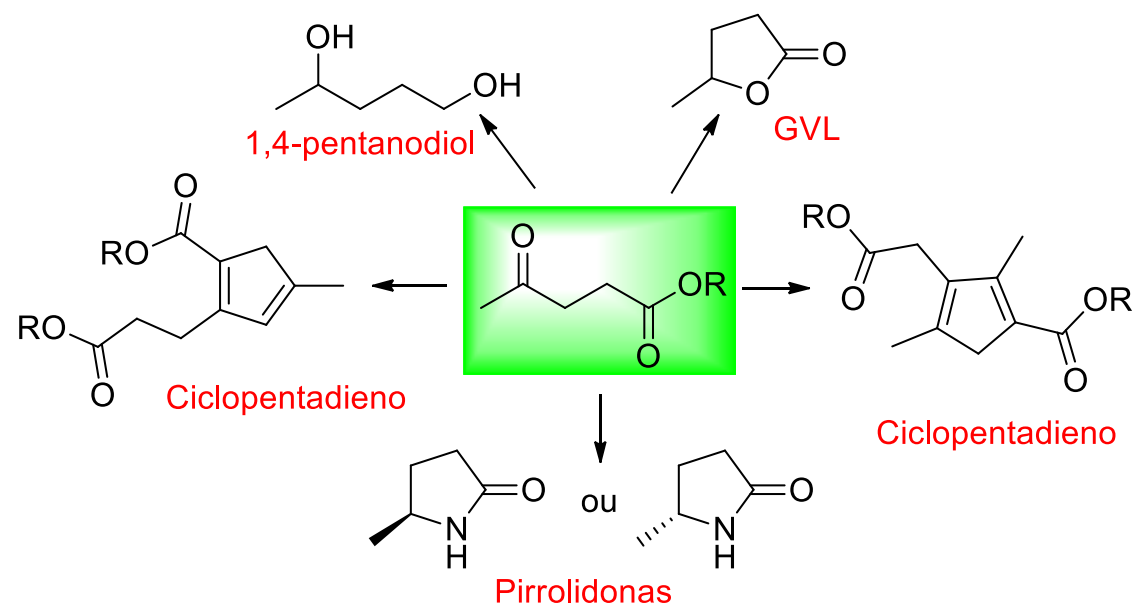




\subsubsection{Angélica lactona}

As angélicas lactonas ( $\alpha$-angélica lactona e $\beta$-angélica lactona) são classificadas como butenolidos que ocorrem naturalmente em algumas espécies de plantas, por exemplo, nas raízes de algumas espécies do gênero Angélica, pertencentes à família Apiaceae, cuja planta inspirou o nome da molécula. ${ }^{59} \mathrm{~A}$ presença das angélicas lactonas é relatada no tabaco, mas não se sabe se a ocorrência é natural ou proveniente da desidratação dos açúcares nas temperaturas usadas para curar o tabaco. ${ }^{60}$

A partir da biomassa, a $\alpha$-angélica lactona ( $\alpha-A L)$ é formada pela condensação intramolecular do ácido levulínico (AL). Em 1940, Helberger et al. divulgaram o preparo da $\boldsymbol{\alpha}-\mathbf{A L}$ via lactonização do $\mathbf{A L}$, catalisada pelo ácido fosfórico, com rendimento de 95\% (Esquema 1). A $\alpha$-AL pode ser isomerizada à $\boldsymbol{\beta}-\mathrm{AL}$, em condições básicas, mas uma vez que essa isomerização proporciona a formação de uma mistura em equilíbrio (que provavelmente apresenta um pequeno valor para a constante de equilíbrio), é muito difícil de fornecer um processo escalável que daria a $\boldsymbol{\beta}$-AL pura em bons rendimentos. Este problema é contornado, segundo descrito por Dell'Acqua et al. (2020), destilando a mistura ao atingir o equilíbrio. Assim, a $\boldsymbol{\beta}$-AL é retirada do meio reacional e mais moléculas da $\boldsymbol{\alpha}$-AL são convertidas em $\boldsymbol{\beta}-\mathbf{A L}$. ${ }^{61,62}$

Esquema 1- Obtenção das angélicas lactonas

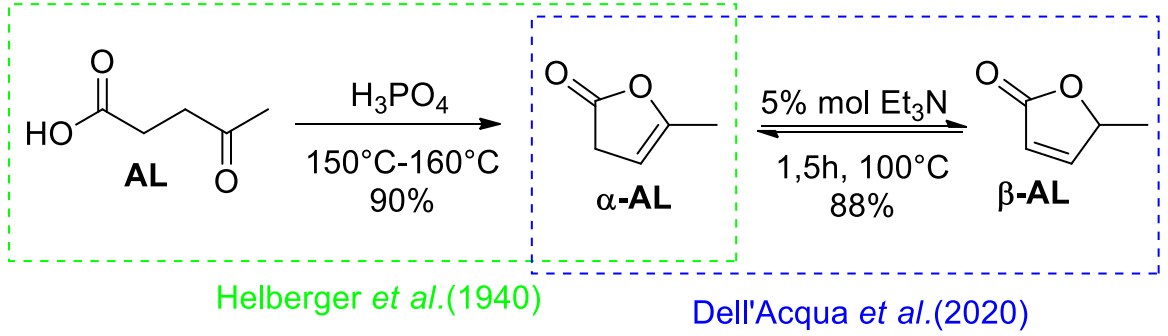

A isomerização enantiosseletiva da $\boldsymbol{\alpha}-\mathbf{A L}$ em $\boldsymbol{\beta}-\mathbf{A L}$ foi relatada via transferências de prótons catalisada pelo alcaloide cinchona (A). Utilizando uma carga de 10 mol\% do catalisador, em diclorometano à $-20^{\circ} \mathrm{C}$ por $60 \mathrm{~h}$, a $\mathbf{\alpha}-\mathbf{A L}$ foi isomerizada com rendimento de $63 \%$ e $92 \%$ de excesso enantiomérico. Os autores propuseram um ciclo catalítico que é iniciado pela formação da ligação de hidrogênio entre a $\boldsymbol{\alpha}-\mathbf{A L}$ e o catalisador (representado em B). A etapa 
determinante é a protonação para formar o intermediário $C$ (em equilíbrio com D) e, em seguida, a $\boldsymbol{\beta}$-AL enantiomericamente enriquecida é produzida (Esquema 2). ${ }^{63}$

Esquema 2- Reação de isomerização enantiosseletiva da $\alpha$-AL

$$
\prod_{0}=0 \quad \frac{10 \mathrm{~mol} \% \mathrm{cat}}{\mathrm{DCM},-20^{\circ} \mathrm{C}} \underset{0}{\longrightarrow}=0
$$

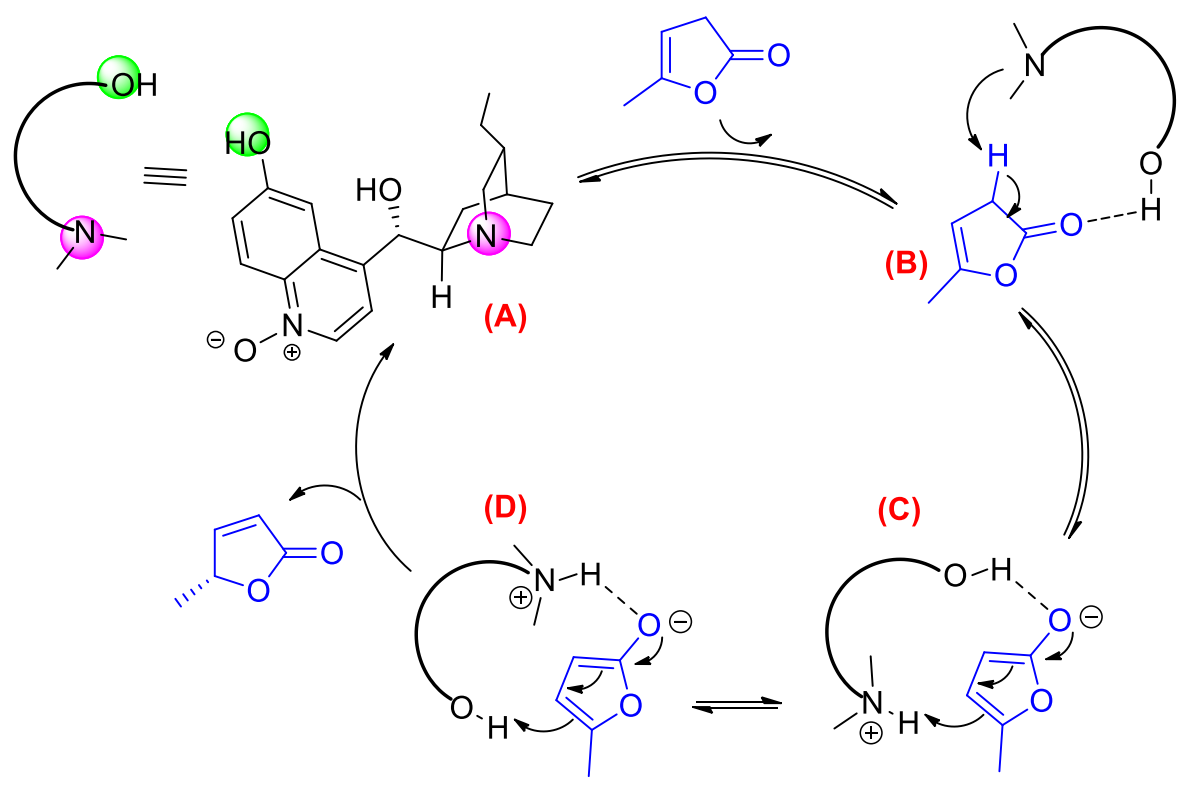

A busca por abordagens mais ecológicas, dedicadas ao desenvolvimento de catalisadores recuperáveis, para a conversão do ácido levulínico em a-AL é investigada devido às crescentes aplicações das angélicas lactonas. ${ }^{64}$ Mascal et al.(2014), por exemplo, relataram o uso do argilomineral montmorilonita, comercialmente disponível (K10) como catalisador para produção das lactonas. Nesse protocolo, empregou-se o uso de uma coluna de fracionamento, sob controle de vácuo $(50 \mathrm{mmHg}$ ), resultando em uma mistura de duas fases: água e produto, que podem ser facilmente separados. O produto é obtido com $92 \%$ de rendimento para mistura $\boldsymbol{\alpha}-\mathbf{A L}$ (majoritário) e $\boldsymbol{\beta}-\mathbf{A L}$ (minoritário). $\mathbf{O}$ catalisador pode ser reutilizado por três ciclos de reação sem perdas no rendimento. ${ }^{65}$

Além das abordagens de destilação, a lactonização em fase de vapor do ácido levulínico, para produzir as angélica lactonas ( $\alpha-\mathbf{A L}, \boldsymbol{\beta}-\mathbf{A L}, \boldsymbol{\gamma}-\mathbf{A L}$ ), foi relatada por Sato et al.(2016). Assim, realizou-se a transformação em reatores 
de vidro de fluxo descendente, à $275^{\circ} \mathrm{C}$ sob condições de pressão reduzida (5 $\mathrm{kPa})$, empregando catalisador do tipo sílica mesoporosa $\left(\mathrm{SiO}_{2}-\mathrm{Al}_{2} \mathrm{O}_{3}\right)$. O rendimento da reação foi alcançado em $87 \%$ contendo a mistura das lactonas. ${ }^{66}$

\subsubsection{Aplicações das angélicas lactonas}

As angélicas lactonas têm sido usadas como materiais de partida em diversas reações por décadas. Suas aplicações, como bloco de construção, variam desde o preparo de moléculas biologicamente ativas a substratos para construção de compostos de valor agregado como, por exemplo, alcanos líquidos. Foi reportado, por Mascal et al.(2014) ${ }^{65}$, uma reação de dimerização através da adição conjugada entre os isômeros $\alpha$ - e $\beta$-AL. A reação proporcionou a produção de um dímero (dímero $\mathbf{A L}$ ) e posterior conversão em uma mistura de hidrocarbonetos ramificados (Esquema 3). Para isso, a mistura das lactonas foi tratada $c 0 m \mathrm{~K}_{2} \mathrm{CO}_{3}$, à $70^{\circ} \mathrm{C}$, proporcionando a produção do dímero com $94 \%$ de rendimento. Em seguida, o dímero foi desoxigenado, usando um catalisador de irídio modificado com ReOx (suportado em sílica), formando os hidrocarbonetos ramificados. Produziu-se a mistura de hidrocarbonetos (C7-C10) com $76 \%$ de rendimento. A produção de hidrocarbonetos com diferentes tamanhos da cadeia carbônica (variando de C7C10) é altamente desejável, uma vez que esses podem ser empregados como combustíveis de avião. ${ }^{67}$

Esquema 3- Formação de hidrocarbonetos a partir das angélicas lactonas
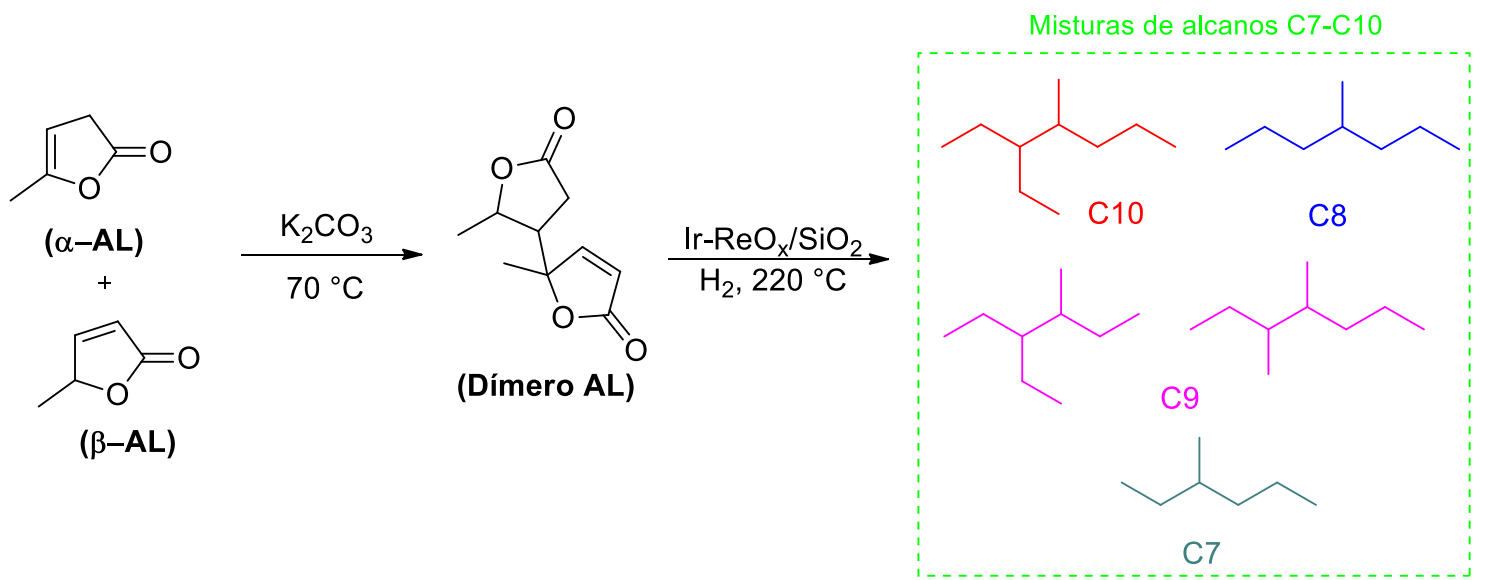
Um dos primeiros relatos do uso da $\boldsymbol{\alpha}-\mathbf{A L}$, como material de partida na síntese total de um produto natural, foi descrito na década de 70 por Ficini et al. (1971). Os autores descreveram o preparo da diidrojasmona e cis-jasmona em três etapas reacionais. $\mathrm{Na}$ primeira etapa, a $\boldsymbol{\alpha}-\mathbf{A L}$ reage frente à inamina ocorrendo a formação do aduto 1 que, em seguida, é hidrolisado fornecendo a dicetona. Por meio da condensação intramolecular de Dieckmann, a dicetona é convertida à diidrojasmona com $80 \%$ ou à cis-jasmona com $90 \%$ de rendimento (Esquema 4). ${ }^{68}$

Esquema 4- Síntese da cis-jasmona e diidrojasmoa a partir da AL

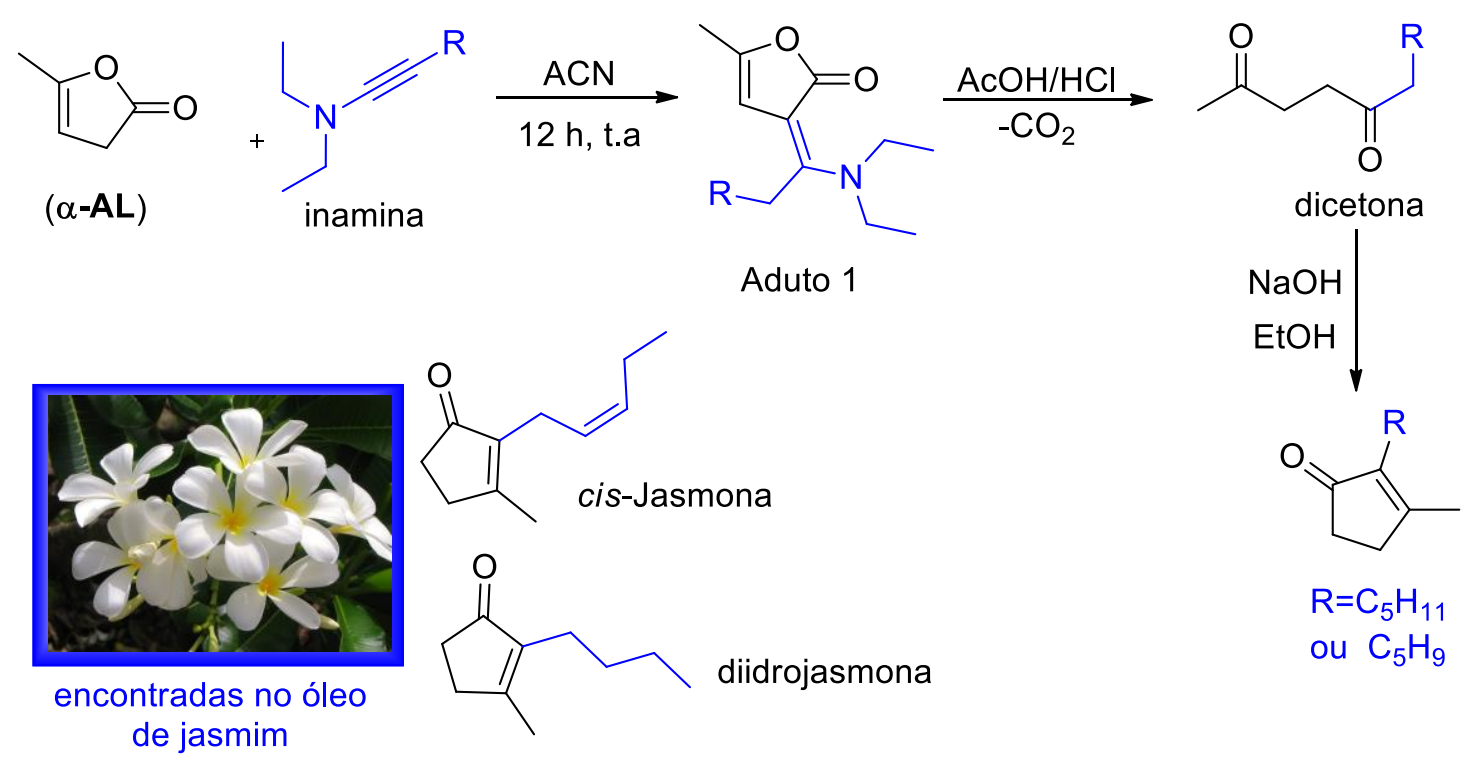

Já na década de 80, Cardellach et al.(1985) reportaram a síntese da mistura racêmica $( \pm)$-blastmicinona. A (+)-blastmicinona é um dos principais componentes do complexo antibiótico Antimicina A1, eficaz contra fungos. A rota sintética para a formação da mistura racêmica foi realizada em 5 etapas com $27 \%$ de rendimento (Esquema 5). A primeira etapa consiste na epoxidação da $\beta$-AL com hipoclorito de sódio, em piridina, fornecendo seletivamente o transepoxidolactona com $54 \%$ de rendimento. Em seguida, a abertura do anel oxirano foi realizada pela adição nucleofílica do íon iodeto e, após eliminação e hidrogenação, forneceu a hidroxilactona quantitativamente. Na quarta etapa, realizou-se a reação de alquilação da hidroxilactona, estereosseletivamente, 
frente ao iodeto de butila (butl). O produto alquilado foi acetilado, de forma sequencial, no qual forneceu a ( \pm )-blastmicinona com $51 \%$ de rendimento. ${ }^{69}$

Esquema 5- Uso da $\beta$-AL no preparo da ( \pm )-blastmicinona

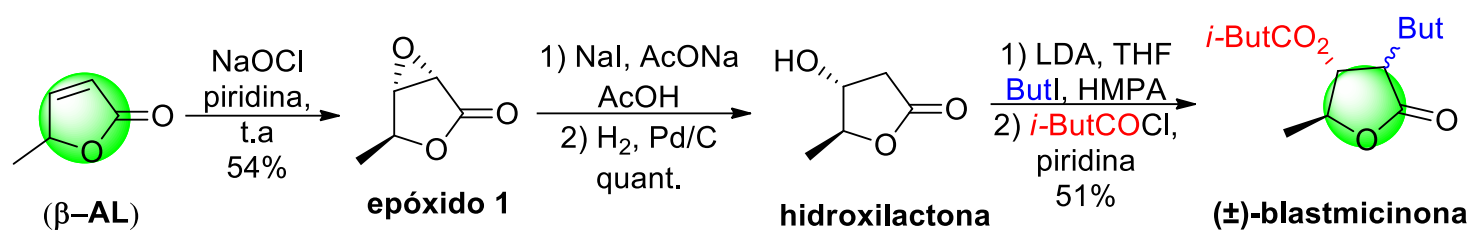

\subsubsection{Formação de pirrolidonas via aminação redutiva do $A L$}

Outra importante aplicação do ácido levulínico na síntese orgânica é como material de partida para produção de 5-metilpirrolidonas. Esta importante classe de compostos contém o núcleo pirrrolidona em diversas estruturas de fármacos, por exemplo, piracetam, aniracetam, pramiracetam, oxiracetam e levetiracetam (fármacos com efeitos nootrópico, neuroprotetor pós-traumático e ação antiepilética. ${ }^{70}$ (Esquema 6).

Esquema 6- Pirrolidonas com atividades farmacológicas

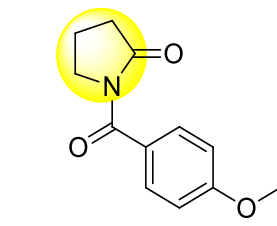

Aniracetam

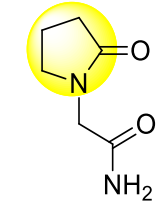

Piracetam

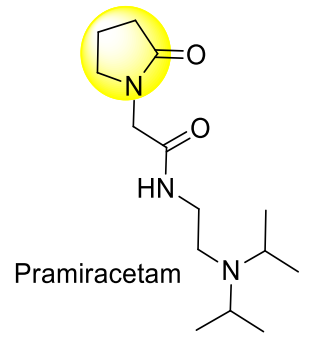

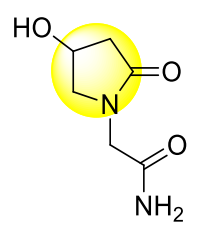

Oxiracetam

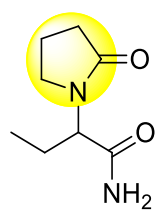

Levetiracetam

Fischmeister et al.(2018) desenvolveram um método para síntese de 5metilpirrolidonas partindo do ácido levulínico e de diversas aminas. A reação de aminação redutiva foi catalisada por um complexo de irídio e utilizou-se $\mathrm{H}_{2}$ como fonte de hidrogênio. Tal reação levou à formação dos produtos desejados com rendimentos entre 74-95\%, o que possibilitou a obtenção de um grande escopo de moléculas. ${ }^{71}$ (Esquema 7). 
Esquema 7- Formação de 5-metilpirrolidinona desenvolvida por Fischmeister et $a l^{71}$

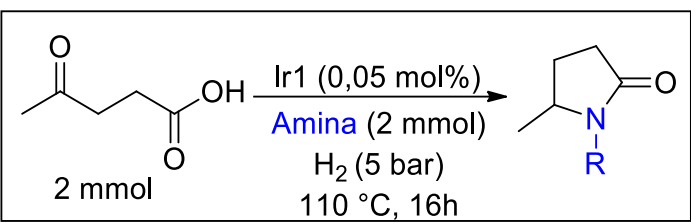

Exemplos do escopo

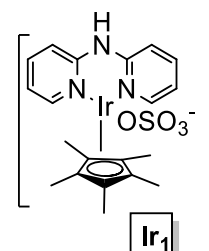

$I r_{1}$<smiles>CC1CCC(=O)N1c1ccccc1</smiles>

$90 \%$

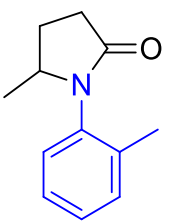

$74 \%$

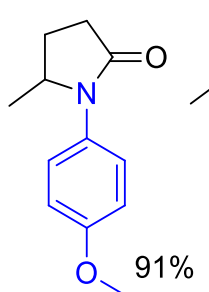

-91\%

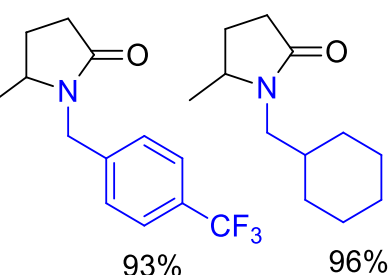

$93 \%$

$96 \%$

(N-anilina)

Outra interessante abordagem, relatada pelos autores, foi realizar a síntese da 5-metilpirrolidona ( $\mathrm{N}$-anilina) de forma sequencial a partir da glicose. Neste processo, a glicose foi hidrolisada, em meio ácido, levando a uma mistura de ácido levulínico, ácido fórmico e as huminas insolúveis, que foram removidas por filtração. A solução foi neutralizada, seguida pela adição de Ir1 e anilina. Ao final do processo foi possível isolar o produto desejado com $31 \%$ de rendimento (Esquema 8). ${ }^{71}$

Esquema 8- Síntese de pirrolidona a partir da glicose

Glicose

$2,5 \mathrm{mmol}$

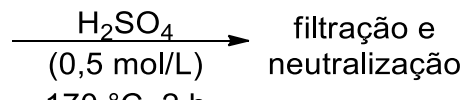
$170^{\circ} \mathrm{C}, 2 \mathrm{~h}$
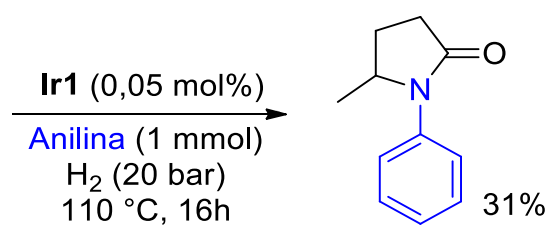

Já no trabalho descrito por Burtoloso et al.(2018), desenvolveu-se a síntese de várias pirrolidonas e a formação de um núcleo tetracíclico altamente complexo. Empregou-se um catalisador mais barato e abundante $\left(\mathrm{Fe}_{3}(\mathrm{CO})_{12}\right)$ e, como fonte de $\mathrm{H}_{2}$, solução aquosa de ácido fórmico (AF). Nesta abordagem, foi possível converter o AL nos produtos desejados com $40-91 \%$ de rendimento em uma única etapa (Esquema 9). ${ }^{72}$ 
Esquema 9- Formação de 5-metilpirrolidinona desenvolvida por Burtoloso et al. ${ }^{72}$

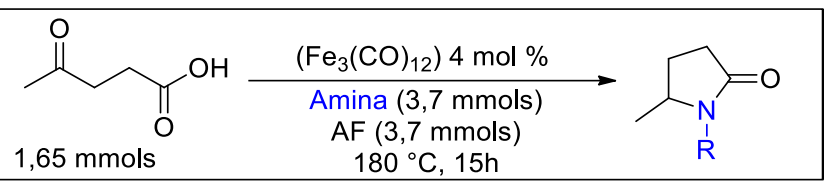

Exemplos do escopo

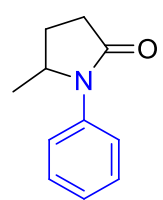

$40 \%$

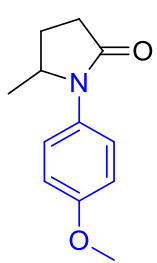

$60 \%$

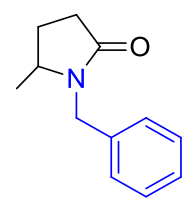

$87 \%$

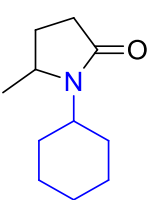

$91 \%$

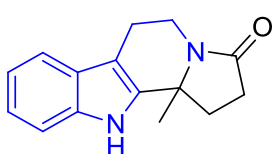

$52 \%$

Por mais que o uso de blocos de construção, oriundos da biomassa, temse mostrado promissor na síntese orgânica, o número de estudos voltados nessa área ainda é escasso. Pode-se mencionar a síntese total de substâncias relativamente complexas a partir do ácido levulínico e seus ésteres como, por exemplo, a obtenção de ciclopentadienos e seus derivados. Os produtos de alto valor agregado (como os citados) podem ser aplicados em diversos setores das indústrias químicas, farmacêuticas e, também, como materiais de partida nas reações de Diels-Alder. ${ }^{73}$

\subsubsection{Formação de ciclopentadienos}

Os métodos clássicos descritos na literatura para síntese de ciclopentadienos, na sua maioria, envolvem ciclos catalíticos complexos, utilizando metais e alquinos como materiais de partida. Por exemplo, no trabalho descrito por Gleiter et al.(2002), a síntese de ciclopentadienos 1,2,3trissubstituídos partindo de acetilenos dialquilados foi relatada. A reação é catalisada por $\mathrm{Co}_{2}(\mathrm{CO})_{8}$, via reação de Pauson-Khand, descrita como uma cicloadição $[2+2+1]$. Tal etapa levou à formação das ciclopentenonas que após tratamento com alquil-lítio, seguido por ácido, forneceram vários ciclopentadienos com diferentes substituintes R'. ${ }^{74}$ Esquema 10. 
Esquema 10- Síntese de vários ciclopentadienos realizada por Gleiter et al. ${ }^{74}$
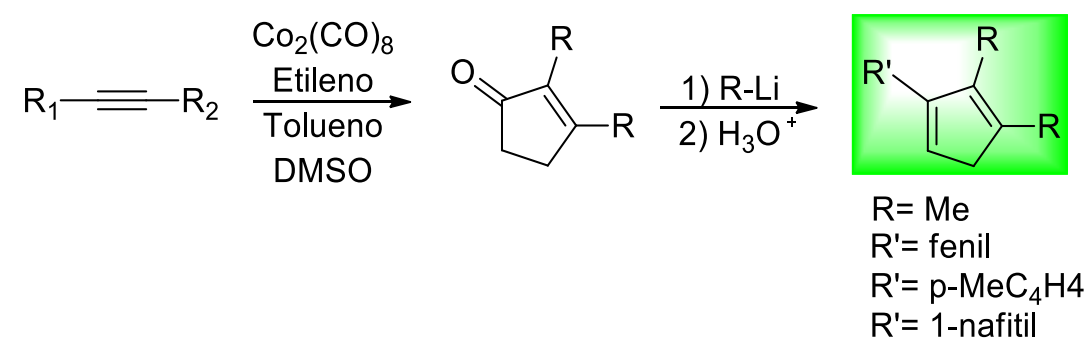

Kotora et al.(2016) reportaram um método, baseado em catalisadores de $\mathrm{Pd}$, via acoplamento cruzado entre alquilacetilenos, haletos alílicos e vinilmetais. Essa nova e curta abordagem (3 etapas), para produção de ciclopentadienos 1,2-substituídos, permitiu a obtenção de um amplo escopo com diferentes ciclopentadienos (isolados em rendimentos de 60-83\%). ${ }^{75}$ Esquema 11.

Esquema 11- Síntese de vários ciclopentadienos realizada por Kotora et $a .^{75}$

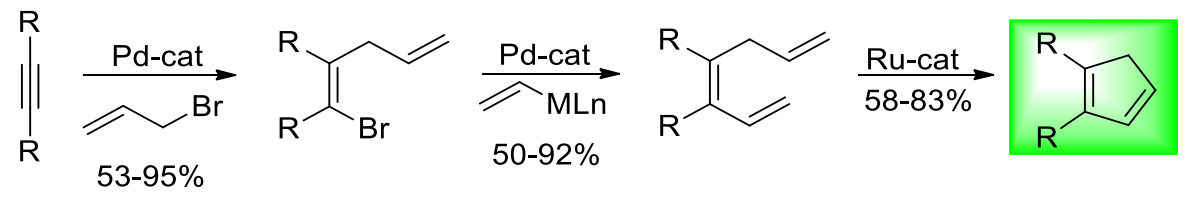

Trofimov et al.(2017) descreveram a síntese de ciclopentadienos, em duas etapas, a partir de acetileno gasoso e várias cetonas. A reação ocorre em meio básico originando o intermediário 2 e, após tratamento com ácido trifluoroacético $\left(\mathrm{CF}_{3} \mathrm{COOH}\right)$, fornece ciclopentadienos 1,2,3,4-tetrassubstituídos com rendimentos entre $50-94 \%$, a depender do grupo $\mathrm{R}$ como substituinte ${ }^{76}$ (Esquema 12).

Esquema 12- Síntese de vários ciclopentadienos realizada por Trofimov et al. ${ }^{76}$

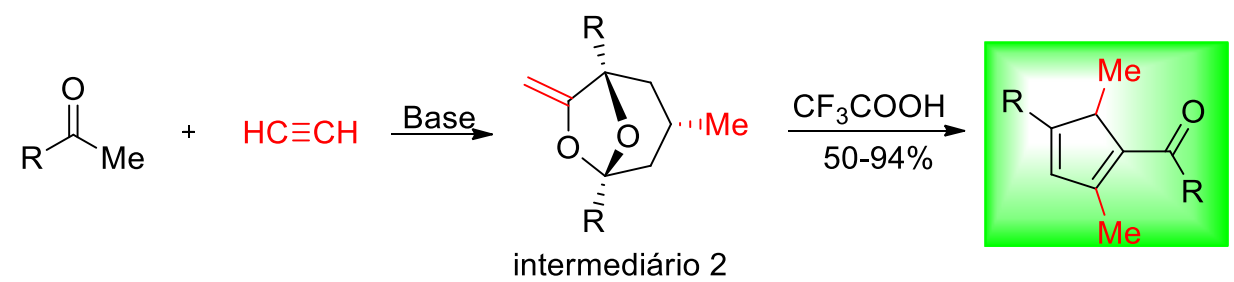


Em outra abordagem mais antiga, relatada por Ueda et al.(1990), um método conveniente para síntese de ciclopentadienos 1,2,3,4-tetrassubstituídos foi desenvolvido. O método foi descrito a partir da reação entre compostos alilideno-trifenilfosforanos e $\alpha$-halocarbonilados, via processo de substituição nucleofílica, seguido por uma reação intramolecular tipo Wittig. Em 12 horas de reação, os produtos foram obtidos com rendimentos entre 48-98\% (Esquema 13)..$^{77}$

Esquema 13- Síntese de vários ciclopentadienos realizada por Ueda et al.

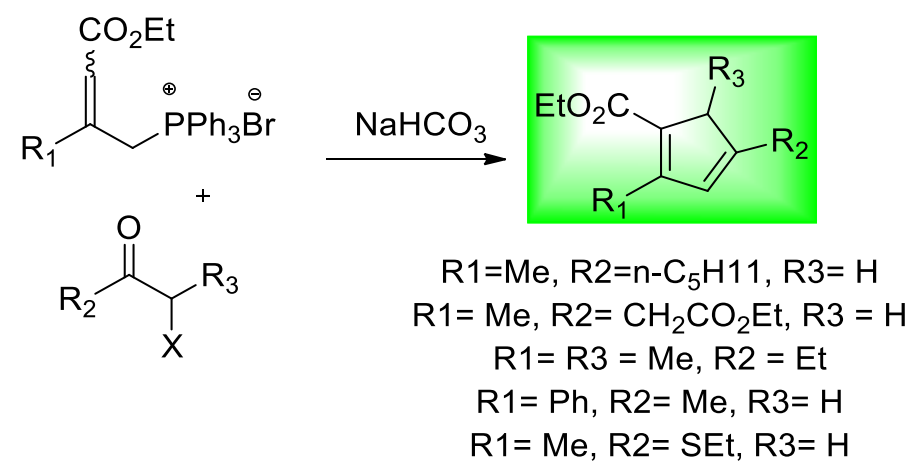

Apesar das metodologias mostradas acima apresentarem estratégias sintéticas interessantes, para a obtenção de ciclopentadienos com alto grau de substituição e com bons rendimentos, alguns métodos fazem uso de materiais de partida complexos e nenhum deles é obtido a partir de recursos renováveis.

Os ciclopentadienos são úteis não apenas como dieno em reações de Diels-Alder mas, também, como ligantes importantes para formação de complexos metálicos com ampla utilidade. Além disso, por meio da redução das ligações duplas dos ciclopentadienos é possível obter ciclopentanos, outra importante classe de compostos. ${ }^{78}$

Nesse sentido, o desenvolvimento de métodos simples e sustentáveis para a preparação de ciclopentadienos e seus derivados altamente substituídos é um dos desafios apresentados no presente capítulo. 


\section{OBJETIVOS}

\subsection{Objetivo geral}

Propõe-se no capítulo I deste trabalho utilizar o levulinato de etila, como bloco de construção, almejando à síntese de moléculas orgânicas com alto valor agregado.

\subsection{Objetivos específicos}

2.2.1. Investigar a reação de adição de Michael entre levulinato de etila e $\beta$ angélica lactona;

2.2.2. Estudar a reatividade, frente a bases e outros reagentes, dos carbonos $\alpha$ à carbonila do levulinato de etila;

2.2.3. Desenvolver rotas sintéticas de fontes renováveis para obtenção de diversos ciclopentadienos, ciclopentanos e derivados substituídos; 


\section{RESULTADOS E DISCUSSÕES}

A priori, o primeiro objetivo a ser realizado consistia na reação de Michael, seguida pela condensação de Dieckmann, entre o Levulinato de Etila (LE) e a $\beta$ angélica lactona ( $\boldsymbol{\beta}-\mathbf{A L})$. Tal reação levaria ao desenvolvimento sintético de diversos ciclopentanos que se iniciaria pela formação do intermediário 1 (Esquema 14).

Esquema 14- Representação para formação de diversos ciclopentanos<smiles>COC(=O)CCC(C)=O</smiles>

(LE)<smiles>C[C@H]1C=CC(=O)O1</smiles>

$(\beta-A L)$
1) Reação de Michael 2) Condensação de Dieckmann

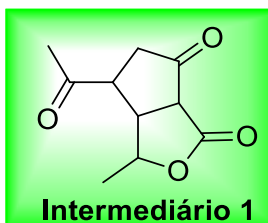

Intermediário 1<smiles>[R]C1CC([R4])C([R])C1[R]</smiles>

Diversos ciclopentanos

O intermediário 1 poderia ter 0 anel lactônico rompido e originar 0 ciclopentano tetrassubstituído A nas possíveis condições reacionais. Uma reação de oxidação, por sua vez, levaria ao composto B. O intermediário 1 poderia, ainda, ser utilizado para síntese de outros ciclopentanos (C-D) e de moléculas mais complexas (Esquema 15).

Esquema 15- Síntese de diversos ciclopentanos

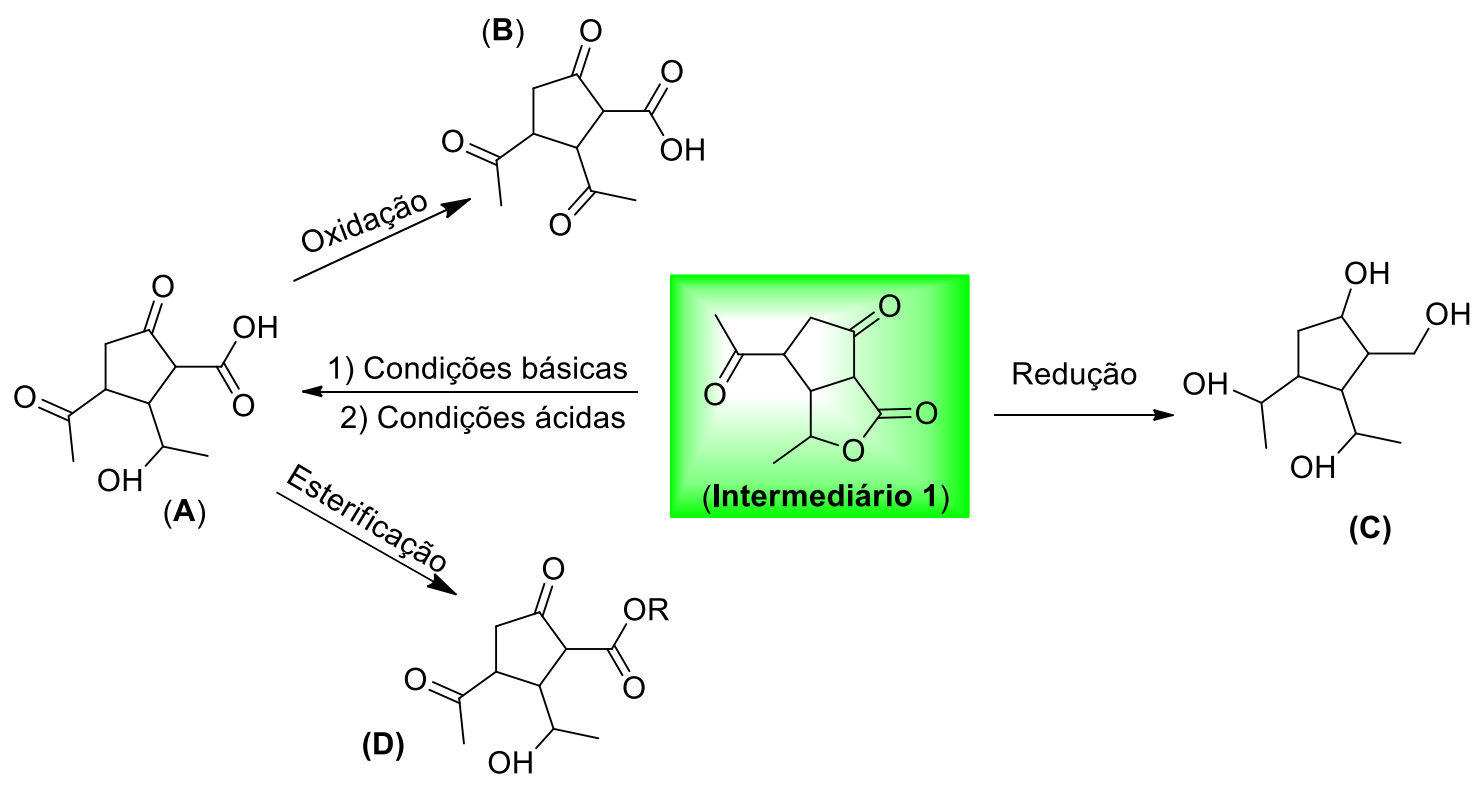




\subsection{Reação de adição de Michael entre levulinato de etila e $\beta$-angélica lactona}

Os estudos foram iniciados com a reação de adição de Michael entre $\beta$ angélica lactona ( $\boldsymbol{\beta}-\mathbf{A L})$ e levulinato de etila (LE). Para tanto, foi necessário realizar uma reação de isomerização da $\alpha$-angélica lactona para $\beta$-angélica lactona, já que esta última não é disponível comercialmente (Esquema 16).

Esquema 16- Reação de isomerização da $\alpha$-angélica lactona ( $\alpha-A L)$

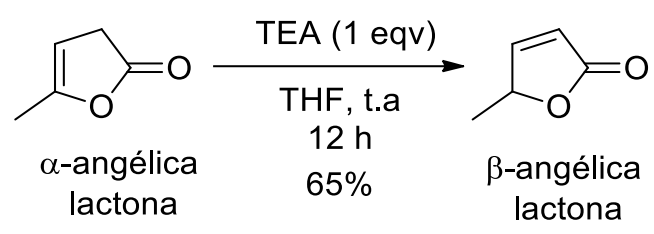

Com a $\boldsymbol{\beta}$-AL preparada, realizaram-se estudos para escolher as condições experimentais adequadas que ocorreria a reação de adição de Michael. A princípio, escolheu-se a base $t$-butóxido de potássio ( $t$-BuOK) para iniciar a exploração (tabela 1). Na entrada 1, empregou-se quantidade equimolar da base e a reação foi realizada em temperatura ambiente $\left(25^{\circ} \mathrm{C}\right)$, porém não foi observado o consumo do material de partida após 24 horas de reação. Ao aumentar a quantidade da base para 2 equivalentes não se observou reações frente ao LE e $\boldsymbol{\beta}$-AL (entrada 2). Na entrada 3, a temperatura da reação foi aumentada para $50^{\circ} \mathrm{C}$, mas não foi observado o consumo do material de partida, novamente.

Para favorecer ainda mais as condições termodinâmicas (formação do enolato mais estável em relação à cetona), utilizou-se uma base menos volumosa (etóxido de sódio) em proporções equimolares ou em excesso. Nessas condições reacionais, (entradas 4 e 5) o LE e a $\boldsymbol{\beta}$-AL também se mantiveram inconsumíveis.

O último teste realizado, dessa abordagem, foi a utilização da base forte e volumosa, hexametildisililazida de lítio (LiHMDS), em condições cinéticas. Ao levar a reação de $-78{ }^{\circ} \mathrm{C}$ para $25^{\circ} \mathrm{C}$, por 5 ou 24 horas, observou-se a formação de uma mistura complexa e a recuperação parcial do material de partida (entradas 6 e 7 ). 
Tabela 1- Condições experimentais para formação do intermediário 1

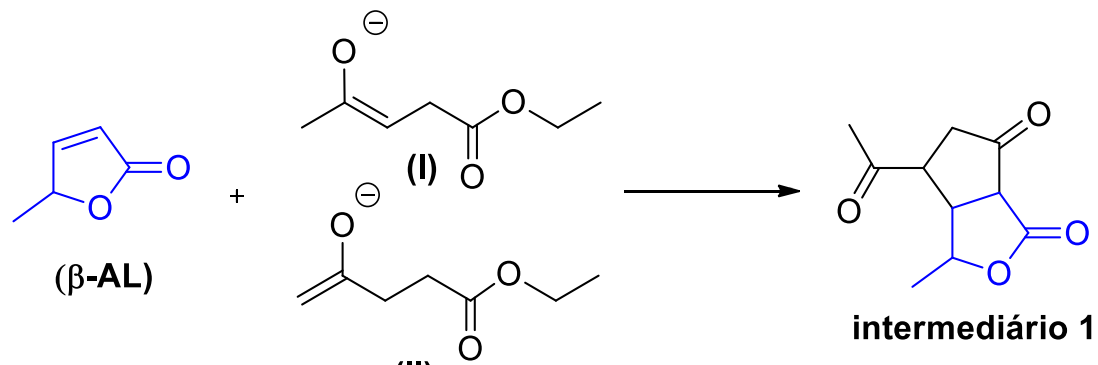

(II)

\begin{tabular}{|c|c|c|c|c|c|c|c|}
\hline Entradas & $\begin{array}{l}\beta-A L \\
\text { (eqv) }\end{array}$ & $\begin{array}{l}\text { LE } \\
\text { (eqv) }\end{array}$ & $\begin{array}{l}\text { Base } \\
\text { (eqv) }\end{array}$ & $\begin{array}{c}\text { Solventes } \\
\text { [mol/L] }\end{array}$ & $\begin{array}{c}\mathrm{t} \\
\text { (horas) }\end{array}$ & $\begin{array}{c}\mathrm{T} \\
\left({ }^{\circ} \mathrm{C}\right)\end{array}$ & (\%) \\
\hline 1 & 1,0 & 1,0 & $\begin{array}{c}t \text {-BuOK } \\
(1,0)\end{array}$ & $\begin{array}{l}\text { THF } \\
{[0,1]}\end{array}$ & 24 & ta & -- \\
\hline 2 & 1,0 & 1,0 & $\begin{array}{c}t \text {-BuOK } \\
(2,0)\end{array}$ & $\begin{array}{l}\text { THF } \\
{[0,1]}\end{array}$ & 24 & ta & -- \\
\hline 3 & 1,0 & 1,0 & $\begin{array}{c}t \text {-BuOK } \\
(1,0)\end{array}$ & $\begin{array}{l}\text { THF } \\
{[0,1]}\end{array}$ & 24 & 50 & -- \\
\hline 4 & 1,0 & 1,0 & $\begin{array}{c}\text { EtONa } \\
(1,0)\end{array}$ & $\begin{array}{c}\mathrm{EtOH} \\
{[0,1]}\end{array}$ & 24 & 50 & -- \\
\hline 5 & 1,0 & 1,0 & $\begin{array}{c}\text { EtONa } \\
(2,0)\end{array}$ & $\begin{array}{c}\mathrm{EtOH} \\
{[0,1]}\end{array}$ & 24 & 50 & -- \\
\hline 6 & 1,0 & 1,0 & $\begin{array}{c}\text { LiHMDS } \\
(1,1)\end{array}$ & $\begin{array}{l}\text { THF } \\
{[0,5]}\end{array}$ & 5 & ta & m.c \\
\hline 7 & 1,0 & 1,0 & $\begin{array}{c}\text { LiHMDS } \\
\quad(1,1)\end{array}$ & $\begin{array}{l}\text { THF } \\
{[0,5]}\end{array}$ & 24 & ta & m.c \\
\hline
\end{tabular}

Legenda: tert-Butóxido de Potássio ( $t$-BuOK); etóxido de sódio (EtONa); hexametildisililazida de lítio (LiHMDS); tedrahidrofurano (THF); etanol (EtOH); temperatura ambiente (t.a); mistura complexa (m.c)

Analisando a reação do ponto de vista mecanístico, a mesma seria desencadeada pela formação dos enolatos I (termodinâmico) e II (cinético) (figura 10). O enolato I é o mais estável, pois é gerado pela abstração do hidrogênio alfa à carbonila mais substituído e seria formado majoritariamente. Após essa etapa, o enolato adicionar-se-ia ao carbono $\beta$ da $\beta$-AL (adição de Michael 1,4) e, em seguida, ocorreria a condensação intramolecular de Dieckmann, fornecendo o intermediário 1 (Vide figura 10 com proposta mecanística). 
Figura 10- Proposta mecanística para formação do intermediário 1

Pka 19-20<smiles>[B]CC=C(CC(=O)OCC)C(C)=O</smiles>

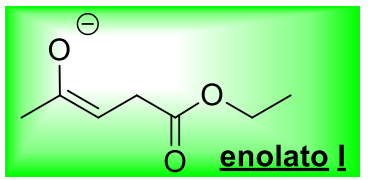

Enolato mais estável<smiles>[B]C[CH]CCCC(=O)OCC[B]C</smiles>

Pka 23-25

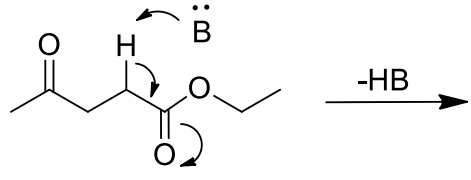<smiles>CCO/C([O-])=C/CC(C)=O</smiles><smiles>CCOC(=O)CC(CC)=C(C)[O-]</smiles>

\section{(Adição de Michael)} meio básico<smiles>CCOC(=O)CC(C(C)=O)C1C2CC1C1(C)OC(CC)(C2)O1</smiles>

meio básico

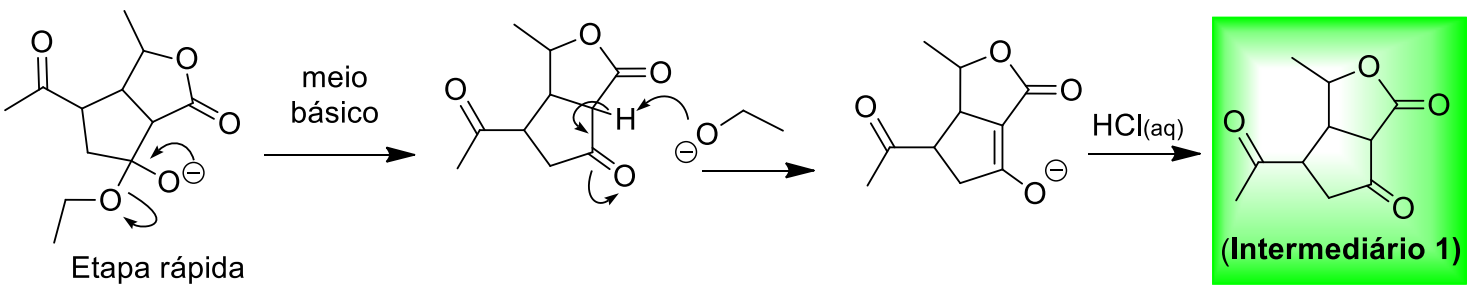

As condições experimentais testadas, na tabela 1, não resultaram na formação de nenhum produto almejado, visto que o LE se mante inconsumível frente a maioria das bases testadas. Apenas foi observado o consumo de uma pequena quantidade do LE quando se utilizou LiHMDS como base. Sendo assim, para não haver gastos desnecessários do material de partida $\boldsymbol{\beta}-\mathbf{A L}$ (que não é obtida comercialmente), optou-se por investigar novas abordagens objetivando conhecer a reatividade dos hidrogênios e carbonos alfa à carbonila do LE.

A primeira abordagem trata-se de uma reação de alquilação com diferentes haletos de alquila. Já a segunda, trata-se da formação de silil-enol éteres. Estas estratégias serão detalhadas nos tópicos seguintes. 


\subsection{Reatividade dos hidrogênios e carbonos alfa à carbonila do levulinato de etila}

Considerando que o valor de pKa de um $\mathrm{H}$-alfa à carbonila é 20, conhecer a reatividade destes hidrogênios na molécula do LE é um ponto crucial para o desenvolvimento do primeiro objetivo. Nesta abordagem, a reação de alquilação foi empregada para trapear os enolatos formados (mais substituído e menos substituído) frente a agentes alquilantes. Caso a reação de alquilação fosse bem-sucedida, levaria a estratégia de uma reação de adição de Michael à $\beta$-AL via enolato. Assim, iria possibilitar a obtenção do intermediário 1, conforme já mostrado nos experimentos do tópico anterior. São apresentadas as condições experimentais na tabela 2.

Ao iniciar os estudos com a base $t$-BuOK e $o$ agente alquilante iodeto de etila, o LE não foi consumido em temperatura ambiente ou à $60^{\circ} \mathrm{C}$ (entradas 1 e 2). Nas entradas 3 e 4 , foi utilizado um haleto de alquila mais reativo (lodeto de alila), porém não foi observado a formação de nenhum produto. Na entrada 5 foi dobrada a quantidade da base, mesmo assim não se observou o consumo do LE. Trocamos, novamente, o haleto de alquila para brometo de alila e modificamos a base para etoxido de sódio (entrada 7). Nessas condições, houve a formação de $15 \%$ do produto de transesterificação com o grupo alil e a recuperação do material de partida. Tal reação deve ter ocorrido, provavelmente, pela existência de água no meio reacional que ocasionou a transformação do brometo de alila em álcool alílico, desencadeando a reação de transesterificação. $\mathrm{Na}$ entrada 8 , aumentou-se a escala da reação para melhor manipular os reagentes em condições anidras utilizando LDA como base. Houve o consumo total do LE nesse experimento, contudo os produtos formados foram apresentados como uma mistura complexa. Como LDA é uma base extremamente forte, O LE foi totalmente consumido. Entretanto, o enolato formado deve ter desencadeado, além da reação de alquilação, uma série de reações de condensação aldólica intermolecular ou intramolecular, levando a formação de uma mistura complexa. 
Tabela 2- Condições experimentais para reação de alquilação do LE

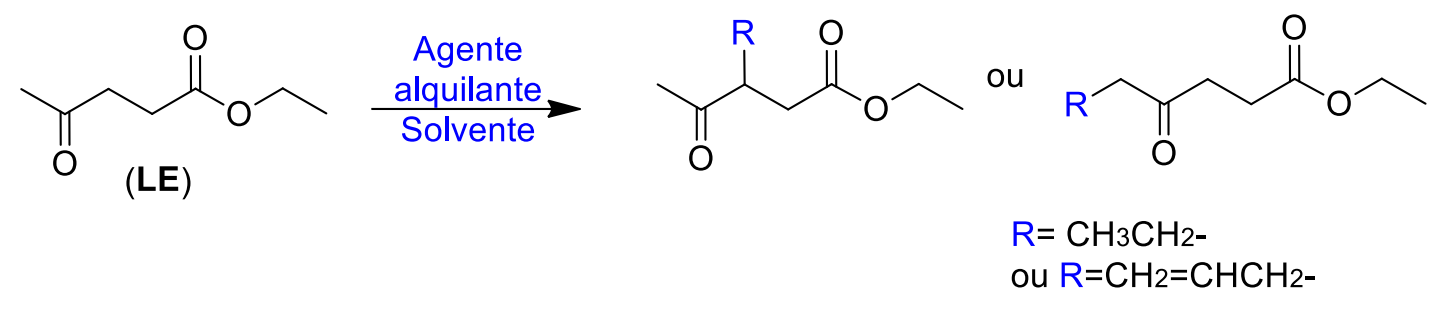

\begin{tabular}{|c|c|c|c|c|c|c|c|}
\hline Entradas & $\begin{array}{c}\text { Haleto } \\
\text { (eqv) }\end{array}$ & $\begin{array}{l}\text { LE } \\
\text { (eqv) }\end{array}$ & $\begin{array}{c}\text { Base } \\
\text { (mmol) }\end{array}$ & $\begin{array}{l}\text { Solvente } \\
\text { [mol/L] }\end{array}$ & $\begin{array}{c}\mathbf{t} \\
\text { (horas) }\end{array}$ & $\begin{array}{c}\mathrm{T} \\
\left({ }^{\circ} \mathrm{C}\right)\end{array}$ & (\%) \\
\hline 1 & $\underset{(1,0)}{\mathrm{IE}}$ & 1,0 & $\begin{array}{c}t \text {-BuOK } \\
(1,0)\end{array}$ & $\begin{array}{l}\text { THF } \\
{[0,1]}\end{array}$ & 24 & ta & --- \\
\hline 2 & $\begin{array}{c}\mathrm{IE} \\
(1,0)\end{array}$ & 1,0 & $\begin{array}{c}t \text {-BuOK } \\
(1,0)\end{array}$ & $\begin{array}{l}\text { THF } \\
{[0,1]}\end{array}$ & 24 & 60 & --- \\
\hline 3 & $\begin{array}{c}\text { IA } \\
(1,1)\end{array}$ & 0,9 & $\begin{array}{c}t \text {-BuOK } \\
(1,1)\end{array}$ & $\begin{array}{c}\text { THF } \\
{[0,09]}\end{array}$ & 24 & ta & --- \\
\hline 4 & $\begin{array}{c}\text { IA } \\
(1,1)\end{array}$ & 0,9 & $\begin{array}{c}t \text {-BuOK } \\
(1,1)\end{array}$ & $\begin{array}{c}\text { THF } \\
{[0,09]}\end{array}$ & 24 & 60 & --- \\
\hline 5 & $\begin{array}{c}\text { IA } \\
(1,1)\end{array}$ & 0,9 & $\begin{array}{c}t \text {-BuOK } \\
(2,2)\end{array}$ & $\begin{array}{c}\text { THF } \\
{[0,09]}\end{array}$ & 24 & 60 & --- \\
\hline 6 & $\begin{array}{c}\text { BA } \\
(1,1)\end{array}$ & 0,9 & $\begin{array}{c}t \text {-BuOK } \\
(1,1)\end{array}$ & $\begin{array}{c}\text { THF } \\
{[0,09]}\end{array}$ & 24 & ta & --- \\
\hline 7 & $\begin{array}{c}\text { BA } \\
(1,0)\end{array}$ & 1,0 & $\begin{array}{c}\text { EtONa } \\
(2,0)\end{array}$ & $\begin{array}{c}\text { EtOH } \\
{[0,1]}\end{array}$ & 24 & 60 & --- \\
\hline 8 & $\begin{array}{l}\text { BA } \\
\text { (3) }\end{array}$ & 1,0 & $\begin{array}{l}\text { LDA } \\
(1,2)\end{array}$ & $\begin{array}{l}\text { THF } \\
{[0,5]}\end{array}$ & $30 \mathrm{~min}$ & ta & m.c \\
\hline
\end{tabular}

Legenda: Iodeto de etila (IE); Brometo de alila (BA); Iodeto de alila (IA); Diisopropilamideto de lítio; mistura complexa (m.c).

Não tendo êxito nesta abordagem, seguimos para a segunda estratégia: formação de silil-enol éteres a partir do LE. Esta estratégia é similar a apresentada anteriormente, na qual os silil-enol éteres formados poderiam ser utilizados como nucleófilos na reação de adição de Michael à $\beta-A L$.

Neste estudo, o tratamento do LE com os agentes sililantes cloreto de $t$ butildimetilsilano (TBS-Cl) ou cloreto de trimetilsilano (TMS-Cl) não levou a obtenção dos produtos desejados em nenhuma das condições apresentadas na tabela 3. Mesmo quando utilizada temperatura alta na presença de base mais forte e não nucleofílica como, por exemplo, DBU (entrada 4), o material de partida foi recuperando em todos os experimentos. 
Tabela 3- Condições experimentais para formação dos silil-enol éteres

\begin{tabular}{|c|c|c|c|c|c|c|c|}
\hline Entradas & (eqv) & $\begin{array}{c}\text { LE } \\
(\text { eqv) }\end{array}$ & $\begin{array}{l}\text { Base } \\
\text { (eqv) }\end{array}$ & $\begin{array}{c}\text { Solventes } \\
{[\mathrm{mol} / \mathrm{L}]}\end{array}$ & $\begin{array}{c}\text { t } \\
\text { (horas) }\end{array}$ & $\mathrm{T}\left({ }^{\circ} \mathrm{C}\right)$ & (\%) \\
\hline 1 & $\begin{array}{c}\text { TBS-CI } \\
(1,1)\end{array}$ & 1,0 & $\begin{array}{l}\text { TEA } \\
(1,0)\end{array}$ & $\begin{array}{l}\text { THF } \\
{[0,1]}\end{array}$ & 12 & 65 & --- \\
\hline 2 & $\begin{array}{c}\text { TBS-CI } \\
(1,1)\end{array}$ & 1,0 & $\begin{array}{c}\text { DIPEA } \\
(1.0)\end{array}$ & $\begin{array}{l}\text { THF } \\
{[0,1]}\end{array}$ & 24 & 65 & --- \\
\hline 3 & $\begin{array}{c}\text { TMS-Cl } \\
(1,1)\end{array}$ & 1,0 & $\begin{array}{l}\text { TEA } \\
(1,0)\end{array}$ & $\begin{array}{l}\text { THF } \\
{[0,1]}\end{array}$ & 24 & 65 & --- \\
\hline 4 & $\begin{array}{c}\text { TBS-Cl } \\
(1,1)\end{array}$ & 1,0 & $\begin{array}{l}\text { DBU } \\
(1,0)\end{array}$ & $\begin{array}{c}\text { tolueno } \\
{[0,1]}\end{array}$ & 24 & 100 & --- \\
\hline
\end{tabular}

Como as três abordagens citadas anteriormente não lograram êxito, a estratégia restante seria a formação de enaminas. As enaminas formadas poderiam atuar como nucleófilos na reação de adição de Michael à $\boldsymbol{\beta}$-AL (levando à formação do intermediário desejado). Para tanto, reações de alquilação a partir das enaminas foram exploradas frente aos haletos: bromoacetato de metila (BAM) e brometo de alila (BA). Em tal estudo, haveria a possibilidade para formação de duas possíveis enaminas que, ao serem tratadas com os brometos de alquila, levariam aos produtos de alquilação.

Na primeira tentativa, com o objetivo de trapear as enaminas formadas na primeira etapa da reação, foi utilizado brometo de alila como agente alquilante. Neste experimento, após o tempo reacional de 6 ou 12 horas, adicionou-se $\mathrm{K}_{2} \mathrm{CO}_{3}$ para neutralizar o ácido $p$-toluenosulfônico $(p-\mathrm{TsOH})$ e, em seguida, filtrou-se a solução e o tolueno foi removido do meio reacional. Depois desta etapa, adicionou-se o haleto $(5,5 \mathrm{mmol})$, o solvente acetonitrila $(\mathrm{ACN}, 8 \mathrm{~mL})$ e deixou-se a mistura reagir por 15 horas (entradas 1 e 2, tabela 4). No entanto, após o período de 15 horas, não foi obtido a formação dos produtos de alquilação. Sendo assim, optou-se por investigar se de fato a enamina havia sido formada. Para tanto, realizou-se um experimento com as condições 
apresentadas na entrada 3 , sem a adição do brometo de alquila, sendo o LE consumido praticamente na íntegra após 6 horas de reação.

Tabela 4- Condições experimentais para reações de alquilação a partir das enaminas

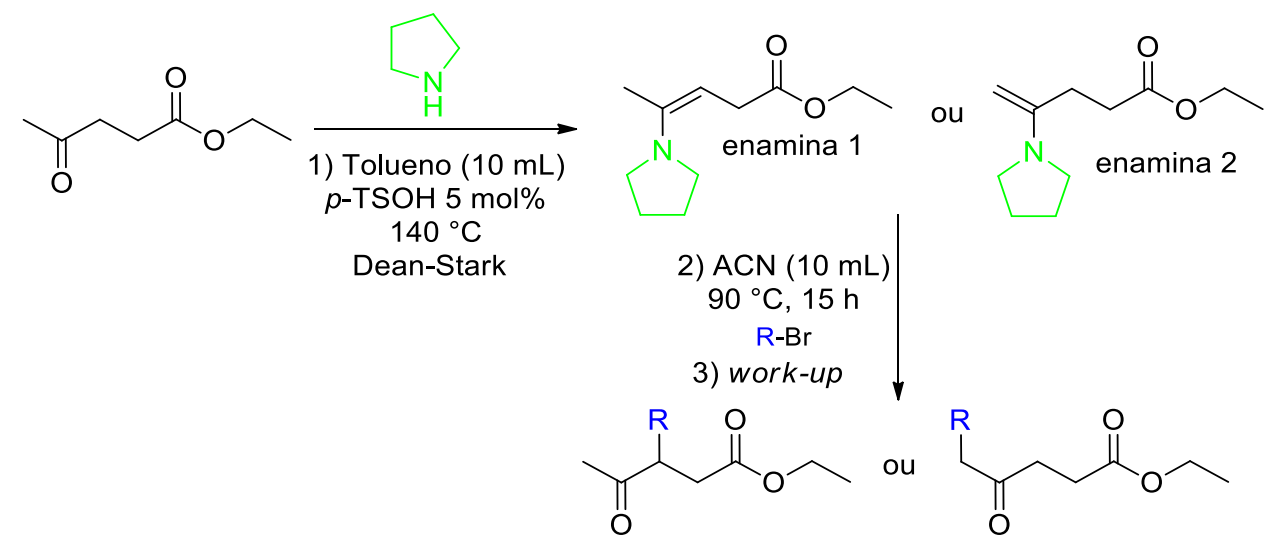

\begin{tabular}{|c|c|c|c|c|c|c|}
\hline Entradas & $\begin{array}{l}\text { Pirrolidina } \\
\quad \text { (eqv) }\end{array}$ & $\begin{array}{c}\text { LE } \\
\text { (eqv) }\end{array}$ & t (horas) & $\mathrm{T}\left({ }^{0} \mathrm{C}\right)$ & $\begin{array}{c}\text { Haletos } \\
\text { (eqv) }\end{array}$ & $(\%)$ \\
\hline 1 & 1,1 & 1,0 & $6 \rightarrow 15$ & $140 \rightarrow 90$ & $\mathrm{BA}(1,1)$ & n.o \\
\hline 2 & 1,1 & 1,0 & $12 \rightarrow 15$ & $140 \rightarrow 90$ & $\operatorname{BAM}(1,1)$ & n.o \\
\hline 3 & 1,1 & 1,0 & 6 & 140 & ----- & n.o \\
\hline
\end{tabular}

Todavia, ao término da reação e após a análise dos dados espectroscópicos de $\mathrm{RMN}$ de ${ }^{1} \mathrm{H}$, notou-se que a enamina não havia sido formada, estando ausentes os valores de deslocamentos químicos em aproximadamente: 4,54, 3,95 e 3,85 ppm nas formas de tripleto e dubletos, respectivamente. Tais sinais são típicos dos hidrogênios da dupla ligação das enaminas (vide figura 11).

Figura 11- Valores de deslocamentos químicos esperados para formação das enaminas

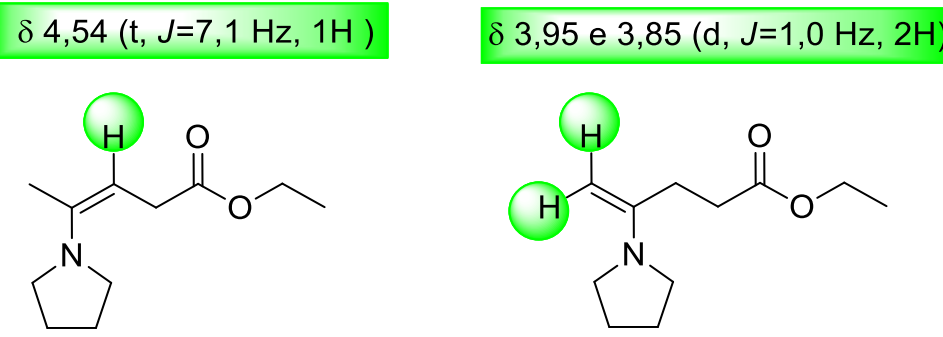


Após uma análise detalhada do espectro de $\mathrm{RMN}$ de ${ }^{1} \mathrm{H}$, concluiu-se que os produtos formados foram gerados pela autocondensação entre duas moléculas de LE. Tais produtos, foram obtidos como os isômeros $E(\mathbf{1 a}), Z(\mathbf{1 b})$, 2a e 2b (sendo os dois primeiros majoritários). Como esses isômeros apresentam fator de retenção próximos, não foi possível a separação dos mesmos por cromatografia em coluna de baixa eficiência.

Os sinais cruciais para caracterização dos isômeros 1a e 1b (Figura 12) foram atribuídos em $\delta 6,09(\mathrm{~m}, 0,4 \mathrm{H})$ e 6,05 $(\mathrm{m}, 0,6 \mathrm{H})$, referentes aos hidrogênios das ligações duplas. Dois dubletos em $\delta 2,10\left(\mathrm{~d}, \mathrm{~J}=1,2 \mathrm{~Hz},-\mathrm{CH}_{3}\right)$ e 1,88 (d, $J=$ $1,4 \mathrm{~Hz},-\mathbf{C H}_{3}$ ) atribuídos para as metilas ligadas aos carbonos $\mathrm{sp}^{2}$. Na figura 13, encontra-se o espectro de RMN de ${ }^{1} \mathrm{H}$. Os compostos $\mathbf{2} \mathbf{a}$ e $\mathbf{2} \mathbf{b}$ serão discutidos mais adiante.

Figura 12- Alguns valores de deslocamentos químicos para 1a e 1b

$$
2,10(d, J=1,2 \mathrm{~Hz})
$$<smiles>CCOC(=O)CCC(=O)c1ccccc1CCC(=O)OCC</smiles>

(1a) $\quad 6,05(\mathrm{~m}, 0,4 \mathrm{H})$

\section{$1,88(\mathrm{~d}, J=1,4 \mathrm{~Hz})$}

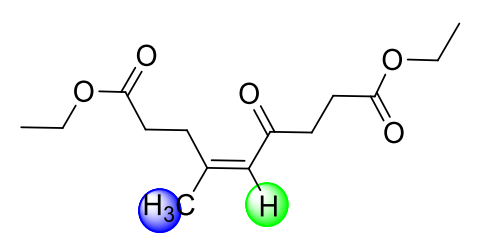

(1b) $6,09(\mathrm{~m}, 0,6 \mathrm{H})$

Figura 13- Espectro de RMN de ${ }^{1} \mathrm{H}$ contendo os compostos $\mathbf{1 a}$ e $\mathbf{1 b}$

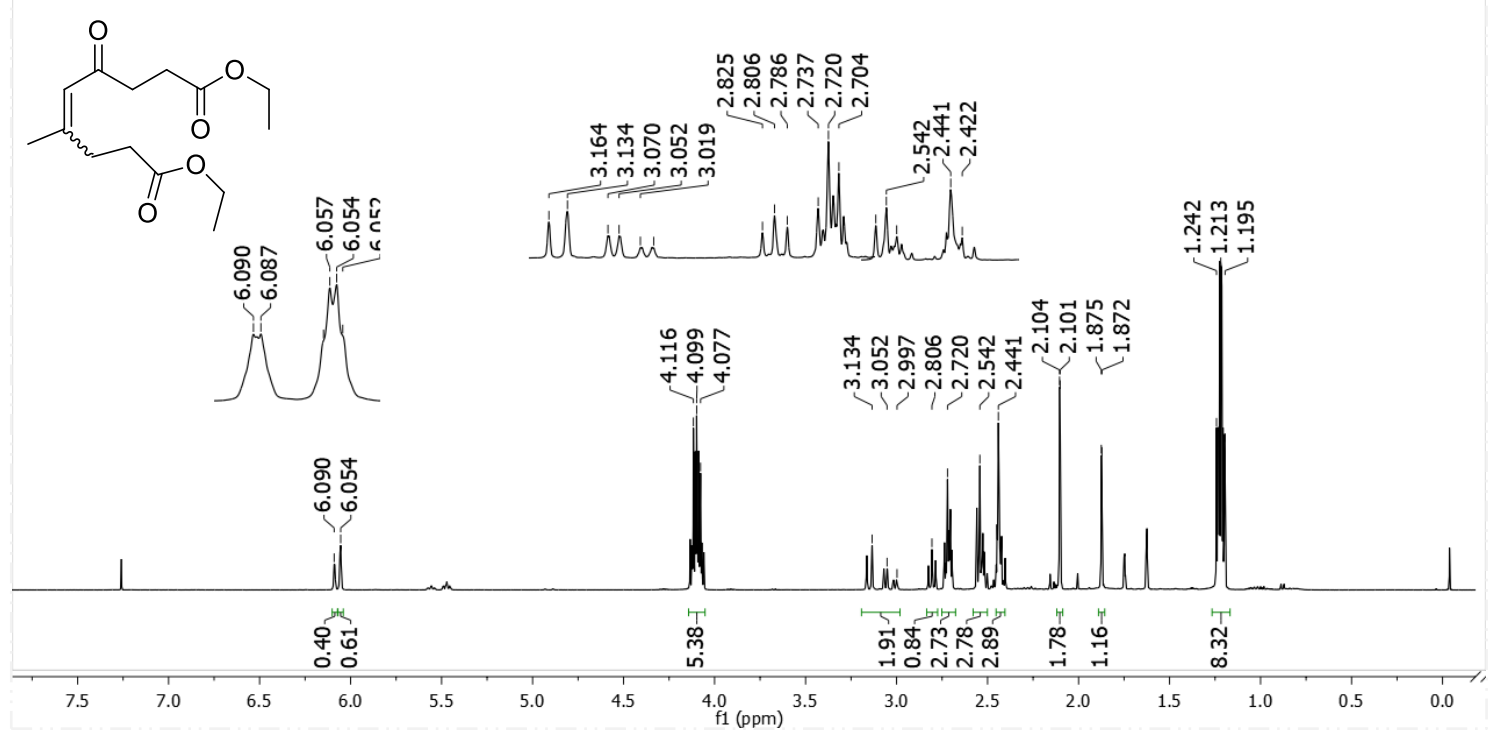


Uma possível proposta mecanística para produção de 1a e 1b é dada por meio do mecanismo via formação das enaminas I e II (figura 14), que podem desencadear a reação por dois caminhos.

Figura 14- Mecanismo para formação das enaminas<smiles>CCOC(=O)CCC(C)OCCCCCCO</smiles><smiles>CCOC(=O)CCC1CCCN1[C@](C)(O)CCC(=O)OCC</smiles><smiles>CCOC(=O)CCC(O)(CC)N1CCCC1</smiles>

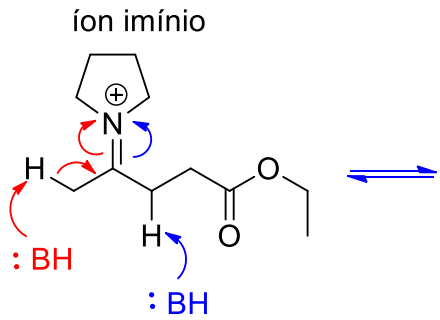

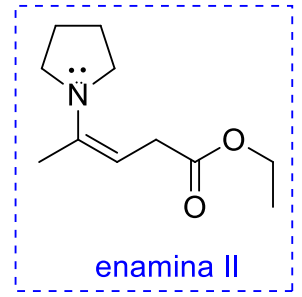<smiles>c1ccccc1</smiles><smiles>C=C(CCC(=O)OCC)C1CCCCC1</smiles>

No primeiro caminho, consta o ataque nucleofílico da enamina I à carbonila ativada do LE pelo ácido $p$-TsOH que, após eliminação de uma molécula de $\mathrm{H}_{2} \mathrm{O}$ e work-up, forma a mistura 1a e 1b (figura 15).

Figura 15 Proposta mecanística via ataque ao íon oxônio<smiles>C=C(CCC(=O)OC(C)C)N1CC2CCC1C2</smiles> 
Já o segundo caminho seria iniciado pelo ataque nucleofílico da enamina I ao íon imínio, formando o intermediário (II). Em seguida, elimina-se uma molécula de pirrolidina e após work-up têm-se os produtos 1a e 1b (figura 16).

Figura 16- Proposta mecanística via ataque ao íon imínio

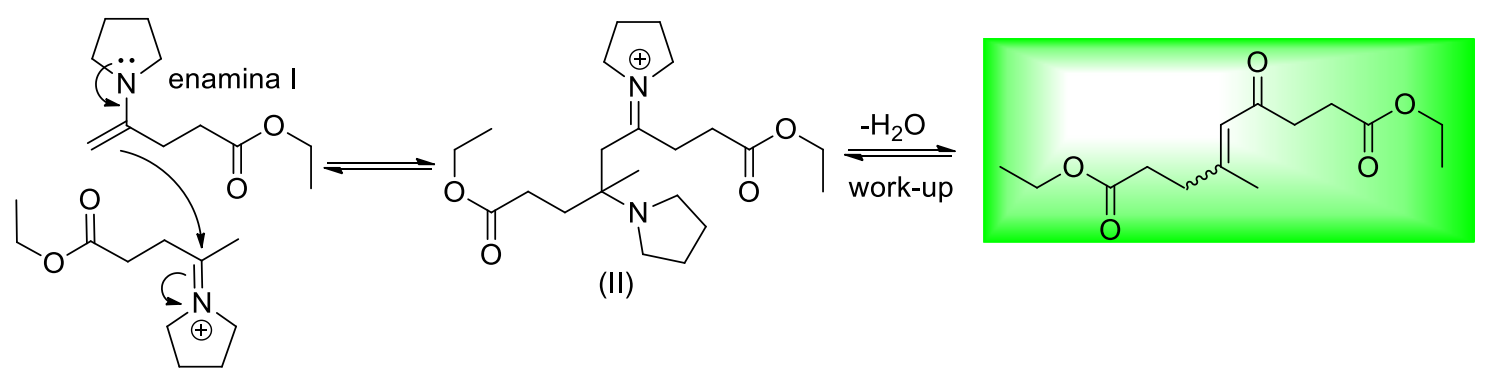

Há dois precedentes na literatura para formação de um produto análogo às estruturas de $\mathbf{1 a}$ e $\mathbf{1 b}$, porém partindo do ácido levulínico e do levulinato de metila. No entanto, as metodologias utilizadas pelos autores envolvem reagentes mais caros e tempos reacionais maiores. ${ }^{79}$

Como os produtos de autocondensação (1a-1b e 2a-2b (pag. 51)) foram isolados entre $37-45 \%$ de rendimento e mostraram-se como intermediários interessantes do ponto de vista estrutural, fez-se uma busca mais detalhada para a melhoria das condições experimentais. $\mathrm{Na}$ tabela 5, são apresentadas as condições utilizadas.

Estudos realizados com aminas distintas foram explorados utilizando morfolina, anilina e ciclohexilamina (entradas 1-3). Porém, após 6 horas de reação, nas condições experimentais testadas, não se observou o consumo do LE, sendo assim, a reação foi mantida por mais tempo. Após completar 15 horas de reação, não se observou a formação de nenhum produto, recuperando-se o LE. Por outro lado, quando benzilamina é utilizada (entrada 4) o LE mostrou-se reativo e foi totalmente consumido em 6 horas de reação, entretanto os produtos desejados não foram formados, mas sim uma mistura complexa contendo outras substâncias não identificadas.

$\mathrm{Na}$ tentativa de obter os produtos sem a necessidade de passar pelo intermediário enamina, realizaram-se experimentos para empregar uma reação de condensação aldólica clássica. Foram usados os catalisadores ácido ou básico, $p$ - $\mathrm{TsOH}, \mathrm{H}_{2} \mathrm{SO}_{4}, \mathrm{HCl}$ ou $\mathrm{NaOH}$, sem a adição das aminas (entradas 5-8), 
mas, novamente, estas condições não levaram à obtenção dos produtos desejados. Esses experimentos ratificaram a importância da formação das enaminas, uma vez que sem tal intermediário não se obtém os produtos de autocondensação almejados.

Nas entradas 9-12, são encontrados os melhores resultados. Em três tentativas, utilizando 1,5 equivalentes de pirrolidina, em diferentes escalas reacionais, o rendimento é apresentado na faixa de 37-44\% (entradas 9-12). 3 equivalentes da pirrolidina (entrada 12) foram utilizados, obtendo-se os produtos com aumento de rendimento, $52 \%$. Nota-se que quando a reação é realizada em escalas maiores (50 ou $150 \mathrm{mmol}$ do LE) o rendimento da reação apresenta um pequeno aumento (entradas 10 e 11). Trocando o tolueno por um solvente ambientalmente mais verde (anisol) não foi obtido o produto desejado na temperatura de $160^{\circ} \mathrm{C}$ por 15 horas. Entretanto, aumentando a temperatura para $180^{\circ} \mathrm{C}$ foram formados os produtos com $28 \%$ de rendimento em 6 horas de reação (entradas 13-14). É necessária uma maior temperatura, pois a mistura azeotrópica anisol/água tem ponto de ebulição maior que a mistura azeotrópica tolueno/água. $\mathrm{Na}$ entrada 15 , foi realizado um experimento modificando o catalisador para o ácido de Lewis $\mathrm{BF}_{3}(\mathrm{OEt})_{2}$, porém com este catalisador não foi observada nenhuma reação. 
Tabela 5- Condições experimentais para formação dos produtos $\mathbf{1 a - 1 b}$ e $\mathbf{2 a - 2 b}$

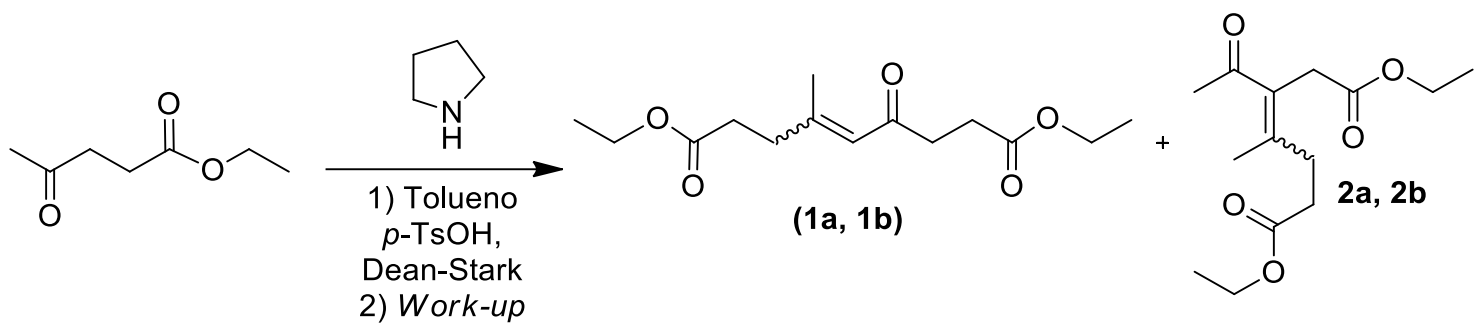

\begin{tabular}{|c|c|c|c|c|c|c|}
\hline Entradas & $\begin{array}{l}\text { LE } \\
\text { (eqv) }\end{array}$ & Aminas (eqv) & $\begin{array}{l}\text { Tolueno } \\
\text { [mol/L] }\end{array}$ & $\begin{array}{c}\mathrm{T} \\
\left({ }^{\circ} \mathrm{C}\right)\end{array}$ & $\begin{array}{c}t \\
(h)\end{array}$ & $(\%)$ \\
\hline 1 & 1,0 & Anilina $(1,1)$ & {$[0,5]$} & 140 & 15 & --- \\
\hline 2 & 1,0 & Ciclohexilamina $(1,1)$ & {$[0,5]$} & 140 & 15 & --- \\
\hline 3 & 1,0 & Morfolina $(1,1)$ & {$[0,5]$} & 140 & 15 & --- \\
\hline 4 & 1,0 & Benzilamina $(1,1)$ & {$[0,5]$} & 140 & 6 & $\begin{array}{c}\text { Mistura } \\
\text { complexa }\end{array}$ \\
\hline $5^{a}$ & 1,0 & --- & {$[0,5]$} & 140 & 24 & --- \\
\hline $6^{a}$ & 1,0 & --- & {$[0,5]$} & 140 & 24 & --- \\
\hline $7^{\mathrm{a}}$ & 1,0 & --- & {$[0,5]$} & 140 & 24 & --- \\
\hline $8^{b}$ & 1,0 & --- & $\mathrm{EtOH}[0,5]$ & 80 & 24 & --- \\
\hline 9 & 1,0 & Pirrolidina $(1,1)$ & {$[0,5]$} & 140 & 6 & 37 \\
\hline $10^{d}$ & 1,0 & Pirrolidina $(1,1)$ & {$[0,6]$} & 140 & 6 & 40 \\
\hline $11^{d}$ & 1,0 & Pirrolidina $(1,1)$ & {$[0,6]$} & 140 & 6 & 44 \\
\hline 12 & 1,0 & Pirrolidina $(3,0)$ & {$[0,5]$} & 140 & 6 & 52 \\
\hline 13 & 1,0 & Pirrolidina $(1,1)$ & Anisol $[0,5]$ & 140 & 15 & --- \\
\hline 14 & 1,0 & Pirrolidina $(1,1)$ & Anisol $[0,5]$ & 180 & 6 & 28 \\
\hline $15^{c}$ & 1,0 & Pirrolidina $(1,1)$ & {$[0,5]$} & 140 & 15 & --- \\
\hline
\end{tabular}

Como já citado, o espectro de RMN de ${ }^{1} \mathrm{H}$ para os compostos $\mathbf{1 a}$ e $\mathbf{1 b}$ apresenta outros sinais que não foram atribuídos à 1a e 1b. Com objetivo de identificar os compostos minoritários, realizou-se uma análise qualitativa por CGEM com o bruto reacional da escala ampliada (após filtração em sílica). Nesta análise pôde-se indicar a quantidade percentual das substâncias presentes, sendo detectado $60 \%$ dos isômeros $\mathbf{1 a}-\mathbf{1} \mathbf{b}, 22 \%$ de $\mathbf{2 a - 2 b}, 15 \%$ de $\mathbf{3}$ e uma 
impureza minoritariamente (3\%) não identificada, vide figura 17. O composto 3 não foi detectado durante o experimento em escala reduzida (5,0 mmol do LE).

Figura 17- Análise qualitativa por CG-EM do bruto reacional

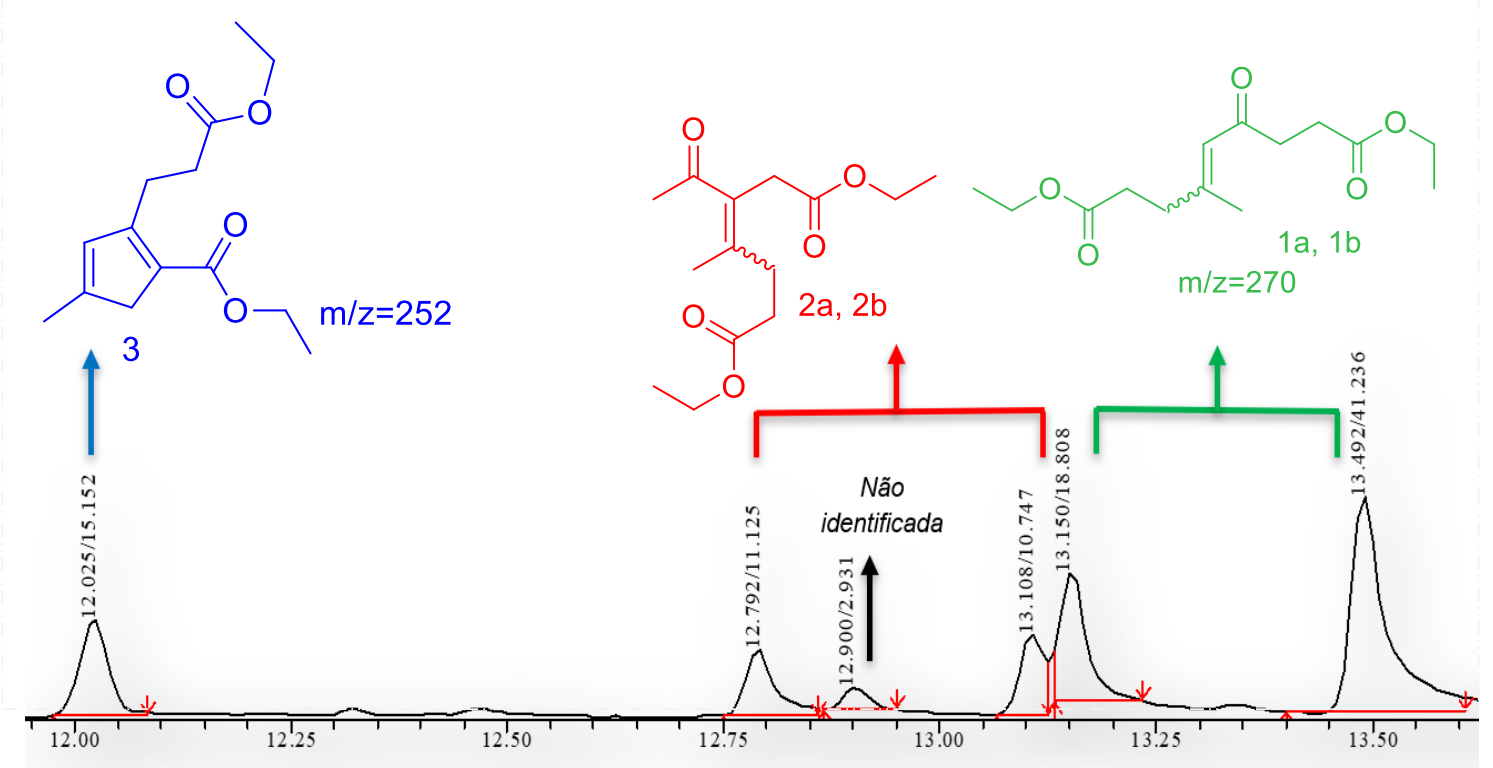

Vale ressaltar que os compostos 1 (isômeros $E+Z$ ) e 2 (isômeros $E+Z$ ) não são passíveis à separação por cromatografia em coluna de baixa eficiência devido ao tempo de retenção muito próximo, porém o composto 3 é facilmente separado. Sendo assim, o rendimento apresentado anteriormente (tabela 5) é constituído pela presença dos respectivos isômeros de 1 e 2 , ou seja, quatro compostos.

Ao observar as estruturas destes interessantes produtos (1a $\mathbf{1} \mathbf{1} \mathbf{b}, \mathbf{2} \mathbf{a} \mathbf{e} \mathbf{2} \mathbf{b})$ nota-se que os mesmos apresentam diversos hidrogênios ácidos, que após remoção poderiam gerar enolatos $\alpha$ à carboxila e/ou $\alpha$ à carbonila. Ao formar 0 enolato a-carboxila poderia ocorrer uma reação de ciclização, intramolecular, originando-se ciclos com 5 átomos de carbonos (semelhantes ao composto 3 ), que é o objetivo principal deste capítulo. Em contrapartida, ao formar o enolato a-carbonila, seria possível levar a uma reação de ciclização formando-se ciclos com 7 átomos de carbonos. Sendo assim, os estudos foram iniciados na busca de condições reacionais, em meio básico, para proporcionar as reações de ciclizações. 
A mistura contendo os produtos 1 e 2 (mistura $E+Z$ ) foi submetida, em uma escala de aproximadamente $2 \mathrm{mmol}$, a diversas condições reacionais básicas (Tabela 6). Durante as reações (monitoradas por CCD), observou-se a formação de um único produto com menor polaridade. Este produto foi purificado e caracterizado como um ciclopentadieno 1,2,4-trissubstituído (4).

Tabela 6- Condições experimentais para formação do ciclopentadieno 4 partindo da mistura dos isômeros 1 e 2

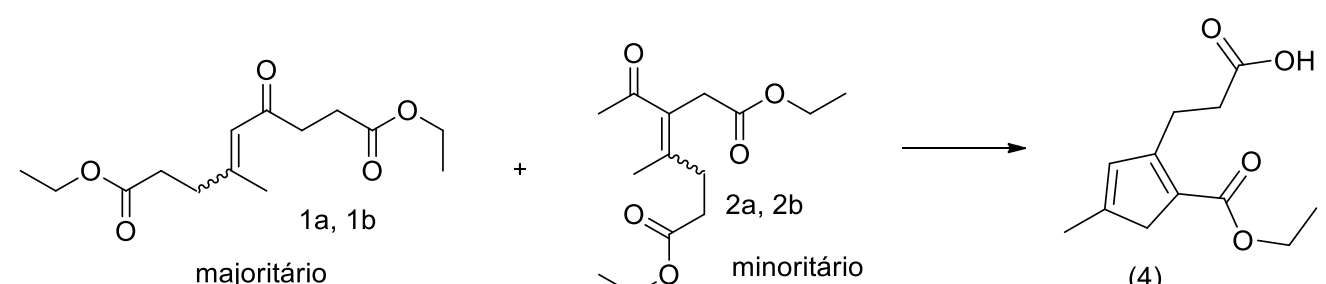

\begin{tabular}{|c|c|c|c|c|c|}
\hline Entradas $^{a}$ & Base (eqv) & $\begin{array}{c}\text { Solvente }[0,2 \\
\mathrm{mol} / \mathrm{L}]\end{array}$ & $\mathrm{T}\left({ }^{0} \mathrm{C}\right)$ & Tempo & $4(\%)$ \\
\hline 1 & EtONa $(2,0)$ & $\mathrm{EtOH}$ & 80 & $20 \mathrm{~min}$. & 20 \\
\hline 2 & EtONa $(1,0)$ & $\mathrm{EtOH}$ & 80 & $30 \mathrm{~min}$. & 44 \\
\hline 3 & EtONa $(1,0)$ & $\mathrm{EtOH}$ & t.a & $12 \mathrm{~h}$ & 40 \\
\hline 4 & EtONa $(1,05)$ & EtOH & 80 & $1 \mathrm{~h}$ & 58 \\
\hline 5 & $\mathrm{NaOH}(1,3)$ & $\mathrm{EtOH}$ & 80 & $30 \mathrm{~min}$. & 55 \\
\hline 6 & $\mathrm{NaOH}(2,0)$ & $\mathrm{EtOH}$ & 80 & $40 \mathrm{~min}$. & 50 \\
\hline 7 & $\mathrm{NaOH}(1,05)$ & EtOH & 80 & $30 \mathrm{~min}$. & 53 \\
\hline 8 & $\mathrm{NaOH}(1,3)$ & $\mathrm{EtOH} / \mathrm{H}_{2} \mathrm{O}$ & 80 & $2 \mathrm{~h}$ & 45 \\
\hline 9 & $\mathrm{KOH}(1,3)$ & $\mathrm{EtOH}$ & 80 & $1 \mathrm{~h}$ & 45 \\
\hline
\end{tabular}

Conforme apresentado na tabela 6, os melhores resultados com menor tempo reacionais são expressos nas entradas 4, 5 e 7 (53-58\% de rendimento). Nas condições experimentais utilizando etóxido de sódio, o rendimento da reação foi um pouco maior (58\%) ao se comparar com os experimentos usando hidróxido de sódio (53\%). Entretanto, a base etóxido de sódio tem maior valor comercial comparando-a com hidróxido de sódio, sendo assim, o hidróxido de sódio foi escolhido como a melhor base. Além disso, a reação utilizando EtONa demora aproximadamente 1 hora para se completar, enquanto com $\mathrm{NaOH}$ é 
necessário, apenas, 30 minutos. Foi testado, ainda, o uso de $\mathrm{KOH}$ como base e misturas de solventes etanol/ $/ \mathrm{H}_{2} \mathrm{O}$ (entradas 8 e 9), porém os rendimentos da reação foram menores (45\%).

Os principais sinais observados no espectro de RMN de ${ }^{1} \mathrm{H}$ (figura 18) para o composto 4 foram verificados em: $\delta 6,22$ (q aparente, $J=1,3 \mathrm{~Hz}, 1 \mathrm{H}, 3-\mathrm{H}$ ) referente a um hidrogênio ligado ao carbono $\mathrm{sp}^{2} ; \delta 4,10(\mathrm{q}, J=7,1 \mathrm{~Hz}, 2 \mathrm{H}$,$\left.\mathrm{OCH}_{2} \mathrm{CH}_{3}\right) ; 1,22\left(\mathrm{t}, J=7,1 \mathrm{~Hz}, 3 \mathrm{H},-\mathrm{OCH}_{2} \mathrm{CH}_{3}\right.$ ) atribuídos para o grupo etoxila; e um sinal, bastante peculiar, em $\delta 3,20$ (q aparente, $J=1,3 \mathrm{~Hz}, 2 \mathrm{H}, 5-\mathrm{H}$ ) designado aos dois hidrogênios metilênicos do ciclopentadieno

Figura 18- Espectro de RMN de ${ }^{1} \mathrm{H}$ do composto 4

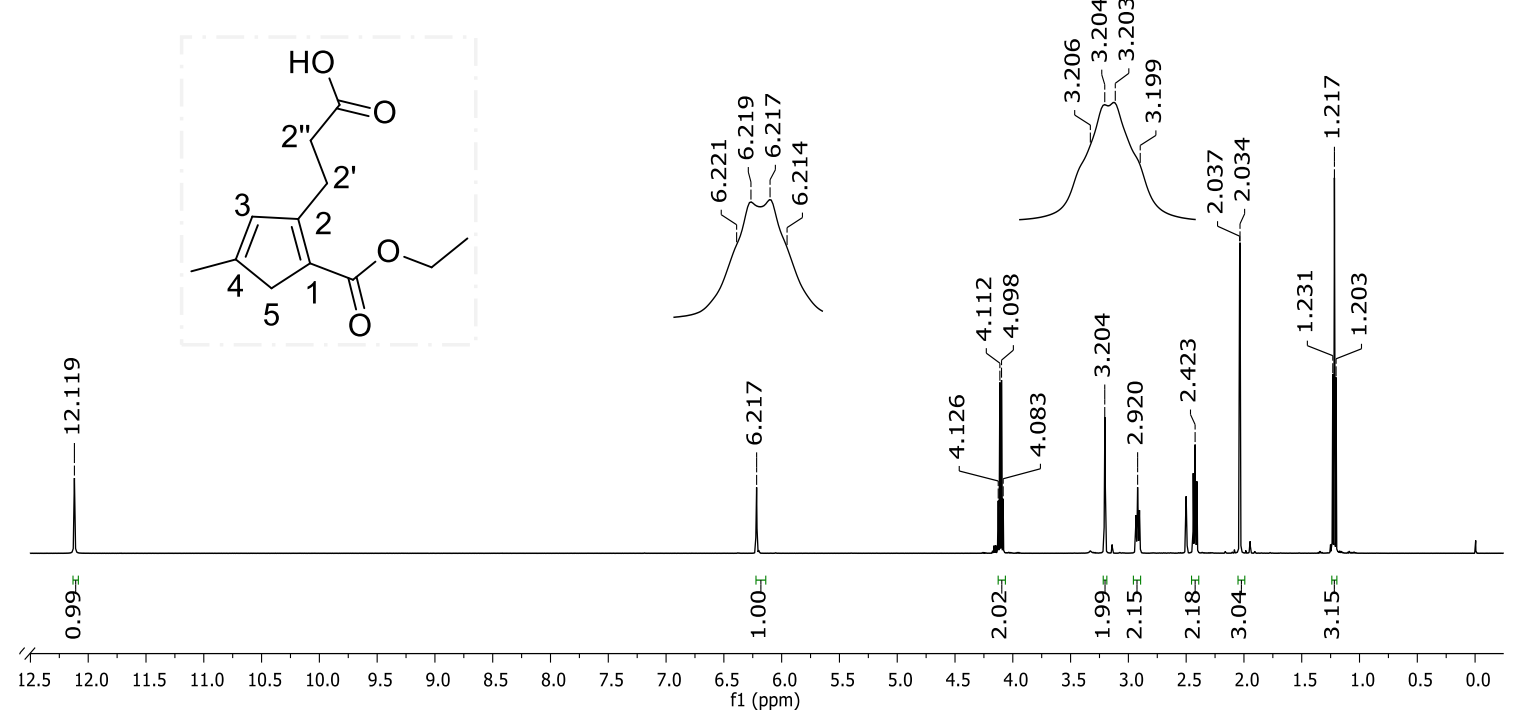

A primeira etapa do mecanismo para a formação dos dienos consiste na produção do enolato (gerado pela abstração do hidrogênio a à carboxila) e, em seguida, há o ataque nucleofílico à carbonila para formação do ciclopenteno. Este é rapidamente desidratado (pelo mecanismo E1cB) formando o dieno 3, que, após hidrólise do éster menos impedido, leva à formação de 4 (Figura 19). 
Figura 19- Mecanismo para formação dos dienos 3 e 4
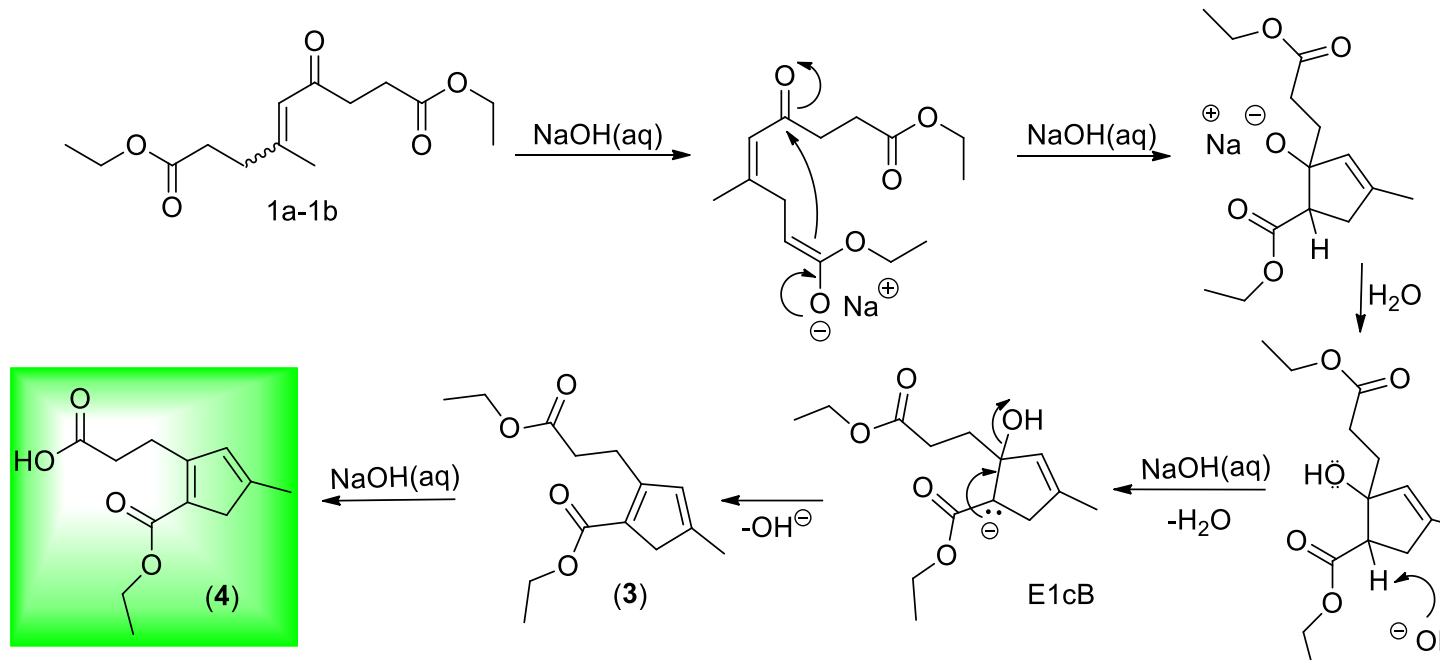

Conforme apresentado anteriormente na figura 17, os compostos isoméricos 2a e $\mathbf{2 b}$ também são obtidos pela autocondensação entre duas moléculas do LE com, aproximadamente, $22 \%$ de rendimento. A obtenção destes isômeros é por meio da reação entre a enamina II e o LE protonado (figura 20) ou íon íminio.

Figura 20- Proposta mecanística para formação de $2(E+Z)$

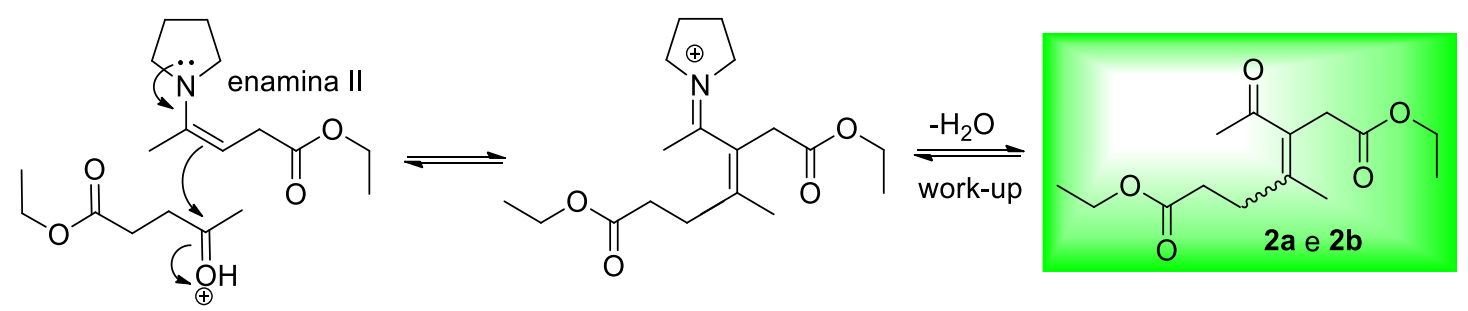

Sabe-se que nas cetonas $\alpha, \beta$-insaturadas o valor de deslocamento químico da carbonila é, geralmente, um pouco abaixo de 200 ppm. Já uma carbonila não conjugada à dupla ligação apresenta deslocamento químico entre 200-220 ppm. Nota-se que tanto os isômeros de 1 e 2 são cetonas insaturadas, porém ao observar o espectro de RMN de ${ }^{13} \mathrm{C}$ (Figura 21), os valores de deslocamentos químicos para às carbonilas dos isômeros de 2 são maiores que o esperado (207 e 206 ppm). Esta anomalia pode ser explicada observando as estruturas tridimensionais dos compostos (Figura 22). Quando se observa os isômeros $E$ e $Z$ de 2, nota-se que as carbonilas estão fora do plano, com isso, os elétrons da ligação dupla não podem ser deslocalizados efetivamente. Isso 
contribui para uma maior desblindagem das carbonilas e, consequentemente, um maior valor de descolamento químico. Por outro lado, nas estruturas $E$ e $Z$ do composto 1 as carbonilas estão no mesmo plano da dupla ligação, assim, o efeito eletrônico de deslocalização dos elétrons entre os orbitais $\pi$ da dupla ligação e da carbonila (através da ressonância) é efetivo e, portanto, colabora para blindagem das carbonilas (198 e 197 ppm).

Figura 21- Espectro de $\mathrm{RMN}$ de ${ }^{13} \mathrm{C}$ da mistura (1a-1b e 2a-2b)

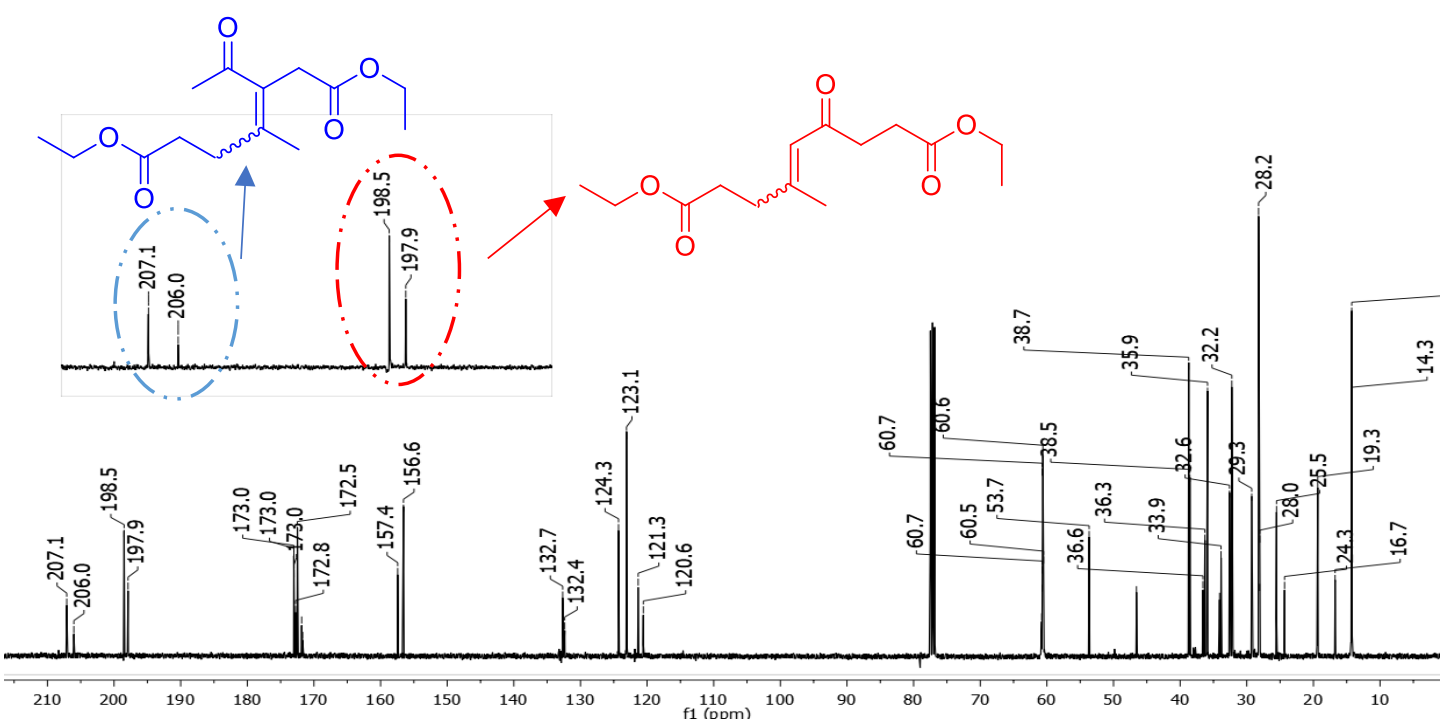

Figura 22- Estruturas 3D dos compostos $\mathbf{1 a}, \mathbf{1} \mathbf{b}, \mathbf{2 a} \mathbf{e} \mathbf{2 b}$

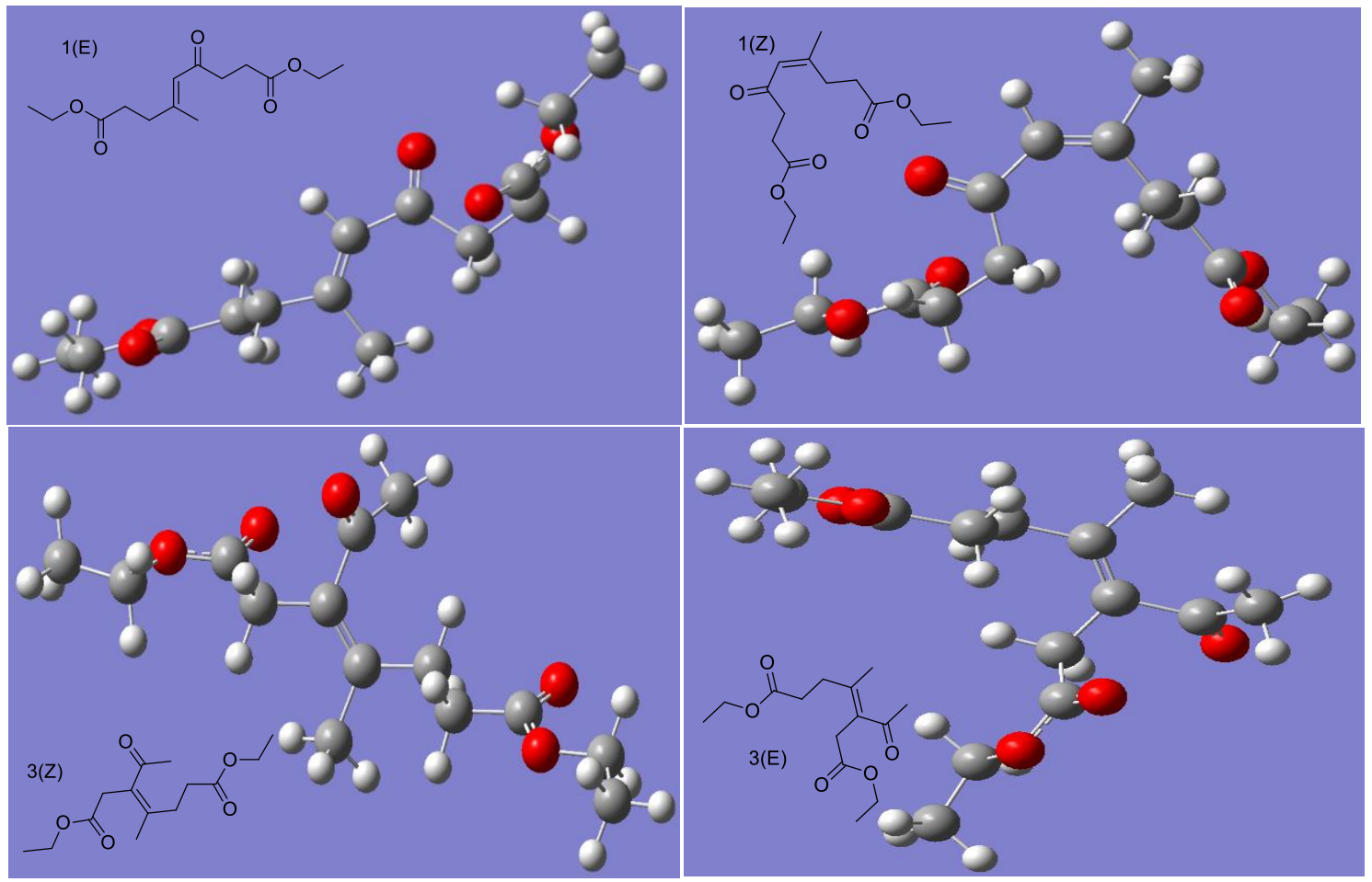


Também já foi mencionado que esses produtos não são separados por cromatografia em coluna de baixa eficiência sendo obtido, juntamente, com os isômeros $1(E+Z)$. Porém, quando esta mistura foi submetida a condições básicas da tabela 6 , não se observa o produto de ciclização para os isômeros do composto 2 . Caso a reação ocorresse, poderia ser formado o ciclopentadieno tetrassubstituído, entretanto, tal composto não foi detectado. No Esquema 17 consta a representação do éster possível a ser formado.

Esquema 17- Possível produto formado a partir de $\mathbf{2 a - 2 b}$

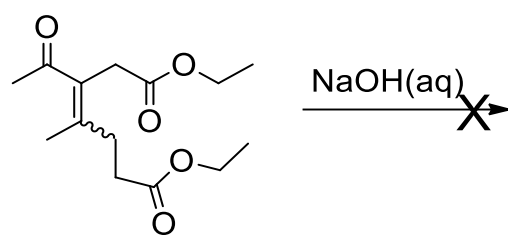

2a, $2 b$

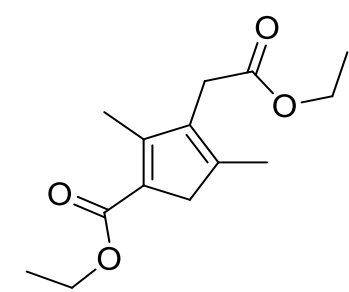

\subsection{Desenvolvimento de rota sintética verde para obtenção de ciclopentadienos e derivados}

Na busca por metodologias "mais verdes" e eficientes, foram investigadas possibilidades para obter os produtos 3 e/ou 4 sem a necessidade de purificação na etapa de formação dos isômeros 1 e 2 . Desse modo, optou-se por realizar um pré-tratamento filtrando o bruto reacional em sílica gel (após o work-up) e, em seguida, submeter a mistura dos compostos (1a-1b, 2a-2b e 3) à condição experimental de ciclização (baseada na entrada 7 da tabela 6 ).

Para início do estudo, empregou-se a condição já estabelecida anteriormente ( 1,1 equivalentes da pirrolidina para 1 equivalente do LE). Nesta condição, o dieno 4 foi obtido com 15\% de rendimento. Por outro lado, o dieno 3 não é detectado na reação (tabela 7 , entrada 1). Quando se utiliza 3 equivalentes da pirrolidina, a produção do dieno 4 é aumentada para $25 \%$ de rendimento (entrada 2). Realizando estas duas condições experimentais em uma escala ampliada (78 mmol do LE), o dieno 4 é obtido com $30 \%$ e $32 \%$ de rendimento. Por outro lado, o dieno 3 é obtido com 4\% de rendimento (entradas 3 e 4). Nas entradas 5 e 6 , escalas reduzida e ampliada, respectivamente, foi 
utilizado 0,5 equivalentes da pirrolidina e, curiosamente, o rendimento do dieno 4 foi 19\% (entrada 5) e 17\% (entrada 6). Nestas condições, não se observa a formação de 4.

Ao substituir o tolueno pelo solvente anisol (entrada 7) foi possível obter $15 \%$ de 3 e $21 \%$ de 4 (rendimentos após purificação). Nesta metodologia, utilizando anisol, foi necessário purificar o bruto reacional em coluna de sílica gel empregando como eluentes: hexano e gradiente da mistura hexano/acetato de etila $(9: 1 ; 7: 3 ; 1: 1)$. Nessa purificação, o dieno 3 já é isolado com o rendimento citado (15\%) e os compostos $\mathbf{1 a}, \mathbf{1} \mathbf{b}, \mathbf{2} \mathbf{a} \mathbf{e} \mathbf{2} \mathbf{b}$ como uma mistura contendo traços de LE. Esta mistura (3,56 g), por sua vez, quando levada a condições de ciclização, forneceu o dieno $4 \mathrm{com} 21 \%$ de rendimento. Sendo assim, optou-se por utilizar tolueno como solvente da reação, pois este é facilmente evaporado e o bruto da reação é apenas tratado por meio de uma filtração em sílica. Além disso, utiliza-se uma pequena quantidade da mistura hexano/acetato de etila (7:3) para realizar a filtração, o que acarreta no uso de uma quantidade menor de solvente.

Tabela 7- Condições experimentais para formação do ciclopentadieno 3 e/ou 4

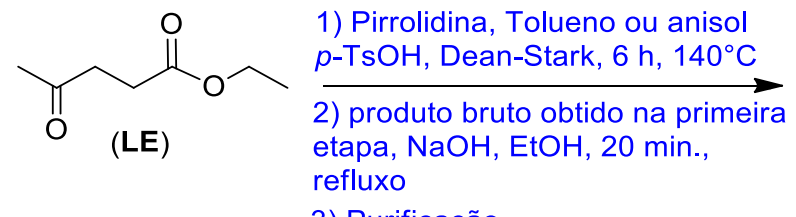

3) Purificação
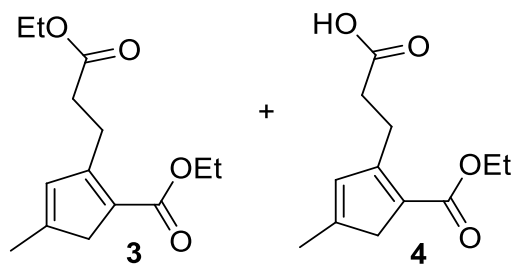

\begin{tabular}{|c|c|c|c|c|c|}
\hline Entradas & $\begin{array}{l}\text { LE } \\
\text { (eqv) }\end{array}$ & $\begin{array}{l}\text { Pirrolidina } \\
\text { (eqv) }\end{array}$ & $\begin{array}{l}\text { Tolueno } \\
\text { [mol/L] }\end{array}$ & $\begin{array}{c}\text { Bruto }(\%)^{\star} \\
(1 \mathrm{a}, 1 \mathrm{~b}, 2 \mathrm{a}, 2 \mathrm{~b}, 3)\end{array}$ & $\begin{array}{c}\text { Dieno } 3 / 4 \\
(\%)\end{array}$ \\
\hline 1 & 1,0 & 1,1 & {$[0,5]$} & 32 & $0 / 15$ \\
\hline 2 & 1,0 & 3,0 & {$[0,5]$} & 45 & $0 / 25$ \\
\hline $3^{a}$ & 1,0 & 1,1 & {$[0,65]$} & 63 & $4 / 30$ \\
\hline $4^{a}$ & 1,0 & 3,0 & {$[0,65]$} & 65 & $4 / 32$ \\
\hline 5 & 1,0 & 0,5 & {$[0,5]$} & 43 & $0 / 19$ \\
\hline $6^{a}$ & 1,0 & 0,5 & {$[0,65]$} & 58 & $0 / 17$ \\
\hline $7^{\mathrm{b}}$ & 1,0 & 1,1 & {$[0,65]$} & --- & $15 / 21$ \\
\hline
\end{tabular}


Com a melhor metodologia alcançada para obter o dieno 4 (entrada 3 da tabela 7), foi explorada uma série de aplicações para agregar valor ao dieno obtido. Deste modo, pôde-se obter outros ciclopentadienos e ciclopentanos trissubstituídos (figura 23). ${ }^{55}$

Figura 23- Alguns compostos preparados a partir do ciclopentadieno 4

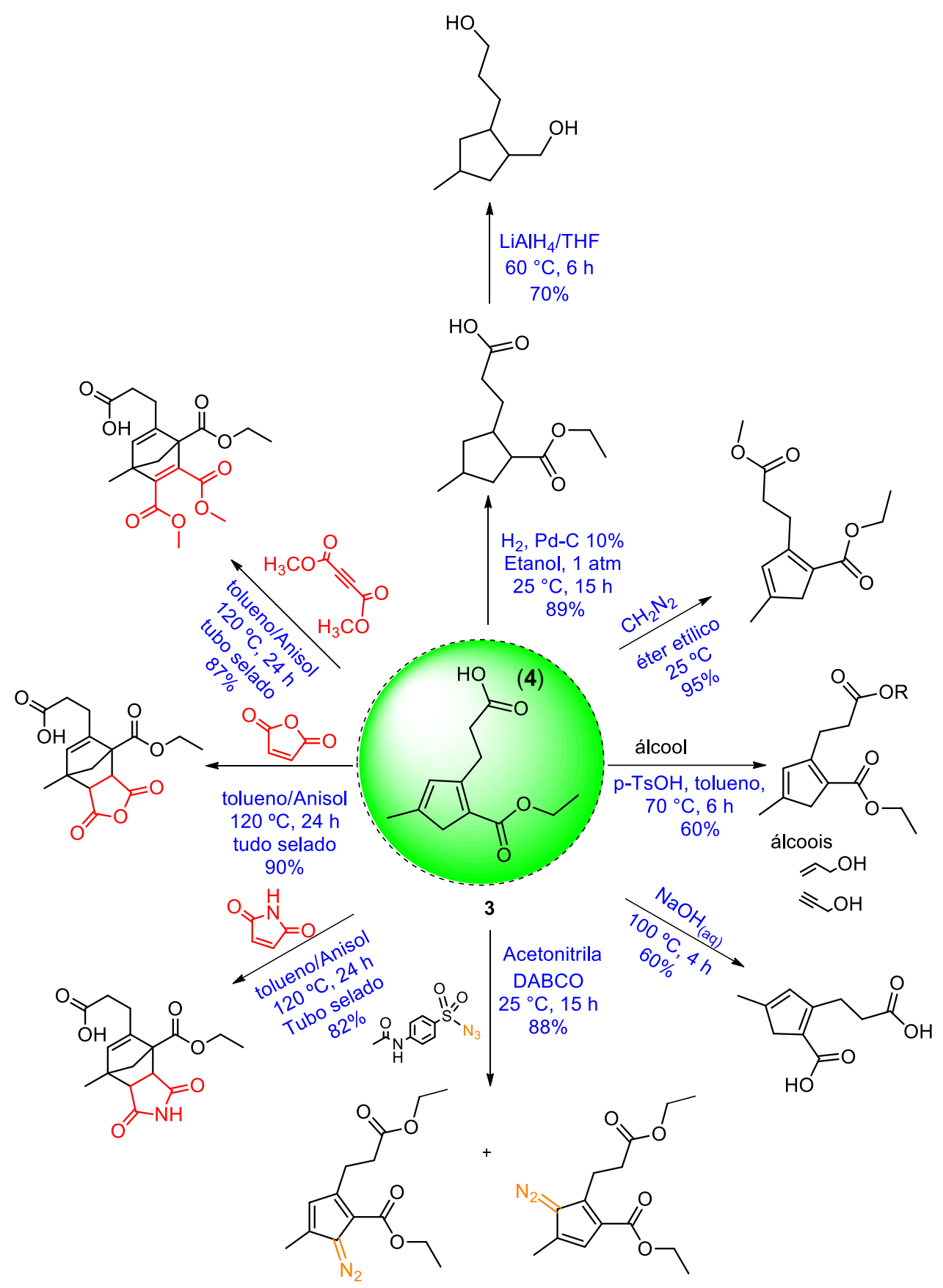




\subsection{Aplicações sintéticas para os ciclopentadienos 3 e 4}

\subsubsection{Formação do diácido 5}

Para iniciar a aplicação sintética do dieno 4 , com objetivo de produzir outras moléculas com alto valor agregado, a primeira reação realizada foi de hidrólise do éster. Para tanto, foi necessário realizar a reação na temperatura de $100^{\circ} \mathrm{C}$ em solução aquosa de $\mathrm{NaOH}$ (2,1 eqv) por 4 horas. Assim, foi obtido o dieno dicarboxílico 5 como 60\% de rendimento (Esquema 18).

Esquema 18- Reação de hidrólise do dieno 4

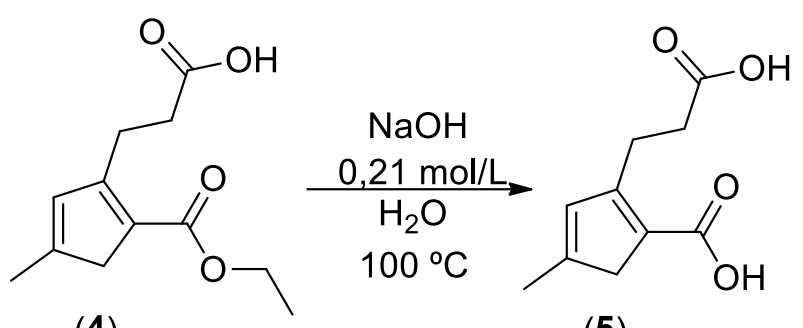

(4)

(5)

\subsubsection{Formação de ésteres: alílico (6), propargílico (7) e metílico (8)}

Foi possível obter a partir do ciclopentadieno 4, por meio da reação de esterificação catalisada por $p$-TsOH ou por tratamento com solução de diazometano, os ésteres: alílico (6), propargílico (7) e metílico (8).

Ao realizar a reação à $100^{\circ} \mathrm{C}$ por 6 horas, foi observada (por CCD) a formação de uma mistura complexa de compostos para síntese de 6 e 7 (entrada 1 e 2, tabela 8). Mesmo com este resultado, optou-se por deixar a reação por mais 9 horas, completando-se assim 15 horas de reação. Contudo, ao analisar a reação por $C C D$, a mesma mistura complexa foi observada (igualmente à analisada com 6 horas de reação). Nas entradas 3 e 4, diminuiu-se a temperatura para $70{ }^{\circ} \mathrm{C}$ e foi observado o consumo do material de partida em 6 horas de reação. Os produtos foram obtidos em uma mistura menos complexa, do que a observada anteriormente, e após purificação, os compostos 6 e 7 foram fornecidos com $60 \%$ de rendimento.

Vale ressaltar que durante a realização dos experimentos também foi testada a catálise básica, porém quando se utiliza bases como, por exemplo, $\mathrm{NaOH}, \mathrm{KOH}, \mathrm{K}_{2} \mathrm{CO}_{3}, \mathrm{Cs}_{2} \mathrm{CO}_{3}$ ou $t-\mathrm{BuOK}$, em diferentes solventes e haletos 
alquilas, sempre era observada a formação de uma mistura complexa não identificada.

Tabela 8- Condições experimentais para formação dos ésteres

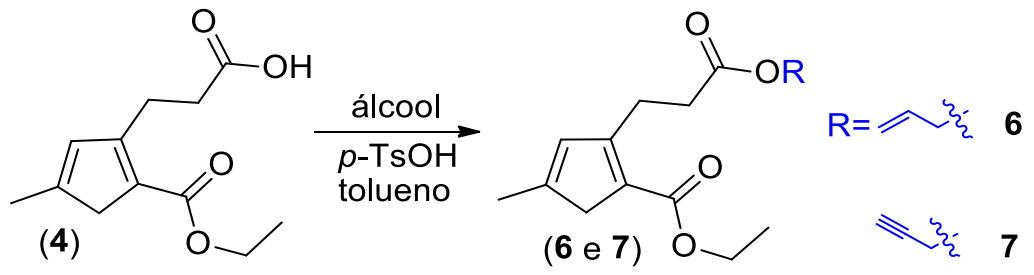

\begin{tabular}{ccccccc}
\hline Entradas & $\begin{array}{c}\text { Dieno } 4 \\
(\mathbf{m m o l})\end{array}$ & Álcoois (eqv) & $\begin{array}{c}\text { Tolueno } \\
{[\mathbf{m o l} / \mathbf{L}]}\end{array}$ & $\begin{array}{c}\mathbf{T} \\
\left({ }^{\circ} \mathbf{C}\right)\end{array}$ & $\begin{array}{c}\mathbf{t} \\
(\mathbf{h})\end{array}$ & $\begin{array}{c}\mathbf{6 ~ e ~ 7 ~} \\
(\%)\end{array}$ \\
\hline 1 & 1,0 & Alílico $(1,0)$ & {$[0,1]$} & 100 & 15 & Mistura \\
2 & 1,0 & Propargilíco $(1,0)$ & {$[0,1]$} & 100 & 15 & Mistura \\
3 & $\mathbf{1 , 0}$ & Alílico $(1,0)$ & {$[0,1]$} & $\mathbf{7 0}$ & $\mathbf{6}$ & $\mathbf{6 0}$ \\
$\mathbf{4}$ & $\mathbf{1 , 0}$ & Propargilíco $(\mathbf{1 , 0 )}$ & {$[\mathbf{0 , 1 ]}$} & $\mathbf{7 0}$ & $\mathbf{6}$ & $\mathbf{6 0}$ \\
\hline
\end{tabular}

Por meio de uma solução de diazometano $(0,6 \mathrm{~mol} / \mathrm{L})$, foi realizada a reação de esterificação, por meio de uma metodologia simples e rápida, fornecendo o éster metílico 8 com 95\% de rendimento (Esquema 19).

Esquema 19- Reação de esterificação com solução de diazometano

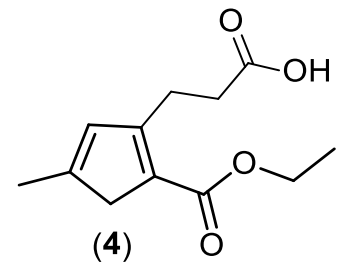

(4)

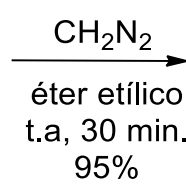

$95 \%$

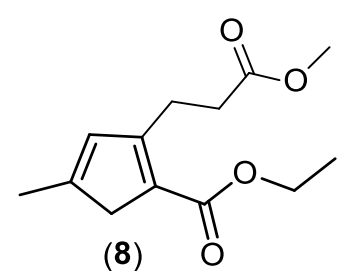

(8)

\subsubsection{Emprego do dieno nas reações de Diels-Alder}

Submeteu-se o dieno 4 à reação de Diels-Alder frente a diferentes dienófilos. Todas as reações foram realizadas em tubo selado por 24 horas, na escala de $0,5 \mathrm{mmol}$ do dieno, utilizando anisol ou tolueno $(2 \mathrm{~mL})$ como solventes. Para início dos estudos, utilizaram-se dienófilos ricos em elétrons (reação na demanda inversa de elétrons). Nas entradas 1 e 2 da tabela 9, foram empregados os éteres: etil vinil e 2,3-diidrofurano. Frente a estes dienófilos, os 
produtos formados não foram resultados de uma reação de Diels-Alder, mas sim, a formação de um grupo protetor na função ácido carboxílico (produtos 9 e 10, figura 24).

Figura 24- Formação de grupo protetor na função ácido carboxílico

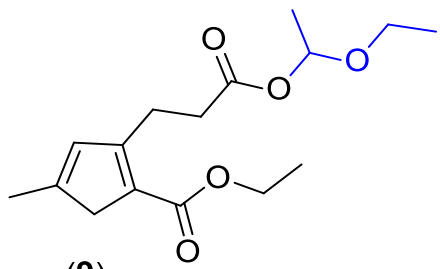

(9)

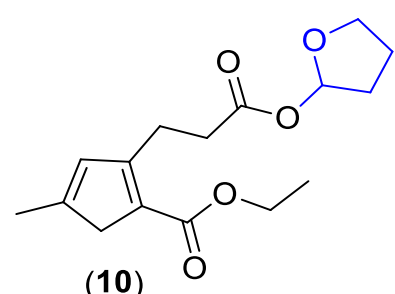

(10)

Provavelmente, estas reações podem estar ocorrendo através da abstração do hidrogênio ácido (por uma das estruturas de ressonância dos dienófilos) e, em seguida, há o ataque nucleofílico da base conjugada do ácido carboxílico aos dienófilos protonados. Vide figura 25 com proposta mecanística.

Figura 25- Proposta mecanística para formação dos compostos 9 e 10

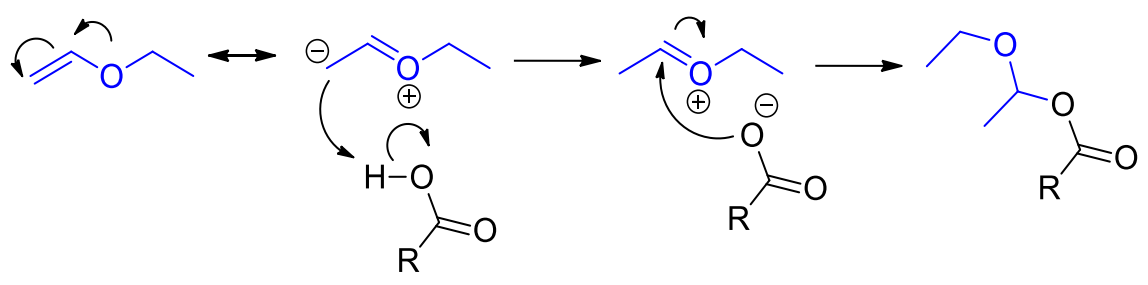

Os dienos (3 e 4) apresentam grupos doadores e retiradores de elétrons, portanto, podem reagir pelas demandas energéticas normal ou inversa. Neste sentido, dienófilos pobres em elétrons passaram a ser explorados (demanda normal de elétrons).

Maleimida, anidrido maléico e acetilenodicarboxilato de metila foram os dienófilos estudados (tabela 9). Iniciando os estudos utilizando 3 ou 2 equivalentes do acetilenodicarboxilato de metila não foi observado o produto da reação de Diels-Alder, mas sim, a formação de uma mistura complexa (entradas 3 e 4). Por outro lado, ao utilizar apenas 1,1 equivalentes do dienófilo o produto foi observado com $87 \%$ de rendimento (entrada 5). Aplicando esta mesma metodologia utilizando maleimida ou anidrido maléico, o produto só foi 
observado quando se empregou 3 equivalentes do dienófilo (entradas 8 e 9), dando origem aos produtos com 82 e 90\% de rendimentos. Utilizando uma quantidade menor destes dienófilos, os produtos desejados não foram formados (entradas 6 e 7 ).

Tabela 9- Estudo das reações de Diels-Alder.

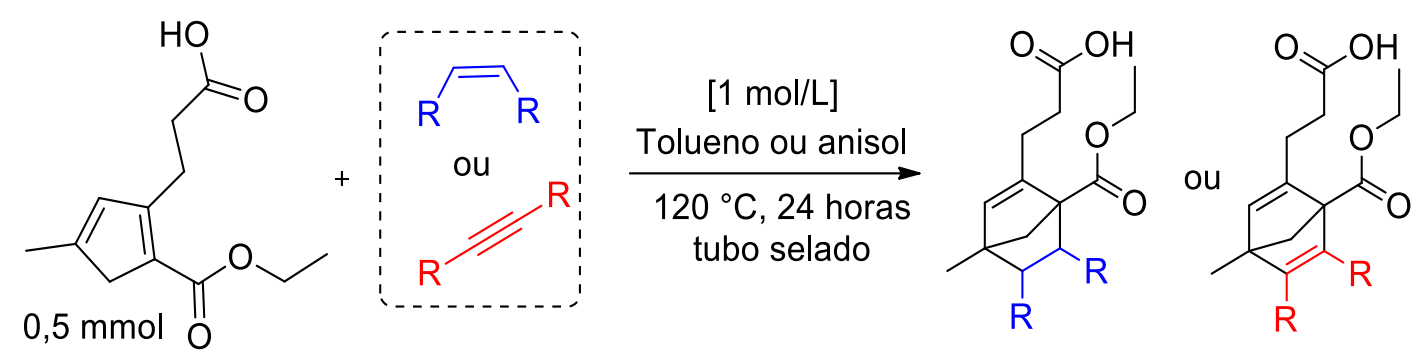

\begin{tabular}{|c|c|c|c|}
\hline Entradas & Dienófilos (eqv) & Produtos & (\%) \\
\hline 1 & $\overbrace{(3,0)}$ & 9 & 72 \\
\hline 2 & $(3,0)$ & 10 & 77 \\
\hline 3 & ${ }^{\mathrm{H}_{3} \mathrm{CO}}(3,0)$ & 11 & -- \\
\hline 4 & $(2,0)$ & 11 & -- \\
\hline 5 & $(1,1)$ & 11 & 87 \\
\hline 6 & $(1,1)$ & 12 & -- \\
\hline 7 & $(2,0)$ & 12 & -- \\
\hline 8 & $(3,0)$ & 12 & 90 \\
\hline 9 & $(3,0)$ & 13 & 82 \\
\hline
\end{tabular}

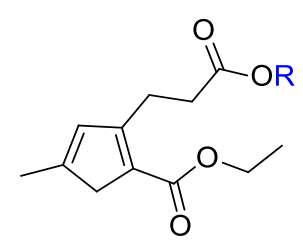

(9) e (10)

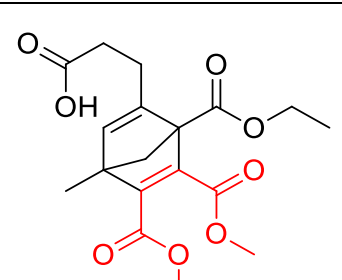

I (11)

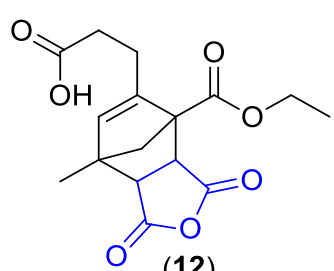

(12)

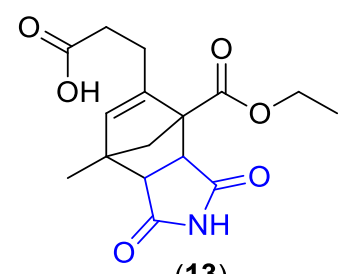

(13) 


\subsubsection{Formação do ciclopentano 14}

O ciclopentano 14 foi preparado com excelente rendimento por meio da hidrogenação do dieno 4 , catalisada por $\mathrm{Pd} / \mathrm{C}(10 \%)$, em pressão atmosférica (1 atm). No primeiro experimento realizado, obteve-se o produto com rendimento de $91 \%$ (na escala de $1 \mathrm{mmol}$ do dieno), não havendo necessidade de otimizar as condições reacionais. O rendimento manteve-se dentro do esperado ao aumentar a escala da reação, sendo possível obter 85\% (9,90 mmol, 2,26 g) de rendimento partindo de 2,61 g (11,65 mmol) do dieno (Tabela 10).

Tabela 10- Condições experimentais para formação do ciclopentano 14
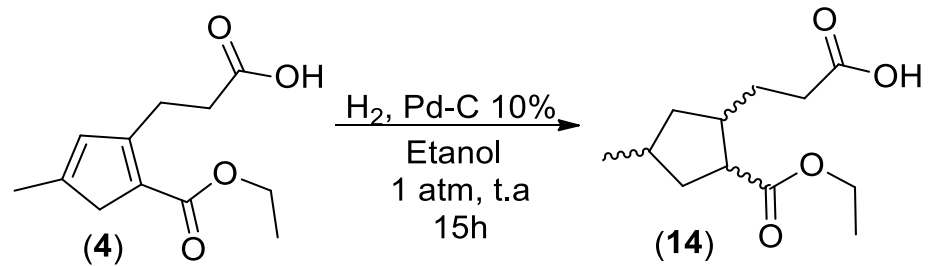

\begin{tabular}{ccccc}
\hline Entradas & $\begin{array}{c}\text { Dieno } \\
(\mathbf{m m o l})\end{array}$ & $\begin{array}{c}\mathbf{P d} / \mathbf{C ~ 1 0 \%} \\
(\mathbf{m g})\end{array}$ & $\begin{array}{c}\text { Etanol } \\
{[\mathbf{m o l} / \mathrm{L}]}\end{array}$ & $\mathbf{1 4}(\%)$ \\
\hline 1 & 1,0 & 44,5 & {$[0,1]$} & 91 \\
2 & 2,0 & 94 & {$[0,1]$} & 80 \\
3 & 11,65 & 522,6 & {$[0,1]$} & 85 \\
\hline
\end{tabular}

Como pode ser observado, a molécula 14 apresenta 3 centros estereogênicos em sua estrutura, portanto, pode existir 8 combinações de estereoisômeros diferentes (4 pares diferentes de enantiômeros). Os espectros de $\mathrm{RMN}$ de ${ }^{1} \mathrm{H}$ e ${ }^{13} \mathrm{C}$ para este composto exibem alta complexidade, sendo assim, foram realizadas análises por CG-FID para separar os diastereoisômeros e confirmar a estrutura de $\mathbf{1 4}$ (figura 26). 
Figura 26- Análise por CG-FID para o composto 14

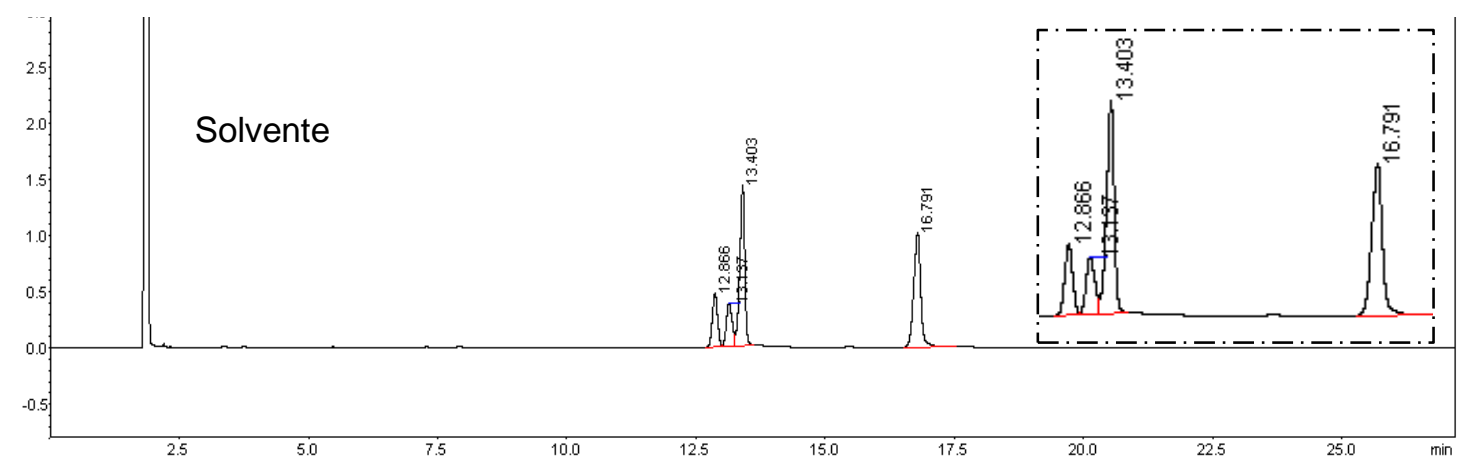

\subsubsection{Formação do ciclopentano 15}

A partir do ciclopentano 14, foi possível reduzir os grupos ácido carboxílico e éster originando o diol primário 15 com rendimentos de $70 \%$ e $80 \%$, a depender da escala trabalhada (tabela 11, entradas 3 e 4). $O$ produto não foi observado utilizando apenas 1,2 equivalentes do agente redutor (entrada 1). Por outro lado, o produto é formado com apenas $40 \%$ de rendimento empregando 2,2 equivalentes (entrada 2) do agente redutor. A estequiometria 1:3 (dieno:agente redutor) é um fator importe, pois nota-se, nas entradas 5 e 6 , à medida que se aumenta a quantidade do hidreto para 4 ou 5 equivalentes o rendimento da reação é diminuído.

Na tentativa de diminuir o número de etapas para obter o composto $\mathbf{1 5}$, foi realizada a síntese, de forma sequencial, partindo de $2,0 \mathrm{mmol}$ (448 $\mathrm{mg}$ ) do dieno 4. Após o térmico da reação de hidrogenação e filtração em celite, o bruto reacional com massa de $452 \mathrm{mg}$ foi submetido às condições experimentais descritas na tabela 11 (entrada 7) e após a etapa de purificação, forneceu o diol 15 com $62 \%$ de rendimento. Vale ressaltar que foi realizada outra rota sintética para ser obtido o composto 15. Esta estratégia consistia na redução (das funções ácido carboxílico e éster) do dieno 4 seguida pela hidrogenação do respectivo diol formado, porém nas tentativas realizadas apenas o grupo ácido carboxílico foi reduzido. Os resultados são apresentados na tabela 12. 
Tabela 11- Condições experimentais para formação do ciclopentano 15

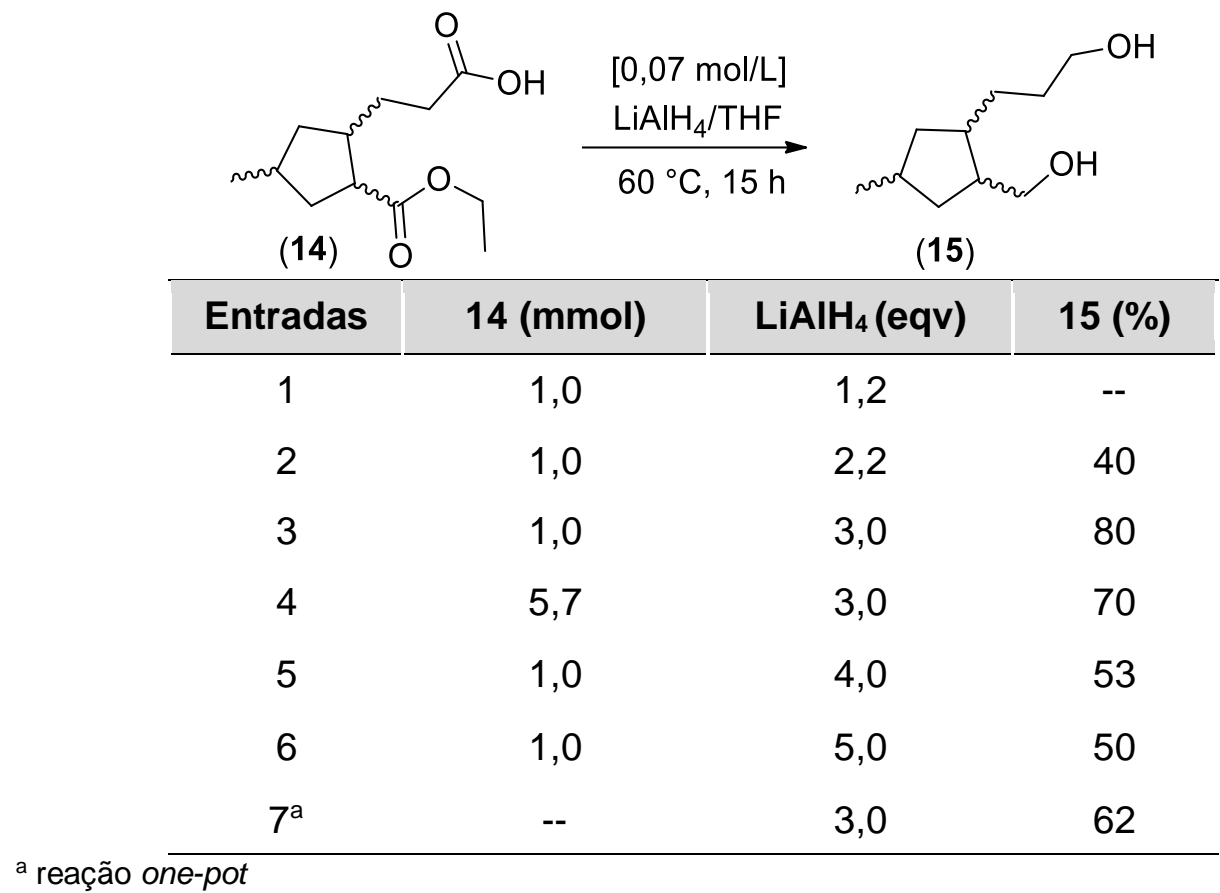

Para reação de redução do dieno 4, ao utilizar de 1-3 equivalentes de hidreto é observado a formação do composto 16 entre $17-28 \%$ de rendimento (entradas 1-3). Quando se utiliza um maior excesso do agente redutor, há formação de uma mistura complexa de produtos (entrada 4). Outros agentes redutores como, por exemplo, boro hidreto de lítio $\left(\mathrm{LiBH}_{4}\right)$ ou hidreto de Diisobutil-alumínio (DIBAL-H) foram testados, mas o dieno 4 não foi consumido. Na figura 27 é apresentado o espectro de RMN de ${ }^{1} \mathrm{H}$ de 16.

Tabela 12- Redução do dieno 4
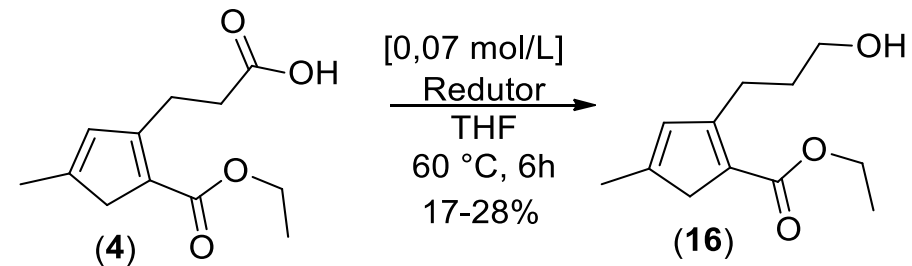

\begin{tabular}{c|c|c|c}
\hline Entradas & $\mathbf{4}$ (mmol) & $\mathrm{LiAlH}_{\mathbf{4}}$ (eqv) & $\mathbf{1 6}(\%)$ \\
\hline 1 & 1,0 & 1,2 & 17 \\
2 & 1,0 & 2,2 & 22 \\
3 & 1,0 & 3,2 & 28 \\
4 & 1,0 & 4,2 & -- \\
\hline
\end{tabular}


Figura 27- RMN de ${ }^{1} \mathrm{H}$ para composto 16

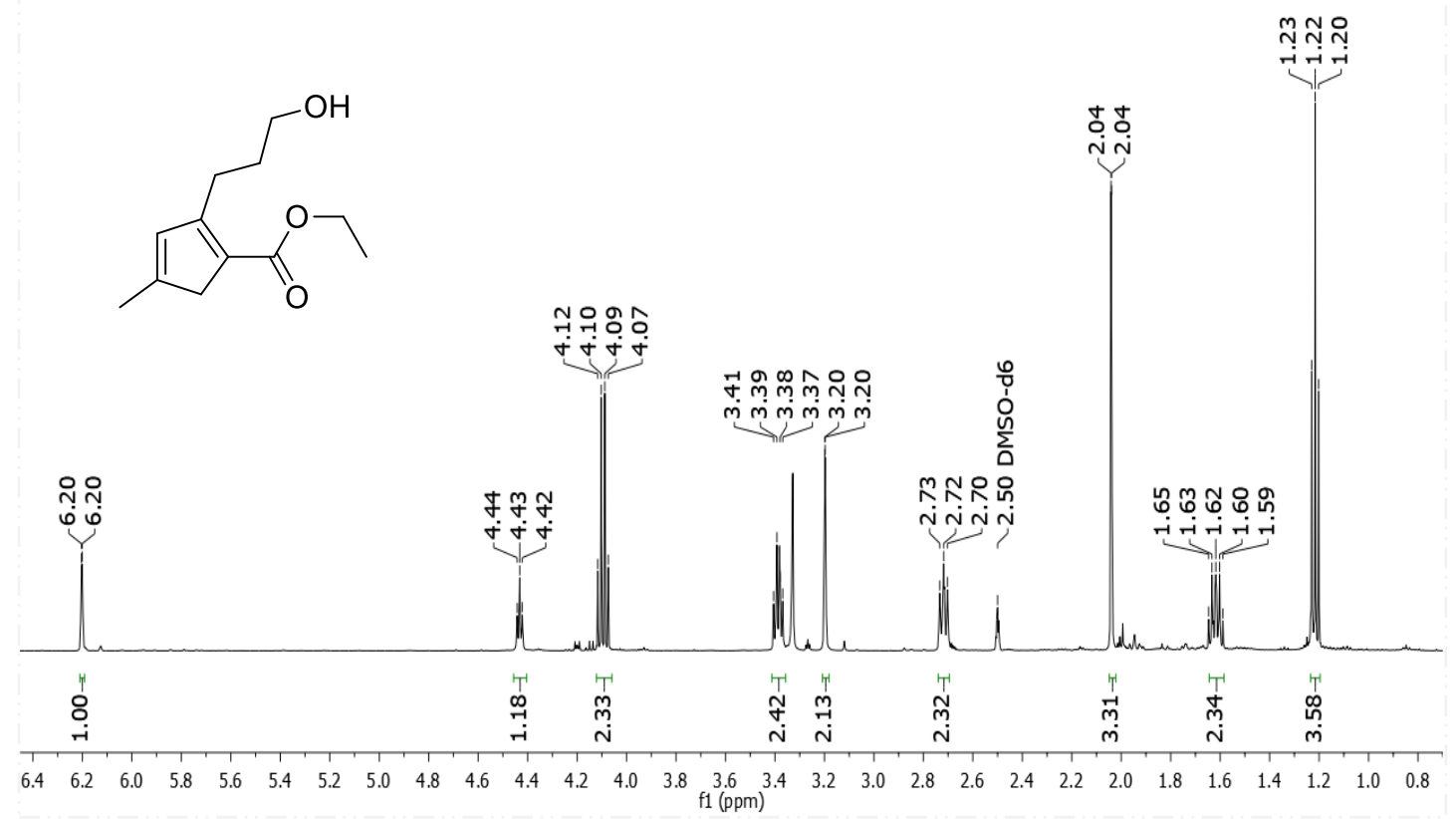

\subsubsection{Formação de diazociclopentadieno}

Os diazociclopentadienos foram obtidos por meio da reação de transferência direta de diazo, utilizando sulfonilazida como reagente de diazotação.

Ao iniciar os estudos, partindo do ciclopentadieno 4, utilizando trietilamina (TEA) como catalisador e as azidas, $p$-Acetamidabenzenosulfonil azida ( $p$ $\mathrm{ABSN}_{3}$ ) ou Tosil azida (TsN $\mathrm{T}_{3}$ ), não foi observada a transferência do grupo diazo após 24 horas de reação (entrada 1 e 2, tabela 13). Por outro lado, ao usar 1,1 ou 2,2 equivalentes da base 1,4-diazabiciclo [2.2.2] octano (DABCO), como catalisador, foi observada a formação de uma mistura complexa de difícil separação (entradas 3-4). Mesmo utilizando um grande excesso da azida, 3 equivalentes, o diazo composto não foi formado (entrada 5).

Como este dieno (4) contém grupo ácido carboxílico $(-\mathrm{COOH})$ e as condições reacionais necessitam de uso da base, para catalisar a reação, é possível que reações laterais (do ácido com a base) dificultaram a formação do diazociclopentadieno, sendo assim, realizou-se o estudo com o dieno dietoxilado (3).

Iniciando os estudos com 1 equivalente do material de partida, da azida e da base, foi possível observar a formação dos diazocompostos 17a e 17b, mas 
os mesmos foram obtidos, juntamente, com uma mistura complexa de produtos (entrada 6). Porém, ao modificar a estequiometria da reação, utilizando excesso da azida (2 equivalentes) e um leve excesso da base (1,1 equivalentes) foi possível obter os diazociclopentadienos 17a e 17b com rendimento de $88 \%$ (entrada 7) na proporção 2:1. Após o sucesso deste resultado, foi verificada a substituição da $p-\mathrm{ABSN}_{3}$ pela $\mathrm{TsN}_{3}$, mas o material de partida não foi consumido (entrada 8).

Tabela 13- Obtenção dos diazociclopentadienos

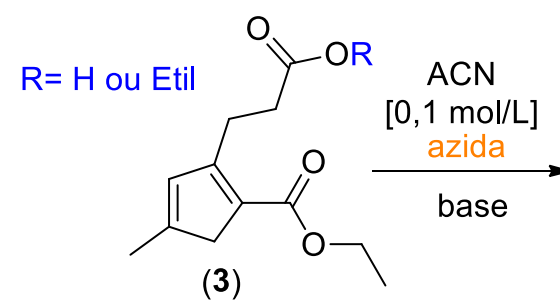

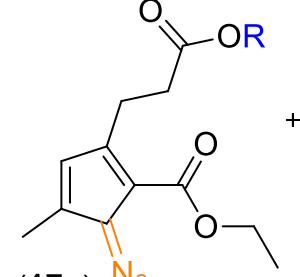

(17a)

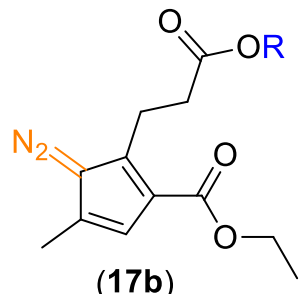

(17b)

\begin{tabular}{|c|c|c|c|c|c|}
\hline Entradas & $\begin{array}{l}\text { Dieno } \\
\text { (mmol) }\end{array}$ & $\begin{array}{l}\text { Azida } \\
\text { (eqv) }\end{array}$ & $\begin{array}{c}\text { Base } \\
(\mathrm{mmol})\end{array}$ & $t(h)$ & $(\%)$ \\
\hline 1 & $\begin{array}{c}\mathbf{4} \\
(1,0)\end{array}$ & $\begin{array}{c}p-\mathrm{ABSN}_{3} \\
1,1\end{array}$ & $\begin{array}{c}\text { TEA } \\
2,1\end{array}$ & 24 & -- \\
\hline 2 & $\begin{array}{c}\mathbf{4} \\
(1,0)\end{array}$ & $\begin{array}{c}\mathrm{TsN}_{3} \\
1,1\end{array}$ & $\begin{array}{l}\text { TEA } \\
2,1\end{array}$ & 24 & -- \\
\hline 3 & $\begin{array}{c}\mathbf{4} \\
(1,0)\end{array}$ & $\begin{array}{c}p-\mathrm{ABSN}_{3} \\
1,1\end{array}$ & $\begin{array}{c}\text { DABCO } \\
2,1\end{array}$ & 15 & $\begin{array}{c}\text { Mistura } \\
\text { complexa }\end{array}$ \\
\hline 4 & $\begin{array}{c}\mathbf{4} \\
(1,0)\end{array}$ & $\begin{array}{c}p-\mathrm{ABSN}_{3} \\
1,1\end{array}$ & $\begin{array}{c}\text { DABCO } \\
1,1\end{array}$ & 15 & $\begin{array}{c}\text { Mistura } \\
\text { complexa }\end{array}$ \\
\hline 5 & $\begin{array}{c}\mathbf{4} \\
(1,0)\end{array}$ & $\begin{array}{c}p-\mathrm{ABSN}_{3} \\
3,0\end{array}$ & $\begin{array}{c}\text { DABCO } \\
2,1\end{array}$ & 15 & $\begin{array}{c}\text { Mistura } \\
\text { complexa }\end{array}$ \\
\hline 6 & $\begin{array}{c}3 \\
(1,0)\end{array}$ & $\begin{array}{c}p-\mathrm{ABSN}_{3} \\
1,0\end{array}$ & $\begin{array}{c}\text { DABCO } \\
1,0\end{array}$ & 15 & $\begin{array}{c}\text { Mistura } \\
\text { complexa }\end{array}$ \\
\hline 7 & $\begin{array}{c}3 \\
(1,0)\end{array}$ & $\begin{array}{c}p-\mathrm{ABSN}_{3} \\
2,0\end{array}$ & $\begin{array}{c}\text { DABCO } \\
1,1\end{array}$ & 15 & 88 \\
\hline 8 & $\begin{array}{c}3 \\
(1,0)\end{array}$ & $\begin{array}{c}\mathrm{TsN}_{3} \\
2.0\end{array}$ & $\begin{array}{c}\text { DABCO } \\
1,1\end{array}$ & 24 & -- \\
\hline
\end{tabular}

Os hidrogênios entre as ligações duplas dos ciclopentadienos tem pka=15 (para dieno não substituído). A abstração destes hidrogênios resulta na formação do ânion ciclopentadienil aromático. A carga negativa deslocalizada sobre os átomos de carbonos possibilita a formação de estruturas de 
ressonância estáveis. Uma dessas estruturas é responsável pela formação de 17b, conforme mostra a figura 28.

Figura 28- Estruturas de ressonância que contribuem para formação de 17a-17b

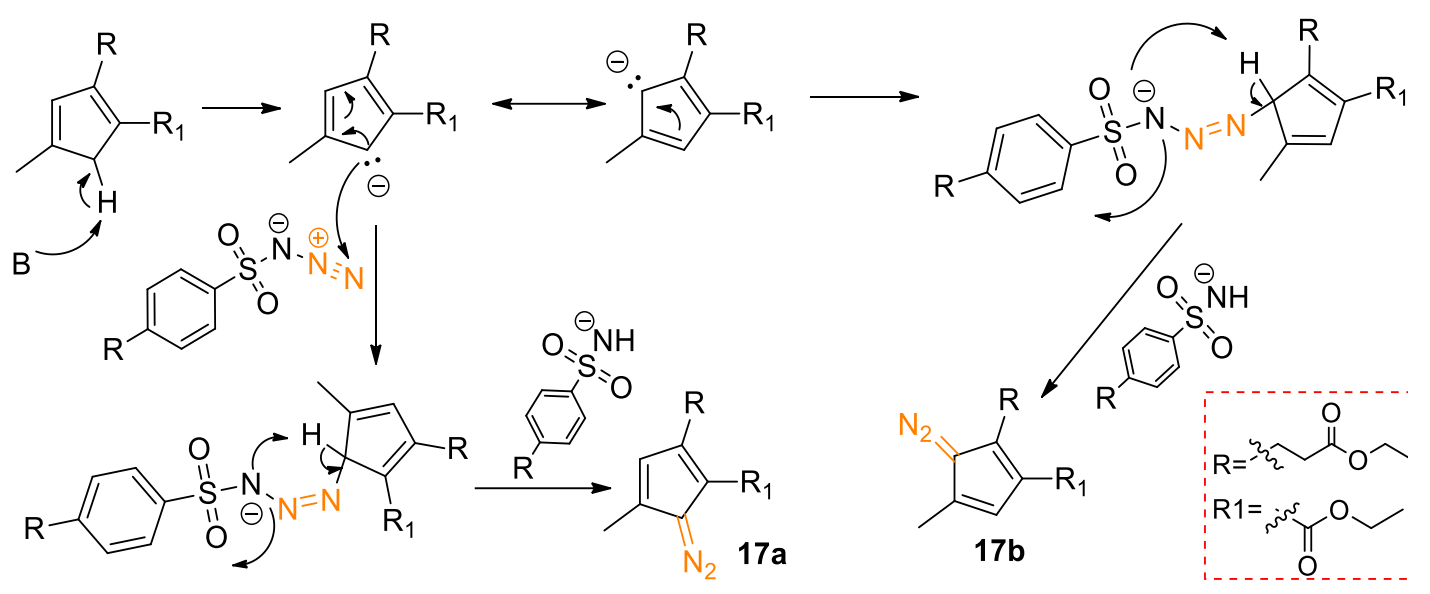

A presença do grupo diazo na molécula é facilmente detectado por IV, uma banda característica apresentada na região de $2095 \mathrm{~cm}^{-1}$, conforme apresentado na figura 29 abaixo.

Figura 29- Espectro de IV dos isômeros 17a-17b

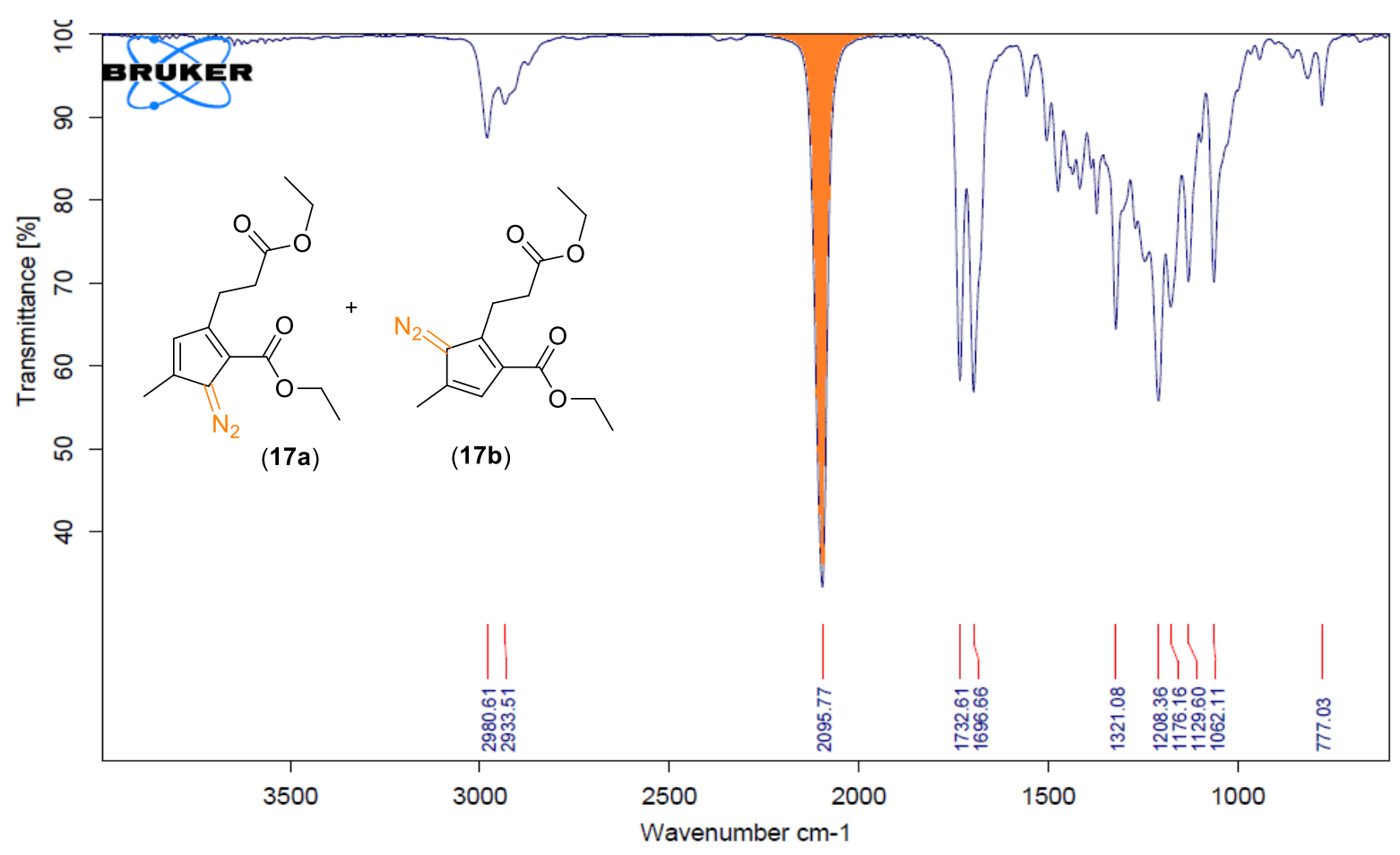


Após algum tempo, foi testada uma reação para formação de enaminas catalisada por $\mathrm{TiCl}_{4} .{ }^{80} \mathrm{Nesta}$ tentativa, foi obtida a produção das enaminas III e IV na proporção de aproximadamente 1:2, respectivamente (Esquema 20). No entanto, mesmo utilizando um grande excesso da morfolina e do $\mathrm{TiCl}_{4}$, ainda sobrava LE no meio reacional, juntamente, com a morfolina. Esta mistura: Morfolina, LE e as enaminas é de difícil separação por destilação. Qualquer aquecimento da mistura em temperaturas maiores que $60^{\circ} \mathrm{C}$, por um tempo longo, levava à autocondensação das enaminas, formando a mistura dos produtos (1a ,1b, 2a e 2b). Mesmo com este problema na separação, o bruto reacional foi submetido a reação de Michael frente à $B-A L$, mas a reação não ocorreu e a enamina foi degradada.

Esquema 20- Formação de enaminas catalisada por $\mathrm{TiCl}_{4}$
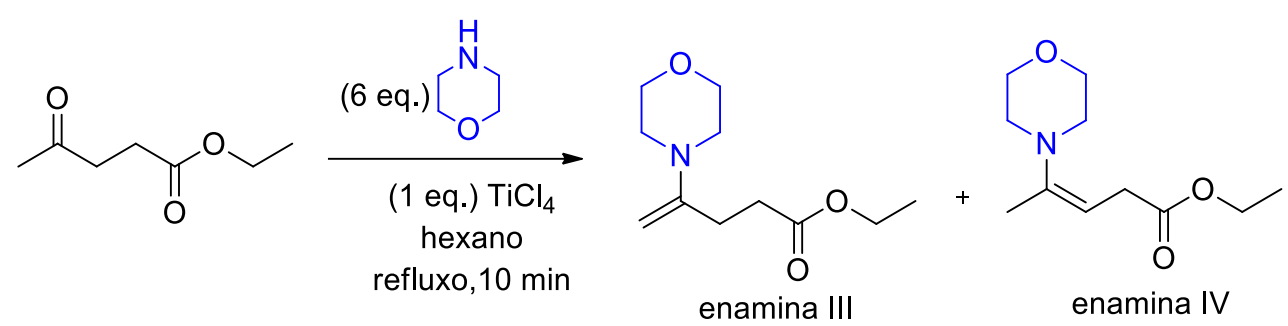

Na figura 30 é apresentado o espectro de RMN de ${ }^{1} \mathrm{H}$ do bruto reacional. Conforme pode ser observado, existe a presença do LE e, também, da morfolina. Não se sabe de fato se a enamina é decomposta após filtração do meio reacional, em Celite ${ }^{\circledR}$, ou se o LE não estava sendo totalmente consumido. 
Figura 30- Espectro de $\mathrm{RMN}$ de ${ }^{1} \mathrm{H}$ do bruto reacional para formação da enaminas catalisada por $\mathrm{TiCl}_{4}$

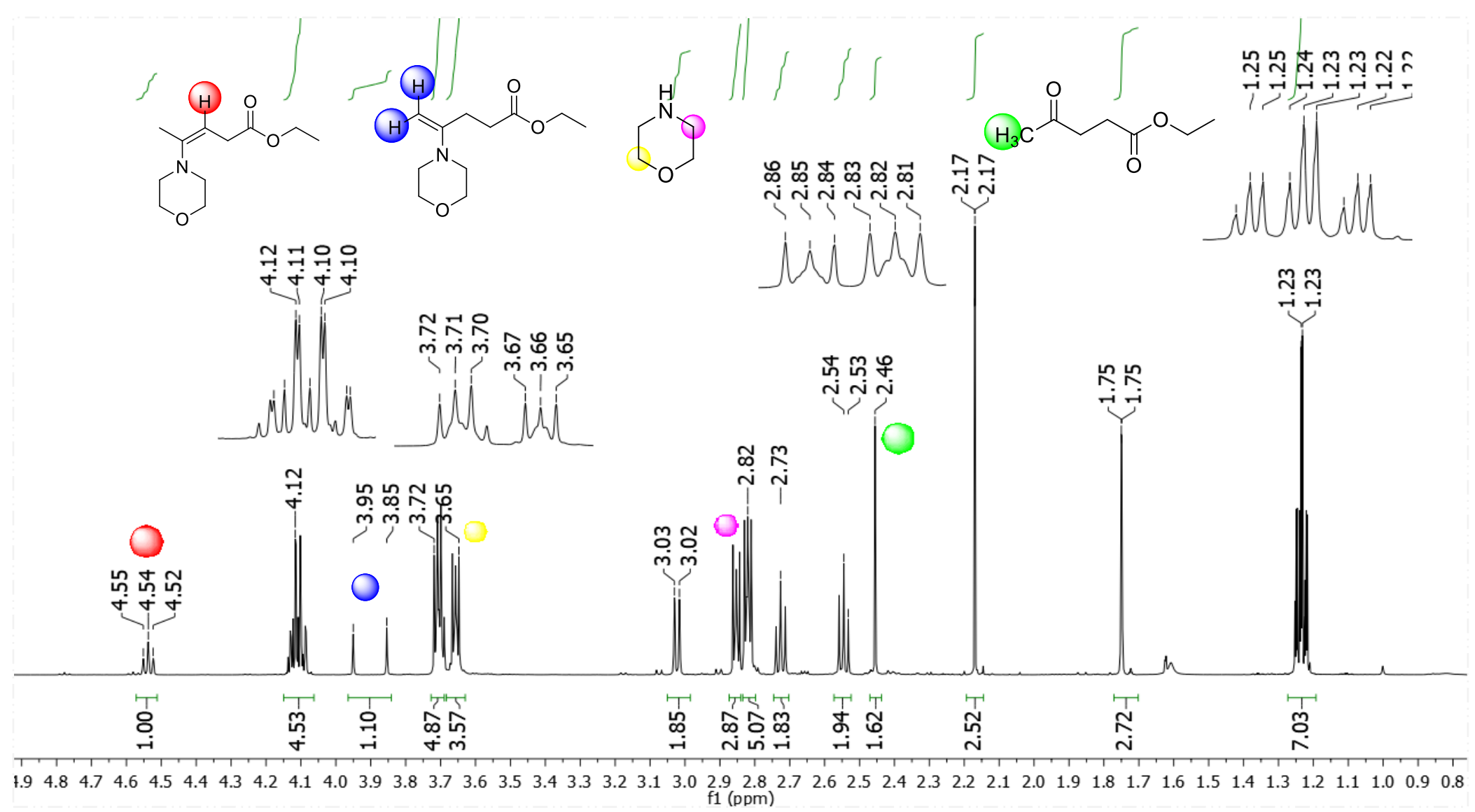




\section{Conclusões}

O estudo relatado neste capítulo mostrou-se como uma abordagem interessante para síntese de ciclopentadienos, ciclopentanos e seus derivados com alto grau de substituição (1,2,4-trissubstituídos), empregando-se reagentes e solventes de baixo custo e ambientalmente amigável. Nessa metodologia, utilizou-se como material de partida o levulinato de etila, um bloco de construção oriundo da biomassa, sendo possível obter um escopo contendo 10 moléculas novas.

Os ciclopentadienos foram alcançados por meio da formação dos intermediários (1a e 1b), obtido pela autocondensação entre duas moléculas do levulinato de etila. A aquisição deste intermediário aborda a formação de enaminas geradas no meio reacional. Nesta estratégia, o ciclopentadieno 1,2,4trissubstituído (composto 4) foi obtido pela reação de condensação intramolecular do intermediário, em meio básico, com rendimento global de aproximadamente $40 \%$, considerando a recuperação de $10 \%$ do levulinato de etila. Este ciclopentadieno mostrou-se extremamente promissor, como um bloco de construção versátil, para diversas aplicações reacionais na síntese orgânica. Obtiveram-se, por meio de 4, produtos com altos rendimentos nas reações de Diels-Alder (82-90\% de rendimento), formação de diazocompostos (88\% de rendimento), ciclopentanos (80-91\% de rendimento) e ésteres alílicos e propargílicos (60\% de rendimento). 
Um novo método para síntese de polióis de cadeia longa a partir da $\gamma$-valerolactona
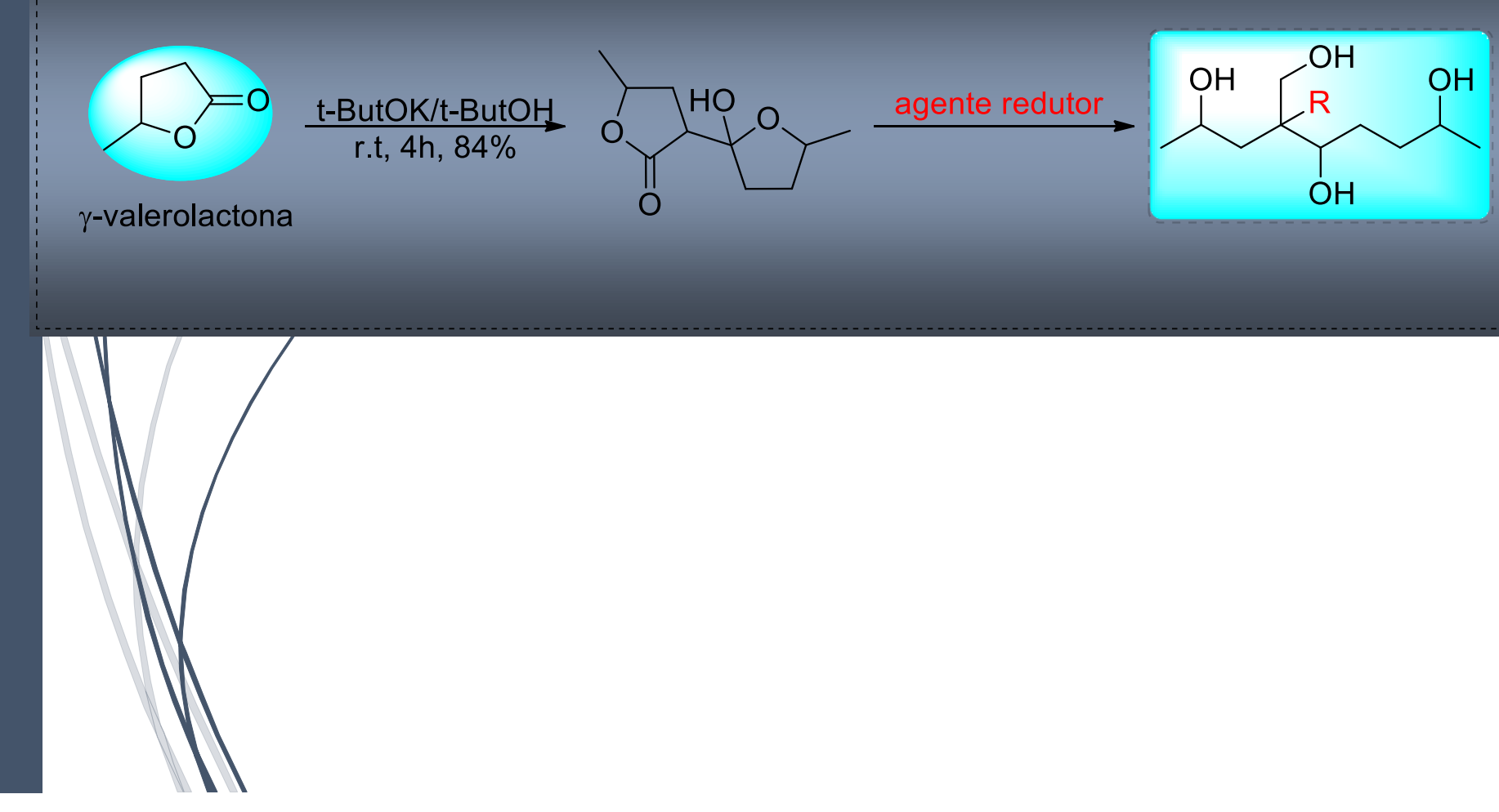


\section{INTRODUÇÃO}

\subsection{Obtenção da $\gamma$-valerolactona (GVL)}

A $\gamma$-valerolactona $(\mathbf{G V L})$ é um éster cíclico com 5 átomos de carbonos oriunda de fonte renovável como, por exemplo, o bagaço da cana-de-açúcar. ${ }^{81}$ Conforme já mencionado no capítulo 1 , a hidrólise da biomassa celulósica produz o ácido levulínico ( $\mathbf{A L}$ ) que proporciona acesso à GVL. A reação envolve a redução da carbonila do $\mathbf{A L}$ (ou seu éster, por exemplo, levulinato de etila ou metila) levando à formação do ácido 4hidroxivalérico (4-HVA ou do 4-hidróxiéster). Em seguida, há a esterificação intramolecular formando, rapidamente, a GVL e a liberação de uma molécula de água (Esquema 21). ${ }^{82}$ Outra possibilidade para obtenção da GVL consiste na reação de hidrogenação das angélicas lactonas, mas esta abordagem é pouco viável, pois o processo ocorre em temperaturas mais elevadas podendo favorecer a polimerização das angélicas lactonas e como isso diminuir o rendimento da reação. ${ }^{83}$

\section{Esquema 21- Conversão da biomassa em GVL}

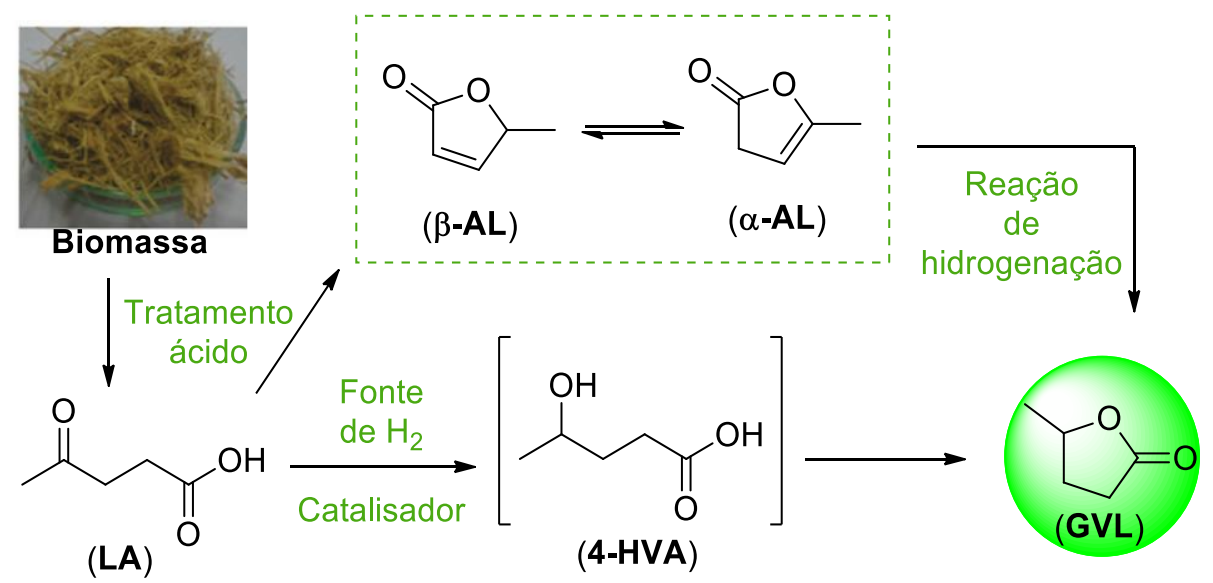

Considerando a importância da GVL como plataforma principal, muitas metodologias foram desenvolvidas para converter o LA em GVL. ${ }^{83-}$ 90. Basicamente, as metodologias envolvem reações de hidrogenação utilizando diferentes fontes de hidrogênio como, por exemplo, hidrogênio molecular, ácido fórmico ou álcoois juntamente com catalisadores 
metálicos homogêneos ou heterogêneos (podendo ocorrer em fase gasosa ou líquida) ${ }^{81-85}$

Um dos trabalhos pioneiros que aborda a hidrogenação do ácido levulínico em fase gasosa é a patente US2786852A (descrita por Dunlop e Madden, 1957). O processo é iniciado fazendo-se passar uma corrente de AL, vaporizado à $200^{\circ} \mathrm{C}$, em conjunto com $\mathrm{H}_{2}$ sobre o catalisador $\left(\mathrm{CuO} / \mathrm{Cr}_{2} \mathrm{O}_{3}\right)$ à pressão atmosférica. A obtenção da GVL foi reportada com um rendimento de $100 \% .{ }^{87}$

Outro trabalho que realiza a reação em fase gasosa é descrito por Upare et al. (2011). Os autores averiguaram a utilização de metais nobres (Ru, Pt, Pd), suportados em carbono ativado. O catalisador que apresentou o melhor desempenho foi o $\mathrm{Ru} / \mathrm{C}$, em consequência da maior dispersão do Ru no suporte de carbono, em comparação aos demais metais (Pt e Pd). A reação foi conduzida à $265{ }^{\circ} \mathrm{C}$, à pressão atmosférica, sendo comprovada a transformação com rendimento $>98 \% .88$

A reação realizada em fase gasosa é uma abordagem bastante atraente, porém, existem algumas desvantagens como, por exemplo, uso de temperaturas elevadas, implicando em um gasto maior de energia para vaporizar o ácido levulínico. Além disso, juntamente com o $\mathbf{A L}$, pode haver traços de ácidos inorgânicos fortes (provenientes do processo de formação do $\mathbf{A L}$ ) e sua vaporização torna-se outro ponto indesejado. Sendo assim, a formação da GVL em fase líquida é a mais desejável. ${ }^{89}$

O uso de hidrogênio molecular para hidrogenação do AL é a rota mais empregada devido à facilidade em separar o hidrogênio do produto final (GVL). Yan et al.(2009) ${ }^{90}$, demostram que catalisadores de Ru/C são superiores aos catalisadores de $\mathrm{Pd} / \mathrm{C}$, Niquel Urushibara e Niquel Raney. De acordo com os autores, a reação é desencadeada pela quimissorção do hidrogênio e do AL nos sítios ativos do catalisador de Ru. Enquanto o hidrogênio adsorve-se, de forma dissociativa, o ácido levulínico liga-se ao sítio ativo através do oxigênio da carbonila (representado em A no Esquema 22). Em sequência, há uma transferência de hidrogênio para o carbono da carbonila, ocorrendo a formação de um intermediário que se estabiliza através da ligação com o $R u$ (representado em B). O intermediário recebe outro hidrogênio levando à obtenção do ácido $\gamma$ hidróxivalérico (4-HVA), o qual sofre lactonização para gerar a GVL 
(representado em C). O catalisador pode ser utilizado em um ciclo de 4 vezes, sem diminuir o rendimento do processo, em condições reacionais brandas à 130 ${ }^{\circ} \mathrm{C}$ e 12 bar de $\mathrm{H}_{2 .}{ }^{90,91}$

Esquema 22-Formação da GVL catalisada por Ru/C

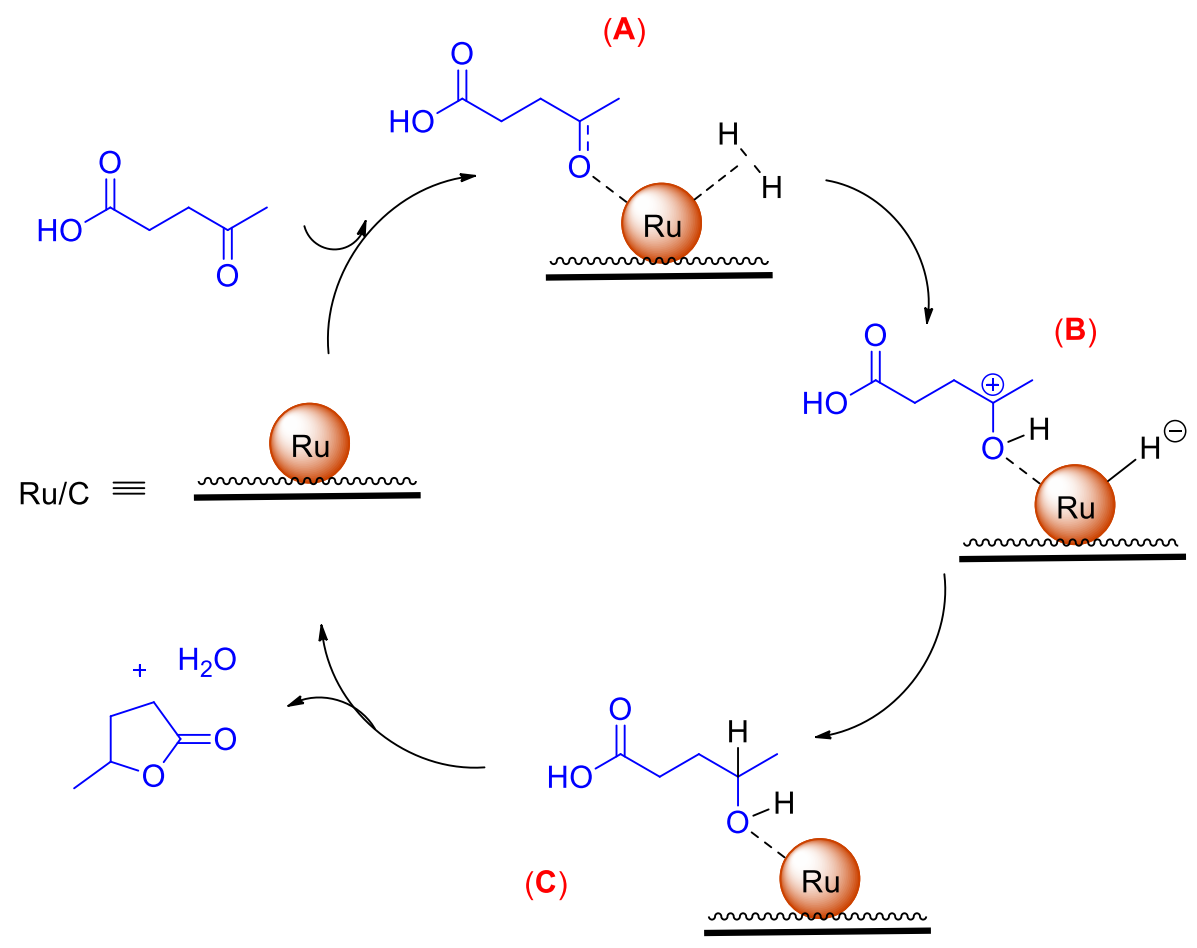

Adaptado de Liguori et al.(2015) ${ }^{91}$

O ácido fórmico (AF) é coproduzido em quantidade equimolar, juntamente com o AL, durante a hidrólise ácida da biomassa, conforme já mencionado no capitulo 1. Sendo assim, a utilização do ácido fórmico como fonte de hidrogênio é uma abordagem conveniente para a obtenção da GVL, pois o hidrogênio necessário para realizar a reação seria gerado in situ pela decomposição do ácido fórmico por um catalisador (geralmente a base de metais nobres). Deste modo, não haveria a necessidade de uso externo de uma fonte de hidrogênio, nem seria necessária uma etapa de purificação do AL para sua separação do AF. 92

A maioria das transformações envolvem o uso de catalisadores com os metais $\mathrm{Ru}, \mathrm{Ni}, \mathrm{Au}$ e outros. ${ }^{93}$ No trabalho reportado por Burtoloso et al.(2015) ${ }^{94}$, o AF é decomposto em $\mathrm{CO}_{2}$ e $\mathrm{H}_{2}$ empregando o catalisador de $\mathrm{Fe}_{3}(\mathrm{CO})_{12}$. A conversão do $\mathbf{A L}$ em GVL é obtida com $92 \%$ de rendimento 
em 15 horas à temperatura de $180^{\circ} \mathrm{C}$. Além disso, os autores relataram o uso do licor bruto (contendo $20 \%$ de $A L$ ), obtido pela hidrólise ácida do bagaço da cana-de-açúcar em uma escala piloto, para conversão diretamente em GVL com rendimento de $50 \%{ }^{94}$

Diversos trabalhos têm se destacado empregando a transformação via $\mathbf{A F}$, mas o grande desafio para utilizá-lo é o desenvolvimento de catalisadores que, além de serem ativos e seletivos, consigam resistir a um meio reacional contendo traços de ácidos inorgânicos. ${ }^{95}$

O uso de álcoois como fonte de hidrogênio é uma alternativa para a produção da GVL. A transferência catalítica de hidrogênio $(\mathrm{TCH})$ ocorre por meio da reação de Meerwein-Ponndorf-Verley (MPV), na qual o grupo cetona do AL é reduzido a seu respectivo álcool (4-HVA) na presença de um álcool secundário como doador de hidreto. Resumidamente, o hidreto é transferido por meio de um estado de transição de seis membros no qual o álcool e a cetona estão interagindo, simultaneamente, com o catalisador (Esquema 23). ${ }^{96}$

\section{Esquema 23- Representação da reação Meerwein-Ponndorf-Verley}

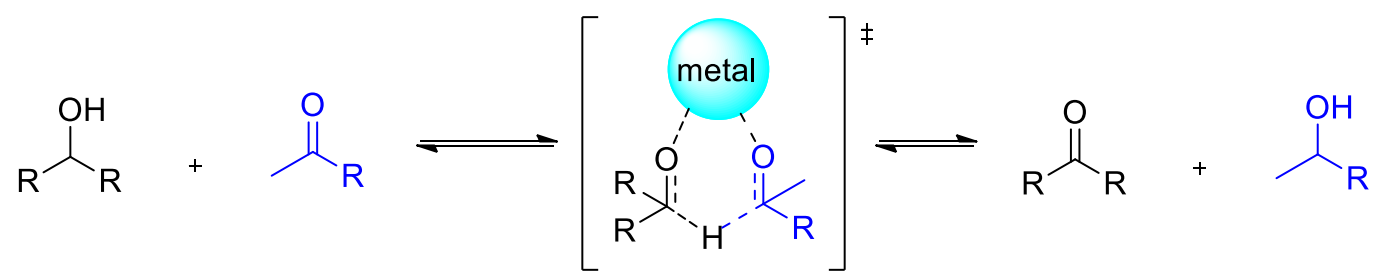

O primeiro trabalho envolvendo a formação de GVL via reação de MPV, a partir do AL e seus ésteres, foi relatado por Chia e Dumesic (2011) ${ }^{96}$ Neste trabalho, os autores avaliaram o uso de variados catalisadores heterogêneos $\left(\mathrm{ZrO}_{2}, \mathrm{MgO} / \mathrm{Al}_{2} \mathrm{O}_{3}, \mathrm{MgO} / \mathrm{ZrO}_{2}, \mathrm{CeZrOx}\right.$ e $\left.\mathrm{Y}-\mathrm{Al}_{2} \mathrm{O}_{3}\right)$ e uma série álcoois (1-butanol, 2-butanol, etanol e isopropanol). O óxido de zircônio apresentou melhor resultado, dentre os óxidos avaliados, empregando-se o 2-butanol como solvente. A transformação ocorreu com rendimento de $92 \%$ à 20 bar de pressão de He e temperatura de $150^{\circ} \mathrm{C} .{ }^{96}$ 


\subsection{Aplicações da $\gamma$-valerolactona (GVL)}

Variadas aplicações podem ser designadas para a GVL como, por exemplo, seu uso como solvente, aditivo para combustível, cosméticos e, ainda, como material de partida na síntese orgânica de uma variedade de compostos. $^{97-103} 1,4$ pentanodiol e 2-metiltetraidrofurano (2-MTHF) são alguns dos exemplos. ${ }^{102}$

O emprego da GVL como aditivo de gasolina, de forma semelhante ao etanol, foi demostrado por Horvath et al. (2008), no qual uma mistura com $10 \%$ (v/v) de GVL e 90\% (v/v) de gasolina apresentou octanagem de 89,2. Valor praticamente idêntico ao obtido quando o etanol é empregado $(89,3) \cdot{ }^{102}$ Já Ismalaj et al. (2014) mostraram o uso da GVL como um solvente alternativo aos polares apróticos oriundos de fontes não renováveis (por exemplo, DMF, tolueno, dioxano), comumente empregados nas reações orgânicas. ${ }^{98}$

A versatilidade da GVL também é aplicada na produção de alcanos com massa molecular variada (C18-C27) que podem ser empregados como combustível. A produção desses combustíveis verdes pode ser obtida pela conversão da GVL em ácido pentenóico. O ácido pentenóico é descarboxilado levando à formação de butenos que, em sequência, são oligorimerizados e convertidos em hidrocarbonetos de cadeia longa. Por exemplo, Bond et al. (2010) realizaram a conversão da GVL em isômeros de ácido pentenóico, empregando-se catalisador de $\mathrm{SiO}_{2} / \mathrm{Al}_{2} \mathrm{O}_{3}$, em reator operando à 36 bar na faixa de 225 a $375{ }^{\circ} \mathrm{C}$. Neste mesmo reator, os isômeros foram convertidos a butenos e $\mathrm{CO}_{2}$ através da descarboxilação dos ácidos (rendimento superior a 99\%). Por fim, a mistura de produtos obtida no primeiro reator era alimentada para um segundo reator, que continha catalisadores ácidos (por exemplo, Amberlyst-70). Nesse reator, ocorre a reação de oligomerização levando à formação dos alcanos de alta massa molecular (rendimento global de 75\%). ${ }^{99}$ (Figura 31)

A partir GVL, na presença do catalisador $\mathrm{Pt}(0,1 \%) / \mathrm{Nb}_{2} \mathrm{O}_{5}$, Serrano-Ruiz et al.(2010) propuseram uma reação de cetonização para promover a formação da 5-nonanona. A abertura da GVL leva à formação de ácido pentenóico que é, simultaneamente, hidrogenado ao ácido pentanóico. O ácido pentanóico é então submetido à reação de cetonização na presença do catalisador de cério-zircônia (CeZrOx). A 5-nonanona é hidrogenada com catalisadores de $\mathrm{Ru} / \mathrm{C}$ para a 
formação dos alcanos C9 que podem ser empregados como aditivo de diesel. ${ }^{100}$ Em outro estudo, Alonso et al. (2010) relataram a conversão da 5-nonanona ao seu respectivo álcool (5-nonanol) e, subsequente, desidratação empregando-se catalisador ácido (amberlyst-70) conduziu à formação dos isômeros do noneno. Os nonenos foram oligorimerizados transformando-se em alcenos com até 18 carbonos $^{101}$ (Figura 31).

Figura 31- Algumas aplicações da GVL

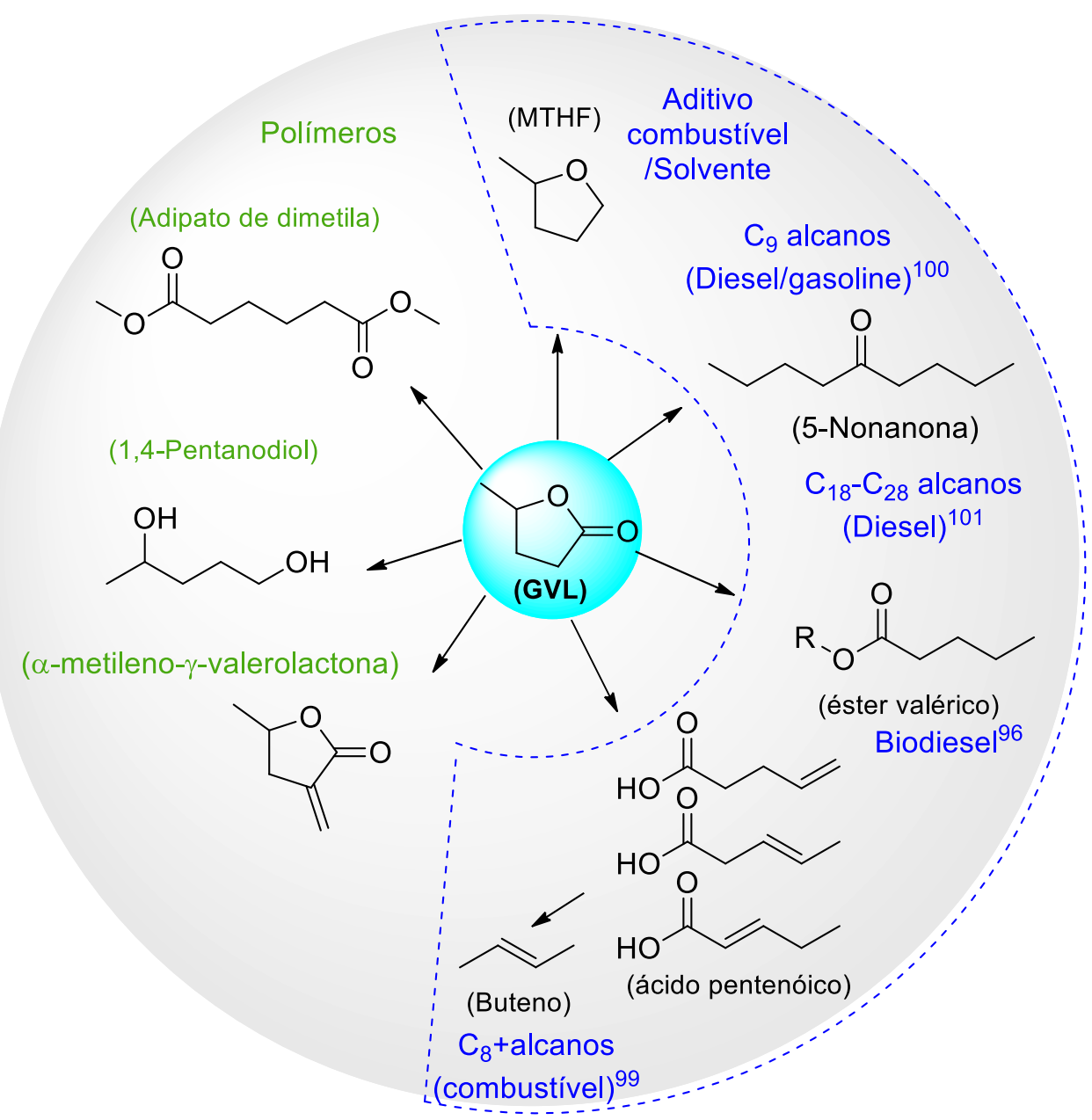

Além das aplicações demostradas, ainda há uma grande quantidade de aplicações cujo objetivo é converter a GVL em outros produtos de maior valor agregado e de grande interesse como, por exemplo, a transformação em adipato de metila, 1,2-pentanodiol e $\alpha$-metileno- $\gamma$-valerolactona, que são precursores para obtenção de polímeros. ${ }^{101-104}$ 
Embora exista um crescimento exponencial no interesse em utilizar a biomassa como matéria-prima renovável para produzir combustíveis e produtos químicos, os principais constituintes produzidos a partir da biomassa são limitados a 5 ou 6 carbonos em suas estruturas. ${ }^{105}$ Neste sentido, métodos que permitirão acesso a esqueletos com unidades de carbonos maiores serão de crucial importância para desenvolver outras moléculas com alto valor agregado. Também, ainda que tenha crescido o interesse no uso de plataformas químicas oriundas da biomassa, na produção de moléculas mais complexas e promissoras, é escasso o uso de tais plataformas para a produção de polióis com cadeia carbônica longa.

\subsection{Síntese de polióis ${ }^{a}$}

Os polióis são uma importante classe de compostos orgânicos, distribuídos no reino vegetal e animal de forma abundante. Apesar de serem uma classe de compostos encontrada na natureza sua extração torna-se economicamente inviável devido a baixas concentrações. Assim, os polióis são obtidos, na sua maioria, através de transformações químicas ou biológicas dos oligossacarídeos. Essas, apesar de serem transformações interessantes do ponto de vista econômico e industrial, ainda se limitam à obtenção de polióis com cadeias contendo de 2 a 6 átomos de carbonos como, por exemplo os glicóis sorbitol, xilitol e eritritol. Além disso, mesmo o material de partida sendo proveniente de uma fonte renovável, o uso direto desses monômeros de carboidrato é difícil devido à grande quantidade da função hidroxila nestes compostos, o que limita também sua utilidade sintética. ${ }^{106-108}$

Quando se trata de polióis com 2 e 3 átomos de carbonos, o 1,3propanodiol e etilenoglicol são os mais almejados. Esses são importantes monômero na síntese de fibras de poliéster e poliurenatanas. ${ }^{109-110}$ O 1,3propanodiol pode ser obtido industrialmente através de processos fermentativos usando xarope de milho ou glicerol de recursos renováveis. ${ }^{111}$ Por outro lado, o etilenoglicol ainda é obtido industrialmente por fontes não renováveis. Recentemente, Beydoun et al.(2020) ${ }^{112}$ fez uso destes e outros polióis para a produção de acetais cíclicos de valor agregado que podem servir como

aReproduzido em partes com permissão a partir de A. S. VIEIRA, A. C. B. BURTOLOSO, C.C. S. P. SOARES e C.S. SANTOS. PROCESSO PARA OBTENÇÃO DE POLIÓIS COM ALTO VALOR AGREGADO A PARTIR DA BIOMASSA E SUAS POSSÍVEIS APLICAÇÕES. Patente BR 1020200216694. 
solventes, aditivos para combustíveis, intermediários farmacêuticos e materiais monoméricos para reação de polimerização. ${ }^{112}$

Outra importante utilização dos polióis é como agente plastificante, substância incorporada a um material rígido usada para aumentar a flexibilidade e conformidade. ${ }^{113}$ Por exemplo, o 1,2,5-pentanotriol é um agente plastificante obtido a partir do álcool do furfural, um derivado da biomassa. ${ }^{114}$ Seu uso foi consolidado por meio da patente americana US2476976 em 1949 que utilizou o poliol como plastificante para alguns materiais derivados do polivinil: acetato de polivinil (PVA), cloreto de polivinil (PVC) e outros produtos similares. ${ }^{115}$

A obtenção do 1,2,5-pentanotriol, a partir do álcool furfurílico, envolve a formação do 6-hidroxi-(2H)-piran-3(6H)-ona (6-HPO) como intermediário por meio do rearranjo de Achmatowicz (figura 32). Esse intermediário sofre redução levando ao triol desejado. Simeonov et al.(2019), por exemplo, reportaram a síntese do 1,2,5-pentanotriol, a partir da plataforma furânica citada, com rendimentos acima de 91\%. Empregou-se na transformação Ru/C como catalisador em um processo contínuo de três etapas. ${ }^{116,117}$

Figura 32- Rearranjo de Achmatowicz para formação do 1,2,5-pentanotriol
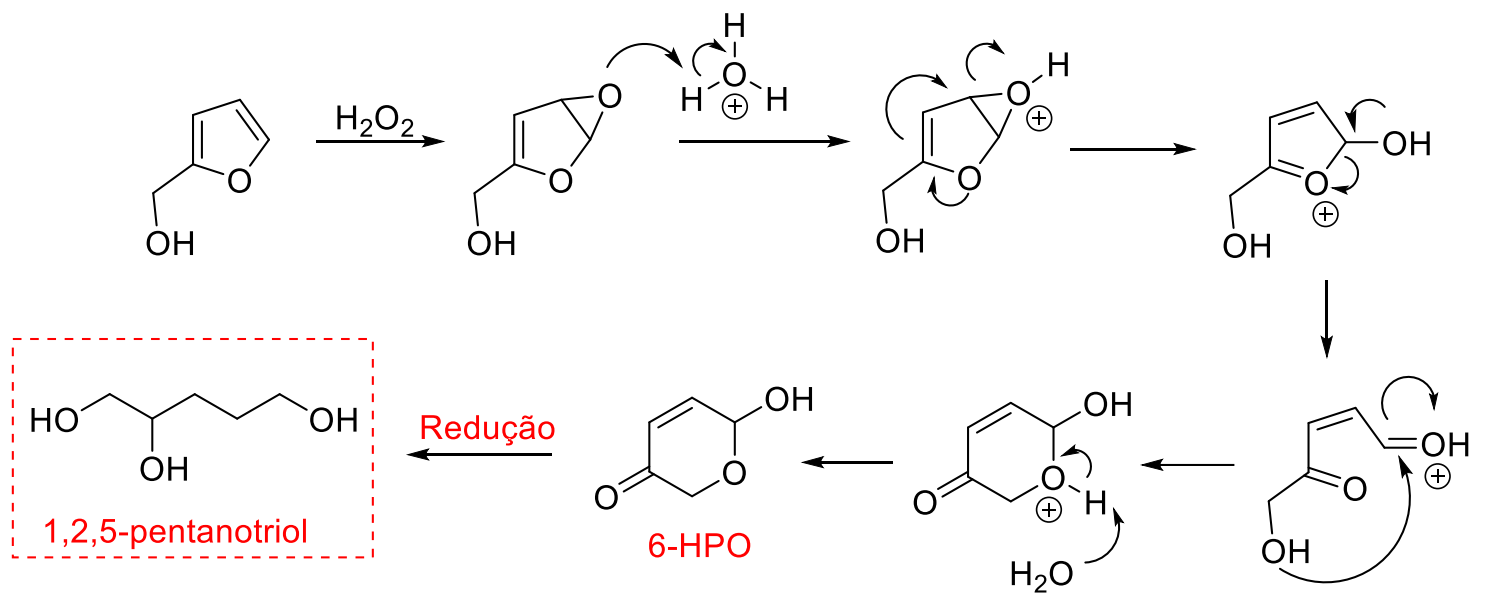

Poucos processos para a produção de polióis, partindo de uma fonte renovável, são encontrados na literatura. A publicação internacional WO 2019/204753 A1 apresenta um processo para a produção de um poliol contendo 6 átomos de carbonos a partir da levoglucosenona. Essa estratégia requer a presença de $\mathrm{H}_{2}$ e do catalisador $\mathrm{Pt} / \mathrm{SiAl}$, em altas temperaturas e pressões. Tal 
metodologia, produziu-se o 1,2,5,6-hexanotetrol com aproximadamente $90 \%$ de rendimento. ${ }^{118}$ (Esquema 24).

Esquema 24- Formação do 1,2,5,6-Hexanotetrol

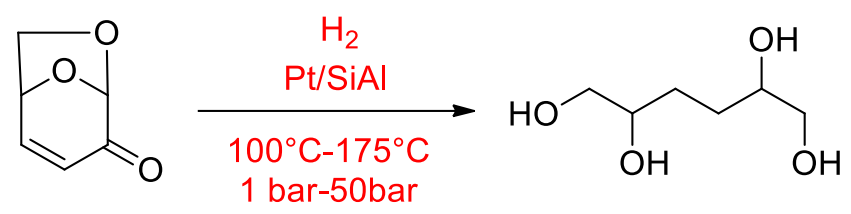

A patente americana US 9199961 B2 e a publicação internacional WO 2011/149339 A1, descrevem um método para produzir 1,2,6-hexanotriol e 1,6haxanodiol a partir do 5 -hidroximetilfurfural em 2 etapas. A reação ocorre na presença de $\mathrm{H}_{2}$, Ni Raney como catalisador e em condições de altas temperaturas e pressão. ${ }^{119}$

O pedido de patente americano US 2014/0275638 A1 relata um procedimento para produzir uma mistura de polióis (trióis e dióis), por meio de uma reação de hidrodeoxigenação em fase aquosa, a partir de um reagente derivado de biomassa (sorbitol). Seu processo é feito utilizando diferentes catalisadores metálicos ( $\mathrm{Pt}, \mathrm{Re}, \mathrm{Ir}, \mathrm{Zr}$ ) heterogêneos bifuncionais a altas temperaturas. Outras patentes também foram publicadas, porém para produzir polióis contendo de 2 a 4 átomos de carbonos (patente WO2006092085A1). ${ }^{120}$

Dessa forma, percebe-se que atualmente não existem registros de polióis com longa cadeia carbônica oriundos de fontes renováveis. Além disso, as patentes mencionadas utilizam catalisadores metálicos caros, a maioria não apresenta rendimentos elevados e, ainda, condições experimentais não tão aprazíveis ao meio ambiente. Neste capítulo, é apresentado um novo método para obtenção de polióis de cadeia longa partindo da GVL. ${ }^{121}$ 


\section{OBJETIVOS}

\subsection{Objetivo geral}

Propõe-se no segundo capítulo deste trabalho, utilizar a $\gamma$-valerolactona para síntese de polióis de cadeia longa.

\subsection{Objetivos específicos}

2.2.1. Explorar a utilização de diferentes bases para obter o produto de condensação de Claisen entre 2 moléculas da $\gamma$-valerolactona (GVL);

2.2.2. Desenvolver uma rota sintética para síntese de polióis partindo do produto de condensação de Claisen;

2.2.3. Estudar reações para aumentar a cadeia carbônica dos polióis obtidos; 


\section{RESULTADOS E DISCUSSÕES}

\subsection{Estudo de bases para reação de condensação de Claisen entre duas moléculas da GVL}

A proposta inicial deste capítulo foi baseada na reação de Claisen que ocorreria entre duas moléculas da GVL originando um composto dicarbonilado (conforme ilustrado no esquema 25). Porém, na prática, observou-se que há formação do hemiacetal 18 e/ou do seu produto de desidratação 19, a depender das condições de work-up. Sendo assim, realizou-se a otimização experimental para favorecer à obtenção de 18 (na tabela 14, são expostos os resultados).

\section{Esquema 25- Proposta para reação de Claisen}

Proposta inicial:

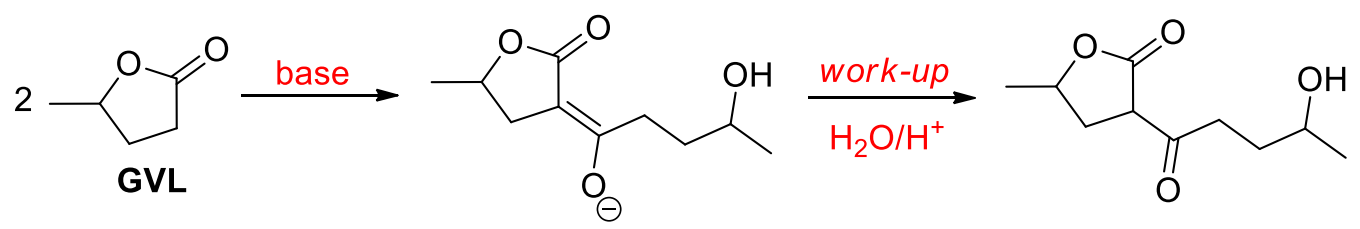

Observado na prática:

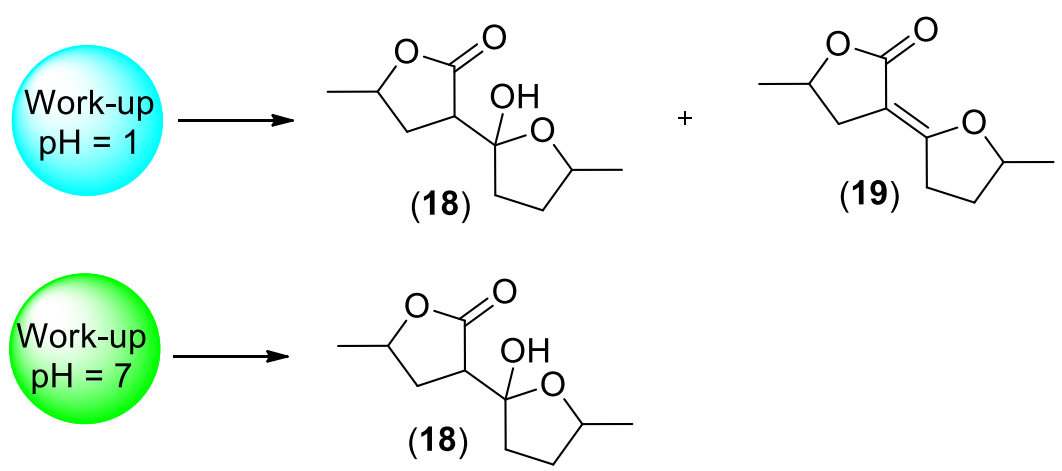

Inicialmente, optou-se por utilizar uma base forte e de baixo custo, etóxido de sódio. O primeiro experimento foi realizado, na concentração de $1 \mathrm{M}$, com aquecimento à $78^{\circ} \mathrm{C}$ por 15 horas (entrada 1, tabela 14). Em tais condições não houve consumo da GVL. Depois, a quantidade da base e a concentração do meio de reação foram aumentadas, novamente, o consumo do material de partida não foi observado, nem com aquecimento ou à temperatura ambiente (entradas 2-3). Na entrada 4, o meio reacional foi diluído e a extração da reação 
foi realizada com solução $1 \mathrm{M}$ de $\mathrm{HCl}_{(\text {(aq) }}(\mathrm{pH}=1)$. Nessas condições, foi obtido rendimento menor que $16 \%$ para formação do composto 19 . Na entrada 5 , começando com 0,5 equivalentes da base e após 5 horas de reação foi adicionado mais 0,2 equivalentes de sódio, para gerar etóxido de sódio in situ, a formação de 19 foi observada com $50 \%$ de rendimento.

$\mathrm{O}$ uso de uma base mais forte que EtONa como, por exemplo, $t$-BuOK foi explorada, juntamente, com a mistura de solventes (tolueno/ t-BuOH (1:1)), no entanto, apenas 3\% de 18 foi formado e 49\% de 19 (entrada 6). Em sequência, foi realizada a reação com apenas $t-\mathrm{BuOH}$ como solvente, em meio mais concentrado à temperatura ambiente, resultando em um rendimento menor que o obtido anteriormente. A mistura foi formada com 26\% de 18 e 19\% de 19.

Nas entradas 8 e 9, ao modificar a forma de work-up da reação de solução de $\mathrm{HCl}_{(\mathrm{aq})}$ para o uso de solução de ácido acético $10 \%(\mathrm{pH}=7$ do meio de reação), houve a formação, somente, do produto $18 \mathrm{com}$ excelente rendimento (85\%). Esses resultados indicaram que o pH para extração é muito importante para formação do produto desejado (18). Ao repetir o experimento em meio mais concentrado, $20 \mathrm{M}$, obteve-se o mesmo rendimento (85\%), porém a alta concentração torna o meio reacional muito viscoso e difícil de manusear (entradas 10). Ao modificar a estequiometria da reação, utilizando 0,5 equivalentes da base, o rendimento da reação diminuiu para $72 \%$ (entrada11).

Modificando o solvente para DMSO ou 2-metiltetra-hidrofurano (2-MTHF), o produto 18 é formado com $73 \%$ ou $72 \%$, respectivamente. Porém, quando se utilizou DMSO o meio reacional ficou sólido, impossibilitando a continuação do experimento (entradas 12 e 13). $\mathrm{O}$ uso da base $\mathrm{NaOH}$ também foi explorado, mas a GVL não foi consumida (entrada 14). Nas entradas 15 e 16, o MeONa foi utilizado em Metanol ou DMSO, mas o rendimento do produto 18 foi inferior à $20 \%$. 
Tabela 14- Otimização das condições reacionais para formação de 18

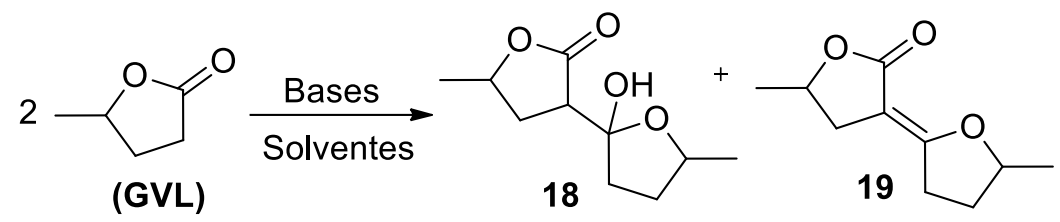

\begin{tabular}{|c|c|c|c|c|c|}
\hline Entrada & Solventes $^{d}$ & $\begin{array}{c}\text { Bases } \\
\left(n^{\circ} . \text { Eqv) }\right.\end{array}$ & [GVL] & $\begin{array}{l}\text { Temperatura- } \\
\text { tempo }\end{array}$ & $18 / 19(\%)^{a}$ \\
\hline 1 & $\mathrm{EtOH}$ & $\begin{array}{c}\text { EtONa } \\
(0,5)\end{array}$ & $1 \mathrm{M}$ & $78^{\circ} \mathrm{C}-15 \mathrm{~h}$ & $0 / 0$ \\
\hline 2 & $\mathrm{EtOH}$ & $\begin{array}{c}\text { EtONa } \\
(0,6)\end{array}$ & $5 \mathrm{M}$ & $78{ }^{\circ} \mathrm{C}-15 \mathrm{~h}$ & $0 / 0$ \\
\hline 3 & $\mathrm{EtOH}$ & $\begin{array}{c}\text { EtONa } \\
(0,6)\end{array}$ & $5 \mathrm{M}$ & $25^{\circ} \mathrm{C}-15 \mathrm{~h}$ & $0 / 0$ \\
\hline $4^{b}$ & $\mathrm{EtOH}$ & $\begin{array}{c}\text { EtONa } \\
(0,6)\end{array}$ & $2 \mathrm{M}$ & $78{ }^{\circ} \mathrm{C}-2 \mathrm{~h}$ & $0 / 16$ \\
\hline $5^{b}$ & $\mathrm{EtOH}$ & $\begin{array}{c}\text { EtONa } \\
(0.7)\end{array}$ & $5 \mathrm{M}$ & $78^{\circ} \mathrm{C}-8,5 \mathrm{~h}$ & $0 / 50$ \\
\hline $6^{\mathrm{b}}$ & $\begin{array}{c}\text { Tolueno/ } \\
t \text {-BuOH (1:1) }\end{array}$ & $\begin{array}{c}t \text {-BuOK } \\
(0,6)\end{array}$ & $1 \mathrm{M}$ & $80^{\circ} \mathrm{C}-2 \mathrm{~h}$ & $3 / 49$ \\
\hline $7^{\mathrm{b}}$ & $t-\mathrm{BuOH}$ & $\begin{array}{c}t \text {-BuOK } \\
(0,6)\end{array}$ & $3 \mathrm{M}$ & $25^{\circ} \mathrm{C}-1 \mathrm{~h}$ & $26 / 19$ \\
\hline $8^{c}$ & $t$-BuOH & $\begin{array}{c}t \text {-BuOK } \\
(0,6)\end{array}$ & $3 \mathbf{M}$ & $25^{\circ} \mathrm{C}-5 \mathrm{~h}$ & $85 / 0$ \\
\hline $9^{c}$ & $t$-BuOH & $\begin{array}{c}t \text {-BuOK } \\
(0,6)\end{array}$ & $5 \mathrm{M}$ & $25^{\circ} \mathrm{C}-4 \mathrm{~h}$ & $84 / 0$ \\
\hline $10^{c}$ & $\mathrm{t}-\mathrm{BuOH}$ & $\begin{array}{c}t \text {-BuOK } \\
(0,6)\end{array}$ & $20 \mathrm{M}$ & $25^{\circ} \mathrm{C}-4 \mathrm{~h}$ & $85 / 0$ \\
\hline $11^{\mathrm{c}}$ & $t-\mathrm{BuOH}$ & $\begin{array}{c}t \text {-BuOK } \\
(0,5)\end{array}$ & $3 \mathrm{M}$ & $25^{\circ} \mathrm{C}-5 \mathrm{~h}$ & $72 / 0$ \\
\hline $12^{c}$ & DMSO & $\begin{array}{c}t \text {-BuOK } \\
(0,6)\end{array}$ & $3 \mathrm{M}$ & $25^{\circ} \mathrm{C}-5 \mathrm{~h}$ & $73 / 0$ \\
\hline $13^{c}$ & 2-MTHF & $\begin{array}{c}t \text {-BuOK } \\
(0,6)\end{array}$ & $3 \mathrm{M}$ & $25^{\circ} \mathrm{C}-5 \mathrm{~h}$ & $72 / 0$ \\
\hline $14^{\mathrm{c}}$ & DMSO & $\begin{array}{c}\mathrm{NaOH} \\
(0,5)\end{array}$ & $3 \mathrm{M}$ & $100^{\circ} \mathrm{C}-1,5 \mathrm{~h}$ & $0 / 0$ \\
\hline $15^{c}$ & $\mathrm{MeOH}$ & $\begin{array}{c}\mathrm{MeONa} \\
(0,6)\end{array}$ & $3 \mathrm{M}$ & $25^{\circ} \mathrm{C}-5 \mathrm{~h}$ & $14 / 0$ \\
\hline $16^{c}$ & DMSO & $\begin{array}{c}\mathrm{MeONa} \\
(0,6)\end{array}$ & $3 \mathrm{M}$ & $25^{\circ} \mathrm{C}-15 \mathrm{~min}$. & $17 / 0$ \\
\hline
\end{tabular}

Com as condições experimentais otimizadas, foi realizada a produção, em larga escala, do composto 18 a partir de $1 \mathrm{~mol}$ da GVL (usando as condições da entrada 10, tabela 14) sob agitação mecânica (figura 33). Assim, o produto desejado foi obtido com o mesmo rendimento $(85 \%)$. Vale ressaltar que para reação em pequena escala (1-5 g GVL) são utilizadas as condições da entrada 
9, pois em condições mais concentradas a reação é altamente viscosa e difícil de manusear, causando perda de material. Na escala de $1 \mathrm{~mol}$ da GVL não foi necessário o uso de solvente anidro.

Figura 33- A) Adição do t-butóxido de potássio à $0^{\circ} \mathrm{C}$; B) Agitação mecânica por 4h; D) final da reação

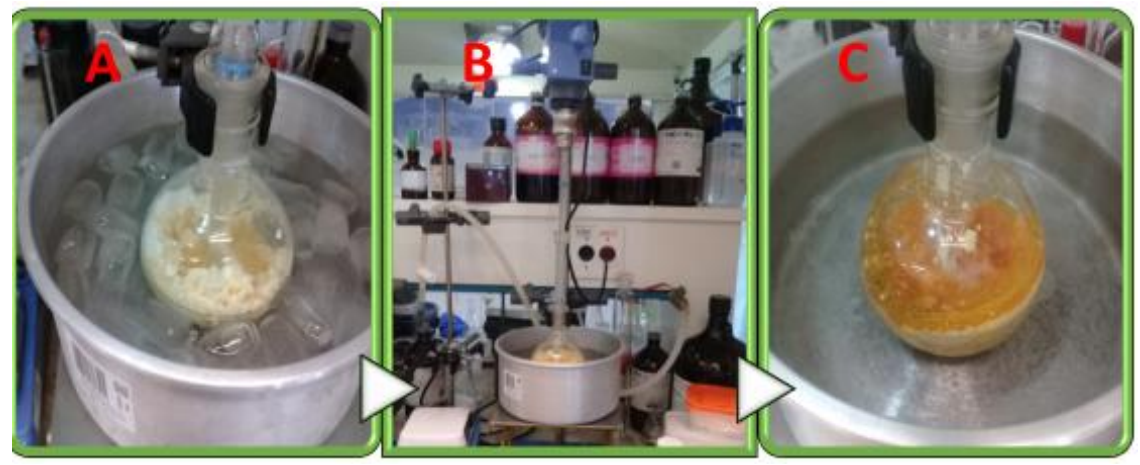

Além disso, investigamos a possibilidade de formar 18 sem o uso de solventes (Tabela 15). Nos testes realizados, na escala de $5 \mathrm{mmol}$ da GVL, 0 produto desejado foi obtido com rendimento inferior (50-76\%) ao procedimento utilizando solvente (82-85\% de rendimento). Nas entradas 1-3, são apresentados os resultados. Ao realizar o experimento com BDU, EtONa ou $\mathrm{K}_{2} \mathrm{CO}_{3}$ como base, a GVL mante-se inconsumível (entradas 4-6).

Tabela 15- Reação sem solvente para formação de 18

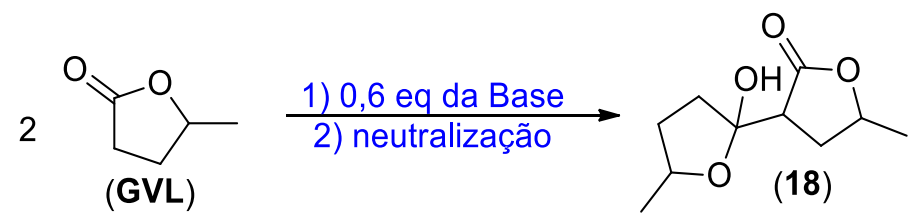

\begin{tabular}{cccc}
\hline Entradas $^{\mathbf{a}}$ & Bases (n'. Eqv) $^{\circ}$ & Temperatura - tempo & $\mathbf{1 8 ~ ( \% )}$ \\
\hline $1^{\mathrm{c}}$ & $\mathrm{t}$-BuOK $(0,6)$ & $100^{\circ} \mathrm{C}-1,5 \mathrm{~h}$ & 76 \\
$2^{\mathrm{c}}$ & $t$-BuOK $(0,6)$ & $25^{\circ} \mathrm{C}-1 \mathrm{~h}$ & 61 \\
$3^{\mathrm{d}}$ & $t$-BuOK $(0,6)$ & $25^{\circ} \mathrm{C}-1 \mathrm{~h}$ & 50 \\
$4^{\mathrm{c}}$ & $\operatorname{EtONa}(0,6)$ & $25^{\circ} \mathrm{C}$ ou $65^{\circ} \mathrm{C}-15 \mathrm{~h}$ & -- \\
$5^{\mathrm{c}}$ & $\mathrm{DBU}(0,6)$ & $25^{\circ} \mathrm{C}$ ou $65^{\circ} \mathrm{C}-15 \mathrm{~h}$ & -- \\
$6^{\mathrm{c}}$ & $\mathrm{K}_{2} \mathrm{CO}_{3}(0,6)$ & $25^{\circ} \mathrm{C}$ ou $65^{\circ} \mathrm{C}-15 \mathrm{~h}$ & -- \\
\hline a Condições de reação: $G V L\left(5\right.$ mmol). ${ }^{b}$ Rendimento isolado. ${ }^{\circ}$ agitação em balão. ${ }^{d}$ Maceração em \\
cadinho de porcelana.
\end{tabular}

Para formação de 18, a primeira etapa da reação envolve a condensação de Claisen entre duas moléculas de GVL, levando ao intermediário A. Após work- 
up, é formado o intermediário B (Aduto de Claisen-forma enólica), que a depender do $\mathrm{pH}$ do meio fornece apenas o produto 18 ou mistura dos produtos 18 e 19. O composto 18 é facilmente desidratado, em $\mathrm{pH}=1$, ocorrendo a eliminação da molécula de $\mathrm{H}_{2} \mathrm{O}$ pelo mecanismo $\mathrm{E} 1$, o que leva à formação de 19 (Figura 34).

Figura 34- Proposta mecanística para formação de 18 e 19

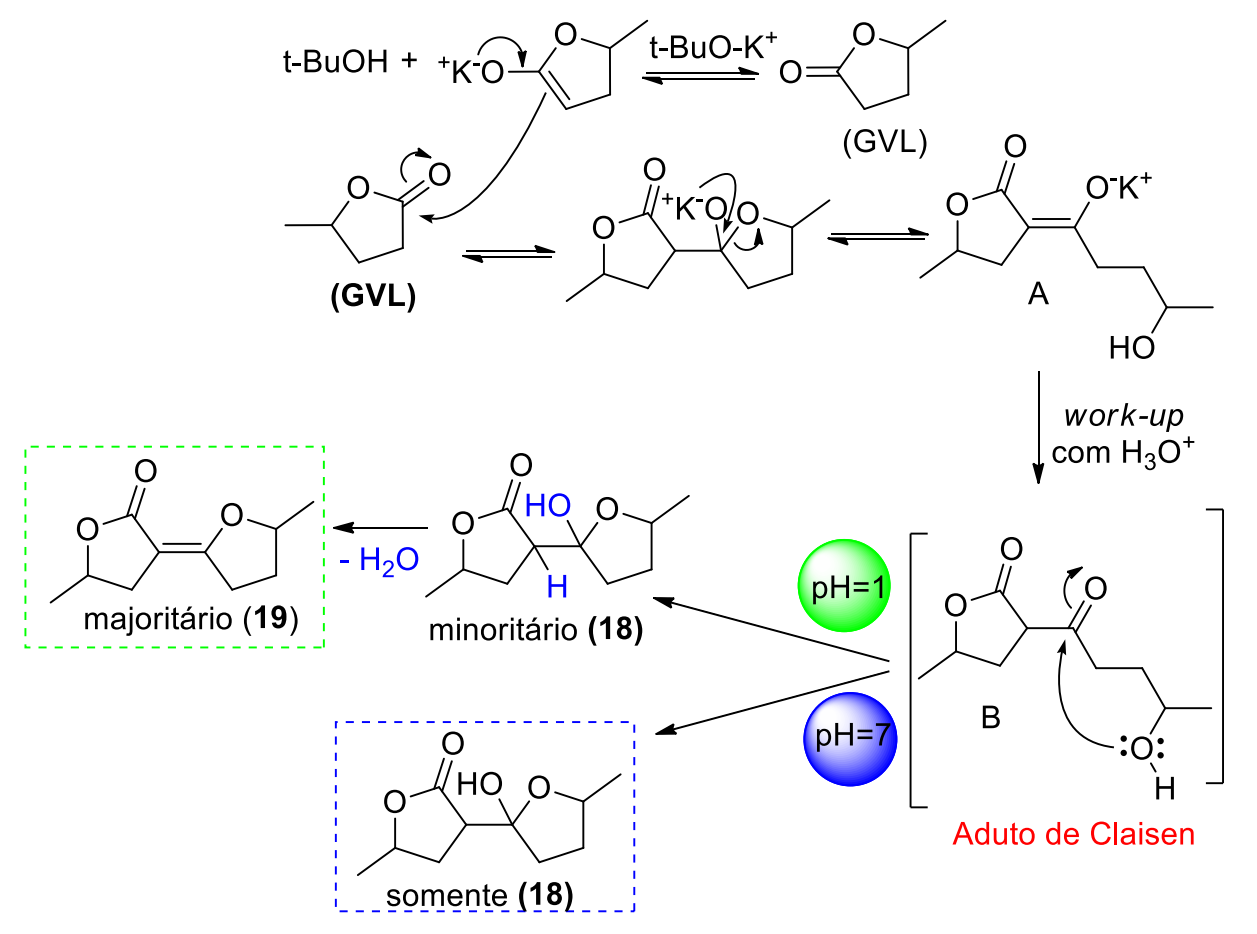

O composto 18, já isolado, foi submetido às condições clássicas da reação de desidratação catalisada pelo ácido $p$-toluenosulfônico ou uma "alternativa verde" com o uso da resina ácida Amberlyst $15^{\circledR}$ (Esquema 26). Com o uso da resina, obteve-se o composto 19 com excelente rendimento (>98\%), sem a necessidade de purificação prévia. Além disso, a resina é facilmente separável da mistura reacional e pode ser reutilizada novamente. Por outro lado, o produto é formado com $90 \%$ de rendimento quando se utilizou o ácido $p$-toluenosulfônico e, também, é necessário purificação por coluna cromatográfica do bruto reacional.

Reduzindo a ligação dupla do composto 19, obteve-se o composto 20 (Esquema 26) com rendimento de $80 \%$ através de uma reação de hidrogenação catalisada por $\mathrm{Pd} / \mathrm{C}$, à temperatura ambiente, sob pressão atmosférica (1 atm). 
O composto 20 poderá ser empregado na obtenção de polióis ou outras aplicações que possibilitem a extensão da cadeia carbônica.

Esquema 26- Alguns compostos preparados a partir de 18

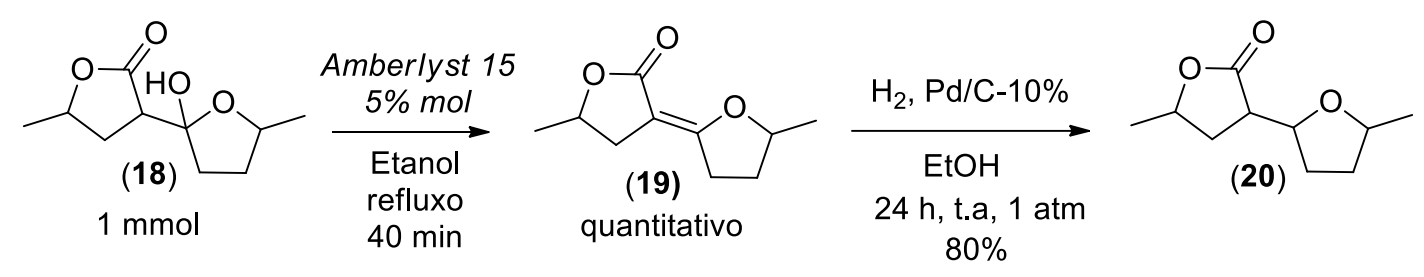

\section{2. $\quad$ Estudo para formação do poliol 21}

Os estudos foram iniciados com a mistura $\mathrm{NaBH}_{4} / \mathrm{CaCl}_{2}$, para gerar o agente redutor $\mathrm{Ca}\left(\mathrm{BH}_{4}\right)_{2}$ in situ, em condições anidras. Nessa tentativa, o poliol $\mathbf{2 1}$ foi obtido com $40 \%$ de rendimento, conforme mostrado na tabela 16, entrada 1 . Dobrando-se a carga do agente redutor, o rendimento manteve-se próximo à $35 \%$.

Quando se empregou $\mathrm{LiAlH}_{4}$ como agente redutor, o produto de interrese não foi formado, sendo obtida a formação de uma mistura complexa de compostos. $\mathrm{Na}$ entrada 4, utilizou-se $\mathrm{NaBH}_{4}$ (3 equivalentes) e $\mathrm{MeOH}$ como solvente, contudo não houve melhora no rendimento. Ao utilizar etanol como solvente e dividir a adição de $\mathrm{NaBH}_{4}$ em duas porções, o rendimento foi de $43 \%$ (entrada 5). Adicionando-se 4 equivalentes de $\mathrm{NaBH}_{4}$ dividido em duas porções iguais, ou seja, no início da reação foi adicionado 2 equivalentes de $\mathrm{NaBH}_{4} \mathrm{e}$ após 30 minutos, adicionou-se mais 2 equivalentes, o poliol foi formado com $85 \%$ de rendimento (entrada 6). O meio reacional foi concentrado para 0,2 M (entrada 7), mas, praticamente, o mesmo rendimento foi obtido (81\%).

$\mathrm{O}$ uso de $\mathrm{LiBH}_{4}$, também, foi testado, mas não houve melhoria no rendimento (entrada 8). Investigou-se a posibilidade de formar o composto $21 \mathrm{sem}$ a utilização de solvente, obteve-se, porém, apenas $30 \%$ do poliol. Devido a alta viscosidade do meio reacional, a mistura tornou-se sólida impossibilitanto a contituidade do experimento. De posse destes dados, realizou-se um experimento (em escala ampliada) sem a necessidade de condições anidras e sem a purificação do composto 18, assim foi possível ober o poliol $21 \mathrm{com} 71 \%$ 
de rendimento partindo de $1 \mathrm{~mol}(100 \mathrm{~g})$ da GVL. Vale ressaltar que quando o experimento é realizado partindo de $20 \mathrm{~g}$ da GVL, é necessário utilizar condições anidras pra manter o rendimento próximo à $80 \%$. Na figura 35 é apresentado o espectro de RMN de ${ }^{1} \mathrm{H}$ do composto 21.

Tabela 16-Otimização das condições para formação do poliol $21^{\text {a }}$<smiles>CC1CC(C2(O)CCC(C)O2)C(=O)O1</smiles>

(18)<smiles>[Z10]C(CC(C)O)C(O)CCC(C)O</smiles>

(21)

\begin{tabular}{|c|c|c|c|c|}
\hline Entradas & Agente redutor (eqv) & Solventes & $T(h)$ & $21(\%)^{d}$ \\
\hline $1^{b}$ & $\mathrm{NaBH}_{4}(2,4) / \mathrm{CaCl}_{2}(1,2)$ & Etanol & 2 & 40 \\
\hline $2^{b}$ & $\mathrm{NaBH}_{4}(4,8) / \mathrm{CaCl}_{2}(2,4)$ & Etanol & 2 & 35 \\
\hline $3^{b}$ & $\mathrm{LiAlH}_{4}(2,5)$ & THF & 1 & -- \\
\hline $4^{b}$ & $\mathrm{NaBH}_{4}(3)$ & $\mathrm{MeOH}$ & 1 & 38 \\
\hline $5^{b}$ & $\mathrm{NaBH}_{4}$ (3) $2 \times 1,5$ eqv & Etanol & 1 & 43 \\
\hline $6^{b}$ & $\mathrm{NaBH}_{4}(4) 2 \times 2 \mathrm{eqv}$ & Etanol & 1 & 85 \\
\hline $7^{c}$ & $\mathrm{NaBH}_{4}(4) 2 \times 2 \mathrm{eqv}$ & Etanol & 1 & 81 \\
\hline $8^{b}$ & $\mathrm{LiBH}_{4}(3)$ & THF & 1 & 69 \\
\hline 9 & $\mathrm{NaBH}_{4}(4) 2 \times 2$ eqv & --- & 1 & 30 \\
\hline
\end{tabular}

Figura 35- Espectro de RMN de ${ }^{1} \mathrm{H}$ do composto 21<smiles>CC(O)CCC(O)C(CO)CC(C)O</smiles>

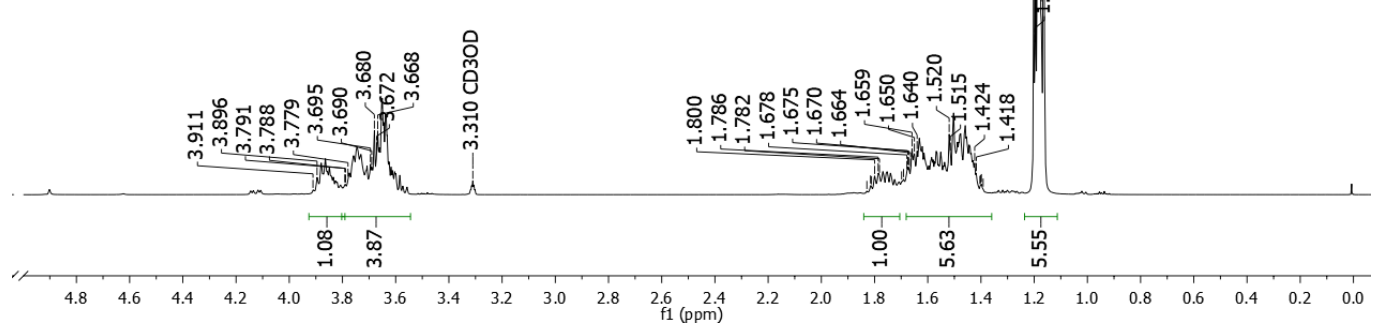


O poliol 21, assim como o hemiacetal 18, tem quatro centros estereogênicos em sua estrutura. Isso significa que são possíveis 16 combinações de estereoisômeros (8 pares diferentes de enantiômeros), o que leva a espectros de $\mathrm{RMN}$ de ${ }^{1} \mathrm{H}$ e ${ }^{13} \mathrm{C}$ altamente complexos, como pode ser observado na figura 35. A figura $\mathbf{3 6}$ mostra a imagem de um cromatograma obtido por CG-EM da redução parcial do hemiacetal 18 , ilustrando a presença de 8 diastereoisômeros do diol 21a em diferentes proporções. Além disso, o poliol 21 foi derivatizado e analisado por CG-EM (pag. 152).

Figura 36-a) Análise por CG-EM da redução parcial de 18. b) Espectros de massa idênticos para todos os 8 picos da figura 36 a

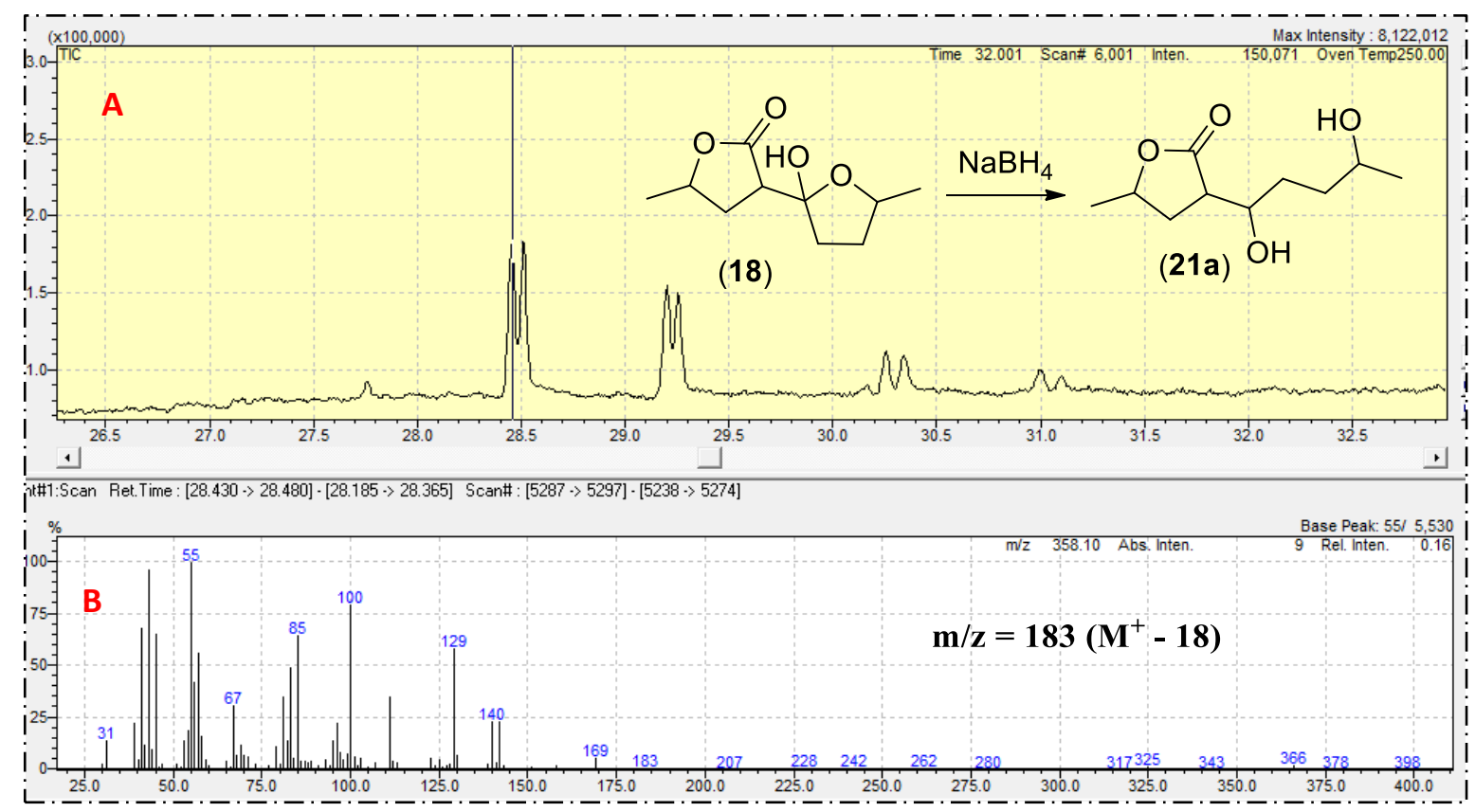

Embora as análises de IV, CG-EM e RMN tenham fornecido evidências inequívocas para a síntese de 18 e 21, decidimos oxidar o poliol 21 a fim de minimizar o número de centros estereogênicos para apenas um. Isso eliminaria as misturas de diastereoisômeros e facilitaria a confirmação estrutural do poliol por RMN. Assim, tentamos realizar a oxidação direta de $\mathbf{2 1}$ com o agente oxidante ácido 2-iodoxibenzóico (IBX), no entanto, houve a ciclização do poliol e a formação de outros compostos em uma mistura complexa. Nesta mistura, foi possível isolar e caracterizar apenas o produto $\mathbf{2 1 b}$ com $11 \%$ de rendimento (Esquema 27). 
Esquema 27-Reação de oxidação com IBX do composto 21<smiles>CC(O)CCC(CO)C(O)CC(C)O</smiles>

(21)

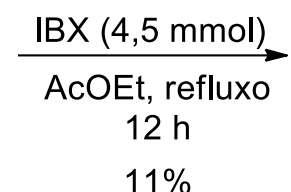

$11 \%$

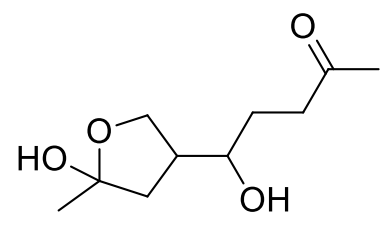

(21b)

Diante dos resultados obtidos, optou-se por realizar a proteção da hidroxila primária empregando diferentes grupos de proteção (TMSCI, TBSCI ou TBDPSCI) para evitar a reação de ciclização intramolecular (tabela 17). Dentre os silanos testados, o cloreto de tert-Butildifenilsilano (TBDPSCI) apresentou maior eficiência, sendo o produto protegido (22) obtido com $60 \%$ de rendimento.

Tabela 17-Reação de proteção do poliol 21

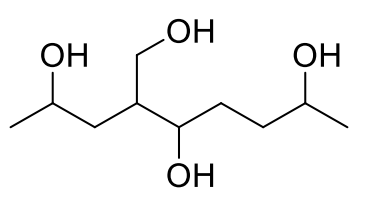

(21) $0,5 \mathrm{mmol}$

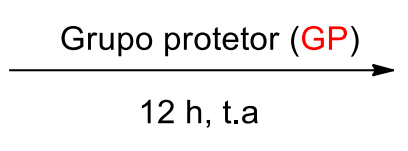

12 h, t.a<smiles>CC(O)CC(O)C(CO[Te])CC(C)O</smiles>

(22)

\begin{tabular}{|c|c|c|c|c|}
\hline Entradas & $\begin{array}{l}\text { Base } \\
\text { (eqv) }\end{array}$ & $\begin{array}{c}\text { Grupo protetor } \\
\text { (eqv) }\end{array}$ & $\begin{array}{c}\text { Solventes } \\
\text { [mol/L] }\end{array}$ & $22(\%)$ \\
\hline 1 & $\begin{array}{l}\text { TEA } \\
(1,1)\end{array}$ & $\begin{array}{c}\text { TBSCl } \\
(1,1)\end{array}$ & $\begin{array}{l}\text { DCM } \\
{[0,1]}\end{array}$ & -- \\
\hline 2 & $\begin{array}{c}\text { Imidazol } \\
(1,1)\end{array}$ & $\begin{array}{c}\text { TMSCI } \\
(1,1)\end{array}$ & $\begin{array}{l}\text { DCM } \\
{[0,1]}\end{array}$ & -- \\
\hline 3 & $\begin{array}{c}\text { Imidazol } \\
(1,1)\end{array}$ & $\begin{array}{c}\text { TBDPSCI } \\
(1,1)\end{array}$ & $\begin{array}{l}\text { THF } \\
{[0,1]}\end{array}$ & 34 \\
\hline 4 & $\begin{array}{c}\text { Imidazol } \\
(1,5)\end{array}$ & $\begin{array}{c}\text { TBDPSCI } \\
(1,5)\end{array}$ & $\begin{array}{l}\text { THF } \\
{[0,1]}\end{array}$ & 60 \\
\hline 5 & $\begin{array}{c}\text { Imidazol } \\
(1,5)\end{array}$ & $\begin{array}{c}\text { TBDPSCI } \\
(1,5)\end{array}$ & $\begin{array}{l}\text { DMF } \\
{[0,5]}\end{array}$ & 50 \\
\hline
\end{tabular}

Ao submeter o produto 22 à oxidação com IBX, foi possível obter 0 composto tricarbonilado $23 \mathrm{com} 55 \%$ de rendimento (Esquema 28). Sendo assim, a confirmação estrutural de 23 por RMN de ${ }^{1} \mathrm{H}$ e ${ }^{13} \mathrm{C}$, MS e IR suportou as estruturas propostas para os compostos 18 e 21 . 
Esquema 28-Reação de oxidação com IBX do composto 22<smiles>CC(O)CCC(O)C(CO[Pb])CC(C)O</smiles>

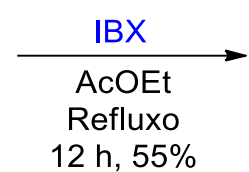<smiles></smiles>

Na figura 37, os espectros de RMN de ${ }^{1} \mathrm{H}$ e ${ }^{13} \mathrm{C}$ para o composto 23 são expostos. É possível observar, no espectro de RMN de ${ }^{1} \mathrm{H}$, a presença de 2 sinais atribuídos para as metilas alfa à carbonila (2,15 e 2,08 ppm) e no espectro de RMN de ${ }^{13} \mathrm{C}$ são observados 3 sinais característicos para as carbonilas do grupo cetona (210, 207 e 206 ppm).

Figura 37-Espectros de $\mathrm{RMN}$ de ${ }^{1} \mathrm{H}$ e ${ }^{13} \mathrm{C}$ do composto 23

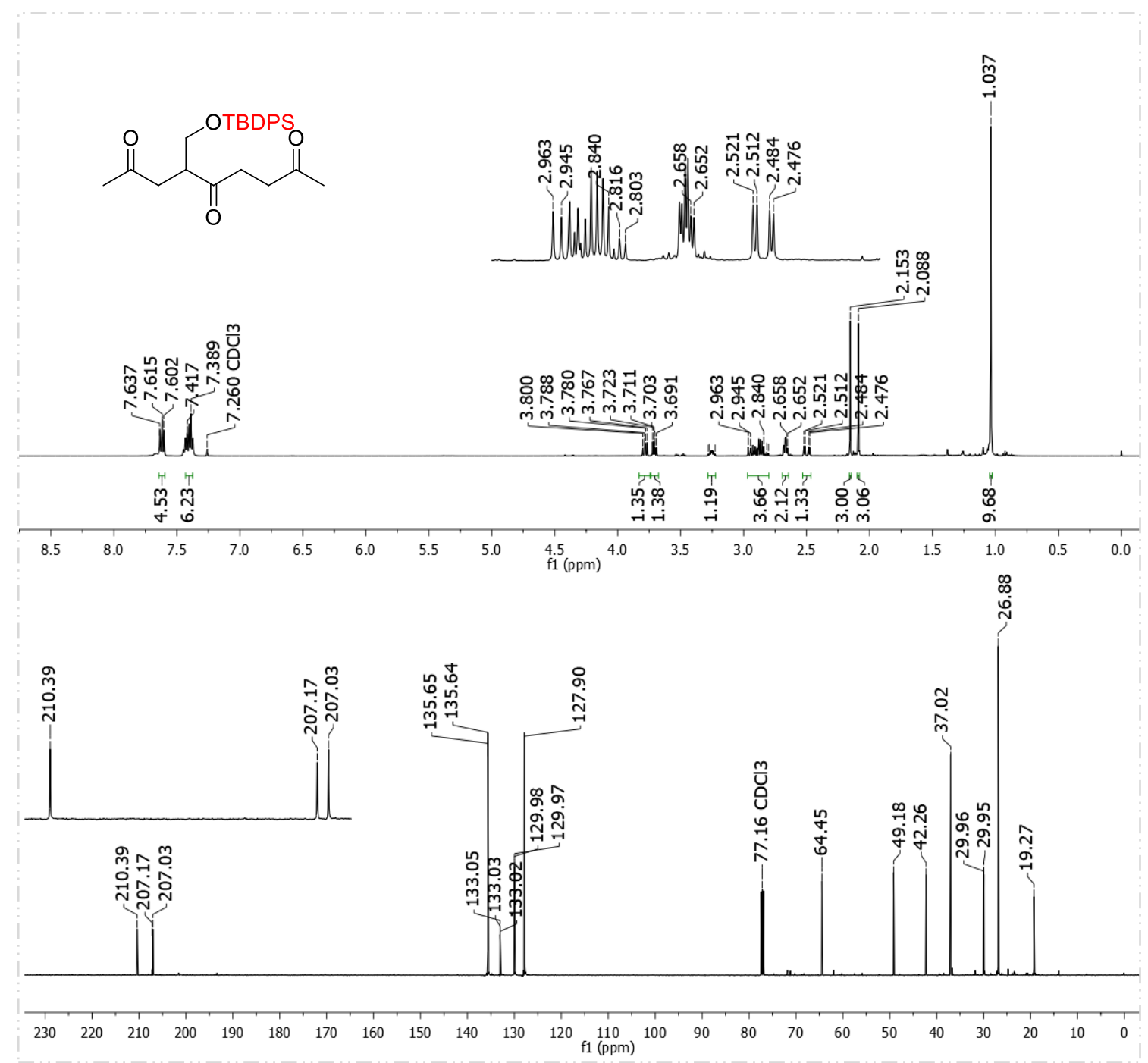




\subsection{Reações de alquilação para aumentar a cadeia carbônica do composto 18}

Sequencialmente, investigou-se uma possível forma para estender a cadeia carbônica do composto 18 (a partir do intermediário $\mathbf{A}$, formado in situ). O intermediário A poderia ser tratado com diferentes agentes alquilantes, em uma reação one-pot, obtendo-se produtos alquilados com cadeia carbônica variada (C3 a C11). Essa proposta é apresentada na Esquema 29.

Esquema 29- Proposta para reação de alquilação one-pot

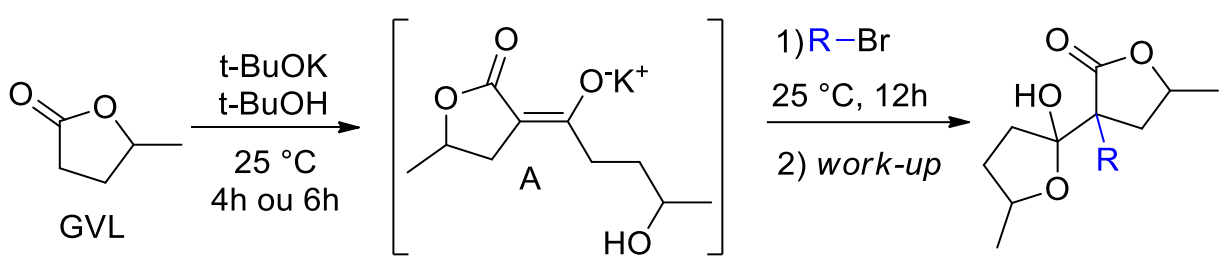

Para esta estratégia, a primeira tentativa foi realizada baseando-se nas condições experimentais já otimizadas para a formação de 18 (entradas 8 ou 9 da tabela 14). O brometo de alila (BA) foi escolhido como agente alquilante modelo para estudar a reação. Em todos os experimentos, a reação foi mantida à temperatura ambiente por 4 ou 6 horas, dependendo da concentração do meio de reação (5 $\mathrm{M}$ ou $3 \mathrm{M}$, respectivamente), seguida pela adição de brometo de alila e mais 12 horas de reação em temperaturas variadas.

Nas entradas 1-3 (tabela 18) a quantidade do agente alquilante foi variada de 0,5-1 equivalente, no entanto, nestas condições, o produto de alquilação desejado (24) não foi formado, mas sim o produto 25 . Variou-se, ainda, a temperatura da reação após a adição do brometo de alquila (para $70^{\circ} \mathrm{C}$, entrada 4), mas, novamente, apenas o produto 25 é formado. Modificou-se a quantidade do agente alquilante (uso em excesso, 2 equivalentes), a concentração do meio reacional e também se alterou o solvente para THF, entretanto, em todas as experiências realizadas (entradas 5-11) o produto 25 foi sempre formado com rendimentos próximos à $50 \%$. Em todos os experimentos, recuperou-se aproximadamente $2 \mathrm{mmol}$ do material de partida (GVL). 
Tabela 18- Otimização das condições reacionais

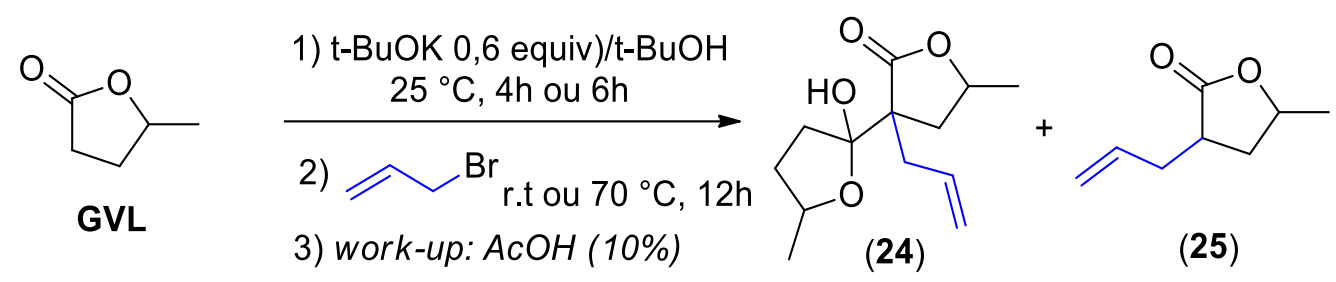

\begin{tabular}{|c|c|c|c|c|c|}
\hline Entradas & Solventes & BA ( $n^{\circ}$. Eqv) & $\mathrm{T}\left({ }^{0} \mathrm{C}\right)$ & $\begin{array}{c}\text { Tempo } \\
\text { (h) }\end{array}$ & ${ }^{d}(\%) 24 / 25$ \\
\hline $1^{b}$ & $t-\mathrm{BuOH}$ & 0,5 & r.t $\rightarrow$ r.t & $4 \rightarrow 12$ & $0 / 38$ \\
\hline $2^{b}$ & $t-\mathrm{BuOH}$ & 0,75 & r.t $\rightarrow$ r.t & $4 \rightarrow 12$ & $0 / 42$ \\
\hline $3^{b}$ & $t-\mathrm{BuOH}$ & 1 & r.t $\rightarrow$ r.t & $4 \rightarrow 12$ & $0 / 48$ \\
\hline $4^{b}$ & $t-\mathrm{BuOH}$ & 1 & r.t $\rightarrow 70$ & $4 \rightarrow 12$ & $0 / 42$ \\
\hline $5^{b}$ & $t-\mathrm{BuOH}$ & 2 & r.t $\rightarrow$ r.t & $4 \rightarrow 12$ & $0 / 52$ \\
\hline $6^{b}$ & $t-\mathrm{BuOH}$ & 2 & r.t $\rightarrow 70$ & $4 \rightarrow 12$ & $0 / 56$ \\
\hline $7^{b}$ & $t-\mathrm{BuOH}$ & 2 & r.t $\rightarrow$ r.t & $4 \rightarrow 12$ & $0 / 53$ \\
\hline $8^{b}$ & THF & 1 & r.t $\rightarrow$ r.t & $4 \rightarrow 12$ & $0 / 52$ \\
\hline $9^{b}$ & THF & 1 & r.t $\rightarrow 70$ & $4 \rightarrow 12$ & $0 / 52$ \\
\hline $10^{c}$ & THF & 1 & r.t $\rightarrow$ r.t & $5 \rightarrow 12$ & $0 / 53$ \\
\hline $11^{c}$ & THF & 1 & r.t $\rightarrow 70$ & $5 \rightarrow 12$ & $0 / 53$ \\
\hline
\end{tabular}

Para verificar se a quantidade da base e o método de work-up favoreciam a formação do produto 24, novos estudos foram realizados (tabela 19). Nesta abordagem, usaram-se como parâmetros fixos: quantidade de brometo de alila (1 equivalente), temperatura (ambiente), tempo de reação (12 h) e concentração (5 M). Nas entradas 1 e 2, foram empregados 0,6 equivalentes da base e work-

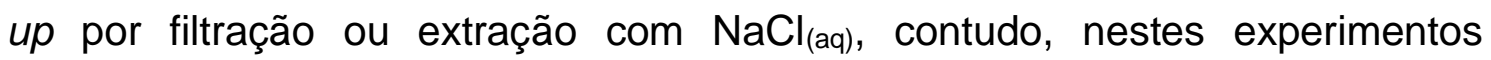
observou-se apenas a formação de 25 e recuperação do material de partida. Quando o número de equivalentes de base foi alterado para quantidades estequiométricas (entrada 3) ou inferiores (entradas 4 e 5), novamente, apenas o produto 25 foi observado e a GVL recuperada. Na entrada 6 , usando 0,4 equivalentes da base, a formação de $\mathbf{2 4}$ foi observada, mas com baixo rendimento (27\%). Com esta nova expectativa, diminuiu-se a quantidade da base para 0,3 equivalente, porém não houve o consumo da GVL. 
Tabela 19- Otimização da quantidade da base e work-upa

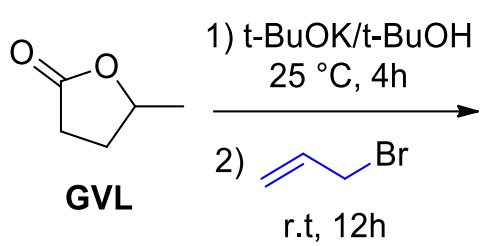

3) work-up

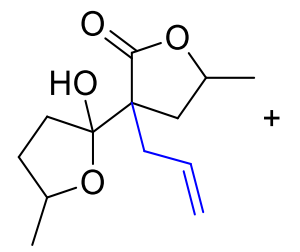

(24)

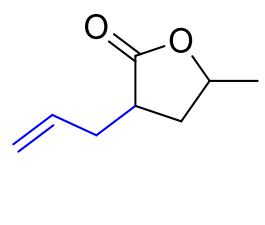

(25)

\begin{tabular}{|c|c|c|c|c|c|}
\hline Entradas & $\begin{array}{c}t \text {-BuOK } \\
\left(n^{\circ} . \text { Eqv) }\right.\end{array}$ & Work-up & $\mathrm{T}\left({ }^{0} \mathrm{C}\right)$ & Tempo (h) & $\begin{array}{c}{ }^{b}(\%) \\
24 / 25\end{array}$ \\
\hline 1 & 0,6 & filtração & r.t $\rightarrow$ r.t & $4 \rightarrow 12$ & $0 / 52$ \\
\hline 2 & 0,6 & $\mathrm{NaCl}_{(\mathrm{aq})}$ & r.t $\rightarrow$ r.t & $4 \rightarrow 12$ & $0 / 52$ \\
\hline 3 & 0,5 & $\mathrm{NaCl}_{(\mathrm{aq})}$ & $r . t \rightarrow r . t$ & $4 \rightarrow 12$ & $0 / 40$ \\
\hline 4 & 0,48 & $\mathrm{NaCl}_{(\mathrm{aq})}$ & r.t $\rightarrow$ r.t & $4 \rightarrow 12$ & $0 / \sim 40$ \\
\hline 5 & 0,45 & $\mathrm{NaCl}_{(\mathrm{aq})}$ & r.t $\rightarrow$ r.t & $4 \rightarrow 12$ & $0 / \sim 40$ \\
\hline 6 & 0,4 & $\mathrm{NaCl}_{(\mathrm{aq})}$ & r.t $\rightarrow$ r.t & $4 \rightarrow 12$ & $27 / 0$ \\
\hline 7 & 0,3 & $\mathrm{NaCl}_{(\mathrm{aq})}$ & r.t $\rightarrow$ r.t & $4 \rightarrow 12$ & $0 / 0$ \\
\hline
\end{tabular}

Como todas as tentativas citadas não levaram aos resultados desejados, optou-se por realizar a reação de alquilação a partir do composto 18, já isolado. Assim, variados experimentos foram averiguados (tabela 20). Na entrada 1, a concentração de 0,2 M, 1,1 equivalentes de carbonato de potássio e brometo de alila foram utilizados. Sob estas condições, obteve-se o produto alquilado desejado (24) com rendimento de $85 \%$ no tempo de 15 horas de reação à $65^{\circ} \mathrm{C}$. $\mathrm{Na}$ entrada 2, o experimento foi realizado na concentração de 0,4 $\mathrm{M}$, reduzindo o tempo da reação para 6 horas na temperatura de $65^{\circ} \mathrm{C}$ ou $55^{\circ} \mathrm{C}$. A base foi reduzida para quantidade estequiométrica, permitindo verificar que o rendimento permanece praticamente o mesmo (80\%, entrada 3).

Em vista dos resultados promissores, modificou-se o agente alquilante para o brometo de benzila e o produto 26 foi obtido com $85 \%$ de rendimento (entrada 4). Na entrada 5, reduziu-se a quantidade do brometo de benzila (para quantidade estequiométrica) visando uma melhor economia dos reagentes, com isso, observa-se semelhante rendimento do produto (80\%). Constatou-se que a temperatura de $55^{\circ} \mathrm{C}$ é necessária. Se a reação for realizada em temperaturas mais altas, o produto formado é degradado e, portanto, o rendimento diminui para $65 \%$ (entrada 6). 
Diante dos resultados obtidos, testou-se o uso de haletos de alquila com 4 e 11 carbonos, para tanto, foi necessário alterar alguns parâmetros como, por exemplo, temperatura e quantidade da base. Ao empregar 1-bromobutano como agente alquilante, nas condições descritas na entrada 7, não foi possível obter 0 produto alquilado. Em temperatura mais baixa e com menor tempo de reação, obteve-se o produto de interesse $\mathbf{2 7}$ com $25 \%$ de rendimento (entrada 8).

$\mathrm{Na}$ entrada 9, a quantidade da base foi aumentada, mas o rendimento permaneceu próximo ao obtido anteriormente, 22\%. Não houve melhoria no rendimento quando a quantidade do 1-bromobutano foi aumentada para 4,0 ou 8,0 equivalentes (entradas 10 e 11).

Com o objetivo de aumentar o rendimento da reação, modificou-se o haleto 1-bromobutano para 1-iodobutano, que é mais reativo do que o primeiro, assim, elevou-se o rendimento para $45 \%$ (entrada 12). Ao usar 1,5 equivalentes da base, o rendimento permaneceu praticamente o mesmo (entrada 13), no entanto, elevando-se a quantidade da base para 2 ou 2,5 equivalentes, observou-se um aumento no rendimento para $65 \%$ (entradas 14 e 15). Vale ressaltar que quando se utilizou 2 equivalentes da base, o material de partida foi recuperado, elevando o rendimento para $87 \%$ (ao considerar sua recuperação). Contudo, fazendo uso de um grande excesso (2,5 equivalentes), observou-se a degradação do material de partida.

Avaliou-se, ainda, o emprego de um haleto de alquila com cadeia carbônica longa (1-iodoundecano). As entradas 16-18 sumarizam os resultados obtidos. A melhor condição encontrada para produção do produto alquilado 28 é apresentada nas entradas 17 e 18, quando 2 ou 2,5 equivalentes da base foram utilizados. Ao empregar uma quantidade menor que 2 equivalentes, o produto desejado é obtido com rendimento menor que 50\% (entrada 16). Vale mencionar que nas reações com os haletos 1-iodobutano e 1-iodoundecano, não há consumo total do material de partida. Nas condições empregadas, sempre se observou a recuperação de aproximadamente 100 mg de 18 (entradas 14 e 17). 
Tabela 20- Otimização das condições para reação de alquilação de 18

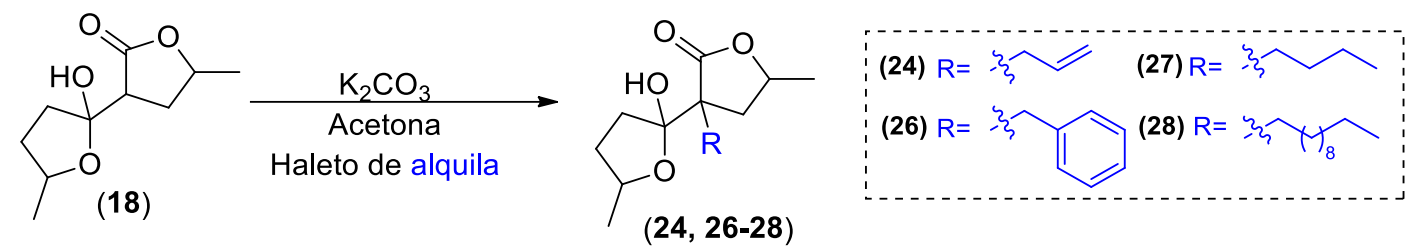

\begin{tabular}{|c|c|c|c|c|c|}
\hline Entradas & $\begin{array}{c}\text { Base } \\
\left(n^{\circ} . \text { Eqv) }\right.\end{array}$ & $\begin{array}{c}\text { Haleto de alquila } \\
\left(n^{\circ} . \text { Eqv) }\right.\end{array}$ & $\mathrm{T}\left({ }^{0} \mathrm{C}\right)$ & $\begin{array}{c}\text { Tempo } \\
\text { (h) }\end{array}$ & (\%) \\
\hline 1 & 1,1 & $\overbrace{1,1} \mathrm{Br}$ & 65 & 15 & 85 \\
\hline 2 & 1,1 & 1,1 & 65 ou 55 & 6 & 86 \\
\hline 3 & 1,0 & 1,1 & 65 ou 55 & 6 & 80 \\
\hline 4 & 1,1 & 1,1 & 55 & 6 & 85 \\
\hline 5 & 1,1 & 1,0 & 55 & 6 & 80 \\
\hline 6 & 1,1 & 1,1 & 65 & 15 & 65 \\
\hline 7 & 1,1 & $\overbrace{1,1} \mathrm{Br}$ & 65 & 12 & -- \\
\hline 8 & 1,1 & 1,1 & 55 & 6 & 25 \\
\hline 9 & 2,0 & 1,1 & 55 & 6 & 22 \\
\hline 10 & 1,1 & 4,0 & 55 & 6 & 26 \\
\hline 11 & 1,1 & 8,0 & 55 & 6 & $\sim 26$ \\
\hline 12 & 1,1 & $\overbrace{1,1}$ & 55 & 6 & 45 \\
\hline 13 & 1,5 & 1,1 & 55 & 6 & 46 \\
\hline 14 & 2,0 & 1,1 & 55 & 6 & $63^{b} / 87^{c}$ \\
\hline 15 & 2,5 & 1,1 & 55 & 6 & 65 \\
\hline 16 & 1,5 & $\widehat{Y_{8}}$ & 55 & 6 & 45 \\
\hline 17 & 2,0 & 1,1 & 55 & 6 & $50^{b} / 66^{c}$ \\
\hline 18 & 2,5 & 1,1 & 55 & 6 & 50 \\
\hline
\end{tabular}

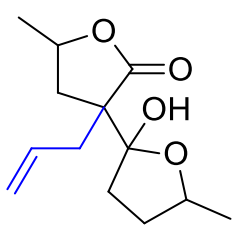

(24)

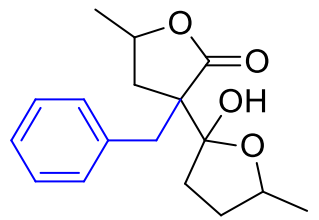

(26)

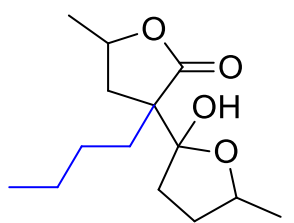

(27)

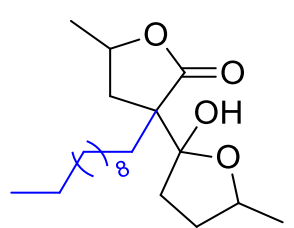

(28)

a Condições reacionais: composto $18(2 \mathrm{mmol}) .{ }^{\mathrm{b}}$ Rendimento isolado não considerando a recuperação do material de partida 18. ${ }^{c}$ Rendimento isolado considerando a recuperação do material de partida 18. 
O uso de haleto de alquila secundário e haleto primário com grupo alquila ramificado como, por exemplo, 2-iodopropano e 2-metil-iodopreno foram testados. Todavia, os produtos desejados não foram obtidos. Nestas reações, traços do material de partida foi recuperado, juntamente, com aproximadamente $50 \%$ da GVL. Outra abordagem diferente foi investigada com o uso de acrilato de metila, visando uma reação de adição de Michael do composto 18 ao acrilato. No entanto, durante a reação houve degradação do material de partida e mais de $70 \%$ da GVL foi recuperada.

\subsection{Obtenção dos polióis de cadeia longa}

Com os produtos de alquilação preparados, realizou-se um experimento para a reação de redução do composto $\mathbf{2 4}$, baseado nas mesmas condições reacionais que a síntese do poliol 21 (entradas 6 ou 7, tabela 16). Entretanto, a reação não levou ao produto desejado, sendo observada a formação do composto 29 como $40 \%$ de rendimento. Mesmo modificando alguns parâmetros como, temperatura, grande excesso do agente redutor e solvente, o mesmo produto continuou a ser formado (Esquema 30). O detalhamento das condições experimentais é apresentado na tabela 21, entradas 1 e 2.

Esquema 30- Formação do produto 29

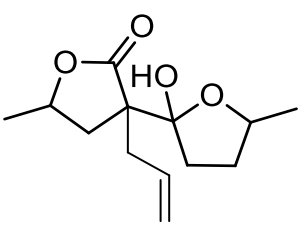

(24)

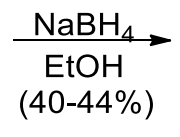

$(40-44 \%)$

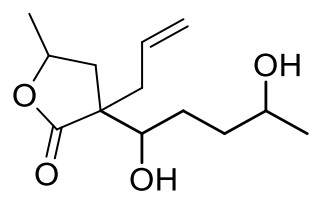

(29)

Diante deste resultado, investigou-se o uso de um agente redutor mais forte, $\mathrm{LiAlH}_{4}$ (entradas 3 e 4 da tabela 21). Em quantidades variando de 2,2-3 equivalentes de $\mathrm{LiAlH}_{4}$, o poliol 30 desejado foi formado com rendimento próximo à $50 \%$. Nestas condições experimentais, há ainda a formação de outros subprodutos não identificados de difícil separação. Desta forma, realizamos a redução usando a mistura $\mathrm{NaBH}_{4} / \mathrm{CaCl}_{2}$ para gerar $\mathrm{Ca}\left(\mathrm{BH}_{4}\right)_{2}$ in situ. Nessa tentativa, o poliol 30 foi obtido com rendimento de 46\% (entrada 5). Quando a quantidade do agente redutor foi dobrada, o rendimento aumentou para $53 \%$ 
(entrada 6). Como o uso da mistura $\mathrm{NaBH}_{4} / \mathrm{CaCl}_{2}$ mostrou-se mais adequada, dentre as condições testadas, os demais produtos alquilados (26-28) foram submetidos às mesmas condições experimentais, podendo originar polióis com cadeias alquílicas variadas de $\mathrm{C} 10$ a C21 (entradas 7-10). Na tabela 21, entradas 7,9 e 10 são expressos os rendimentos.

Tabela 21-Formação de polióis com cadeia longa

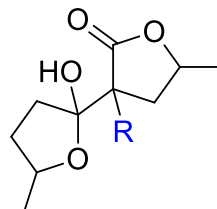

$(24,26-28)$

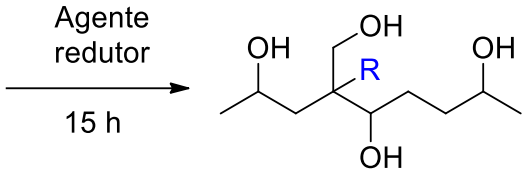

(30-33)

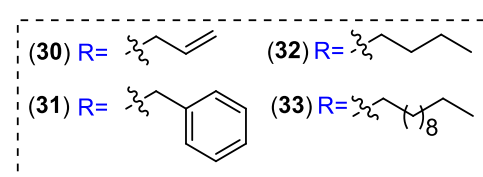




\section{CONCLUSÃO}

Em resumo, desenvolveu-se um método eficiente para síntese direta de várias moléculas de alto valor agregado a partir de uma fonte renovável: $\gamma$ valerolactona (GVL), um bloco de construção barato e de fácil acesso derivado da biomassa. A etapa principal da metodologia, envolve uma condensação de Claisen entre duas moléculas de GVL para fornecer um hemiacetal cíclico 18 com $85 \%$ de rendimento. Após alquilação e/ou redução, este acetal serve como uma nova plataforma para produzir várias moléculas de cadeia ramificada com carbonos que variam de $\mathrm{C} 10$ a C21 e rendimentos entre 40 a 85\%. Este novo método é realizado por meio de uma abordagem simples, sustentável e de fácil manuseio, usando reagentes e solventes de baixo custo.

O potencial desta metodologia também é destacado por sua fácil escalabilidade, partindo de $100 \mathrm{~g}$ da GVL, sem comprometer o rendimento, o que é crucial na indústria química. Os polióis obtidos poderão ser, futuramente, aplicados na obtenção de materiais polímeros e, também, será verificado o seu uso como agente plastificante. 


\section{Estudo visando à síntese de alcaloides contendo núcleo pirrolidínicos: Obtenção da codonopsinina e análogos}

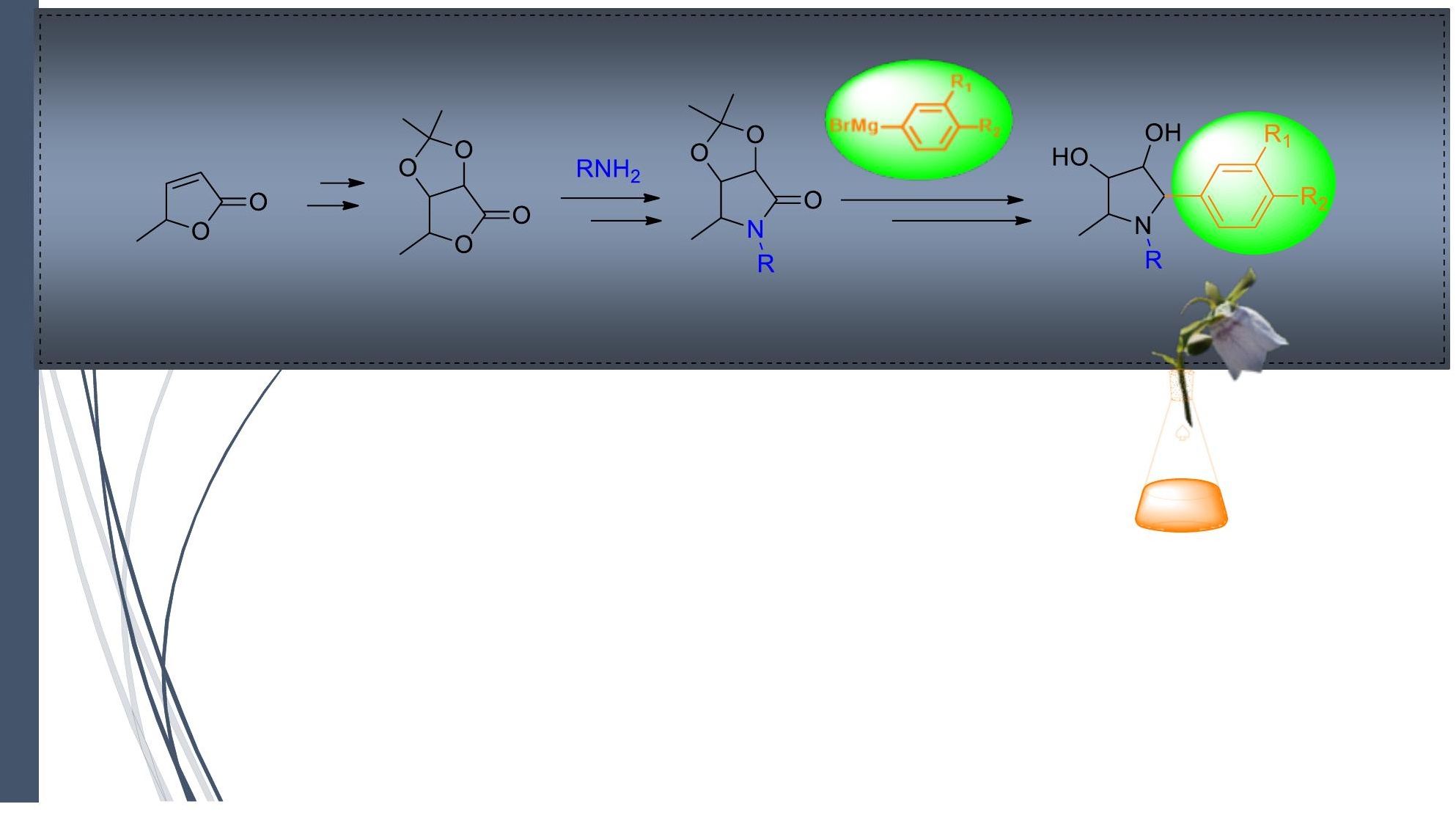




\section{INTRODUÇÃO}

Os alcaloides constituem uma importante classe de metabólitos secundários que podem ser empregados na medicina tradicional e moderna. A definição de alcaloide foi introduzida no ano de 1819, pelo químico alemão Carl Friedrich Wilhelm Meissner, e refere-se a um grupo de compostos básicos contendo nitrogênio de ocorrência natural produzido por uma grande variedade de organismos, incluindo bactérias, fungos, plantas e animais. ${ }^{122,123}$ Como esta definição é muito abrangente, em 1995 a União Internacional de Química Pura e Aplicada (IUPAC) definiu alcaloides como: "Compostos nitrogenados básicos (principalmente heterocíclicos) que ocorrem, em sua maioria, no reino vegetal (mas não excluem aqueles de origem animal). Aminoácidos, peptídeos, proteínas, nucleotídeos, ácidos nucléicos, amino açúcares e antibióticos normalmente não são considerados alcaloides. Por extensão, certos compostos neutros biogeneticamente relacionados aos alcaloides básicos são incluídos". ${ }^{124}$

Historicamente, a partir do século XIX foram registrados os primeiros estudos fitoquímicos, com base científica, que resultaram no isolamento de alcaloides já então conhecidos como medicinais. Tais estudos proporcionaram a obtenção desta classe de metabólitos que se consagrou como princípios ativos eficazes, como, por exemplo, os alcaloides morfina, quinina e cocaína (apresentados na figura 38). ${ }^{125}$

Figura 38- Alcaloides naturais utilizados na medicina

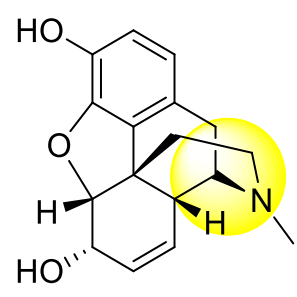

Morfina

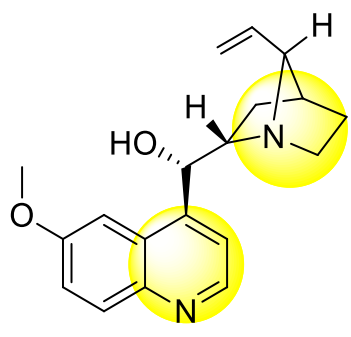

Quinina

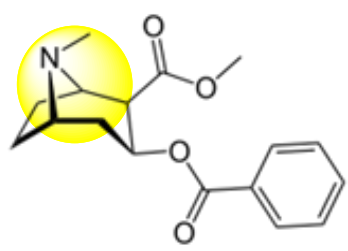

Cocaína

O grande interesse pela síntese ou isolamento dessa classe de composto é atribuído a ampla gama de atividades biológicas encontradas, que variam entre 
antioxidantes, antimaláricos, antiinflamatórios, anticâncer e muitas outras. ${ }^{126}$ Os alcaloides com núcleo pirrolidina, por exemplo, são encontrados na natureza em várias formas como derivados $\mathrm{N}$-metil e destacam-se pelas suas imensas diversidades estruturais e atividades biológicas. ${ }^{127}$ Espécies de plantas popularmente conhecidas carregam em sua composição química variados alcaloides com núcleo pirrolidínico. Por exemplo, o tabaco ( $N$. tabacum), beladona mortal (Atropa belladonna) e coca peruano (Erythroxylon truxillense Rusby). ${ }^{127,129} \mathrm{Na}$ figura 39 , encontram-se as estruturas de alguns alcaloides com núcleo pirrolidínico.

Figura 39-Exemplos de alcaloides com núcleo pirrolidínicos
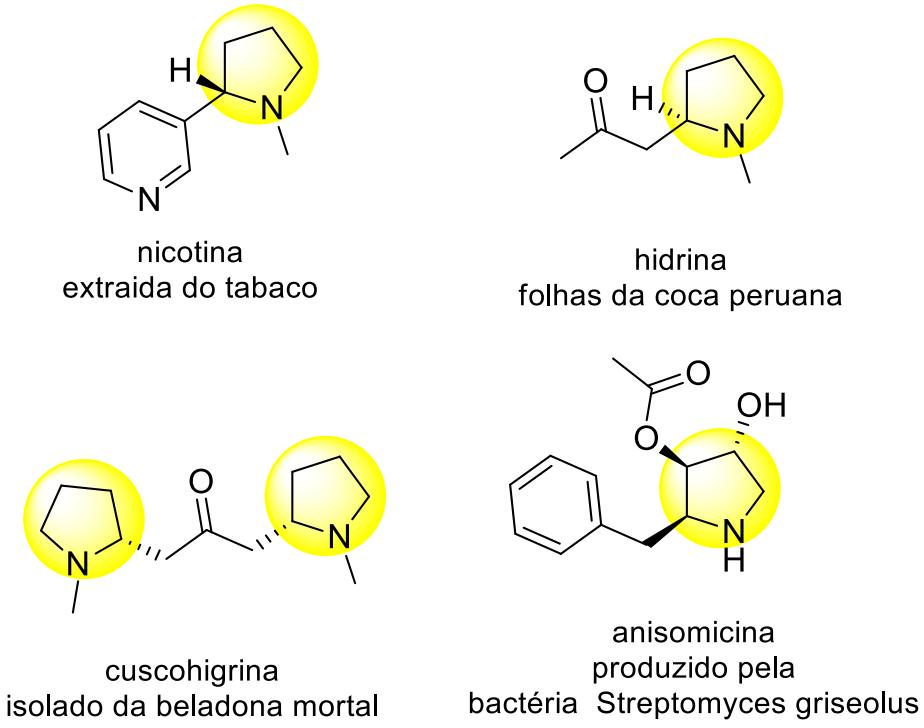

\subsection{Alcaloides pirrolidínicos diidroxilados}

Dentre as classes dos alcaloides existentes, os pirrolidínicos di ou polihidroxilados são potentes inibidores das glicosidases, grupo de enzimas presentes em todos os organismos vivos com funções variadas. Uma destas funções é catalisar a hidrólise das ligações glicosídicas. ${ }^{129,130}$

As glicosidases estão envolvidas na digestão intestinal do amido, na biossíntese de cadeias de oligossacarídeos e na hidrólise de glicoconjugados nos lisossomos. Assim, substâncias inibidoras das glicosidades são almejadas para o tratamento antitumoral, desordens metabólicas e infecções virais. ${ }^{129,130}$ 
Galidesivir, por exemplo, é uma droga antiviral sintética, destinada para o tratamento da hepatite C, ebola, marburgo e zika vírus. Atualmente, a Galidesivir está em fase 1 de testes em humanos para o Covid-19. ${ }^{131}$

Nectrisina (um inibidor de a-glucosidases e a-manosidases, isolada do fungo Nectria Lucida, também foi relatada como tendo atividade para a leucemia, de acordo com testes in vivo em camundongos. Já a (-)-codonopsinina e (-)codonopsina apresentaram atividades antibióticas e hipotensivas sem qualquer efeito negativo ao sistema nervoso central, em testes realizados em animais. $\mathrm{Na}$ figura 40, são apresentados alguns alcaloides naturais e sintéticos com as atividades biológicas citadas. ${ }^{132}$

Figura 40- Alcaloides pirrolidínicos di e poli-hidroxilados<smiles>OCC1N=CC(O)C1O</smiles>

nectrisina<smiles>OC[C@H](O)C1NCC(O)C1O</smiles>

1,4-deoxi-1,4imino-D-mannitol (DIM)<smiles>Nc1ncnc2c([C@@H]3N[C@H](CO)[C@@H](O)[C@H]3O)c[nH]c12</smiles>

galidesivir<smiles>OC[C@H]1N[C@@H](c2ccc(O)cc2)[C@H](O)[C@@H]1O</smiles>

radicamina $B$<smiles>O=C(CCCO)CCC1N[C@H](CO)[C@@H](O)[C@H]1O</smiles>

broussonetinina $\mathrm{A}$<smiles>[R]c1cc([C@@H]2[C@@H](O)[C@@H](O)[C@H](C)N2C)ccc1OC</smiles>

(-)-codonopsinina $(\mathrm{R}=\mathrm{H})$ $(-)$-codonopsina $(\mathrm{R}=\mathrm{OMe})$<smiles>COc1ccc([C@@H]2[C@@H](O)[C@H](O)[C@@H](C)N2C)cc1</smiles>

$(+)$-codonopsinina<smiles>COc1ccc([C@@H]2[C@@H](O)[C@H](O)[C@H](C)N2C)cc1</smiles>

4-epi-(+)-codonopsinina

\subsection{Síntese da codonopsinina}

A (-)-codonopsinina e (-)-codonopsina foram isoladas na década de 1960 da planta Codonopsis Clematidea pertencente à família Campanulaceae. Devido aos promissores resultados da atividade biológica, a síntese da (-)codonopsinina e dos seus epímeros são reportadas desde $1985 .{ }^{133}$ Muitos 
estudos relevantes tiveram sucesso nas rotas sintéticas obtendo os alcaloides com bons rendimentos. ${ }^{134-143}$ A figura 41 apresenta um panorama geral com as propostas mais relevantes.

Figura 41- Algumas sínteses totais da (-)-Codonopsinina e dos seus epímeros

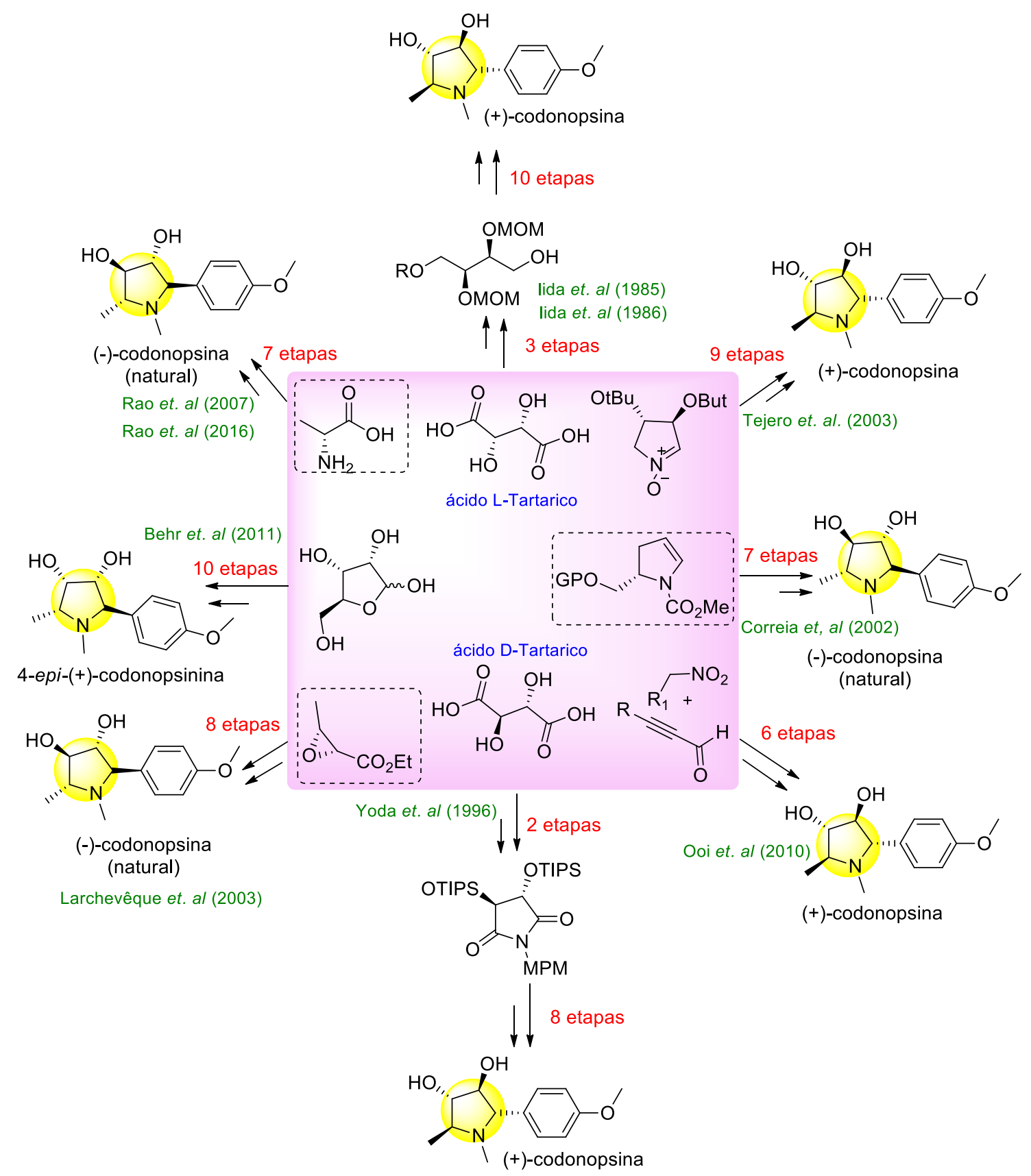

lida et al.(1985 e 1986) ${ }^{137,138}$ reportaram a primeira síntese total da (+)codonopsinina em 13 etapas reacionais, a partir da transformação do ácido-Ltartárico. 10 anos após este relato, Yoda et al.(1996) ${ }^{139}$ utilizaram o ácido D- 
tartárico como material de partida e, passando por uma imida como intermediário chave, foi possível obter a (+)-codonopsinina em 10 etapas reacionais (Esquema 31).

Esquema 31- Síntese da (+)-codonopsinina realizada por Yoda et al.(1996) ${ }^{139}$

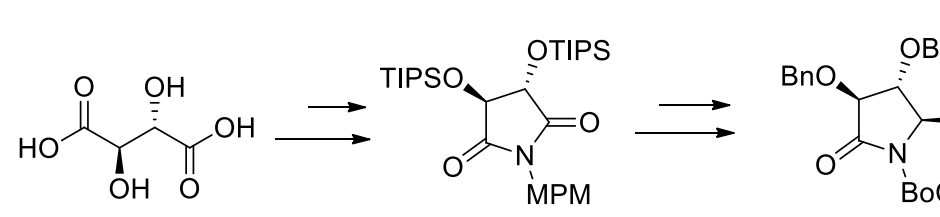

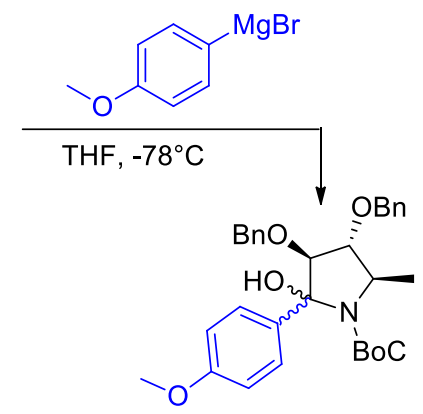

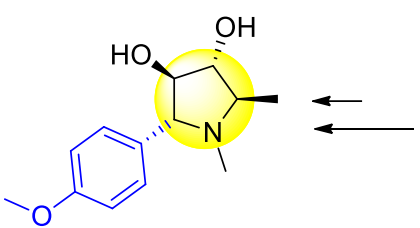

(+)-codonopsinina

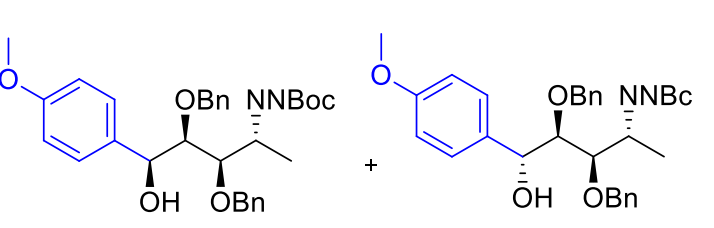

Razão dos diastereoisomeros: (95:5)

Das várias propostas sintéticas reportadas, entre a década de 80-90, nenhuma apresenta de fato a síntese do produto natural (-)-codonopsinina, mas sim, a síntese do enantiômero (+)-codonopsinina e dos seus epímeros. A primeira síntese total da (-)-codonopsinina foi marcada por Correia et al. $(2000)^{140} \mathrm{e}$, após este ano, outras rotas foram surgindo. Das rotas existentes, as que merecem destaque foram às realizadas por Rao et al.(2007) ${ }^{141}$ e Correia et al.(2000), conforme já mencionado.

Em 7 etapas, Correia et al.(2000) relataram a síntese da (-)codonopsinina por meio da reação de Heck com enecarbamatos endocíclicos. A reação, altamente estereosseletiva, ocorreu entre o enecarbamato e 0 tetrafluoroborato de $p$-metoxibenzenodiazônio. Após a reação de Heck, ocorre a conversão do grupo hidroximetil em grupo metil. As etapas chaves envolvem a diidroxilação da ligação dupla, por meio da epoxidação/abertura do epóxido, seguida pela redução do carbamato. Assim, o produto foi formado com $74 \%$ de rendimento (Esquema 32). ${ }^{140}$ 
Esquema 32- Síntese da (-)-codonopsinina realizada por Correia et al.(2000) $)^{140}$

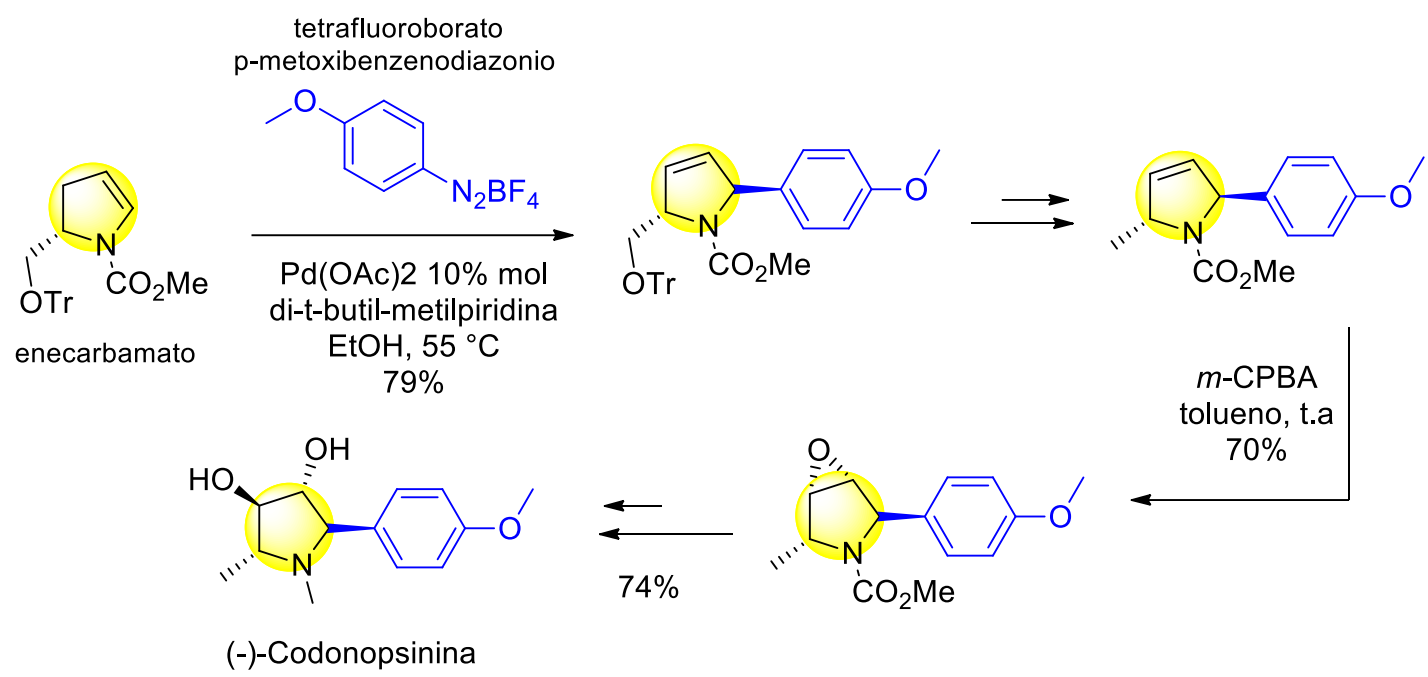

Empregando a D-alanina como material de partida, Roa et al.(2007) ${ }^{141}$ descreveram a síntese total da (-)-codonopsina em 7 etapas. As etapas-chave envolvem uma diidroxilação de Sharpless, ciclização intramolecular, altamente estereosseletiva, do aminocomposto e a remoção do grupo $\mathrm{Cbz}$, levando a formação do produto com rendimento global de 44\% (Esquema 33). ${ }^{141,142}$

Esquema 33- Síntese da (-)-Codonopsina realizada por Roa et al.(2007)

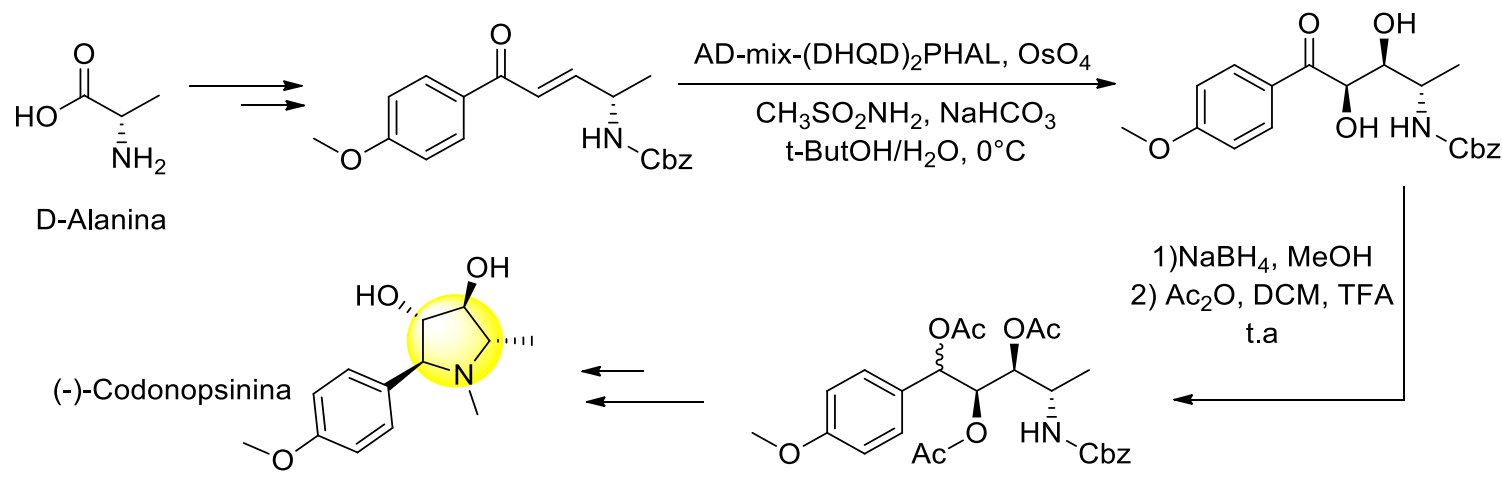

Devido às estruturas moleculares intrigantes e promissoras atividades biológicas, Behr et al.(2011) ${ }^{143}$ inspiraram-se no produto natural (-)codonopsinina para preparar a 4-epi-(+)-codonopsinina e análogos (Esquema 34). Em 10 etapas, a partir da D-ribose como um bloco de construção quiral, realizou-se uma adição nucleofílica, altamente estereosseletiva, de um reagente 
de Grignard a uma ribosilamina protegida. O aminoálcool formado foi mesilado proporcionando a formação, in situ, da pirrolidina tetrassubstituída com $63 \%$ de rendimento. Esta sequência levou a inversão da configuração do carbono C-5. Os autores também relataram que os compostos foram testados e apresentaram forte capacidade de inibir a fucosidase. ${ }^{143}$

Esquema 34- Síntese da 4-epi-(+)-Codonopsinina realizada por Behr et al.(2011)

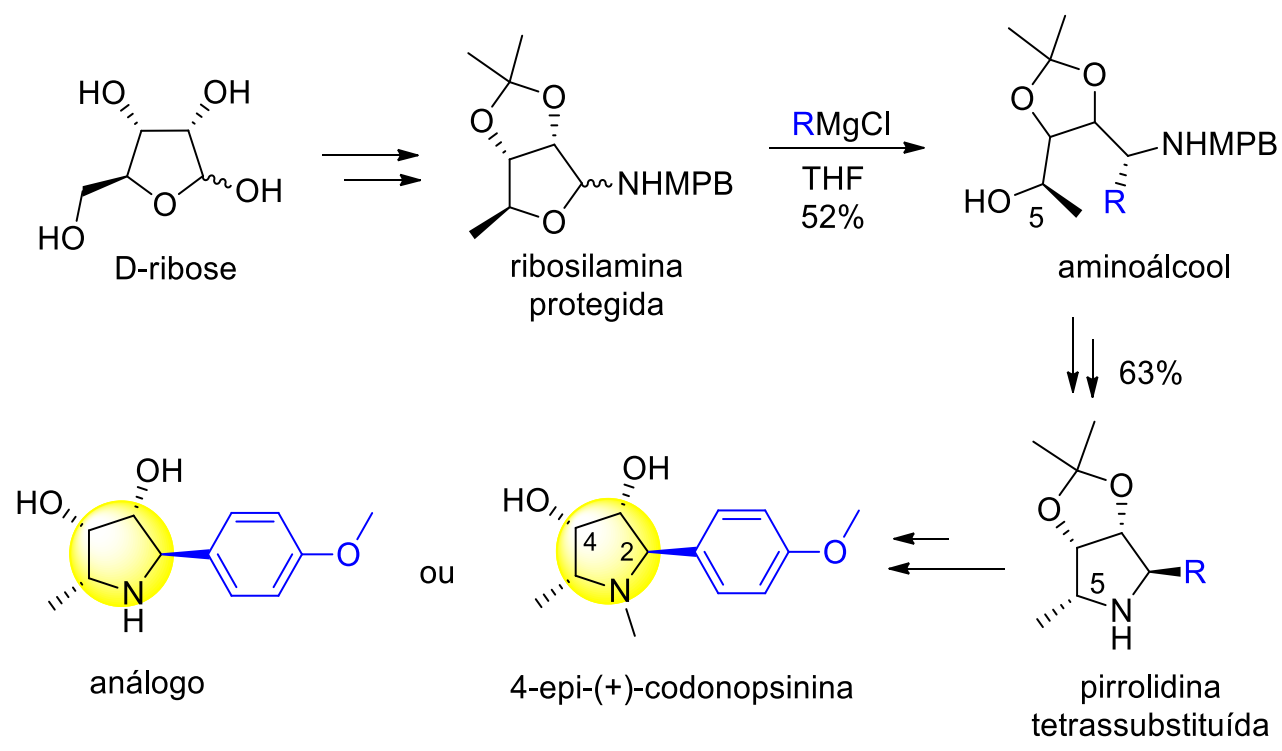

Ainda que diferentes abordagens para a síntese dos núcleos pirrolidínicos sejam comumente encontradas na literatura, muitas rotas são extensas e envolvem materiais de partida e reagentes caros. Neste sentido, o uso da biomassa como bloco de construção para o preparo destes núcleos agregaria um grande valor para estas moléculas. Além disso, a busca por novos compostos de interesse farmacológico faz-se necessária devido a crescente movimentação no mercado farmacêutico e surgimento de novas enfermidades. 


\section{OBJETIVOS}

\subsection{Objetivo geral}

Investigar métodos, para síntese da codonopsinina e de vários alcaloides pirrolidínicos diidroxilados, utilizando como bloco de construção moléculas oriundas da biomassa.

\subsection{Objetivos específicos}

$\checkmark$ Obter modelos de pirrolidonas a partir do ácido levulínico;

$\checkmark$ Estudar as reações para formação da codonopsinina e análogos, empregando as pirrolidonas obtidas;

$\checkmark$ Desenvolver outras possíveis rotas para síntese dos alcaloides pirrolidínicos diidroxilados; 


\section{Resultados e discussões}

\subsection{Proposta sintética da codonopsinina e análogos}

A estratégia inicial visando o preparo do alcaloide codonopsinina e análogos consiste em uma abordagem realizada entre 6 a 7 etapas. Na primeira etapa, haveria o preparo de alguns modelos de pirrolidonas (34), seguindo o protocolo estabelecido por Burtoloso et al.(2018) ${ }^{71}$. Na segunda etapa, as pirrolidonas seriam tratadas frente a bases fortes (LDA ou KHMDS, por exemplo), seguida pela adição de agentes eletrofílicos de selênio ou enxofre. Os intermediários de enxofre ou selênio formados (35) podem ser tratados com oxidantes e/ou bases para eliminação do sulfóxido ou selenóxido, gerando assim, as pirrolidonas insaturadas (36). Na quarta etapa, as pirrolidonas insaturadas seriam diidroxiladas para fornecer seus respectivos dióis cis ou trans (37). Os dióis obtidos seriam protegidos e, em seguida, realizar-se-ia a adição do reagente de Grignard (38). O produto bruto da reação de Grignard poderia ser submetido a redução com hidrosilano ou $\mathrm{NaBH}_{4}$ na presença de ácido. Posteriormente, a reação de desproteção daria origem a codonopsinina e análogos (Observe o esquema $35 \mathrm{com}$ a proposta sintética).

Esquema 35- Proposta para síntese da codonopsinina e análogos

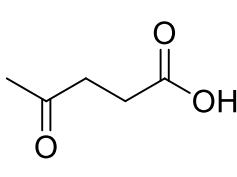

àcido levulinico<smiles>[R]C#CCC1CCC(=O)N1[R]</smiles>

(34)

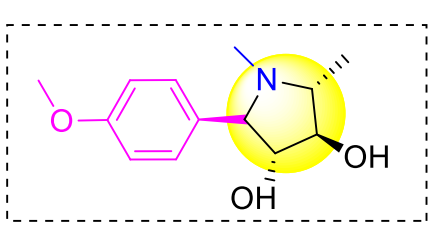

Obtenção da codonopsinina e análogos

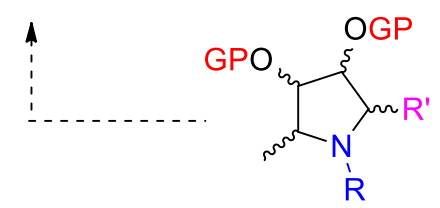

(38)

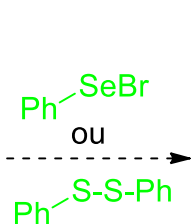

1) $\mathrm{R}^{\prime}-\mathrm{MgBr}$

2) $\mathrm{SiH}(\mathrm{etil})_{3}$ ou

TFA, $\mathrm{NaBH}_{4}$

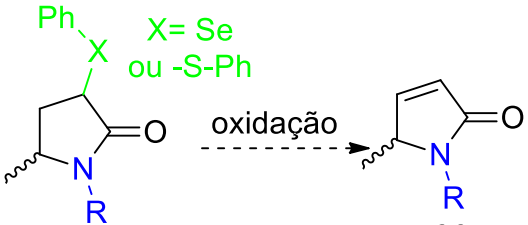

(35)

diidroxilação trans via abertura de epoxido,

(36)

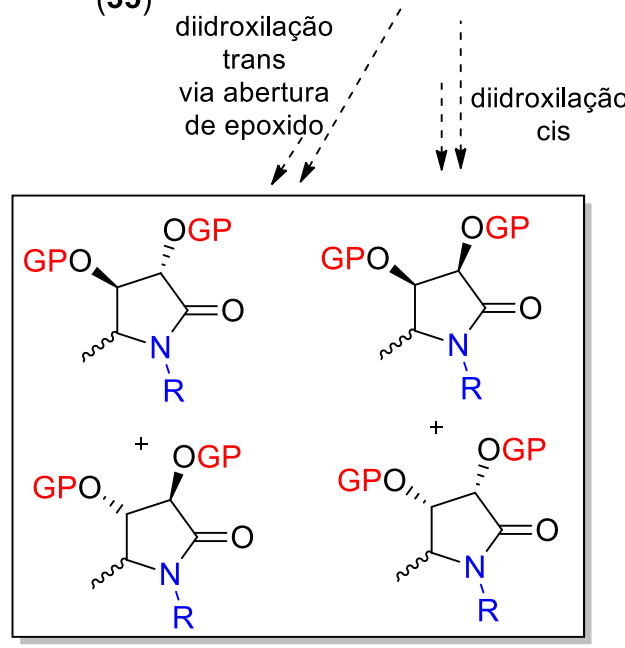

(37) 


\subsection{Rota sintética partindo do ácido levulínico $(A L)$}

\subsubsection{Preparo das pirrolidonas}

Primeiramente, foram sintetizados 2 modelos de pirrolidonas com 89 e $90 \%$ de rendimento em 15 horas de reação, seguindo o protocolo estabelecido por Burtoloso et al.(2018) 72 (esquema 36). Optou-se por utilizar a benzilamina e p-metoxibenzilamina para reação com o ácido levulínico (AL), uma vez que as respectivas pirrolidonas formadas apresentam alto ponto de ebulição. Também, foi levado em consideração que os grupo benzil e $p$-metoxibenzil, por serem volumosos, poderiam favorecer a adição do reagente de Grignard por uma das faces da pirrolidona, o que poderia levar a formação do produto com alta estereosseletividade. Se a reação já fosse iniciada com a pirrolidona com o grupo metil ligado ao nitrogênio, seria difícil operá-la em condições anidras, pois a pirrolidona $\mathrm{N}$-metil é bastante volátil.

Esquema 36- Síntese das pirrolidonas
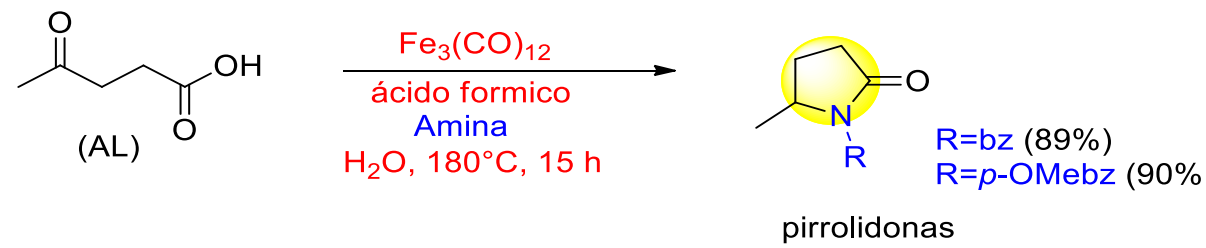

\subsubsection{Reação das pirrolidonas frente aos eletrófilos}

Para otimizar as condições reacionais, utilizou-se a pirrolidona com grupo p-metoxibezil ligado ao nitrogênio (34a) e difenildissulfeto (Ph-S-S-Ph) como eletrófilo. Na entrada 1 da tabela 22, empregou-se 2 equivalentes de LDA e 1,5 equivalente do eletrófilo. Nessas condições, após 2 horas de reação à temperatura ambiente, houve apenas a formação do produto dissulfeto $35 \mathrm{a}$ com $50 \%$ de rendimento. Ratificou-se a estrutura do produto observando o espectro de $R M N$ de ${ }^{1} \mathrm{H}$, notando-se a presença de 14 hidrogênios na região dos aromáticos (figura 42). Empregou-se o uso do co-solvente DMPU com objetivo de melhorar a solubilidade do enolato de lítio no meio reacional, porém não houve sucesso nos resultados e o mesmo rendimento foi obtido para formação 
de 35a (entrada 2). Nas entradas 3 e 4 (sem e com o uso do co-solvente, respectivamente), utilizando-se 1,5 equivalente da base, novamente, apenas 35a é formado.

Adicionou-se, ao meio reacional, a solução do LDA (2 equivalentes) gotagota por 20 minutos com o auxílio de syringe-pump. Após 2 horas de reação, foi observada a formação de outros produtos não detectados anteriormente, sendo assim, optou-se por deixar a reação por um período maior (12 horas). Após 12 horas de reação, obteve-se 35 b com $20 \%$ de rendimento e 35 a com $52 \%$ de rendimento (entrada 5). Nas entradas 6 e 7, 1,5 ou 1 equivalente da base, respectivamente, também foram adicionadas com auxílio de syringe-pump, porém não se observou a formação de 35b. Na primeira, 35a formou-se com $38 \%$ de rendimento. Já na segunda, não se detecta a formação de 35a nem 35b, havendo a recuperação de aproximadamente $70 \%$ do material de partida.

Repetiram-se as condições experimentais da entrada 5 utilizando apenas 1,0 equivalente do eletrófilo, mas não houve melhorias nos resultados (entrada 8). Modificando-se a base para KHMDS (2 equivalentes), houve apenas a formação de 35 a com $15 \%$ de rendimento e recuperação do material de partida (entradas 9).

$\mathrm{Na}$ entrada 10, com o uso de 1,5 equivalentes do eletrófilo brometo de finilsêlenio $(\mathrm{PhSeBr})$ e 2 equivalentes de LDA, observou-se pela primeira vez apenas a formação de 35b com $40 \%$ de rendimento e, também, a recuperação do material de partida ( 35\%). Diminuindo-se a quantidade da base para 1,5 equivalente, houve uma melhoria no rendimento para formação de $35 b$ (60\% de rendimento, entrada 11). Com quantidade equimolar do LDA ou com excesso da Base KHMDS não há consumo do material de partida (entradas 12 e 13).

Vale ressaltar que devido à dificuldade em separar os compostos $35 \mathrm{a}$ e 35b, quando se utiliza Ph-S-S-Ph como eletrófilo, os rendimentos apresentados nas entradas 5 e 8 foram determinados por $\mathrm{RMN}$ de ${ }^{1} \mathrm{H}$. O mesmo ocorre quando se utiliza $\mathrm{PhSeBr}$ como eletrófilo, pois o material de partida e o composto de selênio apresentam $\mathrm{Rf}$ muito próximos (entradas 10 e 11). 
Tabela 22- Formação dos intermediários de enxofre e selênio

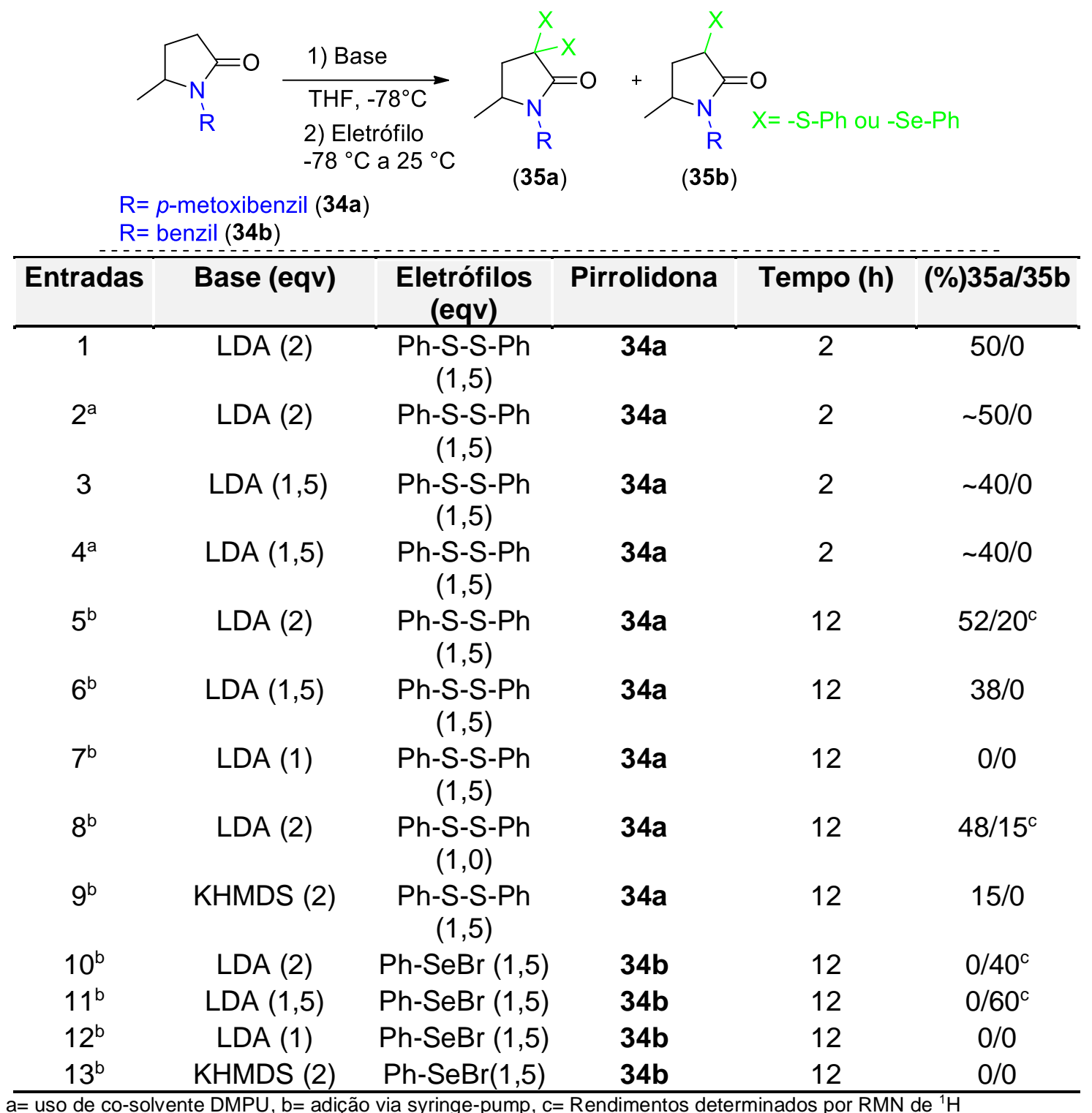

Figura 42- Espectro de $\mathrm{RMN}$ de ${ }^{1} \mathrm{H}$ de $35 \mathrm{a}$

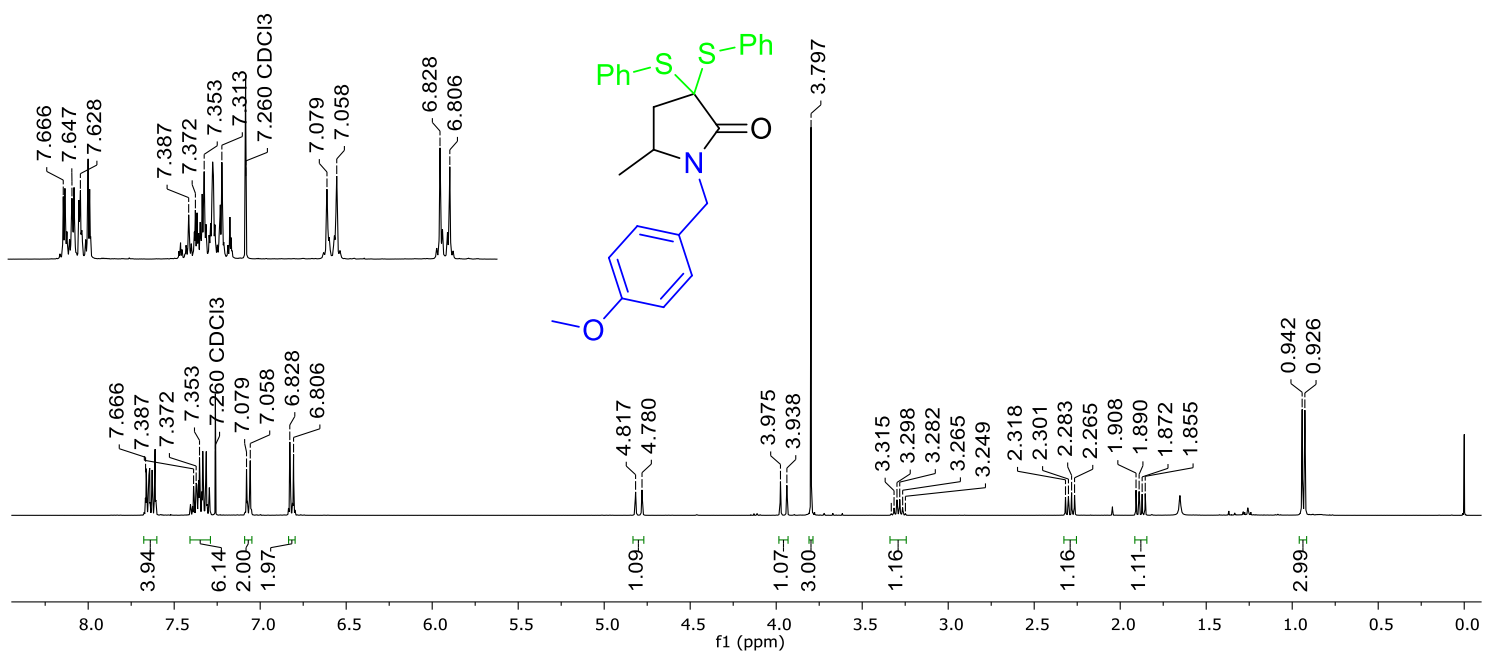


Mesmo com o baixo rendimento para formação dos intermediários $\mathbf{3 5 b}$, os produtos foram submetidos a reação de oxidação/eliminação para obter as pirrolidonas insaturadas correspondentes. Como já mencionando, a formação dos compostos de enxofre foi obtida como uma mistura (dissulfeto e monossulfeto). Quando se submete esta mistura à reação de oxidação, frente aos agentes oxidantes $m$-CPBA ou $\mathrm{H}_{2} \mathrm{O}_{2}$, seguida pela eliminação do sulfóxido, obtém-se a formação da pirrolidona insaturada 36 a com $25 \%$ de rendimento, conforme ilustrado no esquema 37. Mesmo com aquecimento da mistura, em tubo selado, a temperaturas entre $130-150{ }^{\circ} \mathrm{C}$, não houve aumento do rendimento.

Esquema 37- Reação de eliminação do sulfóxido.

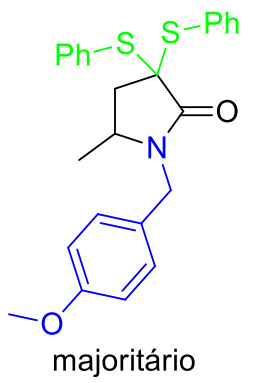

$\sim 2: 1$

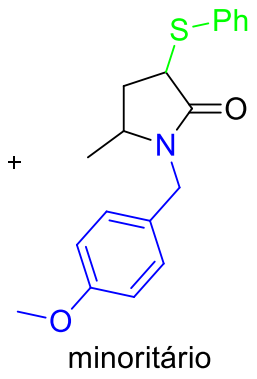

1) $m$-CPBA ou $\mathrm{H}_{2} \mathrm{O}_{2}$ DCM ou $\mathrm{CHCl}_{3}$

2) $\mathrm{NaHCO}_{3}$

Tolueno ou acetonitrila refluxo

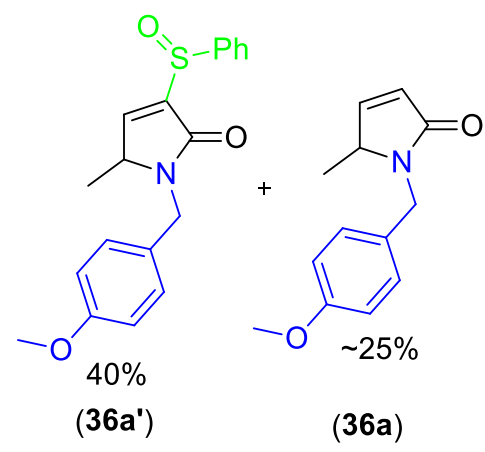

(36a')

$(36 a)$

A formação da dupla ligação de 36 a é constatada pela presença de 2 duplos dubletos em 6,96 $(J=5,9,1,7 \mathrm{~Hz}, 1 \mathrm{H})$ e $6,16(J=5,9,1,7 \mathrm{~Hz}, 1 \mathrm{H})$. Já a formação de 36a' é evidenciada pelo surgimento do dubleto em $6,12(\mathrm{~J}=2,1 \mathrm{~Hz}, 1 \mathrm{H})$. Ambos os espectros são expostos nas figuras 43 e 44, respectivamente.

${ }^{*}$ Figura 43- Espectro de $\mathrm{RMN}$ de ${ }^{1} \mathrm{H}$ do composto $36 \mathrm{a}$

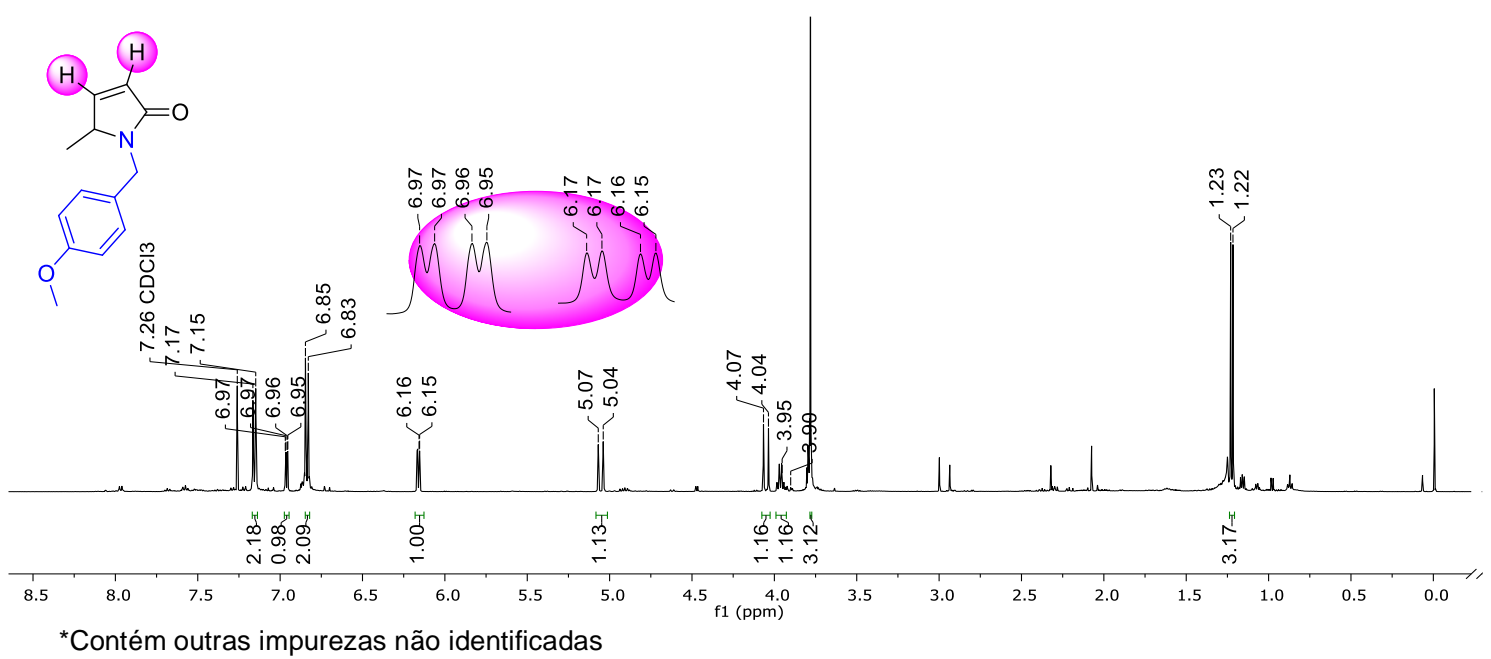


Figura 44- Espectro de RMN de ${ }^{1} \mathrm{H}$ do composto 36a'

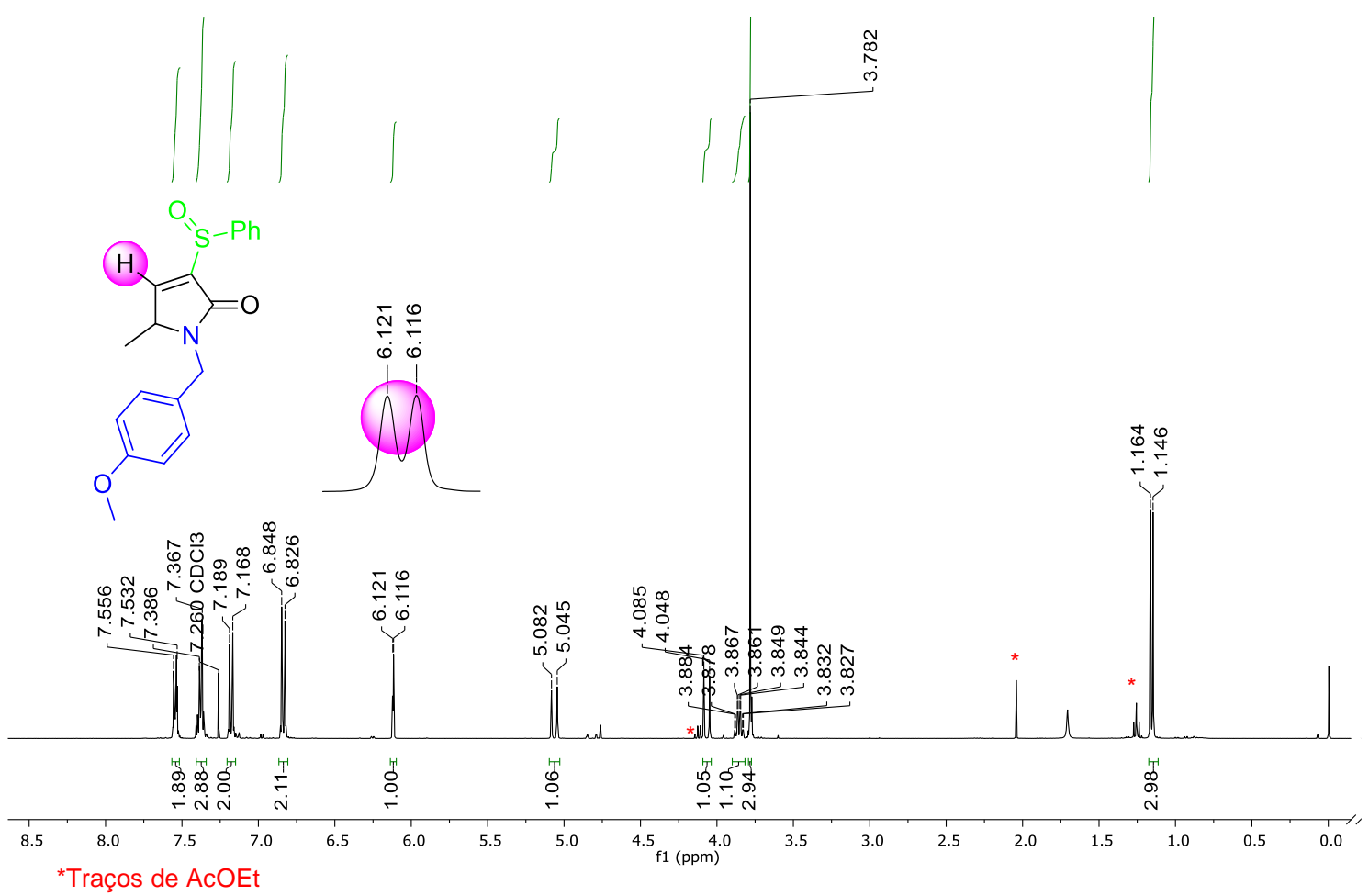

Para os compostos com selênio (entradas 10 e 11 da tabela 22), a eliminação do selenóxido gerou a pirrolidona insaturada (36b) com rendimento de $50 \%$. O selenóxido é mais instável que o sulfóxido quando a molécula apresenta hidrogênios $\beta$-carbonílicos. A eliminação do selenóxido ocorre, sem a necessidade de uso da base, através da eliminação syn intramolecular (Esquema 38).

Esquema 38- Reação de eliminação do Selenóxido
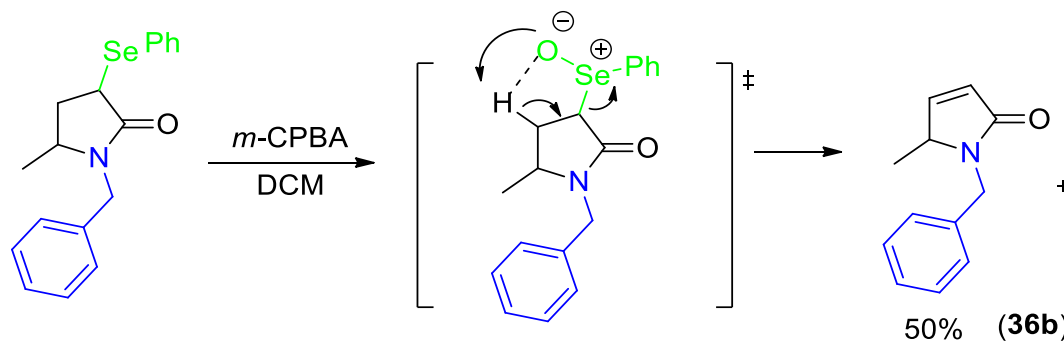

$\mathrm{Ph}-\mathrm{SeOH}$

Ao submeter as pirrolidonas $\alpha, \beta$-insaturadas $(36 a$ e $36 b)$ à reação de epoxidação, apresentadas na tabela 23 , não houve o consumo do material de 
partida em nenhuma das condições testadas. Surpreendentemente, mesmo utilizando quantidades em excesso dos agentes oxidantes, não se observa 0 consumo das pirrolidonas. Infelizmente, não foi possível testar outras condições reacionais. Além disso, com o baixo rendimento e a grande dificuldade para a obtenção de $\mathbf{3 6 a}$ ou $\mathbf{3 6 b}$, a estratégia sintética tornou-se praticamente inviável.

Tabela 23- Reação de epoxidação

\begin{tabular}{|c|c|c|c|c|}
\hline \multicolumn{5}{|c|}{$\begin{array}{l}\mathrm{R}=p \text {-metoxibenzil }(\mathbf{3 6 a}) \\
\mathrm{R}=\text { benzil }(\mathbf{3 6 b})\end{array}$} \\
\hline Entradas & Condições & Pirrolidonas & solventes & $(\%)$ \\
\hline 1 & $\begin{array}{l}2 \text { eqv } m \text {-CPBA } \\
2 \text { eqv } \mathrm{NaHCO}_{3}\end{array}$ & $36 a$ ou $36 b$ & $\begin{array}{l}\mathrm{CHCl}_{3} \text { ou } \\
\mathrm{DCM}\end{array}$ & 0 \\
\hline 2 & $\begin{array}{l}4 \text { eqv } m \text {-CPBA } \\
4 \text { eqv } \mathrm{NaHCO}_{3}\end{array}$ & $36 a$ ou $36 b$ & $\begin{array}{c}\mathrm{CHCl}_{3} \text { ou } \\
\mathrm{DCM}\end{array}$ & 0 \\
\hline 3 & $\begin{array}{c}2 \text { eqv } \mathrm{H}_{2} \mathrm{O}_{2} \\
2 \text { eqv } \mathrm{NaHCO}_{3}\end{array}$ & $36 a$ ou $36 b$ & $\begin{array}{c}\mathrm{CHCl}_{3} \text { ou } \\
\mathrm{DCM}\end{array}$ & 0 \\
\hline 4 & $\begin{array}{c}1 \text { eqv Oxane } \\
1,5 \text { eqv } \mathrm{NaHCO}_{3} \\
\end{array}$ & $36 a$ ou $36 b$ & Acetona $/ \mathrm{H}_{2} \mathrm{O}$ & 0 \\
\hline
\end{tabular}

Em virtude das dificuldades em obter as pirrolidonas insaturadas, investigou-se uma nova rota sintética partindo da $\alpha$-angélica lactona (esquema 39). A proposta consiste na abertura da lactona, sob atmosfera de argônio (ar), utilizando 1,2 equivalentes da amina para formar a amida 39. O tratamento da amida com IBX, seguindo a metodologia descrita por Nicolau et al.(2003), levaria ao composto $\alpha, \beta$-insaturado $\mathbf{4 0}$ sem a necessidade de utilizar condições anidras. A ciclização de $\mathbf{4 0}$, via reação fotoquímica, daria acesso ao hemiaminal 41 , que ao ser tratado com hidrosilanos poderia levar à formação direta da pirrolidona 42.

Na primeira etapa da reação, a amida 39 foi formada com $74 \%$ de rendimento, em 2 horas de reação, à temperatura ambiente. Ao seguir a etapa reacional, porém, o composto $\alpha, \beta$-insaturado 40 não é formado, mesmo utilizando grande excesso de IBX e altas temperatura. Sendo assim, não foi possível avançar nas etapas como proposto no esquema 39. 
Esquema 39- Proposta reacional partindo da $\alpha$-angélica lactona

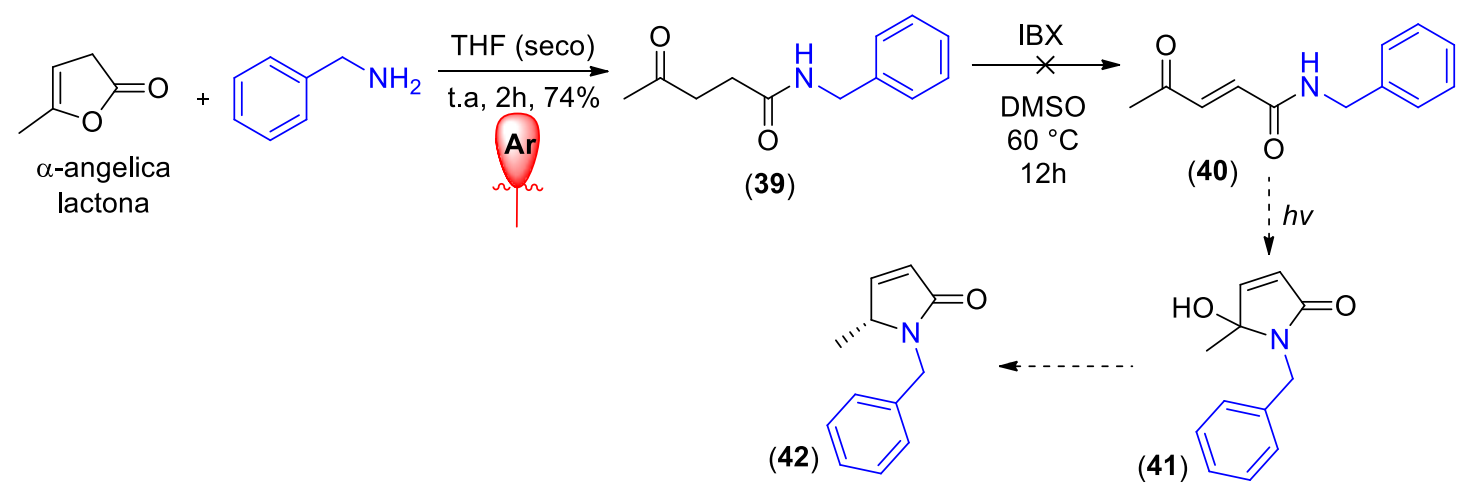

Poderia ser levada em consideração a formação de 40 via adição/eliminação de sulfóxido ou selenóxido, conforme apresentado anteriormente, porém devido às dificuldades encontradas durante o processo, optou-se por estudar uma nova rota sintética. Como o problema na etapa reacional é a dificuldade em formar as pirrolidonas $\alpha, \beta$-insaturadas, estudou-se a possibilidade de iniciar a reação utilizando a $\beta$-angélica lactona ( $\boldsymbol{\beta}$ - $\mathbf{A L})$ como material de partida, uma vez que esta já apresenta a dupla ligação (esquema 40).

A estratégia consiste em realizar a reação de diidroxilação da $\beta$-AL (43), proteção das hidroxilas (44) e abertura da lactona frente a aminas, dando origem a diversas hidroxiamidas (45). Tais amidas sendo tratadas com cloreto de mesila ou tosila, seguida pela ciclização in situ, geraria as pirrolidonas (46). 0 tratamento das pirrolidonas com reagente de Grignard, posterior redução com hidrosilanos e remoção do grupo protetor, possibilitaria a formação dos alcaloides pirrolidínicos (47).

Esquema 40- Proposta reacional partindo da $\beta$-angélica lactona

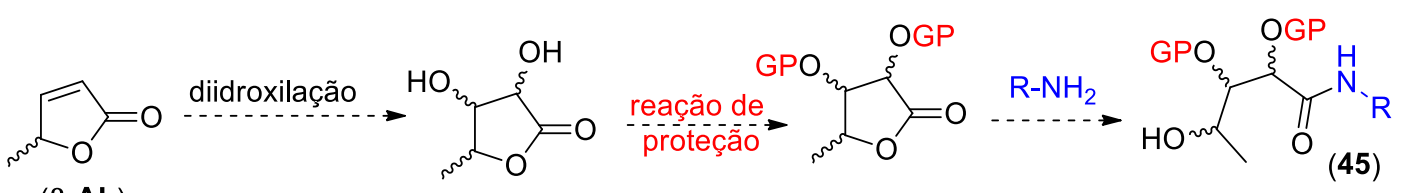
$(\beta-A L)$

(43)

(44)

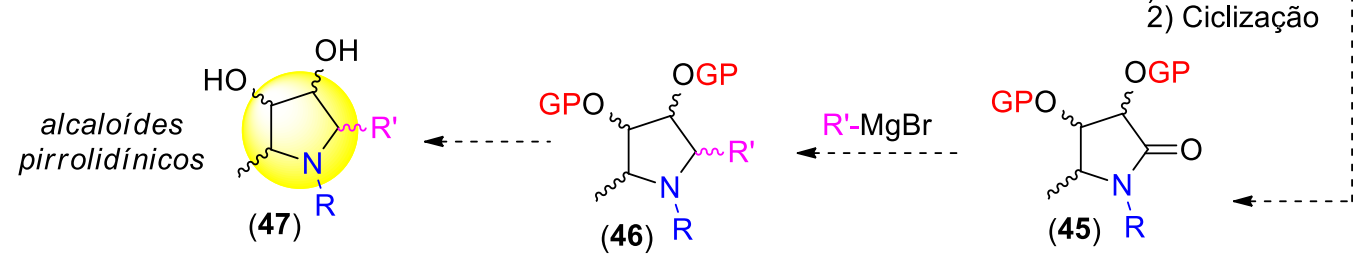




\subsection{Rota sintética partindo da $\beta$-angélica lactona}

A priori, explorou-se a reação de diidroxilação cis da $\boldsymbol{\beta}$-AL. Iniciando com o uso de $\mathrm{RuO}_{4}$ (gerado in situ pela oxidação do $\mathrm{RuCl}_{3} \mathrm{com} \mathrm{NalO}_{4}$ ), foi observada a formação do diol $\mathbf{4 3} \mathrm{com} \mathbf{4 0 \%}$ de rendimento. Por outro lado, a diidroxilação de Upjohn, modificada, empregando osmato de potássio (VI) forneceu o produto com $55 \%$ de rendimento na escala de $1 \mathrm{mmol}$. Quando a escala da reação é ampliada para $20 \mathrm{mmol}$, obtém-se um aumento de $10 \%$ no rendimento (Esquema 41).

Esquema 41- Reação de diidroxilação da $\beta$-angélica lactona
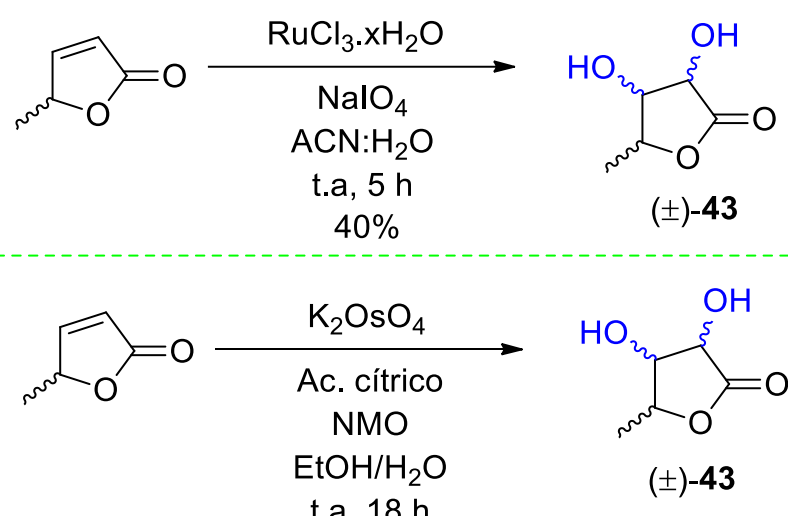<smiles>C[C@@H]1OC(=O)[C@@H](O)[C@@H]1O</smiles>

$( \pm)-43$

$55 \%$ escala de $1 \mathrm{mmol}$ $65 \%$ escala de $40 \mathrm{mmol}$

Apesar do osmato de potássio ser um reagente de custo elevado, o mesmo é utilizado em quantidades catalíticas (0,006 equivalente), sendo regenerado in situ pelo co-oxidante $\mathrm{N}$-óxido de $\mathrm{N}$-metilmorfolina (NMO). No mecanismo da reação, a dupla ligação coordena com o tetróxido de ósmio $\left(\mathrm{OsO}_{4}\right)$ por meio de uma reação de cicloadição [3+2]. Posteriormente, o intermediário é hidrolisado fornecendo o diol e o trióxido de ósmio $\left(\mathrm{OsO}_{3}\right)$. Este é oxidado pelo $\mathrm{NMO}$, regenerando-se a $\mathrm{OsO}_{4}$, que retorna para o ciclo catalítico (figura 45). Já que o tetróxido de ósmio é um oxidante eletrofílico e reage lentamente com as olefinas deficientes em elétrons, utiliza-se ácido cítrico para manter o pH da reação levemente baixo, acelerando a taxa de oxidação da olefina. ${ }^{144}$ 
Figura 45- Mecanismo para diidroxilação da $\beta-A L$

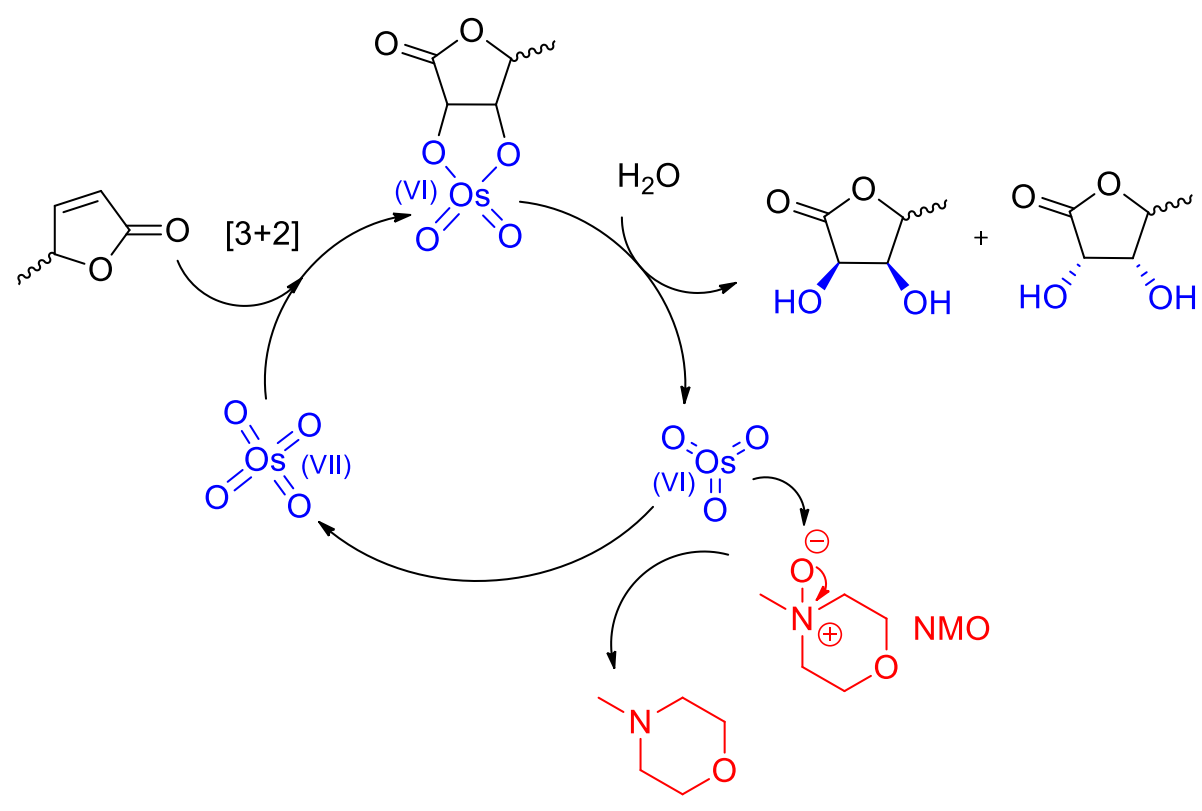

Protegeu-se o diol $\mathbf{4 3}$ utilizando acetona como grupo protetor. A reação foi realizada à temperatura ambiente, em 24 horas, empregando-se a resina ácida Amberlyst $15^{\circledR}$ como catalisador (Esquema 42). Assim, obteve-se o produto $44 \mathrm{com} 80 \%$ de rendimento (na escala de $40 \mathrm{mmol}$ do diol). Vale ressaltar que a resina pode ser reciclada e utilizada por 3 ou mais vezes.

Esquema 42- Reação de proteção do diol 43<smiles>C[C@@H]1OC(=O)[C@@H](O)[C@H]1O</smiles>

$( \pm)-(43)$

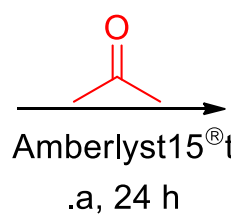

$80 \%$<smiles>C[C@@H]1OC(=O)[C@H]2OC(C)(C)O[C@H]12</smiles>

$( \pm)-44$

De acordo com as análises de RMN de ${ }^{1} \mathrm{H}$ e CG-EM, constatou-se a formação dos diastereoisômeros de 44 na proporção de aproximadamente 7:3. Na figura 46, é apresentado o cromatograma e o espectro de massas, no qual o íon molecular é representado por $\mathrm{m} / \mathrm{z}=157$ referente a $\mathrm{M}-\mathrm{CH}_{3}$. 
Figura 46- Análise realizadas por CG-EM

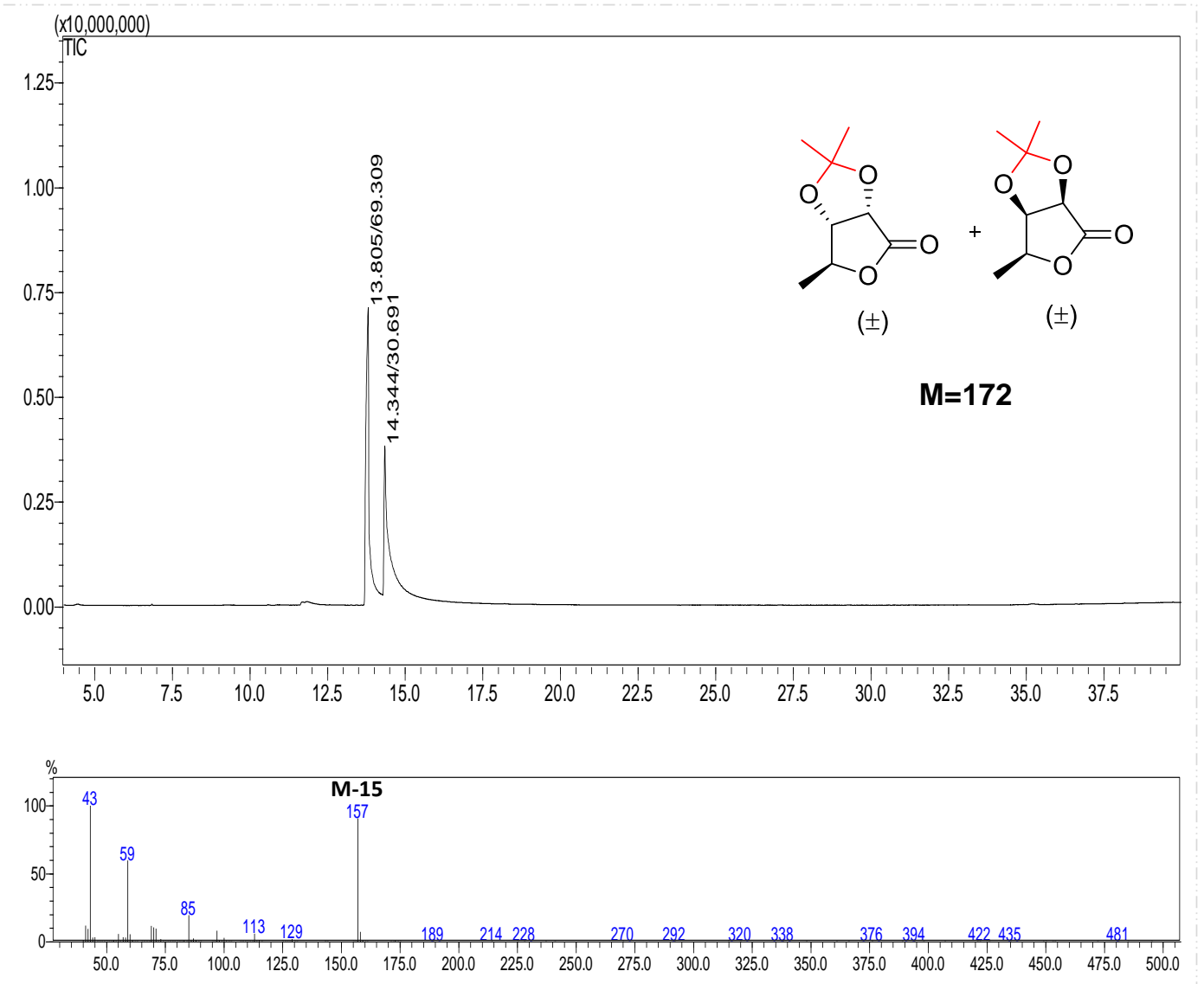

De posse do composto 44, realizou-se o estudo para abertura do anel lactônico utilizando a metilamina e benzilamina para otimizar as condições experimentais. Na entrada 1 da tabela 24, utilizou-se 1,5 equivalentes da benzilamina e THF como solvente. Após 12 horas de reação, em temperatura ambiente, a amida 45 a foi formada com $90 \%$ de rendimento. Como o rendimento da reação já foi bastante elevado, modificou-se a amina para metilamina e, após 3 horas de reação, observou-se o consumo total do material de partida, produzindo $45 \mathrm{~b}$ quantitativamente sem a necessidade de purificação (entrada 2).

Além do menor impedimento estérico da metilamina, que pode ocasionar a abertura da lactona mais rapidamente, a amina em questão é estocada em solução aquosa. Sendo assim, utilizou-se uma mistura de $\mathrm{THF} / \mathrm{H}_{2} \mathrm{O}$ como solvente para verificar se havia melhoria no rendimento da reação frente à benzilamina. Ao completar 5 horas, observou-se o consumo total do material de partida e o produto 45 a foi formado com o mesmo rendimento (90\%), porém em 5 horas de reação (entrada 3). Na entrada 4, foi investigado se a diminuição na 
quantidade da amina afetaria o rendimento da reação e, com apenas 1,1 equivalente da benzilamina, o produto foi formado com mesmo rendimento, entretanto 12 horas de reação, é necessário.

Tabela 24- Otimização da reação para abertura da lactona 44

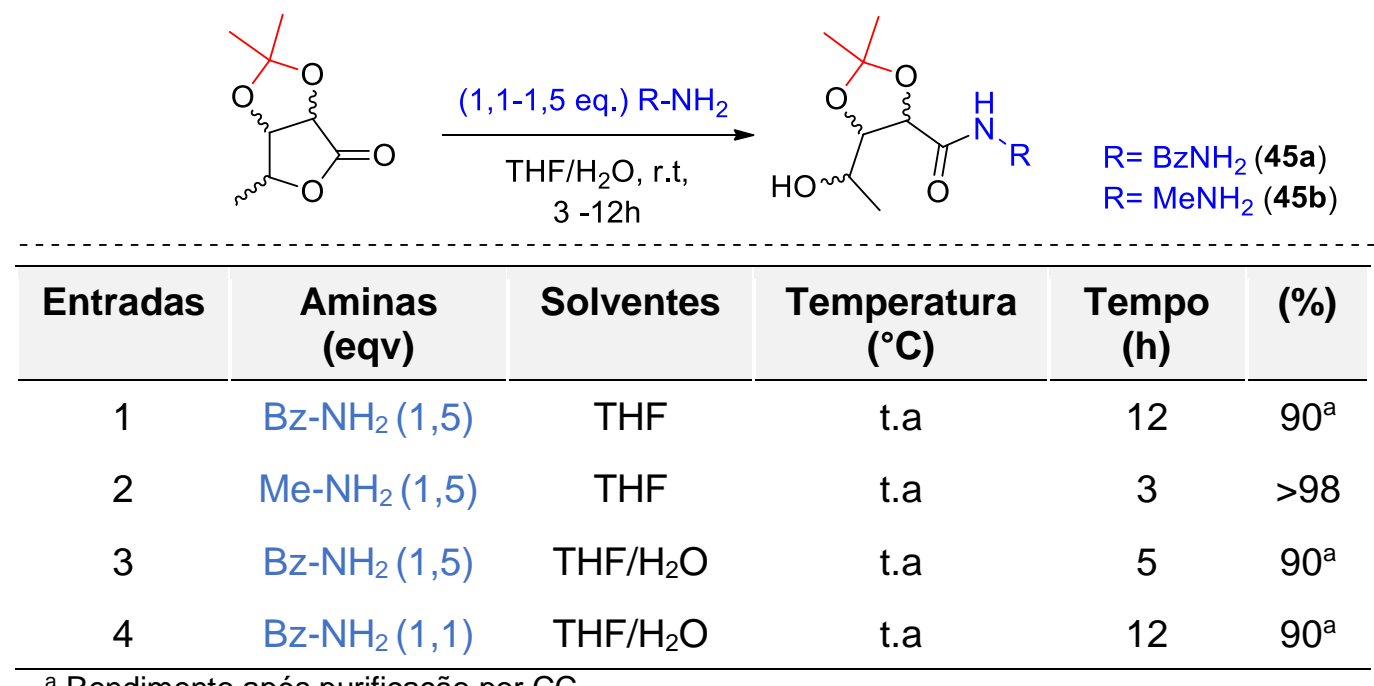

${ }^{a}$ Rendimento após purificação por CC.

Na figura 47, encontra-se o espectro de $\mathrm{RMN}$ de ${ }^{1} \mathrm{H}$ do bruto reacional de 45b e, como pode ser observado, não é necessário purificação por coluna, pois no espectro há, apenas, os sinais referentes ao composto 45b. Os sinais encontram-se duplicados, pois há presença de 2 diastereoisômeros. Os 4 singletos representados em 2,88, 2,87, 2,84 e 2,83 ppm são designados à metila ligada ao nitrogênio que, devido a possibilidade de rotâmeros na molécula, os mesmos são apresentados quadruplicados. Além disso, é possível observar a presença de 2 dubletos; um mais intenso em 1,27 e outros menos intenso em 1,23 ppm, ambos com $\mathrm{J}=6,4 \mathrm{~Hz}$, referentes a metila de $\mathrm{C}-4$. O sinal para $\mathrm{NH}$ é observado em 6,82 e 6,60 ppm.

Ao observar o cromatograma da análise realizada por CG-EM é possível concluir que os diastereoisômeros foram formados na proporção de aproximadamente 85:15. O íon molecular é representado por $\mathrm{m} / \mathrm{z}=204(\mathrm{M}+\mathrm{H})$ e 188 referente à $\left(\mathrm{M}-\mathrm{CH}_{3}\right)$. 
Figura 47- Espectro de RMN do bruto reacional para formação de 45b

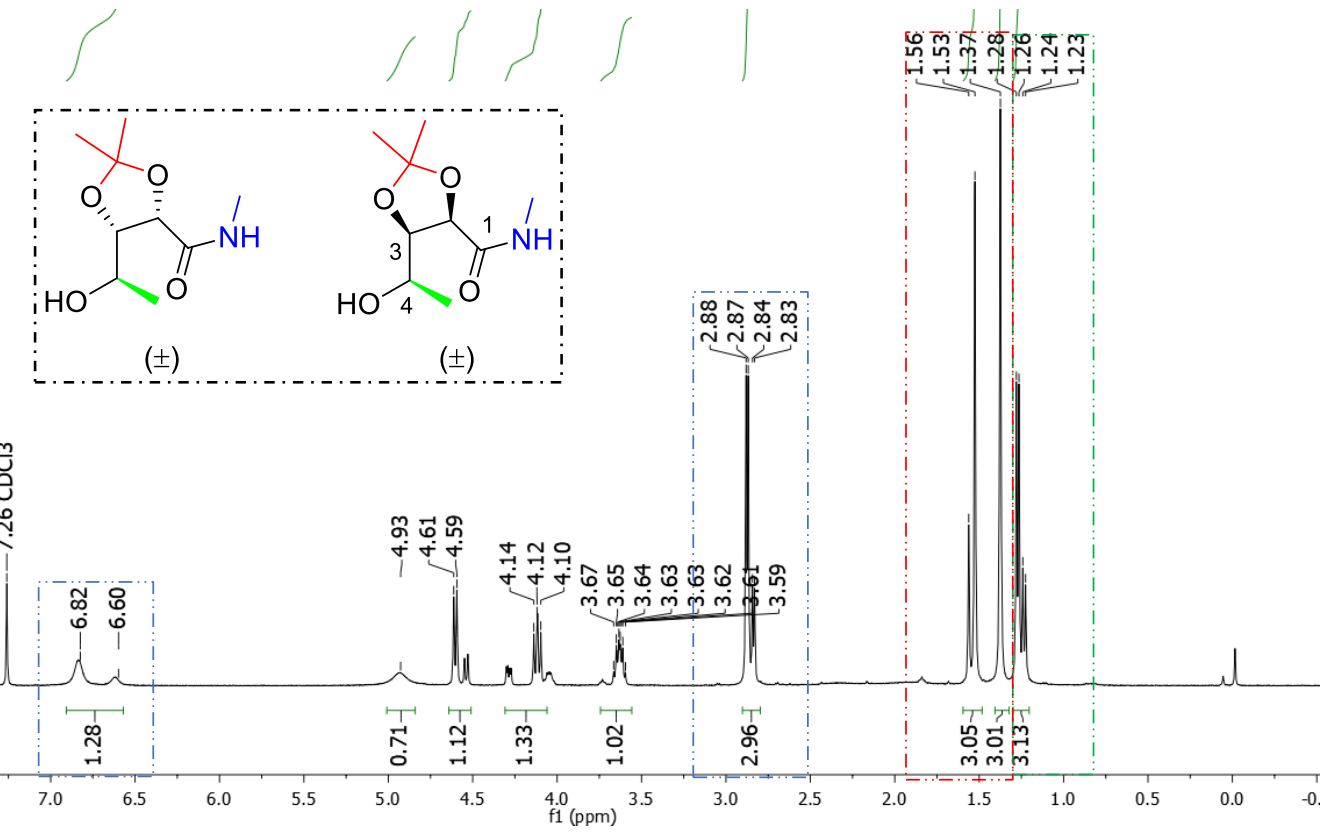

No espectro de $\mathrm{RMN}$ de ${ }^{1} \mathrm{H}$ do bruto reacional da reação com a benzilamina, foram observados outros sinais que não são referentes à mistura dos diastereoisômeros 45a, sendo assim, realizou-se a purificação por coluna (em uma coluna curta de sílica flash), obtendo o produto com $90 \%$ de rendimento, conforme já exibido na tabela 24. No cromatograma do bruto reacional, analisado por CG-EM, é possível notar que se obtêm os diastereoisômeros na proporção 94:6.

Com as condições experimentais otimizadas, expandiu-se o escopo levando a obtenção de diversas amidas, com grupos alifáticos e aromáticos ligados ao nitrogênio (figura 48), em alto rendimento (variando de 90-98\%). Na abertura da lactona, utilizando triptamina e 3-aminopropanol, não foi necessário o uso da mistura THF/ $\mathrm{H}_{2} \mathrm{O}$ como solvente, apenas THF foi utilizado.

As amidas formadas frente às aminas com baixo ponto de ebulição não necessitam de purificação por coluna. Nestes casos, apenas é necessário evaporar o solvente e o excesso das aminas, assim, os produtos já são fornecidos com alto grau de pureza. Por outro lado, quando se utiliza aminas sólidas ou com alto ponto de ebulição, o bruto reacional é filtrado em uma coluna curta com sílica flash usando misturas 70:30, 1:1 de hexano/AcOEt como eluentes. 
Figura 48- Escopo reacional para formação das amidas 45a-45j
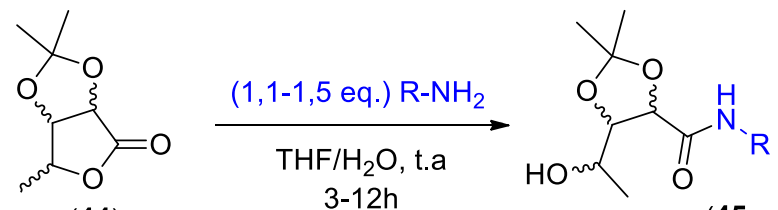

(44)

$(45 \mathrm{a}-45 \mathbf{j})$
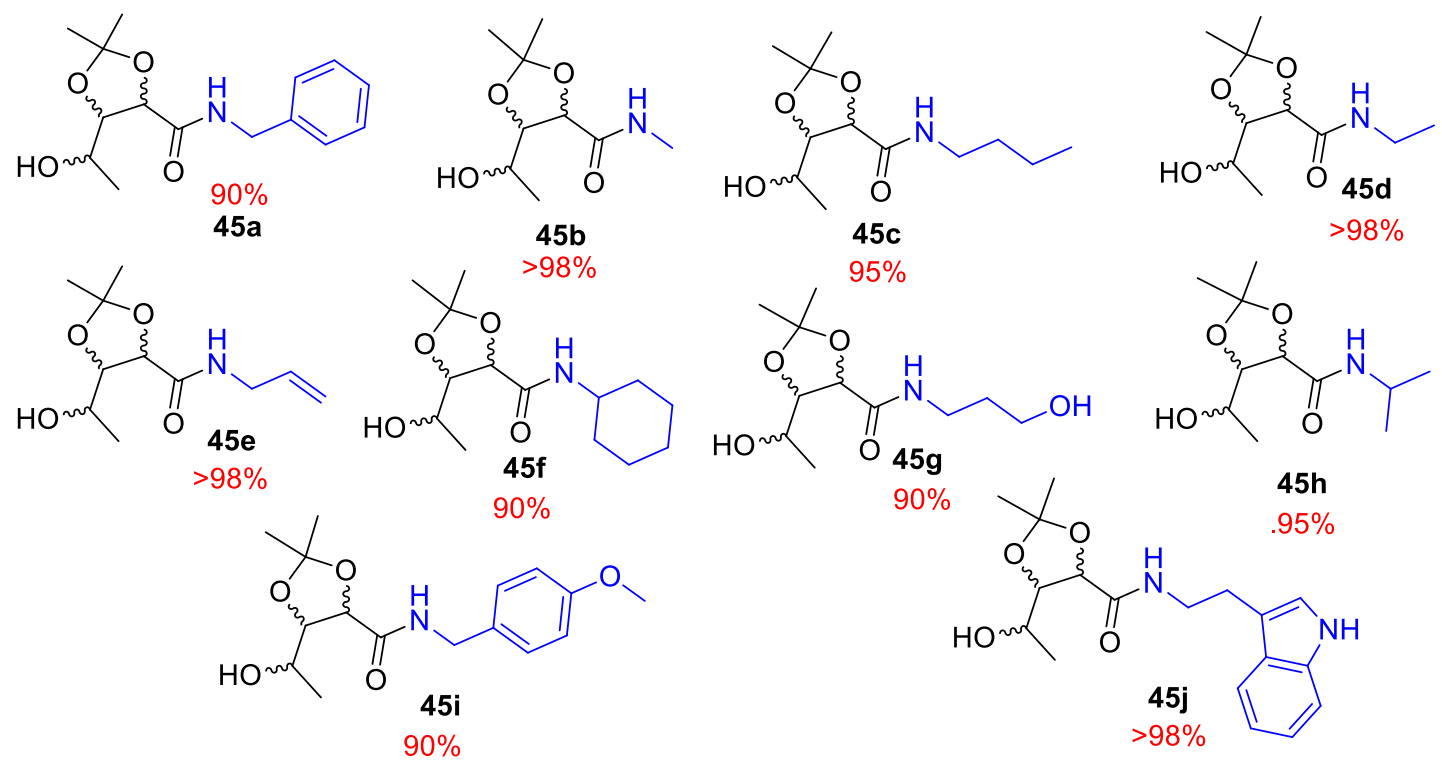

$90 \%$

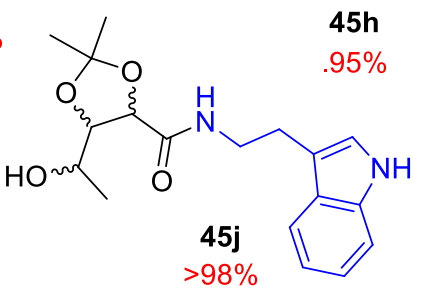

$\mathrm{Na}$ formação do produto 45i, apenas 1 dos diastereoisômeros é detectado. Não se sabe ao certo se houve a epimerização de um dos diastereoisômeros (durante a filtração em sílica) ou se o mesmo foi convertido ao produto 45i1. Na análise realizada por CG-EM (figura 49) do bruto reacional, ao utilizar 1,5 equivalentes da p-metoxibenzilamina, é possível notar a presença de 2 picos. O primeiro, minoritário ( 8\%), com tempo retenção de 30,92 minutos e, o segundo, majoritário ( 92\%) em 32,05 minutos. Ao fragmentar cada pico, percebe-se que o primeiro apresenta $M=291$ e o segundo $M=309$. Este pertencente a amida 45i, já o outro, é atribuído a pirrolidona $45 i 1$ (proveniente da ciclização de 45i). Infelizmente, o composto $45 i 1$ não foi isolado durante a purificação, provavelmente, devido à baixa concentração.

A formação de 45i1 trouxe à tona a hipótese de formar as pirrolidonas sem a necessidade de utilizar intermediários, mesilados ou tosilados, para realizar a reação de ciclização. Talvez, se a quantidade da amina for aumentada e/ou a reação realizada em altas temperaturas, pode haver a ciclização direta das amidas, gerando as pirrolidonas in situ. Futuramente, essa hipótese será investigada. Na figura 49 é apresentado o cromatograma e as fragmentações 
na análise realizada por CG-EM do bruto reacional para formação de $\mathbf{4 5 i}$. Para obtenção de $\mathbf{4 5 g}$, também, é obtido apenas 1 dos diastereoisomêro após a purificação (dados apresentados em anexo, páginas 292-294).

Figura 49- Cromatograma e fragmentações (bruto reacional para formação de 45i)
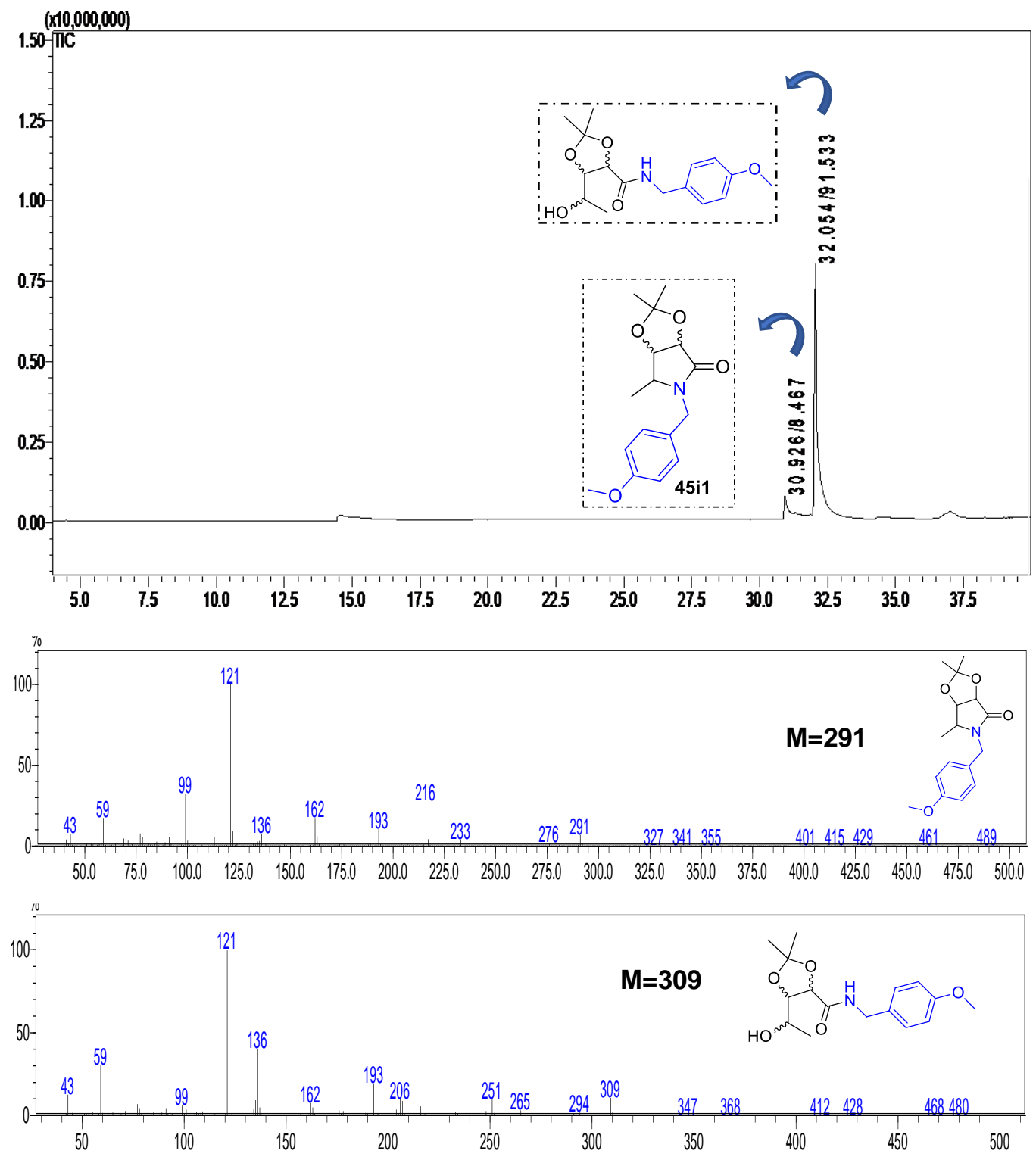

Ao realizar a abertura da lactona frente a arilaminas e com outras aminas mais impedidas, não foi possível obter os produtos desejados nas mesmas condições reacionais apresentadas anteriormente. Mesmo aquecendo a reação a $150^{\circ} \mathrm{C}$, em tubo selado, o material de partida manteve-se inconsumível. Nesse caso, foi necessário o uso de $\mathrm{AlCl}_{3}$ como catalisador. 
Utilizando-se 2 equivalentes de anilina e do catalisador, observou-se 0 consumo do material de partida em 3 horas de reação, a temperatura ambiente, possibilitando a obtenção da amida $\mathbf{4 5 k}$ com $50 \%$ de rendimentos. Na tentativa de expandir o escopo, outras aminas foram exploradas, porém, infelizmente, não se observa a formação dos produtos desejados, sendo recuperado o material de partida. Na figura 50 é apresentado os resultados.

Figura 50- Escopo reacional utilizando $\mathrm{AlCl}_{3}$ como catalisador

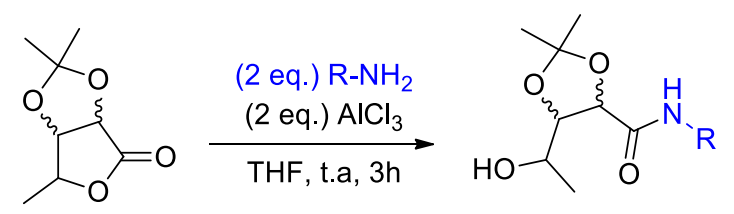

(44)

(45k-45p)

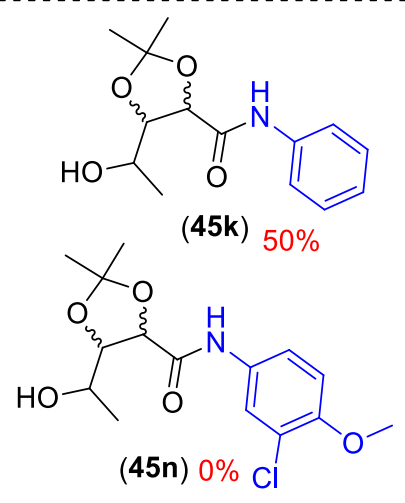<smiles>CC(O)C1OC(C)(C)OC1C(=O)Nc1cccc(Cl)c1</smiles>

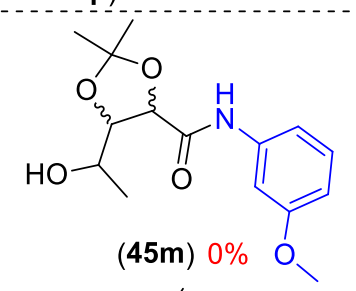<smiles>CC(O)C1OC(C)(C)OC1C(=O)Nc1ccccc1</smiles>

(450) $0 \%$<smiles>CC1CCCCC1NC(=O)C1OC(C)(C)O[C@@H]1C(C)O</smiles>

(45p) $0 \%$

$\mathrm{Na}$ busca por um catalisador mais verde e com o objetivo de expandir o escopo, futuramente, será utilizada a base triazabiciclodecano (TBD) como catalisador para abertura da lactona frente a arilaminas e, também, outras bases mais volumosas. Tal abordagem será baseada no trabalho descrito por Guo et al.(2017)..$^{145}$

\subsubsection{Estudos das reações de ciclização (amidas 45a-45k)}

Após o preparo das amidas, investigaram-se as condições reacionais para a etapa de ciclização. Para estudo inicial, escolheu-se a amida $45 \mathrm{~b}$ como modelo (na tabela 25 são expressos os resultados). Na entrada 1, investigou-se o uso do cloreto de tosila ( $\mathrm{TsCl}$ ) para conversão do álcool no tosilato. Utilizando-se 1,5 equivalente de $\mathrm{TsCl}$ e trietilamina (TEA), não houve o consumo do material de partida. Em seguida, empregou-se o uso o cloreto de mesila ( $\mathrm{MsCl}$ ), que é mais 
reativo que $\mathrm{TsCl}$ frente a álcoois secundários, mas o produto mesilado não foi formado, ocorrendo a formação de uma mistura complexa não identificada (entrada 2). Aumentou-se a quantidade do $\mathrm{MsCl}$ e da base para 4 equivalentes, novamente, há formação da mesma mistura complexa (entrada 3). Ao modificar o solvente para DCM ou utilizando DMAP como base, o mesmo resultado é observado (entradas 4 e 5 ).

Com objetivo de favorecer a reação de ciclização one-pot, foi investigado o uso de base mais forte, $t$-BuOK. Em uma única etapa, usando 2 equivalentes da base e 1,5 de $\mathrm{TsCl}$, observou-se a formação da pirrolidona $46 \mathrm{~b}$ com $35 \%$ de rendimento e recuperação do material de partida (entrada 6). Ao aumentar a quantidade da base para 2,5 equivalentes o rendimento aumenta para $50 \%$, porém ainda não há o consumo completo do material de partida (entrada 7). Vale ressaltar que além da recuperação do material de partida, também é observada a presença do $\mathrm{TsCl}$ no meio reacional.

Tabela 25- Condições reacionais para formação da pirrolidona 46b

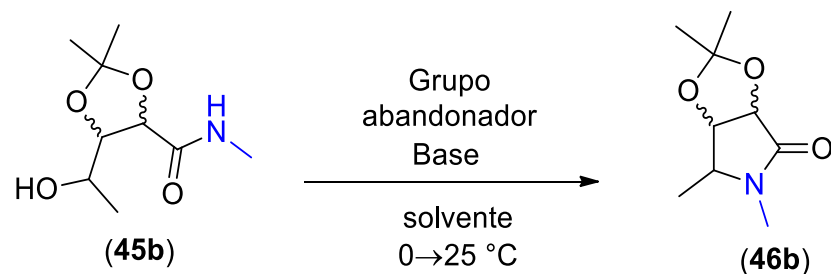

\begin{tabular}{ccccc}
\hline Entrada & Grupo (eqv) & Base (eqv) & solvente & 46b (\%) \\
\hline 1 & $\mathrm{TsCl}(1,5$ eq) & TEA (1,5) & THF & -- \\
2 & $\mathrm{MsCl}(2$ eq) & TEA (2) & THF & -- \\
3 & $\mathrm{MsCl}(4$ eq) & TEA (4) & THF & -- \\
4 & $\mathrm{MsCl}(4$ eq) & TEA (4) & DCM & -- \\
5 & $\mathrm{MsCl}(2$ eq) & DMAP (2) & THF & -- \\
6 & $\mathrm{TsCl}(1,5$ eq) & $\mathrm{t}$-BuOK (2) & THF & $35 \%$ \\
7 & $\mathrm{TsCl}(1,5$ eq) & $\mathrm{t}$-BuOK (2,5) & THF & $50 \%$ \\
\hline
\end{tabular}

O mesmo rendimento (50\%) foi obtido ao submeter a amida $45 \mathrm{c}$ à reação de ciclização. $\mathrm{Na}$ análise por CG-EM, notou-se a presença dos 2 diasteroisômeros de 46b na proporção de $78: 22$. O pico base é representado 
pela $\mathrm{m} / \mathrm{z}=170$, referente à perda da metila $\left(\mathrm{M}-\mathrm{CH}_{3}\right)$. No espectro de $\mathrm{RMN}$ de ${ }^{1} \mathrm{H}$ (anexo, pag. 313), observa-se a presença do grupo metil ligado ao nitrogênio em 2,82 e 2,78 ppm. Além disso, consta no espectro as metilas do grupo protetor na forma de singletos em 1,54, 1,38, 1,35 e 1,33 ppm. Na figura 51 encontra-se 0 cromatograma de CG-EM. Durante a purificação, um dos diastereoisômeros foi isolado, no entanto não é possível distingui-los.

Figura 51 Análise por CG-EM da pirrolidona 46b

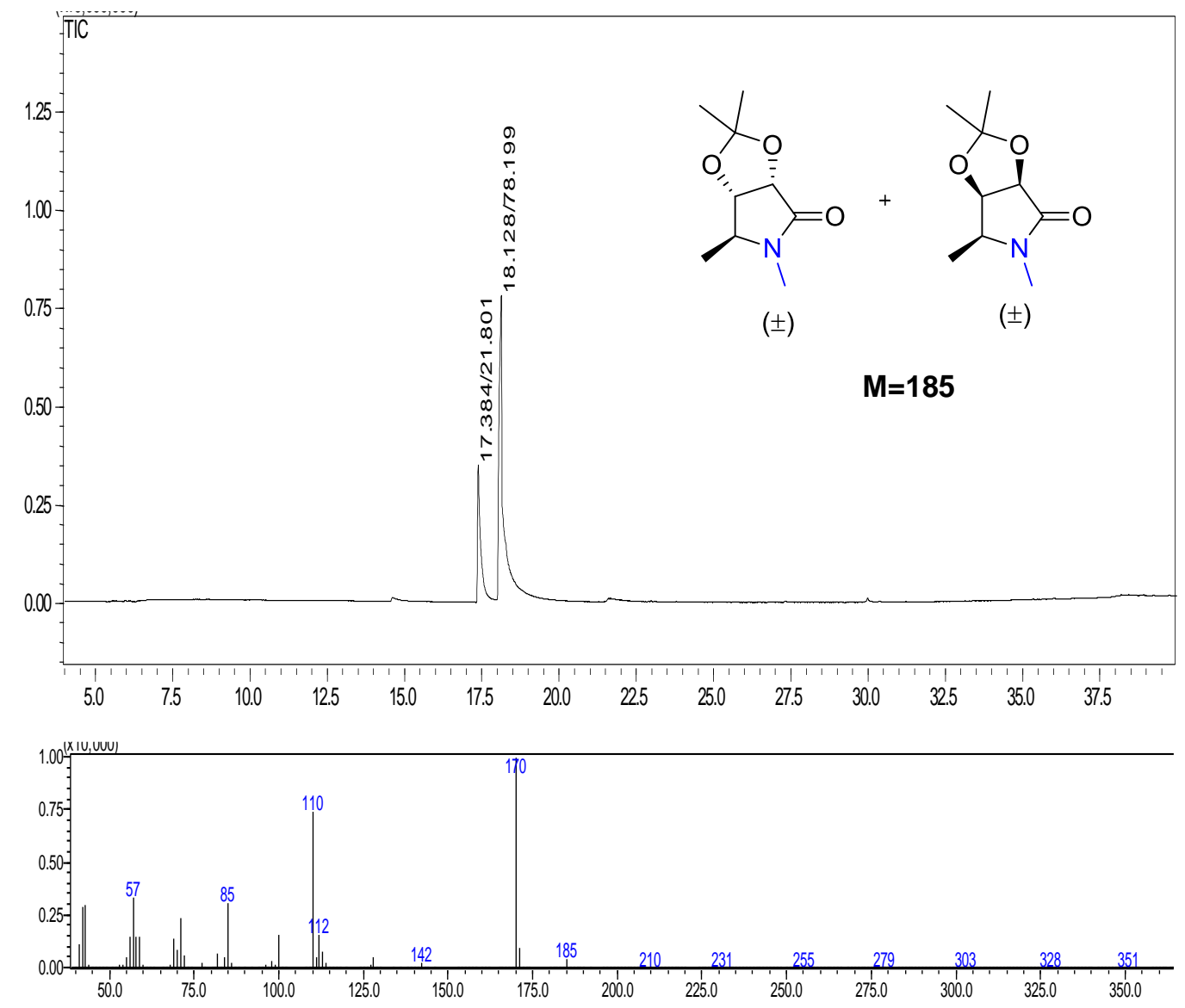

Futuramente, será investigada com maiores detalhes as condições experimentais para reação de ciclização das aminas (45a-45k). Em seguida, será investigada a reação com reagente de Grignard e, posterior, tratamento com trietilsilano ou $\mathrm{NaBH}_{4} / \mathrm{TFA}$. Também, será averiguada a reação de epoxidação da $\beta$-angélica lactona com objetivo de obter o diol trans. Além disso, as pirrolidonas poderão ser convertidas em alcaloides trissubstituídos, por meio da redução da carboxila. No esquema 43 é apresentado as próximas etapas a serem realizadas. 
Esquema 43- Esquema representando as próximas etapas para obtenção dos alcaloides

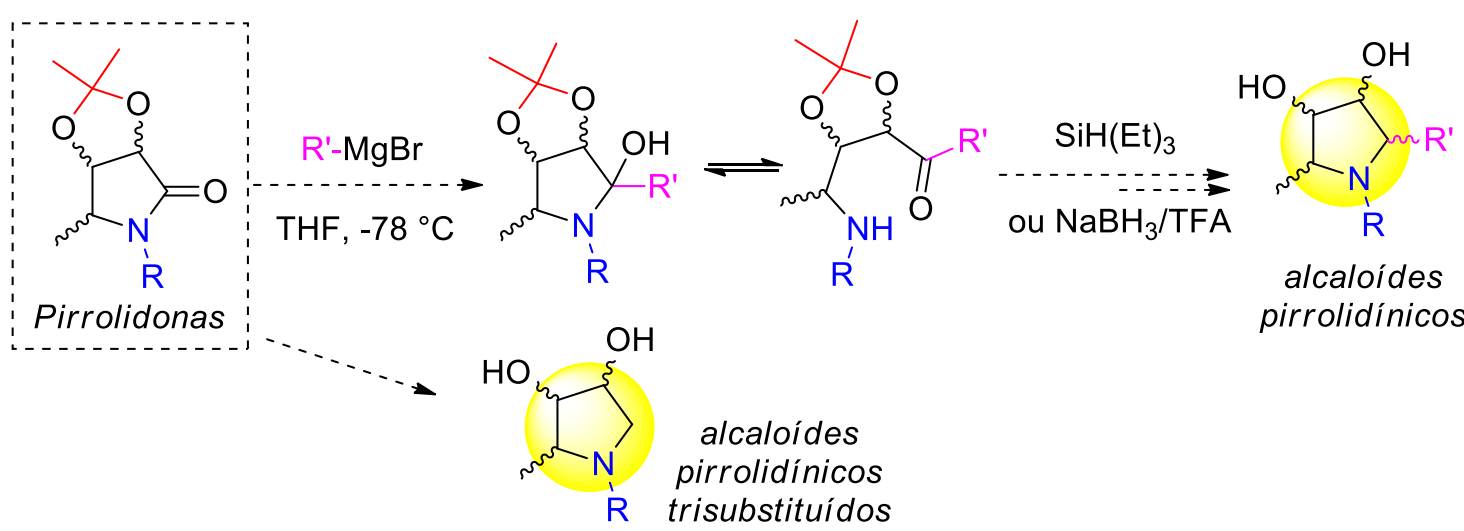




\section{Conclusões e perspectivas}

Os resultados parciais apresentados neste capítulo reforçam o grande potencial da $\beta$-angélica lactona como bloco de construção para a síntese de alcaloides pirrolidínicos diidroxilados. Foi possível obter o produto diidroxilado 43 com rendimento de $65 \%$ (na escala de $40 \mathrm{mmol}$ ). Sua aplicação na formação do produto protegido $\mathbf{4 4}$ gera os diastereoisômeros na proporção 7:3 com rendimento de $80 \%$. Além disso, a aplicação de 43 , para formação do produto 44, pode ser realizada de forma sequencial, sem a prévia purificação por coluna cromatográfica, fornecendo o produto desejado (44) com $70 \%$ de rendimento.

A abertura do anel lactônico de $\mathbf{4 4}$ forneceu as amidas (45a-45k) com bons rendimentos ( $>90 \%$ ) e algumas são obtidas quantitativamente e com alta razão diastereoisomérica. A ciclização das amidas $45 \mathrm{~b}$ e $\mathbf{4 5 c}$ possibilitou a obtenção das pirrolidonas $46 \mathrm{~b}$ e $46 \mathrm{c}$ com rendimento considerável de $50 \%$, sendo ainda necessárias novas investigações para o seu favorecimento.

Com o desenvolvimento de um método que favoreça a ciclização das amidas obtidas (45a-45k), as mesmas podem ser empregadas para o preparo de pirrolidonas que, futuramente, poderão ser convertidas em alcaloides pirrolidínicos trissubstituídos e/ou tetrassubstituídos. Os alcaloides obtidos terão as propriedades biológicas testadas frente as células citotóxicas. 


\section{Parte experimental}
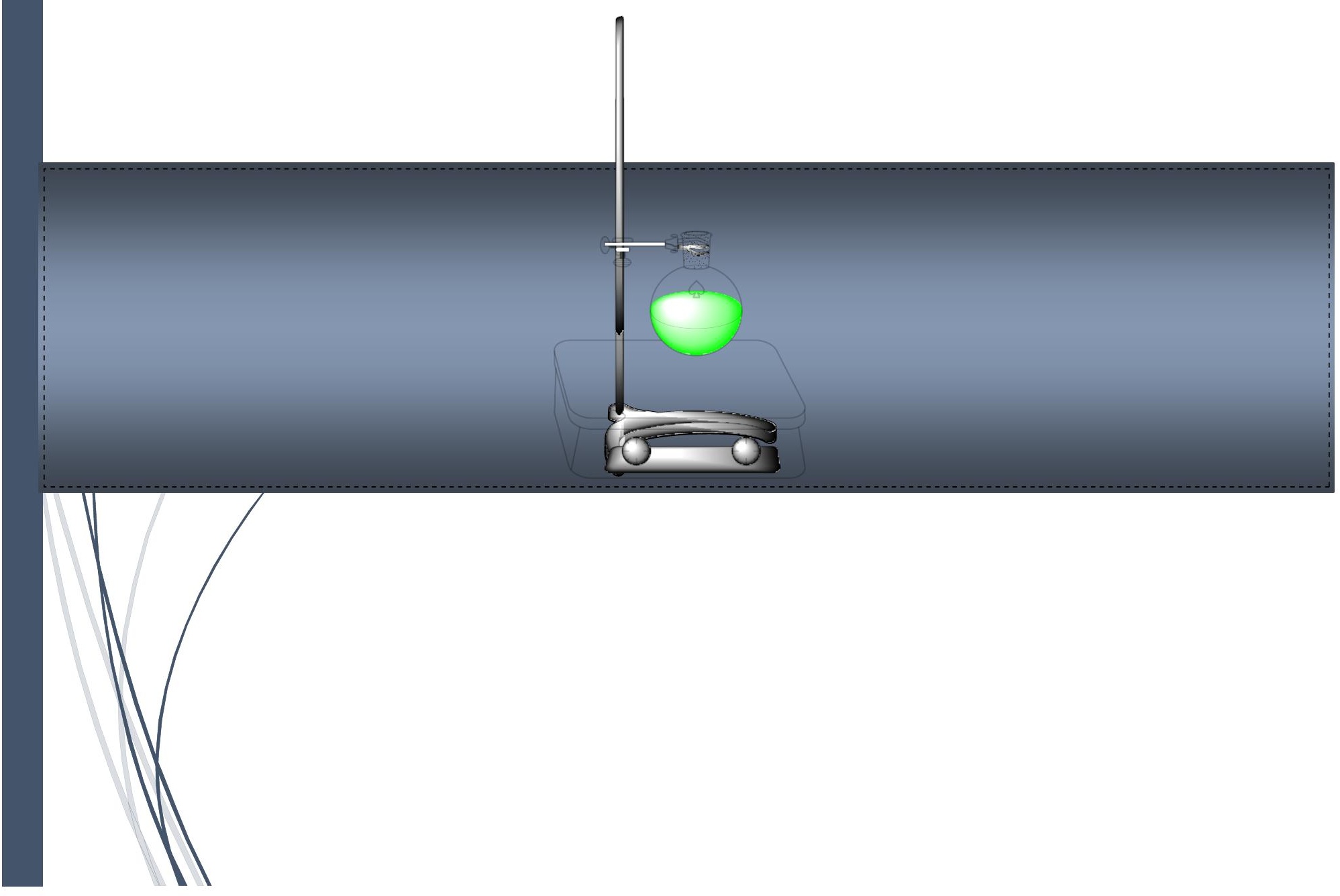


\section{Seção experimental geral}

Todos os produtos químicos foram obtidos pela Sigma-Aldrich $\AA$ e utilizados sem purificação adicional, exceto os solventes etanol e THF, que foram secos sob sódio metálico e destilados em atmosfera inerte de argônio. Para purificação dos compostos, foi utilizado sílica flash gel tamanho do poro $60 \AA$ Á, 220-440 mesh e misturas de hexano/acetato de etila ou acetato de etila/metanol como eluentes. Os deslocamentos químicos de RMN (ס) são relatados em partes por milhão (ppm) e as constantes de acoplamento (J) são relatadas em hertz $(\mathrm{Hz})$. Todas as amostras de RMN foram preparadas usando $\mathrm{CDCl}_{3}, \mathrm{MeOH}_{-} \mathrm{d}_{4}$ ou DMSO-d como solvente. Os espectros de RMN foram obtidos nos espectrômetros Varian Inova Agilent Technologies 400, 500 ou $600 \mathrm{MHz}$. As reações foram acompanhadas por cromatografia em camada delgada (CCD) utilizando sílicagel 60 da Merck e Aldrich, suportadas em placa de alumínio. Foram utilizados como reveladores lâmpada de UV (254 nm), solução básica de permanganato de potássio, solução de $p$-anisaldeído ou solução de CAN. As análises de CGEM foram realizadas no espectrômetro da Shimadzu-CGMS QP 2010 ULTRA. Coluna capilar SLB ${ }^{\circledR}-5 \mathrm{~ms}, 30 \mathrm{~m} \times 0,25 \mathrm{~mm}, 0,25 \mu \mathrm{m}$ utilizando-se o método split, fluxo do gás de arraste $1,0 \mathrm{~mL} / \mathrm{min}$, temperaturas do injetor, $250^{\circ} \mathrm{C}$, interface $230^{\circ} \mathrm{C}$ e da coluna, $60^{\circ} \mathrm{C}$. A temperatura da coluna permaneceu-se constante durante 1 minuto, em seguida, aumentou-se a $5{ }^{\circ} \mathrm{C} / \mathrm{min}$, até atingir a temperatura máxima de $280^{\circ} \mathrm{C}$, permanecendo constante entre 30-40 min. As análises em GC-FID foram realizadas no cromatógrafo da Shimadzu Modelo: GC 2010 - Plus em Coluna capilar Carbowax 20M, $30 \mathrm{~m} \times 0,32 \mathrm{~mm}, 0,15 \mu \mathrm{m}$. 


\section{Capítulo I: Uso do Levulinato de etila como plataforma química}

para produção de ciclopentadienos e seus derivados

\subsection{Auto condensação do levulinato de etila em tolueno}
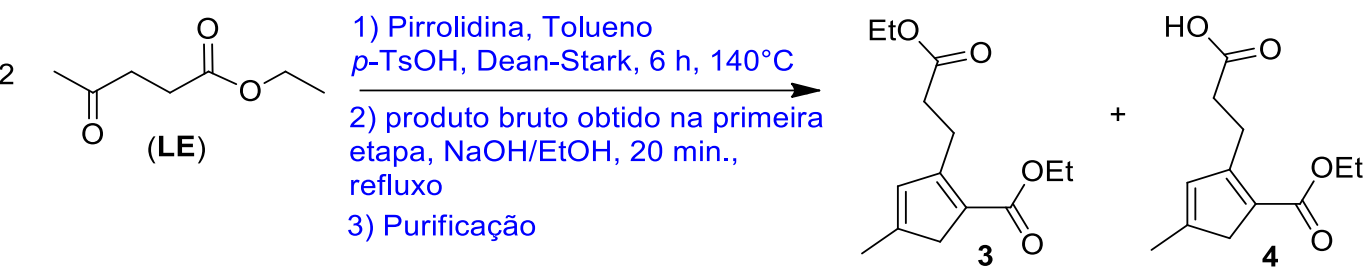

Em um balão de fundo redondo de $250 \mathrm{~mL}$, foram adicionados $78 \mathrm{mmol}$ $(11 \mathrm{~mL}, 11,25 \mathrm{~g})$ de levulinato de etila (LE), $8,8 \mathrm{mmol}(7 \mathrm{~mL}, 6,10 \mathrm{~g})$ de pirrolidina, $120 \mathrm{~mL}$ de tolueno e $5 \mathrm{~mol} \%$ de ácido $p$-tolueno sulfônico (3,9 mmol, 671,6 mg). O balão foi acoplado à aparelhagem Dean-Stark, mais condensador, e o sistema foi levado ao refluxo por 6 horas. Após este tempo, retirou-se o aparato DeanStark, adicionou-se à mistura reacional $60 \mathrm{~mL}$ de $\mathrm{H}_{2} \mathrm{O}$ destilada e levou-se 0 sistema ao refluxo por mais 20 minutos. Em seguida, o balão foi resfriado à 25 ${ }^{\circ} \mathrm{C}$ e o conteúdo foi transferido para um funil de separação. submeteu-se a mistura com 2x60 mL de $\mathrm{H}_{2} \mathrm{O}$ destilada. $\mathrm{O}$ solvente orgânico foi evaporado e ao material bruto foi adicionado cerca de $15 \mathrm{~g}$ de sílica gel flash. Filtrou-se este material em coluna de sílica com os solventes Hexano/Acetato de Etila na proporção 7:3 (1,5 L de solução). O solvente foi evaporado, obtendo-se $6,44 \mathrm{~g}$ (Rendimento bruto 62\%) de um óleo amarelado contendo 1-3 e traços do material de partida (LE). A massa total de $6,44 \mathrm{~g}(23,9 \mathrm{mmol}$ considerando apenas a massa molecular de 1 e $2,(270 \mathrm{~g} / \mathrm{mol})), 80 \mathrm{~mL}$ de etanol e 23,9 mmol de $\mathrm{NaOH}(953,7 \mathrm{mg})$ foram adicionados em um balão de fundo redondo de 125 $\mathrm{mL}$. O balão foi acoplado a um condensador e o sistema foi levado ao refluxo por 40 minutos. Após o término da reação, o balão foi resfriado à $25^{\circ} \mathrm{C}$ e o conteúdo foi transferido para um funil de separação, ao qual adicionaram-se $100 \mathrm{~mL}$ de água destilada e $\mathrm{HCl}_{(\mathrm{aq})}(1,0 \mathrm{~mol} / \mathrm{L})$ até atingir $\mathrm{pH}$ 5. Extraiu-se a solução com $4 \times 60 \mathrm{~mL}$ de acetato de etila. $\mathrm{O}$ solvente foi evaporado e 0 bruto da reação purificado em coluna de sílica gel flash utilizando Hexano/Acetato de Etila nas proporções 7:3 e 1:1. Foram obtidos $548 \mathrm{mg}$ (2,17 mmol, rendimento global: $6 \%)$ 
de 3 como um óleo amarelado e 2,40 g (10,7 mmol, rendimento global: 28\%) de 4 na forma de um sólido levemente amarelado.

Hex/ AcOEt (7:3)
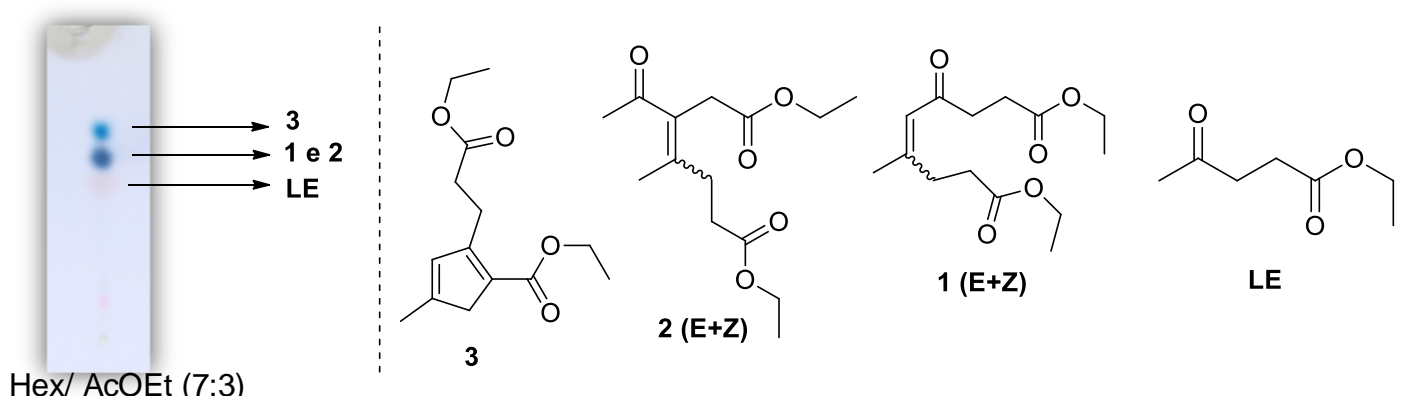

\section{4-Metil-6-oxonon-4-enedioato de dietila (1-E e 1-Z):}

${ }^{1} \mathrm{H}$ NMR (500 MHz, $\mathbf{C D C l}_{3}$ ): $\delta$ 6,10 (largo s, 1H, 5-H), 6.07 (largo s, $1 \mathrm{H}, \mathbf{5 - H}$ ),

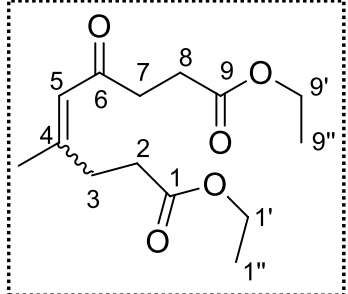

4,16-4,07 (m, 8H, - $\left.\mathrm{OCH}_{2} \mathrm{CH}_{3}\right), 3,19-2,97(\mathrm{~m}, 2 \mathrm{H}, 7-\mathrm{H}), 2,82$ (t, $J=7,7 \mathrm{~Hz}, 1 \mathrm{H}, 7-\mathrm{H}), 2,75-2,70(\mathrm{~m}, 4 \mathrm{H}, 7-\mathrm{H}$ e 8-H), 2,592,50 (m, 4H, 8-H, 2-H), 2,49-2,40 (m, 5H, 2-H, 3-H), 2,12 (d, $\left.J=1,2 \mathrm{~Hz}, 3 \mathrm{H},-\mathrm{CH}_{3}\right), 1,88\left(\mathrm{~d}, \mathrm{~J}=1,2 \mathrm{HZ}, 3 \mathrm{H},-\mathrm{CH}_{3}\right), 1,20-$ $1,29\left(\mathrm{~m}, 12 \mathrm{H},-\mathrm{OCH}_{2} \mathrm{CH}_{3}\right)$.

${ }^{13}$ C NMR (126 MHz, CDCl $)$ ): $\delta$ 198,5 (6-C), 197,9 (6-C), 173,0 (9-C), 173,0 (9C), 173,0 (1-C), 172,8 (1-C), 157,4 (4-C), 156,6 (4-C), 124,3 (5-C), 123,1 (5-C), 60,8 (9'-C), 60,7 (9'-C), 60,7 (9'-C), 60,7 (9'”-C), 38,7 (7-C), 38,5 (7-C), 36,3 (2C), 35,9 (2-C), 32,6 (8-C), 32,2 (8-C), 25,5 (3-C), 24,3 (3-C), 19,4 (-- $\left.\mathbf{C H}_{3}\right)$, 16,7 ($\left.\mathbf{C H}_{3}\right), \quad 14,3\left(-\mathrm{OCH}_{2} \mathbf{C H}_{3}\right), \quad 14,3\left(-\mathrm{OCH}_{2} \mathbf{C H}_{3}\right)$, HRMS ESI-MS m/z: 293,1365 calculado para [M+Na] ${ }^{+} \mathrm{C}_{14} \mathrm{H}_{22} \mathrm{NaO}_{5}$, encontrada 293,1359. IV (vmax, ATR cm ${ }^{-}$ 1): 2977, 2935, 2363, 2320, 1732, 1691, 1623, 1373, 1179, 1106, 1028, 860.

2-(3-etoxi-3-oxopropil) -4-metilciclopenta-1,3-dienocarboxilato de etila (3):

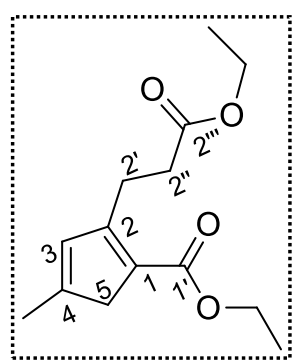

${ }^{1} \mathrm{H}$ NMR (400 MHz, $\mathbf{C D C l}_{3}$ ): $\delta 6,12$ (q aparente, $J=1,3 \mathrm{~Hz}, 1 \mathrm{H}$, H-3), 4,19 (q, $J=7,1 \mathrm{~Hz}, 2 \mathrm{H},-\mathrm{OCH}_{2} \mathrm{CH}_{3}$ ), 4,12 (q, $J=7,1 \mathrm{~Hz}$, $2 \mathrm{H},-\mathrm{OCH}_{2} \mathrm{CH}_{3}$ ), 3,20 (q aparente, $J=1,3 \mathrm{~Hz}, 2 \mathrm{H}, 5-\mathrm{H}$ ), 3,05 (t, $J=7,7 \mathrm{~Hz}, 2 \mathrm{H}, 2$ '-H), 2,55 (t, $J=7,7 \mathrm{~Hz}, 2 \mathrm{H}, 2$ ''-H), 2,06 (d, $J=$ $\left.1,5 \mathrm{~Hz}, 3 \mathrm{H},-\mathrm{CH}_{3}\right), 1,30\left(\mathrm{t}, J=7,1 \mathrm{~Hz}, 3 \mathrm{H},-\mathrm{OCH}_{2} \mathrm{CH}_{3}\right), 1,24$ (t, $\left.J=7,1 \mathrm{~Hz}, 3 \mathrm{H},-\mathrm{OCH}_{2} \mathrm{CH}_{3}\right)$.

${ }^{13}$ C NMR (101 MHz, CDCl 3 ): $\delta$ 172,9 (2'”'-C), 164,5 (1'-C), 158,5 (4-C), 151,4 (1C), 131,5 (3-C), 127,3 (2-C), 60,4 (- $\left.\mathrm{OCH}_{2} \mathrm{CH}_{3}\right), 59,4\left(-\mathrm{OCH}_{2} \mathrm{CH}_{3}\right), 46,0$ (5-C), 
33,5 (2''-C), 24,5 (2'-C), 16,4 (- $\left.\mathrm{CH}_{3}\right), 14,4\left(-\mathrm{OCH}_{2} \mathrm{CH}_{3}\right), 14,2\left(-\mathrm{OCH}_{2} \mathrm{CH}_{3}\right)$. HRMS ESI-MS $\mathrm{m} / \mathrm{z}: 275,1259$ calculado para $[\mathrm{M}+\mathrm{Na}]+\mathrm{C}_{14} \mathrm{H}_{20} \mathrm{NaO}_{4}$, encontrada 275,1244. IV (vmax, ATR cm-1): 2981, 2934, 2912, 1733, 1691, 1623, 1373, 1253, 1178, 1107, 1034, 863.

Ácido 3-(2-(etoxicarbonil) -4-metilciclopenta-1,4-dien-1-il) propanóico (4):

${ }^{1} \mathrm{H}$ NMR (500 MHz, DMSO-d ${ }_{6}$ ): $\delta$ 12,12 (s, 1H, -OH), 6,22 (q aparente, $J=1,3$ $=0$ $\mathrm{Hz}, 1 \mathrm{H}, 3-\mathrm{H}$ ), 4,10 (q, $J=7,1 \mathrm{~Hz}, 2 \mathrm{H},-\mathrm{OCH}_{2} \mathrm{CH}_{3}$ ), 3,20 (q aparente, $J=1,3 \mathrm{~Hz}, 2 \mathrm{H}, 5-\mathrm{H}$ ), 2,92 (t largo, $J=7,3 \mathrm{~Hz}, 2 \mathrm{H}$, 2'-H), 2,42 (broad t, $J=7,3 \mathrm{~Hz}, 2 \mathrm{H}, 2$ ''-H), 2,04 (d, $J=1,4$ $\left.\mathrm{Hz}, 3 \mathrm{H},-\mathrm{CH}_{3}\right), 1,22\left(\mathrm{t}, J=7,1 \mathrm{~Hz}, 3 \mathrm{H},-\mathrm{OCH}_{2} \mathrm{CH}_{3}\right)$.

${ }^{13} \mathrm{C}$ NMR (126 MHz, DMSO-d $\mathbf{d}_{6}$ ): $\delta$ 173,7 (C=0, ácido carboxílico), 163,6 (C=O ester), 158,7 (4-C), 151,4 (1-C), 131,1 (3-C), 126,4 (2C), 58,9 (- $\left.\mathrm{OCH}_{2} \mathrm{CH}_{3}\right), 45,6$ (5-C), 32,8 (2''-C), 24,1 (2'-C), 16,2 (-- $\left.\mathrm{CH}_{3}\right), 14,3$ ($\mathrm{OCH}_{2} \mathrm{CH}_{3}$ ), HRMS ESI-MS m/z: 223,0970 calculado para [M-H] $\mathrm{C}_{12} \mathrm{H}_{15} \mathrm{O}_{4}$,

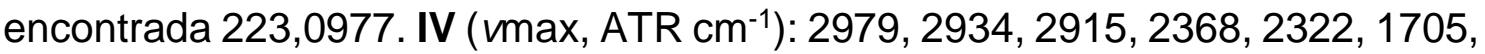
1690, 1621, 1550, 1373, 1252, 1172, 1064,1018, 890, 754.

\subsection{Análise por CG-EM do bruto reacional}

A amostra contendo os compostos 1-3 e traços de LE, obtidos após filtração, foi submetida à análise por GC-EM. As análises foram realizadas no espectrômetro da Shimadzu-CGMS QP 2010 ULTRA em coluna capilar SLB ${ }^{\Theta_{-}}$ $5 \mathrm{~ms}, 30 \mathrm{~m} \times 0.25 \mathrm{~mm}, 0.25 \mu \mathrm{m}$. Utilizou-se o método split com injeção direta (1 $\mu \mathrm{L}$ ), fluxo do gás de arraste $1,7 \mathrm{~mL} / \mathrm{min}$, temperaturas do injetor, $250^{\circ} \mathrm{C}$, interface $230^{\circ} \mathrm{C}$ e da coluna, $50^{\circ} \mathrm{C}$. A temperatura da coluna permaneceu-se constante durante 1 minuto, em seguida, aumentou-se a $1^{\circ} \mathrm{C} / \mathrm{min}$, até atingir a temperatura máxima de $300{ }^{\circ} \mathrm{C}$, permanecendo-se constante entre 24-40 min. 

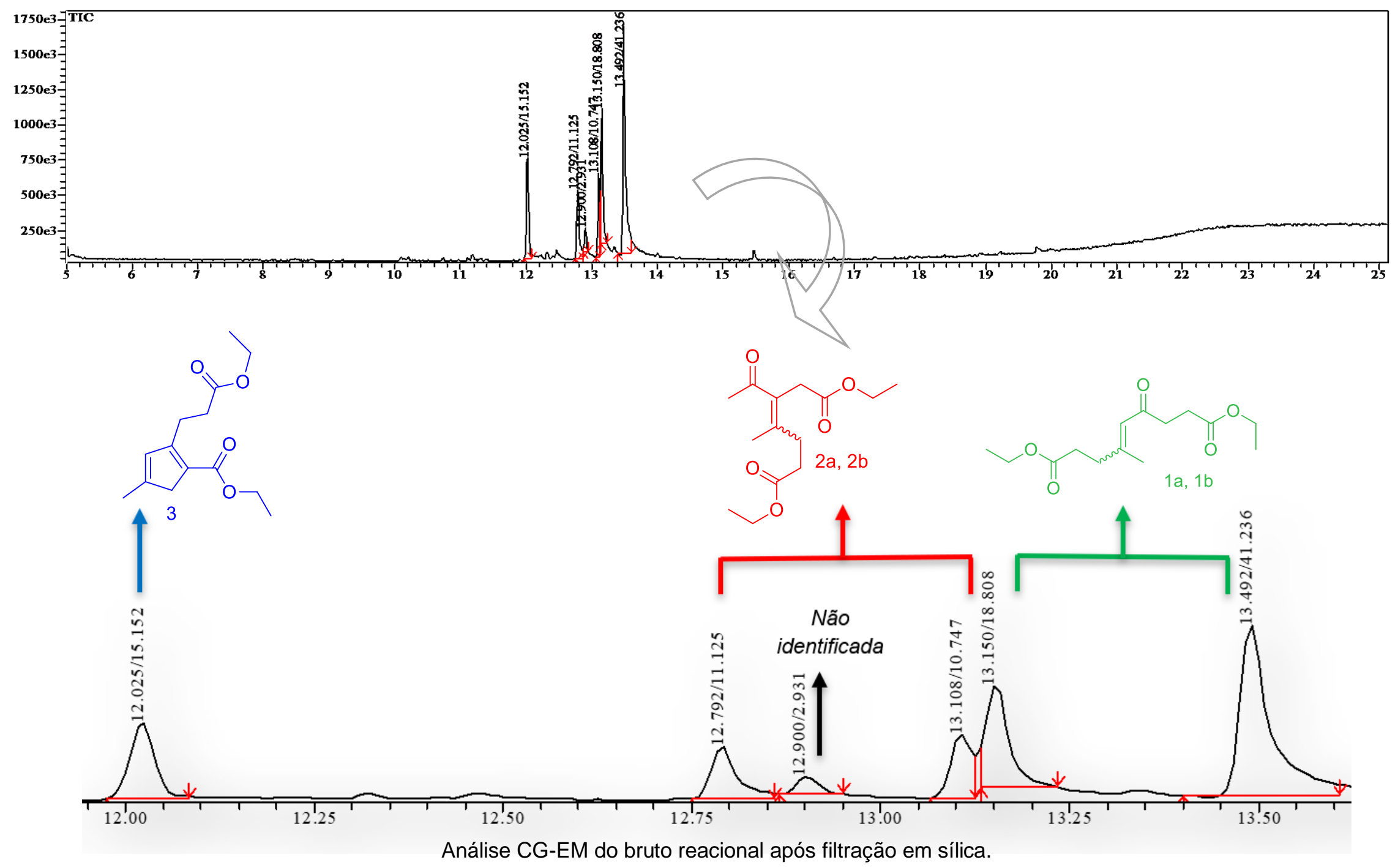

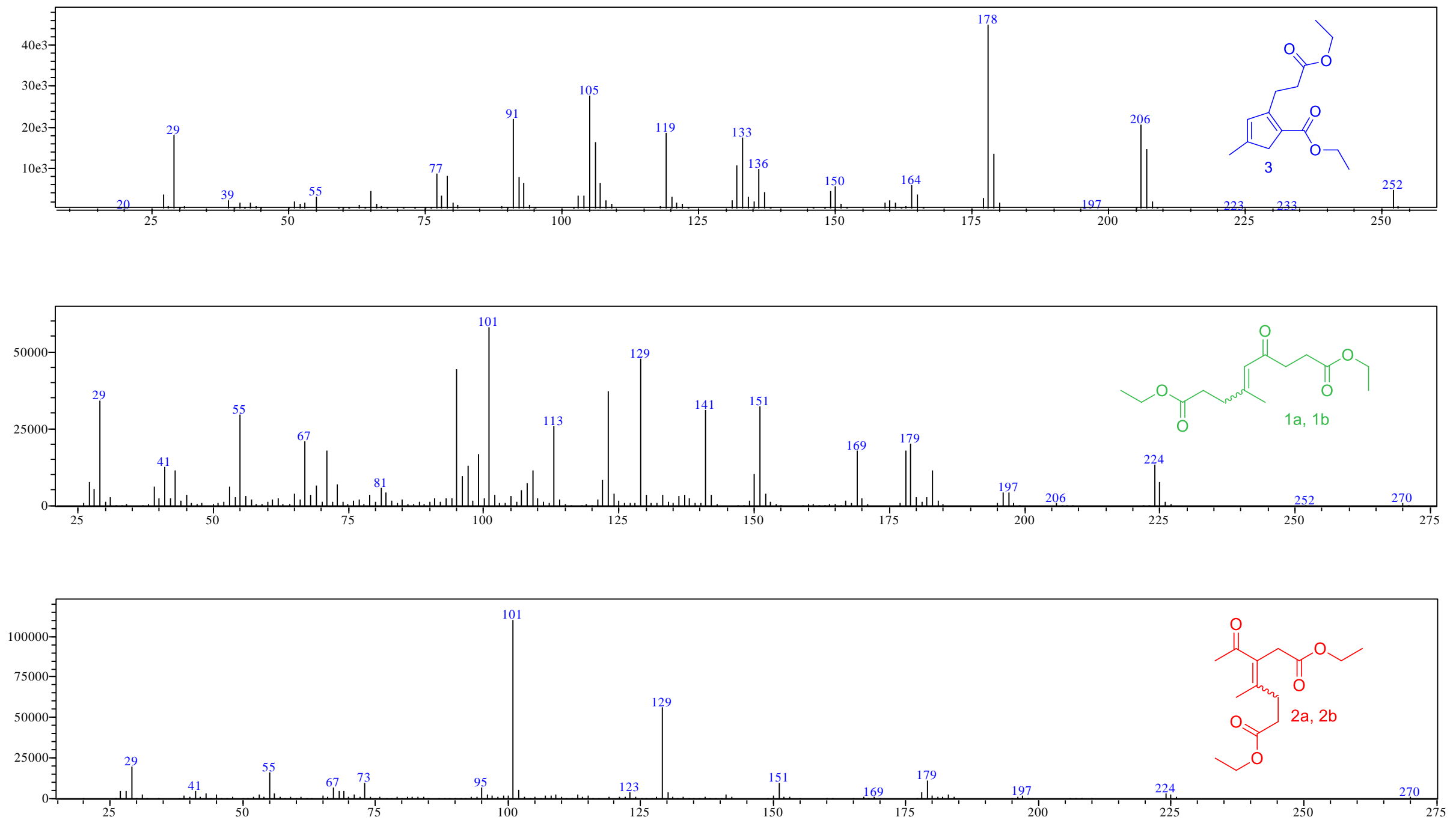

Fragmentação dos picos com tempo de retenção 12,02, (12,79 e 13,10), (13,15 e 13,49). 


\section{Auto condensação do levulinato de etila em anisol}

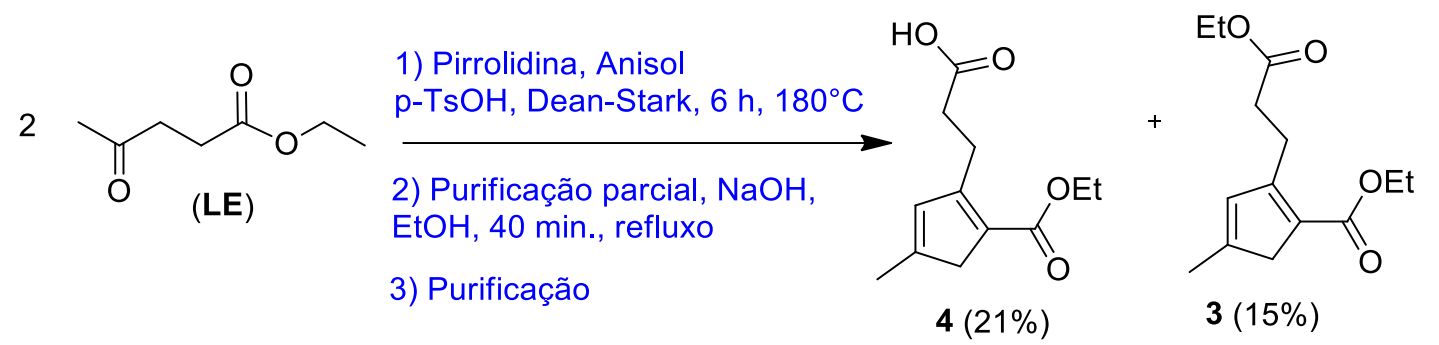

Levulinato de etila (LE) $(78 \mathrm{mmol}, 11 \mathrm{~mL}, 11,25 \mathrm{~g})$, pirrolidina $(85,8 \mathrm{mmol}$, $7 \mathrm{~mL}, 6,10 \mathrm{~g})$, anisol (120 mL) e 5\%mol de ácido $p$-toluenossulfônico $(3,9 \mathrm{mmol}$, $671,6 \mathrm{mg}$ ) foram adicionados em um balão de fundo redondo de $250 \mathrm{~mL}$ acoplado à aparelhagem Dean-Stark, mais condensador. O sistema foi levado ao refluxo por 6 horas e, após este tempo, a mistura foi resfriada à $25^{\circ} \mathrm{C} \mathrm{e}$ adicionou-se $560 \mathrm{mg}(4,05 \mathrm{mmol})$ de $\mathrm{K}_{2} \mathrm{CO}_{3}$. $\mathrm{O}$ material bruto foi filtrado e purificado por cromatografia em coluna flash utilizando misturas do eluente em gradiente Hexano/Acetato de etila $(9: 1 ; 7: 3 ; 1: 1)$, dando origem a um óleo amarelado contendo $3,56 \mathrm{~g}$ de 1 e 2 (13,7 mmol, 34\%) e 1,48 g (5,9 mmol, 15\%) de 3. Para a etapa de ciclização, a mesma sequência foi empregada como descrito no tópico 2.1. O dieno 4 foi obtido com rendimento de $21 \%$ (1,86 g, 8,3 $\mathrm{mmol})$.

\section{Preparo do ciclopentadieno 5}

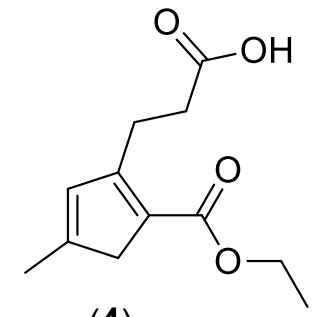

(4)

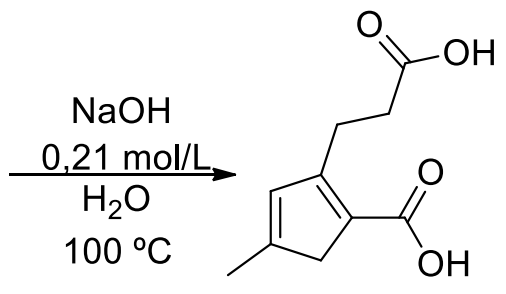

(5)

Em um balão de fundo redondo de $25 \mathrm{~mL}$, foram adicionados $1 \mathrm{mmol}$ do dieno 4 (224 mg), $10 \mathrm{~mL}$ de $\mathrm{H}_{2} \mathrm{O}$ destilada e 2,1 mmol (84 mg) de $\mathrm{NaOH}$. O sistema foi levado ao refluxo por 4 horas e, após o término da reação, a solução foi acidificada com $\mathrm{HCl}_{(\text {aq) }}$ até $\mathrm{pH}=3$. O meio reacional foi extraído com acetato de etila $3 \times 10 \mathrm{~mL}$ e a fase orgânica foi seca com sulfato de sódio anidro. O produto bruto foi purificado em coluna de sílica gel flash com misturas dos solventes 
Hexano/AcOEt (1:1), AcOEt puro e AcOEt/ MeOH (95:5). Dando origem ao composto $5 \mathrm{com} 60 \%(0,60 \mathrm{mmol}, 117,6 \mathrm{mg})$ de rendimento na forma de um sólido amorfo branco.

\section{Ácido 2-(2-carboxietil)-4-metilciclopenta-1,3 dienocarboxílico (5):}

${ }^{1} \mathrm{H}$ NMR (500 MHz, DMSO-d $\mathbf{d}_{6}$ ): $\delta$ 11,99 (s, 1H, -OH), 6,20 (q aparente, $J=1,3$

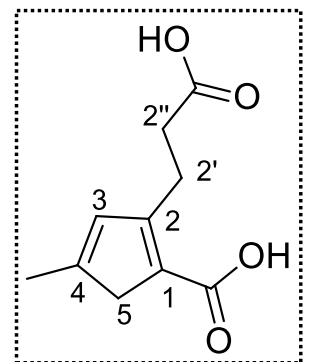

$\mathrm{Hz}, 1 \mathrm{H}, 3-\mathrm{H}$ ), 3,20 (q aparente, $J=1,3 \mathrm{~Hz}, 2 \mathrm{H}, 5-\mathrm{H}$ ), 2,91 (t largo, $J=7,3 \mathrm{~Hz}, 2 \mathrm{H}, 2$ '-H), 2,42 (t largo, $J=7,3 \mathrm{~Hz}, 2 \mathrm{H}, 2$ '"H), 2,03 (d, $\left.J=1,2 \mathrm{~Hz}, 3 \mathrm{H},-\mathrm{CH}_{3}\right)$.

${ }^{13} \mathrm{C}$ NMR (126 MHz, DMSO- $\left.\mathrm{d}_{6}\right): \delta$ 173,9 (C=0, ácido carboxílico, 2"-C), 165,3 (C=0), 157,8 (4-C), 150,9 (1-C), 131,1 (3-C), 127,4 (2-C), 45,7 (5-C), 32,3 (2'’-C), 23,9 (2'-C),

16,3 $\left(-\mathrm{CH}_{3}\right)$, HRMS ESI-MS $\mathrm{m} / z: 219,0633$ calculado para $[\mathrm{M}+\mathrm{Na}]^{+} \mathrm{C}_{10} \mathrm{H}_{12} \mathrm{NaO}_{4}$, encontrada 219,0650. IV ( $\max$, ATR cm-1): 2923, 2857, 2363, 2320, 1708, $1457,1374,1279,1229,1166,1119,1041,770$.

\section{Procedimento geral para preparo dos ciclopentadienos 6 e 7}

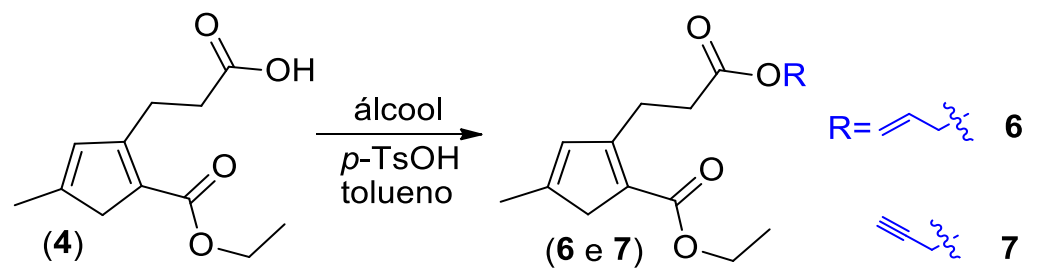

Em um balão de fundo redondo de $25 \mathrm{~mL}$, foram adicionados $1 \mathrm{mmol}$ ( 224 $\mathrm{mg}$ ) do dieno $4,1 \mathrm{mmol}$ dos álcoois alílico $(58,08 \mathrm{mg}, 68 \mu \mathrm{L})$ ou propargílico (56,10 mg, $58 \mu \mathrm{L}), 10 \mathrm{~mol} \%$ de ácido $p$-TsOH $(17,2 \mathrm{mg})$ e $10 \mathrm{~mL}$ de tolueno. Acoplou-se um condensador de refluxo e o sistema foi aquecido na temperatura de $70{ }^{\circ} \mathrm{C}$ por 6 horas. Após este tempo, resfriou-se o meio reacional, adicionouse $10 \mathrm{~mol} \%$ de $\mathrm{K}_{2} \mathrm{CO}_{3}(13,8 \mathrm{mg})$ e, em seguida, a reação foi filtrada e o solvente evaporado. O bruto da reação foi purificado em coluna de sílica gel flash utilizando como eluente Hexano/Acetato de etila (8:2). Obteve-se um óleo amarelado com rendimento de $60 \%$ para ambos os produtos: $6(0,60 \mathrm{mmol}, 150$ $\mathrm{mg})$ e 7 (0,60 mmol, $149 \mathrm{mg})$. 
2-(3-(aliloxi)-3-oxopropil)-4-metilciclopenta-1,3-dienocarboxilato de etila (6):

${ }^{1} \mathbf{H}$ NMR(500 MHz, $\mathbf{C D C l}_{3}$ ): $\delta$ 6,10 (q aparente, $\left.J=1,3 \mathrm{~Hz}, 1 \mathrm{H}, \mathbf{3 - H}\right), 5,87$ (ddt, $J$

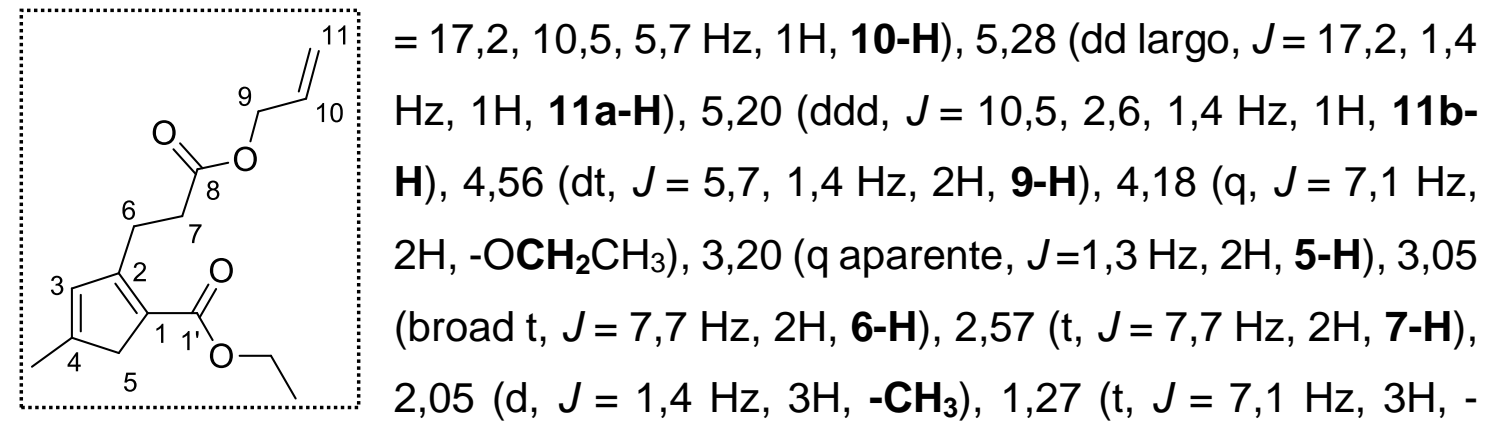

$\mathrm{OCH}_{2} \mathbf{C H}_{3}$ ),

${ }^{13} \mathrm{C}$ NMR (125 MHz, $\mathbf{C D C l}_{3}$ ): $\delta$ 172,7 (8-C=0), 164,4 (1'-C=0), 158,4 (4-C), 151,5 (1-C), 132,3 (10-C), 131,6 (3-C), 127,5 (2-C), 118,2 (11-C), 65,2 (9-C), 59,5 ($\left.\mathrm{OCH}_{2} \mathrm{CH}_{3}\right), 46,1$ (5-C), 33,5 (7-C), 24,6 (6-C), 16,5 (- $\left.\mathrm{CH}_{3}\right), 14,5\left(-\mathrm{OCH}_{2} \mathbf{C H}_{3}\right)$, HRMS ESI-MS m/z: 287,1259 calculado para $[\mathrm{M}+\mathrm{Na}]^{+} \mathrm{C}_{15} \mathrm{H}_{20} \mathrm{NaO}_{4}$, encontrada 287,1258. IV (vmax, ATR cm-1): 2970, 2934, 2362, 2319, 1735, 1695, 1551, $1446,1374,1255,1170,1105,1060,993,930,895,755$.

4-metil-2-(3-oxo-3-(prop-2-in-1-iloxi)propil) ciclopenta-1,3-dienocarboxilato de etila (7):

${ }^{1} \mathbf{H}$ NMR (400 MHz, $\mathbf{C D C l}_{3}$ ): $\delta$ 6,09 (q aparente, $\left.J=1,3 \mathrm{~Hz}, 1 \mathrm{H}, \mathbf{3 - H}\right), 4,65$ (d, J

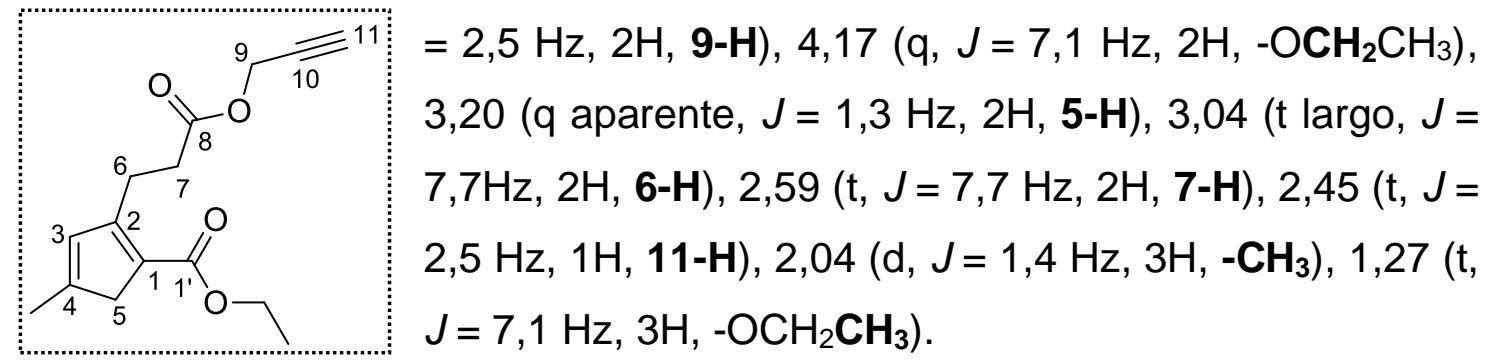

${ }^{13} \mathrm{C}$ NMR (101 MHz, $\mathbf{C D C l}_{3}$ ): $\delta$ 172,2 (8-C=0), 164,5 (1'-C=0), 158,1 (4-C), 151,6 (1-C), 131,6 (3-C), 127,3 (2-C), 77,8 (10-C), 74,9 (11-C), 59,7 (-OCH $\left.\mathrm{CH}_{3}\right), 52,0$ (9-C), 46,1 (5-C), 33,2 (7-C), 24,4 (6-C), 16,5 (- $\left.\mathrm{CH}_{3}\right), 14,5\left(-\mathrm{OCH}_{2} \mathbf{C H}_{3}\right)$, HRMS ESI-MS m/z: 285,1103 calculado para $[\mathrm{M}+\mathrm{Na}]^{+} \mathrm{C}_{15} \mathrm{H}_{18} \mathrm{NaO}_{4}$, encontrada 285,1165. IV (vmax, ATR cm-1): 2978, 2964, 2927, 2850, 2359, 2322, 1707, 1653, 1372, 1235, 1173, 1110, 1094, 1039, 863, 803, 754. 


\section{Preparo do ciclopentadieno 8}
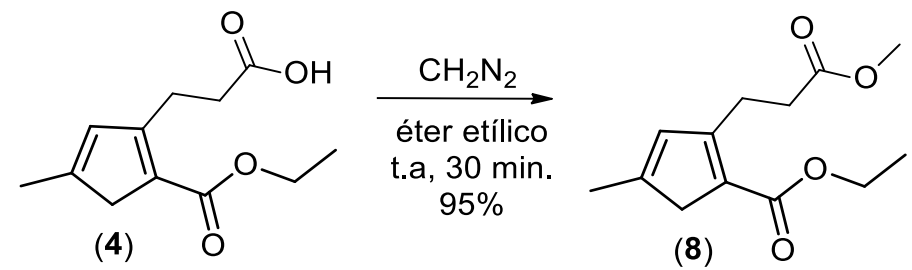

Em um balão de fundo redondo de $25 \mathrm{~mL}$, foram adicionados $1 \mathrm{mmol}$ do dieno 4 (224 mg), $10 \mathrm{~mL}$ de éter etílico e 2,0 mL e solução de diazometano $(0,6$ $\mathrm{mol} / \mathrm{L}$ ), gota a gota, deixou-se o sistema sob agitação à $25^{\circ} \mathrm{C}$ por 5 minutos. Em seguida, o solvente foi evaporado e o material foi purificado em coluna de sílica gel flash utilizando como eluente Hexano/Acetato de Etila (70:30). Foi obtido o composto $8 \mathrm{com}$ rendimento de $95 \%(0,95 \mathrm{mmol}, 226,36 \mathrm{mg})$ na forma de um óleo amarelado.

2-(3-Metoxi-3-oxopropil)-4-metilciclopenta-1,3-dienocarboxilato de etila (8): ${ }^{1} \mathrm{H}$ NMR (500 MHz, $\mathbf{C D C l}_{3}$ ): $\delta 6,06$ (q aparente, $J=1,3 \mathrm{~Hz}, 1 \mathrm{H}, \mathbf{3 - H}$ ), 4,14 (q, $J$

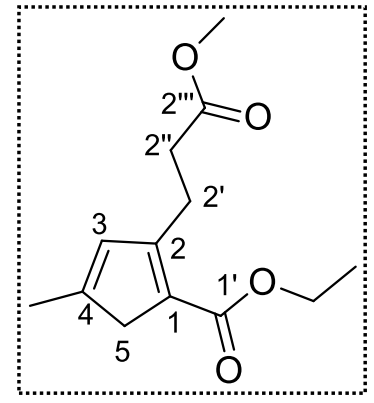

$\left.=7,1 \mathrm{~Hz}, 2 \mathrm{H},-\mathrm{OCH}_{2} \mathrm{CH}_{3}\right), 3,61\left(\mathrm{~s}, 3 \mathrm{H},-\mathrm{OCH}_{3}\right), 3,16$ (q aparente, $J=1,3 \mathrm{~Hz}, 2 \mathrm{H}, 5-\mathrm{H}$ ), 2,99 (t largo, $J=7,3 \mathrm{~Hz}, 2 \mathrm{H}$, 2'-H), 2,50 (t largo, $J=7,3 \mathrm{~Hz}, 2 \mathrm{H}, 2$ ''-H), 2,01 (d, $J=1,4$ $\left.\mathrm{Hz}, 3 \mathrm{H},-\mathrm{CH}_{3}\right), 1,23\left(\mathrm{t}, J=7,1 \mathrm{~Hz}, 3 \mathrm{H},-\mathrm{OCH}_{2} \mathrm{CH}_{3}\right.$ ).

${ }^{13} \mathrm{C}$ NMR (126 MHz, CDCl $)$ : $\delta$ 173,4 (2'"'-C=O), 164,4 (1'C=O), 158,4 (4-C), 151,4 (1-C), 131,5 (3-C), 127,4 (2-C),

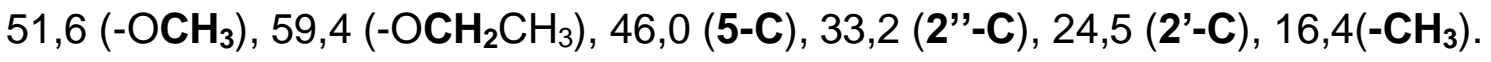
14,4 $\left(-\mathrm{OCH}_{2} \mathrm{CH}_{3}\right)$, ESI-MS m/z: 261,1103 calculado para $[\mathrm{M}+\mathrm{Na}]^{+} \mathrm{C}_{13} \mathrm{H}_{18} \mathrm{NaO}_{4}$, encontrada 261,1137. IV ( $\max$, ATR cm-1): 2978, 2954, 2359, 2322, 1733, 1716, 1437, 1237, 1199, 1173, 1111, 1045, 864, 771. 


\section{Procedimento geral para reação de Diels-Alder}

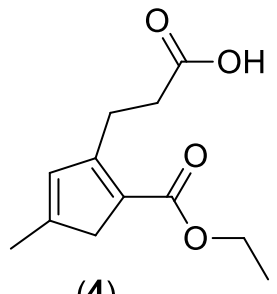

(4)
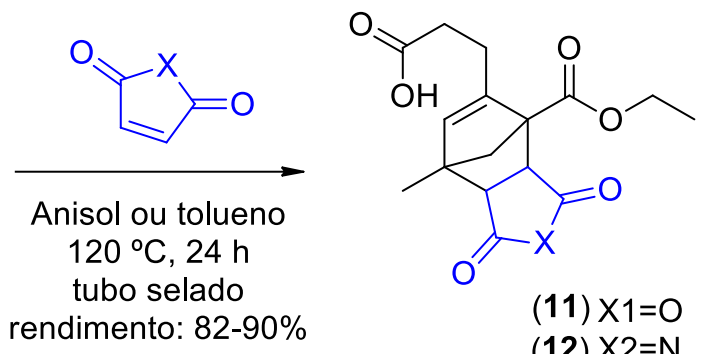

(11) $\mathrm{X} 1=\mathrm{O}$

Sob atmosfera de argônio, 0,5 mmol (112 $\mathrm{mg})$ do dieno 4, 1,5 mmol dos dienófilos maleimida (145,6 mg) ou anidrido maleíco (147,1 mg) e $2 \mathrm{~mL}$ de tolueno ou anisol seco foram adicionados em um tubo selado. Foi acoplado ao tubo um borbulhador e uma bexiga com argônio, no qual passou-se uma corrente de argônio por 5 min e, em seguida, o tubo foi vedado e levado à temperatura de $120^{\circ} \mathrm{C}$ por 24 horas. Após o término da reação, evaporou-se o solvente e o bruto reacional foi purificado em coluna de sílica gel flash com Hexano/acetato de etila: gradiente $(90: 10,70: 30,1: 1) .1190 \%(0,45 \mathrm{mmol}, 144,9 \mathrm{mg})$ como um óleo viscoso e 12 com $82 \%$ de rendimento $(0,45 \mathrm{mmol}, 144,1 \mathrm{mg})$, também na forma de um óleo viscoso.

Ácido 3- (4- (etoxicarbonil) -7-metil-1,3-dioxo-1,3,3a, 4,7,7a-hexa-hidro-4,7metanoisobenzofuran-5-il) propanóico (11):

${ }^{1} \mathrm{H}$ NMR (400 MHz, CDCl 3 ): $\delta$ 8,10 (-OH), 5,76 (t, J=1,9 Hz, 1H, 4-H), 4,32 (q, J

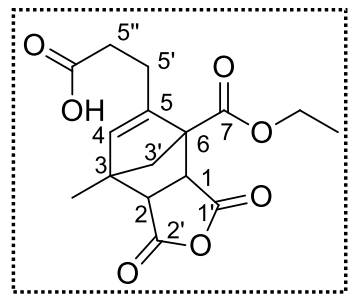
$\left.=7,1 \mathrm{~Hz}, 2 \mathrm{H},-\mathrm{OCH}_{2} \mathrm{CH}_{3}\right), 4,18(\mathrm{~d}, J=8,3 \mathrm{~Hz}, 1 \mathrm{H}, 1-\mathrm{H}), 3,39$ (d, $J=8,3 \mathrm{~Hz}, 1 \mathrm{H}, \mathbf{2}-\mathrm{H}), 2,78-2,66\left(\mathrm{~m}, 2 \mathrm{H}, \mathbf{5}^{\prime}-\mathrm{H}\right), 2,59-2,42$ (m, 2H, 5'-H e 5''-H), 2,35-2,25 (m, 1H, 5'-H), 2,00 (d, J = 8,7 Hz, 1H, 3'-H), 1,82 (d, J= 8,7 Hz, 1H, 3'-H), 1,55 (s, 3H, $\left.-\mathrm{CH}_{3}\right), 1,34\left(\mathrm{t}, \mathrm{J}=7,1 \mathrm{~Hz}, 3 \mathrm{H},-\mathrm{OCH}_{2} \mathbf{C H}_{3}\right)$.

${ }^{13} \mathrm{C}$ NMR (101 MHz, $\mathbf{C D C l}_{3}$ ): $\delta$ 178,2 (C=O, ácido carboxílico), 176,7 (2'-C), 176,6 (1'-C), 170,7 (7-C), 147,2 (5-C), 131,1 (4-C), 63,0 (6-C), 62,3 (- $\left.\mathrm{OCH}_{2} \mathrm{CH}_{3}\right)$, 61,5 (1-C), 53,8 (3-C), 53,4 (2-C), 50,8 (3'-C), 30,9 (5'”-C), 24,1 (5'-C), 17,6 ($\left.\mathbf{C H}_{3}\right), 14,2\left(-\mathrm{OCH}_{2} \mathbf{C H}_{3}\right)$, HRMS ESI-MS m/z: 345,0950 calculado para ([M+Na] ${ }^{+}$ $\mathrm{C}_{16} \mathrm{H}_{18} \mathrm{NaO}_{7}$, encontrada 345,1029. 
Ácido 3- (4- (etoxicarbonil) -7-metil-1,3-dioxo-2,3,3a, 4,7,7a-hexa-hidro-1H4,7-metanoisoindol-5-il) propanóico (12):

${ }^{1} \mathrm{H}$ NMR (500 MHz, $\mathrm{CDCl}_{3}$ ): $\delta$ 9,32 (s, 1H, -NH), 5,63 (t, $\left.J=1,8 \mathrm{~Hz}, 1 \mathrm{H}, 4-\mathrm{H}\right)$,

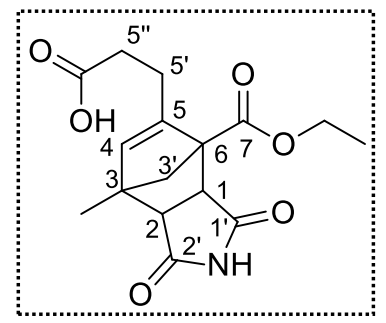
4,24 (q, $\left.J=7,1 \mathrm{~Hz}, 2 \mathrm{H},-\mathrm{OCH}_{2} \mathrm{CH}_{3}\right), 3,87(\mathrm{~d}, J=7,7 \mathrm{~Hz}$, $1 \mathrm{H}, 1-\mathrm{H}), 3,09(\mathrm{~d}, J=7,7 \mathrm{~Hz}, 1 \mathrm{H}, 2-\mathrm{H}), 2,71-2,56(\mathrm{~m}, 1 \mathrm{H}$, 5'-H), 2,51-2,34 (m, 2H, 5'-H e 5''-H), 2,34-2,23 (m, 1H, 5'-H), 1,87 (d, $\left.J=8,4 \mathrm{~Hz}, 1 \mathrm{H}, 3^{\prime}-\mathrm{H}\right), 1,75$ (d, $J=8,4 \mathrm{~Hz}$, $\left.1 \mathrm{H}, 3^{\prime}-\mathrm{H}\right), 1,46\left(\mathrm{~s}, 3 \mathrm{H},-\mathrm{CH}_{3}\right), 1,27(\mathrm{t}, J=7,1 \mathrm{~Hz}, 3 \mathrm{H}$, -

$\mathrm{OCH}_{2} \mathrm{CH}_{3}$ ).

${ }^{13} \mathrm{C}$ NMR (126 MHz, $\mathrm{CDCl}_{3}$ ): $\delta$ 178,6 (C=O, ácido carboxílico, 176,7 (2'-C), 176,6 (1'-C), 170,7 (7-C), 147,2 (5-C), 131,1 (4-C), 63,0 (6-C), 62,3 (-OCH $\left.\mathrm{CH}_{3}\right)$, 61,5 (1-C), 53,8 (3-C), 53,4 (2-C), 50,8 (3'-C), 30,9 (5'”-C), 24,1 (5'-C), 17,6 ($\left.\mathrm{CH}_{3}\right), 14,2\left(-\mathrm{OCH}_{2} \mathrm{CH}_{3}\right)$, HRMS ESI-MS m/z: 344,1110 calculado para $\left([\mathrm{M}+\mathrm{Na}]^{+}\right.$ $\mathrm{C}_{16} \mathrm{H}_{19} \mathrm{NNaO}_{6}$, encontrada 344,1189. IV ( $(\max$, ATR cm-1): 2965, 2933, 2361, 2324, 1709, 1650, 1418, 1303, 1223, 1176, 1096, 860, 830.
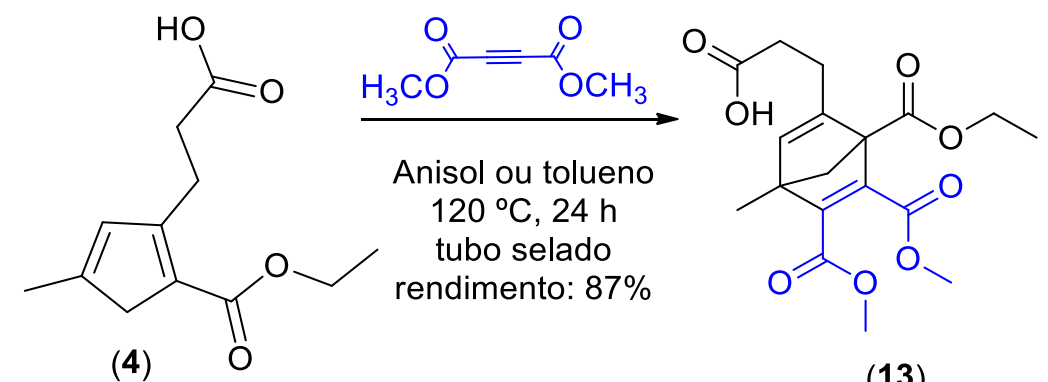

(13)

O mesmo procedimento experimental, descrito para a obtenção de $11 \mathrm{e}$ 12, foi realizado para obter o composto 13 , porém utilizando $0,55 \mathrm{mmol}(78,16$ $\mathrm{mg}$ ) do dienófilo acetilenodicarboxilato de dimetila. O composto 13 foi obtido com um óleo amarelado com 87\% (0,44 mmol, 159,3 mg) de rendimento. 
Ácido 3-(1-(etoxicarbonil)-5,6-bis (metoxicarbonil)-4-metilbiciclo [2.2.1] hepta-2,5-dien-2-il) propanóico (13):

${ }^{1} \mathrm{H}$ NMR (500 MHz, $\mathbf{C D C l}_{3}$ ): $\delta 6,21$ (t, $\left.J=1,1 \mathrm{~Hz}, 1 \mathrm{H}, \mathbf{4 - H}\right), 4,20$ (q, $J=7,1 \mathrm{~Hz}$,

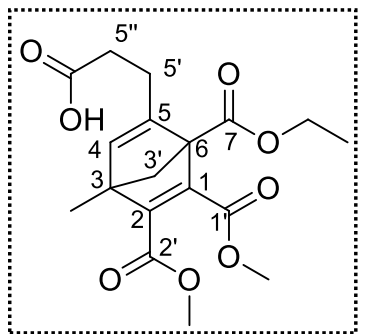
$\left.2 \mathrm{H},-\mathrm{OCH}_{2} \mathrm{CH}_{3}\right), 3,75\left(\mathrm{~s}, 3 \mathrm{H},-\mathrm{OCH}_{3}\right), 3,73\left(\mathrm{~s}, 3 \mathrm{H},-\mathrm{OCH}_{3}\right)$, 2,86-2,78 (m, 1H, 5'-H), 2,68 (m, 1H, 5''-H), 2,48 (d, $J=$ 6,6 Hz, 1H, 3'-H), 2,57-2,39 (m, 2H, 5'-H), 2,34 (d, J = 6,6 $\left.\mathrm{Hz}, 1 \mathrm{H}, 3^{\prime}-\mathrm{H}\right), 1,49\left(\mathrm{~s}, 3 \mathrm{H},-\mathrm{CH}_{3}\right), 1,25(\mathrm{t}, J=7,1 \mathrm{~Hz}, 3 \mathrm{H},-$ $\mathrm{OCH}_{2} \mathrm{CH}_{3}$ ).

${ }^{13} \mathrm{C}$ NMR (126 MHz, $\mathrm{CDCl}_{3}$ ): $\delta$ 178,4 (C=0, ácido carboxílico), 169,6 (7-C), 165,2 (1'-C), 164,6 (2'-C), 155,6 (1-C), 155,0 (2-C), 150,5, 140,4, 77,6 (6-C), 68,3 (3-C), 61,1 (- $\left.\mathrm{OCH}_{2} \mathrm{CH}_{3}\right), 59,0\left(3^{\prime}-\mathrm{H}\right), 52,1\left(-\mathrm{OCH}_{3}\right), 52,0\left(-\mathrm{OCH}_{3}\right), 32,1\left(5^{\prime \prime}-\mathrm{H}\right)$, 24,6 (5'-H), 15,3 (- $\left.\mathbf{C H}_{3}\right), 14,0\left(-\mathrm{OCH}_{2} \mathbf{C H}_{3}\right)$, HRMS ESI-MS m/z: 389,1212 calculado para ([M+Na] ${ }^{+} \mathrm{C}_{18} \mathrm{H}_{22} \mathrm{NaO}_{8}$, encontrada 389,1301. IV (vmax, ATR cm1): 2956, 2935, 2915, 2359, 2322, 1732, 1716, 1558, 1507, 1456, 1436, 1312, $1259,1216,1104,1031,772$.

\section{Procedimento geral para síntese de ciclopentanos 14 e 15}

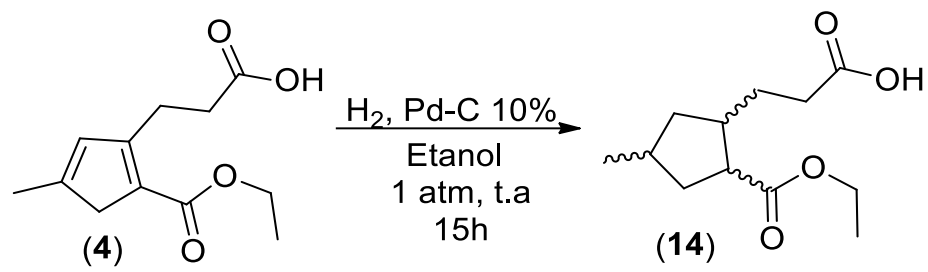

Em um balão de fundo redondo de $25 \mathrm{~mL}$, vedado, contendo $44,8 \mathrm{mg}$ de $\mathrm{Pd} / \mathrm{C}(10 \%)$ seco previamente em sistema de auto vácuo, foram acoplados um borbulhador e uma bexiga contendo argônio. Trocou-se a atmosfera do sistema por 5 minutos e, em seguida, o balão de argônio foi retirado, sendo mantido o borbulhador. Imediatamente, foi acoplado uma bexiga contendo $\mathrm{H}_{2(\mathrm{~g})}$ e, rapidamente, adicionou-se ao meio reacional $1,0 \mathrm{mmol}$ do dieno $4 \mathrm{em} 10 \mathrm{~mL}$ de etanol seco (esta etapa deve ser realizada rapidamente para não causar explosões). Manteve-se o sistema com o borbulhador por $10 \mathrm{~min}$, em seguida, foi retirado e a reação foi mantida à temperatura ambiente sob agitação por 15 horas. Filtrou-se a reação em Celite $\AA$, o solvente foi evaporado e o bruto reacional foi purificado em coluna de sílica gel utilizando como eluente 
Hexano/Acetato de Etila 1:1.14 90\% (0.90 mmol, $205.2 \mathrm{mg})$ de rendimento com aspecto de um óleo incolor. Repetiu-se a reação na escala de 2,61 g (11,65 $\mathrm{mmol})$ do dieno $4(2,61 \mathrm{~g}, 11,65 \mathrm{mmol})$, levando à $85 \%(9,90 \mathrm{mmol}, 2,26 \mathrm{~g}) \mathrm{de}$ rendimento de 14 .

Ácido 3-(2-(etoxicarbonil--4-metilciclopentil) propanóico (14):

${ }^{1} \mathrm{H}$ NMR (500 MHz, $\left.\mathbf{C D C l}_{3}\right): \delta$ 10,71 (s, 1H, -OH), 4,18-4,02 (m, 2H, $\left.-\mathrm{OCH}_{2} \mathrm{CH}_{3}\right)$,

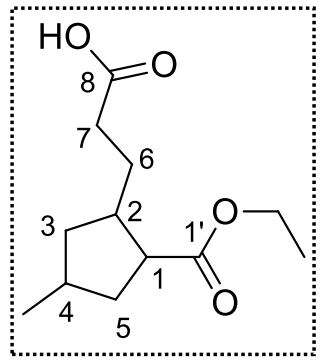
2,81-2,85 (m, 1H, 1-H), 2,40-2,45 (m, 1H, 1-H), 2,36-2,28 (m, $2 \mathrm{H}, 7-\mathrm{H}), 2,20-2,25(\mathrm{~m}, 1 \mathrm{H}, \mathbf{5 - H}), 2,19-2,06(\mathrm{~m}, 1 \mathrm{H}, \mathbf{5 - H}), 2,04-$ 1,91 (m, 1H, 5-H), 1,89-1,80 (m, 1H, 4-H, 5-H), 1,76-1,64 (m, $1 \mathrm{H}, 4-\mathrm{H}), 1,62-1,55(\mathrm{~m}, 1 \mathrm{H}, 4-\mathrm{H}), 1,55-1,47(\mathrm{~m}, 1 \mathrm{H}, 6-\mathrm{H}, \mathbf{4 - H}$, 3-H), 1,47-1,35 (m, 1H, 3-H), 1,29-1,16 (m, 3H, - $\left.\mathrm{OCH}_{2} \mathbf{C H}_{3}\right)$, $1,02\left(\mathrm{~d}, J=6,4 \mathrm{~Hz},-\mathrm{CH}_{3}\right), 0,97\left(\mathrm{~d}, J=6,4 \mathrm{~Hz},-\mathrm{CH}_{3}\right), 0,94$ (d, $\left.J=6,4 \mathrm{~Hz},-\mathrm{CH}_{3}\right), 0,93\left(\mathrm{~d}, J=6,4 \mathrm{~Hz},-\mathrm{CH}_{3}\right), 0,85-0,77(\mathrm{~m}, 1 \mathrm{H}, 7-\mathrm{H})$.

${ }^{13} \mathrm{C}$ NMR (126 MHz, CDCl $)$ ): $\delta$ 179,8 (8-C), 176,6 (1'-C), 176,1 (1'-C), 175,7 (1'C), $60,5\left(-\mathrm{OCH}_{2} \mathrm{CH}_{3}\right), 60,2\left(-\mathrm{OCH}_{2} \mathrm{CH}_{3}\right), 51,1$ (1-C), 49,4 (1-C), 47,1 (1-C), 44,1 (5-C), 42,8 (5-C), 42,1 (2-C), 42,1 (2-C), 40,5 (5-C), 39,9 (5-C), 39,4 (3-C), 38,1 (3-C), 37,3 (3-C), 33,9 (7-C), 33,8 (7-C), 33,1 (7-C), 33,1 (7-C), 32,9 (4-C), 32,8 (4-C), 30,7 (4-C), 30,5 (4-C), 26,7 (6-C), 22,2 (-- $\left.\mathrm{CH}_{3}\right), 20,5\left(-\mathrm{CH}_{3}\right), 20,4\left(-\mathrm{CH}_{3}\right)$, $20,0\left(-\mathrm{CH}_{3}\right), 14,3\left(-\mathrm{OCH}_{2} \mathbf{C H}_{3}\right), 14,3\left(-\mathrm{OCH}_{2} \mathbf{C H}_{3}\right)$, HRMS ESI-MS m/z: 251,1259 calculado para ([M+Na] ${ }^{+} \mathrm{C}_{12} \mathrm{H}_{20} \mathrm{NaO}_{4}$, encontrada 251,1255. IV (vmax, ATR cm1): 2923, 2857, 2363, 2320, 1708, 1457, 1374, 1279, 1229, 1166, 1119, 1041, 770.

\subsection{Ciclopentano 15}

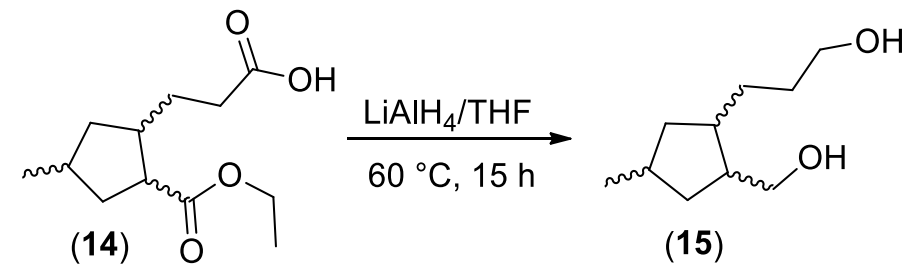

Sob atmosfera de argônio, em um balão de $250 \mathrm{~mL}$ de duas bocas, contendo $16,98 \mathrm{mmol}(644,4 \mathrm{mg})$ de $\mathrm{LiAlH}_{4}$, foi adicionado $90 \mathrm{~mL}$ de THF previamente seco. $\mathrm{O}$ sistema foi resfriado à $0{ }^{\circ} \mathrm{C}$ e, em seguida, adicionou-se 
5,66 mmol (1,295 g) de $14 \mathrm{em} 30 \mathrm{~mL}$ de THF. Após cessar a liberação de hidrogênio, o sistema foi levado ao refluxo por 6 horas. No final da reação, 0 balão foi resfriado à $0{ }^{\circ} \mathrm{C}$ e foram adicionados $40 \mathrm{~mL}$ de etanol e $5 \mathrm{~mL}$ de solução de $\mathrm{NaOH}_{(\mathrm{aq})} 10 \%$. O conteúdo foi filtrado em Celite® e o solvente foi evaporado. Ao bruto reacional foi adicionado, aproximadamente, $1,0 \mathrm{~g}$ de sílica e purificado em coluna de sílica gel flash com Hexano/Acetato de etila (1:1) e acetato de etila puro. Obteve-se $15 \mathrm{com} 70 \%$ (3,96 mmol, 681,5 mg) de rendimento na forma de um óleo incolor com.

\section{3-(2-(hydroxymethyl)-4-methylcyclopentyl)propan-1-ol (15):}

${ }^{1} \mathrm{H}$ NMR (500 MHz, $\mathrm{CDCl}_{3}$ ): $\delta$ 3,65 (dd, $J=10,6,7,2 \mathrm{~Hz}, 1 \mathrm{H}, 1$ '-H), 3,61-3,53 (m,

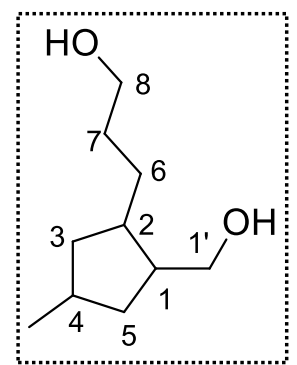
$2 \mathrm{H}, 8-\mathrm{H}), 3,54-3,37$ (m, 1H, 1'-H), 2,96 (s 2H, -OH), 2,21-2,01 (m, 1H, 1-H), 1,98-1,83 (m, 4H, 2-H, 3-H e 5-H), 1,77-1,63 (m, 1H, 1-H), 1,63-1,55 (m, 3H, 2-H e 6-H e 7-H), 1,51-1,39 (m, 2H, 7-H), 1,37-1,12 (m, 1H, 4-H e 7-H), 1,25 -1,13 (m, 1H, 6-H) 0,97 (d, $\left.J=6,0 \mathrm{~Hz},-\mathrm{CH}_{3}\right), 0,94$ (d, $\left.J=6,5 \mathrm{~Hz},-\mathrm{CH}_{3}\right), 0,94$ (d, $J=6,4$ $\left.\mathrm{Hz},-\mathrm{CH}_{3}\right), 0,90(\mathrm{dd}, J=8,2,3,4 \mathrm{~Hz}, 1 \mathrm{H}, 3-\mathrm{H}), 0,85-0,77$ (m, $1 \mathrm{H}, \mathbf{5}-\mathbf{H}), 0,78-0,68(\mathrm{~m}, 1 \mathrm{H}, \mathbf{2}-\mathrm{H})$.

${ }^{13} \mathrm{C}$ NMR (126 MHz, $\mathrm{CDCl}_{3}$ ): $\delta$ 66,8 (8-C), 66,7 (1'-C), 64,1 (1'-C), 62,7 (8-C), 49,1 (1-C), 47,4 (1-C), 44,2 (1-C), 42,7 (2-C), 42,7 (2-C), 41,2 (5-C), 41,2 (5-C), 40,9 (5-C), 40,5 (5-C), 39,2 (3-C), 38,1 (3-C), 37,6 (3-C), 33,5 (7-C), 33,3 (4-C), 32,7 (4-C) 32,4 (4-C), 32,2 (4-C), 31,8 (7-C), 31,4 (7-C), 31,2 (7-C), 26,9 (6-C), 21,2 (-CH$), 20,9\left(-\mathbf{C H}_{3}\right), 20,6\left(-\mathrm{CH}_{3}\right)$, HRMS ESI-MS m/z: 195,1361 calculado para ([M+Na] ${ }^{+} \mathrm{C}_{10} \mathrm{H}_{20} \mathrm{NaO}_{2}$, encontrada 195,1361. IV (vmax, ATR cm-1): 3329, 2936, 2867, 2364, 2320, 1690, 1459, 1372, 1053, 1019, 677.

\subsection{Síntese One-pot do Ciclopentano 15}

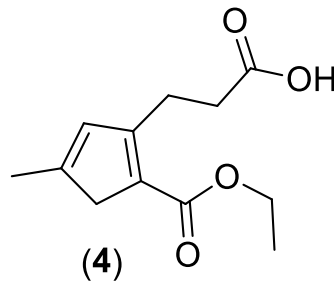

1) $\mathrm{H}_{2}, \mathrm{Pd}-\mathrm{C} 10 \%$

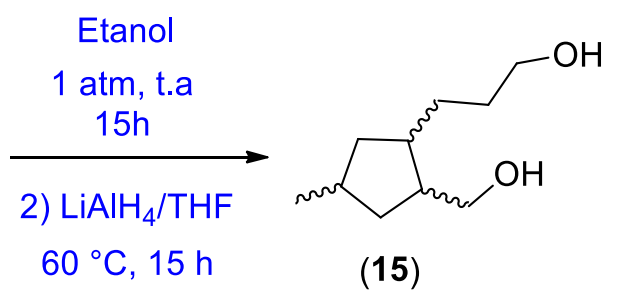


Em um balão de fundo redondo de $50 \mathrm{~mL}$, vedado, contendo $89,6 \mathrm{mg}$ de $\mathrm{Pd} / \mathrm{C}(10 \%)$ seco previamente em sistema de auto vácuo, foram acoplados um borbulhador e uma bexiga contendo argônio. Trocou-se a atmosfera do sistema por 5 minutos e, em seguida, o balão de argônio foi retirado sendo mantido o borbulhador. Imediatamente, foi acoplado uma bexiga contendo $\mathrm{H}_{2(\mathrm{~g})}$ e, rapidamente, foi adicionado $2,0 \mathrm{mmol}(448 \mathrm{mg})$ do dieno $4 \mathrm{em} 20 \mathrm{~mL}$ de etanol de etanol seco (esta etapa deve ser realizada rapidamente para não causar explosões). O sistema foi mantido com o borbulhador por $10 \mathrm{~min}$, em seguida, foi retirado e manteve-se a reação à temperatura ambiente sob agitação por 15 horas. Filtrou-se a reação em Celite®, o solvente foi evaporado e ao bruto reacional adicionou-se $10 \mathrm{~mL}$ de THF seco. Essa mistura foi adicionada a um balão contendo $6,0 \mathrm{mmol}(227,7 \mathrm{mg})$ de $\mathrm{LiAlH}_{4} \mathrm{em} 20 \mathrm{~mL}$ de THF seco, à $0{ }^{\circ} \mathrm{C}$, sob atmosfera de argônio. Após cessar a liberação de hidrogênio, o sistema foi levado ao refluxo por 6 horas. Ao final da reação, o balão foi resfriado à $0{ }^{\circ} \mathrm{C} \mathrm{e}$ adicionaram-se $14 \mathrm{~mL}$ de Etanol e $2 \mathrm{~mL}$ de solução de $\mathrm{NaOH}_{(\text {aq) }} 10 \%$. conteúdo foi filtrado em Celite $\AA^{\circledR}$ e o solvente foi evaporado. Purificou-se o bruto reacional em coluna de sílica gel flash com Hexano/Acetato de etila (1:1) e acetato de etila puro como eluentes. Obteve-se $15 \mathrm{com} 62 \%$ (1,24 mmol, 213,28 $\mathrm{mg}$ ) de rendimento como óleo incolor.

\section{Síntese dos diazocompostos Ciclopentadienos 17a e 17b}

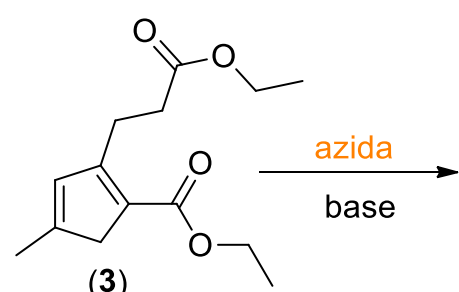

(3)

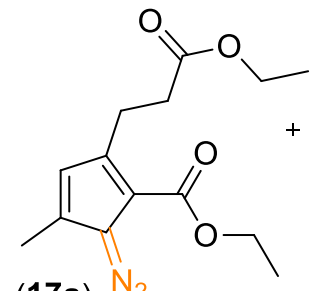

(17a)

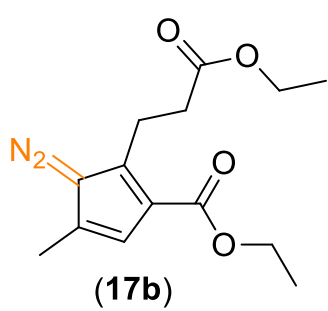

(17b)

$1,0 \mathrm{mmol}(252 \mathrm{mg})$ do dieno 3 dissolvido em $12 \mathrm{~mL}$ de acetonitrila seca foi adicionado à $0{ }^{\circ} \mathrm{C}$, sob atmosfera de argônio, em um balão de fundo redondo de $25 \mathrm{~mL}$ contendo $2,0 \mathrm{mmol}(480,5 \mathrm{mg})$ da $p$-acetamidabenzenosulfonil azida. Em seguida, adicionou-se $1,1 \mathrm{mmol}(123,4 \mathrm{mg})$ de 1,4-diazabiciclo [2.2.2] octano-DABCO e o sistema foi deixado sobre agitação por 15 horas à temperatura ambiente. Ao término da reação, o conteúdo foi transferido para um 
funil de separação ao qual foi adicionado $15 \mathrm{~mL}$ de Acetato de Etila e $10 \mathrm{~mL}$ de solução saturada de $\mathrm{NaCl}$. A fase orgânica foi separada e o solvente evaporado. O bruto reacional foi purificado em coluna de sílica gel flash com Hexano/Acetato e etila (7:3), obtendo-se $17 \mathrm{a}$ e $17 \mathrm{~b}$ com $88 \%$ (0,88 mmol, $244,8 \mathrm{mg})$ de rendimento como um óleo alaranjado.

5-Diazo-2-(3-etoxi-3-oxopropil)-4-metilciclopenta-1,3-dienocarboxilato de etila (17a):

${ }^{1} \mathrm{H}$ NMR (400 MHz, $\mathrm{CDCl}_{3}$ ) 17a: $\delta 5,70$ (dd, $J=1,8,0,7 \mathrm{~Hz}, 1 \mathrm{H}, 5-\mathrm{H}$ ), 4,11 (q, $J$

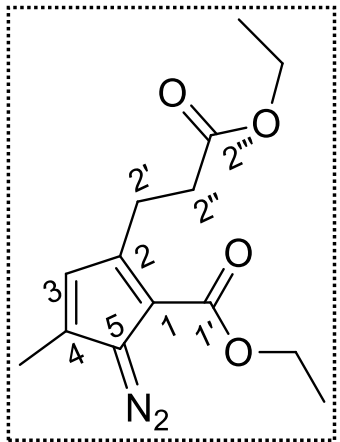
$\left.=7,1 \mathrm{~Hz}, 2 \mathrm{H},-\mathrm{OCH}_{2} \mathrm{CH}_{3}\right), 4,26(\mathrm{q}, J=7,1 \mathrm{~Hz}, 2 \mathrm{H},-$ $\mathrm{OCH}_{2} \mathrm{CH}_{3}$ ), 3,06-3,01 (m, 2H, 2'-H), 2,56-2,50 (m, 2H, 2'"H), 2,19 (d, $\left.J=1,1 \mathrm{~Hz}, 3 \mathrm{H},-\mathrm{CH}_{3}\right), 1,31(\mathrm{t}, J=7,1 \mathrm{~Hz}, 3 \mathrm{H},-$ $\mathrm{OCH}_{2} \mathrm{CH}_{3}$ ), 1,23 (t, $J=7,1 \mathrm{~Hz}, 3 \mathrm{H},-\mathrm{OCH}_{2} \mathrm{CH}_{3}$ ),

${ }^{13} \mathrm{C}$ NMR (126 MHz, CDCl 3 ) 17a: $\delta, 173,1$ (2'"'-C), 164,2 (1'C), 142,1 (4-C), 137,2 (1-C), 120,0 (3-C), 117,3 (2-C), 60,4 $\left(-\mathrm{OCH}_{2} \mathrm{CH}_{3}\right), 59,8\left(-\mathrm{OCH}_{2} \mathrm{CH}_{3}\right), 34,7($ 2'-C), 24,9 (2'-C), $14,4\left(-\mathrm{OCH}_{2} \mathrm{CH}_{3}\right), 14,3\left(-\mathrm{OCH}_{2} \mathrm{CH}_{3}\right), 12,7\left(-\mathrm{CH}_{3}\right)$.

3-Diazo-2- (3-etoxi-3-oxopropil) -4-metilciclopenta-1,4-dienocarboxilato de etila (17b):

${ }^{1} \mathrm{H}$ NMR (400 MHz, $\mathrm{CDCl}_{3}$ ) 17b: 6,06 (q, $\left.J=1,3 \mathrm{~Hz}, 1 \mathrm{H}\right), 4,11$ (dd, $J=14,4,7,1$

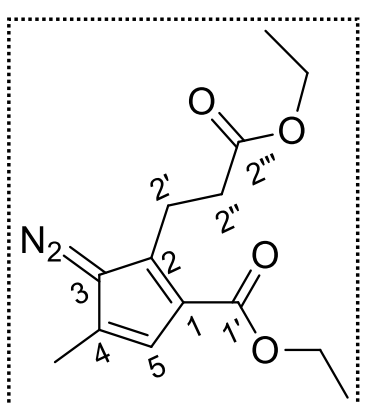
$\left.\mathrm{Hz}, 2 \mathrm{H},-\mathrm{OCH}_{2} \mathrm{CH}_{3}\right), 4,11$ (q, $J=7,1 \mathrm{~Hz}, 2 \mathrm{H},-\mathrm{OCH}_{2} \mathrm{CH}_{3}$ ), 3,06-3,01 (m, 2H, 2'-H), 2,66 (t, $J=6,7 \mathrm{~Hz}, 1 \mathrm{H}, 2$ ''-H), 2,14 (d, $\left.J=1,3 \mathrm{~Hz}, 2 \mathrm{H},-\mathrm{CH}_{3}\right), 1,31$ (t, $J=7,1 \mathrm{~Hz}, 3 \mathrm{H},-\mathrm{OCH}_{2} \mathbf{C H}_{3}$ ), $1,23\left(\mathrm{t}, J=7,1 \mathrm{~Hz}, 3 \mathrm{H},-\mathrm{OCH}_{2} \mathrm{CH}_{3}\right)$,

${ }^{13} \mathrm{C}$ NMR (126 MHz, CDCl 3 ) 17b: 173,2 (2'"-C), 162,7 (1'C), 139,21 (4-C), 125,7, (1-C), 113,1 (2-C), 118,6 (3-C), 60,3 (- $\left.\mathrm{OCH}_{2} \mathrm{CH}_{3}\right), 59,6\left(-\mathrm{OCH}_{2} \mathrm{CH}_{3}\right), 34,3$ (2'-C), 22,1 (2'”-C), 14,3 (- $\left.\mathrm{OCH}_{2} \mathbf{C H}_{3}\right)$, 14,2 (- $\left.\mathrm{OCH}_{2} \mathrm{CH}_{3}\right), 12,3\left(-\mathrm{CH}_{3}\right)$, HRMS ESI-MS m/z: 301,1164 calculado para $\left([\mathrm{M}+\mathrm{Na}]^{+} \mathrm{C}_{14} \mathrm{H}_{18} \mathrm{~N}_{2} \mathrm{NaO}_{4}\right.$, encontrada 301,1233. IV (vmax, ATR cm-1): 2980, 2933, 2095,1732, 1696, 1321, 1208, 1176, 1129, 1062, 815, 777. 
10. Capitulo II: Um novo método para síntese de polióis de cadeia longa a partir da $\gamma$ - valerolactona

\section{Síntese do composto 18}

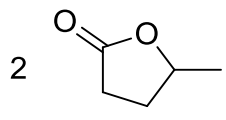

(GVL)

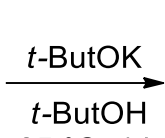

$25^{\circ} \mathrm{C}, 4 \mathrm{~h}$

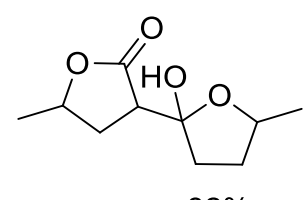

(18)

GVL ( $1 \mathrm{~mol}, 100 \mathrm{~g}$ ) e $50 \mathrm{~mL}$ de $t$-butanol $(t-\mathrm{BuOH})$ foram adicionados em um balão de $250 \mathrm{~mL}$ de 2 bocas. A mistura foi resfriada à $0^{\circ} \mathrm{C}$, por 5 minutos, $\mathrm{e}$ em seguida foi adicionado aos poucos $0,6 \mathrm{~mol}(67,3 \mathrm{~g})$ de $t$-butóxido de potássio ( $t$-BuOK). A reação foi mantida à $0{ }^{\circ} \mathrm{C}$, por aproximadamente 15 minutos, seguida pela agitação em temperatura ambiente $\left(25^{\circ} \mathrm{C}\right)$ por 4 horas com o auxílio de um agitador mecânico. Após o final da reação, água destilada foi adicionada ao resíduo $(50 \mathrm{~mL})$ e o $\mathrm{pH}$ foi ajustado para 7 com uma solução aquosa de ácido acético $10 \%$. O produto bruto foi extraído com acetato de etila $(3 \times 200 \mathrm{~mL})$, a fase orgânica foi seca com sulfato de sódio anidro e o solvente evaporado. $O$ resíduo resultante foi mantido sob vácuo $\left(\mathrm{à} 25^{\circ} \mathrm{C}\right.$ ) dando origem a 18 na forma de um óleo amarelado, viscoso, com rendimento de $82 \%(0,41 \mathrm{~mol}, 82 \mathrm{~g})$. Não é necessário outro tipo de purificação e o produto deve ser estocado em freezer.

\section{2-hidroxi-5,5'-dimetil-hexa-hidro- [2,3'-bifuran] -2'(3'H)-ona (18):}

Mistura diastereoisomérica, ${ }^{1} \mathrm{H}$ NMR $\left(500 \mathrm{MHz}, \mathrm{CDCl}_{3}\right)$ : $\delta 4,72-4,59(\mathrm{~m}, 0,6 \mathrm{H})$

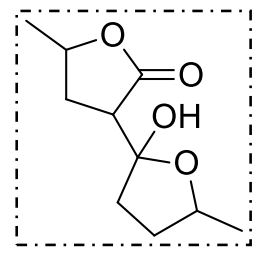

4,57-4,39 (m, 1H) 4,35-4,22 (m, 0,8H) 4,15-4,05 (m, 0,6H), 3,052,90 (m, 1H), 2,41-2,25 (m, 1H), 2,23-2,09 (m, 1H), 2,00-1,70 (m, $5 \mathrm{H}), 1,44-1,29(\mathrm{~m}, 6 \mathrm{H}), 1,22-1,19(\mathrm{~m}, 3 \mathrm{H}),{ }^{13} \mathrm{C}$ NMR (126 MHz, $\left.\mathrm{CDCl}_{3}\right)$ : $\delta 178,3,178,1,178,0,177,9,105,4,105,2,104,8,104,6$, $78,2,78,1,76,1,75,7,75,6,74,9,74,8,48,6,48,3,46,7,46,6,37,0,36,9,36,1$, $36,0,32,8,32,5,32,3,32,1,32,06,31,04,23,0,22,9,21,7,20,6,21,0,20,8,20,7$, HRMS ESIMS m/z: 223,09463 calculado para $[\mathrm{M}+\mathrm{Na}]+\mathrm{C}_{10} \mathrm{H}_{16} \mathrm{O}_{4} \mathrm{Na}$, encontrada 
223,09632. IV (vmax, ATR cm$^{-1}$ ): 3477, 2972, 2926, 1753, 1719, 1455, 1385, 1349, 1190, 1124, 1105, 1074, 1054, 1005, 953, 934, 882, 668.

\section{Síntese dos compostos 19 e 20}

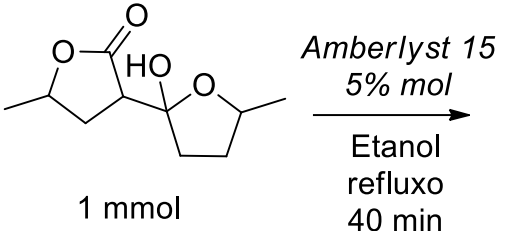

(18)

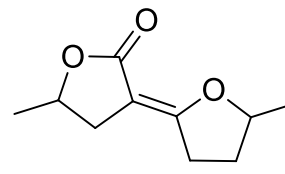

quantitativo

(19)

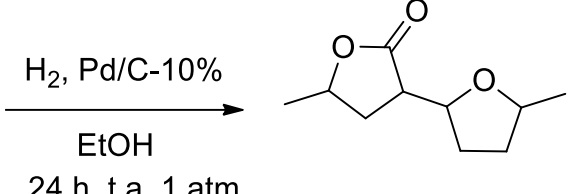

$80 \%$

(20)

Em um balão de fundo redondo de $10 \mathrm{~mL}$, foram adicionados $1 \mathrm{mmol}$ (200 $\mathrm{mg}$ ) do composto $18,5 \mathrm{~mol} \%(10 \mathrm{mg})$ da resina Amberlyst ${ }^{\circledR} 15$ e $5 \mathrm{~mL}$ de etanol. O sistema foi levado ao refluxo por 40 minutos. Após este tempo, filtrou-se o meio reacional e o solvente foi removido, obtendo-se $0,90 \mathrm{mmol}(163,8 \mathrm{mg}) \mathrm{de}$ 19 como um sólido branco. Este sólido foi dissolvido em $10 \mathrm{~mL}$ de etanol seco e adicionado, sob atmosfera de argônio, em um balão de $25 \mathrm{~mL}$ contendo $33 \mathrm{mg}$ de $\mathrm{Pd}-\mathrm{C} 10 \%$ seco previamente em sistema de auto vácuo. Em seguida, foram acoplados ao balão um borbulhador e uma bexiga contendo $\mathrm{H}_{2(\mathrm{~g})}$. O sistema foi mantido com o borbulhador por $10 \mathrm{~min}$, na sequência, foi retirado e a reação foi mantida à temperatura ambiente sob agitação constante por 15 horas. Filtrou-se a reação em Celite ${ }^{\circledR}$ e o bruto reacional purificado em coluna de sílica gel utilizando como eluente Hexano/Acetato de Etila (70:30). Obteve-se 20 com 80\% $(0,80 \mathrm{mmol}, 149 \mathrm{mg})$ como um óleo incolor.

(Z)-5,5'-dimetil-4,4',5,5'-tetra-hidro-2'H, 3H-[2,3'-bifuranilideno]-2'-ona (19): Mistura diastereoisomérica, ${ }^{1} \mathrm{H}$ NMR $\left(500 \mathrm{MHz}, \mathrm{CDCl}_{3}\right): \delta 4,76-4,45(\mathrm{~m}, 2 \mathrm{H})$,

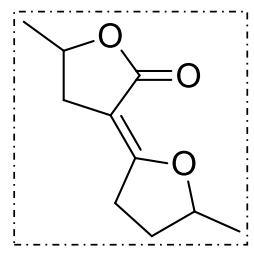

$3,413,24(\mathrm{~m}, 1 \mathrm{H}), 3,08-2,79(\mathrm{~m}, 2 \mathrm{H}), 2,53-2,32(\mathrm{~m}, 1 \mathrm{H}), 2,31-$ 2,15 (m, 1H), 1,75-1,56 (m, 1H), 1,42-1,27 (three d, J = 6,2 Hz, 6H). ${ }^{13} \mathbf{C}$ NMR (126 MHz, $\mathbf{C D C l}_{3}$ ): $\delta$ 172,9, 169,2, 169,1, 93,9, $93,8,81,3,81,2,73,7,73,6,32,97,32,9,31,5,31,4,29,7,29,6$, 22,6, 22,50, 20,6. HRMS ESIMS m/z: 183,10212 calculado para $[\mathrm{M}+\mathrm{H}]+$ $\mathrm{C}_{10} \mathrm{H}_{14} \mathrm{O}_{3} \mathrm{Na}$, encontrada 183,10145. IV (vmax, ATR $\mathbf{~ c m}^{-1}$ ): 1725, 1660, 1382, $1334,1301,1248,1226,1178,1131,1044,995,976,942,860,823,770,753$, 679. 


\section{5,5'-Dimetil-hexa-hidro-[2,3'-bifuran]-2'(3'H)-ona (20):}

Mistura diastereoisomérica, ${ }^{1} \mathrm{H}$ NMR $\left(500 \mathrm{MHz}, \mathrm{CDCl}_{3}\right): \delta$ 4,54-4,42 $(\mathrm{m}, 1 \mathrm{H})$,

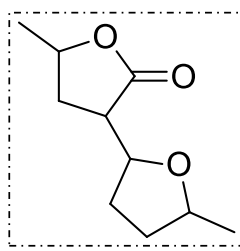
4,29-4,06 (m, 2H), 3,06 (dois ddd, J = 11,6, 9,0, 4,2 Hz, 1H), 2,78$2,66(\mathrm{~m}, 0,2 \mathrm{H}), 2,44-2,33(\mathrm{~m}, 1 \mathrm{H}), 2,13-1,60(\mathrm{~m}, 4 \mathrm{H}), 1,51-1,43$ (m, 1H), 1,41 (dois d, $J=6,2 \mathrm{~Hz}, 3 \mathrm{H}$ ), 1,19 (dois $d, J=6,1 \mathrm{~Hz}, 3 \mathrm{H}$ ). ${ }^{13} \mathrm{C}$ NMR (126 MHz, $\mathrm{CDCl}_{3}$ ): $\delta$ 176,9, 176,6, 176,4, 79,7, 77,2, $77,1,76,8,76,1,76,0,75,8,75,5,75,1,75,0,46,6,46,3,45,2,45,1,44,3,34,1$, $33,2,33,1,32,8,32,7,32,6,31,8,29,8,28,4,28,0,27,3,21,4,21,2,21,1,21,0$, 20,9, 20,8. HRMS ESIMS m/z: 207,09971 calculado para [M+Na]+ $\mathrm{C}_{10} \mathrm{H}_{17} \mathrm{O}_{3} \mathrm{Na}$, encontrada 207,09894. IV (vmax, ATR cm$^{-1}$ ): 2971, 2932, 2874, 1764, 1455, 1386, 1346, 1176, 1120, 1088, 1054, 1025, 984, 940, 655.

\section{Síntese do poliol 21}

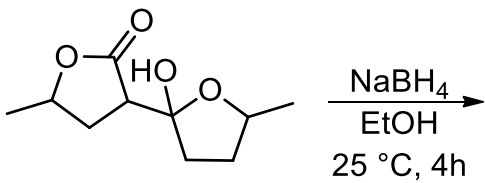

(18)

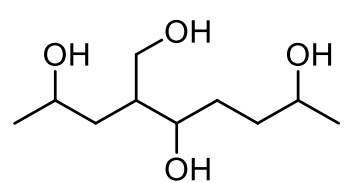

(21)

O composto $18(0,42 \mathrm{~mol}, 86 \mathrm{~g})$ e $450 \mathrm{~mL}$ de etanol foram adicionados em um balão de fundo redondo de $1 \mathrm{~L}$. Em seguida, a mistura foi resfriada à $0{ }^{\circ} \mathrm{C}$, por 5 minutos, e adicionou-se, aos poucos, 0,42 mol (15,8 g) de borohidreto de sódio. A reação foi agitada com auxílio de um agitador mecânico por aproximadamente 5 minutos e, na sequência, foi levada à $25^{\circ} \mathrm{C}$ por 30 minutos com agitação constante. Passados os 30 minutos, a mistura racional foi resfriada novamente e adicionou-se mais $0,42 \mathrm{~mol}$ de borohidreto de sódio. Após 5 minutos à $0{ }^{\circ} \mathrm{C}$, a reação foi mantida sob agitação por 4 horas à temperatura ambiente $\left(25^{\circ} \mathrm{C}\right)$. Para finalizar a reação, a mistura foi resfriada à $0{ }^{\circ} \mathrm{C}$ e foram adicionados $40 \mathrm{~mL}$ de etanol e $100 \mathrm{~mL}$ de solução saturada de cloreto de amônio. Após cessar a liberação de hidrogênio, a solução foi filtrada através de Celite ${ }^{\circledR}$ e o solvente foi removido. O produto bruto foi purificado por filtração em sílica, utilizando acetato de etila puro (4 litros) e 3,5 litros da mistura acetato de etila/Metanol (95:5). A fração recolhida na mistura acetato de etila/metanol foi 
evaporada e o produto foi mantido sob alto vácuo dando origem a um óleo incolor 21, altamente viscoso, com rendimento de $72 \%(0,33 \mathrm{~mol}, 68 \mathrm{~g})$. O solvente utilizado na filtração pôde ser recuperado e utilizado novamente.

\section{4-(Hidroximetil) nonano-2,5,8-triol (21):}

Mistura diastereoisomérica, ${ }^{1} \mathrm{H}$ NMR (500 MHz, MeOH-d5): $\delta$ 3,91-3,81 (m,

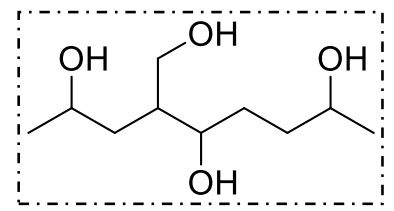

$1 \mathrm{H}), 3,79-3,67(\mathrm{~m}, 4 \mathrm{H}), 1,82-1,70(\mathrm{~m}, 1 \mathrm{H}), 1,69-1,39(\mathrm{~m}$, $5 \mathrm{H}), 1,19-1,16(\mathrm{~m}, 6 \mathrm{H}) .{ }^{13} \mathrm{C}$ NMR (126 MHz, MeOH-d5): $\delta$ $74,5,74,2,74,1,73,9,73,7,73,5,73,4,73,2,68,9,68,8$, $68,7,68,6,68,5,68,4,68,3,68,2,67,5,67,2,66,9,66,8,66,6,64,5,64,0,63,9$, $63,4,63,2,45,2,44,8,44,7,44,2,44,1,43,6,43,5,39,4,39,3,38,6,37,6,37,1$, $37,0,36,9,36,9,36,8,36,7,36,6,31,7,31,6,31,5,31,4,31,3,31,2,31,1,24,4$, 24,3, 24,1, 24,0, 23,7, 23,6, 23,5. HRMS ESMS m/z: 229,14158 calculado para $[\mathrm{M}+\mathrm{Na}]+\mathrm{C}_{10} \mathrm{H}_{22} \mathrm{O}_{4} \mathrm{Na}$, encontrada 229,14396. IR (vmax, ATR $\mathbf{~ c m}^{-1}$ ): 3287 , 2960, 2922, 1416, 1368, 1329, 1118, 935, 747,93.

\section{Derivatização do composto 21}

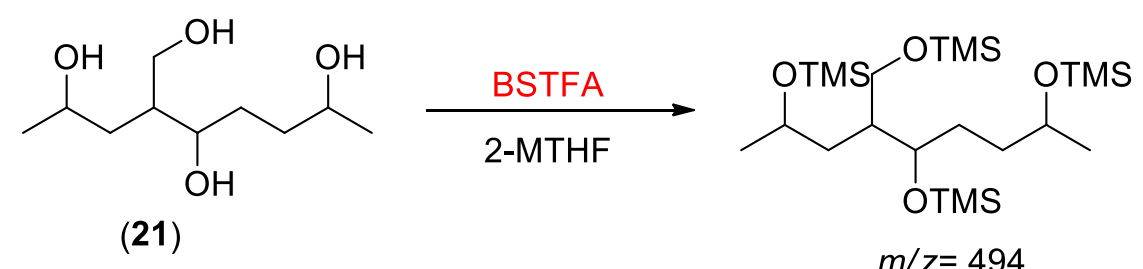

(21c)

O composto 21 ( $5 \mathrm{mg}, 0,024 \mathrm{mmol}$ ), 0,5 mL de 2-metil-tetrahidrofurano seco e $200 \mu \mathrm{L}$ de N,O-Bis(trimetilsilil)trifluoroacetamida (BSTFA) foram adicionados a um balão de fundo redondo de $5 \mathrm{~mL}$. Em seguida, a reação foi aquecida à $60^{\circ} \mathrm{C}$ durante $2 \mathrm{~h}$. $\mathrm{O}$ sistema foi resfriado à $25^{\circ} \mathrm{C}$ e uma alíquota de $100 \mu \mathrm{L}$ foi diluída em $5 \mathrm{~mL}$ de diclorometano. Uma alíquota desta solução foi filtrada (filtro Chromafil, Macherey-Nagel, tamanho de poro 0,45 $\mu \mathrm{m}$ ) e injetada no GC-EM. As análises GC-EM foram realizadas em equipamento modelo Shimadzu-CGMS QP 2010 ULTRA em coluna capital RESTEK Rtx-5MS difenil $5 \% / 95 \%$ dimetil polissiloxano $30 \mathrm{~m} \times 0,25 \mathrm{~mm}, 0,25 \mu \mathrm{m}$. Fluxo de gás $(\mathrm{He}) 1,33$ $\mathrm{mL} / \mathrm{min}$, injetor $300{ }^{\circ} \mathrm{C}$, interface $330^{\circ} \mathrm{C}$. A temperatura da coluna foi iniciada a 
partir de $45^{\circ} \mathrm{C}$, mantida por 1 minuto e aumentada para $170{ }^{\circ} \mathrm{C}$ na taxa de 10 ${ }^{\circ} \mathrm{C} / \mathrm{min}$, permanecendo constante por $3 \mathrm{mim}$. Em seguida, foi aquecido para 330 ${ }^{\circ} \mathrm{C}$ a uma taxa de $10^{\circ} \mathrm{C} / \mathrm{min}$.

Cromatograma do composto sililado $(\mathbf{2 1 c})$ :

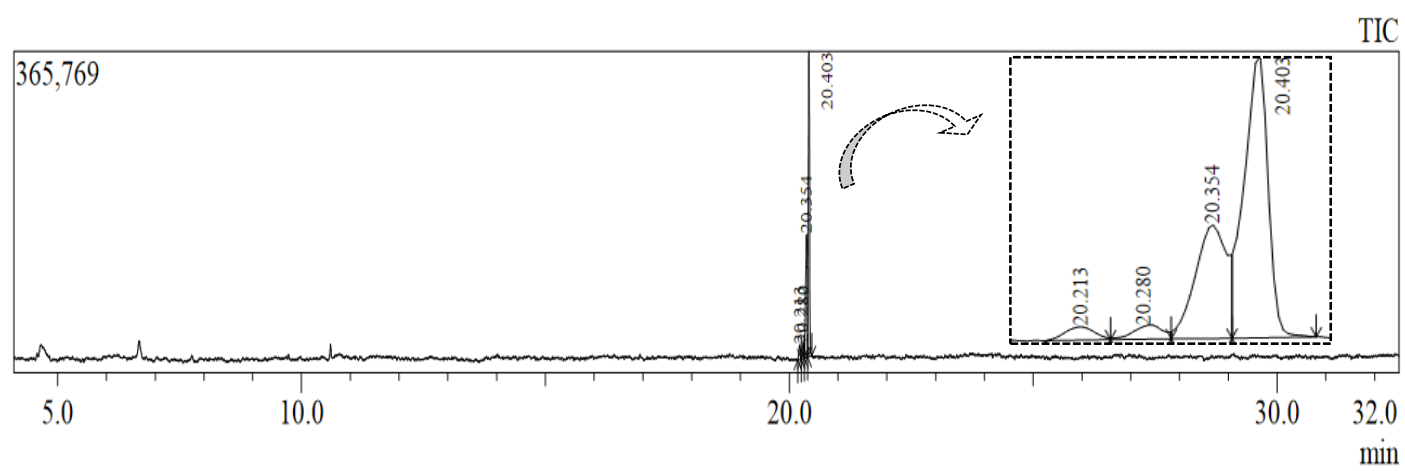

Fragmentações dos picos com tempo de retenção A) 20,213, B) 20,280, C) 20,354 , D) 20,403 .
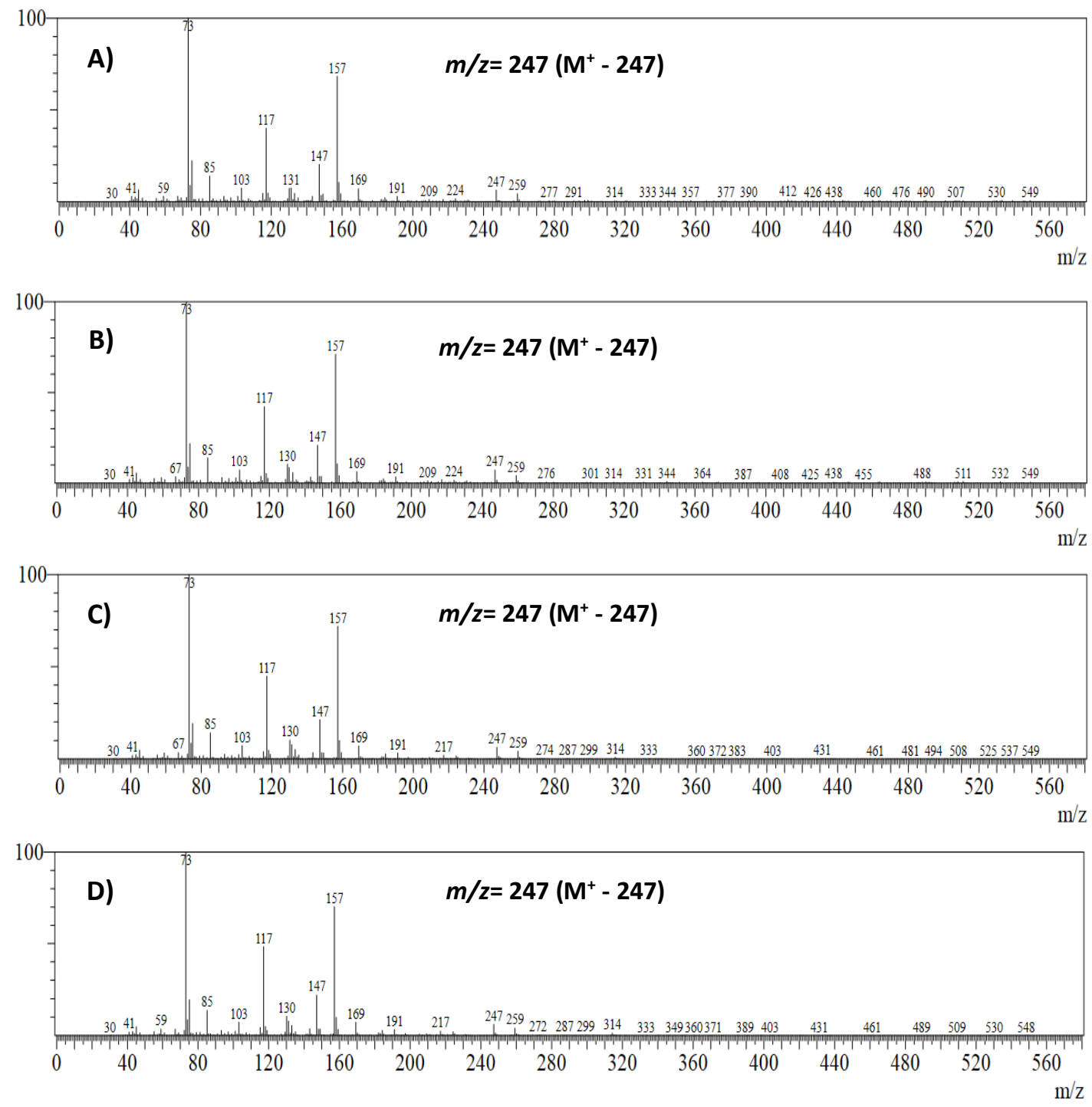


\section{Reação de proteção do composto 21}

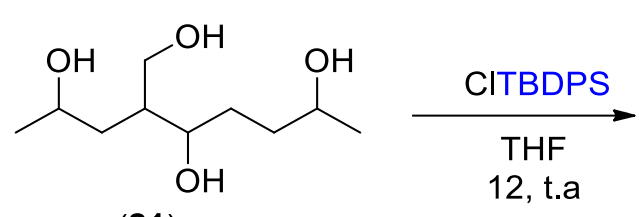

(21)

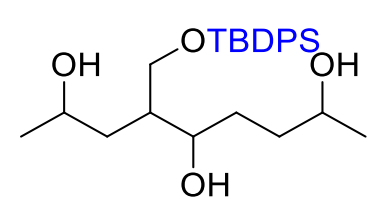

(22)

$1 \mathrm{mmol}$ de poliol 21 (206 mg), $5 \mathrm{~mL}$ de THF seco foram adicionados em um balão de fundo redondo de $25 \mathrm{~mL}$ sob atmosfera de argônio. A mistura foi resfriada à $0^{\circ} \mathrm{C}$ e, na sequência, adicionaram-se gota a gota de cloreto de $t$ butildifenilsilano (1,5 mmol, 412,29 mg, $390 \mu \mathrm{L})$ e 1,5 mmol de imidazol $(102,12$ $\mathrm{mg}$ ). A reação foi agitada à $25^{\circ} \mathrm{C}$ por 15 horas e, após esse período, a mistura foi resfriada e finalizada com $5 \mathrm{~mL}$ de solução saturada de $\mathrm{NaCl}$. Realizou-se a extração do produto com acetato de etila $(3 \times 20 \mathrm{~mL})$. O solvente foi concentrado sob vácuo e o resíduo purificado por cromatografia em coluna flash, empregando como eluente hexano/acetato de etila (70:30) e acetato de etila puro. Obtendose $60 \%$ (267 mg, 0,6 mmol) de rendimento do composto 22 na forma de óleo incolor.

\section{4-(( $(t$-butildifenilsilil)oxi)metil)nonano-2,5,8-triol (22):}

Mistura diastereoisomérica, ${ }^{1} \mathrm{H}$ NMR $\left(400 \mathbf{~ M H z}, \mathbf{C D C l}_{3}\right): \delta 7,72-7,70(\mathrm{~m}, 1 \mathrm{H})$,

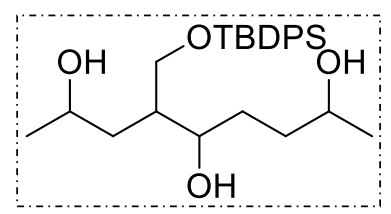

7,66-7,63 (m, 3H), 7,44-7,35 (m, 6H), 3,84-3,48 (m, 7H), $1,67-1,41(\mathrm{~m}, 6 \mathrm{H}), 1,22-1,11(\mathrm{~m}, 6 \mathrm{H}), 1,06(\mathrm{~s}, 3 \mathrm{H}), 1,05$ (s, 9H). ${ }^{13} \mathrm{C}$ NMR (101 MHz, $\left.\mathbf{C D C l}_{3}\right): \delta 136,0,135,8$, $135,6,135,7,135,5,134,9,133,0,130,2,130,2,129,7,128,0,127,9,127,8$, $127,7,77,4,75,0,74,6,74,3,74,2,74,0,68,6,68,5,68,2,67,7,66,9,66,5,66,3$, $65,7,65,5,65,3,43,8,43,3,42,6,38,4,37,6,37,4,36,9,36,8,36,4,35,8,35,7$, $31,9,31,3,31,0,29,8,29,6,27,2,27,1,27,0,26,9,26,6,24,4,24,3,24,0,23,9$, 23,7, 23,4, 23,3, 19,3, 19,2, 19,1. HRMS ESIMS m/z: 467,25936 calculado para [M+Na]+ $\mathrm{C}_{26} \mathrm{H}_{40} \mathrm{O}_{4} \mathrm{SiNa}$, encontrada 467,25867. IV (vmax, ATR $\mathbf{~ m}^{-1}$ ): 3326 , 3070, 3049, 2961, 2929, 2857, 1589, 1471, 1461, 1427, 1390, 1375, 1362, 1336, 1111, 1074, 1029, 822, 740, 701, 610. 
16. Reação de oxidação do composto 22:<smiles>CC(O)CCC(O)C(CO[Pb])CC(C)O</smiles>

(22)

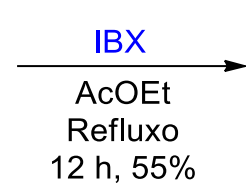

12 h, $55 \%$

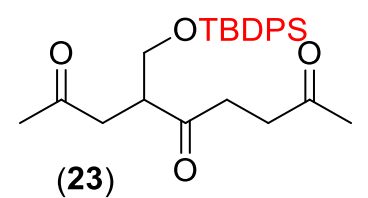

(23)

Em um balão de fundo redondo de $10 \mathrm{~mL}$, foram adicionados $0,60 \mathrm{mmol}$ (267 mg) do composto 22, $5 \mathrm{~mL}$ de acetato de etila grau HPLC e 1,83 mmol (504 $\mathrm{mg}$ ) de ácido 2-iodoxibenzóico (IBX). A reação foi levada ao refluxo por 15 horas sob atmosfera de argônio, em seguida, a solução resultante foi filtrada através de Celite $\AA$ e o solvente evaporado. O resíduo foi purificado por cromatografia em coluna flash empregando como eluente hexano/Acetato de etila (80:20). Obtendo-se 55\% (0,162 mmol, 73,6 mg) de rendimento do composto 23 como um óleo amarelado.

4-(((t-Butildifenilsilil)oxi)metil)nonano-2,5,8-triona (23):

${ }^{1} \mathrm{H}$ NMR (500 MHz, $\left.\mathbf{C D C l}_{3}\right): \delta$ 7,66-7,57 (m, 4H), 7,45-7,37 (m, 6H), 3,78 (dd, J $=10,1,6,3 \mathrm{~Hz}, 1 \mathrm{H}), 3,71(\mathrm{dd}, \mathrm{J}=10,1,6,3 \mathrm{~Hz}, 1 \mathrm{H}), 3,25$
$(\mathrm{~m}, 1 \mathrm{H}), 2,97-2,79(\mathrm{~m}, 3 \mathrm{H}), 2,67(\mathrm{td}, \mathrm{J}=6,4,3,0 \mathrm{~Hz}, 2 \mathrm{H})$, $1,04(\mathrm{~s}, 9 \mathrm{H})$.

${ }^{13} \mathrm{C}$ NMR (126 MHz, $\left.\mathbf{C D C l}_{3}\right): \delta$ 210,3, 207,1, 206,9, 135,6, 135,5, 133,0, 132,9, $129,9,129,8,127,8,64,4,49,1,42,2,36,9,29,9,29,8,26,8,19,2$. HRMS ESIMS m/z: 461,21241 calculado para $[\mathrm{M}+\mathrm{Na}]+\mathrm{C}_{26} \mathrm{H}_{34} \mathrm{O}_{4} \mathrm{SiNa}$, encontrada 461,21176, IV (vmax, ATR cm$^{-1}$ ): 3071, 3049, 2956, 2931, 2896, 2857, 1710, 1589, 1472, 1427, 1392, 1360, 1239, 1188, 1165, 1107, 1008, 822, 789, 741, 702, 611. 


\section{Reação de alquilação do composto 18}
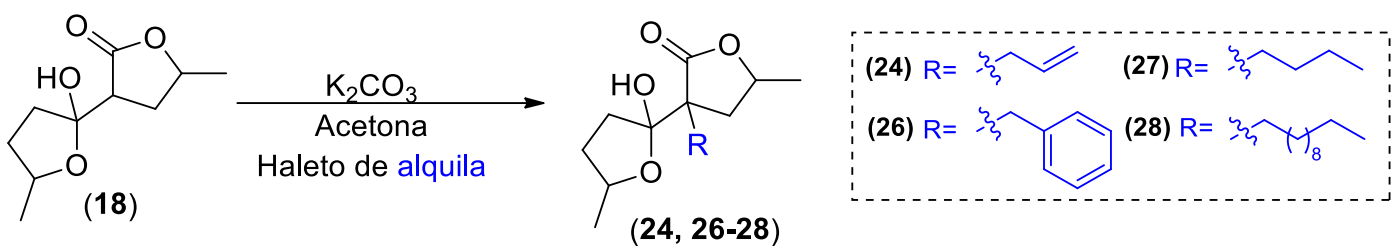

O composto 18 ( $5 \mathrm{mmol}, 1,0 \mathrm{~g}), 12 \mathrm{~mL}$ de acetona, $5,5 \mathrm{mmol}(760,1 \mathrm{mg})$ de carbonato de potássio $\left(\mathrm{K}_{2} \mathrm{CO}_{3}\right)$ e $5,5 \mathrm{mmol}$ de brometo de alila $(665 \mathrm{mg}, 476$ $\mu \mathrm{L})$ ou $5,5 \mathrm{mmol}$ de brometo de benzila $(940,7 \mathrm{mg}, 654 \mu \mathrm{L})$ foram adicionados em um balão de fundo redondo de $25 \mathrm{~mL}$. Em seguida, submeteu-se a reação ao refluxo por 6 horas. Depois desse tempo, a mistura foi filtrada e o solvente evaporado. O produto bruto foi purificado por cromatografia em coluna com sílica flash, empregando hexano/Acetato de etila (8:2) como eluente, dando origem ao composto 24 como um óleo ligeiramente amarelo $86 \%$ (4,3 mmol, 1,036 mg) de rendimento. Obteve-se o composto 26, como um sólido branco, com $80 \%(4,0$ mmol, $1,16 \mathrm{~g}$ ) de rendimento.

Para obter os compostos 27 e 28 o mesmo procedimento foi utilizado, porém aumentou-se a quantidade da base para $10 \mathrm{mmol}(1,38 \mathrm{~g})$ de $\mathrm{K}_{2} \mathrm{CO}_{3} \mathrm{e}$ como haleto de alquila foram utilizados $5,5 \mathrm{mmol}(1,55 \mathrm{~g}, 1,27 \mathrm{~mL})$ de 1 iodoundecano ou 1-iodobutano (1,012 g, $626 \mu \mathrm{L})$. O composto 27 foi obtido com rendimento de $63 \%$ (3,15 mmol, $800 \mathrm{mg}$ ) e o composto $28 \mathrm{com} 50 \%$ (2,5 mmol, $885,8 \mathrm{mg}$ ) de rendimento.

\section{3'-alil-2-hidroxi-5,5'-dimetil-hexa-hidro-[2,3'-bifurano]-2'(3'H)-ona (24):}

Mistura diastereoisomérica, ${ }^{1} \mathrm{H}$ NMR $\left(500 \mathrm{MHz}, \mathrm{CDCl}_{3}\right): \delta$ 5,82-5,56 $(\mathrm{m}, 1 \mathrm{H})$,

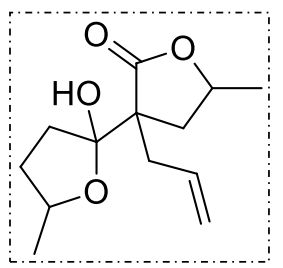
5,25-5,10 (m, 2H), 4,66-4,56 (m, 0,6H), 4,54-4,43 (m, 0,7H), 4,41-4,30 (m, 0,6H), 4,16 (m, 0,5H), 2,83 (m, 1H), 2,30-2,11 (m, $2 \mathrm{H}), 2,07-1,98(\mathrm{~m}, 2 \mathrm{H}), 1,97-1,88(\mathrm{~m}, 1 \mathrm{H}), 1,84(\mathrm{~m}, 1 \mathrm{H}), 1,76-$ $1,67(\mathrm{~m}, 1 \mathrm{H}), 1,65-1,54(\mathrm{~m}, 1 \mathrm{H}), 1,46-1,40(\mathrm{~m}, 1 \mathrm{H}), 1,39(\mathrm{~d}, \mathrm{~J}=$ 6,3 Hz), 1,38 (d, J = 6,3 Hz), 1,32 (d, J = 6,3 Hz), 1,21 (d, J = 6,3 Hz), 1,20-1,12 (m, 1H). ${ }^{13} \mathrm{C}$ NMR (126 MHz, $\mathbf{C D C l}_{3}$ ): $\delta$ 180,9, 180,7, 180,4, 180,3, 133,6, 133,5, $133,2,133,1,133,0,132,9,132,6,132,4,131,6,131,5,120,4,120,3,120,1$, $120,0,119,9,119,8,119,7,119,6,119,5,119,4,119,3,108,4,108,3,107,9$, 
$107,7,107,6,107,5,107,3,78,2,78,2,75,9,75,6,75,5,74,9,74,8,74,4,74,3$, $55,7,55,4,55,3,54,9,39,3,39,2,38,5,38,4,38,3,36,9,36,6,35,9,35,7,35,6$, $34,9,33,6,33,6,32,2,32,1,32,0,31,9,23,0,22,9,21,7,21,6,21,5,21,4,20,7$, 20,6. HRMS ESIMS m/z: 263,12593 calculado para $[\mathrm{M}+\mathrm{Na}]^{+} \mathrm{C}_{13} \mathrm{H}_{20} \mathrm{O}_{4} \mathrm{Na}$, encontrada 263,12514, IV (vmax, ATR cm$^{-1}$ ): 3479, 2974, 2929, 2873, 1740, 1445, 1383, 1349, 1204, 1066, 1003, 927, 880, 652.

Mistura diastereoisomérica 25 (2:1), ${ }^{1} \mathrm{H}$ NMR (400 MHz, $\mathrm{CDCl}_{3}$ ): $\delta$ 5,83-5,66

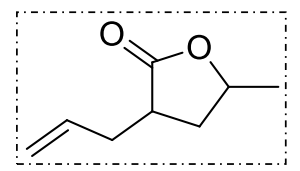
(m, 1H), 5,16-5,02 (m, 2H), 4,64 (ddd, J = 7,4, 6,4, 5,1 Hz, 0,5), 4,53-4,43 (m, 0,8H), 2,80-2,66 (m, 1H), 2,66-2,50 (m, 1H), 2,48-2,38 (m, 1H), 2,32-2,18 (m, 1H), 2,13 (dt, J = 13, 7,4 Hz, 0,6H), 1,97 (ddd, J = 13, 9,2, 5,1 Hz, 0,5H), 1,52 (td, J = 12,3, 10,3 Hz, 1H), 1,40 (d, J = 6,4 Hz, 2H), 1,36 (d, J = 6,4 Hz, 1H).

${ }^{13} \mathrm{C}$ NMR (126 MHz, $\mathbf{C D C l}_{3}$ ): $\delta$ 178,8, 178,3, 134,7, 134,6, 117,9, 117,6, 75,3, 75,2, 41,2, 39,1, 36,4, 34,8, 34,4, 34,3, 21,4, 21,1. IV (vmax, ATR cm ${ }^{-1}$ ): 3079, 2978, 1762, 1642, 1454, 1386, 1349, 1177, 1121, 1070, 1037, 1002, 948, 917, 656.

\section{3'-Benzil-2-hidroxi-5,5'-dimetil-hexa-hidro- [2,3'bifuran]-2'(3'H)-ona (26)}

Mistura diastereoisomérica, ${ }^{1} \mathrm{H}$ NMR $\left(400 \mathbf{~ M H z}, \mathbf{C D C l}_{3}\right): \delta 7,48-7,10(\mathrm{~m}, 6 \mathrm{H})$,

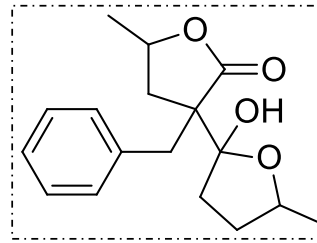

$4,95(\mathrm{~d}, \mathrm{~J}=1,6 \mathrm{~Hz}, 0,5 \mathrm{H}), 4,82-4,80(\mathrm{~s}, 0,5 \mathrm{H}), 4,42(\mathrm{q}, \mathrm{J}=$ 6,3 Hz, 1H), 4,25-4,12 (m, 0,7H), 3,57-3,46 (dd, J = 13,5, $8,0 \mathrm{~Hz}, 1 \mathrm{H}), 3,28-3,18(\mathrm{~m}, 1 \mathrm{H}), 2,66(\mathrm{dd}, \mathrm{J}=13,5,6,0 \mathrm{~Hz}$,

$1 \mathrm{H}), 2,34-2,15(\mathrm{~m}, 2 \mathrm{H}), 2,15-1,65(\mathrm{~m}, 5 \mathrm{H}), 1,53-1,35(\mathrm{~m}$, $0,8 \mathrm{H}), 1,34(\mathrm{~d}, \mathrm{~J}=6,3 \mathrm{~Hz}, 1 \mathrm{H}), 1,23(\mathrm{~d}, \mathrm{~J}=6,3 \mathrm{~Hz}, 2 \mathrm{H}), 1,18(\mathrm{~d}, \mathrm{~J}=6,3 \mathrm{~Hz}, 2 \mathrm{H})$, $1,16(\mathrm{~d}, \mathrm{~J}=6,3 \mathrm{~Hz}, 1 \mathrm{H}), 0,74(\mathrm{~d}, \mathrm{~J}=6,3 \mathrm{~Hz}, 0,3 \mathrm{H}), 0,68(\mathrm{~d}, \mathrm{~J}=6,3 \mathrm{~Hz}, 0,2 \mathrm{H}) \cdot{ }^{13} \mathrm{C}$ NMR (101 MHz, CDCl $)$ : $\delta 181,3,181,1,181,0,136,3,136,2,130,4,129,9,129,7$, $129,7,128,7,128,6,128,5,127,9,127,7,127,1,108,2,108,0,78,4,74,6,74,5$, $74,6,57,3,57,2,56,8,40,7,40,6,36,8,36,4,34,9,33,7,33,6,32,3,32,0,31,9$, 23,0, 21,5, 21,4, 20,7. HRMS ESIMS m/z: 313,14158 calculado para [M+Na]+ $\mathrm{C}_{17} \mathrm{H}_{22} \mathrm{O}_{4} \mathrm{Na}$, encontrada 313,14093, IV (vmax, ATR $\mathbf{~ m m}^{-1}$ ): 3472, 3062, 3030, 2973, 2931, 2872, 2357, 1737, 1673, 1495, 1446, 1382, 1351, 1193, 1003, 946 , 770, 729, 703. 
3'-Butil-2-hidroxi-5,5'-dimetil-hexa-hidro-[2,3'-bifurano]-2'(3'H)-ona (27):

Mistura diastereoisomérica, ${ }^{1} \mathbf{H}$ NMR $\left(500 \mathbf{~ M H z}, \mathbf{C D C l}_{3}\right): \delta 4,75$ (d, J = 1,9 Hz,

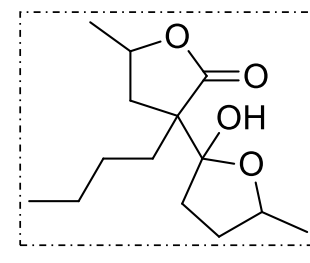

0,25H), 4,68-4,44 (m, 1H), 4,36 (dquin, $J=12,9,6,4 \mathrm{~Hz}$, $0,6 \mathrm{H}), 4,24-4,09(\mathrm{~m}, 0,5 \mathrm{H}), 2,35-2,09(\mathrm{~m}, 1 \mathrm{H}), 2,12-1,44(\mathrm{~m}$, $6 \mathrm{H}$ ), 1,49-1,10 (m, 10H), 0,98-0,79 (three t, $\mathrm{J}=7,1 \mathrm{~Hz} 3 \mathrm{H}$ ).

${ }^{13} \mathrm{C}$ NMR (101 MHz, $\left.\mathbf{C D C l}_{3}\right): \delta 181,5,181,3,181,1,180,9$, $108,7,108,6,108,2,108,0,78,1,75,0,74,9,74,8,74,8,74,2,74,2,55,6,55,4$, $55,0,37,4,37,1,34,9,34,8,34,7,33,5,32,0,31,9,27,0,27,2,27,1,23,1,23,0$, 23,0, 22,9, 21,9, 21,8, 20,7, 13,9, 13,7. HRMS ESIMS m/z: 279,15723 calculado para $[\mathrm{M}+\mathrm{Na}]+\mathrm{C}_{14} \mathrm{H}_{24} \mathrm{O}_{4} \mathrm{Na}$, encontrada 279,15697. IV (vmax, ATR $\left.\mathbf{c m}^{-1}\right)$ : 3475 , 2964, 2933, 2870, 1755, 1455, 1380, 1348, 1188, 1121, 1065, 1008, 946, 893, 650.

2-Hidroxi-5,5'-dimetil-3'-undecil-hexa-hidro-[2,3'-bifuran]-2'(3'H)-ona (28):

Mistura diastereoisomérica, ${ }^{1} \mathbf{H}$ NMR $\left(500 \mathbf{~ M H z}, \mathbf{C D C l}_{3}\right): \delta 4,74(\mathrm{~d}, \mathrm{~J}=1,9 \mathrm{~Hz}$,

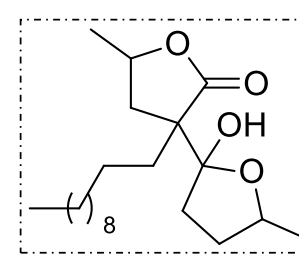
$0,3 \mathrm{H}), 4,62-4,49(\mathrm{~m}, 1 \mathrm{H}), 4,40-4,28(\mathrm{~m}, 0,6 \mathrm{H}), 4,22-3,99(\mathrm{~m}$, $1 \mathrm{H}), 2,28-2,12(\mathrm{~m}, 2 \mathrm{H}), 2,07-1,47(\mathrm{~m}, 7 \mathrm{H}), 1,47-1,33(\mathrm{~m}$, $4 \mathrm{H}), 1,33-1,13(\mathrm{~m}, 19 \mathrm{H}), 0,87(\mathrm{t}, \mathrm{J}=7,0 \mathrm{~Hz}, 3 \mathrm{H})$.

${ }^{13} \mathrm{C}$ NMR (101 MHz, $\left.\mathbf{C D C l}_{3}\right): \delta 181,4,181,3,181,1,181,0$, $108,7,108,6,108,2,108,0,78,1,74,9,74,8,74,2,55,5,55,0,37,5,37,2,35,1$, $34,9,33,7,33,6,32,0,31,9,31,9,30,5,30,0,30,0,29,7,29,6,29,5,29,4,29,3$, 28,5, 25,1, 25,1, 23,0, 22,7, 22,0, 20,7, 14,1. HRMS ESIMS m/z: 377,26678 calculado para [M+Na]+ $\mathrm{C}_{21} \mathrm{H}_{38} \mathrm{O}_{4} \mathrm{Na}$, encontrada 377,26688 . IV (vmax, ATR $\mathbf{c m}^{-1}$ ): 3477, 2922, 2855, 1745, 1456, 1377, 1350, 1198, 1068, 942, 877, 726, 647.

18. Formação de polióis de cadeia longa

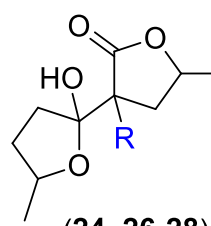

$(24,26-28)$

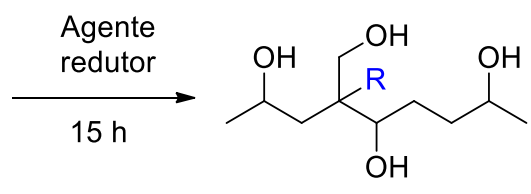

(30-33)

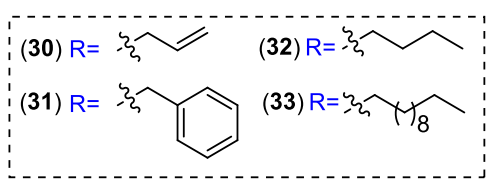

4,8 mmol (182 mg) de $\mathrm{NaBH}_{4}, 2,4 \mathrm{mmol}$ de $\mathrm{CaCl}_{2}(266 \mathrm{mg}$ ) foram adicionados, sob atmosfera de argônio, em um balão de fundo redondo de 10 
$\mathrm{mL}$ contendo $5 \mathrm{~mL}$ de etanol seco. A mistura foi resfriada à $0{ }^{\circ} \mathrm{C}$ seguida pela adição dos compostos 24, 26, 27 ou 28 ( $1 \mathrm{mmol}$ em 0,3 mL de etanol seco). Após 5 minutos à $0^{\circ} \mathrm{C}$, a reação foi levada à temperatura ambiente $\left(25^{\circ} \mathrm{C}\right)$ e mantida sob agitação por $12 \mathrm{~h}$. Para finalizar, resfriou-se a reação e foram adicionados 1 $\mathrm{mL}$ de etanol e $1 \mathrm{~mL}$ de solução saturada de cloreto de amônio. Esta solução foi filtrada através de Celite $\AA^{\circledR}$ e o solvente removido. O produto bruto foi purificado por coluna cromatografia com flash, utilizando uma mistura de acetato de etila/MeOH (95:5) como eluente para a purificação dos compostos 30 e 31. Para purificação de 32 e 33 empregou-se acetato de etila puro. Rendimentos: 53\% (0,53 mmol, 130,4 mg) de $\mathbf{3 0}, 60 \%$ (0,60 mmol, $178 \mathrm{mg})$ de $\mathbf{3 1}, 45 \%$ (0,45 mmol, $118 \mathrm{mg})$ de 32 e $40 \%(0,40 \mathrm{mmol}, 144 \mathrm{mg})$ de 33 como um óleo incolor.

\section{4-alil-4-(hidroximetil)nonano-2,5,8-triol (30):}

Mistura diastereoisomérica, ${ }^{1} \mathrm{H}$ NMR (500 MHz, MeOH-d4): $\delta$ 5,96-5,73 (m,

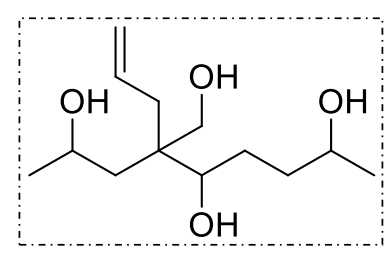
$1 \mathrm{H}), 5,16-4,99(\mathrm{~m}, 2 \mathrm{H}), 4,05-3,94(\mathrm{~m}, 1 \mathrm{H}), 3,73(\mathrm{~m}, 1 \mathrm{H})$, $3,66-3,57(m, 1 H), 3,59-3,36(m, 2 H), 2,35-2,19(m, 1 H)$, $1,77-1,27(\mathrm{~m}, 7 \mathrm{H}), 1,21-1,12(\mathrm{~m}, 6 \mathrm{H})$.

${ }^{13} \mathrm{C}$ NMR (126 MHz, MeOH-d4): $\delta$ 135,98, 135,95, 135,75, $135,71,118,16,118,14,118,10,118,08,77,05,76,65,68,98,68,91,68,89$, $68,45,68,36,66,54,66,49,64,73,64,50,64,27,45,90,45,87,45,72,45,66$, $43,59,43,57,39,00,37,89,37,78,37,57,37,50,37,50,37,49,28,70,28,26$, 25,39, 25,38, 25,03, 24,90, 23,70, 23,66, 23,65. HRMS ESIMS m/z: 269,17288 calculado para $[\mathrm{M}+\mathrm{Na}]+\mathrm{C}_{13} \mathrm{H}_{26} \mathrm{O} 4 \mathrm{Na}$, encontrada 269,17265 , IV (vmax, ATR cm $^{-1}$ ): 3300, 2966, 2928, 2245, 1638, 1446, 1417, 1374, 1120, 1035, 907, 727.

\section{4-Benzil-4-(hidroximetil)nonano-2,5,8-triol (31):}

Mistura diastereoisomérica, ${ }^{1} \mathbf{H}$ NMR $\left(500 \mathbf{~ M H z}, \mathbf{C D C l}_{3}\right): \delta 7,35-7,02(\mathrm{~m}, 5 \mathrm{H})$,

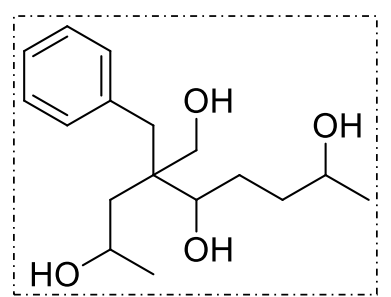
$4,28-3,24(\mathrm{~m}, 6 \mathrm{H}), 2,91-2,40(\mathrm{~m}, 2 \mathrm{H}), 1,92-1,39(\mathrm{~m}, 6 \mathrm{H})$, $1,19(\mathrm{~d}, \mathrm{~J}=6,2 \mathrm{~Hz}, 6 \mathrm{H}), 1,15(\mathrm{~d}, \mathrm{~J}=6,2 \mathrm{~Hz}, 6 \mathrm{H}) .{ }^{13} \mathrm{C}$ NMR (126 MHz, CDC $\left._{13}\right): \delta 137,9,137,8,130,7,130,6,128,2$, $126,3,77,4,76,3,76,1,68,3,68,2,67,9,67,8,67,7,65,6$, $65,5,64,4,64,3,64,2,62,7,62,7,45,2,45,1,41,7,41,6$, $38,0,37,9,36,9,36,4,36,4,36,4,29,1,28,4,27,2,25,3,25,2,23,9,23,5,23,4$. HRMS ESIMS m/z: 319,18853 calculado para $[\mathrm{M}+\mathrm{Na}]+\mathrm{C}_{17} \mathrm{H}_{28} \mathrm{O}{ }_{4} \mathrm{Na}$, encontrada 
319,19133, IV (vmax, ATR cm$^{-1}$ ): 3314, 2964, 2929, 2245, 1602, 1494, 1453, 1422, 1374, 1335, 1120, 908, 728, 701, 645.

4-Butil-4-(hidroximetil)nonano-2,5,8-triol (32):

Mistura diastereoisomérica, ${ }^{1} \mathrm{H}$ NMR (500 MHz, $\mathrm{CDCl}_{3}$ ): $\delta 4,41$ (s, 3H), 4,02-

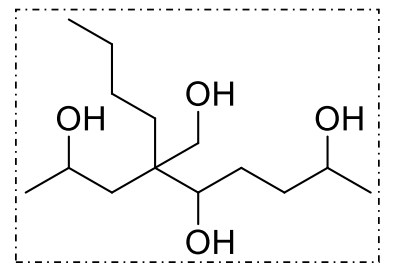
$3,97(\mathrm{~m}, 1 \mathrm{H}), 3,91-3,61(\mathrm{~m}, 2 \mathrm{H}), 3,60-3,29(\mathrm{~m}, 2 \mathrm{H}), 1,91-$ $145(\mathrm{~m}, 5 \mathrm{H}), 1,35-1,29(\mathrm{~m}, 1 \mathrm{H}), 1,25-1,09(\mathrm{~m}, 10 \mathrm{H}), 0,86$ (three t, J = 7,1 Hz, 3H). ${ }^{13} \mathbf{C}$ NMR (126 MHz, $\mathbf{C D C l}_{3}$ ): 77,7, $77,4,77,3,71,8,71,2,68,4,67,7,67,5,66,5,66,4,64,2$, $64,2,63,4,61,6,61,7,43,6,43,3,43,2,43,2,42,1,42,0,37,2,36,4,32,4,32,2$, $31,8,29,7,28,4,26,9,25,5,25,1,25,0,23,9,23,9,23,8,23,7,23,3,23,2,19,3$, 14,2, 14,1, 14,0. HRMS ESIMS m/z: 285,20418 calculado para [M+Na]+ $\mathrm{C}_{14} \mathrm{H}_{30} \mathrm{O}_{4} \mathrm{Na}$, encontrada 285,20691. IV (vmax, ATR $\mathbf{~ m m}^{-1}$ ): 3307, 2960, 2929, 2871, 1718, 1672, 1457, 1374, 1337, 1121, 1032, 948, 753, 729, 661.

4-(Hidroximetil)-4-undecilnonano-2,5,8-triol (33):

Mistura diastereoisomérica, ${ }^{1} \mathrm{H}$ NMR $\left(500 \mathbf{~ M H z}, \mathrm{CDCl}_{3}\right): \delta 3,75-3,65(\mathrm{~m}, 2 \mathrm{H})$,<smiles>CCCC(CO)(CC(C)O)C(O)CCC(C)O</smiles>
$3,63-3,50(\mathrm{~m}, 2 \mathrm{H}), 3,51-3,29(\mathrm{~m}, 4 \mathrm{H}), 2,06-1,43(\mathrm{~m}, 6 \mathrm{H})$, 1,42-0,98 (m, 20H), 0,91 (t, J = 7,2 Hz, 1H), 0,87 (t, J = 7,2 $\mathrm{Hz}, 2 \mathrm{H}) .{ }^{13} \mathrm{C}$ NMR (101 MHz, $\left.\mathrm{CDCl}_{3}\right): \delta 71,8,71,2,68,7$, $67,6,66,0,64,5,61,9,43,2,43,2,41,6,37,3,36,6,36,4$, $33,2,32,8,32,6,32,0,31,8,30,8,30,7,30,7,29,8,29,7,29,7,29,6,29,5,28,6$, $26,9,25,7,25,5,25,4,24,1,24,0,23,5,23,4,23,3,22,9,22,8,22,7,19,4,15,4$, 14,2, 14,03. HRMS ESIMS m/z: 383, 31373 calculado para [M+Na]+ $\mathrm{C}_{21} \mathrm{H}_{44} \mathrm{O}_{4} \mathrm{Na}$, encontrada 383,31764. IV (vmax, ATR $\mathbf{~ c m}^{-1}$ ): 3302, 2959, 2922, 2852, 1457, 1374, 1336, 1122, 1033, 945, 720. 
19. Capítulo III: Estudo visando à síntese de alcaloides contendo núcleo pirrolidínicos: Obtenção da codonopsinina e análogos

\section{Isomerização da $\alpha$-angélica lactona}

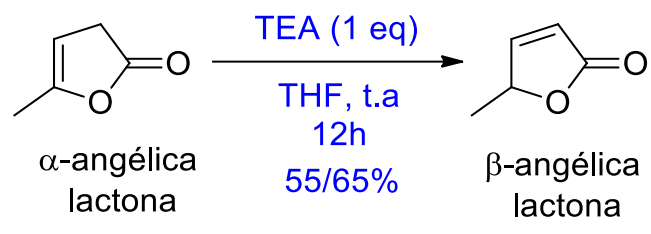

Em um balão de fundo redondo de $500 \mathrm{~mL}$, foram adicionados $150 \mathrm{~mL}$ de THF, $20 \mathrm{~g} \mathrm{(204} \mathrm{mmol)} \mathrm{de} \alpha$-angélica lactona e $204 \mathrm{mmol}(28 \mathrm{~mL})$ de trietilamina. O balão foi vedado e mantido sob agitação por 12 horas. Em seguida, evaporouse 0 solvente e purificou-se o bruto reacional por cromatografia flash empregando hexano/AcOEt (9:1 e 7:3) como eluente. Rendimento 55\% (11 g, $112 \mathrm{mmol}$ ) sem a recuperação do material de partida e $65 \%$ considerando a recuperação do material de partida.

\section{$\beta$-angélica lactona:}

${ }^{1} \mathrm{H} \mathrm{NMR}\left(400 \mathrm{MHz}, \mathrm{CDCl}_{3}\right): \delta 7.45(\mathrm{dd}, J=5.7,1.6 \mathrm{~Hz}, 1 \mathrm{H}), 6.09$ $(\mathrm{dd}, J=5.7,2.0 \mathrm{~Hz}, 1 \mathrm{H}), 5.13(\mathrm{qt}, J=6.9,1.6 \mathrm{~Hz}, 1 \mathrm{H}), 1.45(\mathrm{~d}, J=$ $6.9 \mathrm{~Hz}, 1 \mathrm{H}) .{ }^{13} \mathrm{C}$ NMR (101 MHz, $\left.\mathrm{CDCl}_{3}\right): \delta 173.1,157.3,121.3,79.6,18.8$.

\section{Reação de diidroxilação da $\beta$-angélica lactona}

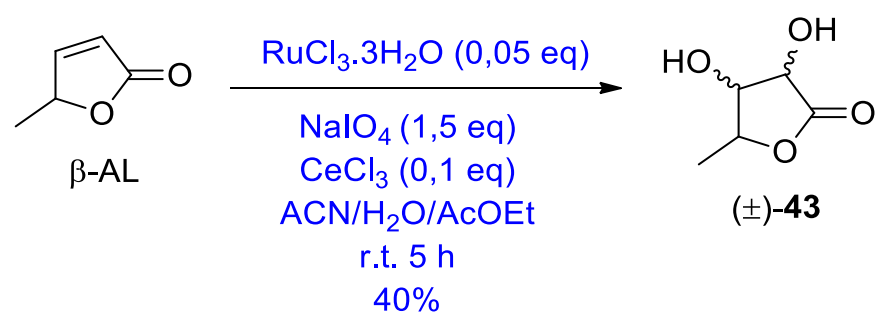

\section{Método 1:}

Cloreto de cério (III) heptahidratado (150 mg, 0,4 mmol) foi adicionado em uma solução de periodato de sódio (1,28 g, 6,0 mmol) em água ( $8 \mathrm{~mL})$. A mistura foi agitada à temperatura ambiente durante 15 minutos e, em seguida, AcOEt(12 
$\mathrm{mL}) / \mathrm{ACN}(24 \mathrm{~mL})$ foram adicionados. Levou-se a reação à $0{ }^{\circ} \mathrm{C}$ e $52 \mathrm{mg}(0,2$ $\mathrm{mmol}$ ) de cloreto de rutênio (III) triidratado foi adicionado ao meio. Agitou-se a mistura durante 5 minutos e, na sequência, uma solução da $\beta$-angélica lactona (4 mmol, $392 \mathrm{mg}$ ) em AcOEt (12 mL) foi adicionada ao meio. A reação foi mantida sob agitação à temperatura ambiente por 5 horas. Após este tempo, adicionouse $20 \mathrm{~mL}$ de solução aquosa saturada de tiossulfato de sódio penta-hidratado e extraiu-se com AcOEt (60 mL por 4 vezes). A fase orgânica foi seca sobre $\mathrm{MgSO}_{4}$ e o produto bruto purificado por cromatografia flash, empregando misturas de hexano:AcOEt (3:7) e acetato de etila puro como eluente. Obteve-se 43, sólido branco, com 40\% de rendimento (1,6 mmol, $209 \mathrm{mg})$ dos diastereoisômeros.

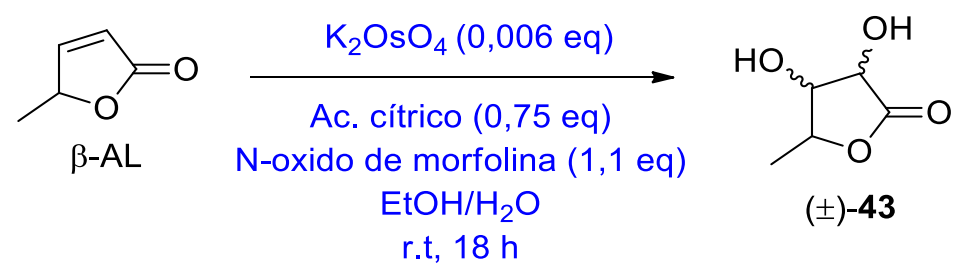

\section{Método 2:}

$\mathrm{N}$-óxido de 4-metilmorfolina (5,15 g, $44 \mathrm{mmol})$ foi adicionado a um balão de fundo redondo de $250 \mathrm{~mL}$ contendo: $\alpha$-angélica lactona $(40 \mathrm{mmol}, 3,92 \mathrm{~g}$ ), osmato de potássio $(\mathrm{VI})$ diidratado $(0,24 \mathrm{mmol}, 88 \mathrm{mg}$,) e ácido cítrico $(5,76 \mathrm{~g}$, $30 \mathrm{mmol})$ em uma mistura 1:1 de etanol/água $(80 \mathrm{~mL})$. A reação foi agitada à temperatura ambiente durante 18 horas e finalizada com uma solução aquosa de tiossulfato de sódio penta-hidratado $(10 \mathrm{~mL})$. Extraiu-se a mistura com AcOEt (40 mL) e a fase orgânica foi seca sobre $\mathrm{MgSO}_{4}$. Purificou-se o produto bruto por cromatografia flash empregando hexano/AcOEt (3:7) e acetato puro como eluente. Obteve-se 43, sólido branco, com $65 \%$ de rendimento $(26 \mathrm{mmol}, 3,43$ g) dos diastereoisômeros.

\section{3,4-diidroxi-5-metildiidrofuran-2 (3H)-ona (43):}

${ }^{1} \mathrm{H}$ NMR (500 MHz, DMSO- $d_{6}$ ) Mistura diastereoisomérica: $\delta 5.74(\mathrm{~d}, J=7.3 \mathrm{~Hz}$,<smiles>CC1OC(=O)C(O)C1O</smiles>
$1 \mathrm{H}), 5.39(\mathrm{~d}, J=3.3 \mathrm{~Hz}, 1 \mathrm{H}), 4.52-4.39(\mathrm{~m}, 1 \mathrm{H})$, $4.35(\mathrm{q}, J=6.5 \mathrm{~Hz}, 1 \mathrm{H}), 3.98-3.86(\mathrm{~m}, 1 \mathrm{H}), 1.27$ (d, $J=6.9 \mathrm{~Hz}, 3 \mathrm{H}) . \delta 5.72(\mathrm{~d}, J=5.1 \mathrm{~Hz}, 0,26 \mathrm{H})$, $5.29(\mathrm{~d}, J=3.9 \mathrm{~Hz}, 0,34 \mathrm{H}), 4.43-4.41(\mathrm{~m}, 0,32 \mathrm{H}), 4.04(\mathrm{~d}, J=3.8 \mathrm{~Hz}, 0,31 \mathrm{H})$, 
1.23 (d, $J=6.5 \mathrm{~Hz}, 1 \mathrm{H}$ ). ${ }^{13} \mathrm{C}$ NMR (126 MHz, DMSO-d6): $\delta$ 175.9, 80.9, 72.2, 68.2, 17.8, 176.4, 76.0, 71.0, 70.5, 14.0. IV: 3405.66, 2985.70, 2928.51, 1761.87, $1701.55,1636.10,1448.41,1385.88,1359.62,1338.88,1187.71,1144.19$, 1099.73, 1063.53. 1023.16, 965.16, 922.80, 884.91, 836.99, 760.05.

\section{Reação de proteção do composto 43}

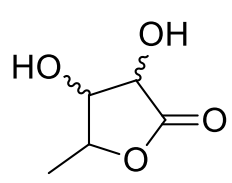

$( \pm)-43$

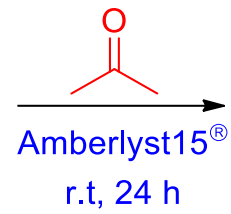

$80 \%$

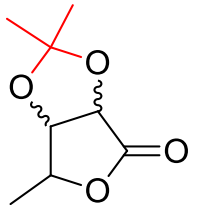

$( \pm)-44$

Em um balão de fundo redondo de $250 \mathrm{~mL}$, contendo $150 \mathrm{~mL}$ de acetona (previamente seca sob peneira molecular), foram adicionados $40 \mathrm{mmol}$ de 43 $(5,28 \mathrm{~g})$ e $264 \mathrm{mg}$ da resina amberlyst $15 \AA$. Agitou-se a reação à temperatura ambiente por 24 horas e, em seguida, a resina foi filtrada e o solvente evaporado. O produto bruto foi purificado por cromatografia flash empregando hexano/AcOEt (7:3). Obteve-se 44, sólido branco, com $80 \%$ de rendimento (32 mmol, 5,5 g) dos diastereoisômeros.

\section{2,2,6-trimetildi-hidrofuro[3,4-d][1,3]dioxol-4(3aH)-ona(44):}

Mistura diastereoisomérica

${ }^{1} \mathrm{H}$ NMR $\left(400 \mathrm{MHz}, \mathrm{CDCl}_{3}\right): \delta(4.81 \mathrm{~d}, J=5.3 \mathrm{~Hz}, 4.78 \mathrm{~d}, J=5.5 \mathrm{~Hz}, 1 \mathrm{H}), 4.69-$<smiles>CC1(C)OC2OC(C)(C)C(OC(=O)C(C)(C)C)C2O1</smiles>
$4.62(\mathrm{~m}, 1 \mathrm{H}), 4.50(\mathrm{~d}, J=5.6 \mathrm{~Hz}, 1 \mathrm{H}),(1.49 \mathrm{~s}, 1.47 \mathrm{~s}$, $4 \mathrm{H}),(1.39 \mathrm{~s}, 1,37 \mathrm{~s}, 5 \mathrm{H}) .{ }^{13} \mathrm{C}$ NMR (101 MHz, $\left.\mathrm{CDCl}_{3}\right)$ : $\delta$ 174.06, 173.79, 113.94, 113.93, 80.41, 79.02, 79.01, $77.53,76.57,75.96,74.76,26.77,25.94,25.65,19.63$ 14.46. IV: 2989.29, 2939.82, 1776.78, 1456.14, 1377.33, 1351.43, 1265.70, 1215.65, 1181.38, 1086.38, 969.36, 916.23, 854.21, 793.75, 771.48, 705.88, 624.24. 


\section{Abertura da lactona 44}

\section{Método 1:}

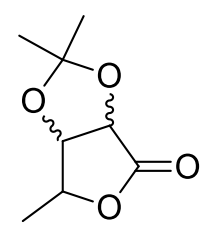

$( \pm)-44$

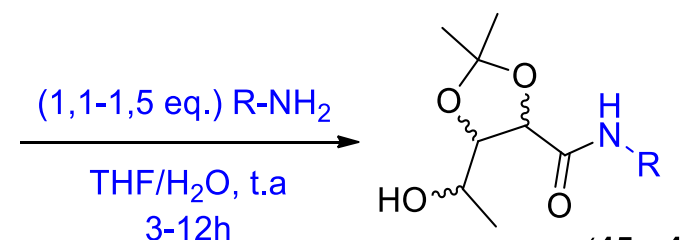

$(45 \mathrm{a}-45 \mathrm{j})$

Em um balão de fundo redondo de $5 \mathrm{~mL}$, foram adicionados $1 \mathrm{mmol}$ (172 $\mathrm{mg})$ de 44, $1 \mathrm{~mL}$ da mistura $\mathrm{THF} / \mathrm{H}_{2} \mathrm{O}(1: 1)$ e $1,5 \mathrm{mmol}$ da amina. A reação foi mantida sob agitação por 3 horas à temperatura ambiente. Evaporou-se 0 solvente e o produto bruto foi seco em auto vácuo, resultando nas amidas $45 \mathrm{~b}$ 45e como sólidos amarelados com rendimentos $>95 \%$.

Para formação das amidas $\mathbf{4 5 a}$, 45f-45h utilizou-se 1,1 equivalente das aminas e 12 horas de reação. Na produção de $45 \mathbf{i}$ e $45 \mathbf{j}$, apenas THF (1mL) foi usado como solvente. Purificou-se o bruto reacional por cromatografia flash empregando hexano:AcOEt (7:3). Obtiveram-se: 45a (90\% de rendimento, sólido amarelado), $45 \mathrm{f}$ (90\% de rendimento, sólido branco), $45 \mathrm{~g}$ (90\% de rendimento, sólido branco), 45h (95\% de rendimento, sólido amarelado), 45i (90\% de rendimento, sólido amarelado), 45j (98\% de rendimento, sólido marrom).

\section{N-benzil-5-(1-hidroxietil)-2,2-dimetil-1,3-dioxolano-4-carboxamida (45a):}

\section{Mistura diastereoisomérica}

${ }^{1} \mathrm{H}$ NMR (600 MHz, $\left.\mathrm{CDCl}_{3}\right)$ : $\delta 7.37-7.20(\mathrm{~m}, 5 \mathrm{H}), 7.16$ e $6.91(\mathrm{~s}, 1 \mathrm{H}) 4.93(\mathrm{~s}$,

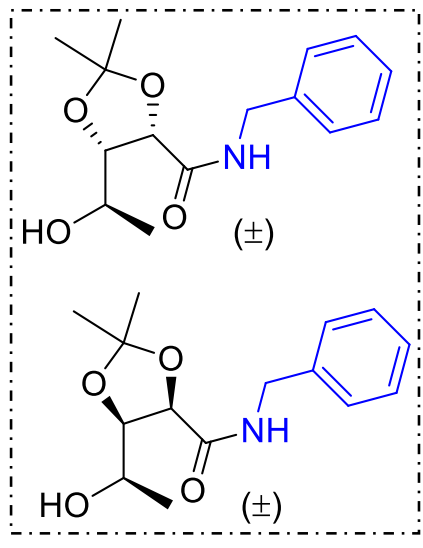
$1 \mathrm{H}), 4.67(\mathrm{~d}, J=7.3 \mathrm{~Hz}$ e $4.60 \mathrm{~d}, J=7.9 \mathrm{~Hz}, 1 \mathrm{H}), 4.55$ (dd, $J=14.9,6.2 \mathrm{~Hz}, 1 \mathrm{H}), 4.47$ (dd, $J=14.8,5.8 \mathrm{~Hz}, 1 \mathrm{H}$ ), 4.32 (dd, $J=7.9,3.3 \mathrm{~Hz}$ e 4.16 (dd, $J=9.1,7.4 \mathrm{~Hz}, 1 \mathrm{H}$ ), $3.73-3.66(\mathrm{~m}, 1 \mathrm{H}), 1.53$ e $1.48(\mathrm{~s}, 3 \mathrm{H}), 1.38(\mathrm{~s}, 3 \mathrm{H})$, 1.31 e $1.27(\mathrm{~d}, J=6.1 \mathrm{~Hz}, 3 \mathrm{H}) .{ }^{13} \mathrm{C}$ NMR $(151 \mathrm{MHz}$, $\left.\mathrm{CDCl}_{3}\right): \delta 171.74,170.02,137.84,137.36,129.01$, $128.86,127.90,127.85,127.69,127.60,110.22,109.57$, $82.93,81.02,77.32,76.15,66.83,65.29,43.28,43.17$, 27.18, 26.84, 24.64, 24.42, 20.31, 20.17. IV: 3416.02, 3368.85, 2986.82, 2933.96, 2893.09, 1651.19, 1606.39, 1526.63, 1497.28, 1453.93, 1426.24, 
$1383.03,1372.67,1309.14,1247.24,1214.68,1159.02,1112.73,1068.95$, 1027.92, 968.45, 905.69, 874.30, 796.26, 731.58, 697.23.

5-(1-hidroxietil)-N, 2,2-trimetil-1,3-dioxolano-4-carboxamida (45b): Mistura diastereoisomérica

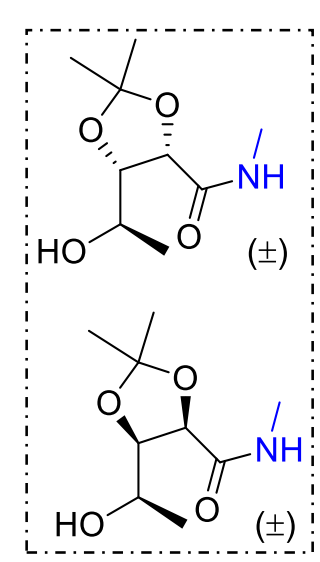

${ }^{1} \mathrm{H}$ NMR (400 MHz, $\left.\mathrm{CDCl}_{3}\right) \delta 6.82$ e $6.60(\mathrm{~s}, 1 \mathrm{H}), 4.93(\mathrm{~s}, 1 \mathrm{H})$, 4.60 e $4.54(\mathrm{~d}, J=7.4 \mathrm{~Hz}, 1 \mathrm{H}), 4.29$ (dd, $J=7.7,3.1 \mathrm{~Hz}$ e 4.19 $-4.02(\mathrm{~m}, 1 \mathrm{H}), 3.63(\mathrm{~m} .1 \mathrm{H}), 2.88,2.87,2.84$ e $2.83(\mathrm{~s}, 3 \mathrm{H})$, 1.56, 1.53 e $1.37(\mathrm{~s}, 3 \mathrm{H}), 1.27$ e $1.23(\mathrm{~d}, J=6.5 \mathrm{~Hz}, 3 \mathrm{H}) .{ }^{13} \mathrm{C}$ NMR (101 MHz, $\left.\mathrm{CDCl}_{3}\right) \delta 172.34,110.05,109.45,82.79$, $80.85,77.31,76.14,66.77,65.38,27.17,26.82,25.97,25.86$, 24.56, 24.36, 20.14, 20.06. IV: $3429.53,3379.61,2986.63$, $2936.81,2901.87,1652.89,1540.50,1450.03,1410.21$, 1383.78, 1373.77, 1310.22, 1247.04, 1216.51, 1160.23, 1114.74, 1069.08, $1019.63,1001.64,969.31,927.67,876.96,834.94,795.64,655.55$.

N-butil-5-(1-hidroxitila)-2,2-dimetil-1,3-dioxolane-4-carboxamida

(45c): Mistura diastereoisomérica

${ }^{1} \mathrm{H}$ NMR (400 MHz, $\left.\mathrm{CDCl}_{3}\right): \delta 6.83$ e $6.60(\mathrm{~s}, 1 \mathrm{H}), 4.58(\mathrm{~d}, J=7.3 \mathrm{~Hz}$ e $4.52(\mathrm{~d}$, (t) $J=7.9 \mathrm{~Hz}, 1 \mathrm{H}), 4.28(\mathrm{dd}, J=7.8,3.6 \mathrm{~Hz}$ e $4.11(\mathrm{dd}, J=$ $9.2,7.3 \mathrm{~Hz}, 1 \mathrm{H}), 3.70-3.55(\mathrm{~m}, 1 \mathrm{H}), 3.44-3.16(\mathrm{~m}, 2 \mathrm{H})$, 1.56 e $1.52(\mathrm{~s}, 3 \mathrm{H}), 1.51-1.45(\mathrm{~m}, 2 \mathrm{H}), 1.37(\mathrm{~s}, 3 \mathrm{H}), 1.38$ - $1.29(\mathrm{~m}, 2 \mathrm{H}), 1.27(\mathrm{~d}, J=6.2 \mathrm{~Hz}$ e $1.23(\mathrm{~d}, J=6.5 \mathrm{~Hz}$, $3 \mathrm{H}), 0.92(\mathrm{t}, J=7.3 \mathrm{~Hz}, 3 \mathrm{H}) \cdot{ }^{13} \mathrm{C}$ NMR (101 MHz, $\left.\mathrm{CDCl}_{3}\right)$ : $\delta 171.42,169.84,109.90,109.31,82.73,80.81,77.15$, $77.02,76.03,66.63,65.31,38.84,38.73,31.43,31.36$ $27.07,26.77,24.51,24.34,20.04,19.99,19.98,19.93$, 13.68, 13.64. IV: $3416.02,3368.85,2986.82,2933.96,2893.09,1651.19$, $1526.63,1453.93,1372.67,1214.68,1159.02,1068.95,874.30,697.23$ 
N-etil-5-(1-hidroxietil)-2,2-dimetil-1,3-dioxolano-4-carboxamida

(45d):

Mistura diastereoisomérica

${ }^{1} \mathrm{H}$ NMR (600 MHz, $\mathrm{CDCl}_{3}$ ) $\delta 6.82$ (s, 1H), 4.58 (d, J = $7.3 \mathrm{~Hz}$ e 4.52 (d, J = 7.9

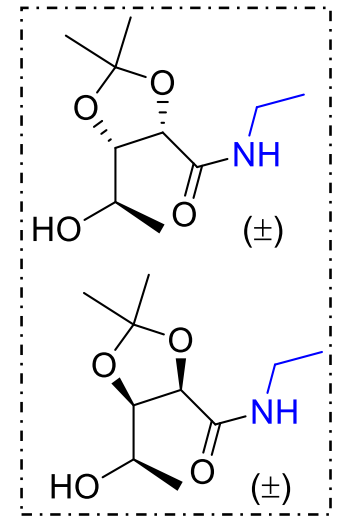

$\mathrm{Hz}, 1 \mathrm{H}), 4.27$ (dd, $J=7.9,3.5 \mathrm{~Hz}$ e $4.16-4.08 \mathrm{~m}, 1 \mathrm{H}), 4.04$ ( $q d, J=6.5,3.5 \mathrm{~Hz}$ e $3.68-3.59 \mathrm{~m}, 1 \mathrm{H}), 3.39-3.26(\mathrm{~m}, 2 \mathrm{H})$, 1.56 (s e $1.52 \mathrm{~s}, 3 \mathrm{H}), 1.37$ (s, 3H), 1.27 (d, J = 6.2 Hz e 1.23 $\mathrm{d}, J=6.5 \mathrm{~Hz}, 3 \mathrm{H}), 1.17$ (t, J=7.2 Hz, 3H). ${ }^{13} \mathrm{C} \mathrm{NMR}(151 \mathrm{MHz}$, $\left.\mathrm{CDCl}_{3}\right) \delta 171.52,169.92,110.06,109.46,82.84,80.91,77.24$ $76.14,66.75,65.43,34.20,33.99,27.18,26.86,24.63,24.44$, $20.09,14.82,14.71$.

\section{N-(but-3-en-1-il)-5-(1-hidroxietil)-2,2-dimetil-1,3-dioxolano-4-carboxamida} (45e): Mistura diastereoisomérica

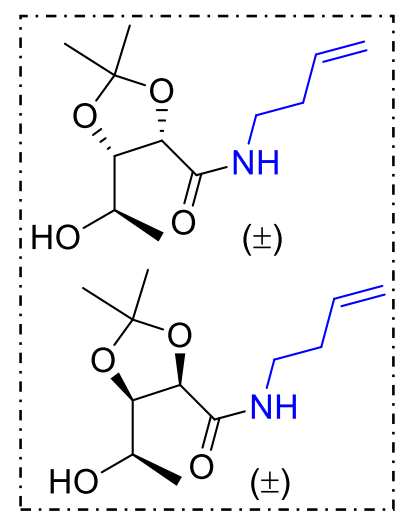

${ }^{1} \mathrm{H}$ NMR (400 MHz, $\mathrm{CDCl}_{3}$ ): $\delta 6.93$ e 6.67 (s, 1H), 5.83 (ddt, $J=17.1,10.3,5.4 \mathrm{~Hz}, 1 \mathrm{H}), 5.26-5.11(\mathrm{~m}, 1 \mathrm{H}), 4.62(\mathrm{~d}, J$ $=7.3 \mathrm{~Hz}$ e $4.55(\mathrm{~d}, J=7.9 \mathrm{~Hz}, 1 \mathrm{H}), 4.34-4.21(\mathrm{~m}$ e 4.13 $\mathrm{dd}, J=9.2,7.3 \mathrm{~Hz}, 1 \mathrm{H}), 4.03-3.83(\mathrm{~m}, 2 \mathrm{H}), 3.70-3.52$ $(\mathrm{m}, 1 \mathrm{H}), 1.57,1.53$ e $1.38(\mathrm{~s}, 6 \mathrm{H}), 1.28(\mathrm{~d}, J=6.2 \mathrm{~Hz}$ e 1.24 $\mathrm{d}, J=6.5 \mathrm{~Hz}, 3 \mathrm{H}) \cdot{ }^{13} \mathrm{C}$ NMR (101 MHz, $\left.\mathrm{CDCl}_{3}\right): \delta 171.52$, $169.83,133.69,133.24,133.22,116.69,116.59,110.02$ 109.39, 82.73, 80.84, 77.15, 77.03, 76.00, 66.62, 65.18, 41.34, 41.28, 27.05, 26.71, 24.48, 24.28, 20.09, 19.98. IV: 3421.47, 3335.77, 3231.52, 2985.11, 2933.20, 2879.58, 1653.98, 1638.80, 1532.00, 1422.27, 1382.14, 1265.80, $1252.42,1217.29,1161.09,1075.25,1058.23,922.50,877.59,733.59$.

N-ciclohexil-5-(1-hidroxietil)-2,2-dimetil-1,3-dioxolano-4-carboxamida (45f): Mistura diastereoisomérica

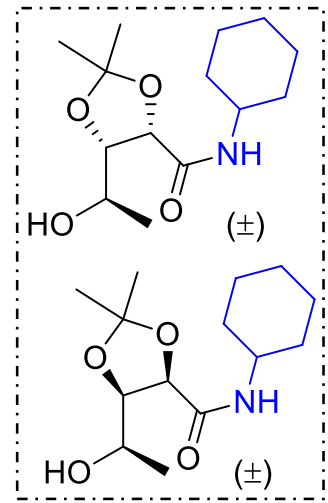

${ }^{1} \mathrm{H}$ NMR (600 MHz, $\left.\mathrm{CDCl}_{3}\right): \delta \delta 6.75$ e $6.52(\mathrm{~s}, 1 \mathrm{H}), 5.00$ (s, 1H), 4.58 (d, J=7.3 Hz e 4.52 (d, J=7.8 Hz, 1H), 4.29 (dd, J $=7.8,3.7 \mathrm{~Hz}, 4.12 \mathrm{dd}, J=9.2,7.3 \mathrm{~Hz}, 1 \mathrm{H}), 3.82(\mathrm{~d}, J=4.1$ $\mathrm{Hz}, 1 \mathrm{H}), 3.65(\mathrm{dd}, J=9.1,6.0 \mathrm{~Hz}, 1 \mathrm{H}), 1.95-1.84(\mathrm{~m}, 3 \mathrm{H})$, $1.76-1.66(\mathrm{~m}, 3 \mathrm{H}), 1.62(\mathrm{dt}, J=13.4,4.1 \mathrm{~Hz}, 1 \mathrm{H}), 1.58 \mathrm{e}$ $1.54(\mathrm{~s}, 3 \mathrm{H}), 1.44-136(\mathrm{~m}, 3 \mathrm{H}), 1.39(\mathrm{~m}, 3 \mathrm{H}), 1.29(\mathrm{~d}, J=6.2$ $\mathrm{Hz}$ e $1.26 \mathrm{~d}, J=6.5 \mathrm{~Hz}, 3 \mathrm{H}), 1.24-1.15(\mathrm{~m}, 3 \mathrm{H})$. 
${ }^{13} \mathrm{C}$ NMR (151 MHz, $\left.\mathbf{C D C l}_{3}\right): \delta 170.63,169.04,110.07,109.47,82.95,80.99$, $77.25,76.18,66.74,65.53,48.10,47.79$, 33.16, 32.94, 32.90, 32.70, 27.25, 26.95, 25.61, 25.52, 24.87, 24.80, 24.75, 24.68, 24.55, 20.17, 20.06.

IV: 3410.79, 2977.33, 2935.87, 2879.96, 1651.14, 1529.07, 1458.96, 1427.85, 1371.67, 1309.22, 1262.98, 1240.86, 1216.80, 1161.38, 1113.22, 1069.21, 878.86 .

5-(1-hidroxitila)-N-(3-hidroxipropil)-2,2-dimetil-1,3-dioxolane-4carboxamida (45g): Apenas um diastereoisômero

${ }^{1} \mathrm{H}$ NMR (600 MHz, $\left.\mathrm{CDCl}_{3}\right): \delta 7,27(\mathrm{~s}, 1 \mathrm{H}), 4.89(\mathrm{~s}, 1 \mathrm{H}), 4.61(\mathrm{~d}, J=7.3 \mathrm{~Hz}, 1 \mathrm{H})$, $\begin{array}{lll} & 4.12(\mathrm{dd}, J=9.1,7.4 \mathrm{~Hz}, 1 \mathrm{H}), 3.67(\mathrm{t}, J=5.7 \mathrm{~Hz}, 1 \mathrm{H}), \\ & \end{array}$ 172.55, 110.21, 82.81, 77.19, 66.84, 60.00, 36.62, 31.81, 27.18, 24.65, 20.13. IV: 3363.91, 2986.37, 2935.03, 2883.18, 1645.04, 1535.58, 1430.50, 1374.02, 1216.70, 1068.47, 875.54.

5-(1-hidroxitila)-N-isopropil-2,2-dimetil-1,3-dioxolane-4-carboxamida (45h): ${ }^{1} \mathrm{H}$ NMR (600 MHz, $\mathrm{CDCl}_{3}$ ): diastereoisômero $1 \delta 6.42$ (s, 1H), 4.50 (d, J=7.8<smiles>CC(C)NC(=O)C1OC(C)(C)O[C@H]1C(C)(C)C</smiles>
$\mathrm{Hz}, 1 \mathrm{H}), 4.27$ (dd, $J=7.8,3.6 \mathrm{~Hz}, 1 \mathrm{H}), 4.12-3.95(\mathrm{~m}, 2 \mathrm{H})$, $1.56(\mathrm{~s}, 3 \mathrm{H}), 1.37(\mathrm{~s}, 3 \mathrm{H}), 1.24(\mathrm{~d}, J=6.5 \mathrm{~Hz}, 3 \mathrm{H}), 1.16(\mathrm{t}, J=$ $5.9 \mathrm{~Hz}, 6 \mathrm{H}) .{ }^{13} \mathbf{C}$ NMR (151 $\left.\mathbf{~ M H z}, \mathbf{C D C l}_{3}\right) \delta$ 168.97, 109.33, $( \pm) \quad 80.84,76.02,65.35,40.97,26.78,24.40,22.52,22.50,19.95$.

${ }^{1} \mathrm{H}$ NMR (600 MHz, $\mathrm{CDCl}_{3}$ ): diastereoisômero $2 \delta 6.66(\mathrm{~s}, 1 \mathrm{H}), 4.98(\mathrm{~s}, 1 \mathrm{H})$, $4.56(\mathrm{~d}, J=7.3 \mathrm{~Hz}, 1 \mathrm{H}), 4.22-3.98(\mathrm{~m}, 2 \mathrm{H}), 3.64$ (ddd, $J=8.9,6.0,2.4 \mathrm{~Hz}, 1 \mathrm{H})$, $1.52(\mathrm{~s}, 3 \mathrm{H}), 1.37(\mathrm{~s}, 3 \mathrm{H}), 1.27(\mathrm{~d}, J=6.1 \mathrm{~Hz}, 3 \mathrm{H}), 1.21-1.16(\mathrm{~m}, 6 \mathrm{H}) .{ }^{13} \mathrm{C}$ NMR (151 MHz, $\mathrm{CDCl}_{3}$ ) $\delta 170.72,110.07,82.93,77.21,66.73,41.49,27.20,24.73$, 22.90, 22.53, 20.16. IV: 3417.05, 3378.15, 2987.42, 2935.22, 2837.09, 1651.80, $1612.55,1512.89,1245.30,1215.94,1175.76,1071.75,1032.81,875.32$, 830.84 . 


\section{5-(1-hidroxitila)-N-(4-metoxibenzyl)-2,2-dimetila-1,3-dioxolane-4-}

\section{carboxamida (45i): Apenas 1 diastereoisômero}

${ }^{1} \mathrm{H}$ NMR (600 MHz, $\left.\mathrm{CDCl}_{3}\right): \delta 7.19(\mathrm{~d}, J=8.4 \mathrm{~Hz}, 2 \mathrm{H}), 7.08(\mathrm{~s}, 1 \mathrm{H}), 6.88(\mathrm{~d}, J=$

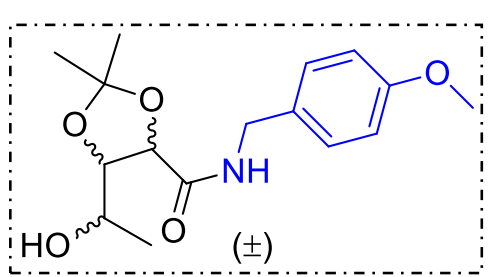

$8.4 \mathrm{~Hz}, 2 \mathrm{H}), 4.95(\mathrm{~s}, 1 \mathrm{H}), 4.65(\mathrm{~d}, J=7.3 \mathrm{~Hz}, 2 \mathrm{H})$, 4.47 (dd, $J=14.6,6.1 \mathrm{~Hz}, 1 \mathrm{H}$ ), 4.38 (dd, $J=14.6,5.7$ $\mathrm{Hz}, 1 \mathrm{H}), 4.14(\mathrm{dd}, J=9.1,7.3 \mathrm{~Hz}, 1 \mathrm{H}), 3.80(\mathrm{~s}, 3 \mathrm{H})$, $3.71-3.65(\mathrm{~m}, 1 \mathrm{H}), 1.46(\mathrm{~s}, 3 \mathrm{H}), 1.37(\mathrm{~s}, 3 \mathrm{H}), 1.30$ $(\mathrm{d}, J=6.1 \mathrm{~Hz}, 3 \mathrm{H}) \cdot{ }^{13} \mathbf{C}$ NMR (151 $\left.\mathbf{M H z}, \mathbf{C D C l}_{3}\right): \delta$ 171.58, 159.32, 129.43, 129.04, 114.37, 110.18, 82.93, 77.32, 66.82, 55.43, 42.80, 27.18, 24.66, 20.17. IV: 3416.02, 3368.85, 2986.82, 2933.96, 2893.09, 1651.19, 1606.39, 1526.63, 1497.28, 1453.93, 1426.24, 1383.03, 1372.67, 1309.14, 1247.24, 1214.68, $1159.02,1112.73,1068.95,1027.92,968.45,905.69,874.30,796.26,731.58$, 697.23.

\section{N-(2-(1H-indol-3-yl)ethyl)-5-(1-hidroxitila)-2,2-dimetila-1,3-dioxolane-4- carboxamida (45j)}

${ }^{1} \mathrm{H}$ NMR (600 MHz, $\mathrm{CDCl}_{3}$ ): diastereoisômero $1 \delta 8.17$ (s, 1H), 7.61 (d, J= 8.0

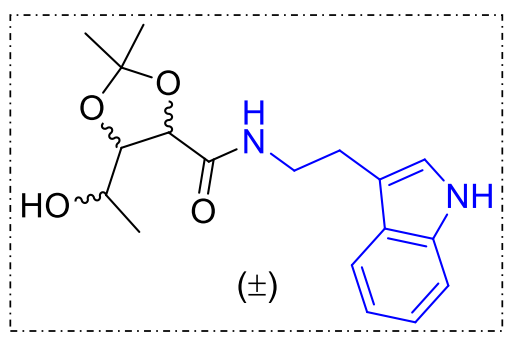
$\mathrm{Hz}, 1 \mathrm{H}), 7.38(\mathrm{~d}, J=8.0 \mathrm{~Hz}, 1 \mathrm{H}), 7.21(\mathrm{t}, J=7.5 \mathrm{~Hz}$, $1 \mathrm{H}), 7.14(\mathrm{t}, J=7.5 \mathrm{~Hz}, 1 \mathrm{H}), 7.04(\mathrm{~d}, J=1.9 \mathrm{~Hz}, 1 \mathrm{H})$, $4.99(\mathrm{~s}, 1 \mathrm{H}), 4.72-4.39(\mathrm{~m}, 1 \mathrm{H}), 4.28-4.03(\mathrm{~m}$, $1 \mathrm{H}), 3.79-3.68(\mathrm{~m}, 1 \mathrm{H}), 3.66-3.52(\mathrm{~m}, 2 \mathrm{H}), 3.02$ (t, $J=6.8 \mathrm{~Hz}, 2 \mathrm{H}), 1.32(\mathrm{~s}, 3 \mathrm{H}), 1.27$ (d, $J=6.2 \mathrm{~Hz}$,

$3 \mathrm{H}), 1.24$ (s, 3H). ${ }^{13} \mathbf{C}$ NMR (151 MHz, $\mathbf{C D C l}_{3}$ ) $\delta$ 171.67, 136.57, 127.23, 122.46, 122.25, 119.74, 118.79, 112.49, 111.40, 110.00, 82.81, 77.30, 66.78, 39.37, 26.77, 25.29, 24.58, 20.12. ${ }^{1} \mathrm{H}$ NMR (600 MHz, DMSO- $\left.d_{6}\right)$ : diastereoisômero 2 $\delta 10.82$ (s, 1H), 7.64 (t, J=5.9 Hz, 1H), 7.56 (dd, J=7.9, $1.0 \mathrm{~Hz}, 1 \mathrm{H}), 7.33$ (dd, $J=7.9,1.0 \mathrm{~Hz}, 1 \mathrm{H}), 7.16(\mathrm{~d}, J=2.3 \mathrm{~Hz}, 1 \mathrm{H}), 7.06(\mathrm{ddd}, J=8.1,6.9,1.2 \mathrm{~Hz}, 1 \mathrm{H})$, 6.98 (ddd, $J=7.9,6.9,1.0 \mathrm{~Hz}, 1 \mathrm{H}), 4.42(\mathrm{~d}, J=7.3 \mathrm{~Hz}, 1 \mathrm{H}), 4.36(\mathrm{~d}, J=5.6 \mathrm{~Hz}$, $1 \mathrm{H}), 4.06(\mathrm{dd}, J=7.3,5.3 \mathrm{~Hz}, 1 \mathrm{H}), 3.71(\mathrm{q}, J=5.8 \mathrm{~Hz}, 1 \mathrm{H}), 3.41-3.36(\mathrm{~m}, 2 \mathrm{H})$, 2.83 (hept, $J=7.3 \mathrm{~Hz}, 2 \mathrm{H}$ ), 1.46 (s, 3H), 1.29 (s, 3H), 1.07 (d, $J=6.4 \mathrm{~Hz}, 3 \mathrm{H}$ ). ${ }^{13}$ C NMR (151 MHz, DMSO) $\delta 168.91,136.28,127.13,122.72,120.95,118.31$, 118.22, 111.54, 111.37, 108.70, 81.56, 75.93, 64.37, 26.52, 24.98, 20.27. IV: 3410.23, 2985.65, 2931.66, 2855.72, 1651.90, 1525.73, 1450.71, 1381.37, $1215.78,1160.05,1104.64,1067.83,875.30$. 


\section{Abertura da lactona 44}

\section{Método 2:}

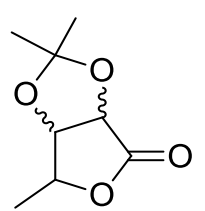

(44)

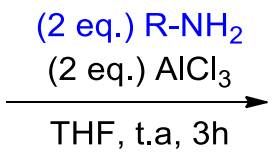

$\mathrm{HO}$<smiles>[R]NC(=O)[C@H]1OC(C)(C)O[C@@H]1C(C)O</smiles>

(45k)

Em um vial de $2 \mathrm{~mL}$, foram adicionados $0,2 \mathrm{~mL}$ de THF anidro, 0,4 mmol de anilina (37 mg) e 0,4 mmol de $\mathrm{AlCl}_{3}(53,3 \mathrm{mg}$ ). Agitou-se a mistura por 5 minutos à $0{ }^{\circ} \mathrm{C} \mathrm{e}$, em seguida, adicionou-se, lentamente, $0,2 \mathrm{mmol}$ de $44(34,4 \mathrm{mg}) \mathrm{em}$ $0,2 \mathrm{~mL}$ de THF anidro. A reação foi mantida sob agitação à temperatura ambiente por 15 horas e finalizada com uma solução aquosa de $\mathrm{NaCl}(2 \mathrm{~mL})$. Extraiu-se a mistura com AcOEt ( $3 \times 2 \mathrm{~mL}$ ) e a fase orgânica foi seca sob $\mathrm{MgSO}_{4}$. Purificou-se o produto bruto por cromatografia flash empregando misturas de hexano/AcOEt (9:1 e 1:1) como eluentes. Obteve-se $45 \mathrm{~K}$, sólido amarelado, com $50 \%$ de rendimento.

\section{5-(1-hidroxitila)-2,2-dimetil-N-fenil-1,3-dioxolane-4-carboxamida(45k):}

\section{Mistura diastereoisomérica}

${ }^{1} \mathrm{H}$ NMR (600 MHz, $\mathrm{CDCl}_{3}$ ) $\delta 8.57(\mathrm{~s}, 1 \mathrm{H}), 7.55(\mathrm{~d}, J=1.1 \mathrm{~Hz}, 2 \mathrm{H}), 7.38-7.34$<smiles>CC1(C)OC(C(=O)Nc2ccccc2)C(C(=O)OC2C3OC(C)(C)OC(OC2(C)C)C(O)C3O)O1</smiles>
$(\mathrm{m}, 2 \mathrm{H}), 7.18(\mathrm{t}, J=7.4 \mathrm{~Hz}, 1 \mathrm{H}), 4.71(\mathrm{~d}, J=7.3 \mathrm{~Hz}, 1 \mathrm{H})$, $4.21(\mathrm{dd}, J=9.2,7.3 \mathrm{~Hz}, 2 \mathrm{H}), 3.81-3.74(\mathrm{~m}, 1 \mathrm{H}), 1.64(\mathrm{~s}$, $3 \mathrm{H}), 1.44(\mathrm{~s}, 3 \mathrm{H}), 1.31(\mathrm{~d}, J=6.2 \mathrm{~Hz}, 3 \mathrm{H}) .{ }^{13} \mathrm{C}$ NMR (151 $\left.\mathbf{M H z}, \mathbf{C D C l}_{3}\right) \delta 170.00,136.36,129.32,125.46,120.16$, $110.57,83.19,66.74,27.20,24.69,20.12$. 


\section{Formação da pirrolidona 46b}

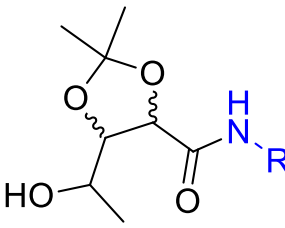

(45b e 45c)

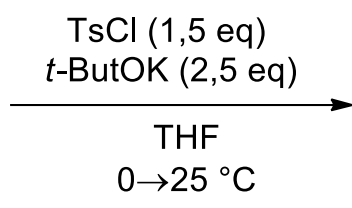

$0 \rightarrow 25^{\circ} \mathrm{C}$<smiles>[2H]N1C(=O)[C@H]2OC(C)(C)O[C@@H]2C1C</smiles>

(46b e 46c)

0,5 mmol de 45b ou 45c, $2 \mathrm{~mL}$ de THF anidro, 0,75 $\mathrm{mmol}(143 \mathrm{mg}) \mathrm{de}$ $\mathrm{TsCl}$ e 1,25 mmol (140 mg) de $t$-BuOK, foram adicionados sob atmosfera de argônio, à $0{ }^{\circ} \mathrm{C}$, em um balão de fundo redondo de $10 \mathrm{~mL}$. Manteve-se a reação à $0{ }^{\circ} \mathrm{C}$ por 5 minutos e, em seguida, foi levada à $25^{\circ} \mathrm{C}$, agitando-se por $24 \mathrm{~h}$. Adicionou-se à mistura $2 \mathrm{~mL}$ de solução saturada de $\mathrm{NaCl}$ e extraiu-se com AcOEt $(3 \times 5 \mathrm{~mL})$. A fase orgânica foi seca e o bruto reacional purificado por cromatografia flash empregando misturas hexano:AcOEt (7:3 e 1:1). Rendimento de $50 \%(0,25 \mathrm{mmol}, 46 \mathrm{mg})$ da mistura dos 2 diastereoisômeros de $46 \mathbf{b}$. Rendimento de 34\% (0,17 mmol, 31,5 mg) para apenas 1 diastereoisômero. 50\% de rendimento da mistura dos 2 diastereoisômeros de 46c.

\section{2,2,5,6-tetrametildhydro-3aH-[1,3]dioxolo[4,5-c]pyrrol-4(5H)-one}

(46b):

\section{Mistura de diastereoisômeros}

${ }^{1} \mathrm{H}$ NMR (600 MHz, $\left.\mathrm{CDCl}_{3}\right): \delta 4.66-4.58(\mathrm{~m}, \mathrm{e} 4.31 \mathrm{~d}, \mathrm{~J}=5.8,2 \mathrm{H}), 3.68-3.61$

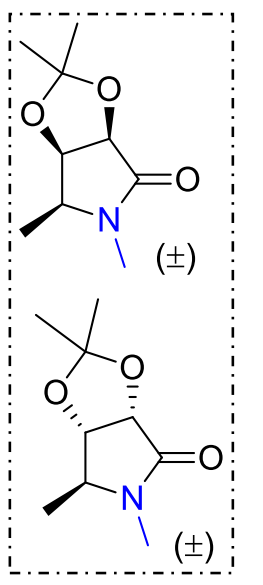
( $\mathrm{m}$, e $3.59-3.53 \mathrm{~m}, 1 \mathrm{H}), 2.82$ (s e $2.78 \mathrm{~s}, 3 \mathrm{H}$ ), $1.38 \mathrm{~s}, 1.35 \mathrm{~s}, 1.33$ $(\mathrm{s}, 6 \mathrm{H}), 1.30(\mathrm{~d}, J=6.6 \mathrm{~Hz}$ e $1.21 \mathrm{~d}, J=6.8 \mathrm{~Hz}, 3 \mathrm{H}) .{ }^{13} \mathrm{C}$ NMR $(151$ $\left.\mathbf{M H z}, \mathrm{CDCl}_{3}\right): \delta 171.22,170.57,112.43,78.79,77.90,77.04$, $75.09,59.65,55.89,28.03,27.16,27.13,27.00,26.04,25.82$, $17.69,13.24$.

${ }^{1} \mathrm{H}$ NMR (600 MHz, $\mathrm{CDCl}_{3}$ ): Apenas 1 diastereoisômero $\delta 4.62$ $(\mathrm{m}, 2 \mathrm{H}), 3.65(\mathrm{qd}, J=6.6,4.4 \mathrm{~Hz}, 1 \mathrm{H}), 2.79(\mathrm{~s}, 3 \mathrm{H}), 1.39(\mathrm{~s}, 3 \mathrm{H})$,

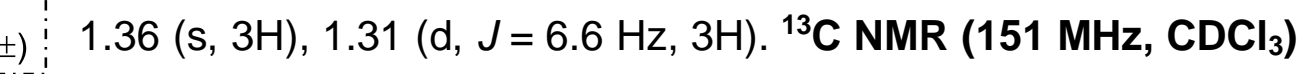
$\delta 171.24,112.47,77.93,75.11,55.91,27.18,27.02,26.06,13.26$. IV: 2981.97, $2953.44,2938.08,2894.06,1699.82,1683.66,1474.95,1456.41,1429.74$, $1374.91,1287.38,1241.88,1211.27,1142.70,1125.32,1055.49,1006.85$, $872.42,802.06,736.98,712.81,651.45,634.96$. 
5-butil-2,2,6-trimethyldhydro-3aH-[1,3]dioxolo[4,5-c]pyrrol-4(5H)-one (46c): Mistura de diastereoisômeros

${ }^{1} \mathrm{H}$ NMR $\left(600 \mathrm{MHz}, \mathrm{CDCl}_{3}\right): \delta 4.68-4.56(\mathrm{~m} \mathrm{e} 4.31 \mathrm{~d}, J=5.6 \mathrm{~Hz}, 2 \mathrm{H}), 3.72$ (dd, J $J=6.6,4.6 \mathrm{~Hz}$ e $3.66(\mathrm{~d}, J=7.0 \mathrm{~Hz}, 1 \mathrm{H}), 3.56(\mathrm{~m}, 1 \mathrm{H}), 2.95(\mathrm{~m}$, e $2.85(\mathrm{~m}, J=13.7,8.4,5.1,1.0 \mathrm{~Hz}, 1 \mathrm{H}), 1.56-1.44(\mathrm{~m}, 2 \mathrm{H})$, $1.42-1.17(\mathrm{~m}, 15 \mathrm{H}), 0.90(\mathrm{td}, J=7.4,2.5 \mathrm{~Hz}, 3 \mathrm{H}) .{ }^{13} \mathrm{C}$ NMR (151 MHz, $\left.\mathrm{CDCl}_{3}\right): \delta 171.06,170.57,112.38,112.36,78.96$,

(士) $77.92,77.46,75.21,56.90,53.92,40.11,39.79,29.52,28.82$, $27.33,27.14,26.19,26.05,20.26,19.93,17.98,13.86,13.79$, 13.38. IV: $2985.61,2959.24,2934.29,2873.14,1693.27$, $1456.47,1426.08,1373.36,1294.15,1233.62,1213.22$, $( \pm) \quad 1160.41,1129.24,1109.90,1080.11,1010.00,868.79,749.24$. 


\section{Referências}

1 MORGAN, H. M.; BU, Q.; LIANG, J.; LIU, Y.; MAO, H.; SHI, A.; LEI, H.; RUAN, R. A review of catalytic microwave pyrolysis of lignocellulosic biomass for value-added fuel and chemicals. Bioresource Technology, Amsterdam, v. 230, p. 112-121, 2017.

$2 \mathrm{MAI}$, E. F. Hidrogenação do ácido levulínico a gama-valerolactona empregando carbeto de molibdênio suportado. 2015.193 f. Tese (Doutorado em Engenharia Química) - Escola de Química, Universidade Federal do Rio de Janeiro, Rio de Janeiro, 2015.

3 ISIKGOR, F. H.; BECER, C. R. Lignocellulosic biomass: a sustainable platform for the production of bio-based chemicals and polymers Polymer Chemistry, Cambridge, v. 6, p. 4497-4559, 2015.

4 CHERUBINI, F. The biorefinery concept: using biomass instead of oil for producing energy and chemicals Energy Conversion and Management, London, v. 51, p. 1412-1421, 2010.

5 CLARK, J. H. Perspective green chemistry for the second generation biorefinery-sustainable chemical manufacturing based on biomass. Journal of Chemical Technology \& Biotechnology, Oxford, v. 82, p. 603-609, 2017.

6 CLIMENT, M. J.; CORMA, A.; IBORRA, S. Conversion of biomass platform molecules into fuel additives and liquid hydrocarbon fuels. Green Chemistry, Cambridge, v. 16, p. 516, 2014.

7 SILVA, M. R. V.; RAMOS, R. F.; GILSON, I. K.; MORELATO, R. R.; RADUNZ, A. L.; CABRERA, L. C. Energia eólica, solar e de biomassa: uso, perspectiva e desafios. Biodiversidade, Cuiabá, v. 19, p. 137-144, 2020.

8 DEMIRBAŞ, A. Biomass resource facilities and biomass conversion processing for fuels and chemicals. Energy Conversion and Management, London, v. 42, n. 11, p. 1357-1378, 2001.

9 KAMM, B.; KAMM, M. Biorefineries-multi product processes. Advances in Biochemical Engineering/Biotechnology, New York, v. 105, p. 175-204, 2006.

10 KAMM, B.; KAMM, M. Principles of biorefineries mini-review. Applied Microbiology and Biotechnology, Heidelberg, v. 64, p.137-145, 2004.

11 KAMM, B.; KAMM, M. Biorefinery-systems. Chemical and Biochemical Engineering Quarterly, Zagreb, v. 18, p. 1-6, 2004.

12 GALLO, J. M. R.; TRAPP, M. A. The chemical conversion of biomassderived saccharides: An overview. Journal of the Brazilian Chemical Society, São Paulo, v. 28, n. 9, p. 1586-1607, 2017. 
13 GÉRARDY, R.; DEBECKER, D. P.; ESTAGER, J.; LUIS, P.; MONBALIU, J. C. M. Continuous flow upgrading of selected C2-C6platform chemicals derived from biomass. Chemical Reviews, Washington, v. 120, n. 15, p. 7219-7347, 2020.

14 GALKIN, K. I.; ANANIKOV, V. P. When will 5-Hydroxymethylfurfural, the "Sleeping Giant" of sustainable chemistry, awaken? Sustainable Chemistry, Basel, v. 12, n. 13, p. 2976-2982, 2019.

15 PISHVAEE, M. S.; MOHSENI, S.; BAIRAMZADEH, S. An overview of biomass feedstocks for biofuel production. In: PISHVAEE, M. S.; MOHSENI, S.; BAIRAMZADEH, S. Biomass to biofuel supply chain design and planning under uncertainty: concepts and quantitative methods. London: Elsevier, 2021. p. 1-20.

16 SANTOS, F. A.; QUEIRÓZ, J. H. de; COLODETTE, J. L.; FERNANDES, S. A.; GUIMARÃES, V. M.; REZENDE, S. T. Potencial da palha de cana-deaçúcar para produção de etanol. Química Nova, São Paulo, v. 35, n. 5, p. 1004-1010, 2012.

17 TAYYAB, M.; NOMAN, A.; WAHEED, S.; ISLAM, W.; ARAFAT, Y.; ALI, F.; ZAYNAB, M.; LIN, S.; ZHANG, H.; LIN, W. Bioethanol production from lignocellulosic biomass by environment-friendly pretreatment methods : a review. Applied Ecology and Environmental Research, Budapest, v. 16, n. 1, p. 225-249, 2017.

18 ABO, B. O.; GAO, M.; WANG, Y.; WU, C.; MA.; WANG, Q. Lignocellulosic biomass for bioethanol: an overview on pretreatment, hydrolysis and fermentation processes. Reviews on Environmental Health, Berlin, v. 34, n. 1, p. 57-68, 2019.

19 XIN, X.; DELL, K.; UDUGAMA, I. A.; YOUNG, B. R.; BAROUTIAN, S. Transforming biomass pyrolysis technologies to produce liquid smoke food flavouring. Journal of Cleaner Production, Amsterdam, v. 294, n.1, p. 125368 , 2020.

20 LOOW, Y. L.; WU, T. Y.; JAHIM, J. M.; MOHAMMAD, A. W.; TEOH, W. H. Typical conversion of lignocellulosic biomass into reducing sugars using dilute acid hydrolysis and alkaline pretreatment. Cellulose, Dordrecht, v. 23, n. 3, p. 1491-1520, 2016.

21 PARK, J.; JONES, B.; KOO, B.; CHEN, X.; TUCKER, M.; YU, J. H.; PSCHORN, T.; VENDITTI, R.; PARK, S. Use of mechanical refining to improve the production of low-cost sugars from lignocellulosic biomass. Bioresource Technology, Amsterdam, v. 199, n.1, p. 59-67, 2016.

22 LIU, Y.; NIE, Y.; LU, X.; ZHANG, X.; HE, H.; PAN, F.; ZHOU, L.; LIU, X.; JI, $X . ;$ ZHANG, S. Cascade utilization of lignocellulosic biomass to high-value products. Green Chemistry, Cambridge, v. 21, n. 13, p. 3499-3535, 2019. 
23 PEREPELKIN, K. E. Renewable plant resources and processed products in chemical fibre production. Fibre Chemistry, New York, v. 36, n. 1, p. 161-176, 2004.

24 PAUDEL, S. R.; BANJARA, S. P.; CHOI, O. K.; PARK, K. Y.; KIM, Y. M.; LEE, J. W. Pretreatment of agricultural biomass for anaerobic digestion: current state and challenges. Bioresource Technology, Amsterdam, v. 245, n.1, p. 1194-1205, 2017.

25 ZHANG, Y.; HE, H.; LIU, Y.; WANG, Y.; HUO, F.; FAN, M.; ADIDHARMA, H.; LI, X.; ZHANG, S. Recent progress in theoretical and computational studies on the utilization of lignocellulosic materials. Green Chemistry, Cambridge, v. 21, n. 1, p. 9-35, 2019.

26 METZGER, J. O.; HÜTTERMANN, A. Sustainable global energy supply based on lignocellulosic biomass from afforestation of degraded areas. Naturwissenschaften, Heidelberg, v. 96, n. 2, p. 279-288, 2009.

27 DUTTA, S.; WU, K. C. W.; SAHA, B. Emerging strategies for breaking the 3D amorphous network of lignin. Catalysis Science and Technology, New York, v. 4, n. 11, p. 3785-3799, 2014.

28 VANNESTE, J.; ENNAERT, T.; VANHULSEL, A.; SELS, B. Unconventional pretreatment of lignocellulose with low-temperature plasma. Sustainable Chemistry, Basel, v. 10, n. 1, p. 14-31, 2017.

29 KUMAR, R.; BHAGIA, S.; SMITH, M. D.; PETRIDIS, L.; ONG, R. G.; CAI, C. M.; MITTAL, A.; HIMMEL, M. H.; BALAN, V.; DALE, B. E.; RAGAUSKAS, A. J.; SMITH, J. C.; WYMAN, C. E. Cellulose-hemicellulose interactions at elevated temperatures increase cellulose recalcitrance to biological conversion. Green Chemistry, Cambridge, v. 20, n. 4, p. 921-934, 2018.

30 WANG, H.; GURAU, G.; ROGERS, R. D. Ionic liquid processing of cellulose. Chemical Society Reviews, Cambridge, v. 41, n. 4, p. 1519-1537, 2012.

31 MUSSATTO, S. I.; ROCHA, G. J. M.; ROBERTO, I. C. Hydrogen peroxide bleaching of cellulose pulps obtained from brewer's spent grain. Cellulose, Dordrecht, v. 15, n. 4, p. 641-649, 2008

32 WERPY, T.; PETERSEN, G. Top value added chemicals from biomass. The Pacific Northwest National Laboratory, Richland, v. 1, p. 1-76, 2004.

33 CLIMENT, M. J.; CORMA, A.; IBORRA, S. Conversion of biomass platform molecules into fuel additives and liquid hydrocarbon fuels. Green Chemistry, Cambridge, v. 16, n. 2, p. 516-547, 2014.

34 LIN, Q.; LI, Y. H.; TANG, Z. R.; XU, Y. J. Valorization of biomass-derived platform molecules via photoredox sustainable catalysis. Transactions of Tianjin University, Tianjin, v. 26, n. 5, p. 325-340, 2020. 
35 GIRISUTA, B.; JANSSEN, L. P. B. M.; HEERES, H. J. Green chemicals: a kinetic study on the conversion of glucose to levulinic acid. Chemical

Engineering Research and Design, London, v. 84, p. 339-349, 2006.

36 DE SOUZA, R. O. M. A.; MIRANDA, L. S. M.; LUQUE, R.

Bio(chemo)technological strategies for biomass conversion into bioethanol and key carboxylic acids. Green Chemistry, Cambridge, v. 16, n. 5, p. 2386-2405, 2014.

37 HAYES, D. J. M. Biomass composition and its relevance to biorefining. In: TRIANTAFYLLIDIS, K. S.; LAPPAS, A. A.; STÖCKER, M. (ed.). The role of catalysis for the sustainable production of bio-fuels and bio-chemicals. Amsterdam: Elsevier, 2013.

38 GIRISUTA, B.; HEERES, H. J. Levulinic acid from biomass: synthesis and applications. In: FANG, Z; SMITH JUNIOR, R. L.; QI, X. Production of platform chemicals from sustainable resources. Singapore: Springer, 2017. p. 143-169.

39 MELLMER, M. A.; GALLO, J. M. R.; MARTIN ALONSO, D.; DUMESIC, J. A. Selective production of levulinic acid from furfuryl alcohol in THF solvent systems over H-ZSM-5. ACS Catalysis, Washington, v. 5, n. 6, p. 3354-3359, 2015.

40 SEEMALA, B.; HARITOS, V.; TANKSALE, A. Levulinic acid as a catalyst for the production of 5-hydroxymethylfurfural and furfural from lignocellulose biomass. ChemCatChem, Weinheim, v. 8, n. 3, p. 640-647, 2016.

41 MURZIN, D. Y.; MURZINA, E. V.; AHO, A.; KAZAKOVA, M. A.; SELYUTIN, A. G.; KUBICKA, D.; KUZNETSOV, V. L.; SIMAKOVA, I. L. Aldose to ketose interconversion: galactose and arabinose isomerization over heterogeneous catalysts. Catalysis Science and Technology, Cambridge, v. 7, n. 22, p. 5321-5331, 2017.

42 GALAVERNA, R.; PASTRE, J. C. Produção de 5-(Hidroximetil)furfural a partir de biomassa: desafios sintéticos e aplicações como bloco de construção na produção de polímeros e combustíveis líquidos. Revista Virtual de Quimica, São Paulo, v. 9, n. 1, p. 248-273, 2017.

43 PILEIDIS, F. D.; TITIRICI, M. M. Levulinic acid biorefineries: new challenges for efficient utilization of biomass. Sustainable Chemistry, Basel, v. 9, n. 6, p. 562-582, 2016.

44 PACE, V.; HOYOS, P.; CASTOLDI, L.; MARÍA, P. D.; ALCÁNTARA, A. R. 2Methyltetrahydrofuran (2-MeTHF): a biomass-derived solvent with broad application in organic chemistry. Sustainable Chemistry, Basel, v. 8, p. 13691379, 2012. 
45 FELÍCIO, L. B. A.; FERREIRA, J.; BENTLEY, M. V. B.; BAGNATO, V. S.; TEDESCO, A. C.; SOUZA, C. S. A terapia fotodinâmica com ácido 5aminolevulínico como modalidade de tratamento para neoplasias cutâneas não-melanoma Topical 5-aminolevulinic acid photodynamic therapy as a treatment modality for nonmelanoma skin câncer. Anais Brasileiros de Dermatologia, São Paulo, v. 83, p. 309-316, 2008.

46 DEMOLIS, A.; ESSAYEM, N.; RATABOUL, F. Synthesis and applications of alkyl levulinates. ACS Sustainable Chemistry \& Engineering, Washington, v. 2, p. 1338-1352, 2014.

47 SAH, P. P. T.; MA, S. Y. Levulinic acid and its esters. Journal of the American Chemical Society, Washington, v. 52, n.1, p. 4880-4883, 1930.

48 ENUMULA, S. S.; GURRAM, V. R. B.; CHADA, R. R.; BURRI, D. R.; KAMARAJU, S. R. R. Clean synthesis of alkyl levulinates from levulinic acid over one pot synthesized WO3-SBA-16 catalyst. Journal of Molecular Catalysis A: chemical, Amsterdam, v. 426, n.1, p. 30-38, 2017.

49 FABA, L.; DIÁZ, E.; ORDÓÑEZ, S. Base-catalyzed condensation of levulinic acid: a new biorefinery upgrading approach. ChemCatChem, Weinheim, v. 8, n.1, p. 1490-1494, 2016.

50 LIMA, C. G. S.; MONTEIRO, J. L.; DE MELO LIMA, T.; WEBER PAIXÃO, M.; CORRÊA, A. G. Angélica Lactones: From Biomass-Derived Platform Chemicals to Value-Added Products. Sustainable Chemistry, Basel, v. 11, n. 1, p. $25-47,2018$.

51 GONZÁLEZ MALDONADO, G. M.; ASSARY, R. S.; DUMESIC, J. A.; CURTISS, L. A. Acid-catalyzed conversion of furfuryl alcohol to ethyl levulinate in liquid ethanol. Energy and Environmental Science, Cambridge, v. 5, n. 10, p. 8990-8997, 2012.

52 BANKOLE, K. S. Uncatalysed esterifoication of biomass derived carboxylic acids. 2011. $198 \mathrm{f}$. Thesis (PhD - Doctor of Philosophy) - University of lowa, lowa, 2011.

53 PASQUALE, G.; VÁZQUEZ, P.; ROMANELLI, G.; BARONETTI, G. Catalytic upgrading of levulinic acid to ethyl levulinate using reusable silicaincluded Wells-Dawson heteropolyacid as catalyst. Catalysis Communications, Amsterdam, v. 18, p. 115-120. 2012.

54 MOURELLE-INSUA, Á.; ZAMPIERI, L. A.; LAVANDERA, I.; GOTORFERNÁNDEZ, V. Conversion of $\gamma$ - and $\delta$-Keto esters into optically active lactams. Transaminases in cascade processes. Advanced Synthesis and Catalysis, Weinheim, v. 360, n. 4, p. 686-695, 2018. 
55 SANTOS, C. S.; BURTOLOSO, A. C. B. Direct synthesis of highly substituted cyclopentadienes and derivatives from the self-condensation of renewable ethyl levulinate. European Journal of Organic Chemistry, Weinheim, v. 2018, n. 45, p. 6350-6354, 2018.

56 LI, Z.; OTSUKI, A. L.; MASCAL, M. Production of cellulosic gasoline: via levulinic ester self-condensation. Green Chemistry, Cambridge, v. 20, n. 16, p. 3804-3808, 2018.

57 ZHAO, T.; JU, Z.; ZHANG, Y.; HAN, L.; XIAO, W. Specific role of aluminum site on the activation of carbonyl groups of methyl levulinate over $\mathrm{Al}(\mathrm{OiPr}) 3$ for $\gamma$-valerolactone production. Chemical Engineering Journal, Amsterdam, v. 390, p. 124505, 2020.

58 YAN, L.; YAO, Q.; FU, Y. Conversion of levulinic acid and alkyl levulinates into biofuels and high-value chemicals. Green Chemistry, Cambridge, v. 19, n. 23, p. 5527-5547, 2017.

59 ZVIELY, M.; GIGER, R.; ABUSHKARA, E.; KERN, A.; SOMMER, H.; BERTRAM, H-J.; KRAMMER, GE.; SCHMIDT, CO.; STUMPE, W.; WERKHOFF, P. Applications of chromatographic and spectroscopic methods for solving quality problems in several flavor aroma chemicals. In: SWIFT, K. A. $D$. (ed). Advances in flavours and fragrances: from the sensation to the senses. Cambridge: Royal Society of Chemistry, 2002. p. 39-53.

60 MCADAM, K.; ENOS, T.; GOSS, C.; KIMPTON, H.; FAIZI, A.; EDWARDS, S.; WRIGHT, C.; PORTER, A.; RODU, B. Analysis of coumarin and angélica lactones in smokeless tobacco products. Chemistry Central Journal, London, v. 12, n. 162 , p. $1-16,2018$.

61 HELBERGER, J. H.; ULUBAY, H. S. Ein einfaches Verfahren zur Gewinnung von Inosinsäure. Liebigs Annalen der Chemie, Weinheim, v. 562, p. 215-220, 1949.

62 VRIES, J. G. De; ACQUA, A. D.; STADLER, B. M. Scalable synthesis and polymerisation of a $\beta$-angélica lactone derived monomer. Green Chemistry, Basel, v. 22, n. 16, p. 5267-5273, 2020.

63 XUE, X.; LI, X.; YU, A.; YANG, C.; SONG, C.; CHENG, J. Mechanism and selectivity of bioinspired cinchona alkaloid derivatives catalyzed asymmetric ole fi $\mathrm{n}$ isomerization : a computational study. Journal of the American Chemical Society, Washington, v. 135, p. 7462-7473, 2013.

64 AYODELE, O. O.; DAWODU, F. A.; YAN, D.; LU, X.; XIN, J.; ZHANG, S. Hydrodeoxygenation of angélica lactone dimers and trimers over silica-alumina supported nickel catalyst. Renewable Energy, Oxford, v. 86, p. 943-948, 2016. 
65 MASCAL, M.; DUTTA, S.; GANDARIAS, I. Hydrodeoxygenation of the angélica lactone dimer, a cellulose-based feedstock: simple, high-yield synthesis of branched C7-C10 gasoline-like hydrocarbons. Angewandte Chemie - International Edition, Weinheim, v. 53, n. 7, p. 1854-1857, 2014.

66 SUN, D.; TAKAHASHI, Y.; YAMADA, Y.; SATO, S. Efficient formation of angélica lactones in a vapor-phase conversion of levulinic acid. Applied Catalysis A: general, Amsterdam, v. 526, p. 62-69, 2016.

67 DÍAZ-PÉREZ, M. A.; SERRANO-RUIZ, J. C. Catalytic production of jet fuels from biomass. Molecules, Basel, v. 25, n. 4, 2020.

68 PICINI, J.; D’ANGELO, J.; CENGT, JP.; NOIRE, J. Synthese de la dihydrojasmone et de la cis jaswne, a partir de l'angdlicalactone. Tetrahedron Letters, Oxford, v. 53, n. 19, p. 1969-1571, 1971.

69 CARDELLACH, J.; FONT, J.; ORTUÑO, R. M. Highly stereo and regiocontrolled synthesis of both racemic and optically active (-)-blastmycinone. Tetrahedron Letters, Oxford, v. 26, n. 23, p. 2815-2816, 1985.

70 GUALTIERI, F.; MANETTI, D.; ROMANELLI, MN. Design and study of piracetam-like nootropics, controversial members of the problematic class of cognition-enhancing drugs. Current Pharmaceutical Design, Sharjah, v. 8, n.2, p. 125-38, 2002.

71 WANG, S.; HUANG, H.; BRUNEAU, C.; FISCHMEISTER, C. Selective and efficient iridium catalyst for the reductive amination of levulinic acid into pyrrolidones. Sustainable Chemistry, Basel, v. 10, n. 21, p. 4150-4154, 2017.

72 METZKER, G.; DIAS, R. M. P, BURTOLOSO, A. C. Iron-catalyzed reductive amination from levulinic and formic acid aqueous solutions: an approach for the selective production of pyrrolidones in biorefinery facilities. ChemistrySelect, Weinheim, v. 3, p. 368-372, 2018.

73 MASSON, G.; LALLI, C.; BENOHOUD, M.; DAGOUSSET, G. Catalytic enantioselective [4 + 2]-cycloaddition: a strategy to access aza-hexacycles. Chemical Society Reviews, Cambridge, v. 42, n. 3, p. 902-923, 2013.

74 RAUSCH, B. J.; GLEITER, R.; ROMINGER, F. Synthesis and cyclic voltammetry of 1,2,3-trisubstituted bis(cyclopentadienyl) zirconium dichlorides. Journal of Organometallic Chemistry, Amsterdam, v. 658, p. 242-250, 2002.

75 TOPOLOVČAN, N.; PANOV, I.; KOTORA, M. Synthesis of 1,2-disubstituted cyclopentadienes from alkynes using a catalytic haloallylation/cross-

coupling/metathesis relay. Organic Letters, Washington, v. 18, n. 15, p. 36343637, 2016. 
76 SCHMIDT, E. Y.; BIDUSENKO, I. A.; USHAKOV, I. A.; VASHCHENKO, A. V.; TROFIMOV, B. A. Decorated cyclopentadienes from acetylene and ketones in just two steps. Organic Letters, Washington, v. 19, n. 12, p. 3127-3130, 2017.

77 HATANAKA, M.; HIMEDA, Y.; UEDA, I. The reaction of allylidene triphenylphosphoranes with a-halocarbonyl compounds: a convenient synthesis of cyclopentadienes. Journal of the Chemical Society. Chemical communications, Cambridge, n. 7, p. 526-527, 1990.

78 FUNEL, J.-A.; ABELE, S. Industrielle anwendungen der diels-alder-reaktion. Angewandte Chemie, Weinheim, v. 125, n. 14, p. 3912-3955, 2013.

79 SCHULZ, V. G.; STEGLICH, W. N-(Trimethylsilyl)aminosäuretrimethylsilylester als reagenzien zur gerichteten selbstkondensation von methylketonen unter milden bedingungen. Angewandte Chemie, Weinheim, v. 89, n. 4, p. 255-256, 1977.

80 MUKAIYAMA, T. Titanium tetrachloride in organic synthesis [new synthetic methods (21)]. Angewandte Chemie International Edition in English, Weinheim, v. 16, n. 12, p. 817-826, 1977.

81 ALONSO, D. M.; WETTSTEIN, S. G.; DUMESIC, J. A. Gammavalerolactone, a sustainable platform molecule derived from lignocellulosic biomass. Green Chemistry, Cambridge, v. 15, n. 3, p. 584-595, 2013.

82 GEBOERS, J.; WANG, X.; DE CARVALHO, A. B.; RINALDI, R. Densification of biorefinery schemes by $\mathrm{H}$-transfer with Raney $\mathrm{Ni}$ and 2-propanol: a case study of a potential avenue for valorization of alkyl levulinates to alkyl $y$ hydroxypentanoates and $\mathrm{y}$-valerolactone. Journal of Molecular Catalysis A: chemical, Amsterdam, v. 388-389, p. 106-115, 2014.

83 AL-SHAAL, M. G.; HAUSOUL, P. J. C.; PALKOVITS, R. Efficient, solventfree hydrogenation of $\alpha$-angélica lactone catalysed by $\mathrm{Ru} / \mathrm{C}$ at atmospheric pressure and room temperature. Chemical Communications, Cambridge, v. 50, n. 71, p. 10206-10209, 2014.

84 DENG, L.; ZHAO, Y.; LI, J.; FU, Y.; LIAO, B.; GUO, Q. X. Conversion of levulinic acid and formic acid into $Y$-valerolactone over heterogeneous catalysts. Sustainable Chemistry, Basel, v. 3, n. 10, p. 1172-1175, 2010.

85 GALLETTI, A. M. R.; ANTONETTI, C.; DE LUISE, V.; MARTINELLI, M. A sustainable process for the production of $\mathrm{Y}$-valerolactone by hydrogenation of biomass-derived levulinic acid. Green Chemistry, Cambridge, v. 14, n. 3, p. 688-694, 2012.

86 WRIGHT, W. R. H.; PALKOVITS, R. Development of heterogeneous catalysts for the conversion of levulinic acid to $y$-valerolactone. Sustainable Chemistry, Basel, v. 5, n. 9, p. 1657-1667, 2012. 
87 DUNLOP, A. P.; MADDELS, J. W.; FOREST, P.; QUAKER, T.; COM, O. Process of preparing gamma-valerolactone. Depositante: DUNLOP, A. P.; MADDELS, J. W.; FOREST, P.; QUAKER, T.; COM, O. US2786852A. Depósito: 19 Aug. 1953. Concessão 26 Mar. 1957.

88 UPARE, P. P.; LEE, J.-M.; HWANG, D. W.; HALLIGUDI, S. B.; HWANG, Y. K.; CHANG, J.-S. Selective hydrogenation of levulinic acid to $Y$-valerolactone over carbon-supported noble metal catalysts. Journal of Industrial and Engineering Chemistry, Washington, v. 17, n. 2, p. 287-292, 2011.

89 BALLA, P.; PERUPOGU, V.; VANAMA, P. K.; KOMANDUR, V. R. C. Hydrogenation of biomass-derived levulinic acid to $Y$-valerolactone over copper catalysts supported on ZrO2. Journal of Chemical Technology and Biotechnology, Oxford, v. 91, n. 3, p. 769-776, 2016.

90 YAN, Z. P.; LIN, L.; LIU, S. Synthesis of Y-valerolactone by hydrogenation of biomass- derivedLevulinic acid over Ru/C catalyst. Energy and Fuels, Washington, v. 23, n. 8, p. 3853-3858, 2009.

91 LIGUORI, F.; MORENO-MARRODAN, C.; BARBARO, P. Environmentally friendly synthesis of $y$-valerolactone by direct catalytic conversion of renewable sources. ACS Catalysis, Washington, v. 5, n. 3, p. 1882-1894, 2015.

92 ASHOKRAJU, M.; MOHAN, V.; MURALI, K.; RAO, M. V.; RAJU, B. D.; RAO, K. S. R. Formic acid assisted hydrogenation of levulinic acid to $\mathrm{Y}$-valerolactone over ordered mesoporous $\mathrm{Cu} / \mathrm{Fe}_{2} \mathrm{O}_{3}$ catalyst prepared by hard template method. Journal of Chemical Sciences, Karnataka, v. 130, n. 2, p. 1-8, 2018.

93 LUO, W.; DEKA, U.; BEALE, A. M.; VAN ECK, E. R. H.; BRUIJNINCX, P. C. A.; WECKHUYSEN, B. M. Ruthenium-catalyzed hydrogenation of levulinic acid: Influence of the support and solvent on catalyst selectivity and stability. Journal of Catalysis, Maryland Heights, v. 301, p. 175-186, 2013.

94 METZKER, G.; BURTOLOSO, A. C. B. Conversion of levulinic acid into $\mathrm{Y}^{-}$ valerolactone using $\mathrm{Fe}_{3}(\mathrm{CO})_{12}$ : mimicking a biorefinery setting by exploiting crude liquors from biomass acid hydrolysis. Chemical Communications, Cambridge, v. 51, n. 75, p. 14199-14202, 2015.

95 HUSSAIN, S. K.; VELISOJU, V. K.; RAJAN, N. P.; KUMAR, B. P.; CHARY, K. V. R. Synthesis of $y$-Valerolactone from Levulinic Acid and Formic Acid over Mg-Al Hydrotalcite Like Compound. ChemistrySelect, Weinheim, v. 3, n. 22, p. 6186-6194, 2018.

96 CHIA, M.; DUMESIC, J. A. Liquid-phase catalytic transfer hydrogenation and cyclization of levulinic acid and its esters to $\gamma$-valerolactone over metal oxide catalysts. Chemical Communications, Cambridge, v. 47, n. 44, p. 1223312235, 2011. 
97 HORVÁTH, I. T.; MEHDI, H.; FÁBOS, V.; BODA, L.; MIKA, L. T. YValerolactone-a sustainable liquid for energy and carbon-based chemicals. Green Chemistry, Cambridge, v. 10, n. 2, p. 238-24, 2008.

98 ISMALAJ, E.; STRAPPAVECCIA, G.; BALLERINI, E.; ELISEI, F.; PIERMATTI, O.; GELMAN, D.; VACCARO, L. $y$-valerolactone as a renewable dipolar aprotic solvent deriving from biomass degradation for the Hiyama reaction. ACS Sustainable Chemistry and Engineering, Washington, v. 2, n. 10, p. 2461-2464, 2014.

99 BOND, J. Q.; ALONSO, D. M.; WANG, D.; WEST, R. M.; DUMESIC, J. A. Integrated catalytic conversion of $\mathrm{Y}$-valerolactone to liquid alkenes for transportation fuels. Science, Washington, v. 327, n. 5969, p. 1110-1114, 2010.

100 SERRANO-RUIZ, J. C.; WANG, D.; DUMESIC, J. A. Catalytic upgrading of levulinic acid to 5-nonanone. Green Chemistry, Cambridge, v. 12, 574-577, 2010.

101 ALONSO, D. M.; BOND, J. Q.; SERRANO-RUIZ, J. C.; DUMESIC, J. A. Production of liquid hydrocarbon transportation fuels by oligomerization of biomass-derived C9 alkenes. Green Chemistry, Cambridge, v. 12, n. 6, p. 992-99, 2010.

102 MEHDI, H.; FÁBOS, V.; TUBA, R.; BODOR, A.; MIKA, L. T.; HORVÁTH, I. $T$. Integration of homogeneous and heterogeneous catalytic processes for a multi-step conversion of biomass: From sucrose to levulinic acid, $y$ valerolactone, 1,4-pentanediol, 2-methyl-tetrahydrofuran, and alkanes. Topics in Catalysis, New York, v. 48, p. 49-54, 2008.

103 MANZER, L. E. Catalytic synthesis of a-methylene-y-valerolactone: A biomass-derived acrylic monomer. Applied Catalysis A: general, Amsterdam, v. 272, n. 1-2, p. 249-256, 2004.

104 YANG, Y.; WEI, X.; ZENG, F.; DENG, L. Efficient and sustainable transformation of gamma-valerolactone into nylon monomers. Green Chemistry, Cambridge, v. 18, n. 3, p. 691-694, 2016.

105 SUBRAHMANYAM, A. V.; THAYUMANAVAN, S.; HUBER, G. W. C-C bond formation reactions for biomass-derived molecules. Sustainable Chemistry, Basel, v. 3, n. 10, p. 1158-1161, 2010.

106 LIU, X.; WANG, X.; YAO, S.; JIANG, Y.; GUAN, J.; MU, X. Recent advances in the production of polyols from lignocellulosic biomass and biomass-derived compounds. RSC Advances, Cambridge, v. 4, n. 90, p. 49501-49520, 2014.

107 KIRPLUKS, M.; KALNBUNDE, D.; WALTEROVA, Z.; CABULIS, U. Rapeseed Oil as feedstock for high functionality polyol synthesis. Journal of Renewable Materials, Henderson, v. 5, n. 3-4, p. 258-270, 2017. 
108 MANAS, M. G.; CAMPOS, J.; SHARNINGHAUSEN, L. S.; LIN, E.; CRABTREE, R. H. Selective catalytic oxidation of sugar alcohols to lactic acid. Green Chemistry, Cambridge, v. 17, n. 1, p. 594-600, 2015.

109 BEHR, A.; EILTING, J.; IRAWADI, K.; LESCHINSKI, J.; LINDNER, F. Improved utilisation of renewable resources: new important derivatives of glycerol. Green Chemistry, Cambridge, v. 10, n. 1, p. 13-30, 2008.

110 ZHOU, C. H.; BELTRAMINI, J. N.; LU, G. Q. Chemoselective catalytic conversion of glycerol as a biorenewable source to valuable commodity chemicals. Chemical Society Reviews, Cambridge, v. 37, n. 3, p. 527-549, 2008.

111 JU, J. H.; WANG, D.; HEO, S. Y.; KIM, M. S.; SEO, J. W.; KIM, Y. M.; KIM, D. H.; KANG, S. A.; KIM, C. H.; OH, B. R. Enhancement of 1,3-propanediol production from industrial by-product by Lactobacillus reuteri $\mathrm{CH} 53$. Microbial Cell Factories, London, v. 19, n. 1, p. 1-10, 2020.

112 BEYDOUN, K.; KLANKERMAYER, J. Efficient Plastic Waste Recycling to Value-Added Products by Integrated Biomass Processing. Sustainable Chemistry, Basel, v. 13, n. 3, p. 488-492, 2020.

113 TOXQUI-TERÁN, A.; LEYVA-PORRAS, C.; RUÍZ-CABRERA, M. A.; CRUZ-ALCANTAR, P.; SAAVEDRA-LEOS, M. Z. Thermal study of polyols for the technological application as plasticizers in food industry. Polymers, Basel, v. 10 , n. 5 , p. 1-13, 2018.

114 CAO, Y.; NIU, W.; GUO, J.; XIAN, M.; LIU, H. Biotechnological production of 1,2,4-butanetriol: An efficient process to synthesize energetic material precursor from renewable biomass. Scientific Reports, London, v. 5, p. 1-9, 2015.

115 MAXIMILIEN G.; CLEMENT, C. E. Plasticized cellulose derivative, Depositante: MAXIMILIEN G.; CLEMENT, C. E. US2476976A. Depósito: 22 Oct. 1945. Concessão 24 Jan. 1941.

116 SIMEONOV, S. P.; LAZAROVA, H. I.; MARINOVA, M. K.; POPOVA, M. D. Achmatowicz rearrangement enables hydrogenolysis-free gas-phase synthesis of pentane-1,2,5-triol from furfuryl alcohol. Green Chemistry, Cambridge, v. 21, n. 20, p. 5657-5664, 2019.

117 SIMEONOV, S. P.; RAVUTSOV, M. A.; MIHOVILOVIC, M. D. Biorefinery via Achmatowicz Rearrangement: Synthesis of Pentane-1,2,5-triol from Furfuryl Alcohol. Sustainable Chemistry, Basel, v. 12, n. 12, p. 2748-2754, 2019.

118 KRISHNA, S. H.; HUBER, G. W.; DUMESIC, J. A. Catalytic production of 1,2,5,6-hexanetetrol from levoglucosenone. Depositante: KRISHNA, S. H.; HUBER, G. W.; DUMESIC, J. A. WO2019204753A1. Depósito: 24 Oct. 2018. Concessão 24 Jan. 2019. 
119 VRIES, J. G.; PHUA, T. H.; CABRERA, I. V. M.; HEERES, H. J.

Preparation of caprolactone, caprolactam, 2,5-tetrahydrofuran-dimethanol, 1,6-hexanediol or 1,2,6-hexanetriol from 5-hydroxymethyl-2-

furfuraldehyde. Depositante: VRIES, J. G. De; PHUA, T. H.; CABRERA, I. V. M.; HEERES, H. J. WO2011149339A1. Depósito: 26 May 2010. Concessão: 1

Dec. 2011.

120 HUBER, G. W.; KIM, Y. T. Method for preparing triols and diols from biomass-derived reactants. Depositante: HUBER, G. W.; KIM, Y. T. US20140275638A1. Depósito: 15 mar 2013. Concessão: 18 Sep 2014.

121 SANTOS, C. S.; SOARES, C. C. S. P.; VIEIRA, A. S.; BURTOLOSO, A. C. $B$. Synthesis of long-chain polyols from the Claisen condensation of $\mathrm{Y}$ valerolactone. Green Chemistry, Basel, v. 21, n. 23, p. 6441-6450, 2019.

122 MEISSNER, C. F. W. Uber ein neues Pflanzenalkali (Alkaloid). The Journal of Chemical Physics, Melville, n. 25, p. 379, 1819.

123 HESSE, M. Alkaloids: nature's curse or blessing? [S. I.]: Verlag Helvetica Chimica Acta, 2002.

124 MOSS, G. P.; SMITH, P. A. S.; TAVERNIER, D. Glossary of class names of organic compounds and reactivity intermediates based on structure (IUPAC Recommendations 1995). Pure and Applied Chemistry, Berlin, v. 67, n. 8-9, p. 1307-1375, 1995.

125 CADAR, E.; TOMESCU, A.; ERIMIA, C. L.; MUSTAFA, A.; SîRBU, R. The impact of alkaloids structures from naturalcompounds on public health.

European Journal of Social Sciences Education and Research, Brussels, v. 5, n. 1, p. 34, 2015.

126 QIU, S.; SUN, H.; ZHANG, A. H.; XU, H. Y.; YAN, G. L.; HAN, Y.; WANG, $X$. J. Natural alkaloids: basic aspects, biological roles, and future perspectives.

Chinese Journal of Natural Medicines, Beijing, v. 12, n. 6, p. 401-406, 2014.

127 O'HAGAN, D. Pyrrole, pyrrolidine, pyridine, piperidine and tropane alkaloids. Natural Product Reports, Cambridge, v. 17, n. 5, p. 435-446, 2000.

128 BHAT, C.; TILVE, S. G. Recent advances in the synthesis of naturally occurring pyrrolidines, pyrrolizidines and indolizidine alkaloids using proline as a unique chiral synthon. RSC Advances, Cambridge, v. 4, n. 11, p. 5405, 2014.

129 CARROLL, A. W.; PYNE, S. G. The history of the glycosidase inhibiting hyacinthacine c-type alkaloids: from discovery to synthesis. Current Organic Synthesis, Sharjah, v. 16, n. 4, p. 498-522, 2019.

130 YAMASHITA, T.; YASUDA, K.; KIZU, H.; KAMEDA, Y.; WATSON, A. A.; NASH, R. J.; FLEET, G. W. J.; ASANO, N. New polyhydroxylated pyrrolidine, piperidine, and pyrrolizidine alkaloids from Scilla sibirica. Journal of Natural Products, Washington, v. 65, n. 12, p. 1875-1881, 2002. 
131 IVÁN LOZADA-REQUENA; PONCE, C. N. COVID-19: respuesta inmune y perspectivas terapéuticas. Revista Peruana de Medicina Experimental y

Salud Pública, Lima, v. 37, n. 2, p. 312-9, 2020.

132 CHANG, Y. F.; GUO, C. W.; CHAN, T. H.; PAN, Y. W.; TSOU, E. L.; CHENG, W. C. Parallel synthesis of natural product-like polyhydroxylated pyrrolidine and piperidine alkaloids. Molecular Diversity, Dordrecht, v. 15, n. 1, p. 203-214, 2011.

133 HE, J. Y.; MA, N.; ZHU, S.; KOMATSU, K.; LI, Z. Y.; FU, W. M. The genus Codonopsis (Campanulaceae): a review of phytochemistry, bioactivity and quality control. Journal of Natural Medicines, Tokyo, v. 69, n. 1, p. 1-21, 2014.

134 HADDAD, M.; LARCHEVÊQUE, M. Diastereocontrolled synthesis of (-)codonopsinine. Synlett, Stuttgart, n. 2, p. 274-276, 2003.

135 GOTI, A.; CICCHI, S.; MANNUCCI, V.; CARDONA, F.; GUARNA, F.; MERINO, P.; TEJERO, T. Iterative Organometallic Addition to Chiral Hydroxylated Cyclic Nitrones: highly stereoselective syntheses of $\alpha, \alpha^{\prime}-$ and $\alpha, \alpha-$ substituted hydroxypyrrolidines. Organic Letters, Washington, v. 5, n. 22, p. 4235-4238, 2003.

136 URAGUCHI, D.; NAKAMURA, S.; OOI, T. Catalytic asymmetric direct henry reaction of ynals: Short syntheses of (2S,3R)-(+)-xestoaminol C and (-)codonopsinines. Angewandte Chemie - International Edition, Weinheim, v. 49, n. 41, p. 7562-7565, 2010.

137 IIDA, H.; YAMAZAKI, N.; TOKYO, C. K. Synthesis of (+)-codonopsinine: determination of absolute configuration of natural (-)-codonopsinine.

Tetrahedron Letters, Oxford, v. 26, n. 27, p. 3255-3258, 1985.

138 IIDA, H.; YAMAZAKI, N.; KIBAYASHI, C. Total synthesis of (+)codonopsinine and its stereoisomers: stereochemical assignment of natural (-)codonopsinine. Journal of Organic Chemistry, Washington, v. 52, n. 10, p. 1956-1962, 1987.

139 YODA, H.; NAKAJIMA, T.; TAKABE, K. Total synthesis of natural (-)codonopsinine employing stereoselective reduction of quaternary $\alpha$ hydroxypyrrolidine. Tetrahedron Letters, Oxford, v. 37, n. 31, p. 5531-5534, 1996.

140 SEVERINO, E. A.; CORREIA, C. R. D. Heck arylation of endocyclic enecarbamates with diazonium salts. Improvements and a concise enantioselective synthesis of (-)-codonopsinine. Organic Letters, Washington, v. 2, n. 20, p. 3039-3042, 2000.

141 REDDY, J. S.; RAO, B. V. A short, efficient, and stereoselective total synthesis of a pyrrolidine alkaloid: (-)-Codonopsinine. Journal of Organic Chemistry, Washington, v. 72, n. 6, p. 2224-2227, 2007. 
142 LINGAMURTHY, M.; JAGADEESH, Y.; RAMAKRISHNA, K.; RAO, B. V. DDQ-Promoted Benzylic/Allylic sp3 C-H Activation for the Stereoselective Intramolecular C-N Bond Formation: Applications to the Total Synthesis of (-)Codonopsinine, (+)-5-epi-Codonopsinine, (+)-Radicamine B, and (-)Codonopsinol. Journal of Organic Chemistry, Washington, v. 81, n. 4, p. 1367-1377, 2016.

143 KOTLAND, A.; ACCADBLED, F.; ROBEYNS, K.; BEHR, J. B. Synthesis and fucosidase inhibitory study of unnatural pyrrolidine alkaloid 4-epi-(+)codonopsinine. Journal of Organic Chemistry, Washington, v. 76, n. 10, p. 4094-4098, 2011.

144 SUNDERMEIER, U.; DOEBLER, C.; BELLER, M. Recent developments in the osmium-catalyzed dihydroxylation of olefins. ChemInform, Weinheim, v. 36, 2005.

145 GUO, W.; GÓMEZ, J. E.; MARTíNEZ-RODRÍGUEZ, L.; BANDEIRA, N. A. G.; BO, C.; KLEIJ, A. W. Metal-free synthesis of $n$-aryl amides using organocatalytic ring-opening aminolysis of lactones. Sustainable Chemistry, Basel, v. 10, n. 9, p. 1969-1975, 2017. 


\section{Anexos}

Espectro de RMN de ${ }^{1} \mathrm{H}$ contendo os compostos $\mathbf{1 a}, \mathbf{1} \mathbf{b}, \mathbf{2} \mathbf{a}$ e $\mathbf{2} \mathbf{b}$
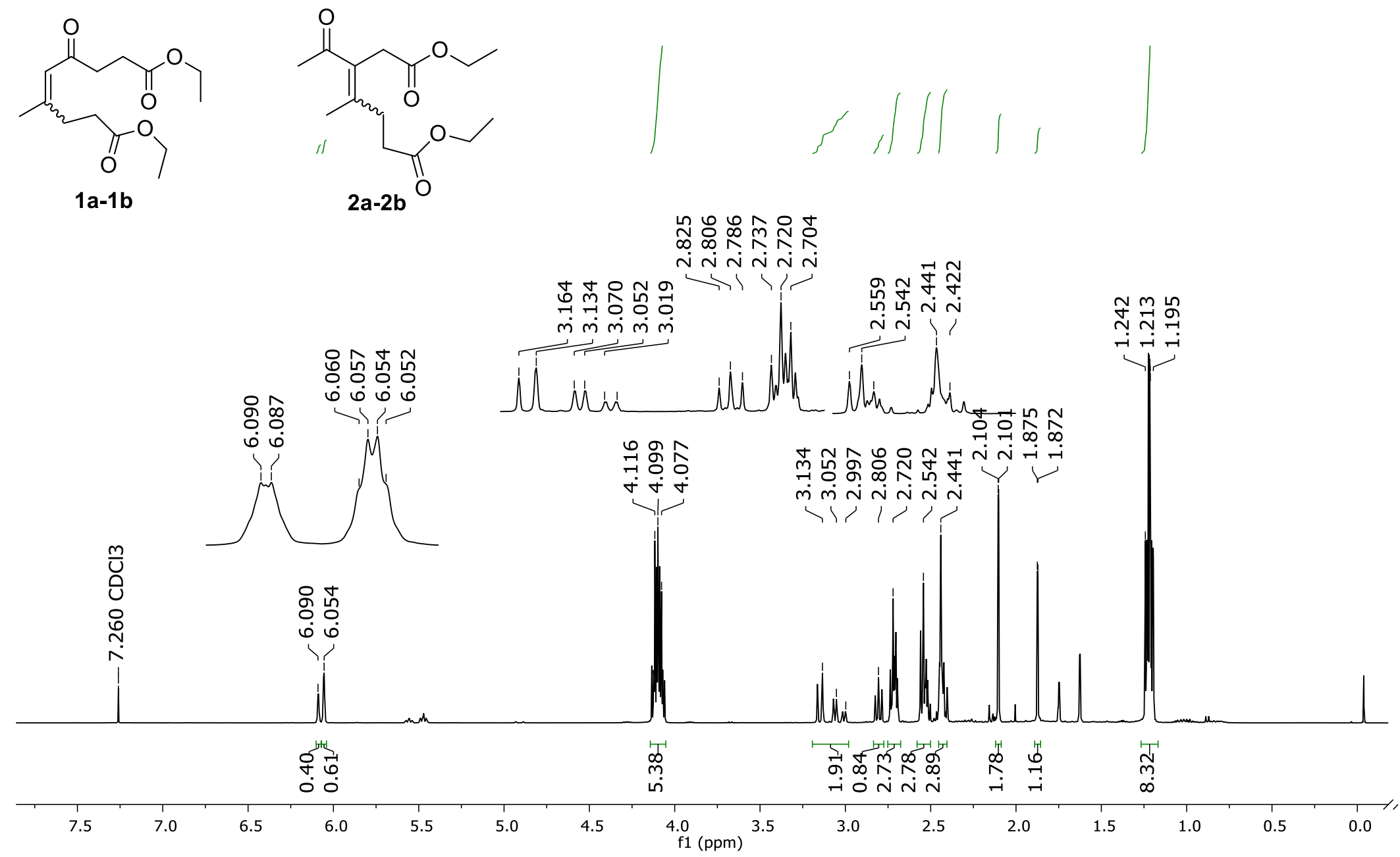


\section{Anexos}

Espectro de RMN de ${ }^{13} \mathrm{C}$ contendo os compostos $\mathbf{1 a}, \mathbf{1} \mathbf{b}, \mathbf{2 a}$ e $\mathbf{2} \mathbf{b}$
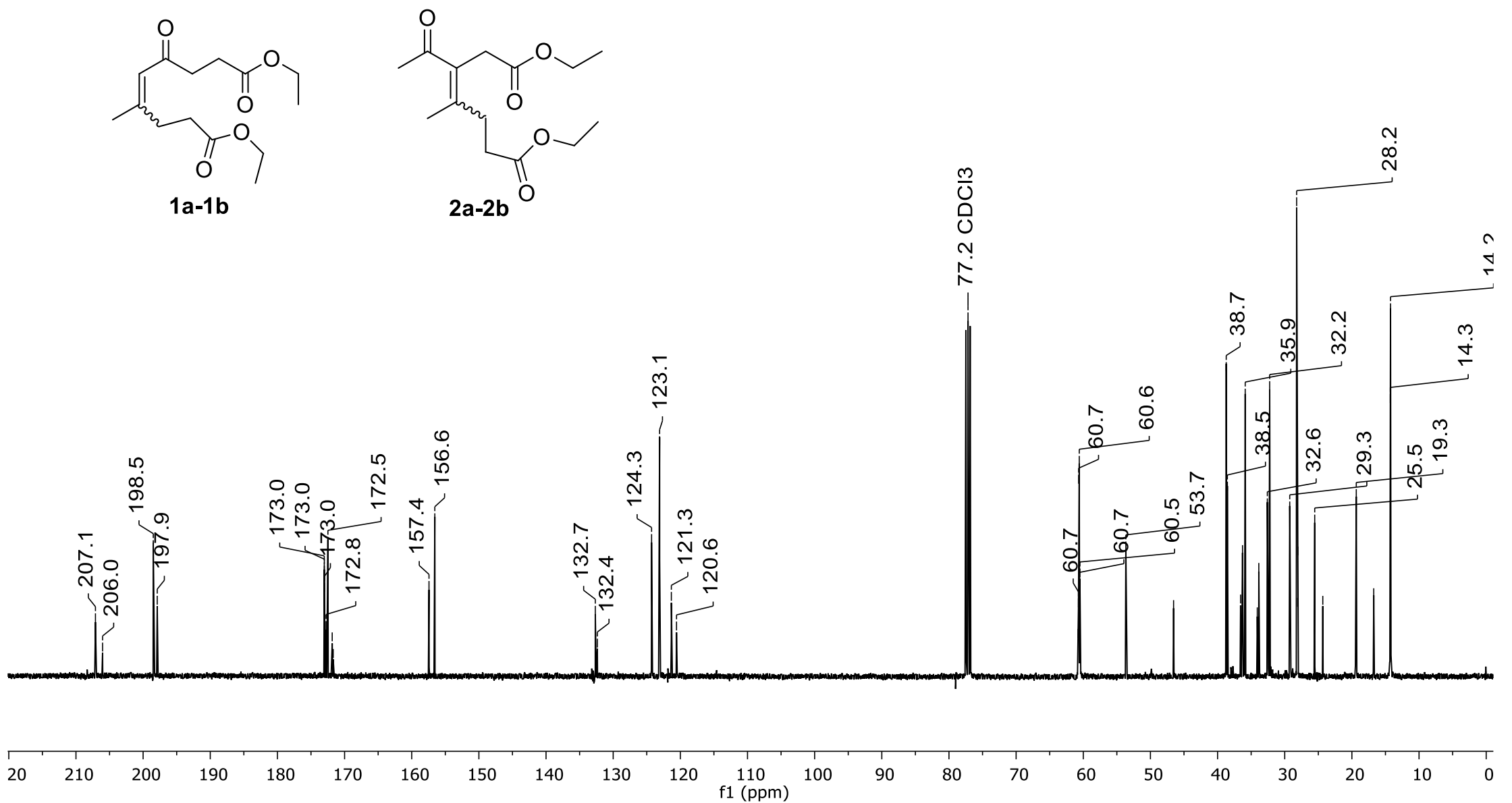
Anexos

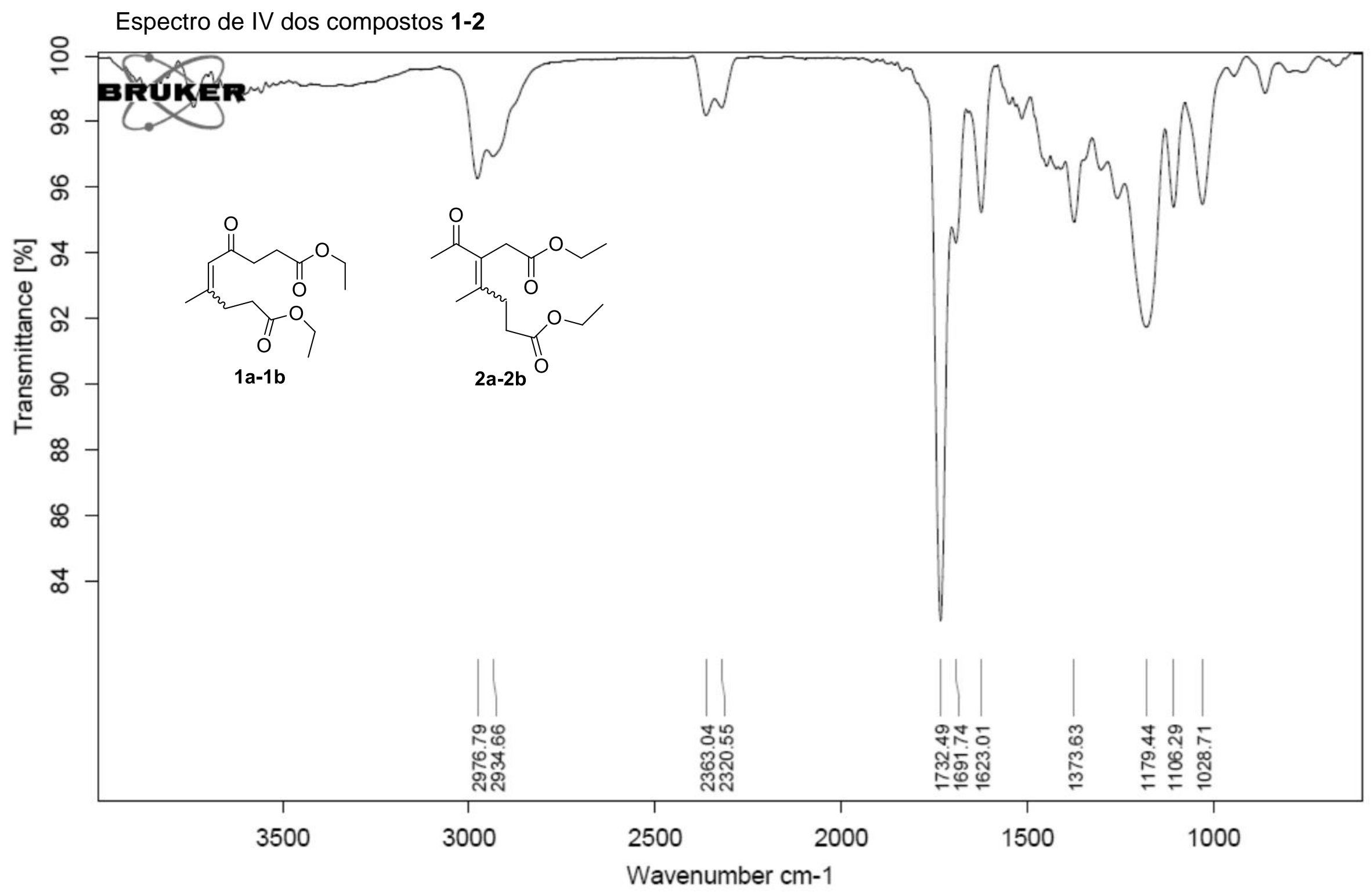




\section{Anexos}

\section{Espectro de RMN de ${ }^{1} \mathrm{H}$ do composto 3}

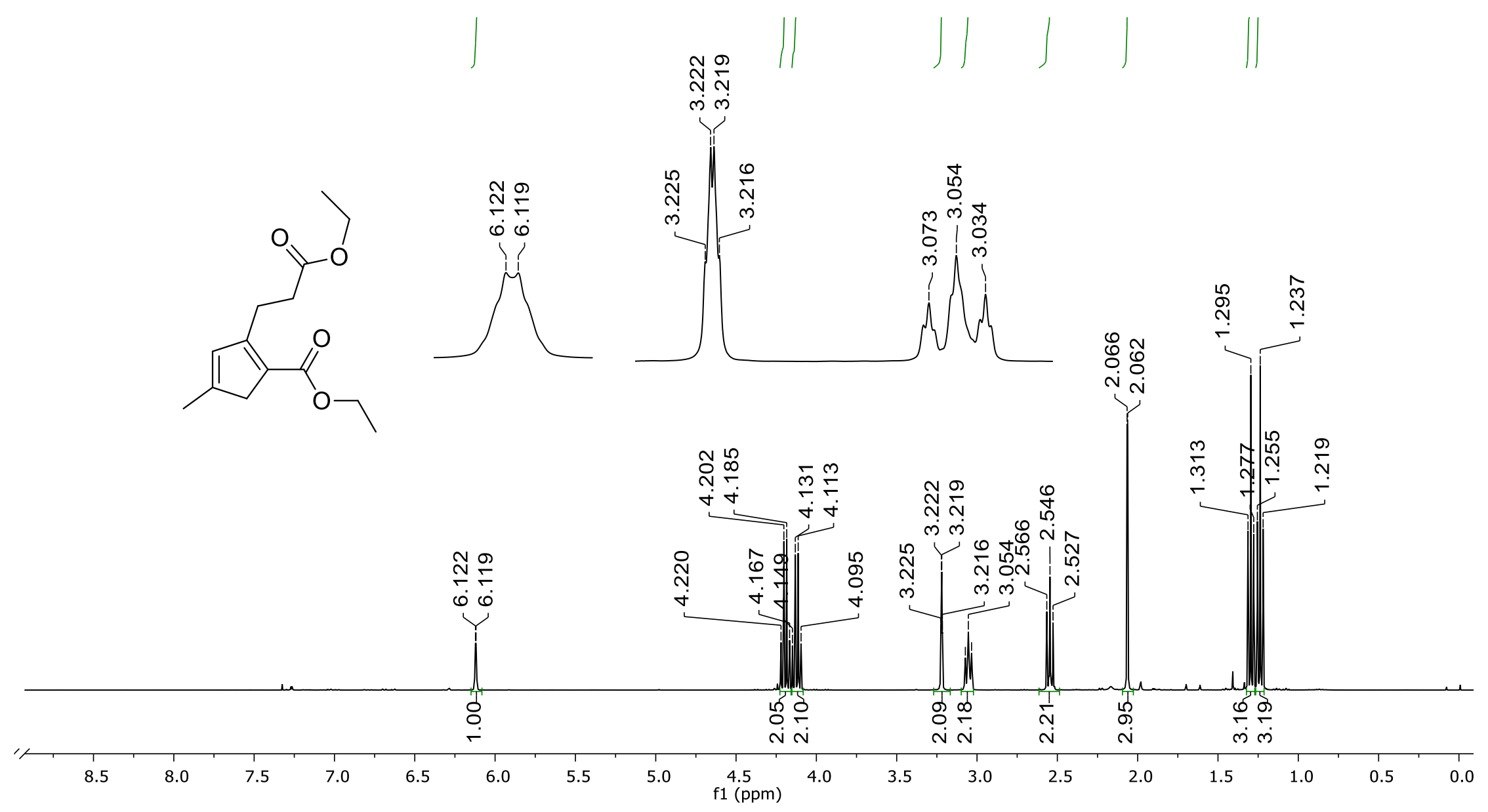




\section{Anexos}

\section{Espectro de RMN de ${ }^{13} \mathrm{C}$ do composto 3}
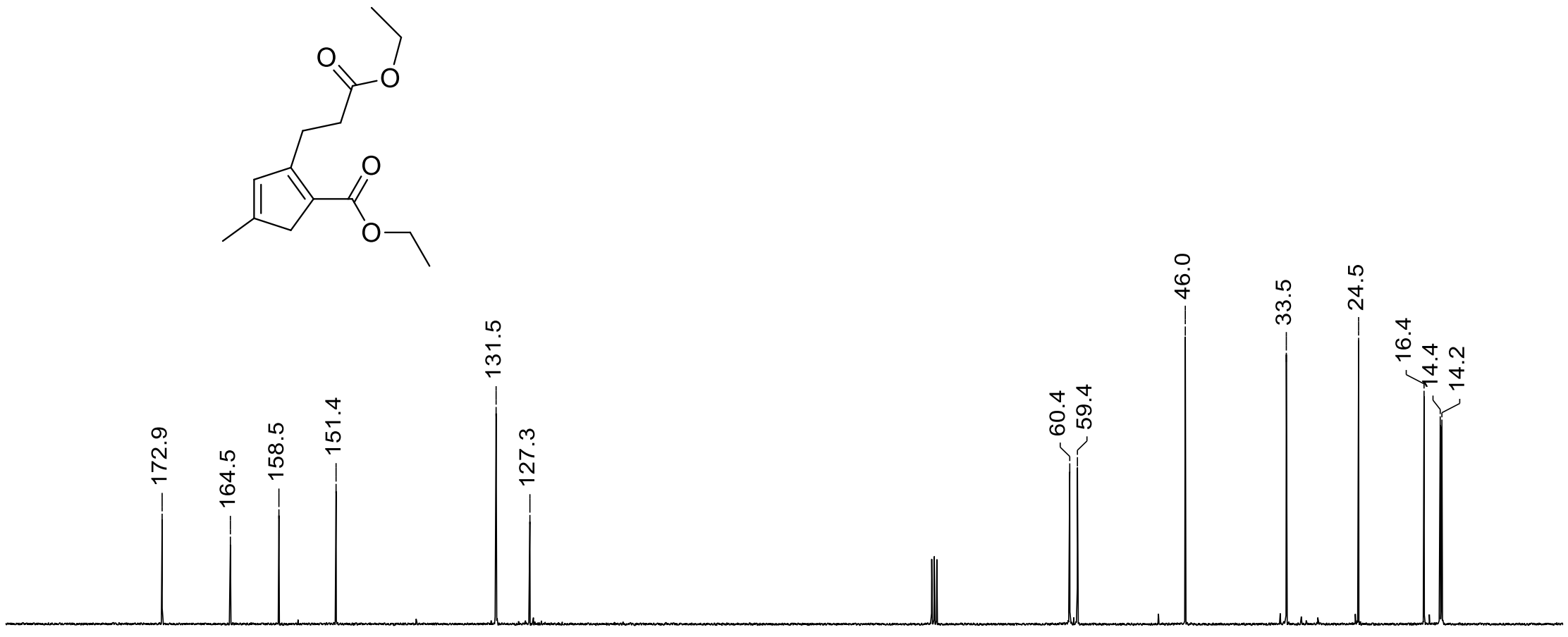

$190 \quad 180$

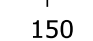

140

$130 \quad 120$

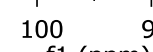

f1 (ppm) 
$\underline{\text { Anexos }}$

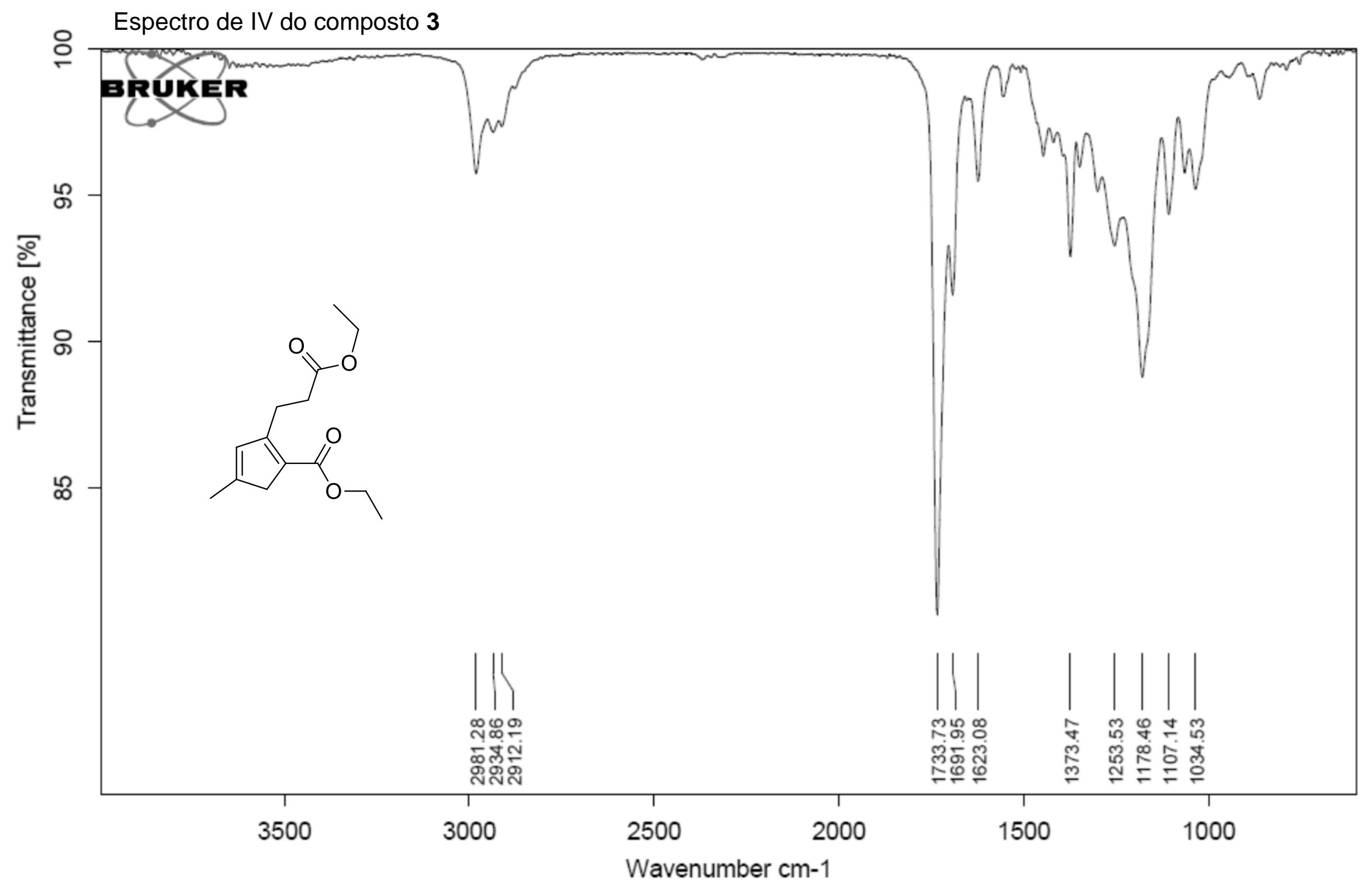


$\underline{\text { Anexos }}$

Espectro de RMN de ${ }^{1} \mathrm{H}$ do composto 4

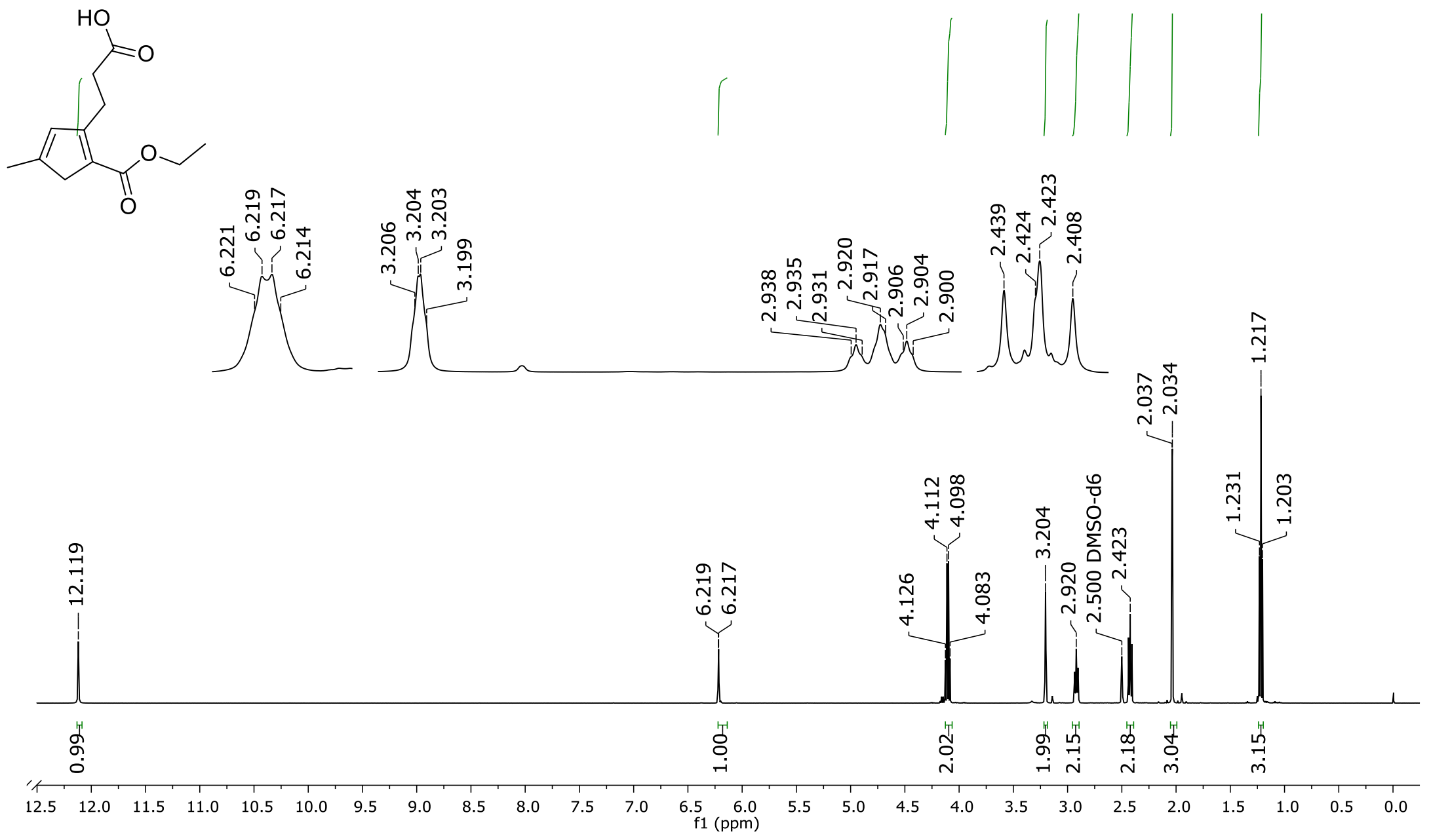

192 


\section{Anexos}

\section{Espectro de RMN de ${ }^{13} \mathrm{C}$ do composto 4}

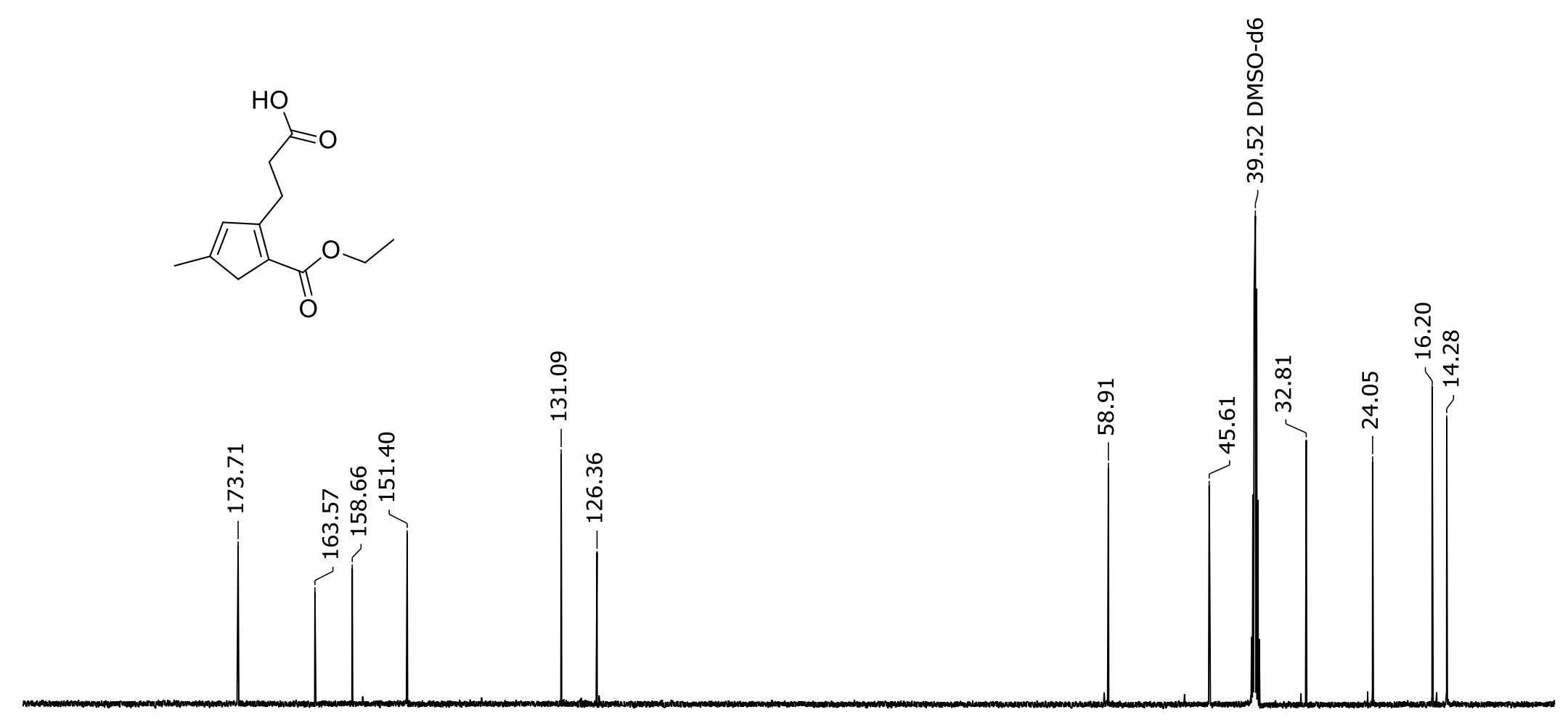

$$
\text { / }
$$

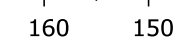

$140 \quad 130$

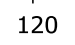

$110 \quad \begin{array}{r}100 \\ \mathrm{f} 1(\mathrm{ppm})\end{array}$ 
Anexos

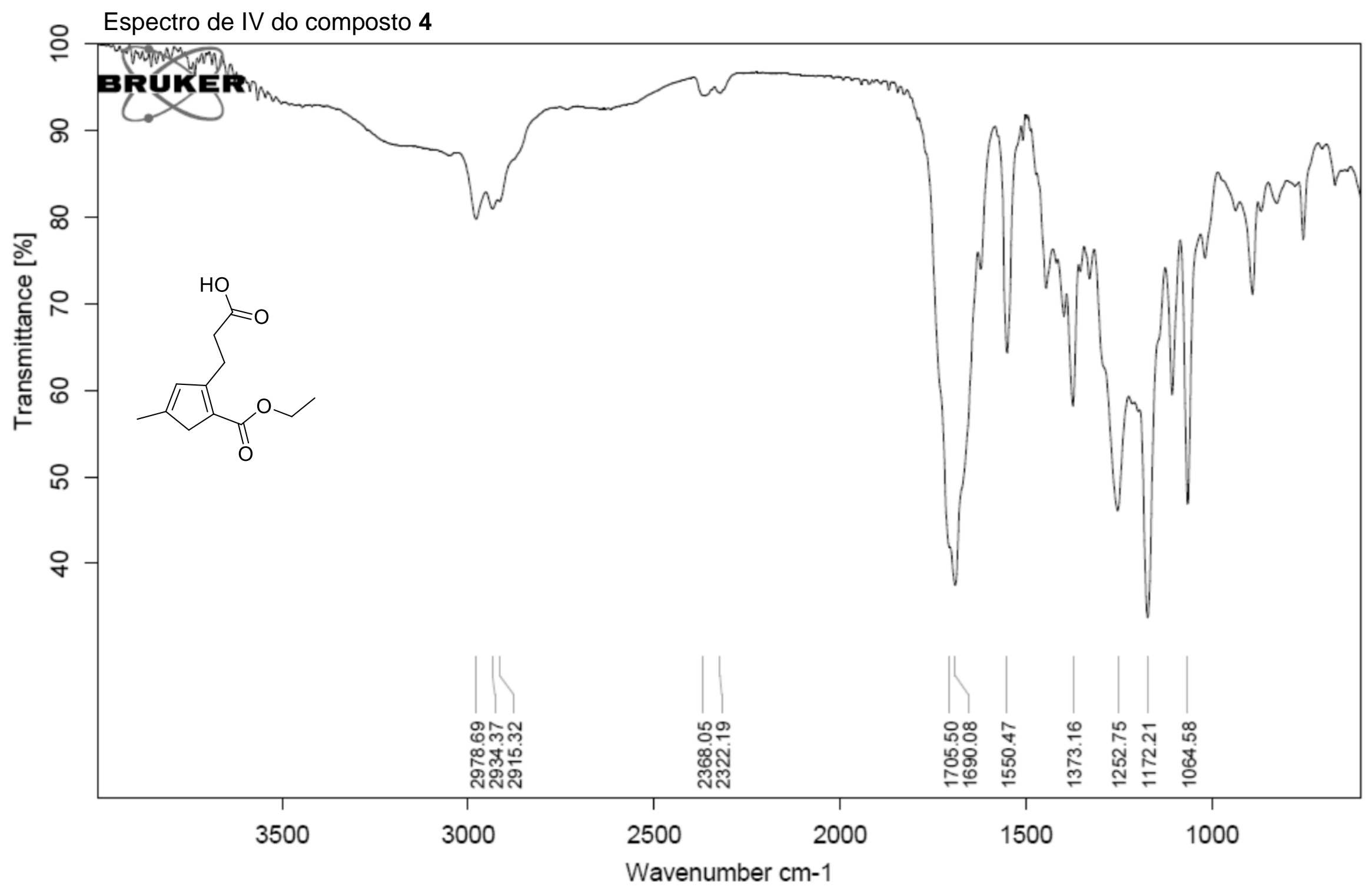




\section{Anexos}

\section{Espectro de HMBC do composto 4}
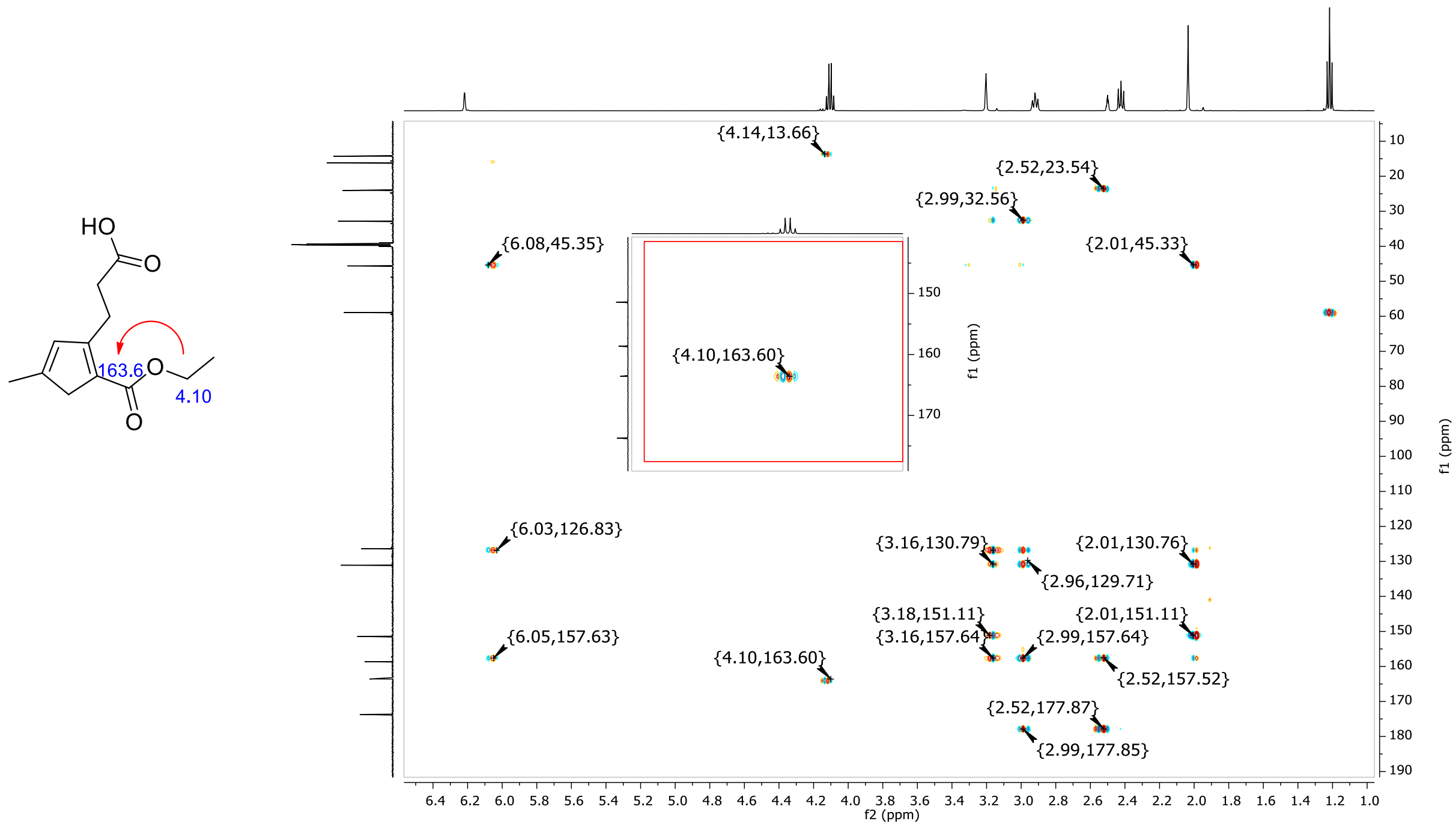


\section{Anexos}

\section{Espectro de RMN de ${ }^{1} \mathrm{H}$ do composto 5}
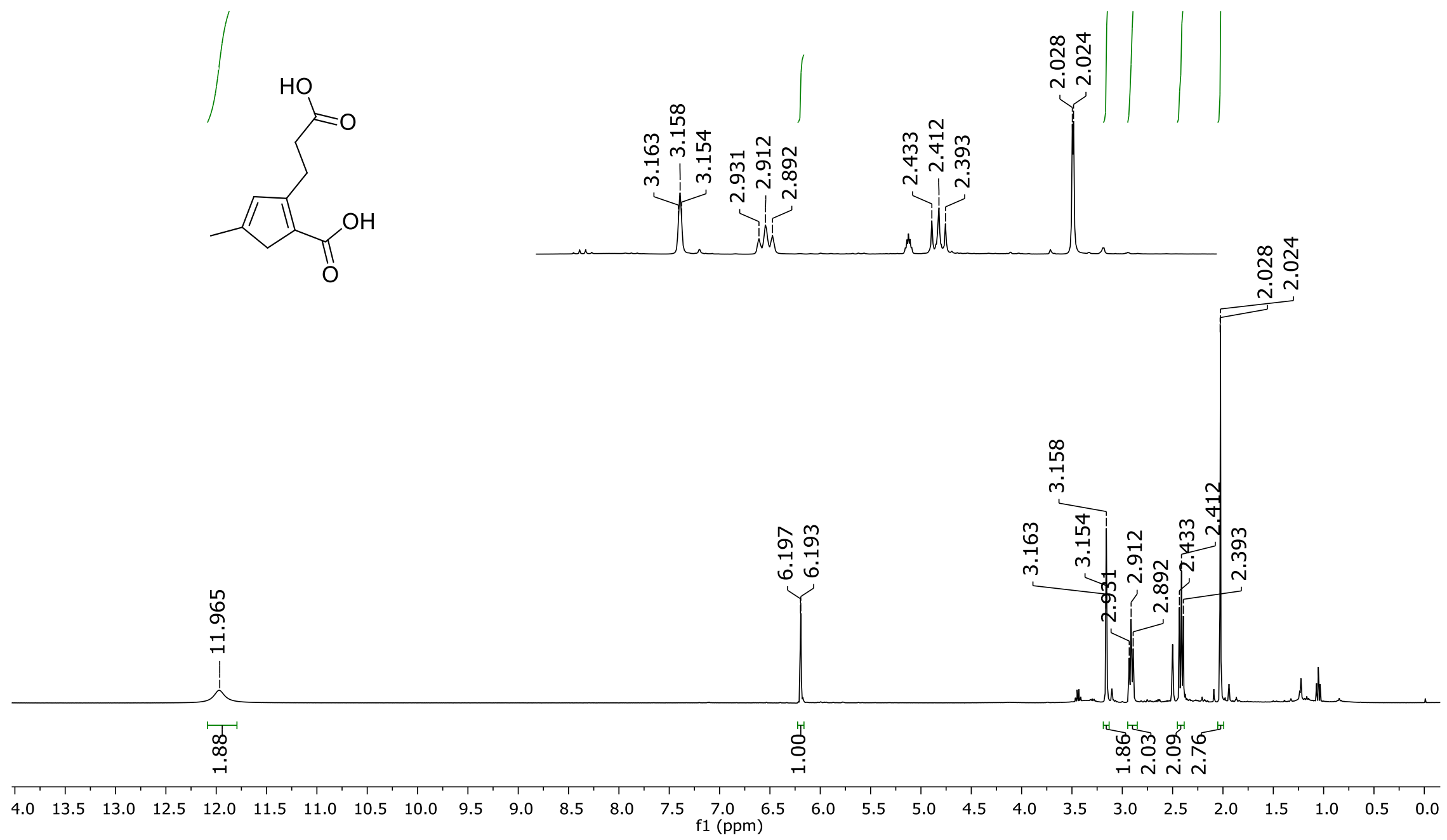

Espectro de RMN de ${ }^{13} \mathrm{C}$ do composto 5 
Anexos
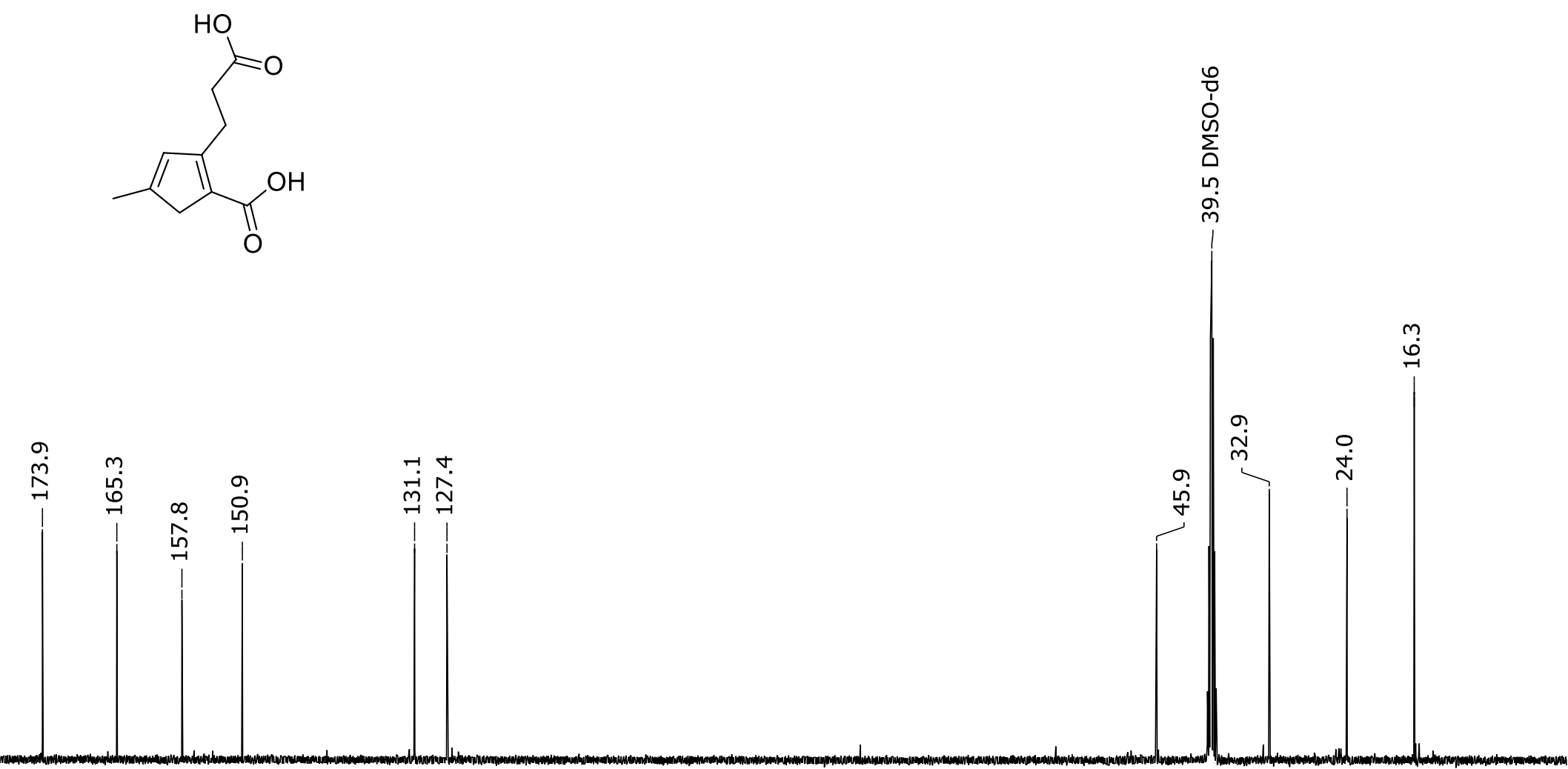

곡 


\section{Anexos}

\section{Espectro de RMN de ${ }^{1} \mathrm{H}$ do composto 6}
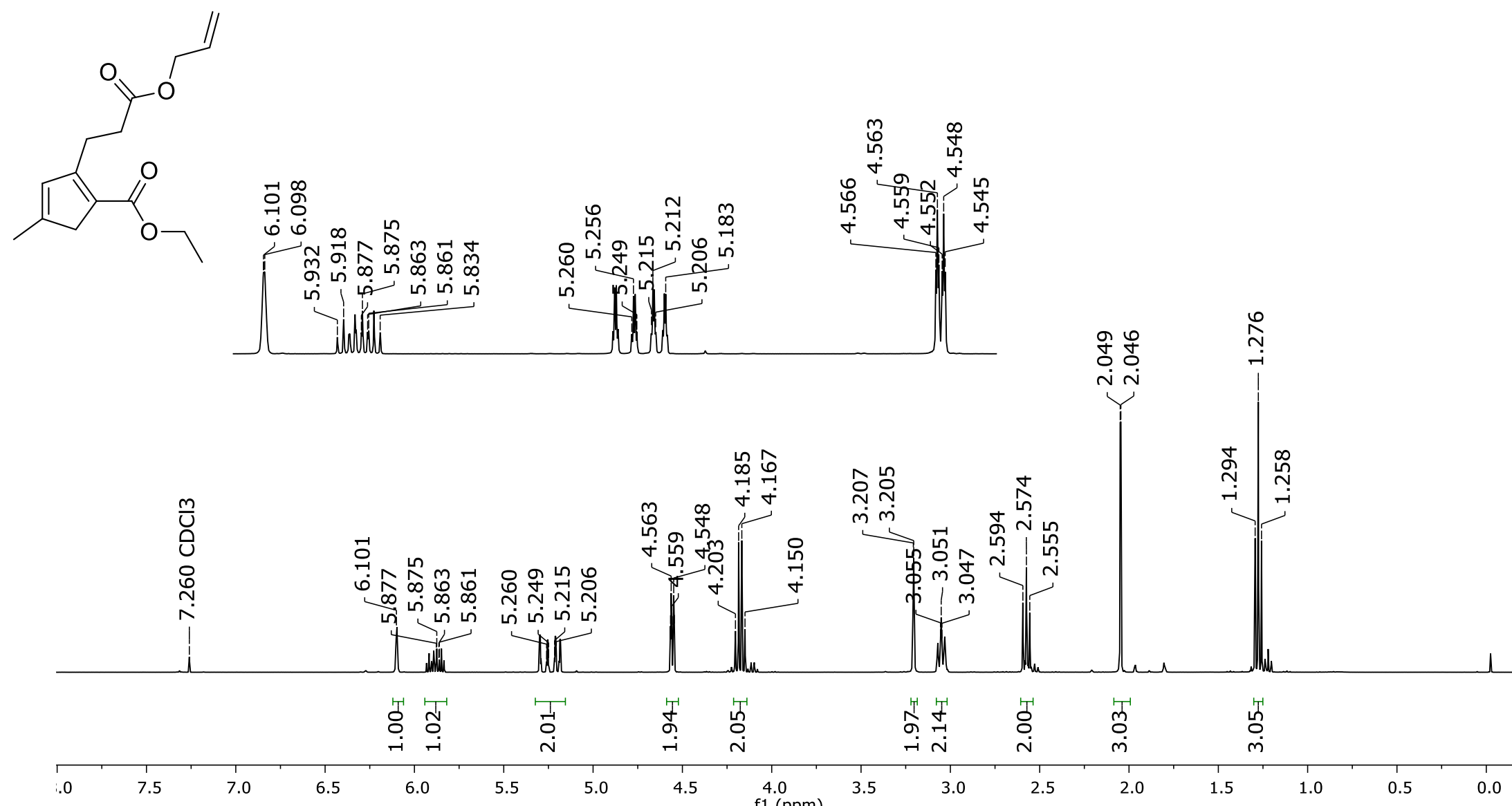


\section{Anexos}

\section{Espectro de RMN de ${ }^{13} \mathrm{C}$ do composto 6}
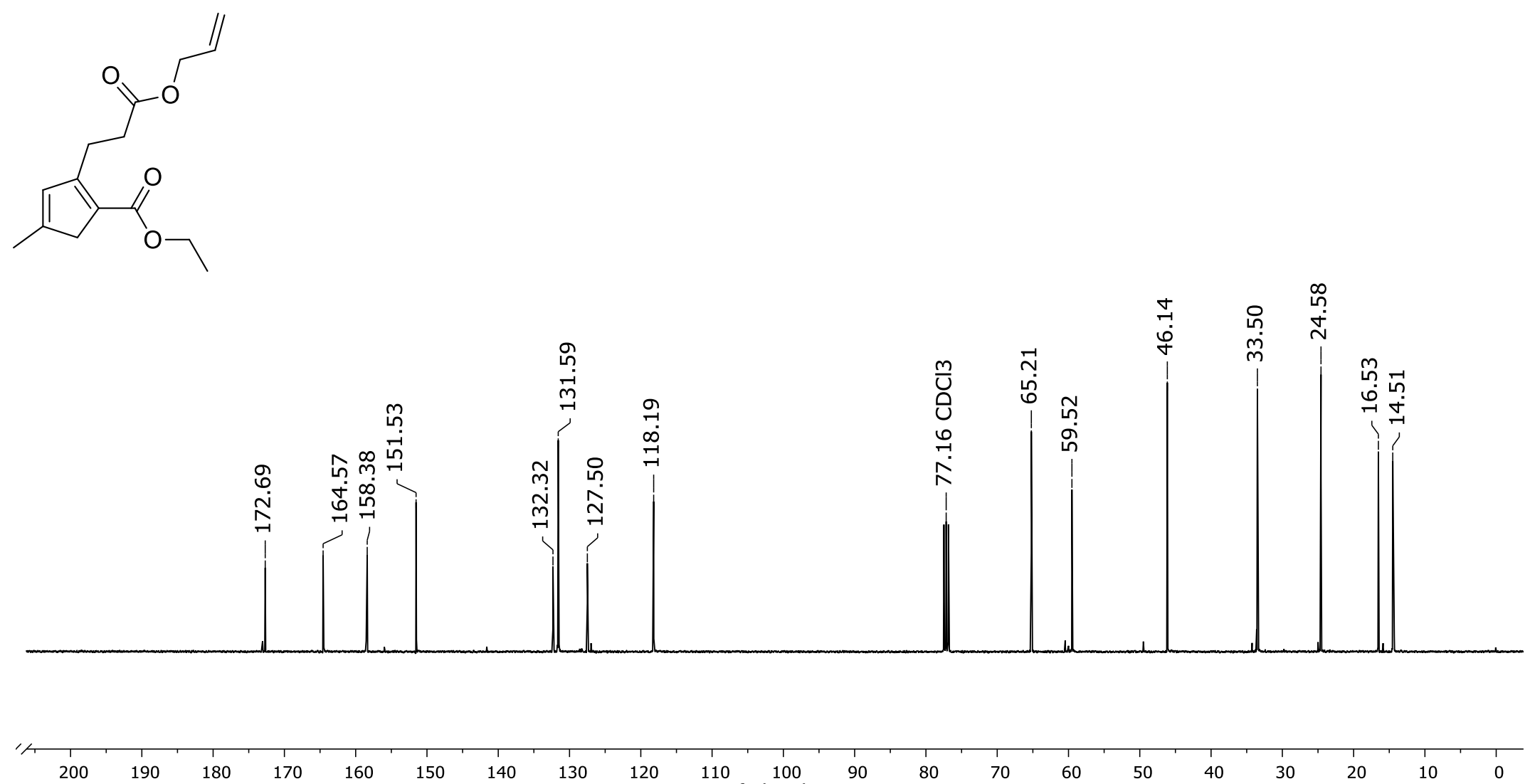

$160 \quad 150$

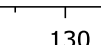

$110 \quad \begin{aligned} & 100 \\ & 10\end{aligned}$

$$
60
$$


Anexos

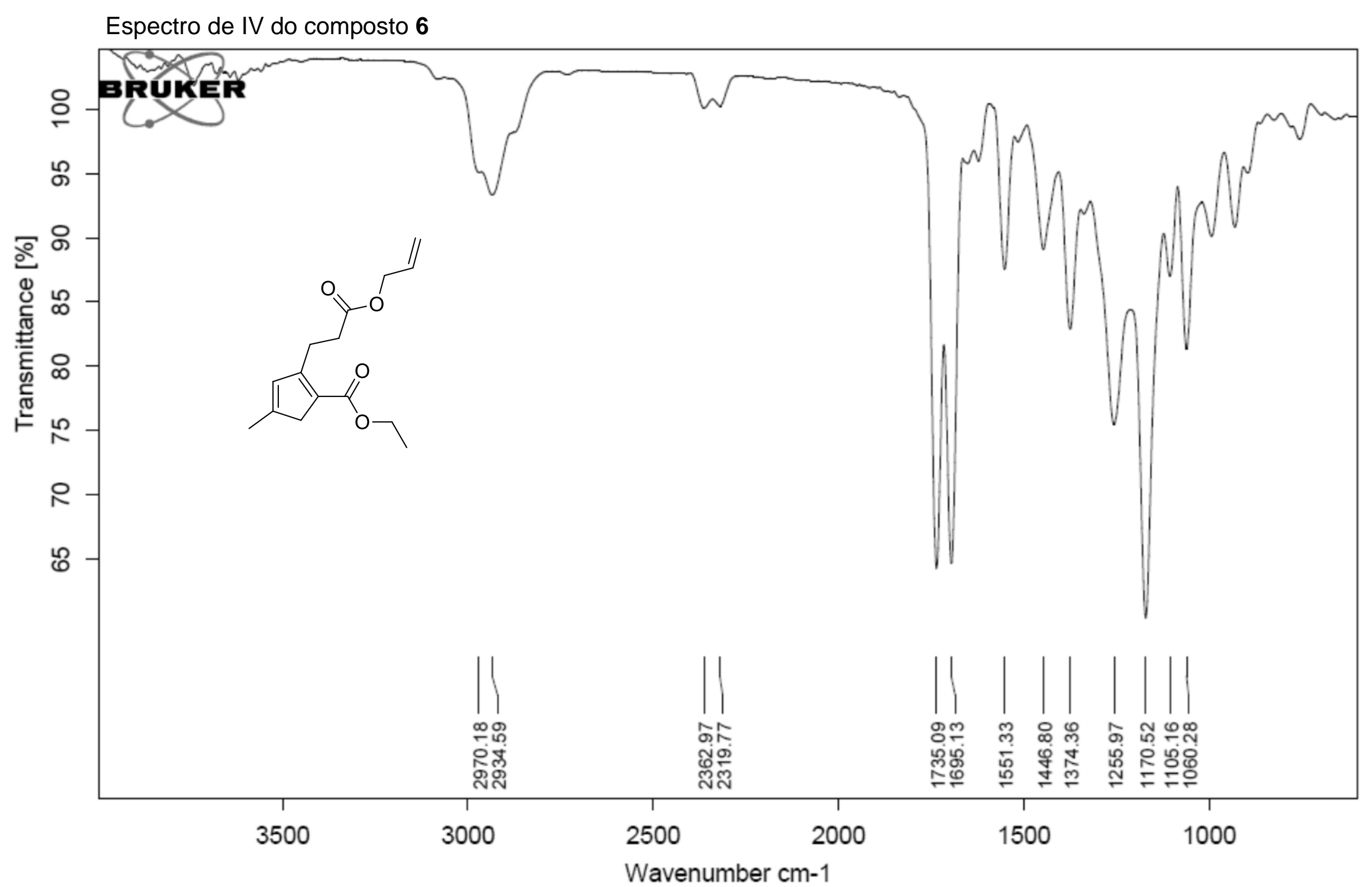




\section{Anexos}

\section{Espectro de RMN de ${ }^{1} \mathrm{H}$ do composto 7}
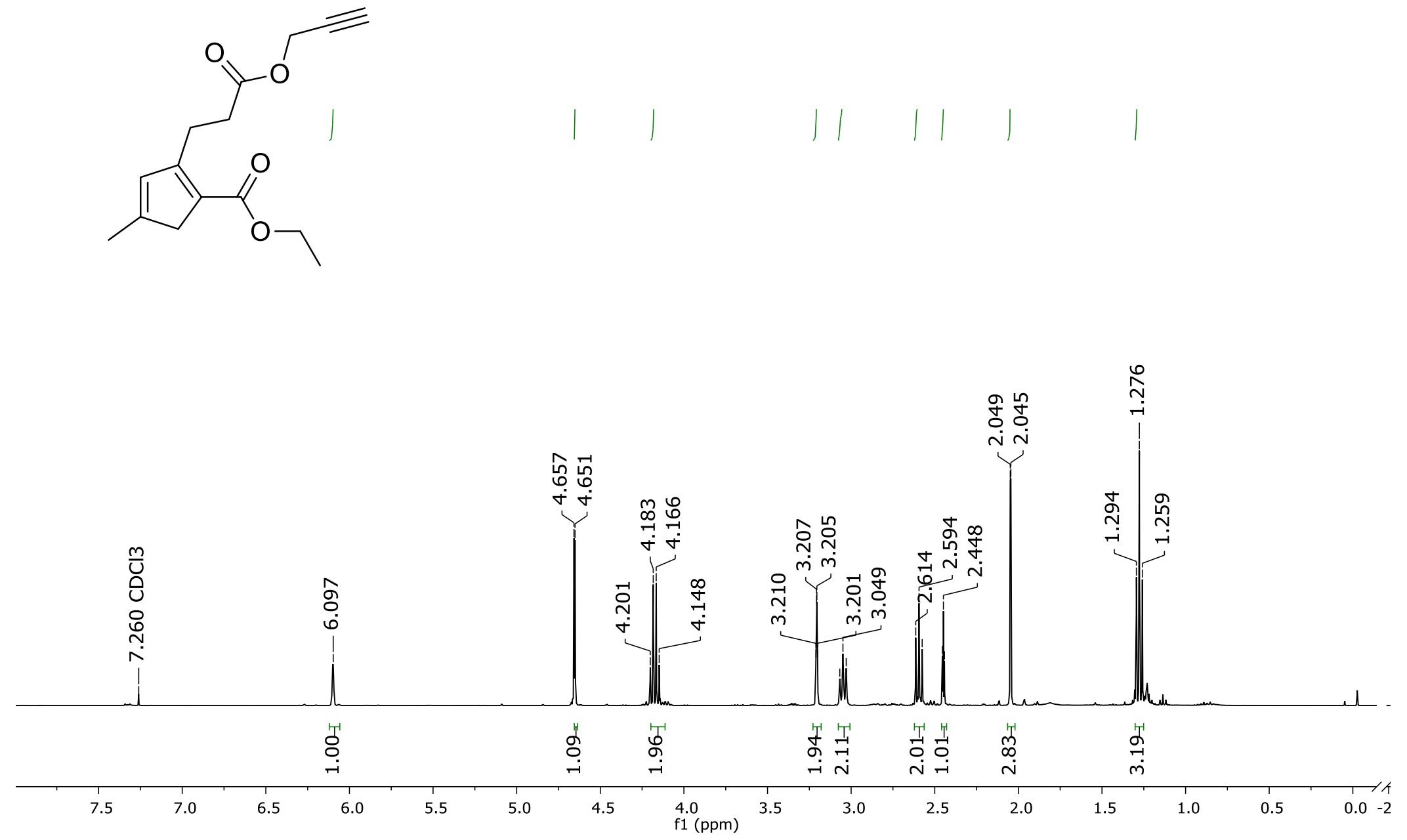


\section{Anexos}

\section{Espectro de RMN de ${ }^{13} \mathrm{C}$ do composto 7}
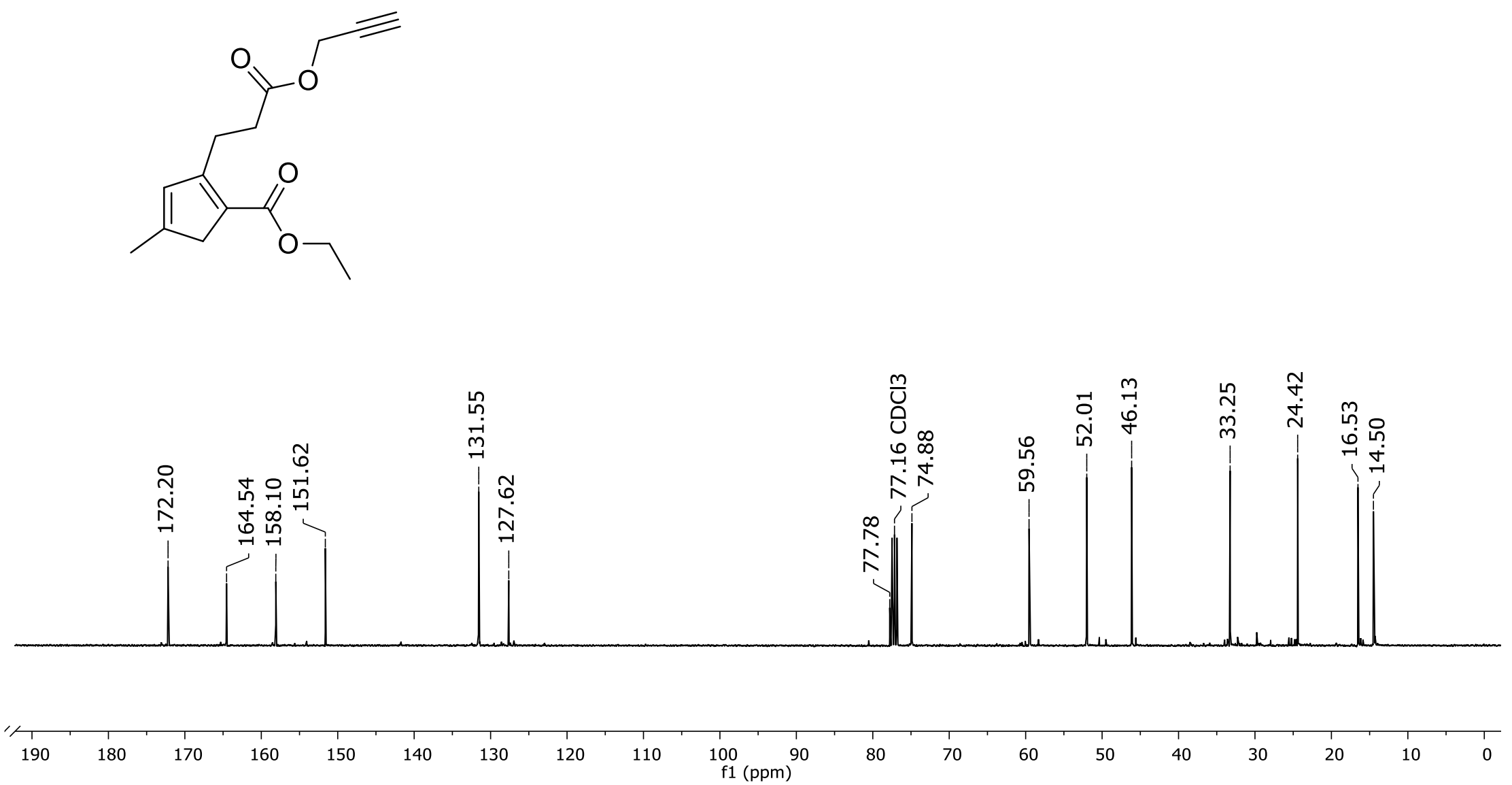
Anexos

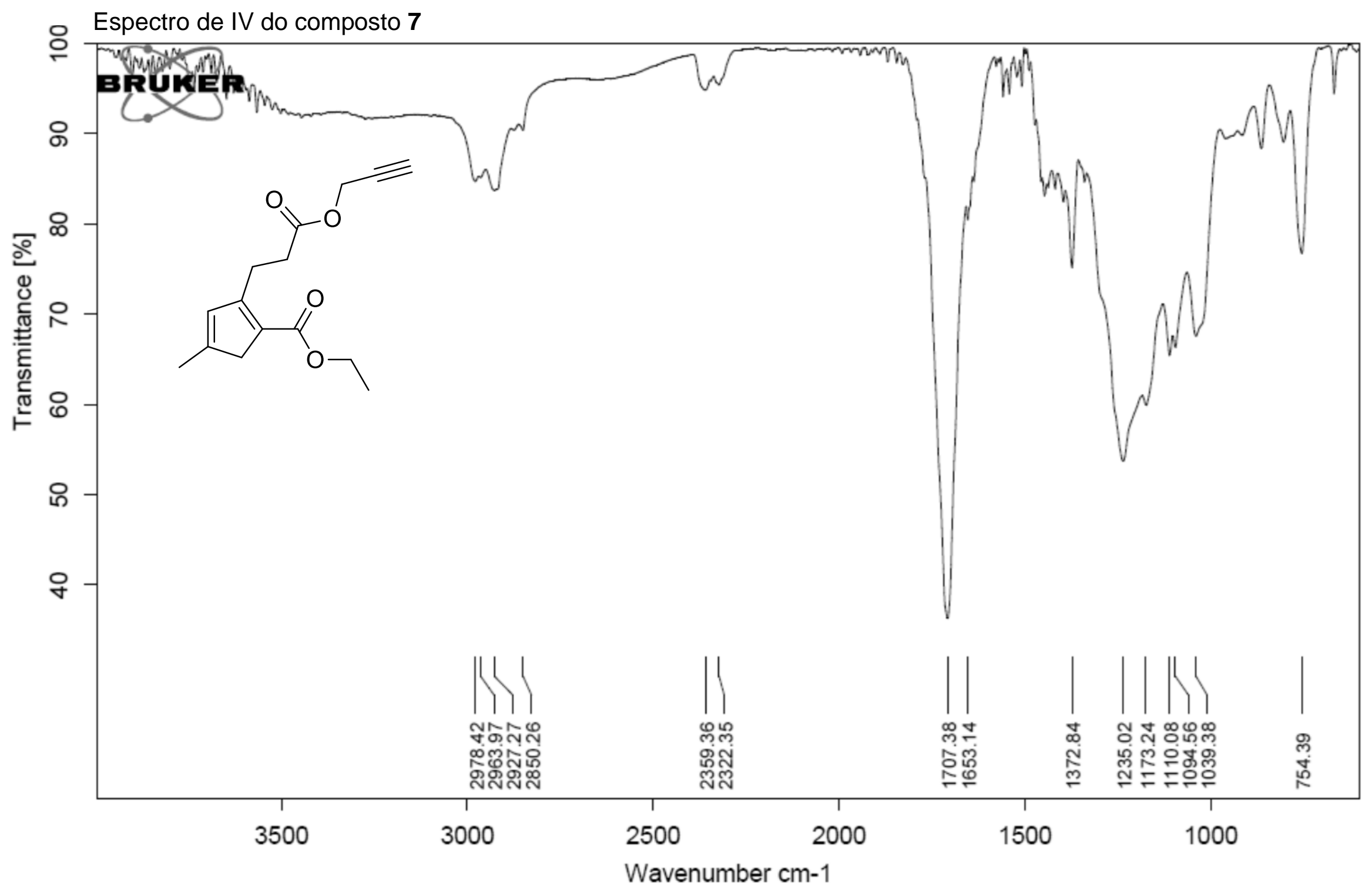




\section{Anexos}

\section{Espectro de RMN de ${ }^{1} \mathrm{H}$ do composto 8}
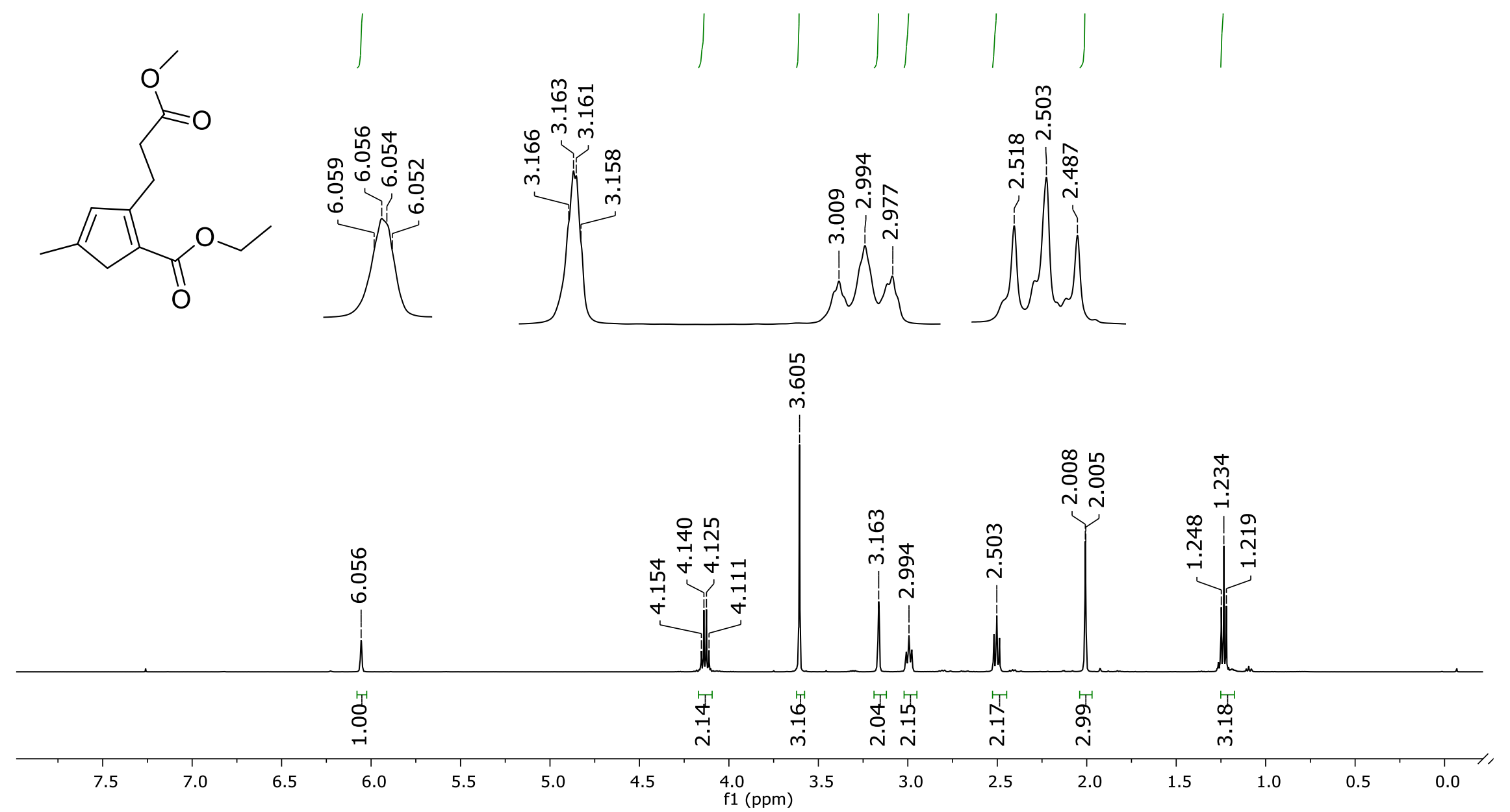


\section{Anexos}

\section{Espectro de RMN de ${ }^{13} \mathrm{C}$ do composto 8}
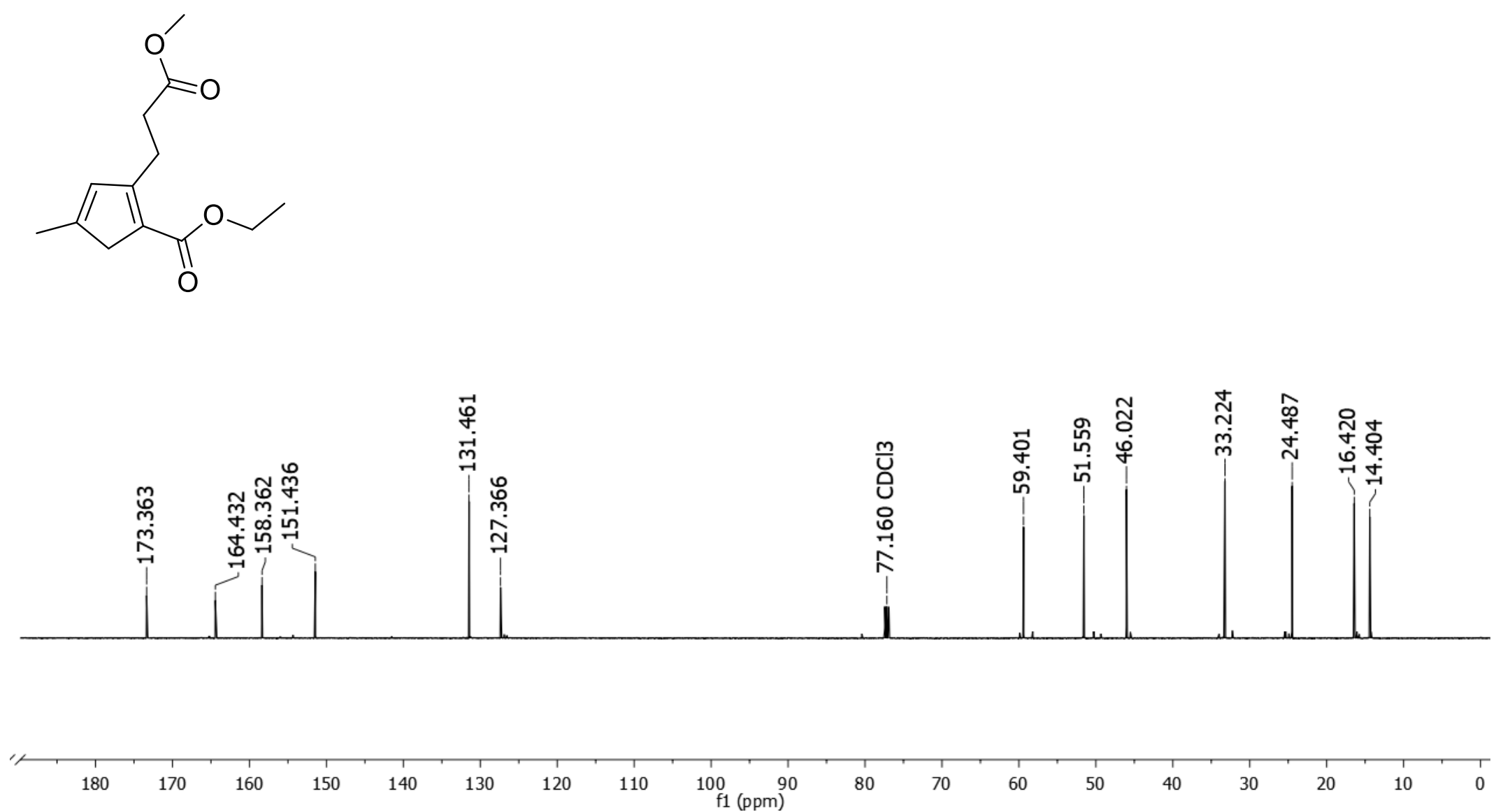
Anexos

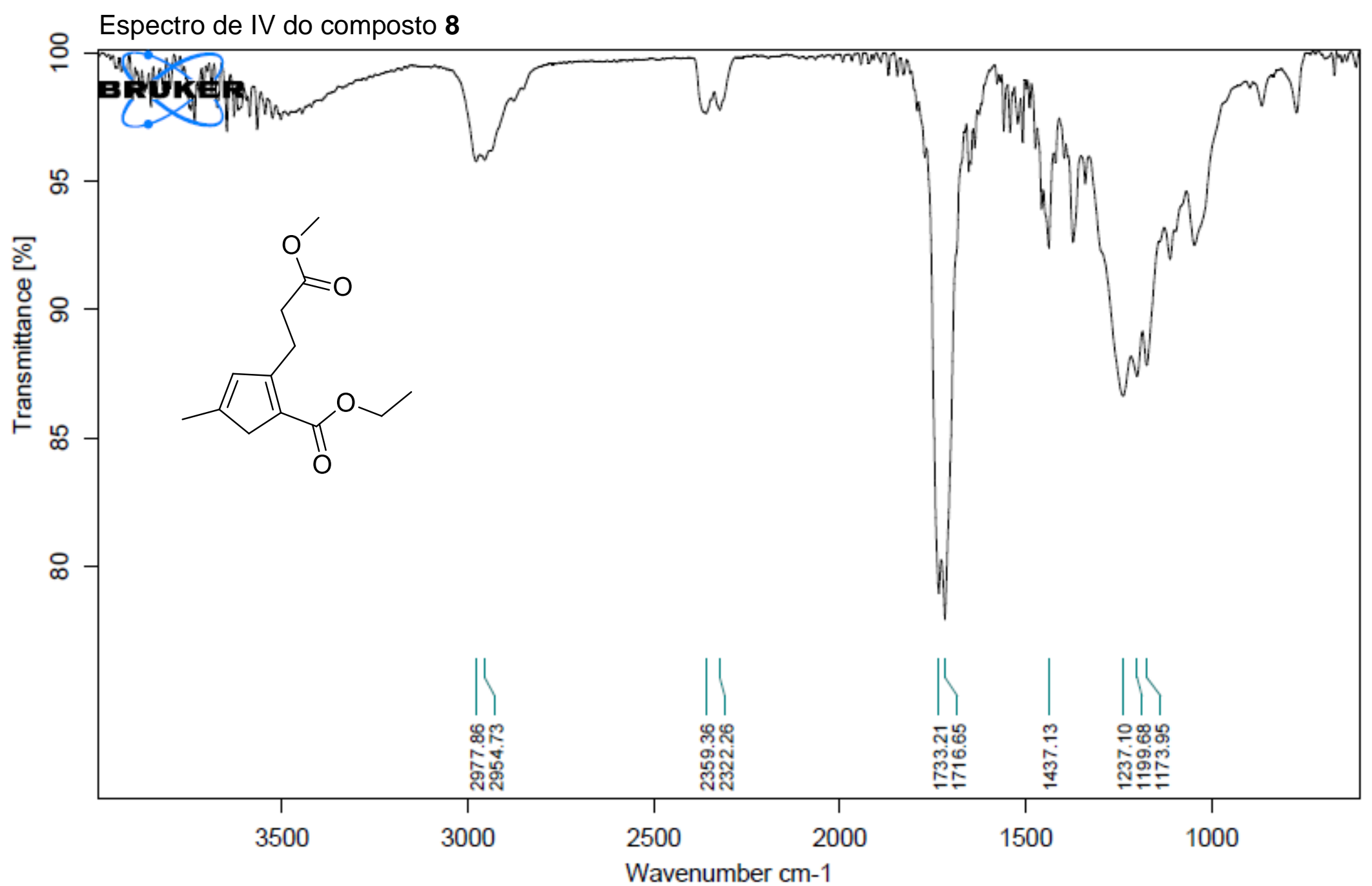




\section{Anexos}

\section{Espectro de RMN de ${ }^{1} \mathrm{H}$ do composto 11}
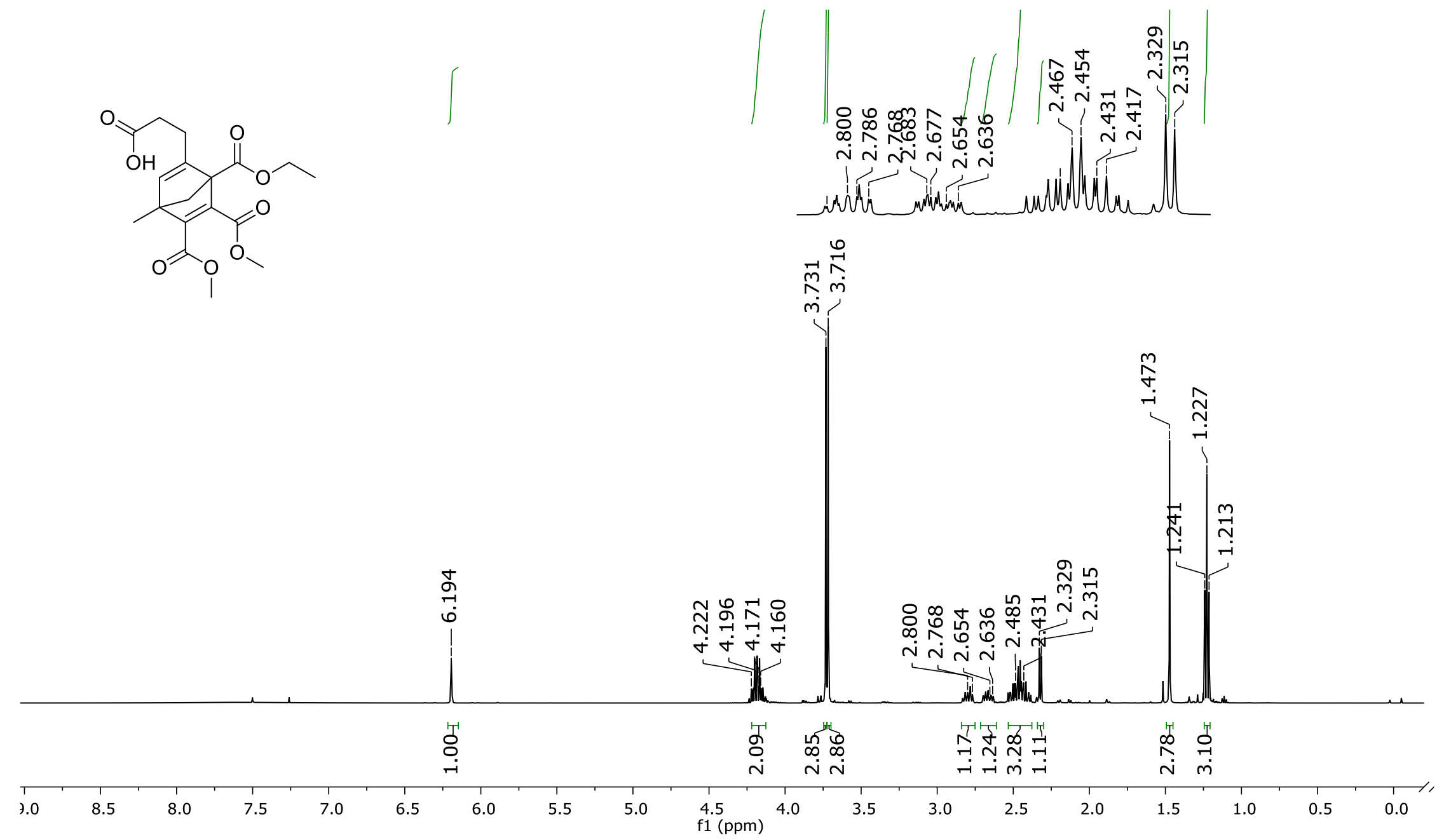


\section{Anexos}

\section{Espectro de RMN de ${ }^{13} \mathrm{C}$ do composto 11}
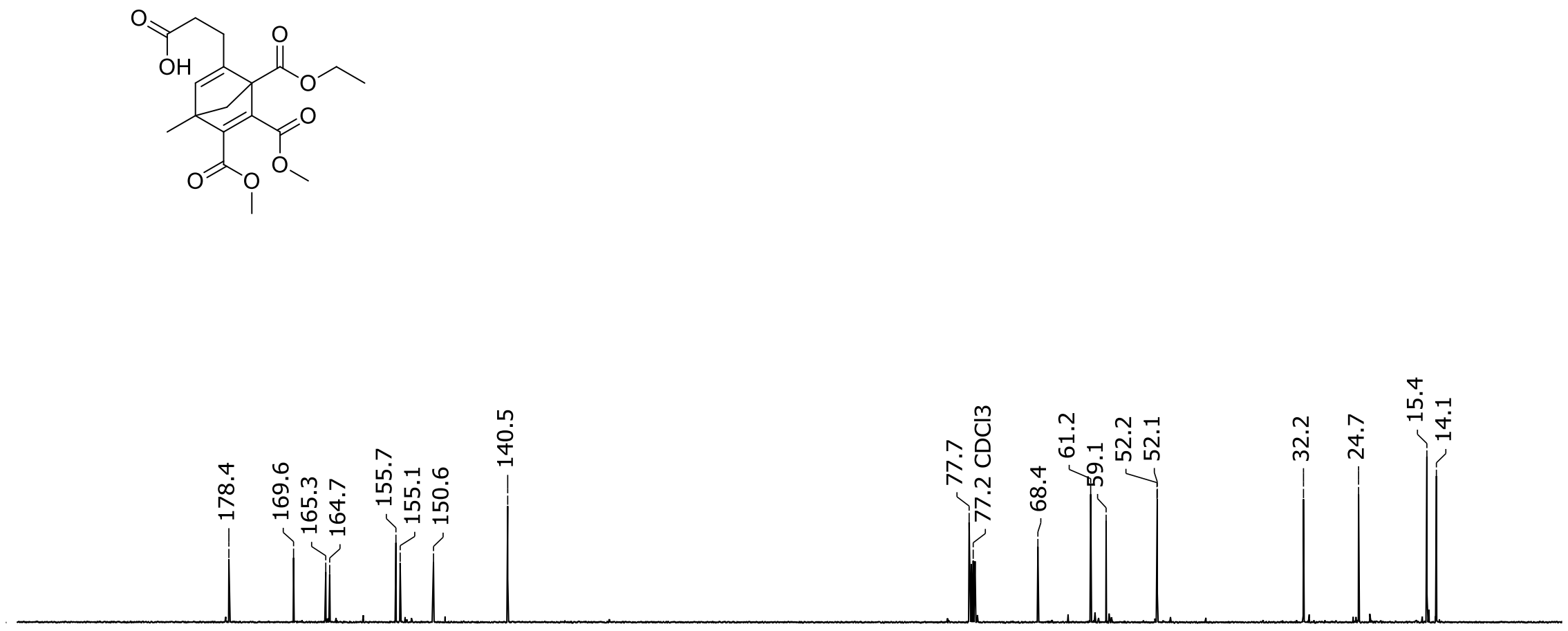

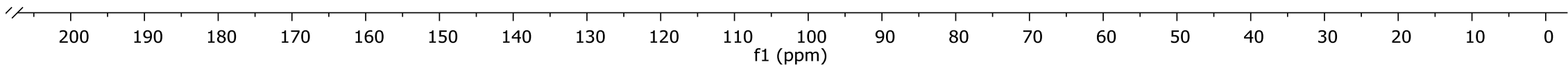


Anexos

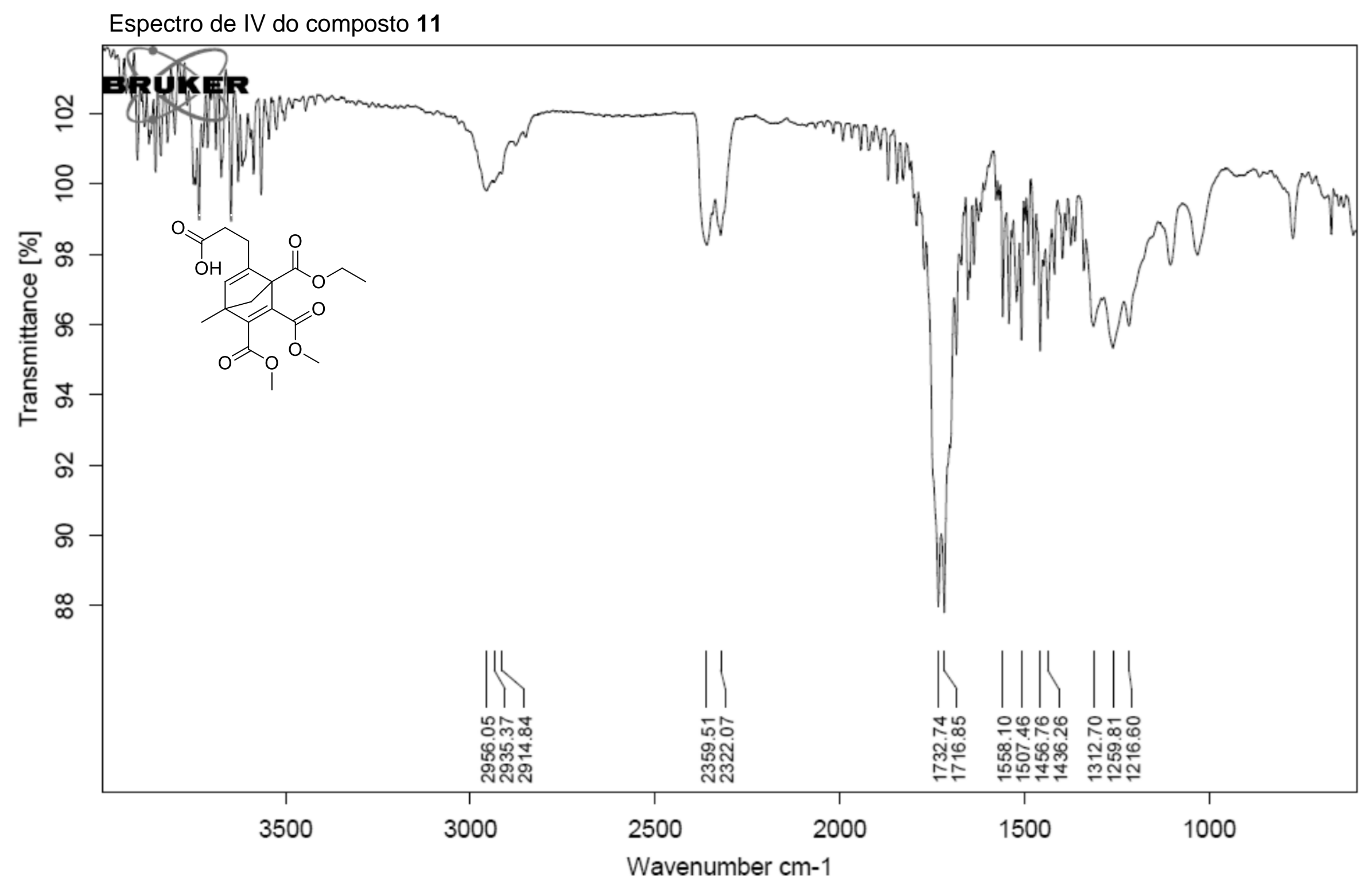




\section{Anexos}

\section{Espectro de $\mathrm{RMN}$ de ${ }^{1} \mathrm{H}$ do composto 12. Mistura diastereoisomérica}
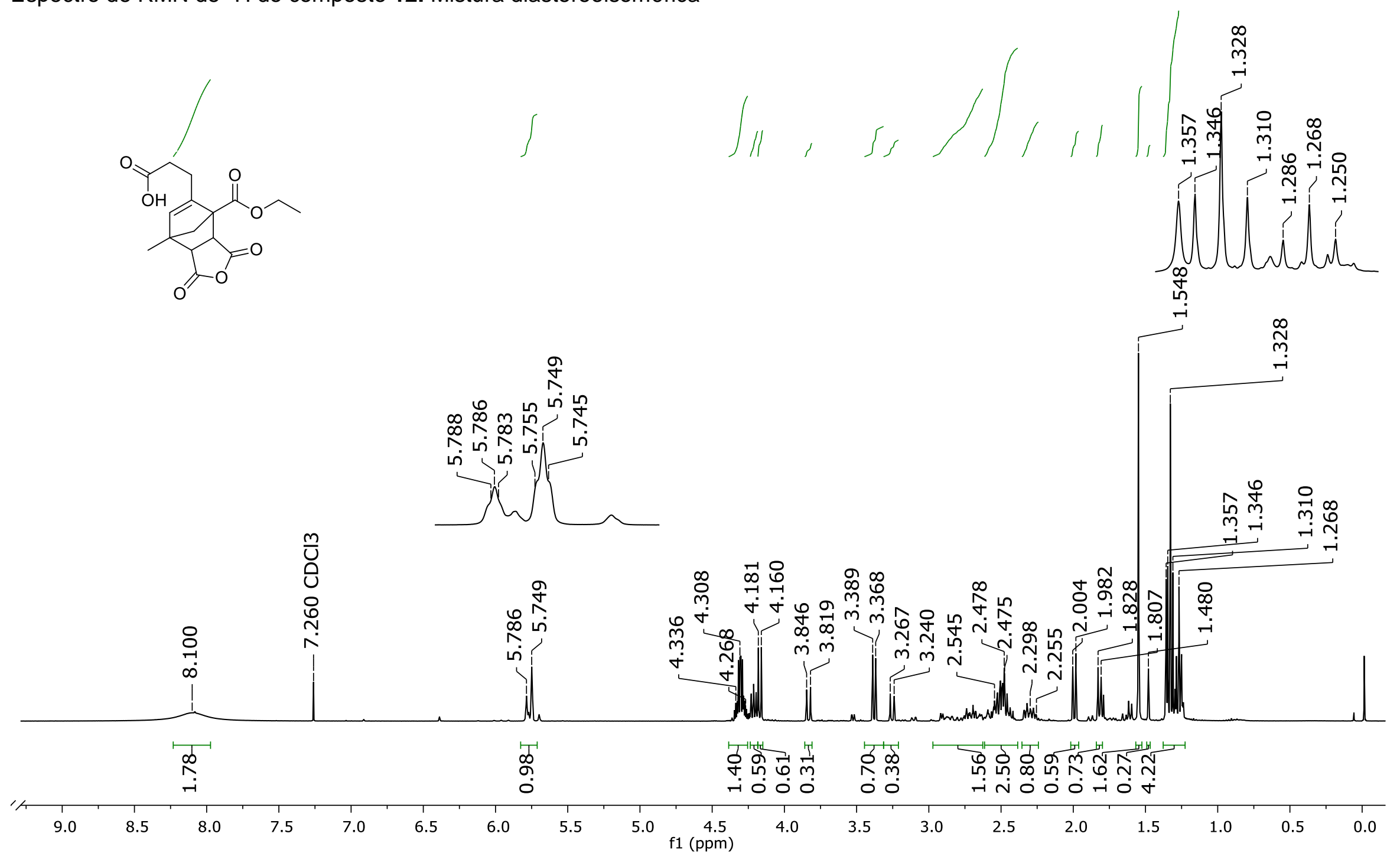


\section{Anexos}

\section{Espectro de RMN de ${ }^{13} \mathrm{C}$ do composto 12. Mistura diastereoisomérica}
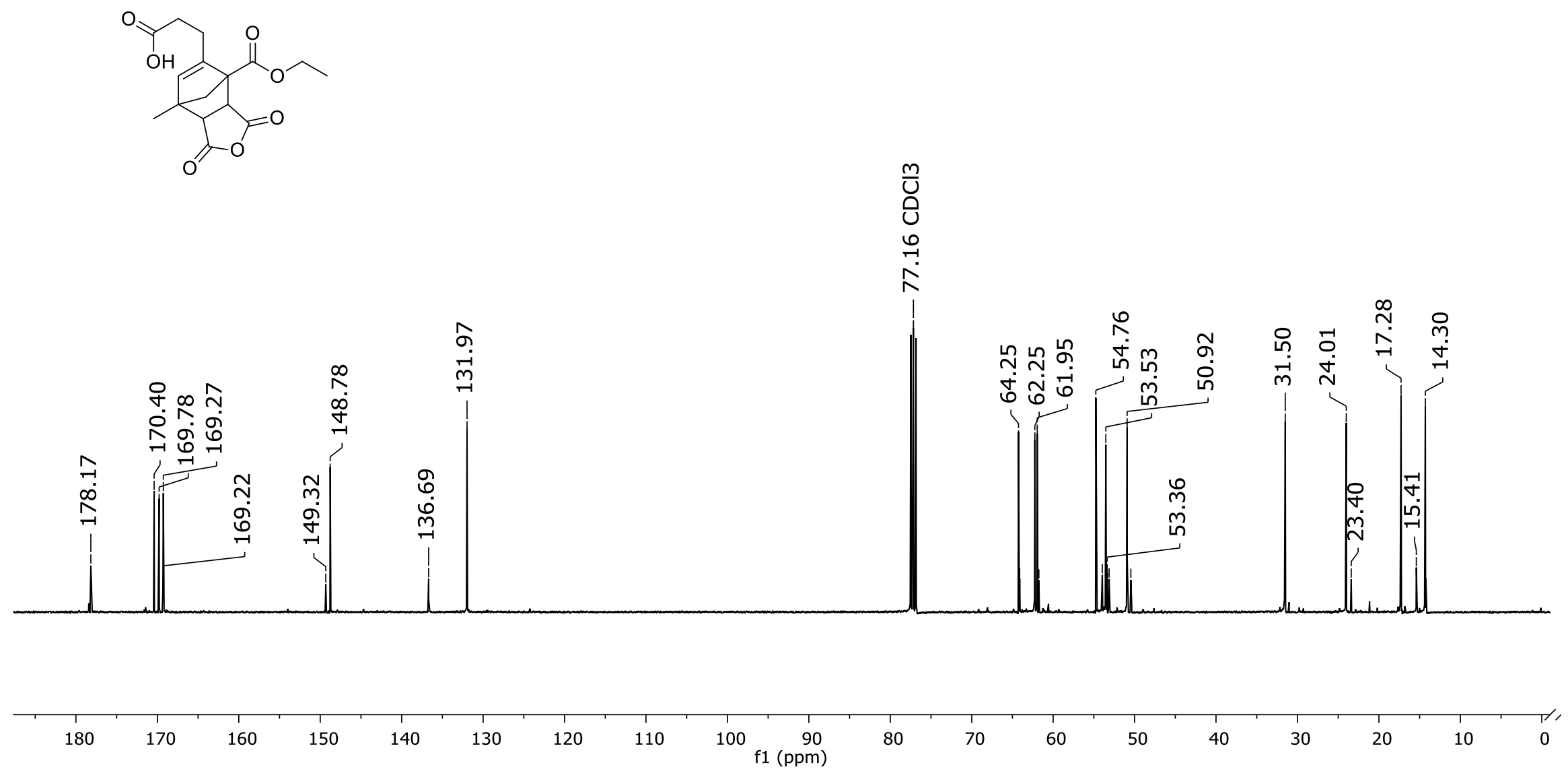


\section{Anexos}

\section{Espectro de RMN de ${ }^{1} \mathrm{H}$ do composto 13}
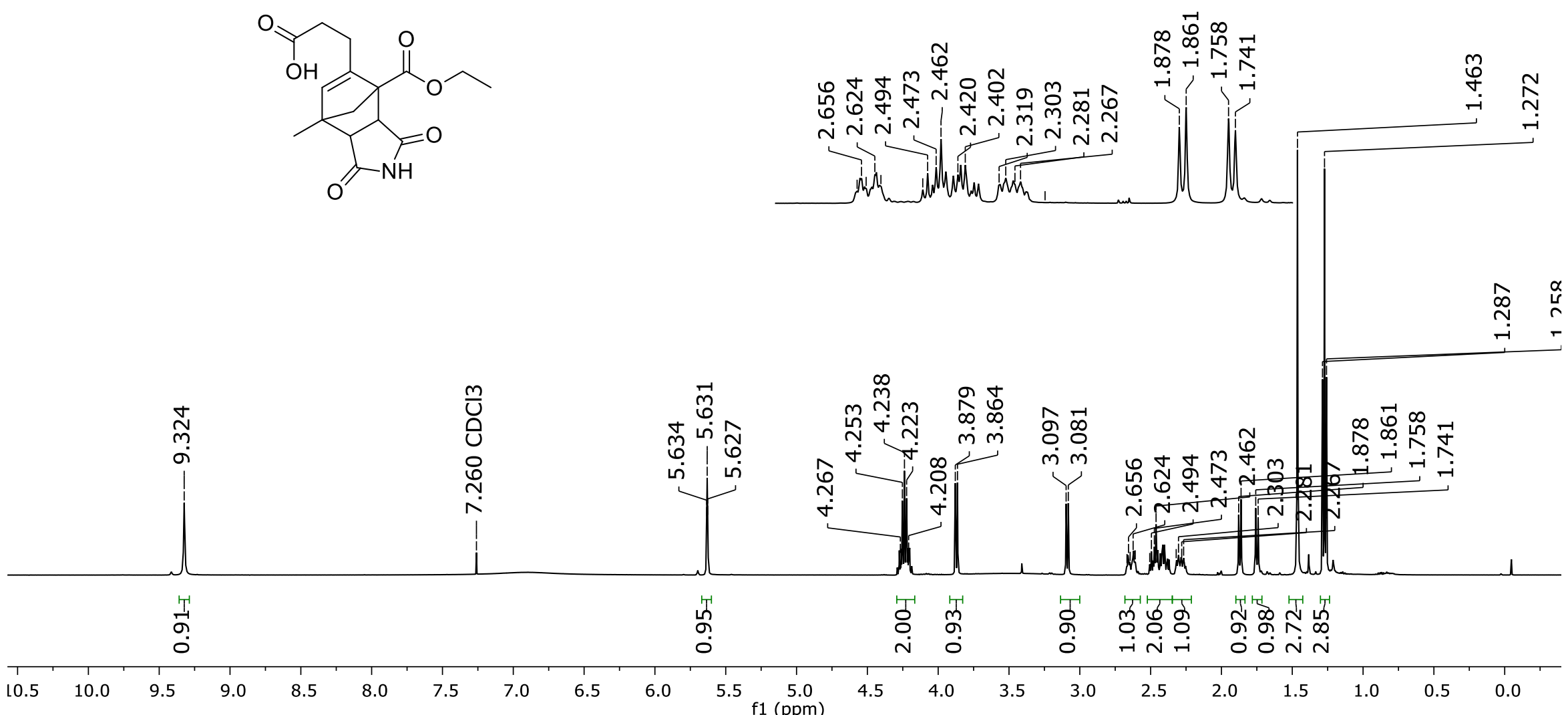


\section{Anexos}

\section{Espectro de RMN de ${ }^{13} \mathrm{C}$ do composto 13}
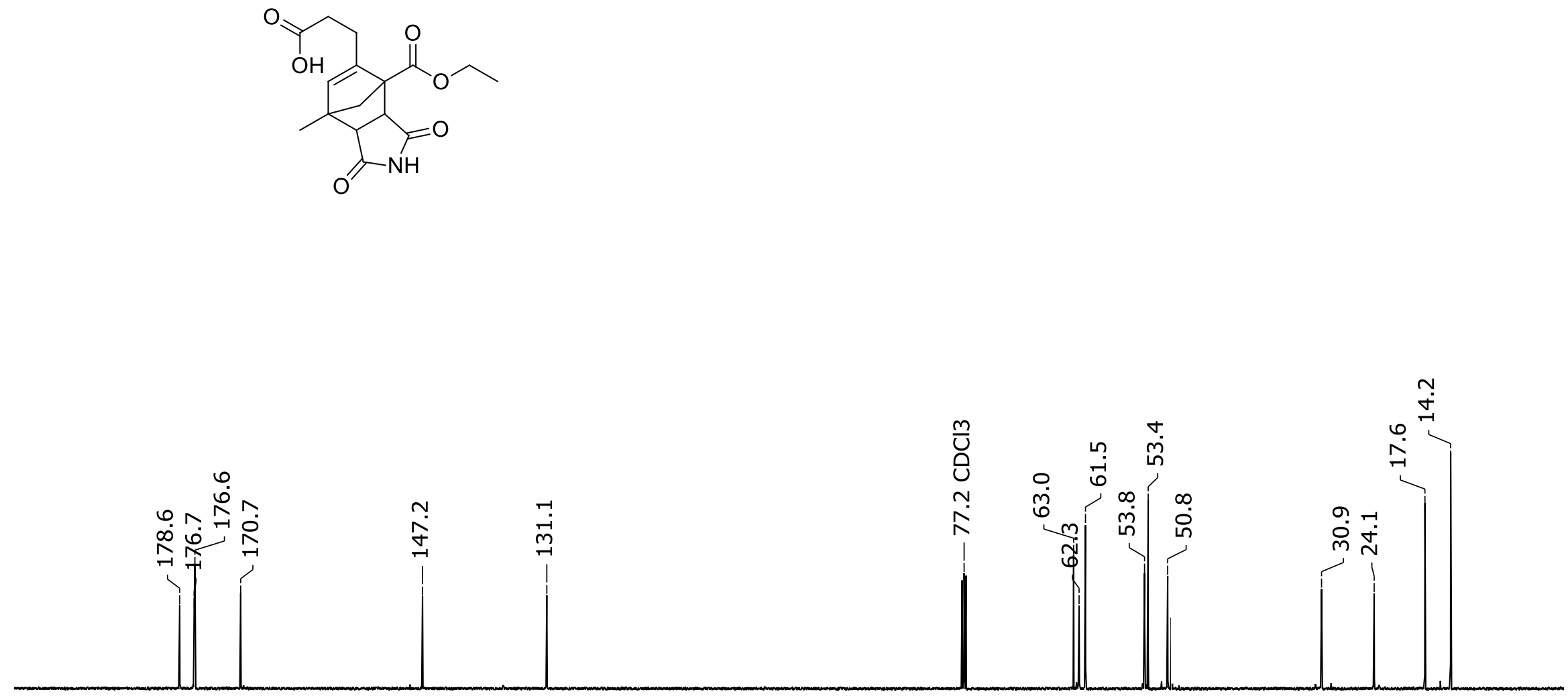
Anexos

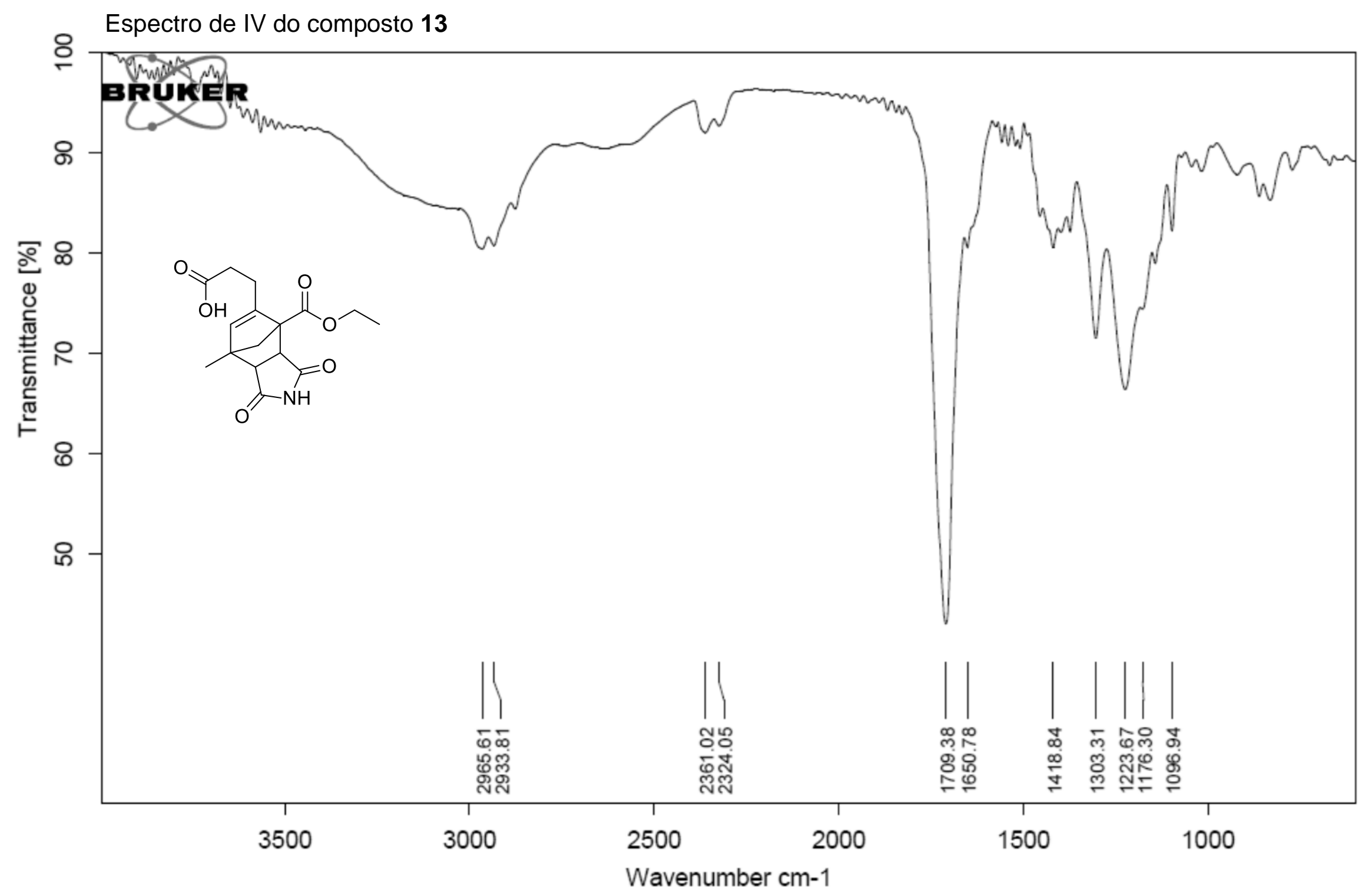




\section{Anexos}

Espectro de $\mathrm{RMN}$ de ${ }^{1} \mathrm{H}$ do composto 14. Mistura diastereoisomérica

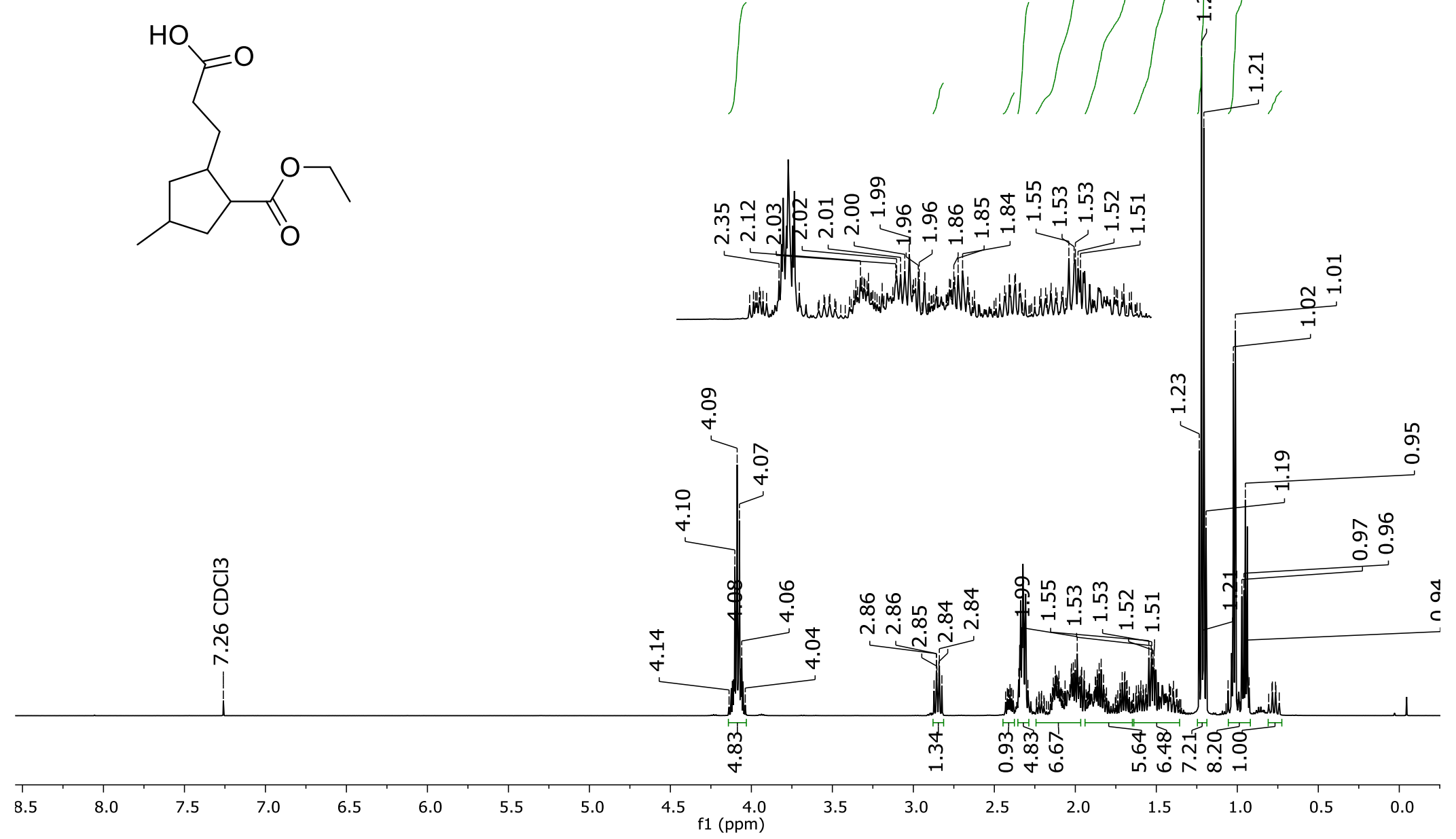




\section{Anexos}

\section{Espectro de RMN de ${ }^{13} \mathrm{C}$ do composto 14. Mistura diastereoisomérica}
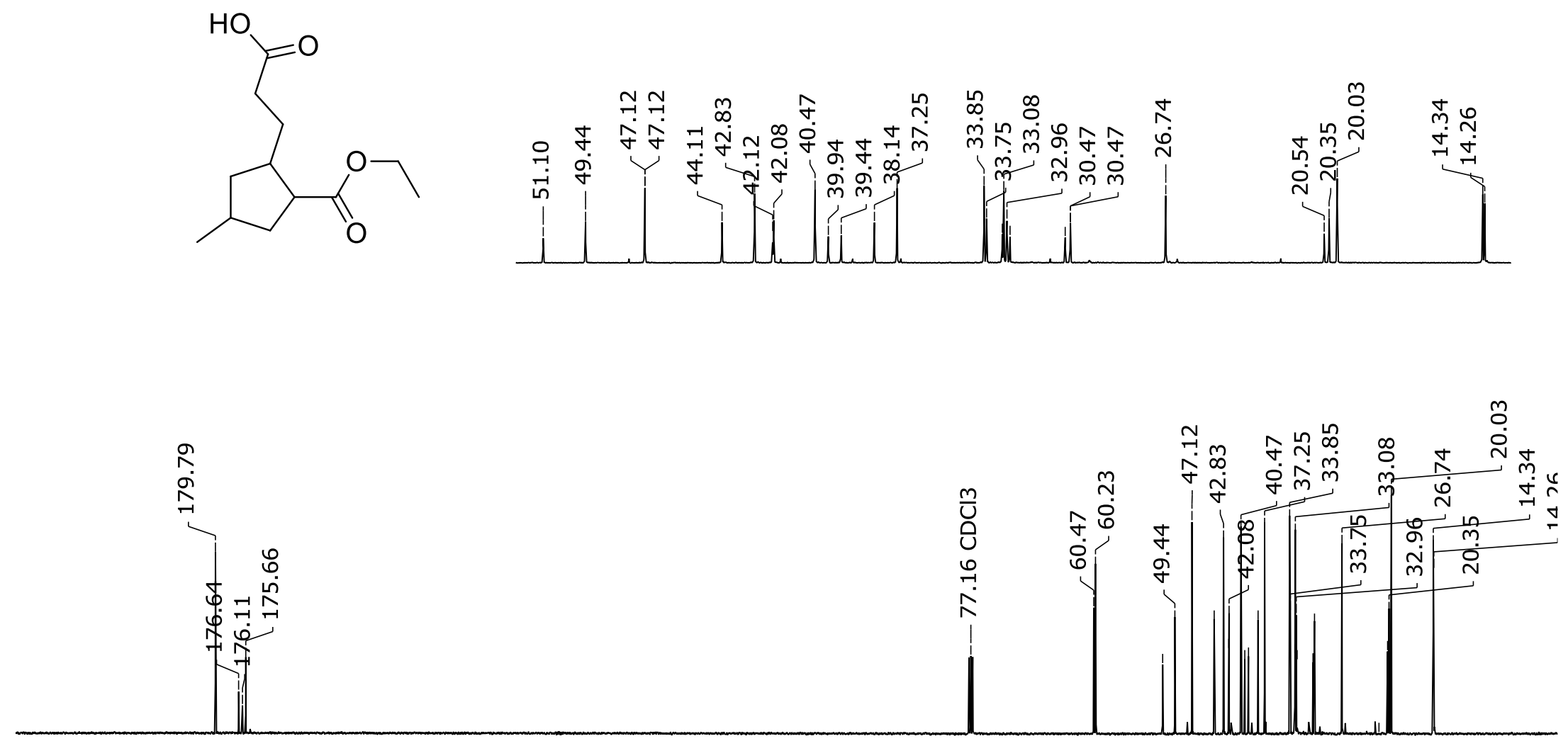

$200 \quad 190 \quad 180$

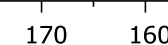

$150 \quad 140$

$\begin{array}{llll}130 & 120 & 110 & 100\end{array}$ 
Anexos

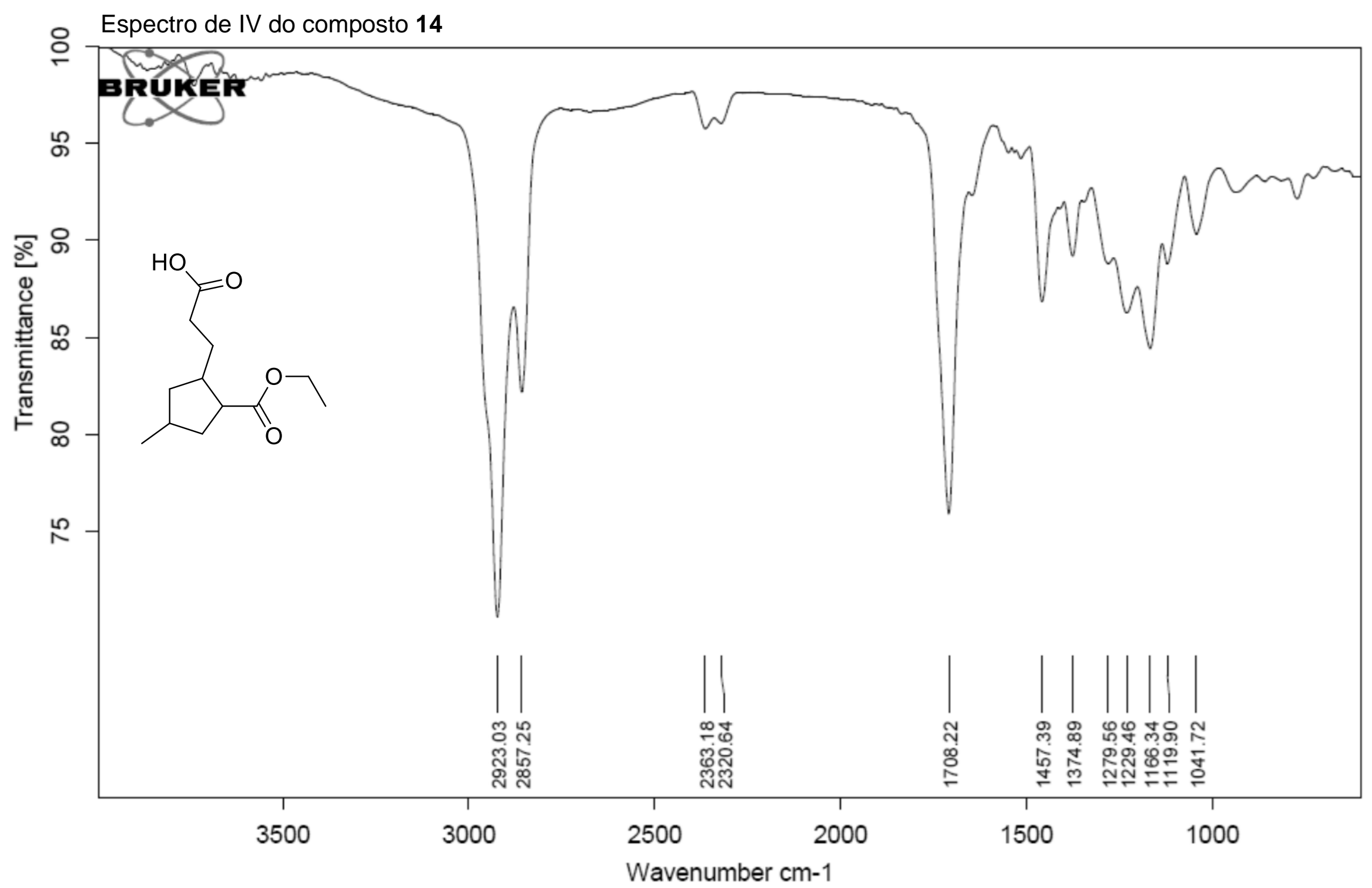




\section{Anexos}

Cromatogramas análises da mistura diastereoisomérica: CG-MS (A) and CG-FID (B)
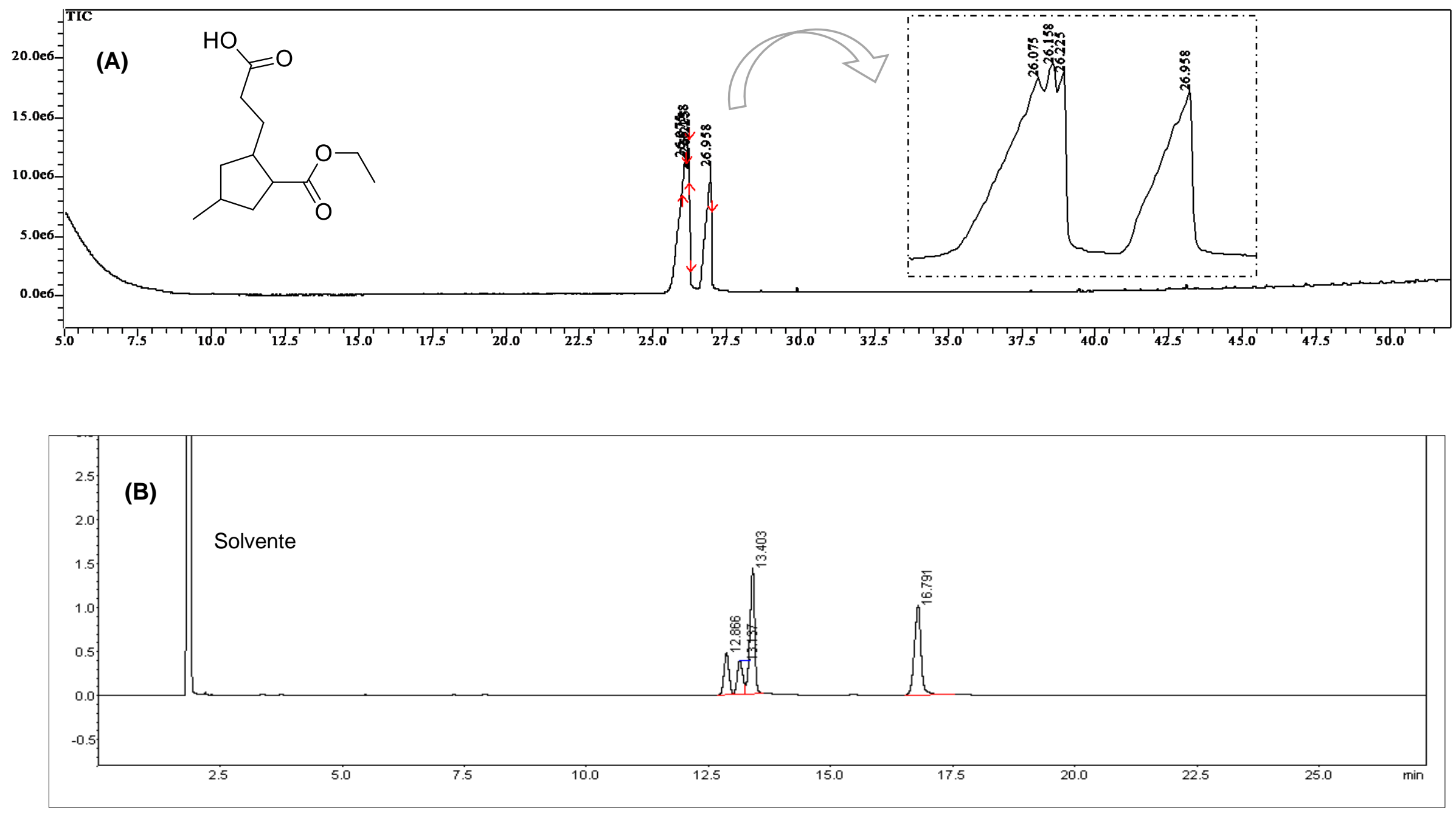


\section{Anexos}

\section{Espectro de RMN de ${ }^{1} \mathrm{H}$ do composto 15. Mistura diastereoisomérica}

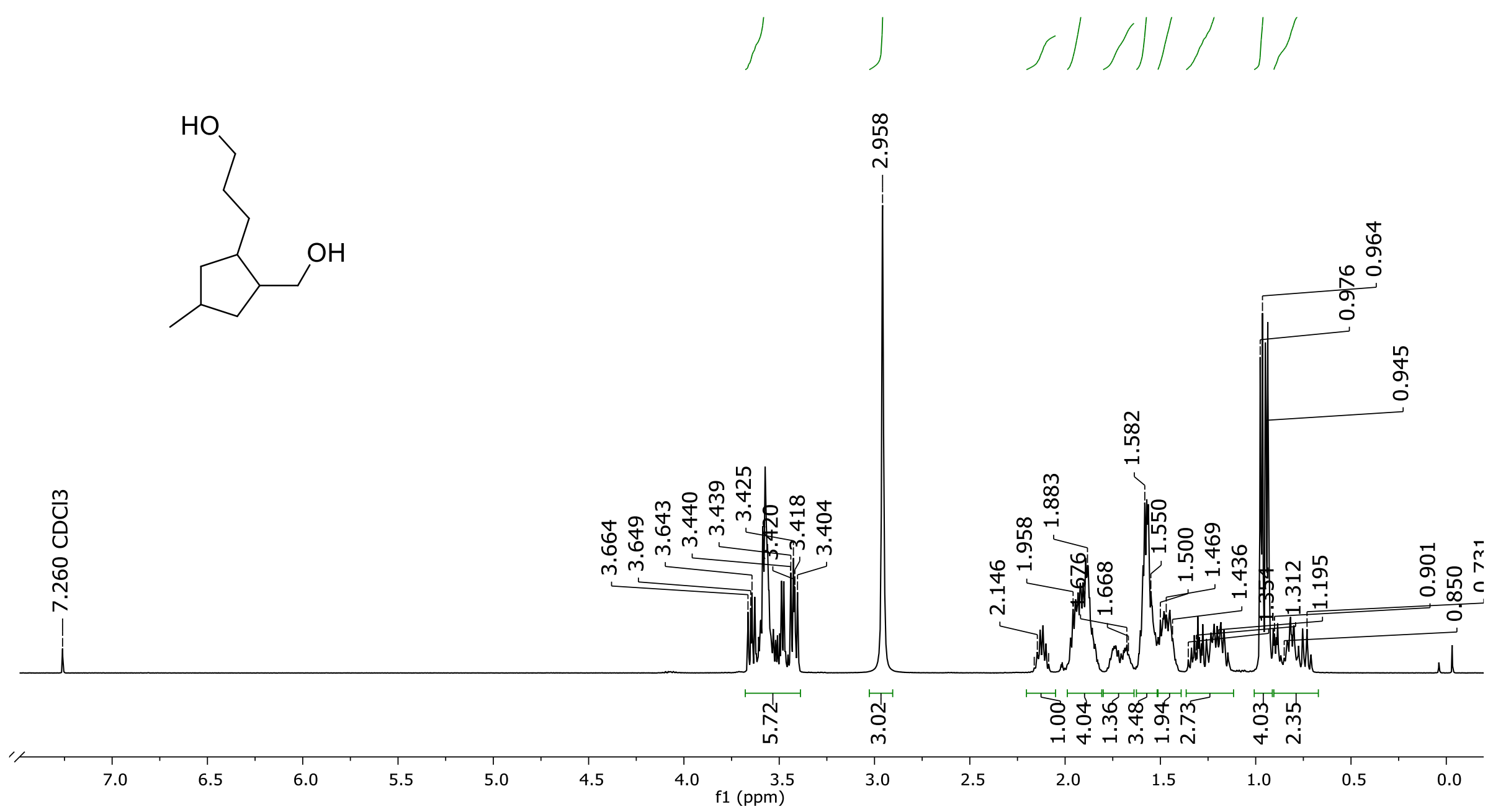




\section{Anexos}

\section{Espectro de RMN de ${ }^{13} \mathrm{C}$ do composto 15. Mistura diastereoisomérica}
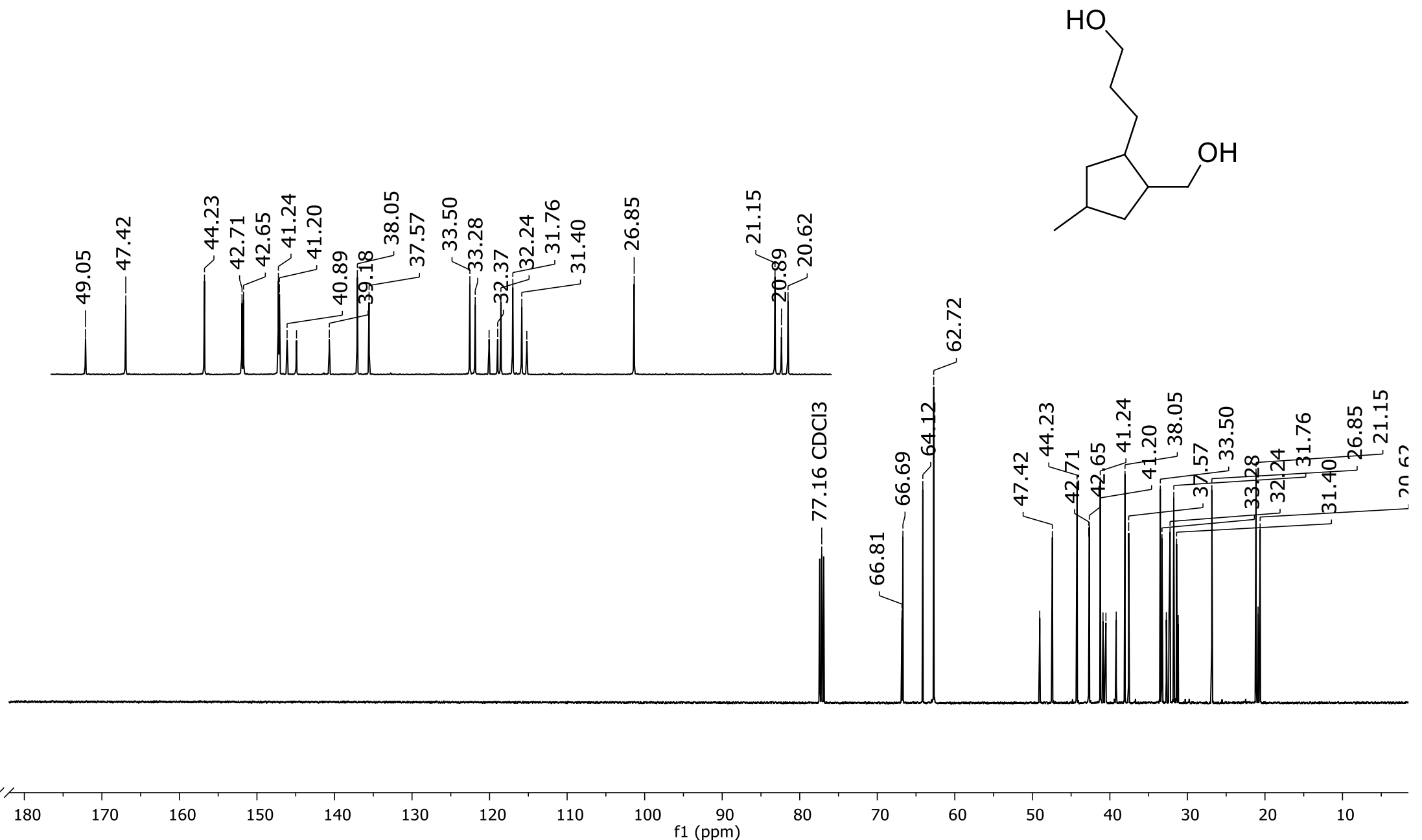
Anexos

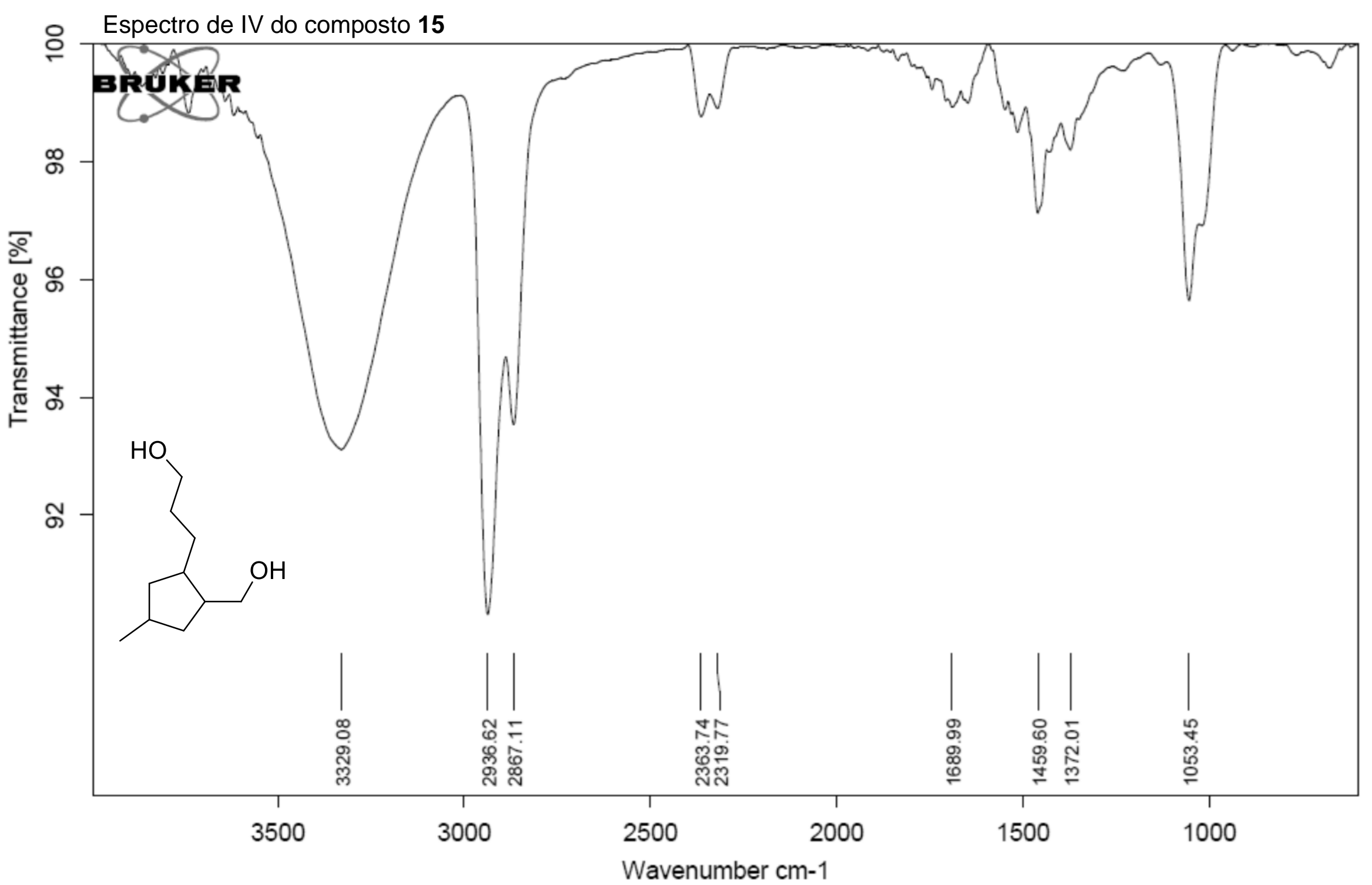




\section{Anexos}

\section{Espectro de $\mathrm{RMN}$ de ${ }^{1} \mathrm{H}$ do composto $17 \mathrm{a}$ e 17b. Mistura isómeros}

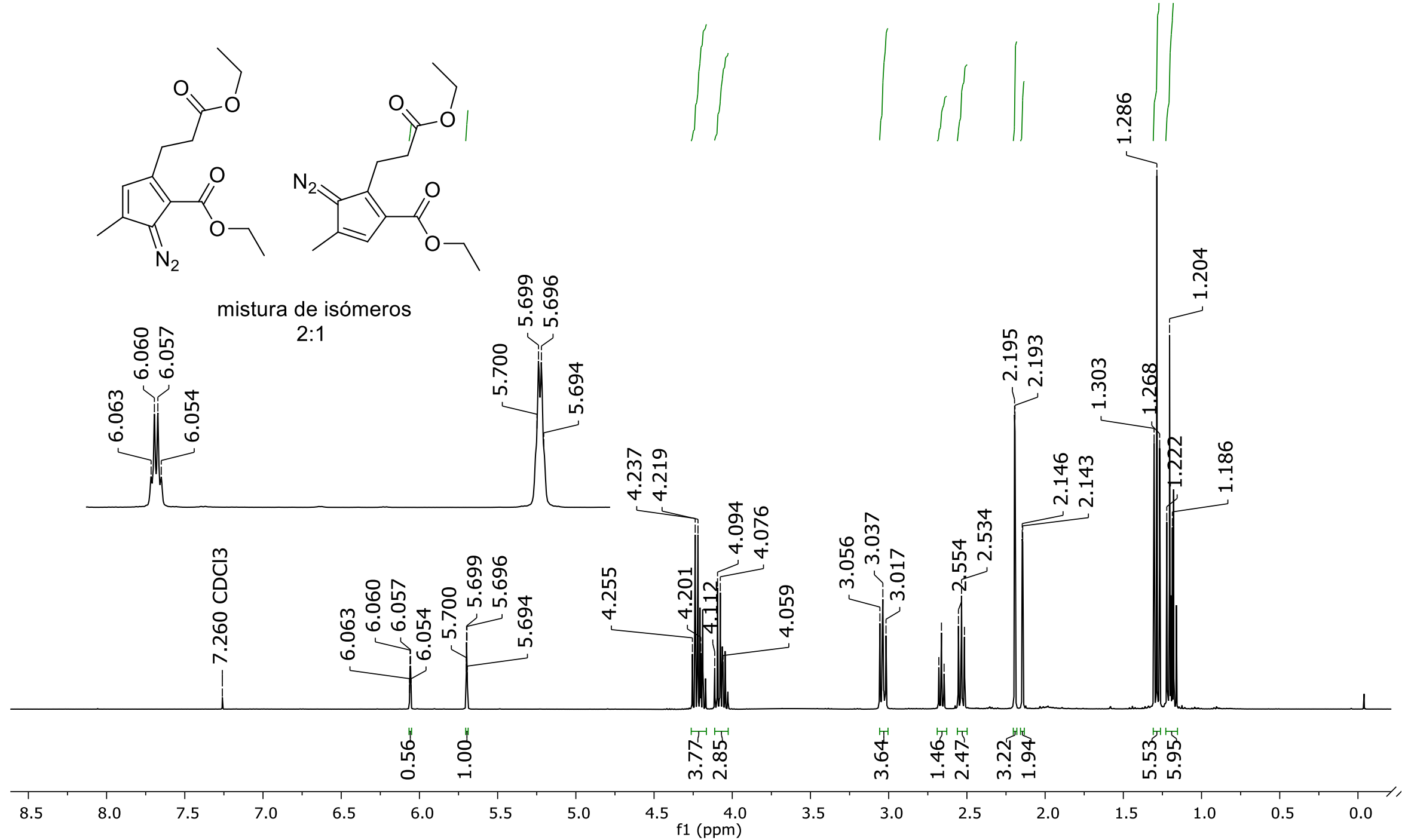




\section{Anexos}

\section{Espectro de $\mathrm{RMN}$ de ${ }^{13} \mathrm{C}$ do composto $17 \mathrm{a}$ e 17b. Mistura isómeros}

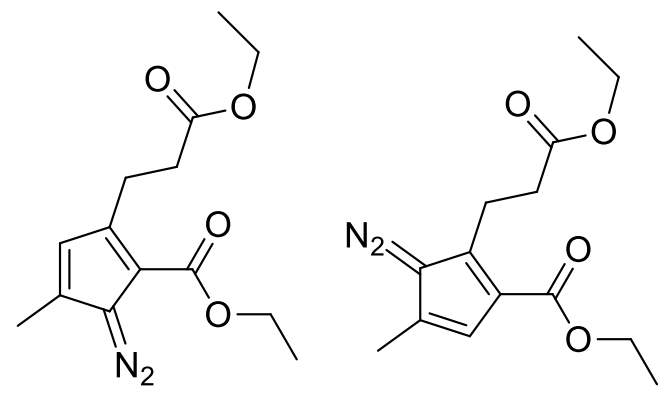

mistura de isómeros

2:1
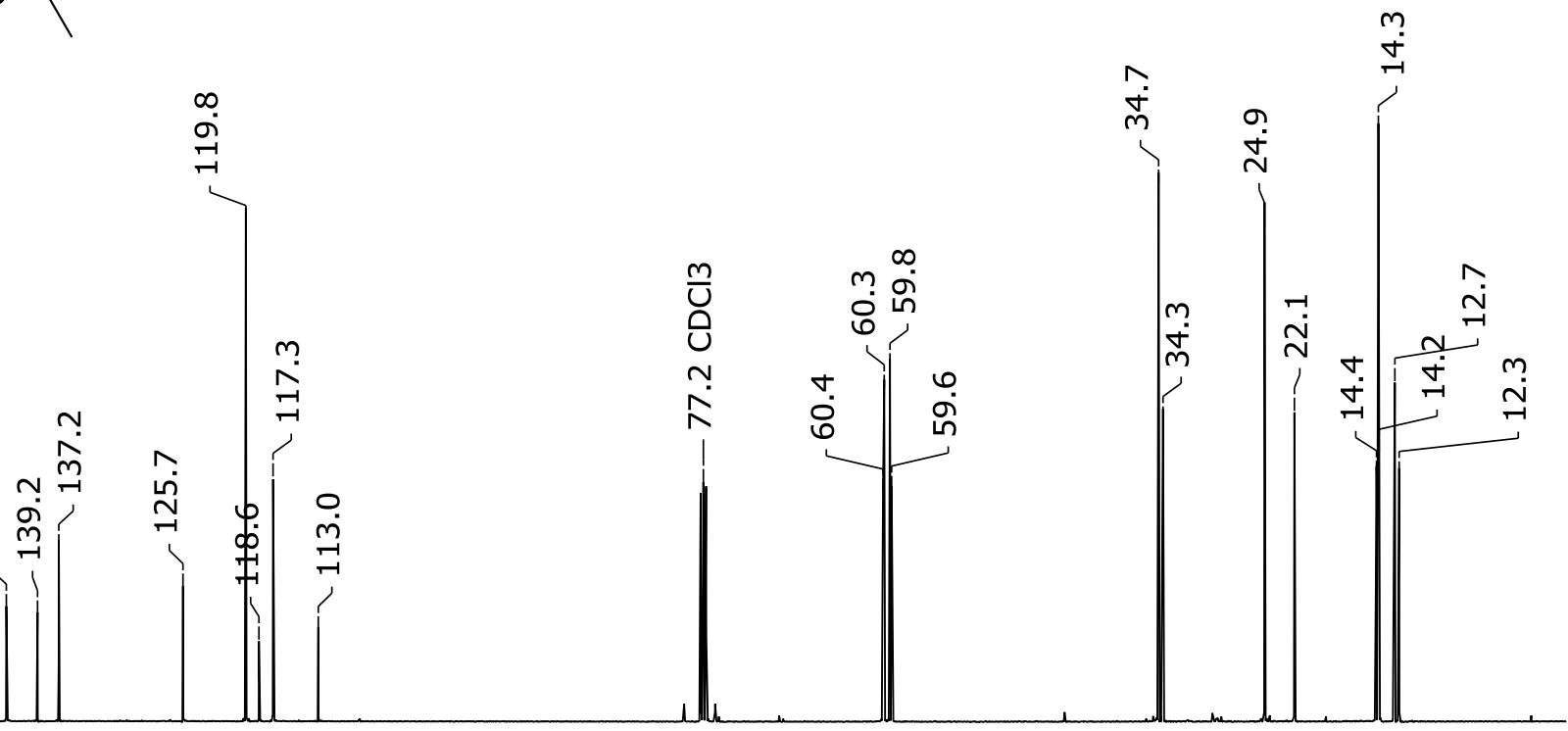
Anexos

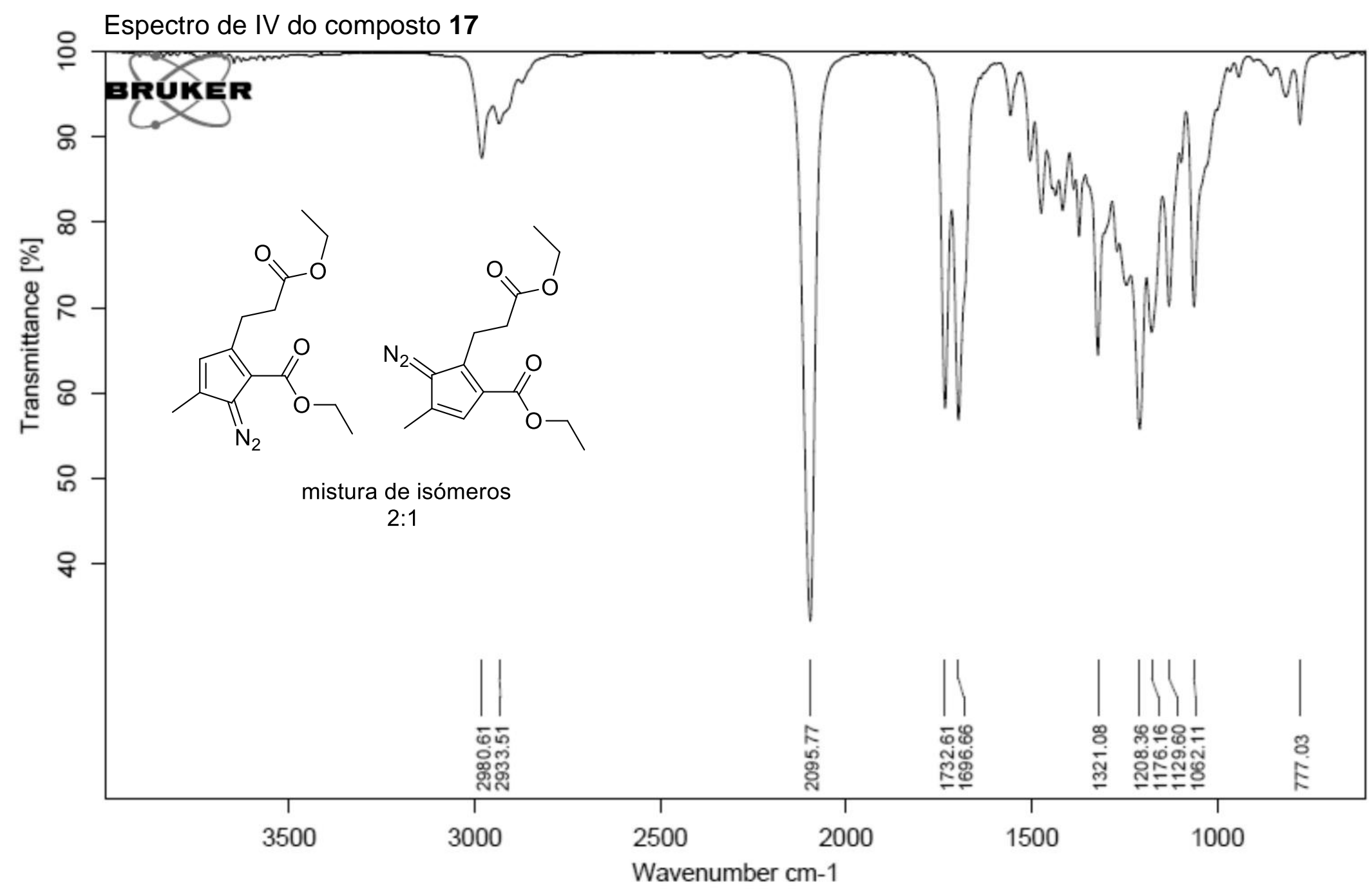




\section{Anexos}

Espectro de RMN de ${ }^{1} \mathrm{H}$ do composto 18. Mistura de diastereoisômeros
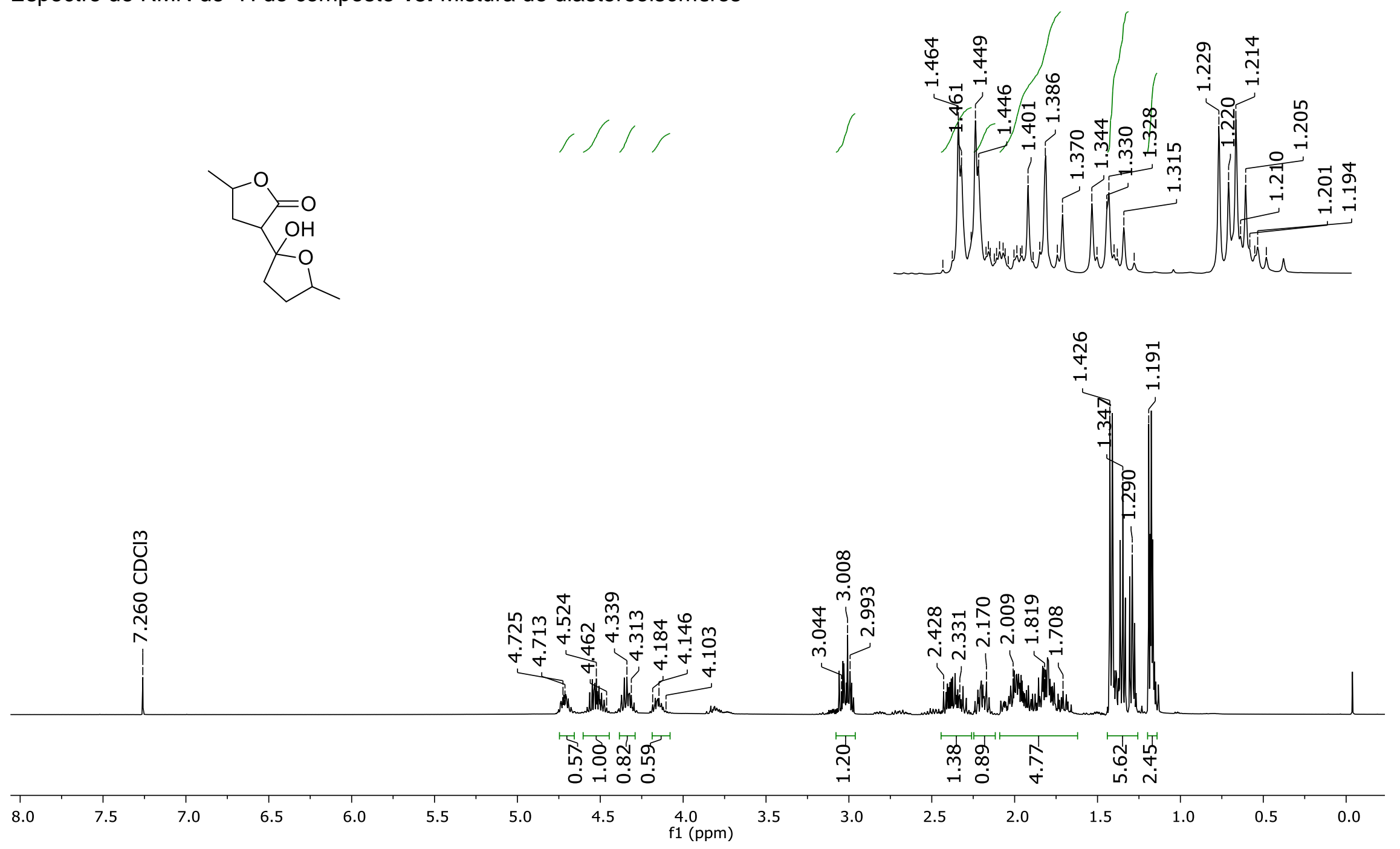


\section{Anexos}

\section{Espectro de RMN de ${ }^{13} \mathrm{C}$ do composto 18. Mistura de diastereoisômeros}
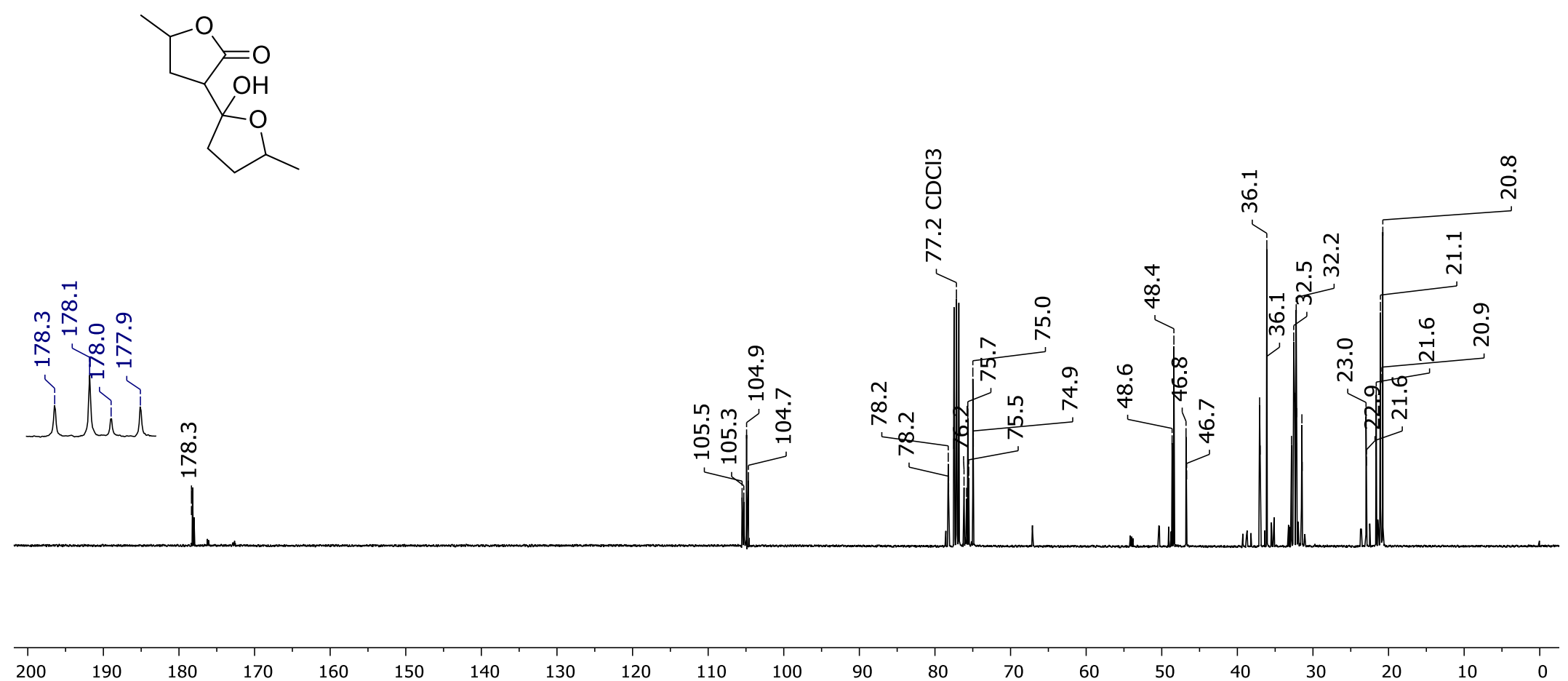

160

$50 \quad 140$

120

$110 \quad 100$

f1 (ppm) 
Anexos

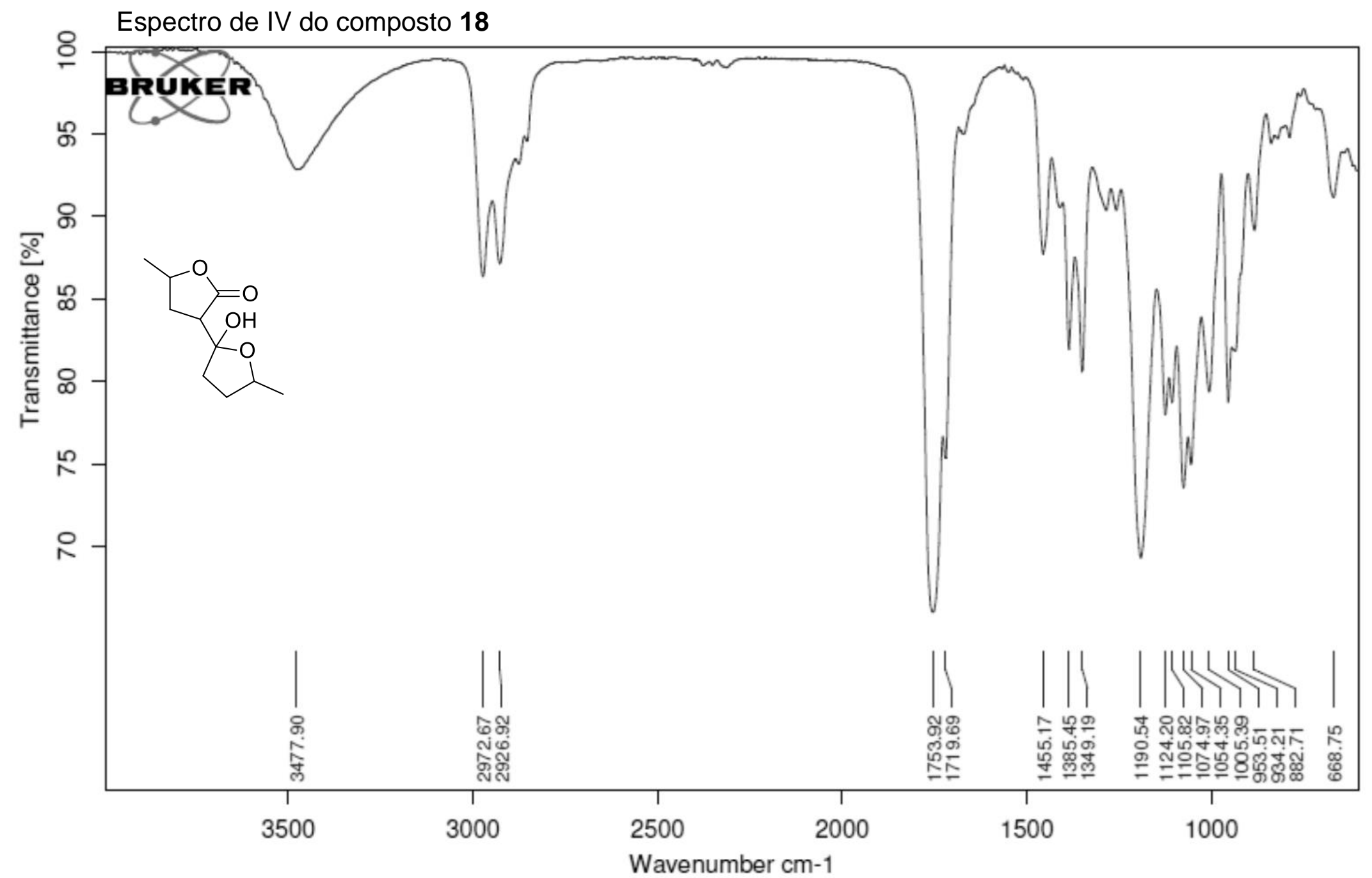




\section{Anexos}

\section{Espectro de RMN de ${ }^{1} \mathrm{H}$ do composto 19. Mistura de diastereoisômeros}
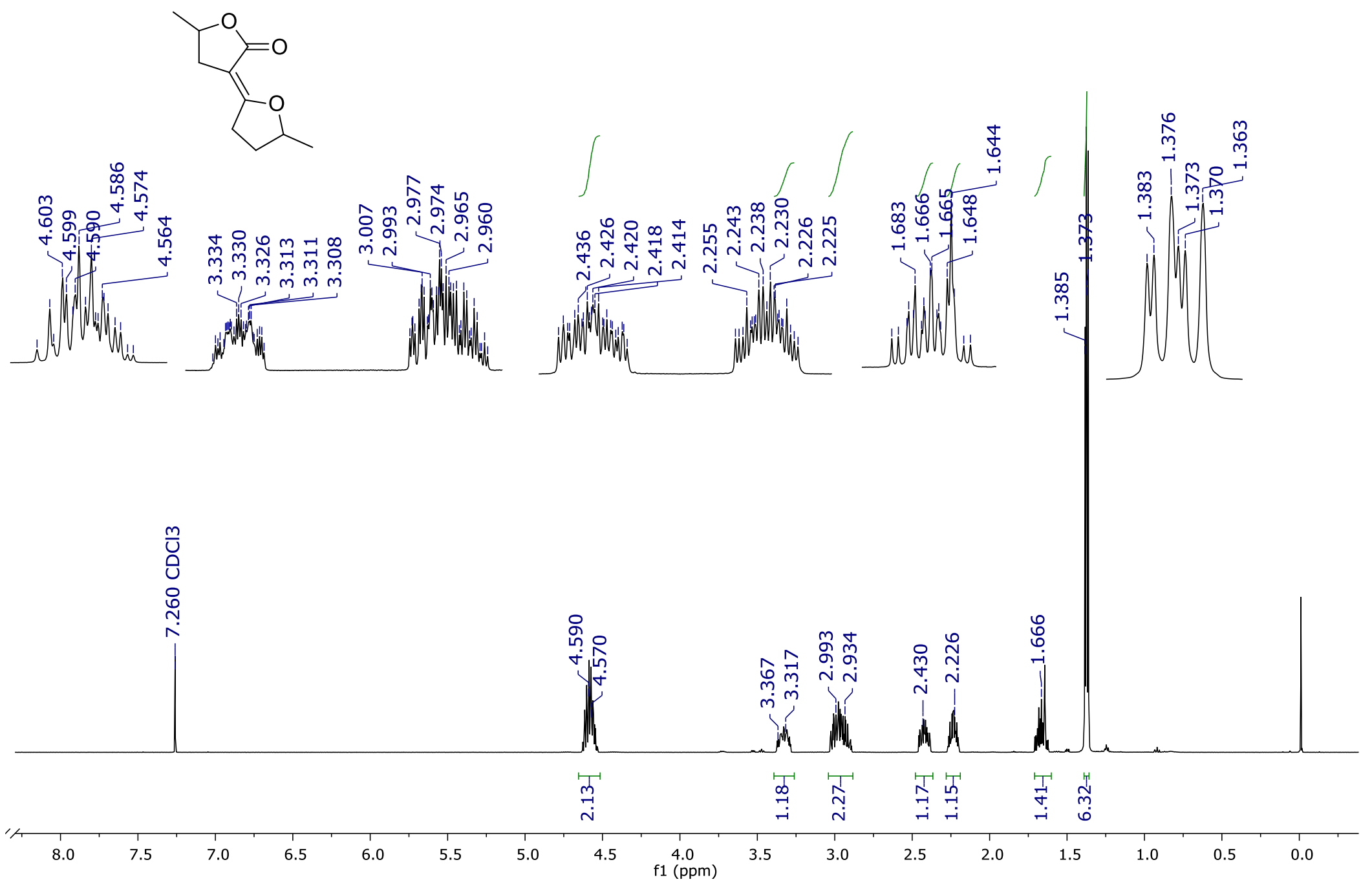


\section{Anexos}

\section{Espectro de RMN de ${ }^{13} \mathrm{C}$ do composto 19. Mistura de diastereoisômeros}
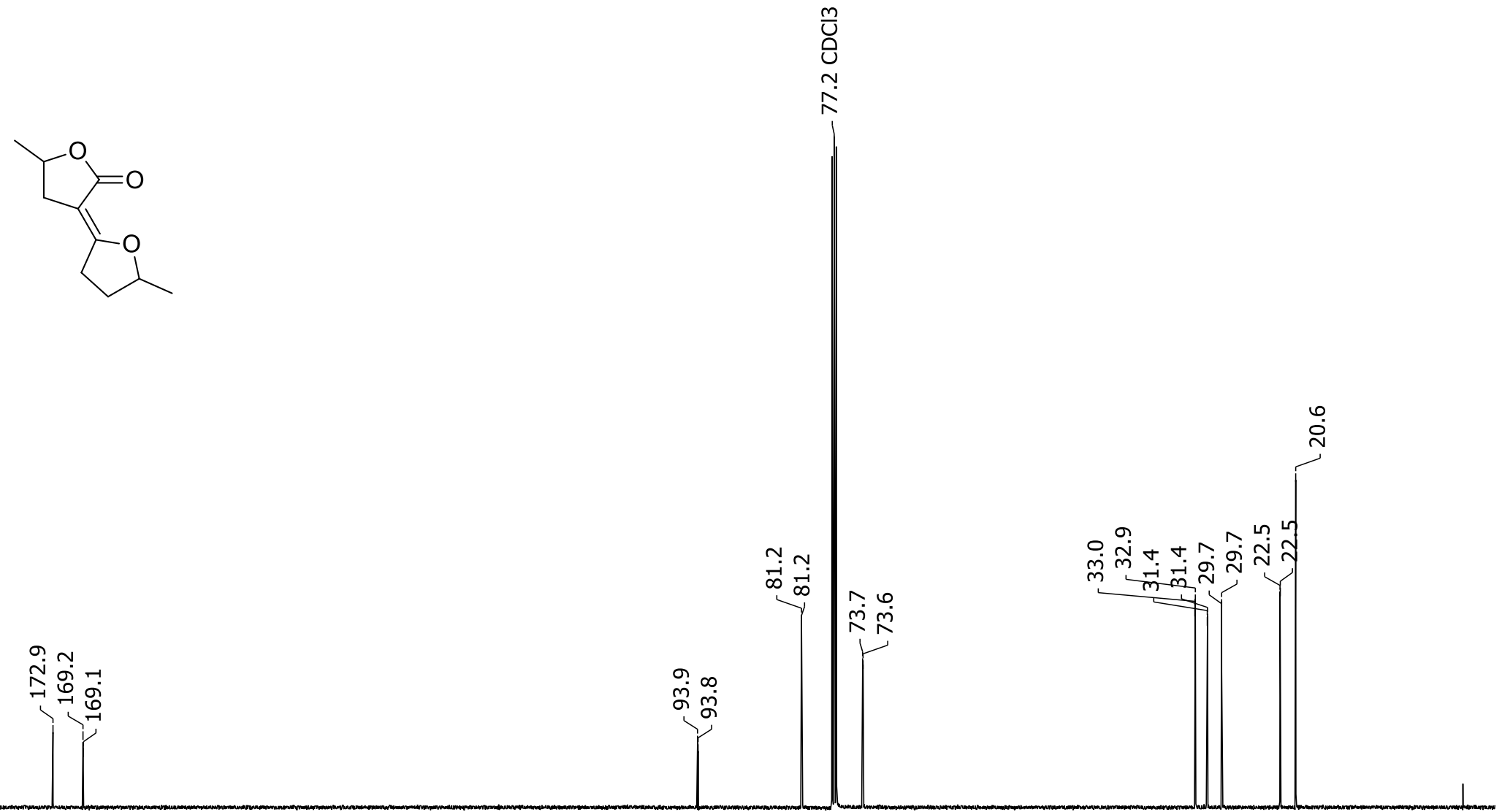

180

160

150

$140 \quad 130$

120

110

$100 \quad 90$

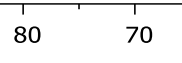

$60 \quad 50$

40

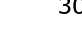


Anexos

Espectro de IV do composto 19

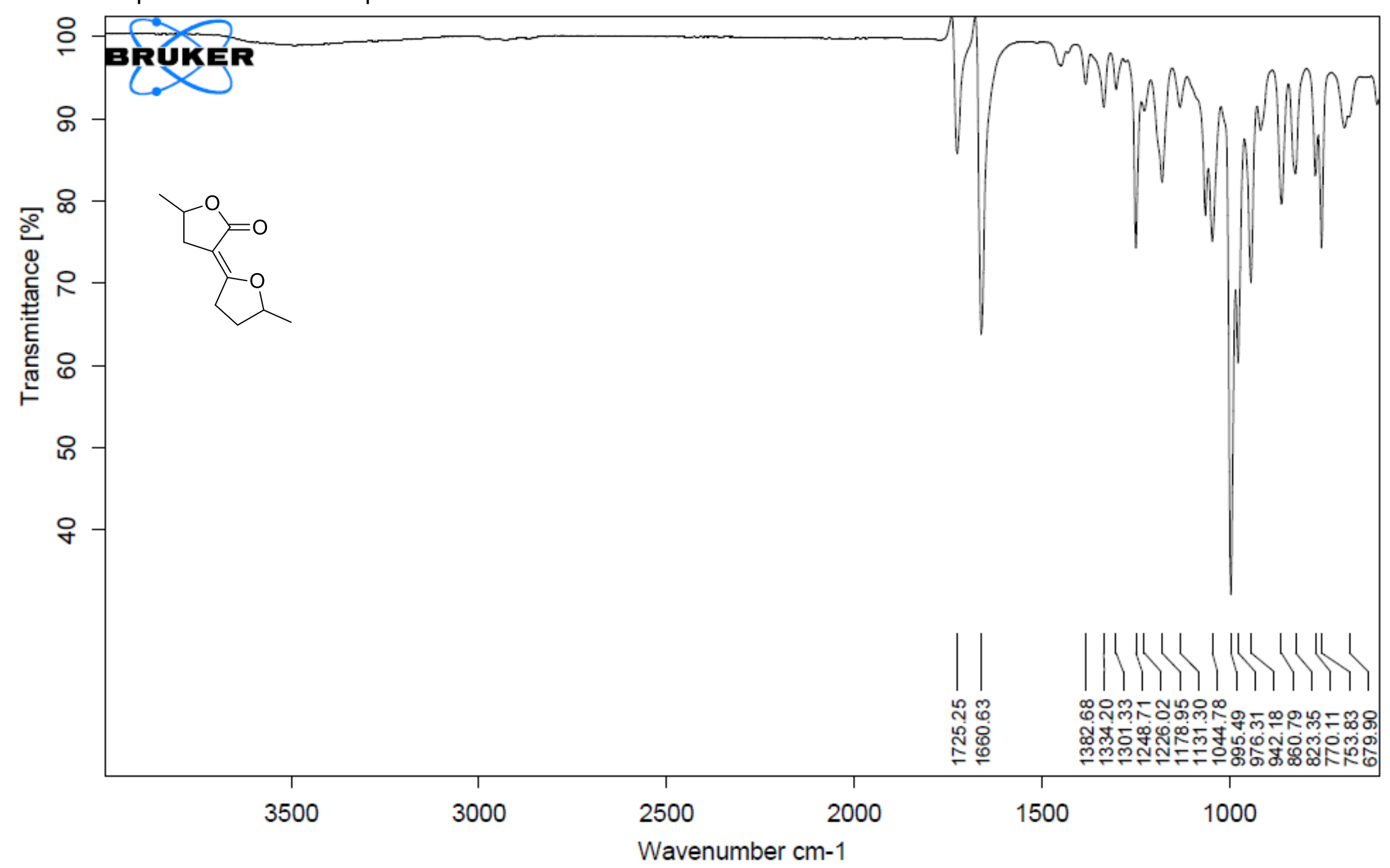




\section{Anexos}

Espectro de RMN de ${ }^{1} \mathrm{H}$ do composto 20. Mistura de diastereoisômeros

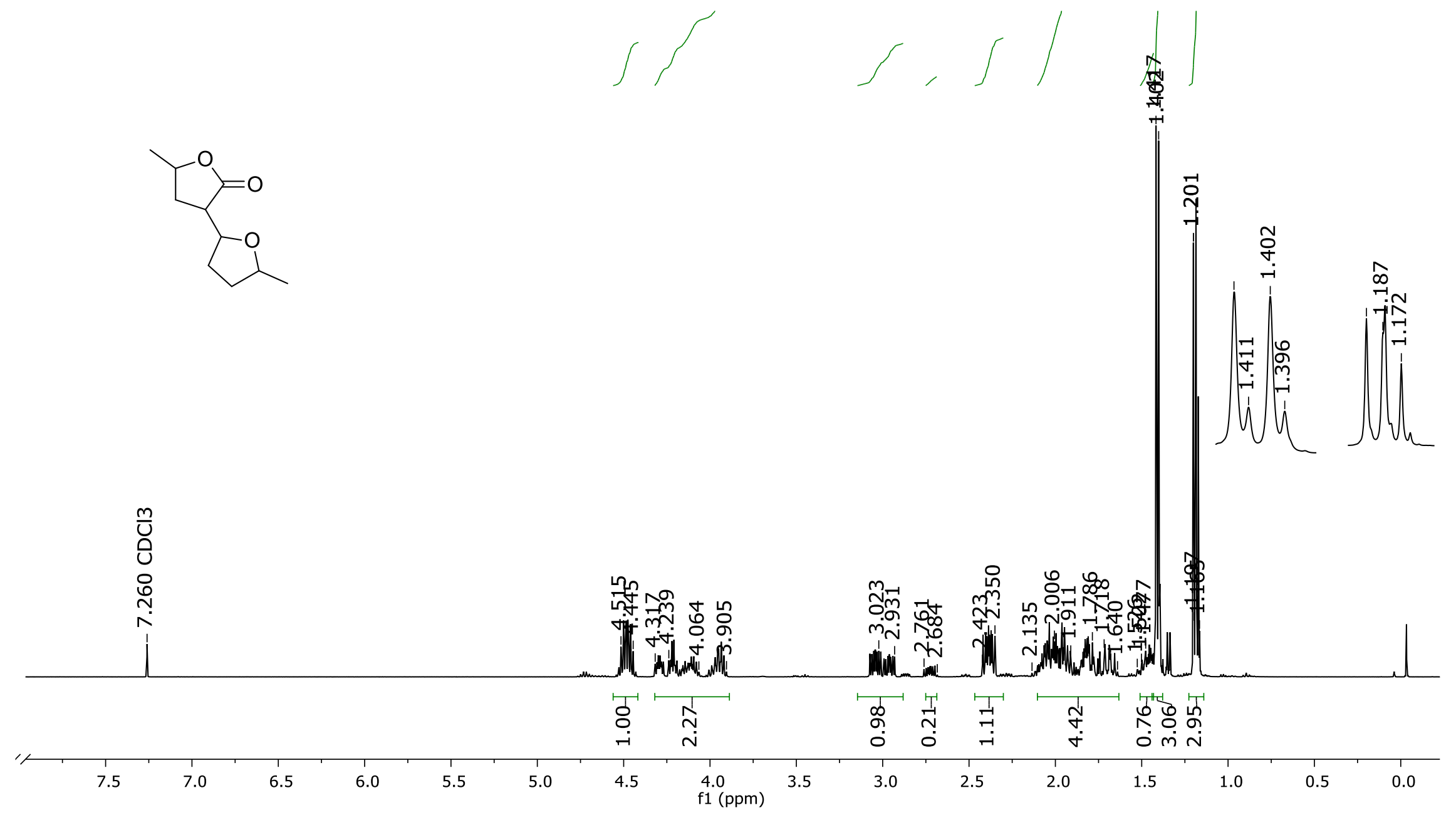




\section{Anexos}

Espectro de RMN de ${ }^{13} \mathrm{C}$ do composto 20. Mistura de diastereoisômeros
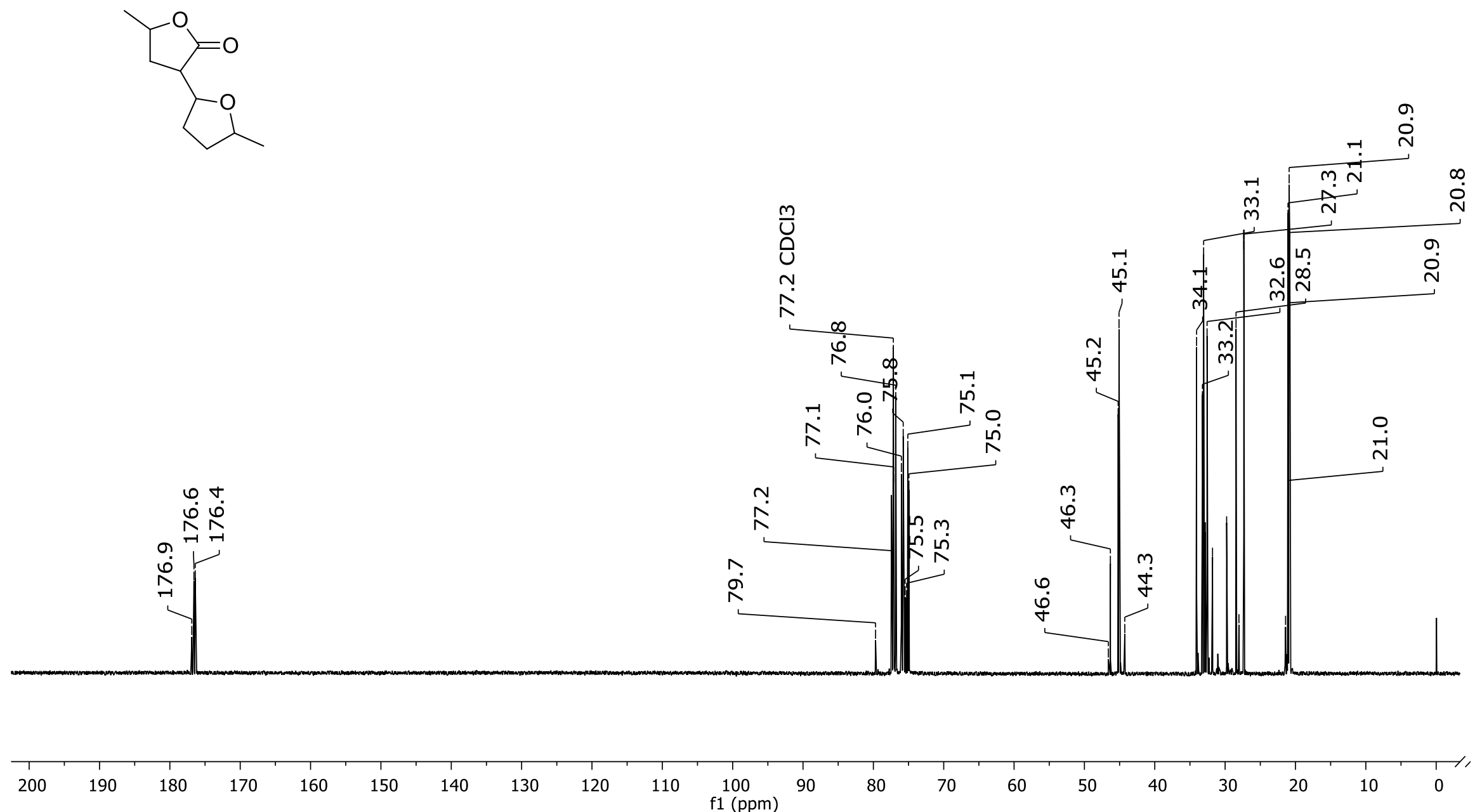
$\underline{\text { Anexos }}$

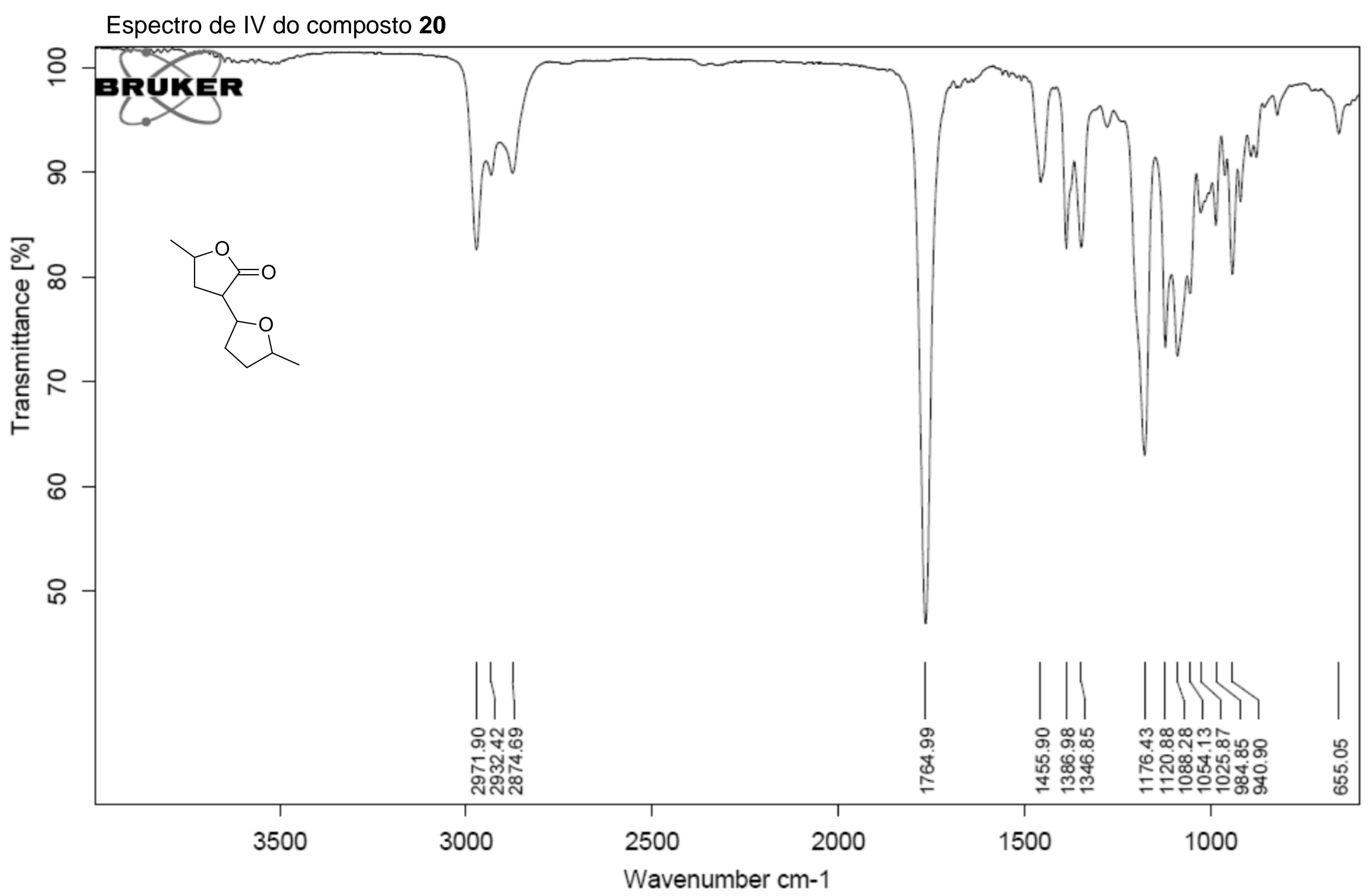




\section{Anexos}

\section{Espectro de RMN de ${ }^{1} \mathrm{H}$ do composto 21. Mistura de diastereoisômeros}
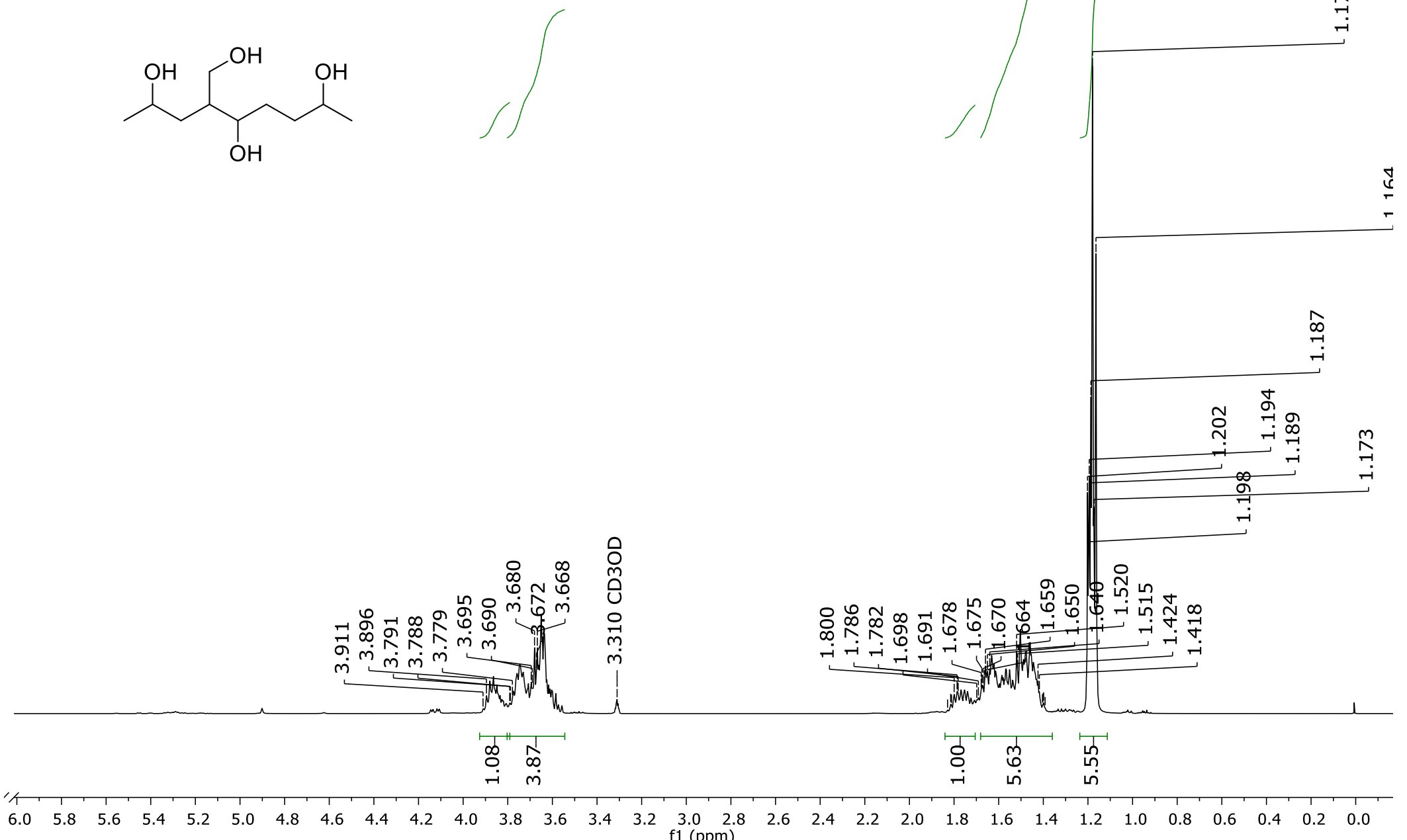


\section{Anexos}

\section{Espectro de RMN de ${ }^{13} \mathrm{C}$ do composto 21. Mistura de diastereoisômeros}

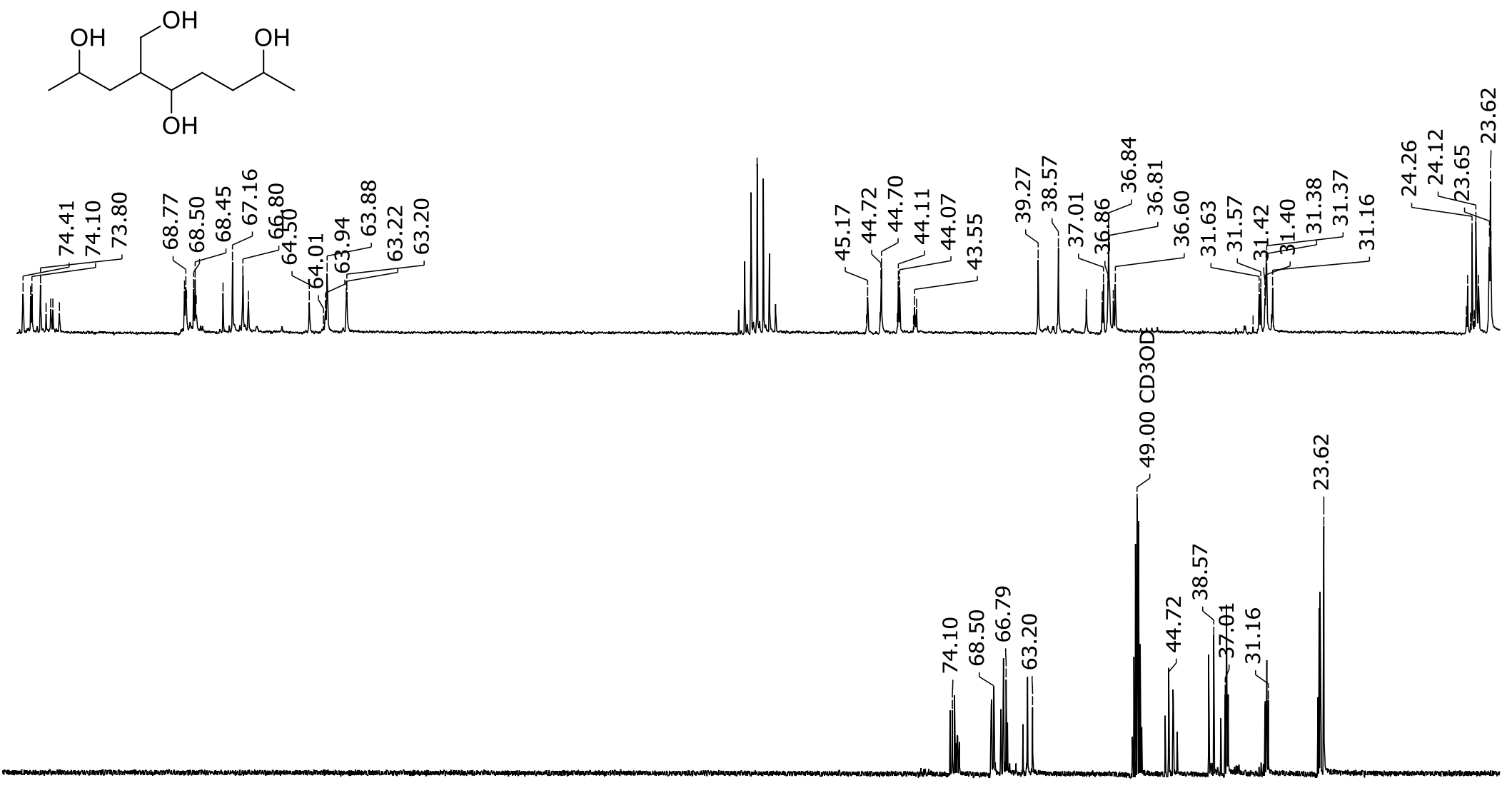


Anexos

Espectro de IV do composto $\mathbf{2 1}$

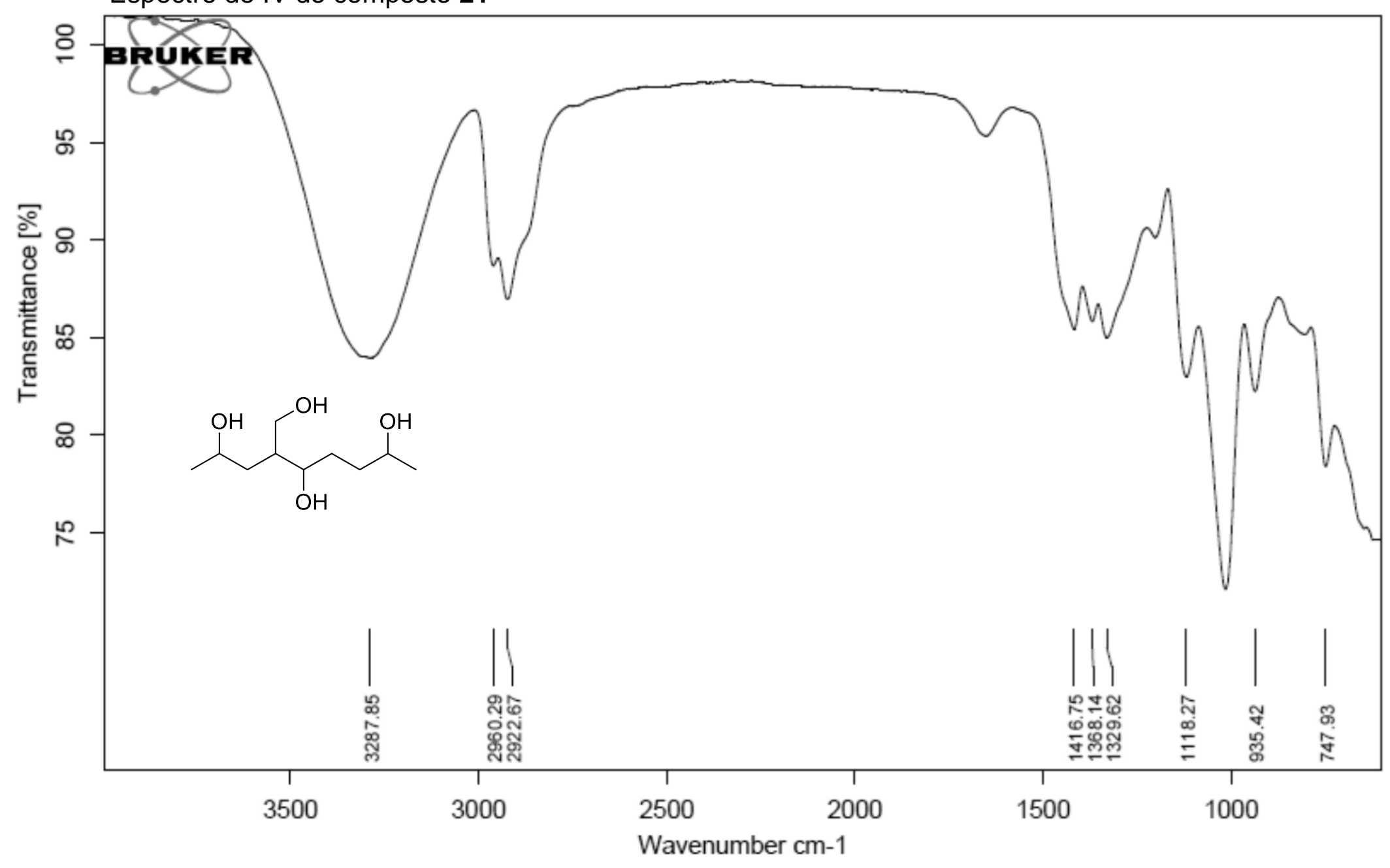




\section{Anexos}

\section{Espectro de RMN de ${ }^{1} \mathrm{H}$ do composto 22. Mistura de diastereoisômeros}

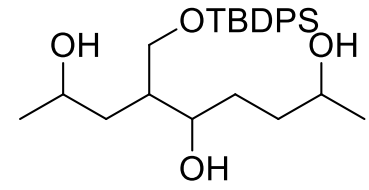

ตู้ ํ.

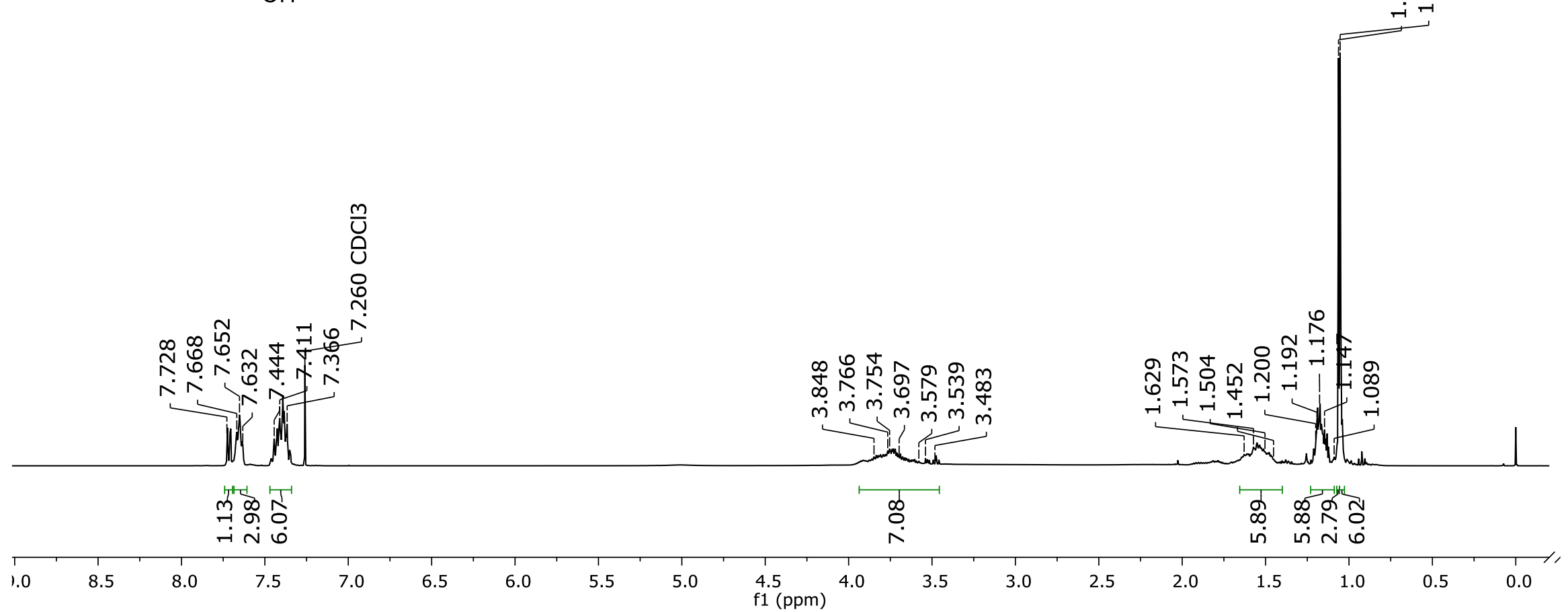




\section{Anexos}

Espectro de RMN de ${ }^{13} \mathrm{C}$ do composto 22. Mistura de diastereoisômeros

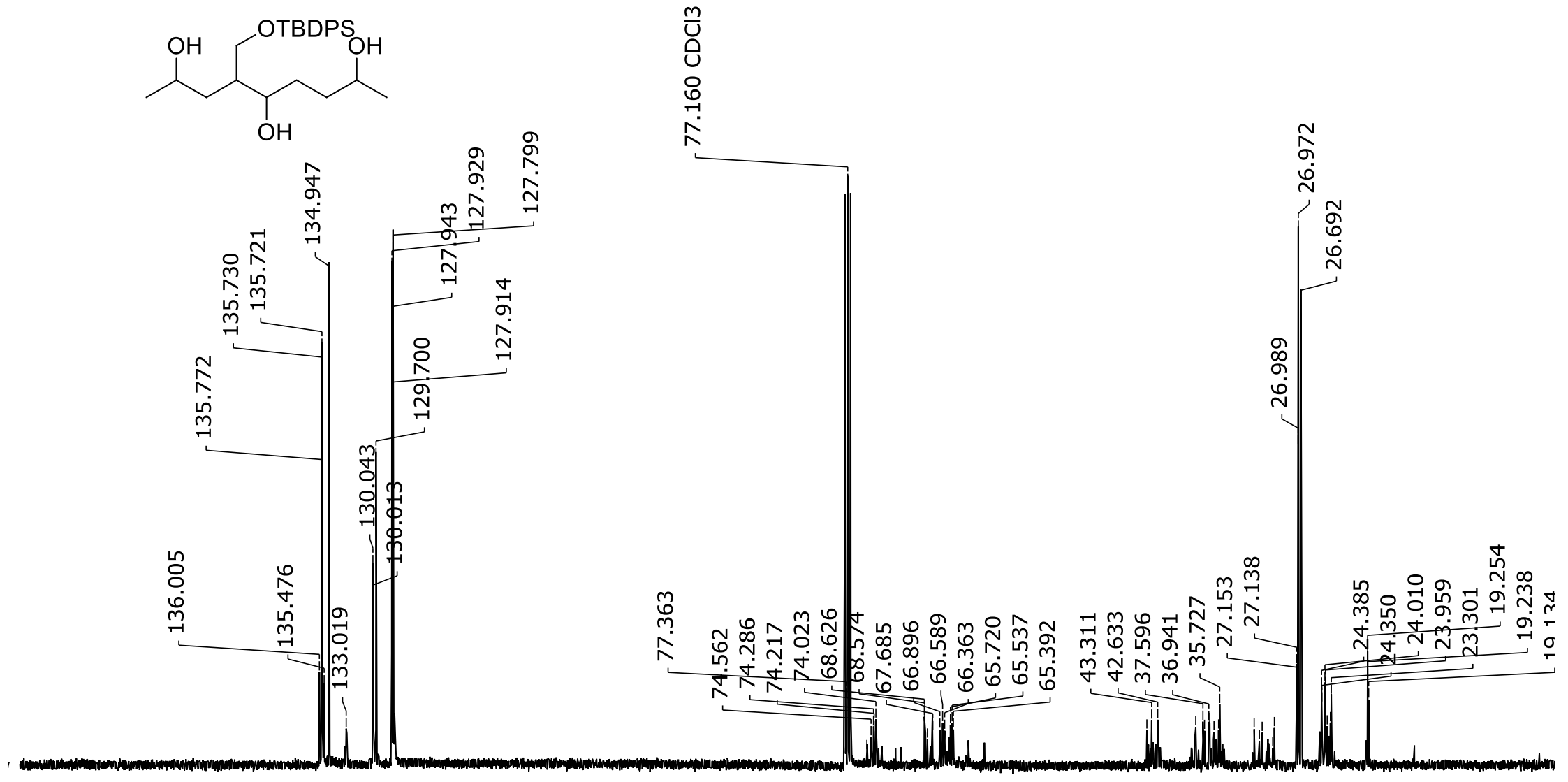

$160 \quad 150 \quad 140$

130

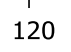

110

100

$90{ }_{\mathrm{f} 1(\mathrm{ppm})}^{80}$

60

50

40

30

20

$10 \quad 0$ 
Anexos

Espectro de IV do composto 22

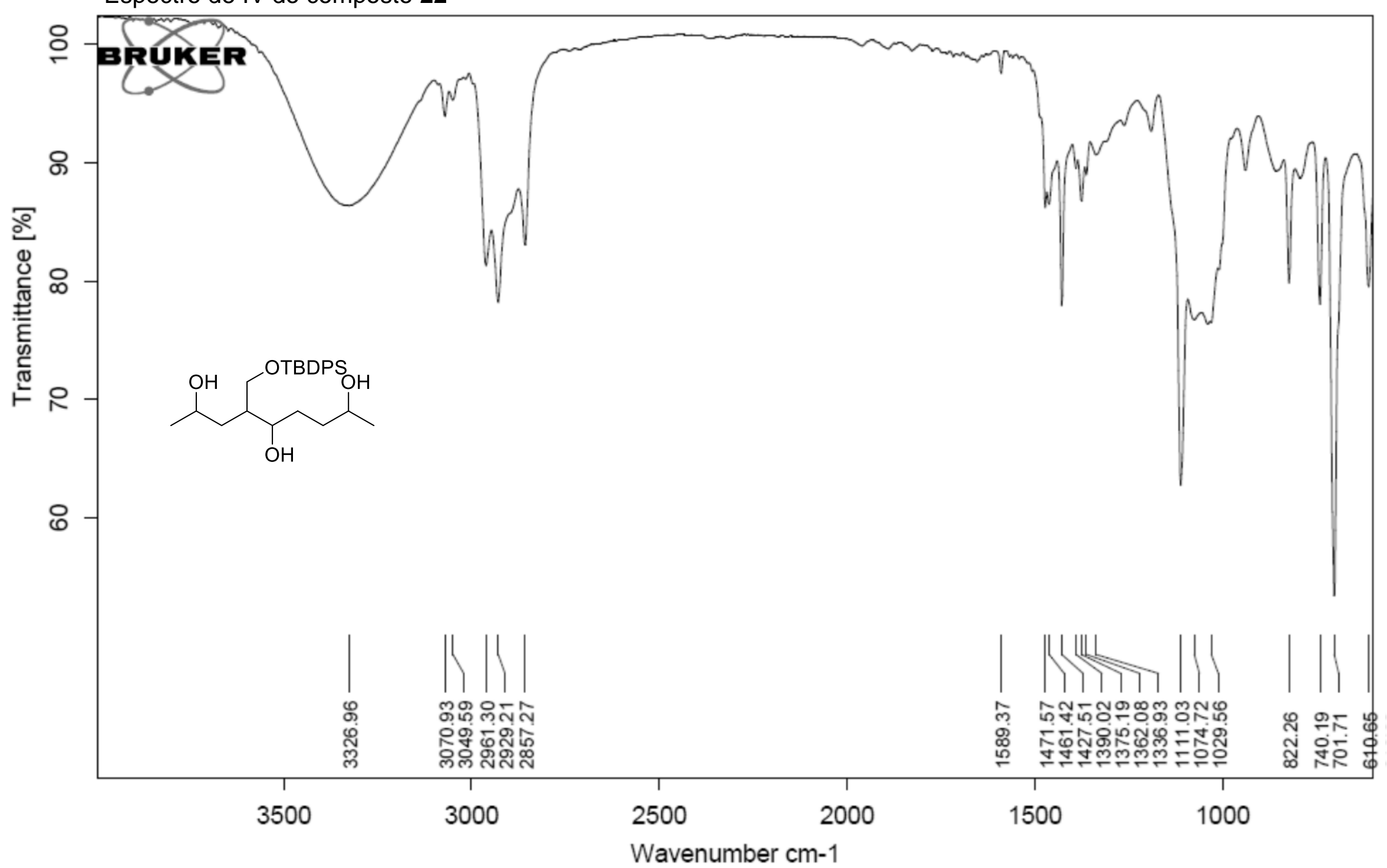




\section{Anexos}

\section{Espectro de RMN de ${ }^{1} \mathrm{H}$ do composto 23. Mistura de diastereoisômeros}<smiles>CC(=O)CCC(=O)C(CO[Pb])CC(C)=O</smiles>
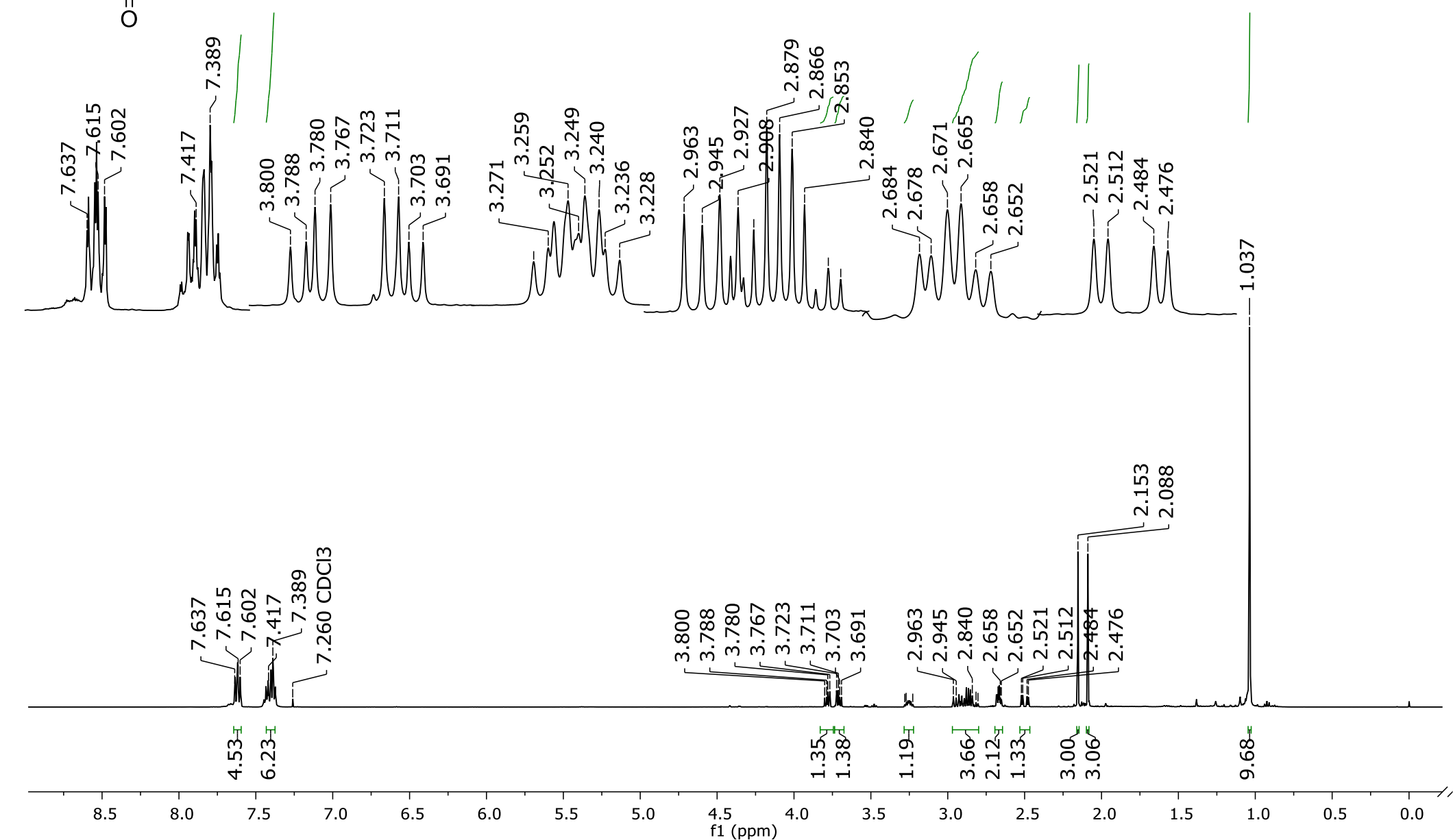


\section{Anexos}

\section{Espectro de RMN de ${ }^{13} \mathrm{C}$ do composto 23. Mistura de diastereoisômeros}
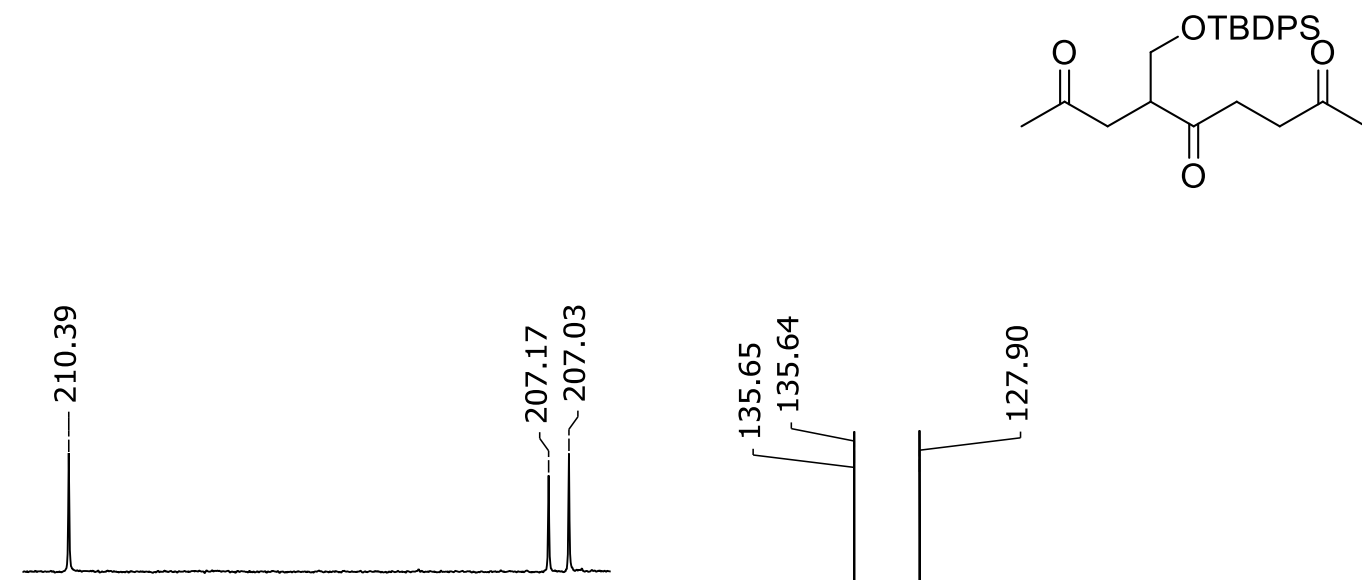

ลุำ

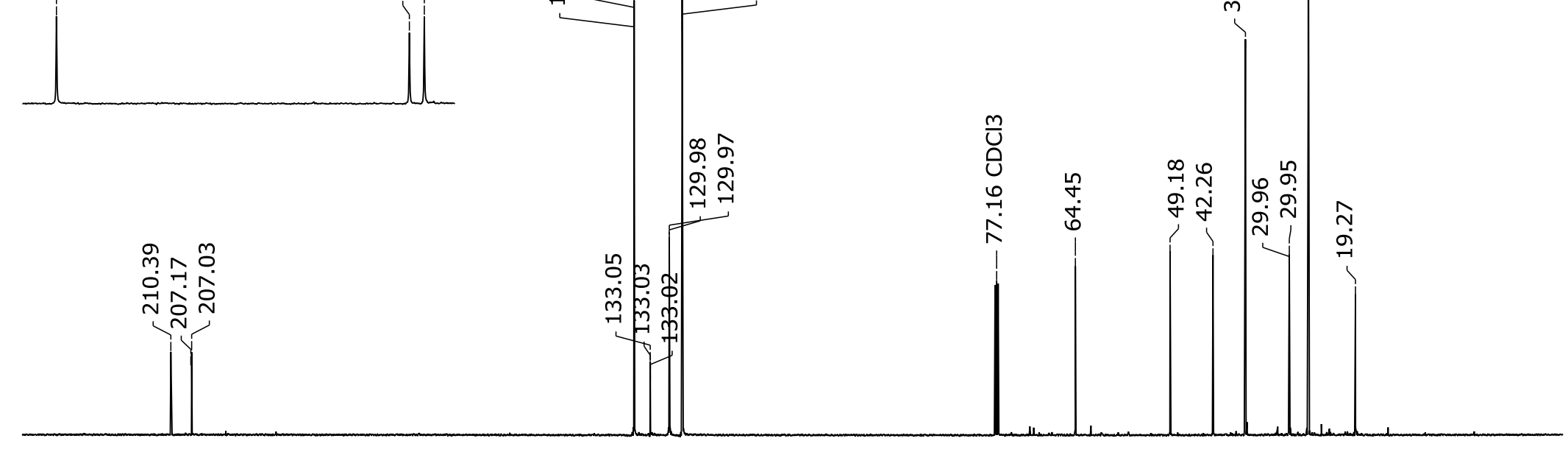

$\stackrel{1}{2}$

$230 \quad 220$

210200

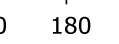

$\begin{array}{llll}70 & 160 & 150 & 140\end{array}$ $30 \quad 120 \underset{\mathrm{f} 1(\mathrm{ppm})}{110} 100$ 
$\underline{\text { Anexos }}$

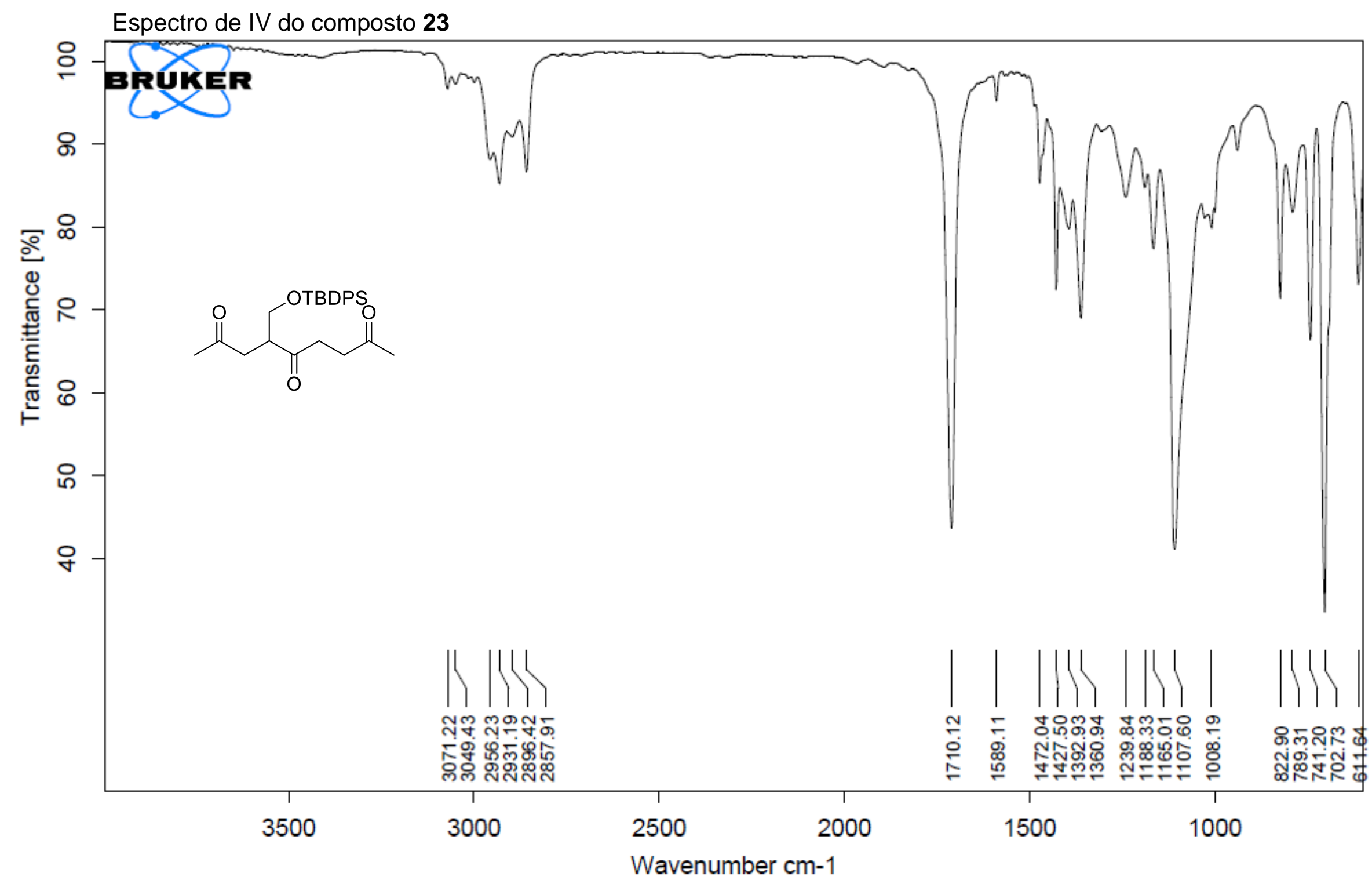


Espectro de RMN de ${ }^{1} \mathrm{H}$ do composto 24. Mistura de diastereoisômero
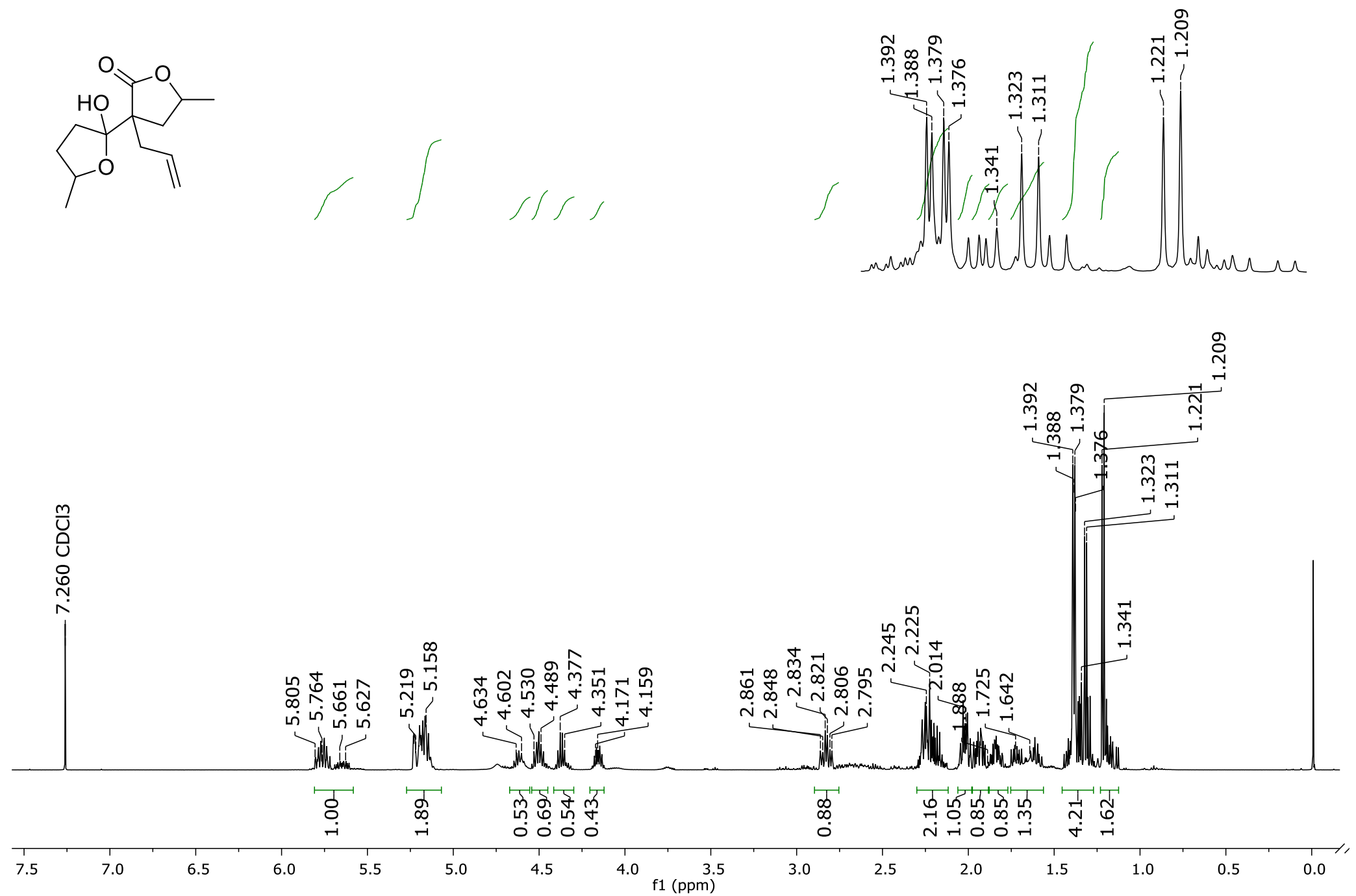


\section{Anexos}

\section{Espectro de RMN de ${ }^{13} \mathrm{C}$ do composto 24. Mistura de diastereoisômeros}
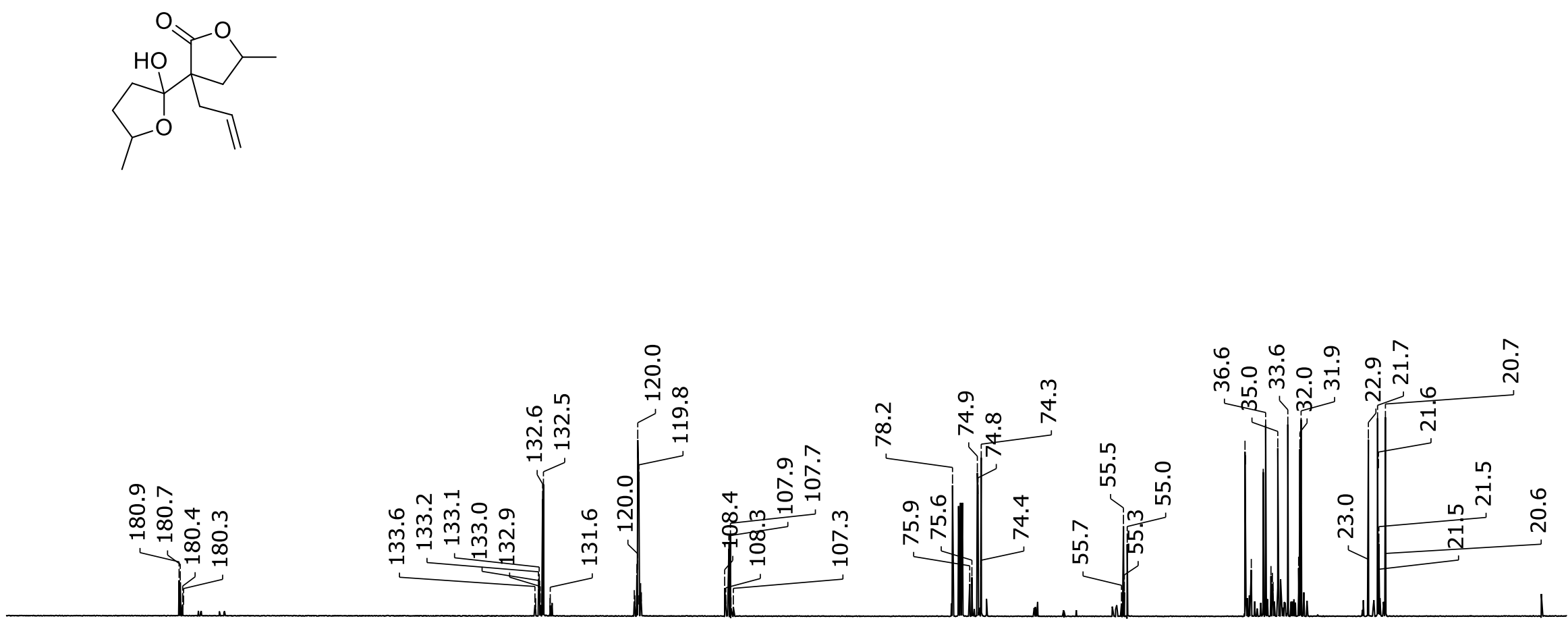

$200 \quad 190 \quad 180$

160

$150 \quad 140$

130

120

$110 \quad \begin{aligned} & 100 \\ & \mathrm{f} 1(\mathrm{ppm})\end{aligned}$

$80 \quad 70 \quad 60$

50

40

30

20

100 
Anexos

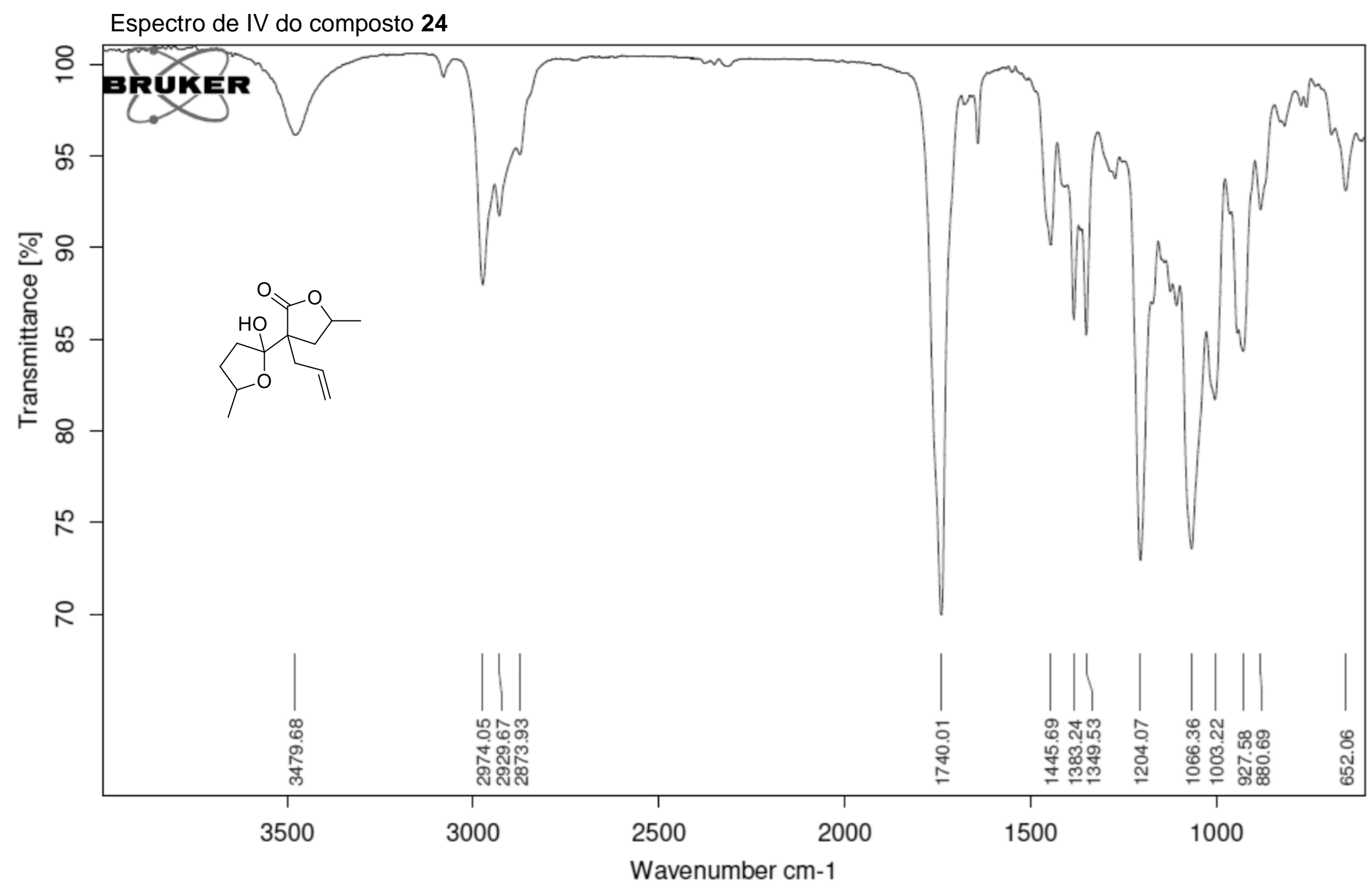




\section{Anexos}

Espectro de RMN de ${ }^{1} \mathrm{H}$ do composto 25. Mistura de diastereoisômeros

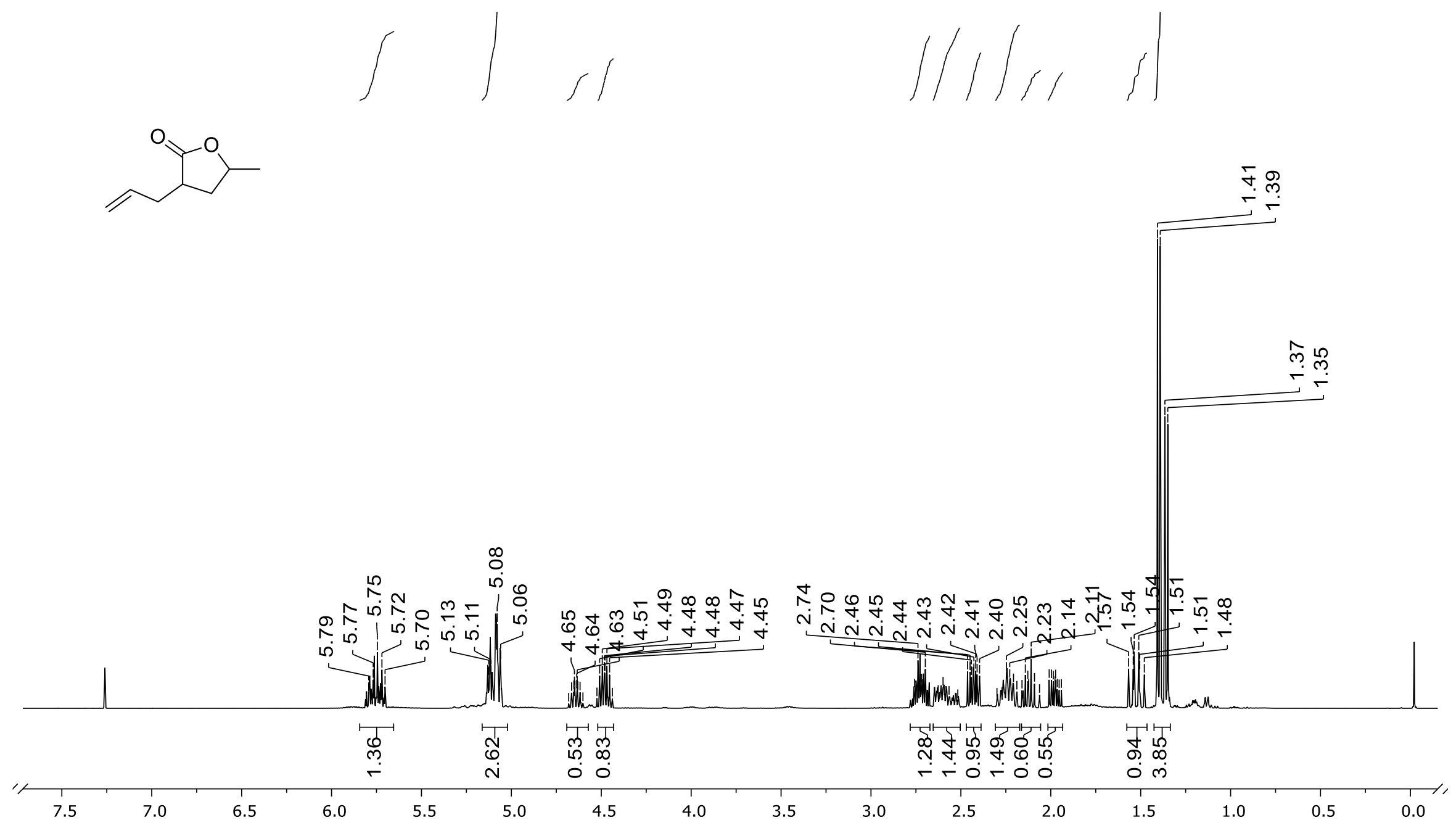




\section{Anexos}

\section{Espectro de RMN de ${ }^{13} \mathrm{C}$ do composto 25. Mistura de diastereoisômeros}
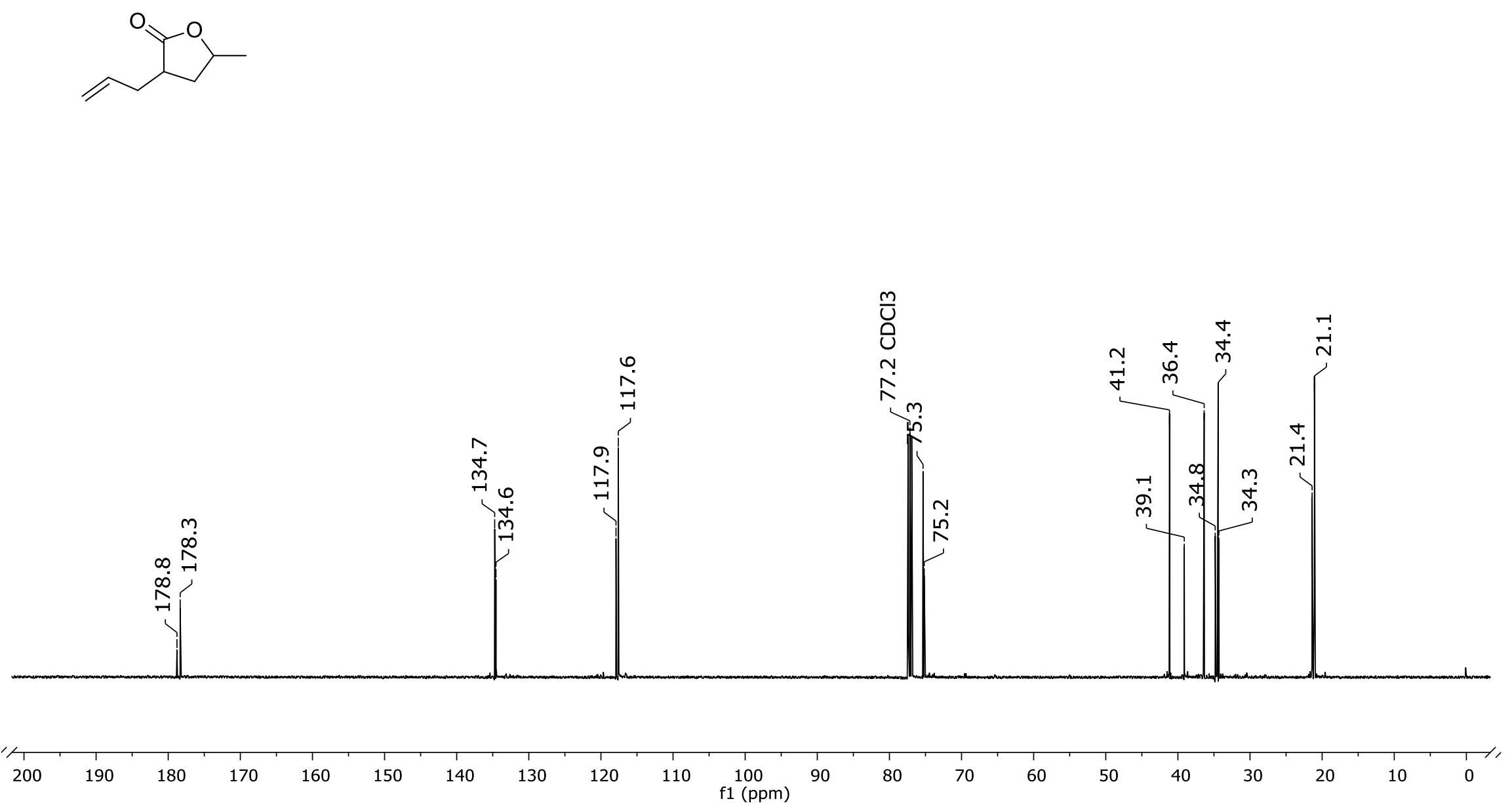
Anexos

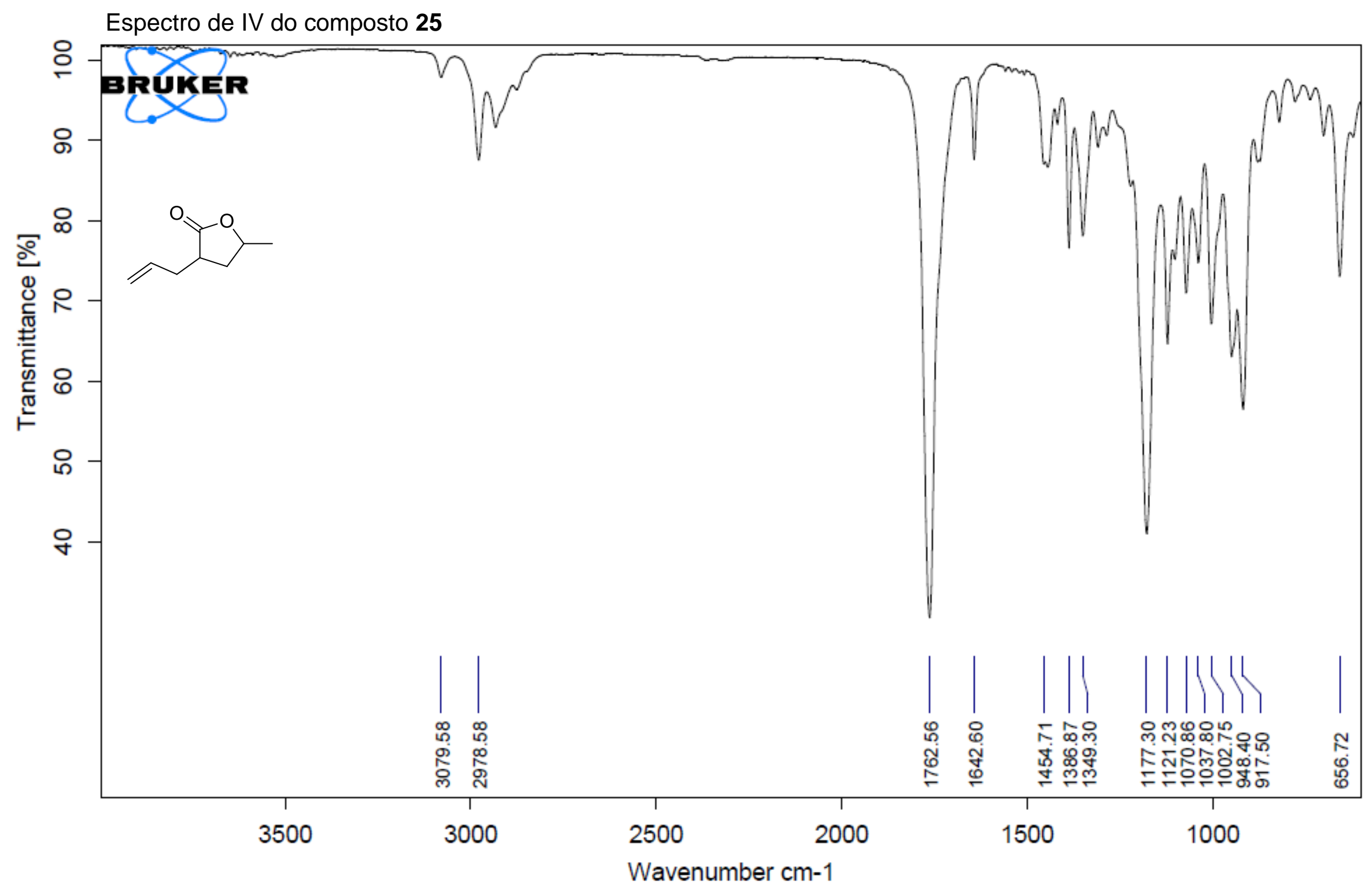




\section{Anexos}

\section{Espectro de RMN de ${ }^{1} \mathrm{H}$ do composto 26. Mistura de diastereoisômeros}
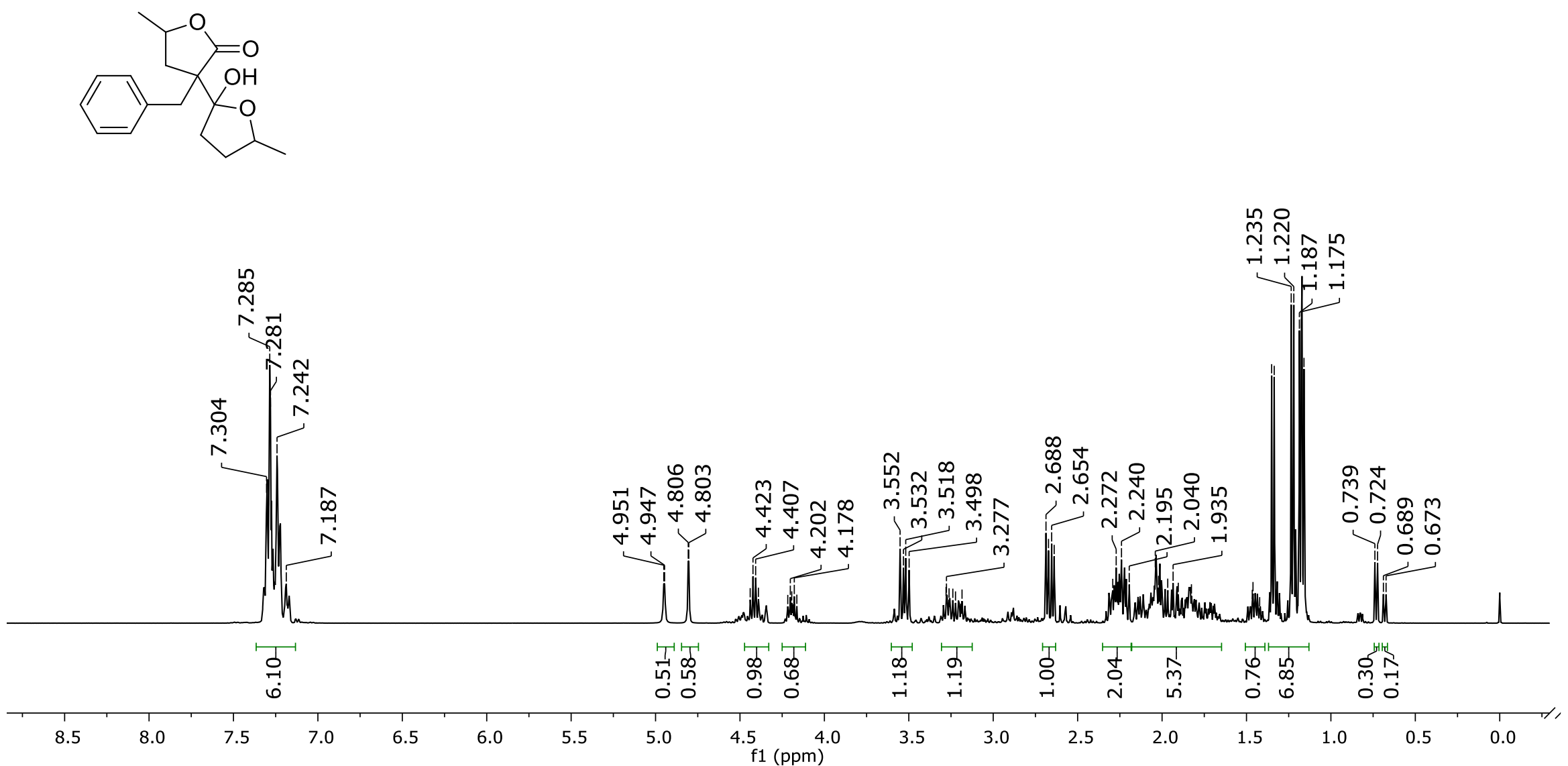


\section{Anexos}

Espectro de RMN de ${ }^{13} \mathrm{C}$ do composto 26. Mistura de diastereoisômeros

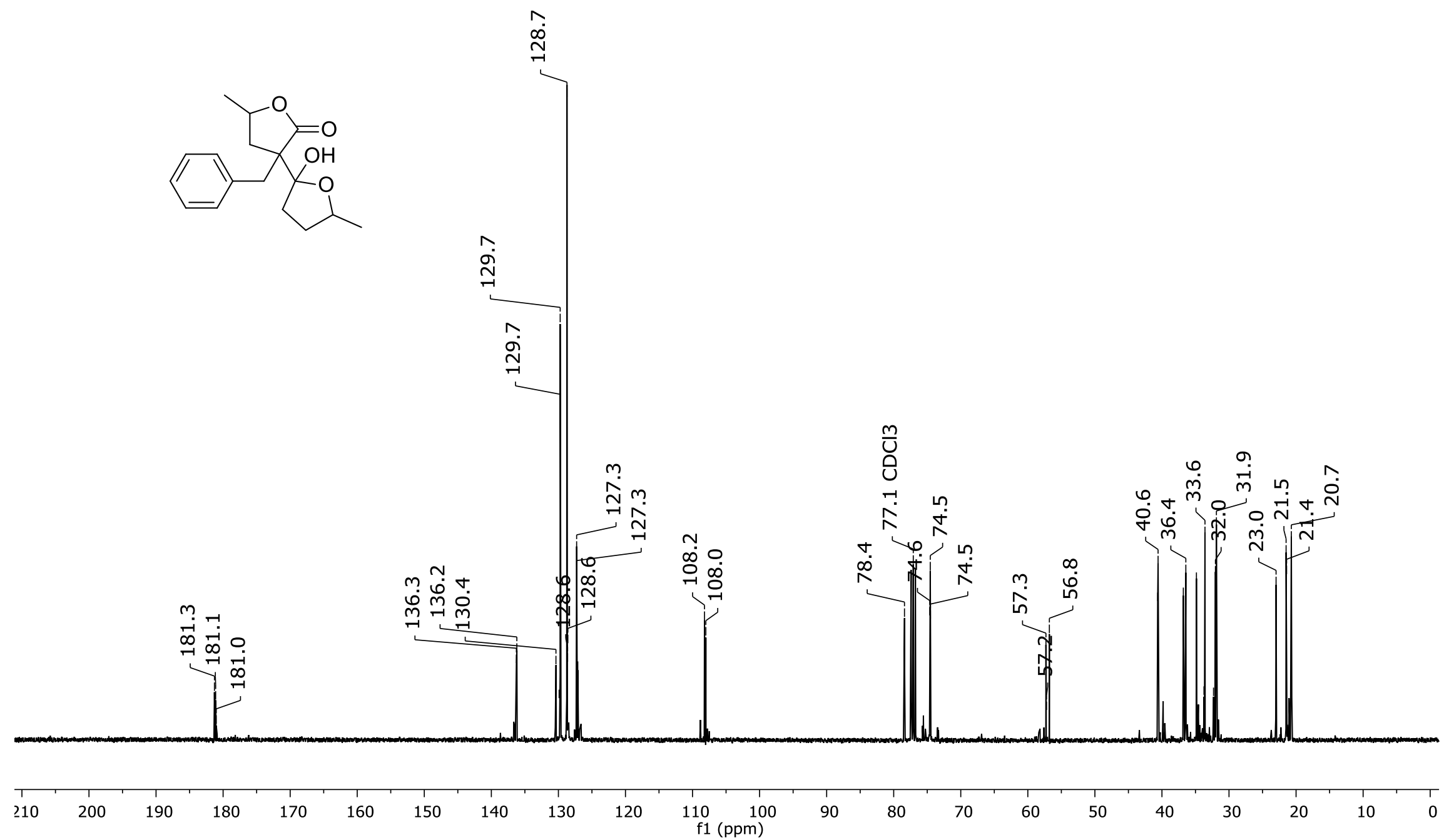


$\underline{\text { Anexos }}$

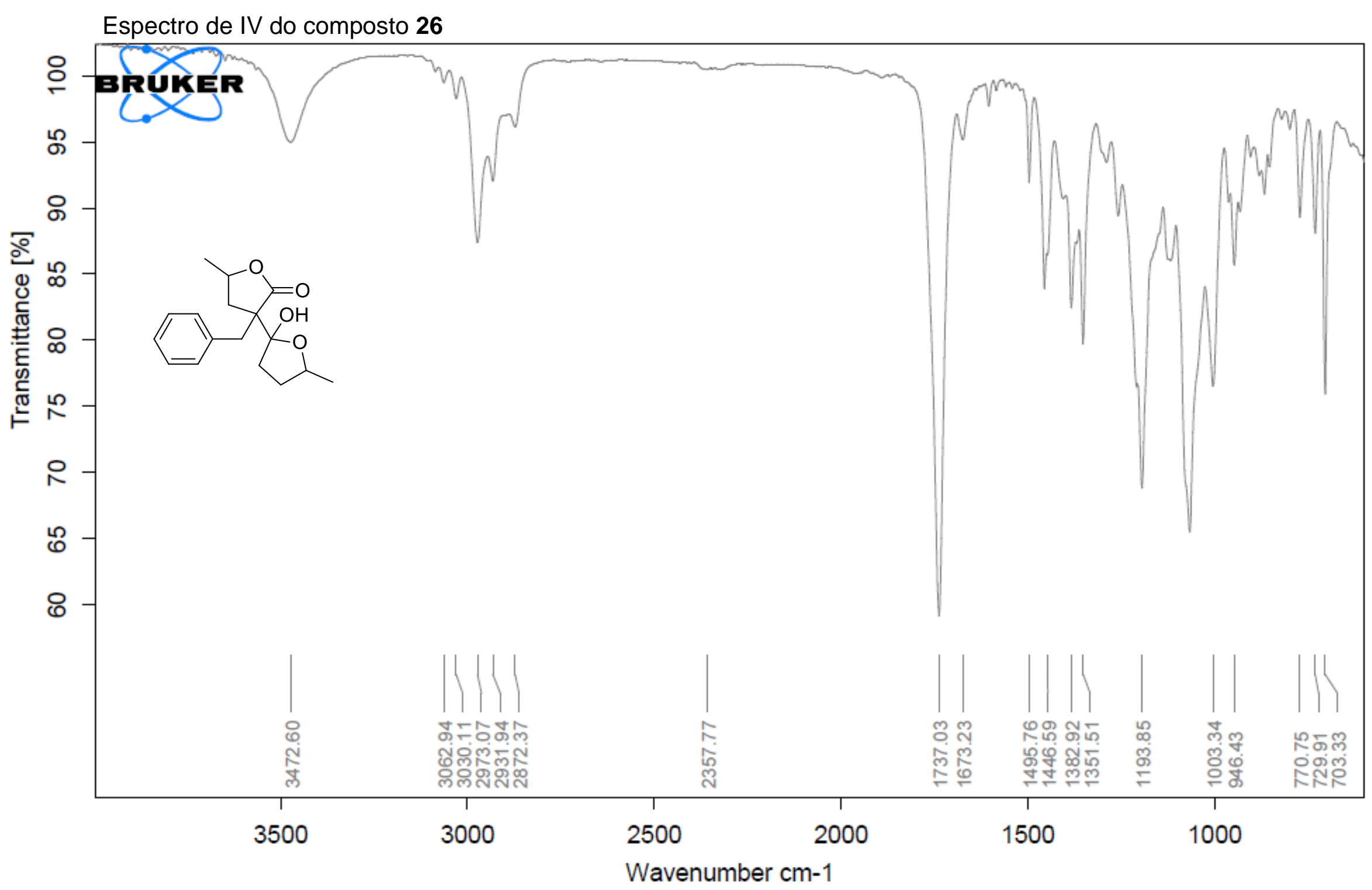




\section{Anexos}

\section{Espectro de RMN de ${ }^{1} \mathrm{H}$ do composto 27. Mistura de diastereoisômeros}

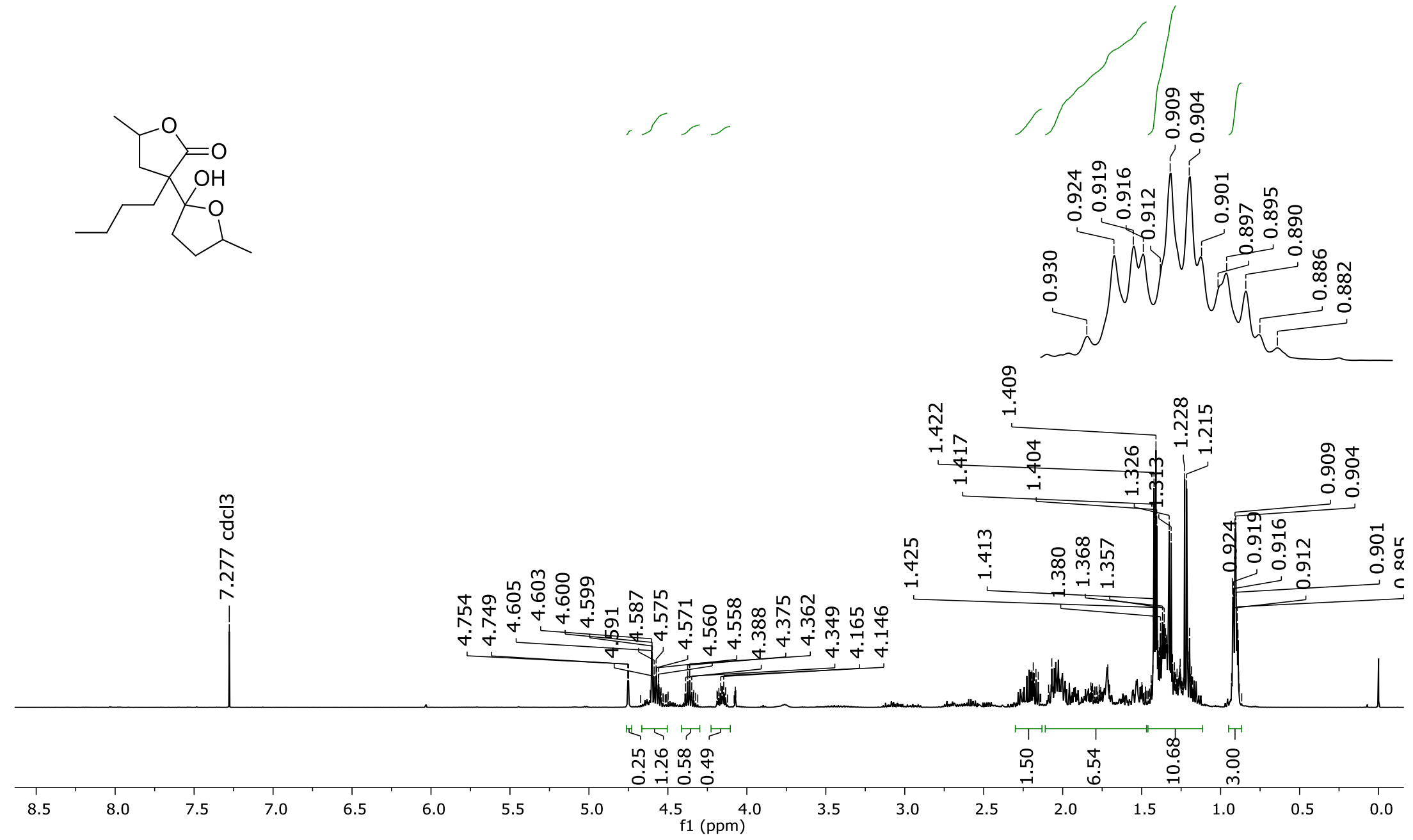




\section{Anexos}

\section{Espectro de RMN de ${ }^{13} \mathrm{C}$ do composto 27. Mistura de diastereoisômeros}
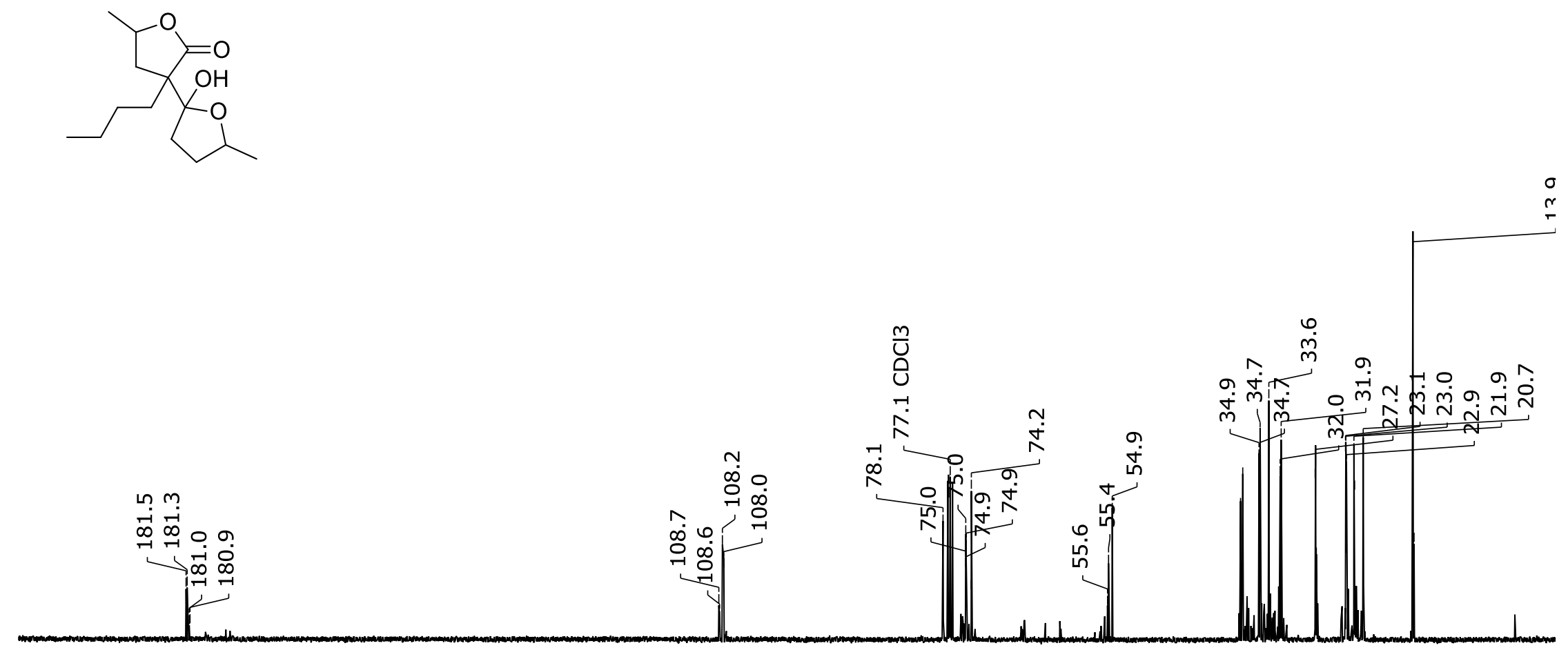
Anexos

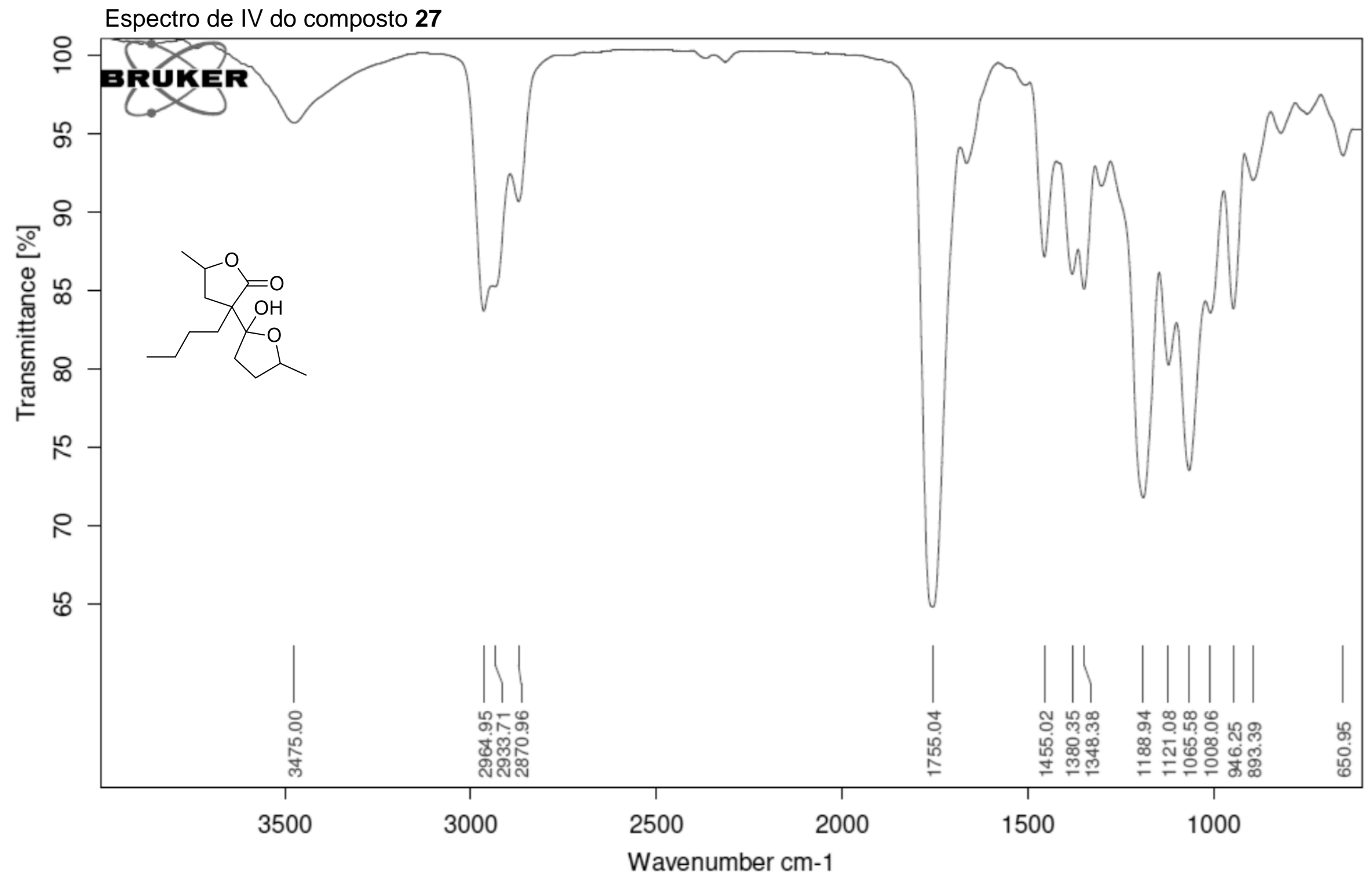




\section{Anexos}

Espectro de RMN de ${ }^{1} \mathrm{H}$ do composto 28. Mistura de diastereoisômeros

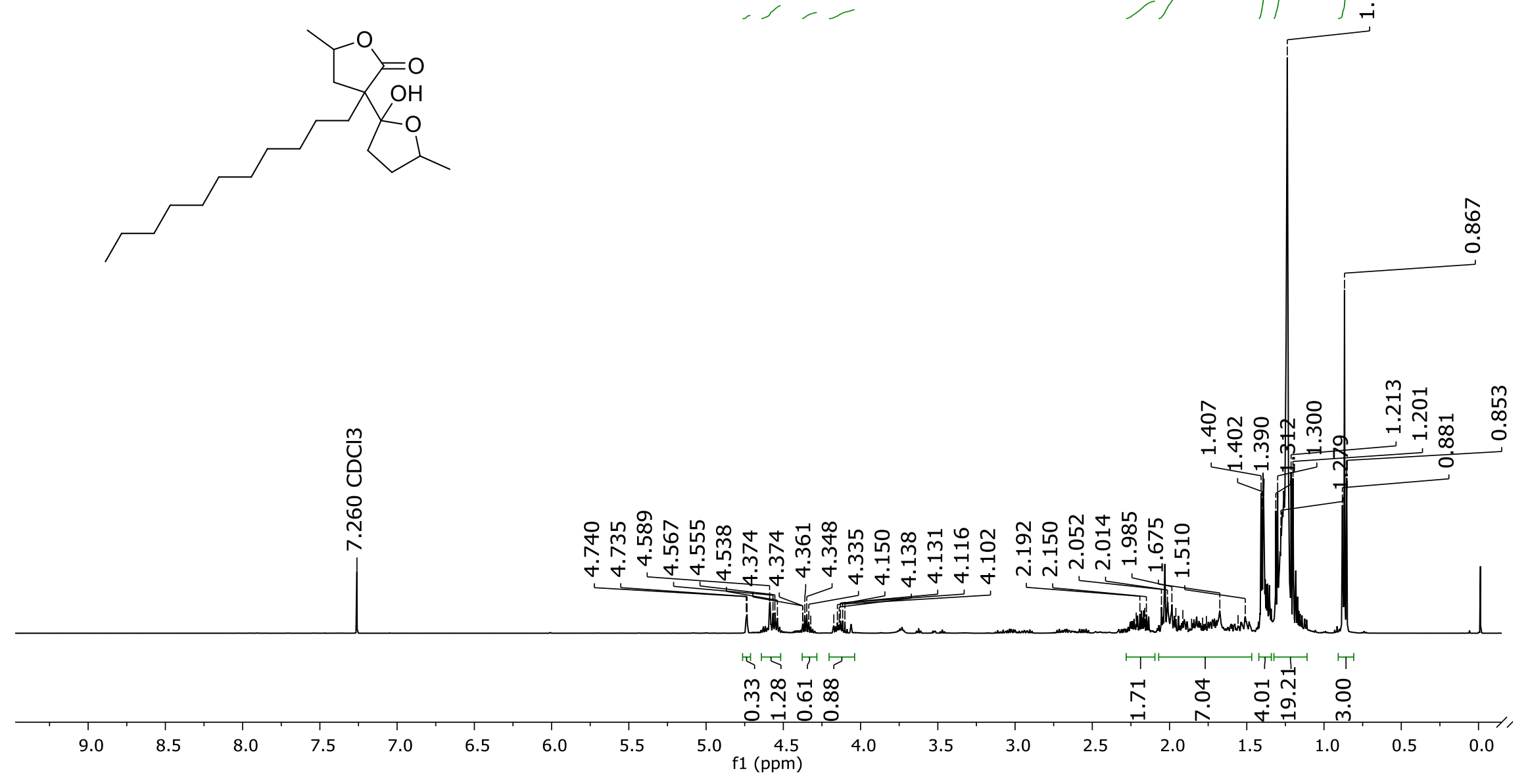




\section{Anexos}

\section{Espectro de RMN de ${ }^{13} \mathrm{C}$ do composto 28. Mistura de diastereoisômeros}
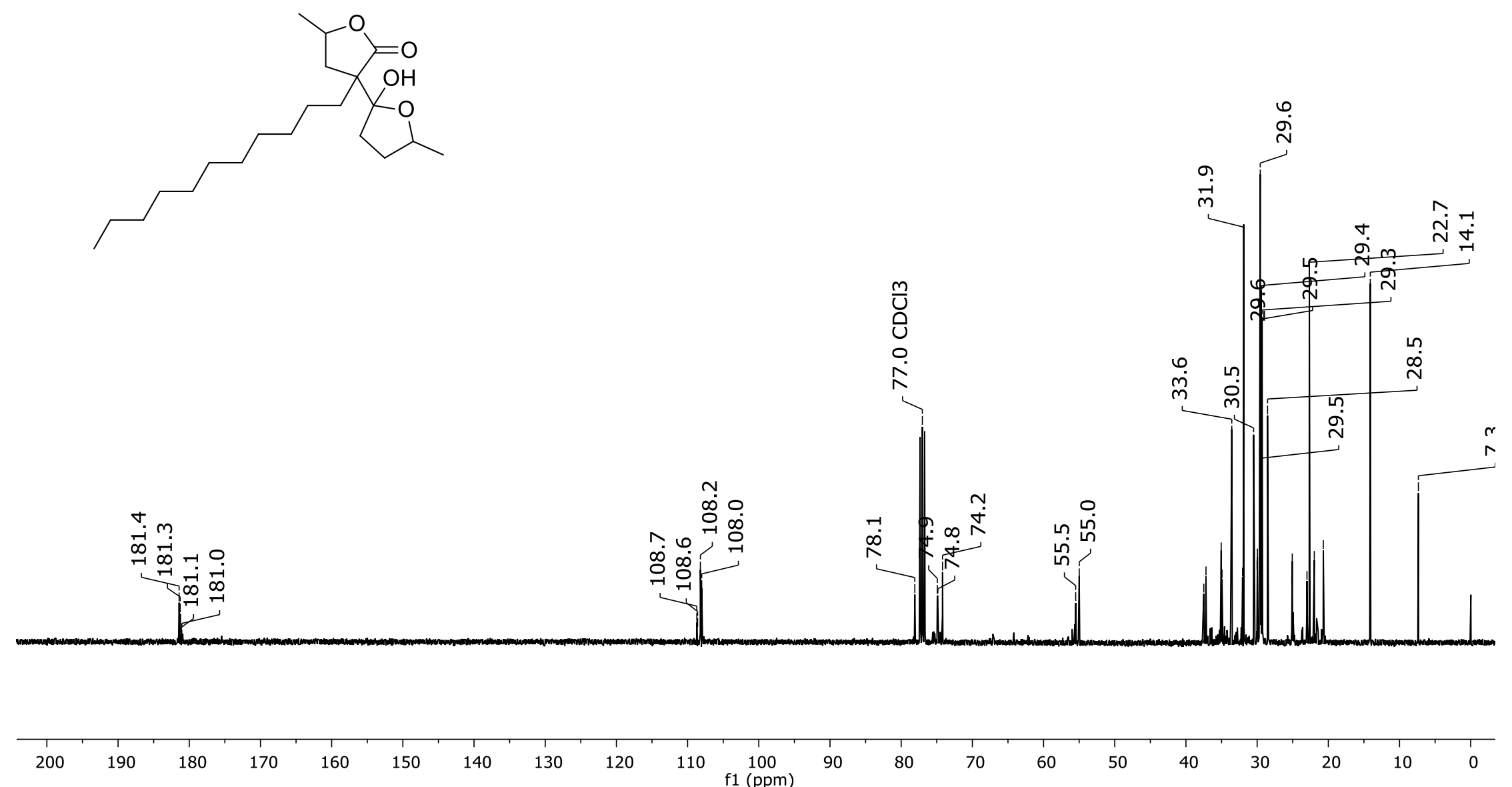
$\underline{\text { Anexos }}$

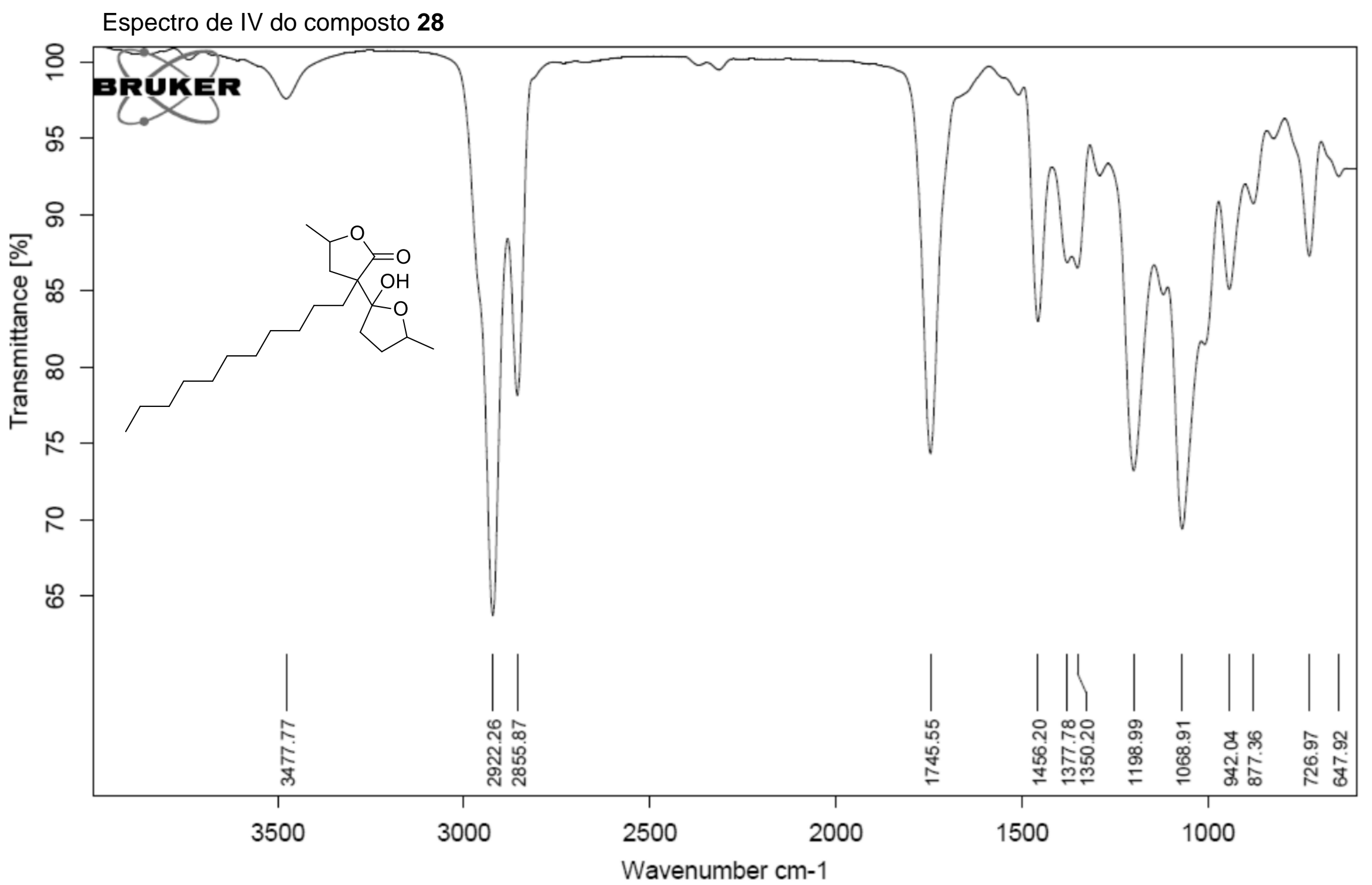




\section{Anexos}

\section{Espectro de RMN de ${ }^{1} \mathrm{H}$ do composto 29. Mistura de diastereoisômeros}

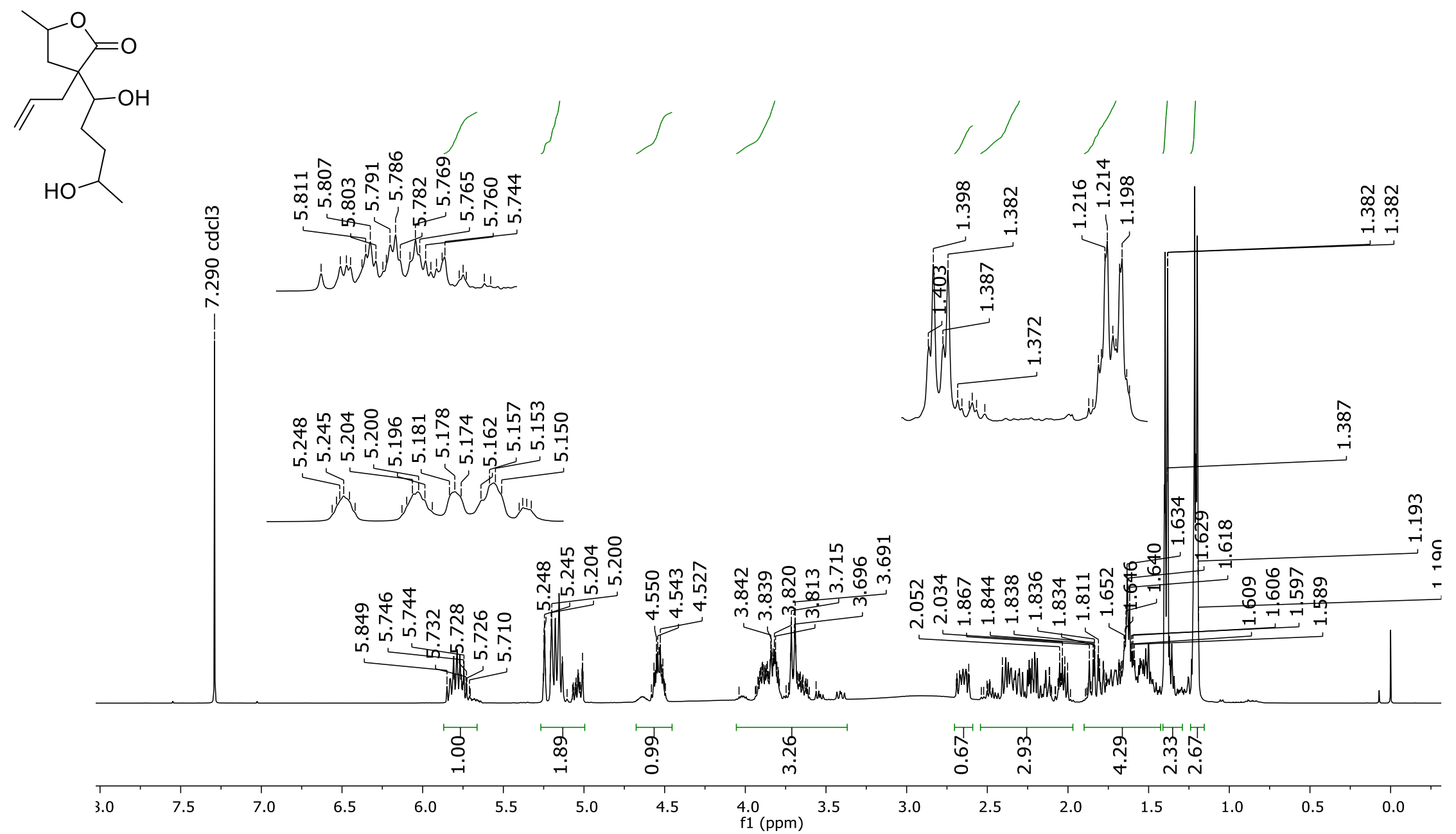




\section{Anexos}

Espectro de RMN de ${ }^{13} \mathrm{C}$ do composto 29. Mistura de diastereoisômeros<smiles>C=CCC1(C(O)CCC(C)O)CC(C)OC1=O</smiles>

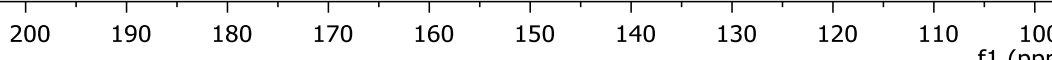

บุ

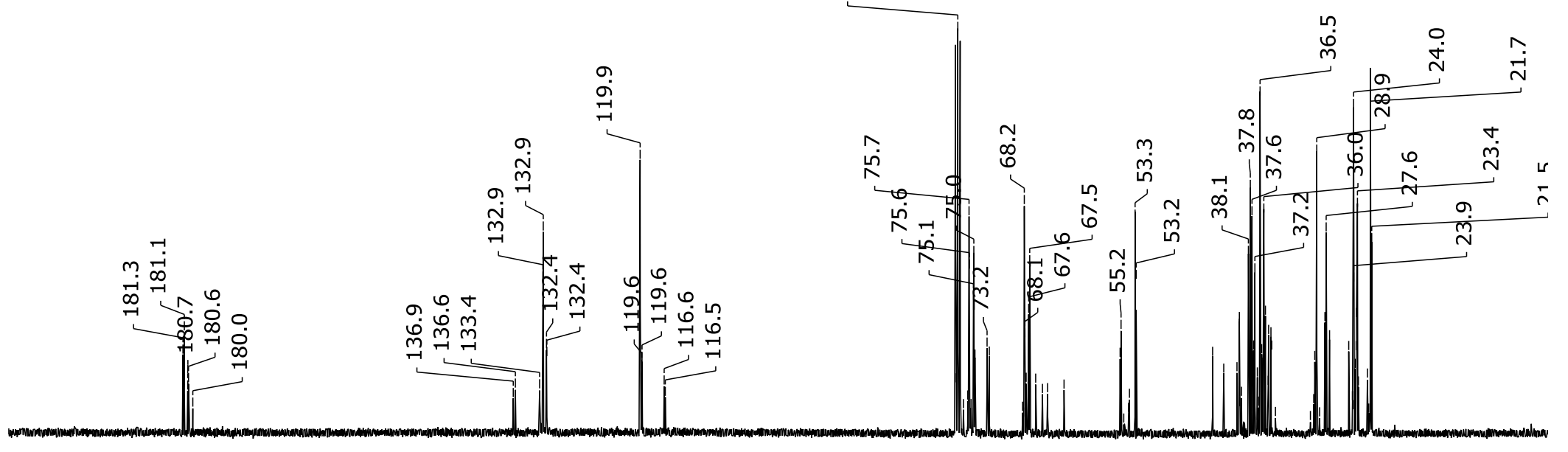


Anexos

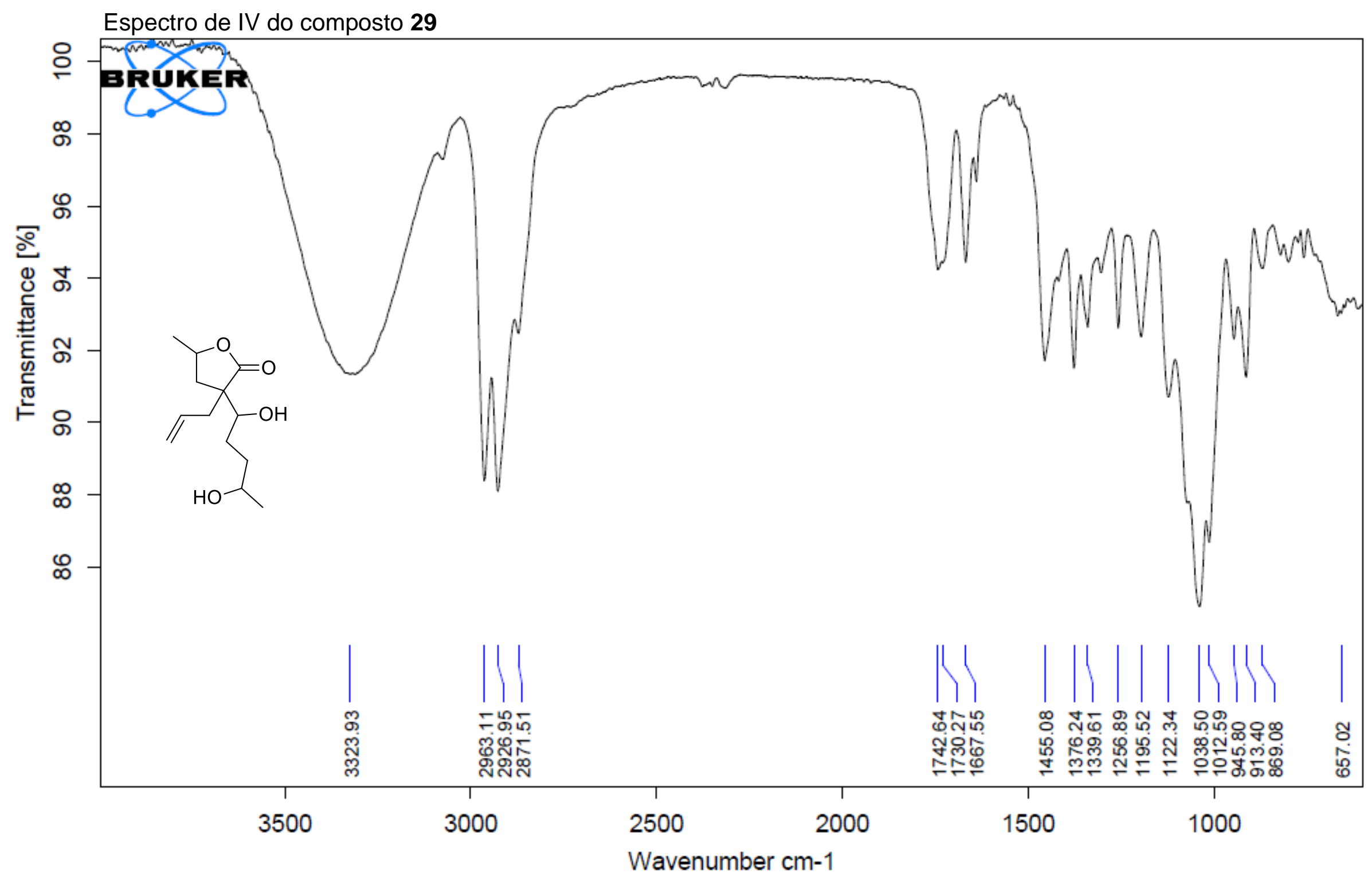




\section{Anexos}

\section{Espectro de RMN de ${ }^{1} \mathrm{H}$ do composto 30. Mistura de diastereoisômeros}

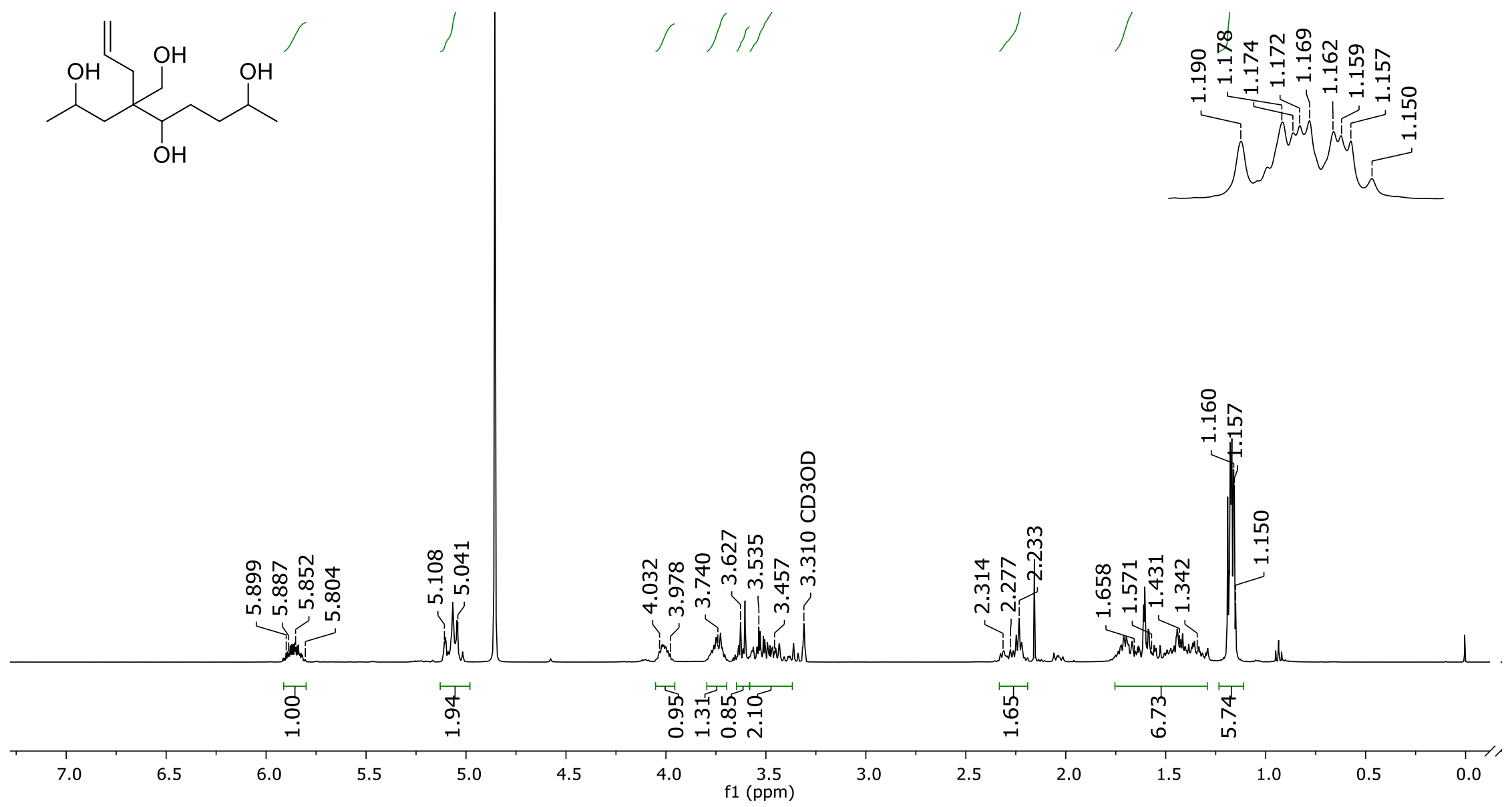




\section{Anexos}

\section{Espectro de RMN de ${ }^{13} \mathrm{C}$ do composto 30 . Mistura de diastereoisômeros}
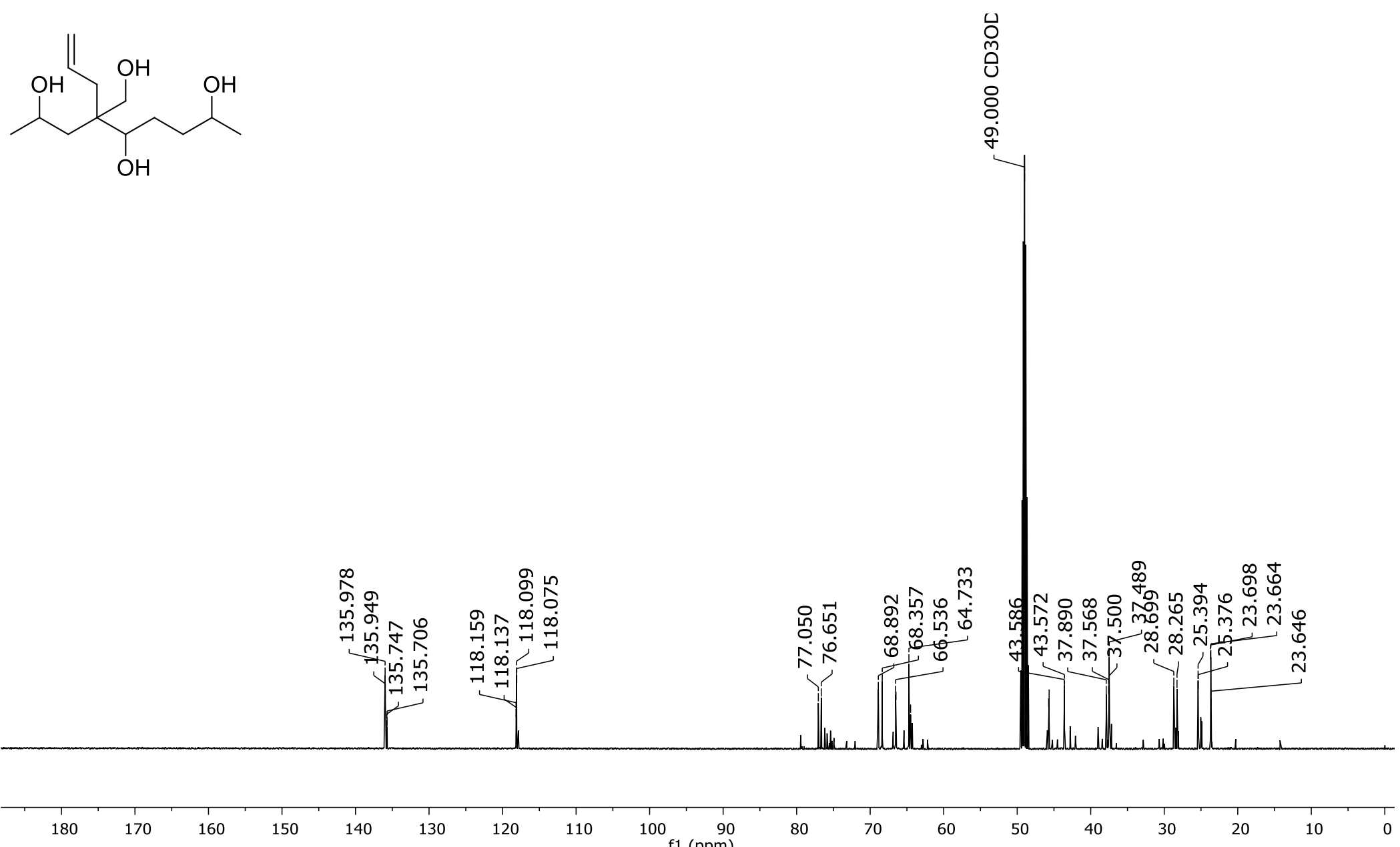
$\underline{\text { Anexos }}$

Espectro de IV do composto $\mathbf{3 0}$

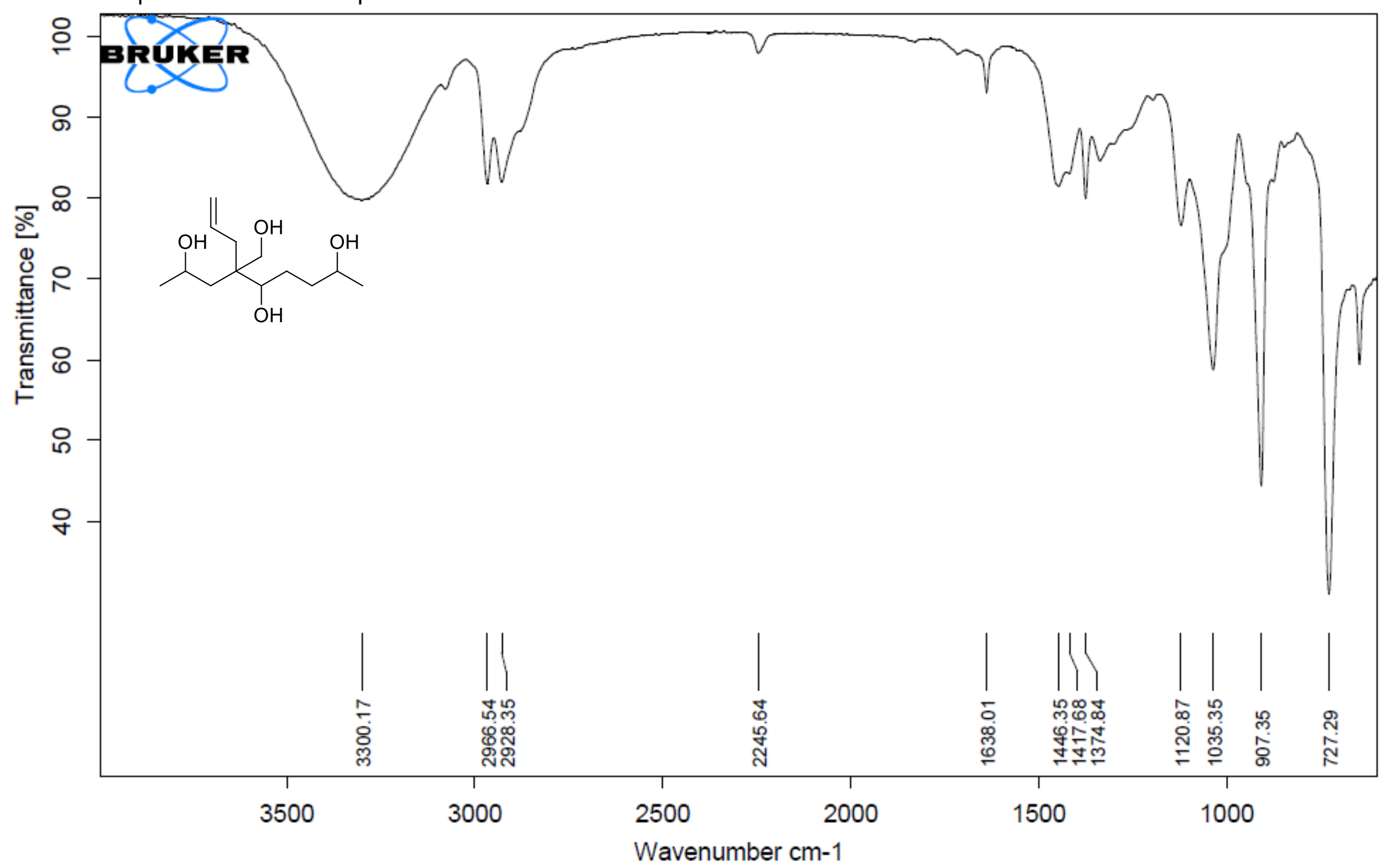




\section{Anexos}

\section{Espectro de RMN de ${ }^{13} \mathrm{C}$ do composto 31. Mistura de diastereoisômeros}
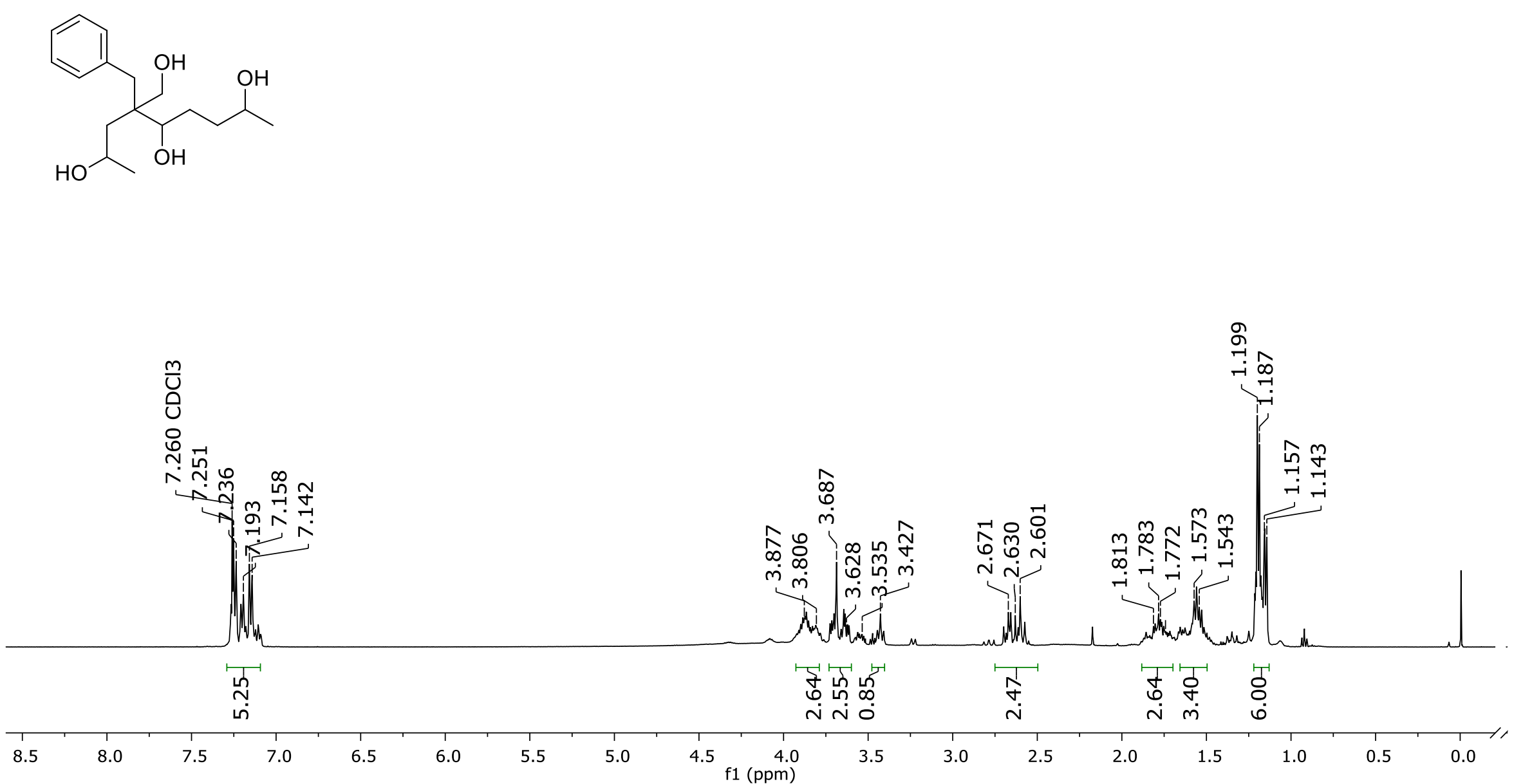


\section{Anexos}

\section{Espectro de RMN de ${ }^{13} \mathrm{C}$ do composto 31. Mistura de diastereoisômeros}
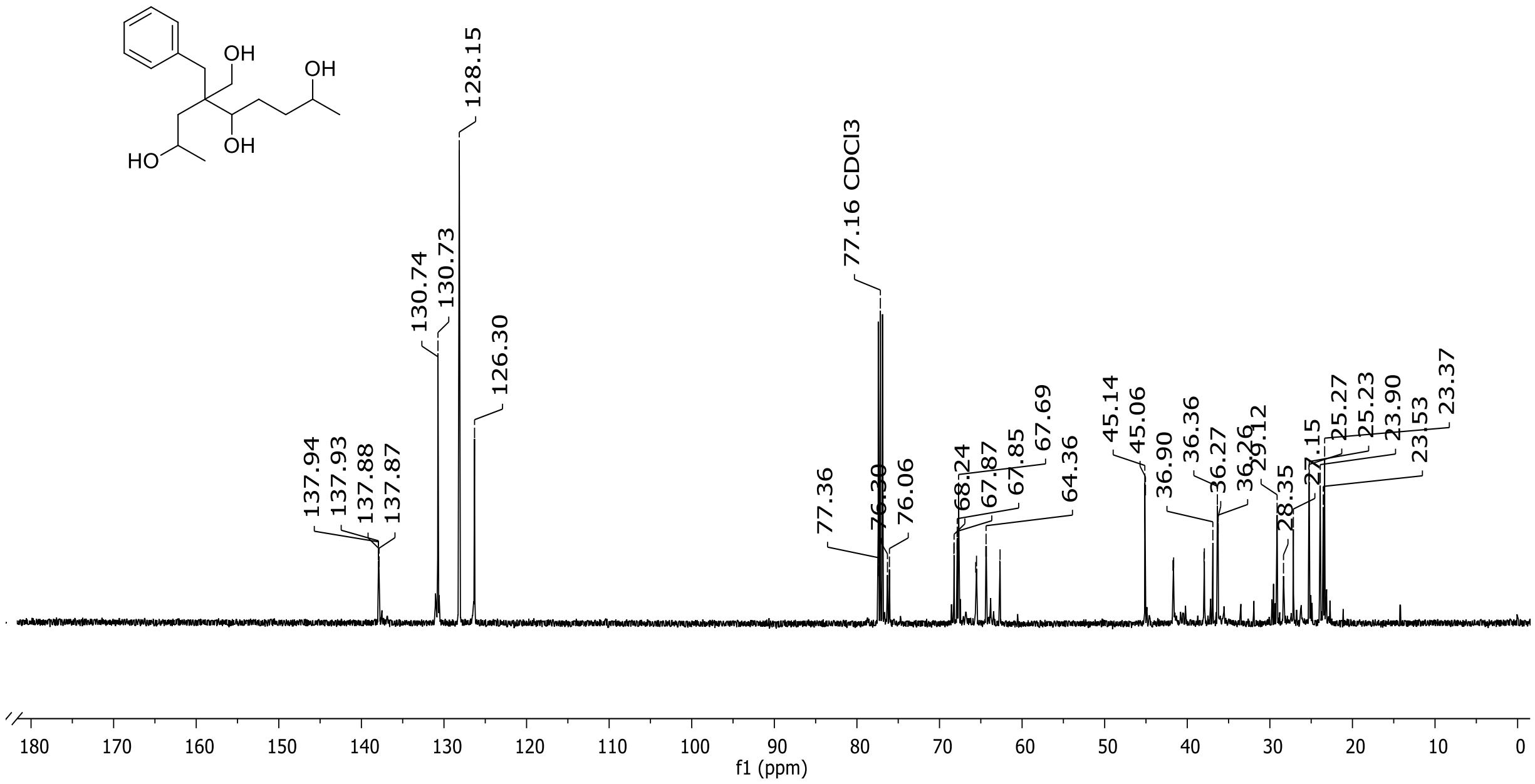
Anexos

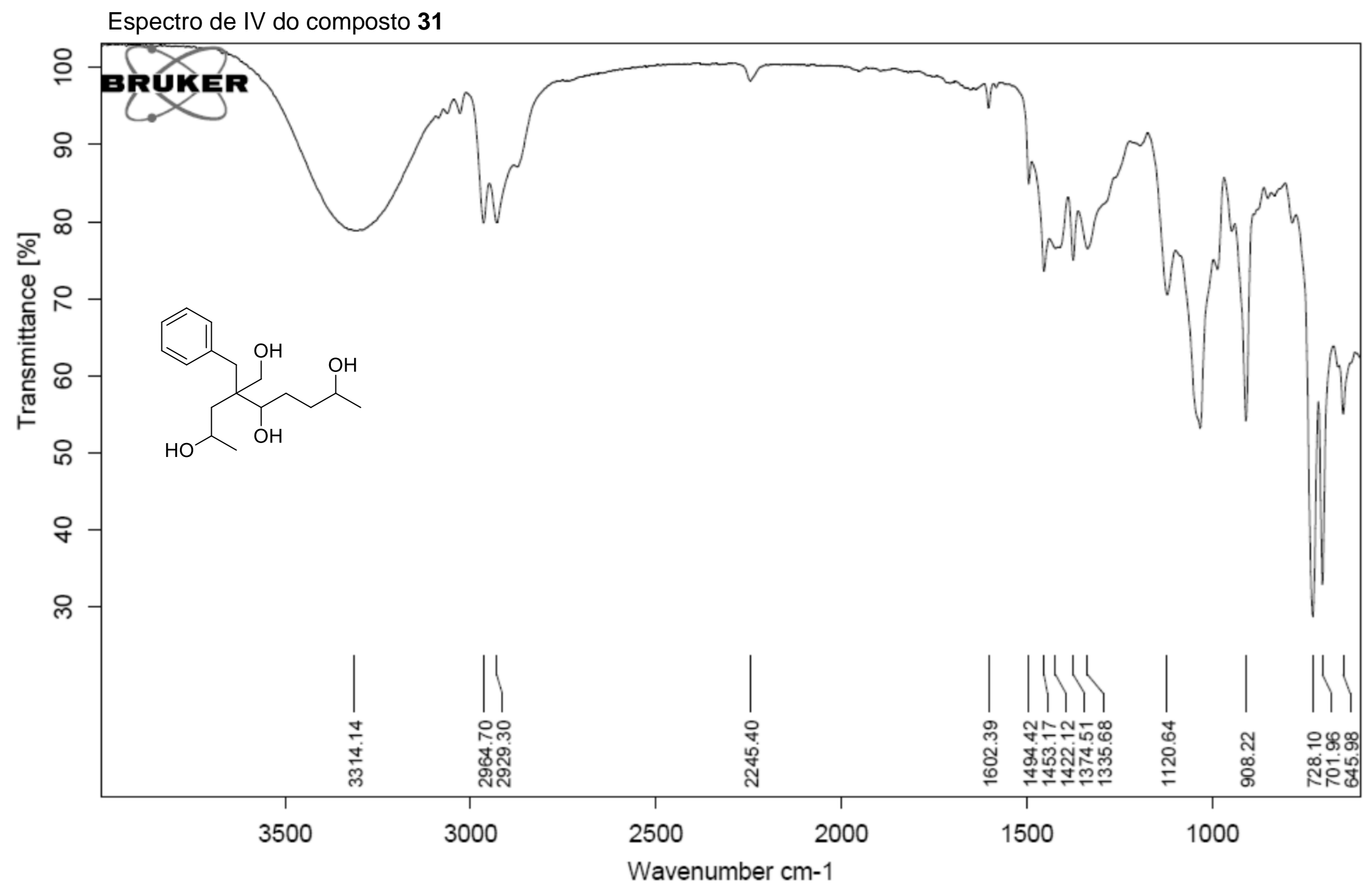




\section{Anexos}

\section{Espectro de RMN de ${ }^{1} \mathrm{H}$ do composto 32. Mistura de diastereoisômeros}
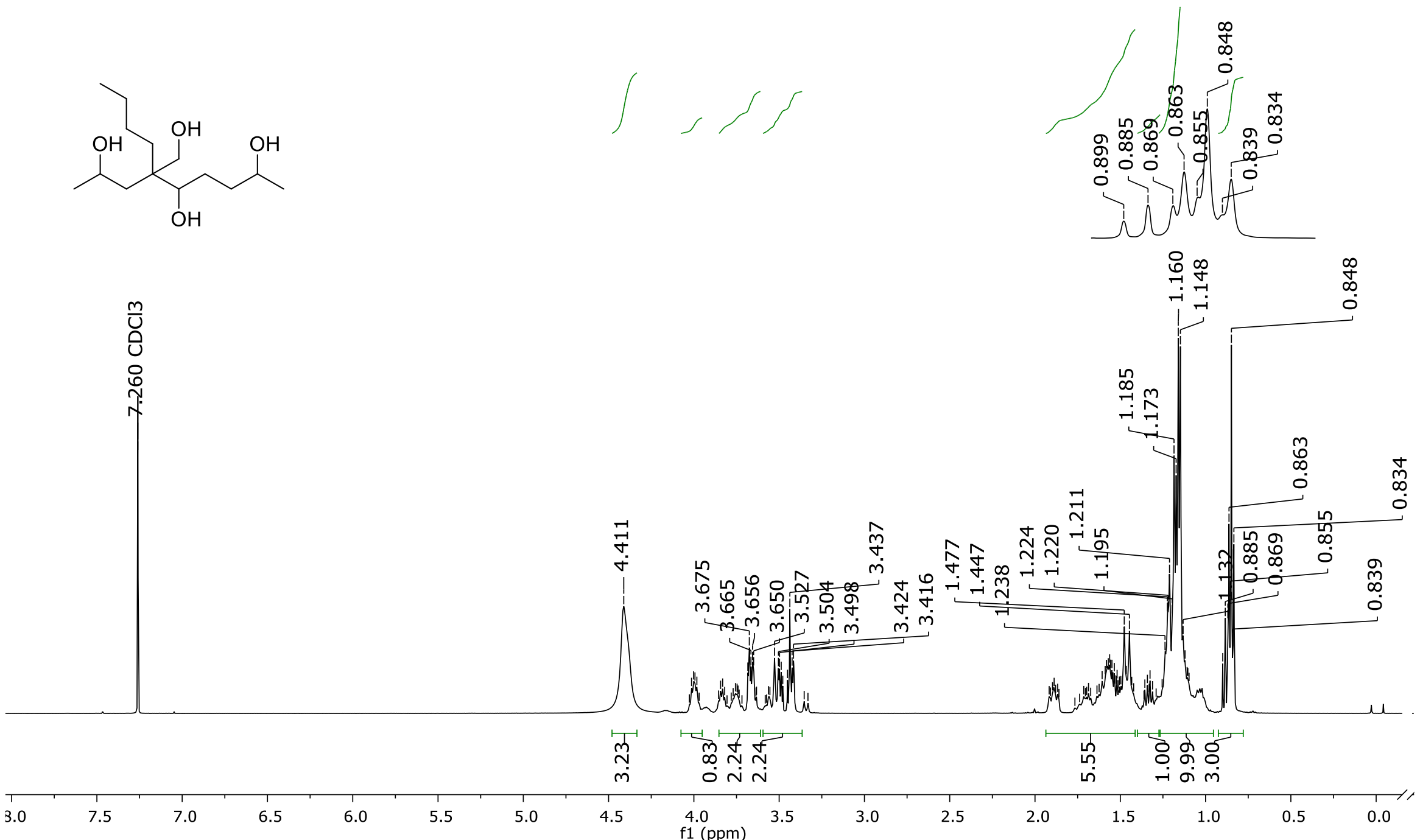


\section{Anexos}

\section{Espectro de RMN de ${ }^{13} \mathrm{C}$ do composto 32. Mistura de diastereoisômeros}
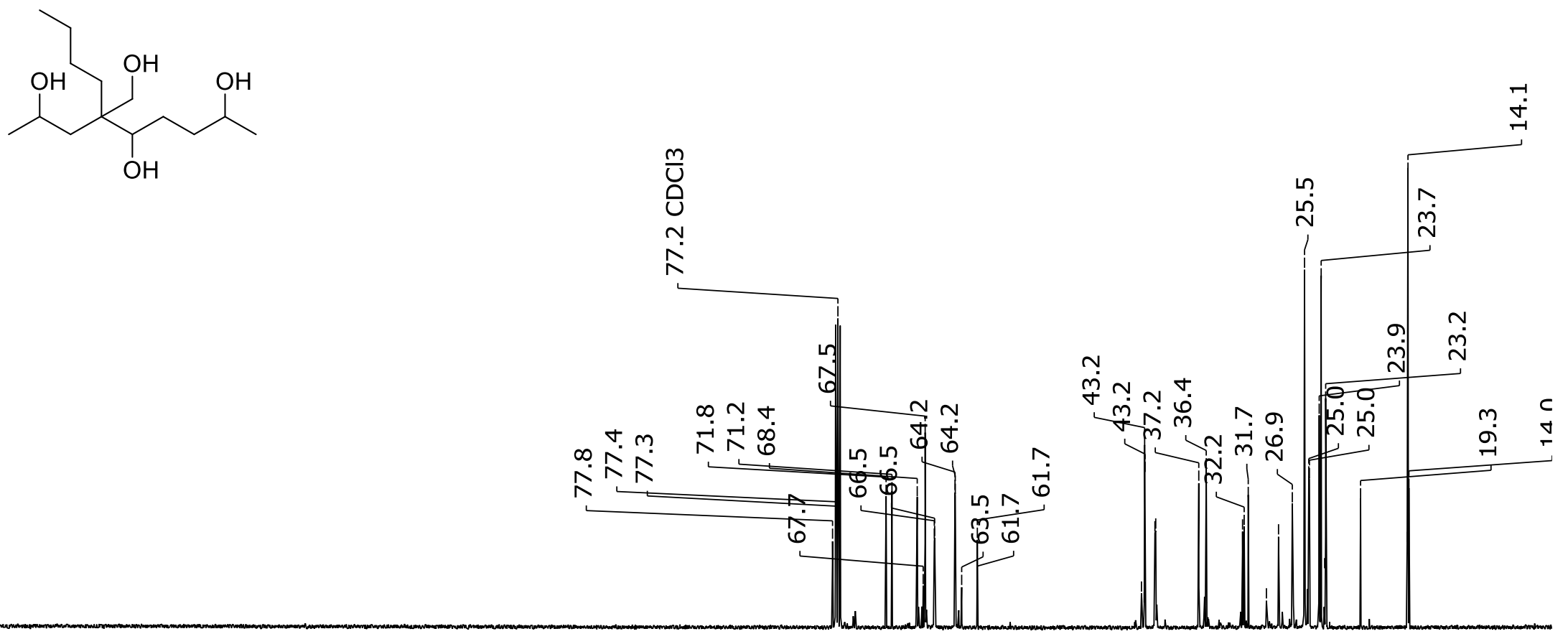

180

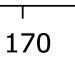


Anexos

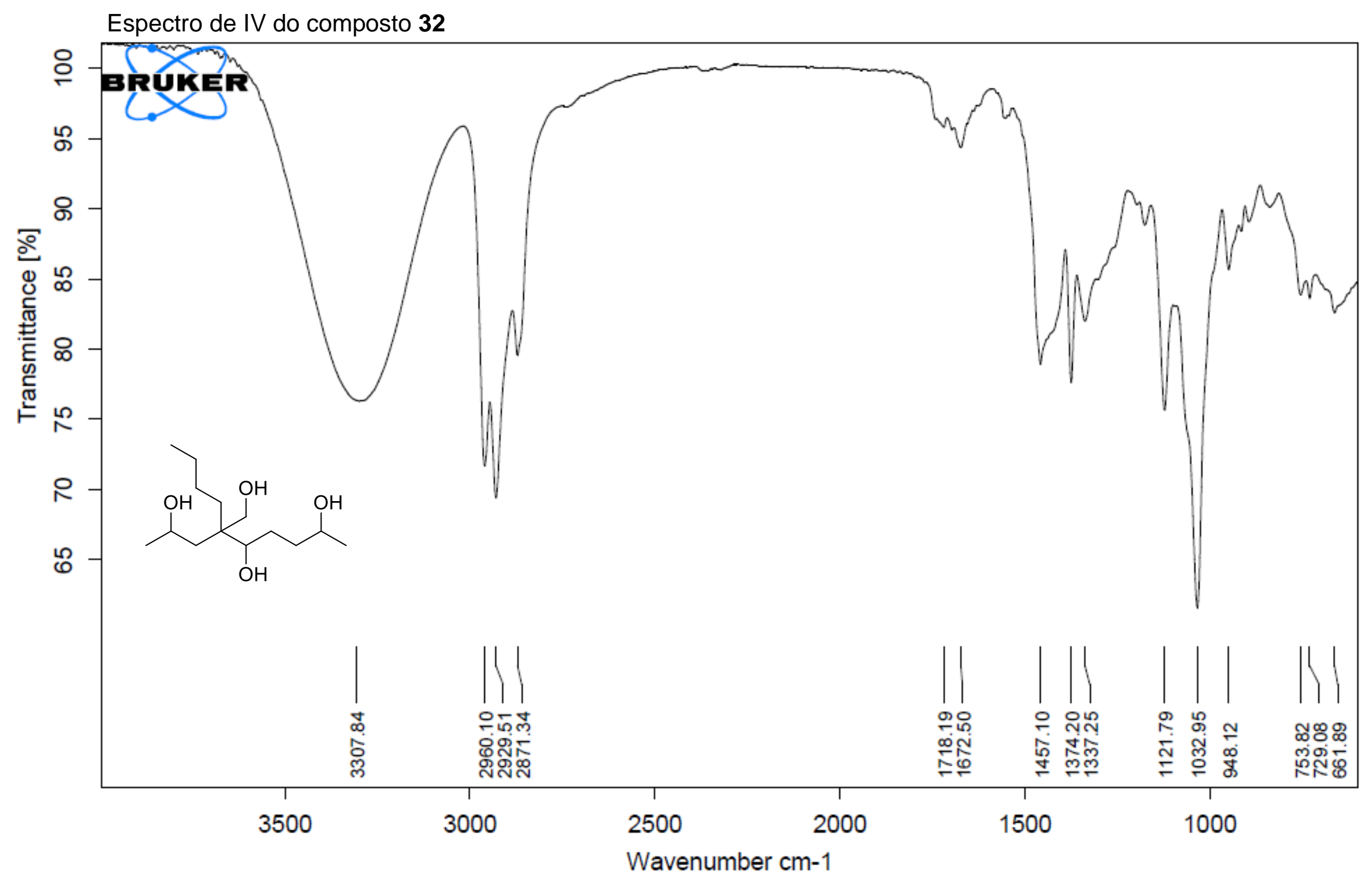




\section{Anexos}

\section{Espectro de RMN de ${ }^{1} \mathrm{H}$ do composto 33. Mistura de diastereoisômeros}

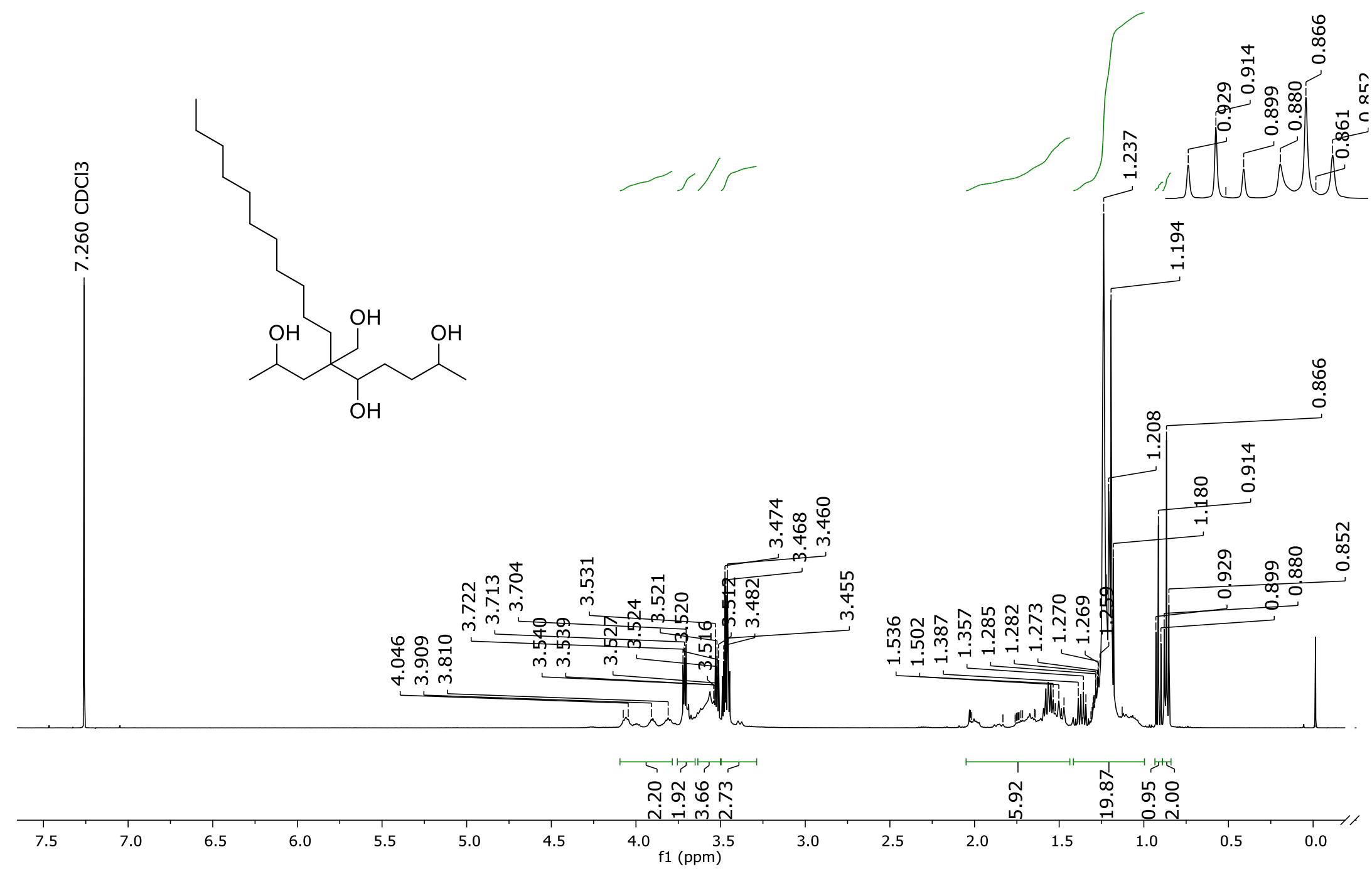




\section{Anexos}

Espectro de RMN de ${ }^{13} \mathrm{C}$ do composto 33. Mistura de diastereoisômeros
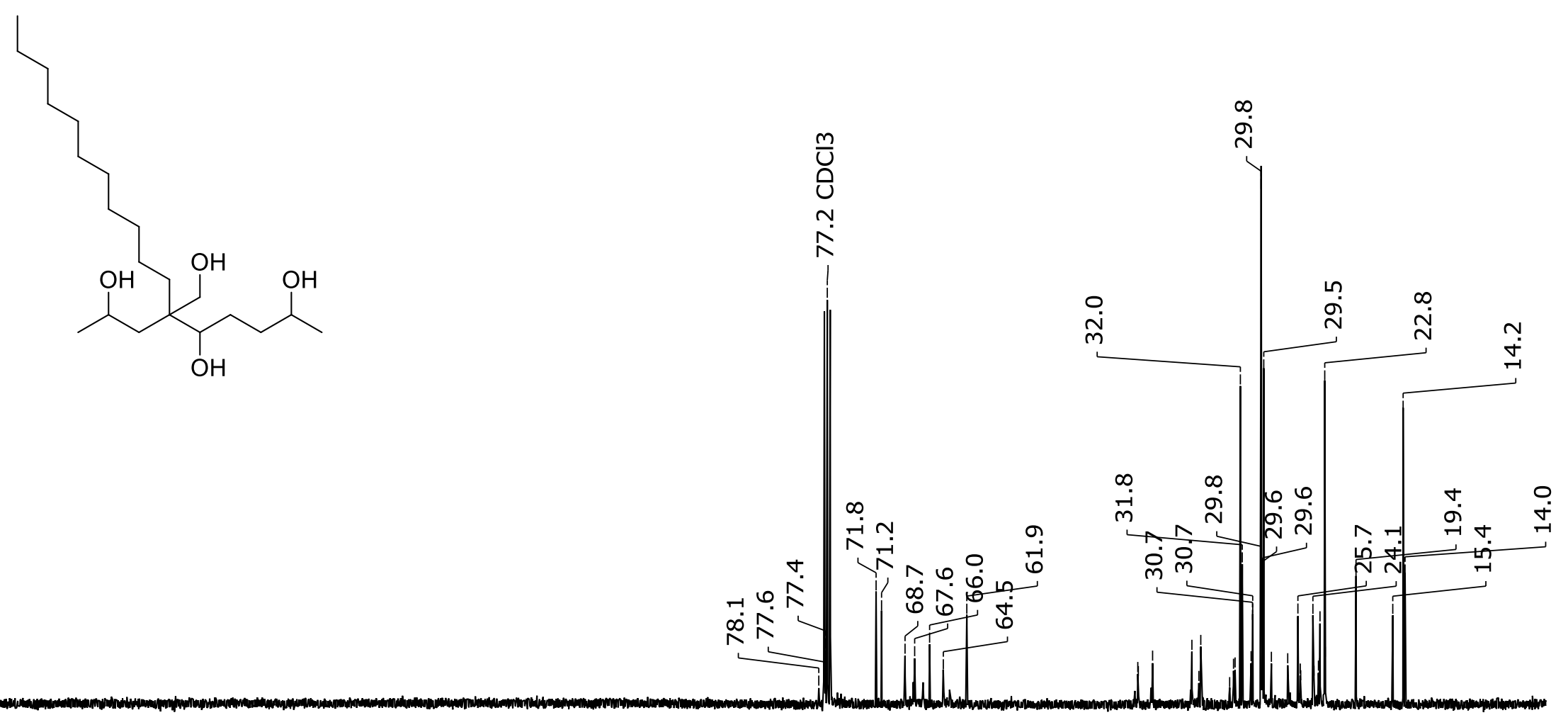


\section{Anexos}

Espectro de IV do composto 33

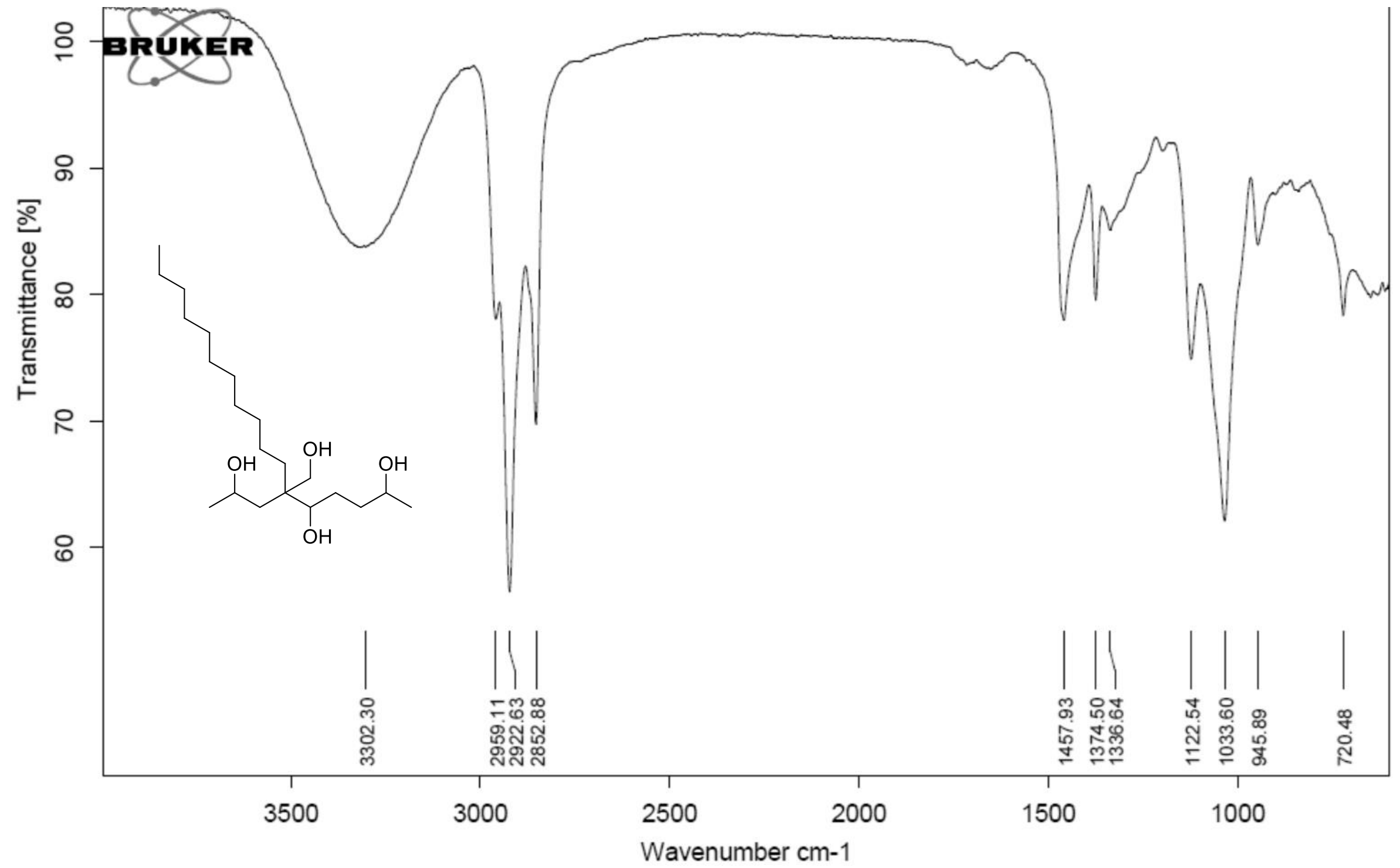




\section{Anexos}

RMN de ${ }^{1} \mathrm{H}$ da $\beta$-angélica lactona

$$
\bigcap_{0}=0
$$

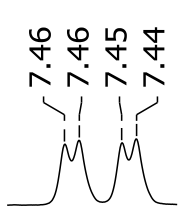

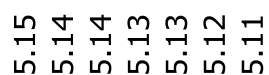

$\longrightarrow 1$

Mńr

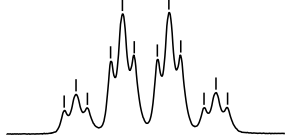

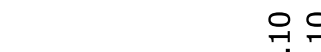

울 울

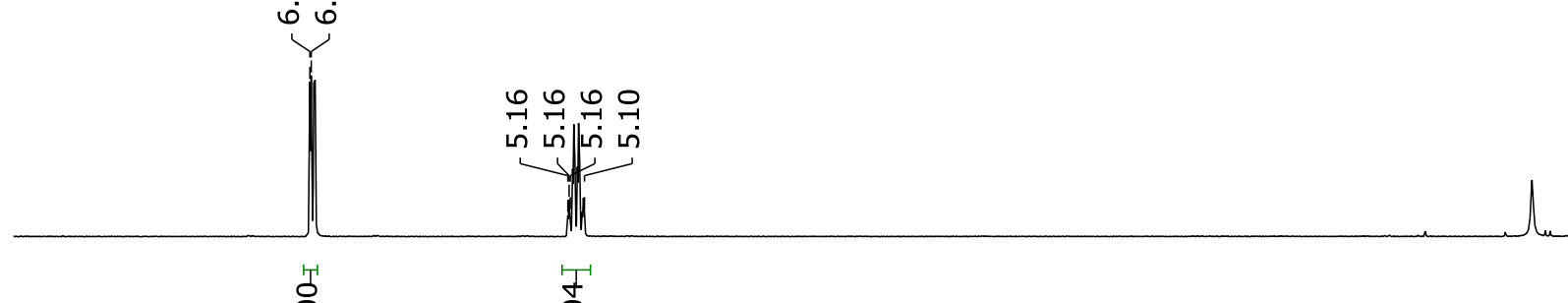

Ti1

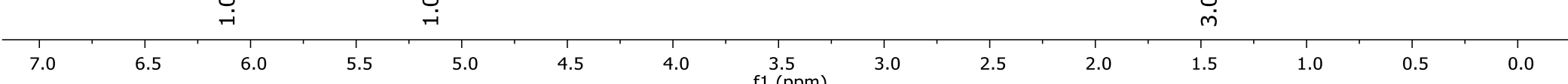




\section{Anexos}

RMN de ${ }^{13} \mathrm{C}$ da $\beta$-angélica lactona

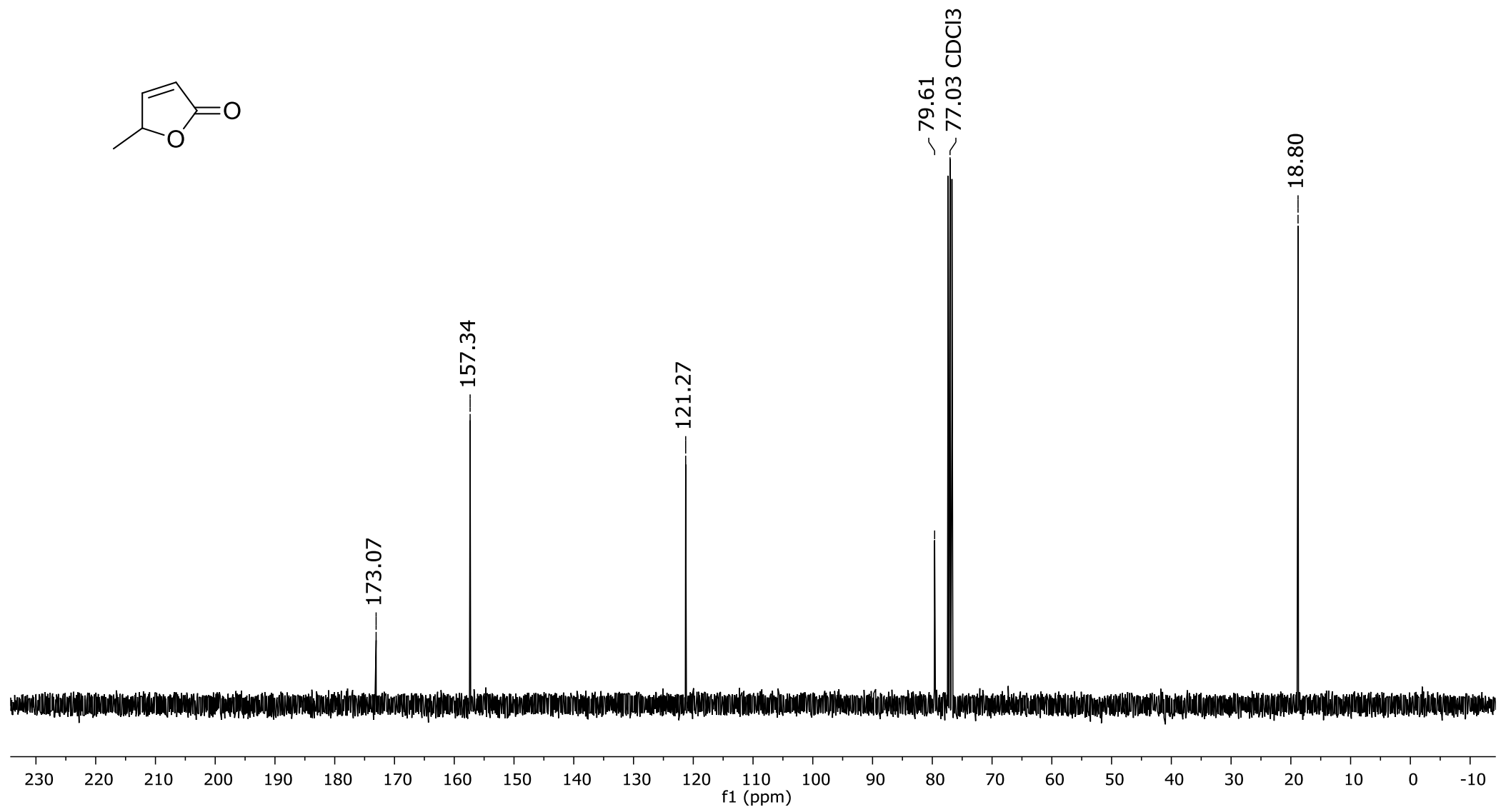




\section{Anexos}

RMN de ${ }^{1} \mathrm{H}$ de 43. Bruto reacional (escala de $2 \mathrm{mmol}$ via método 1). Mistura diastereoisomérica

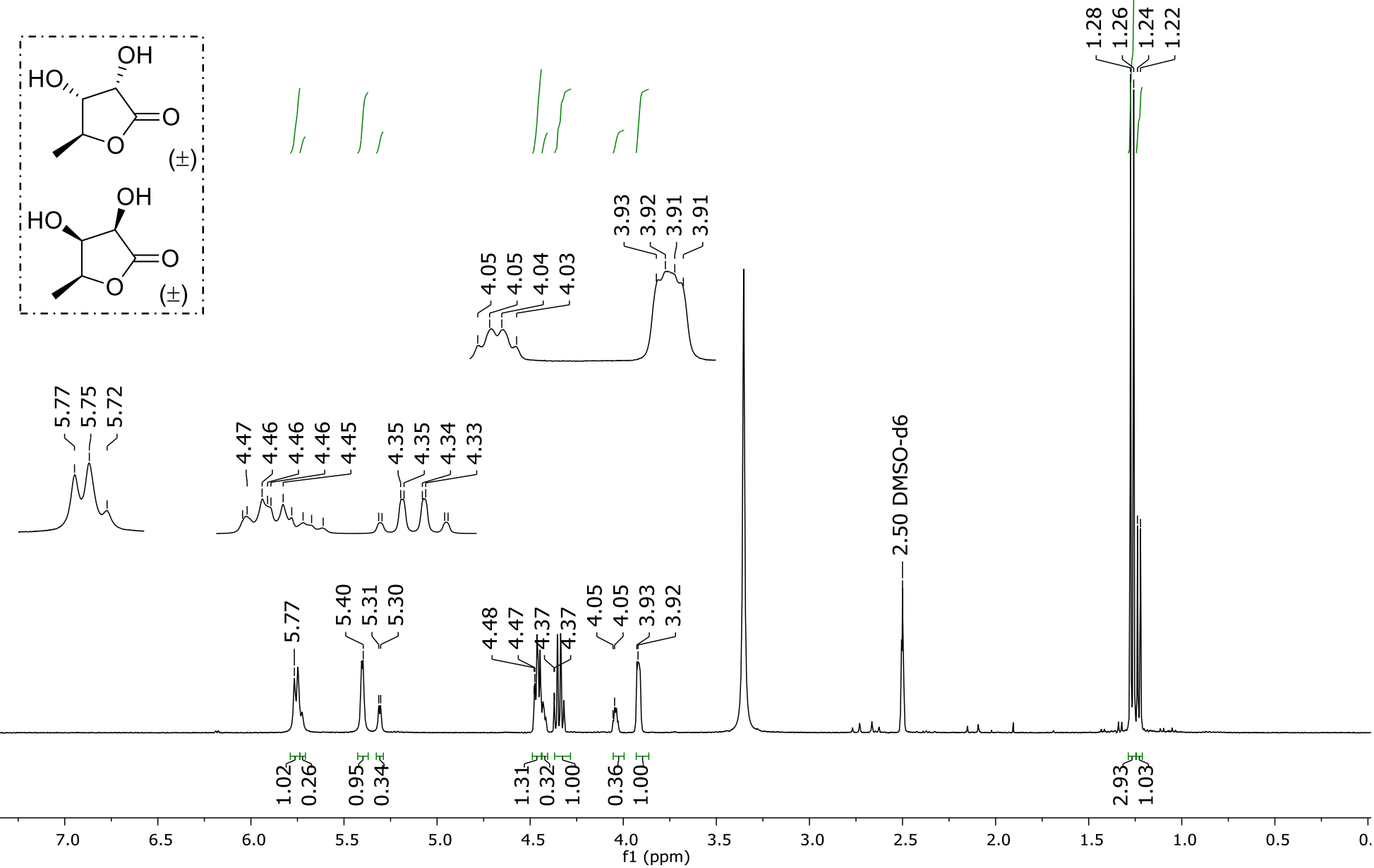




\section{Anexos}

RMN de ${ }^{13} \mathrm{C}$ de 43. Bruto reacional (escala de $2 \mathrm{mmol}$ via método 1). Mistura diastereoisomérica
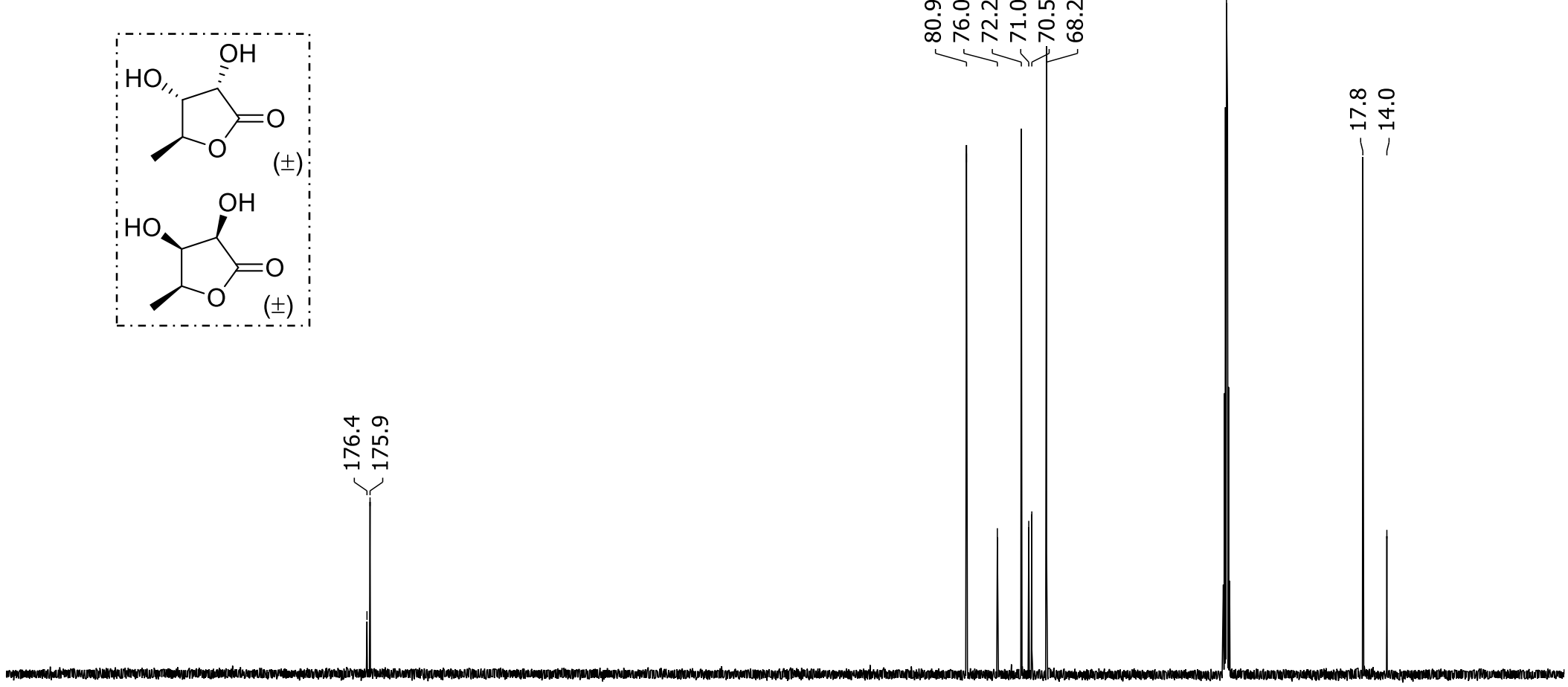

$\begin{array}{llllllllllllllllllllllllllllllllllll}230 & 220 & 210 & 200 & 190 & 180 & 170 & 160 & 150 & 140 & 130 & 120 & 110 & 100 & 90 & 80 & 70 & 60 & 50 & 40 & 30 & 20 & 10 & 0 & -10\end{array}$ 
Anexos

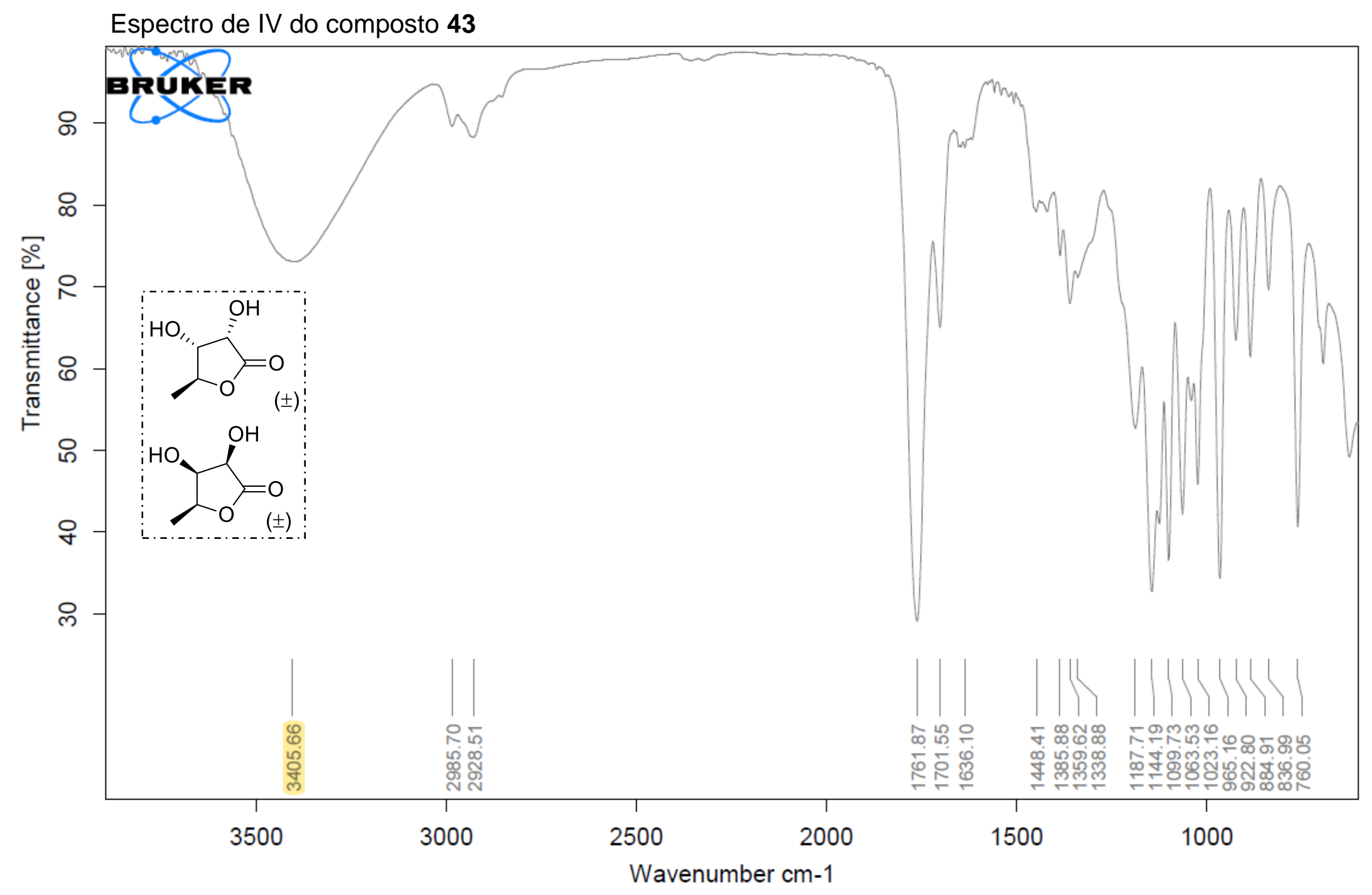




\section{Anexos}

\section{$\mathrm{RMN}$ de ${ }^{1} \mathrm{H}$ de 44. Mistura diastereoisomérica}
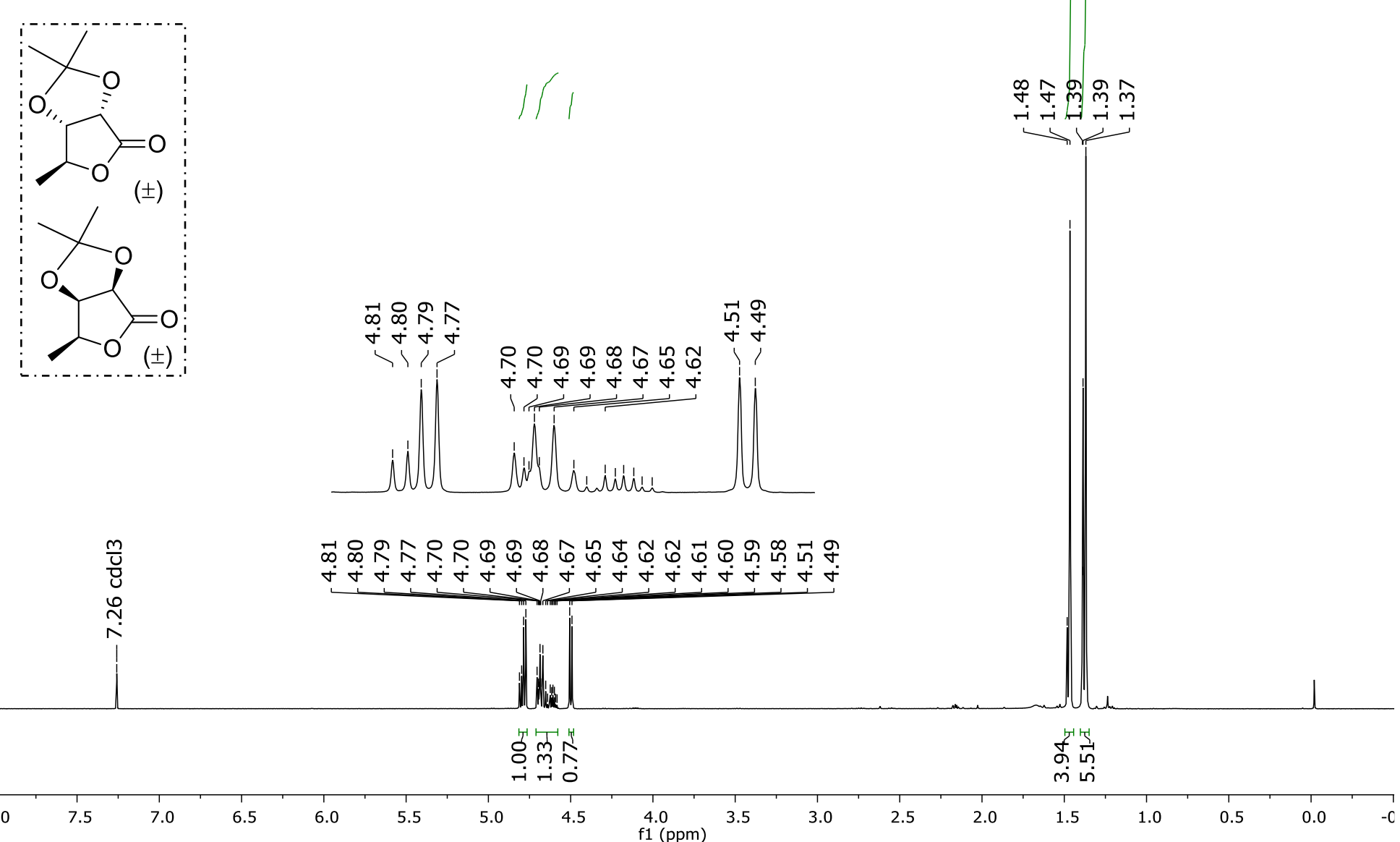


\section{Anexos}

$\mathrm{RMN}$ de ${ }^{13} \mathrm{C}$ de 44. Mistura diastereoisomérica

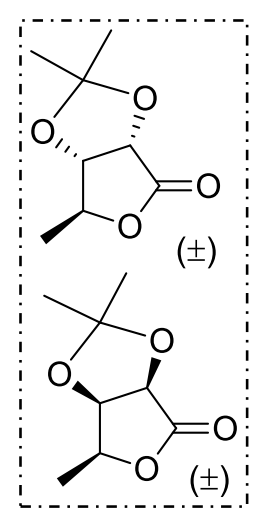

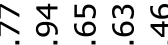

ஸे ผ่ํ்

$\dot{m} \stackrel{m}{=}$

옹

$\stackrel{+}{\stackrel{4}{n}}$

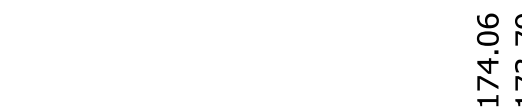

บั

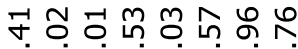

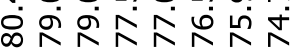
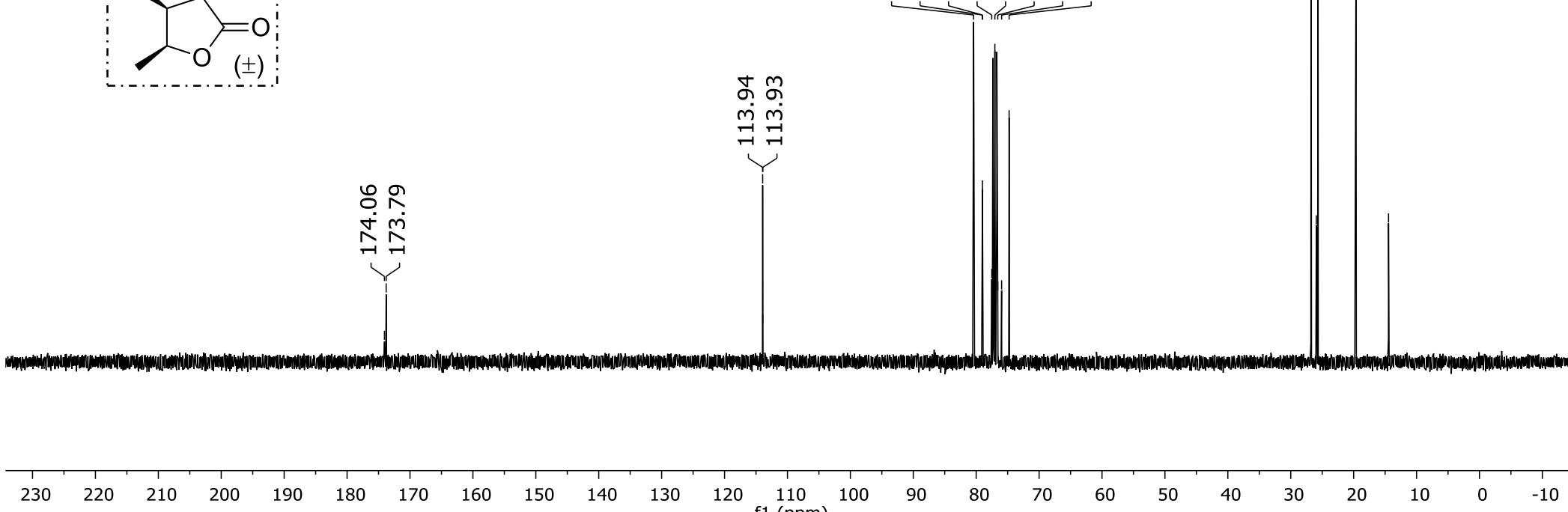


\section{Anexos}

\section{Análise por CG-EM de 44. Mistura diastereoisomérica}

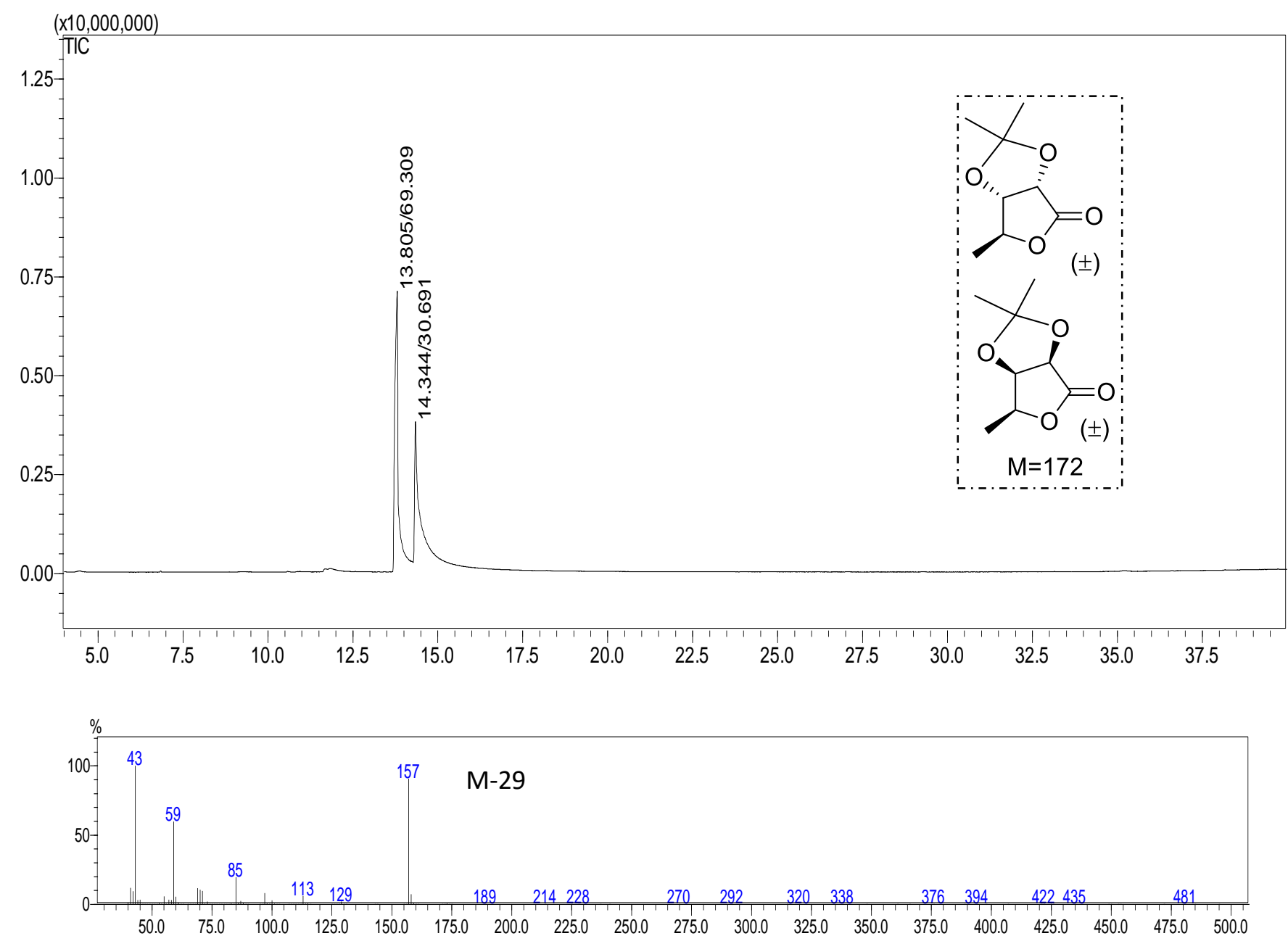


Anexos

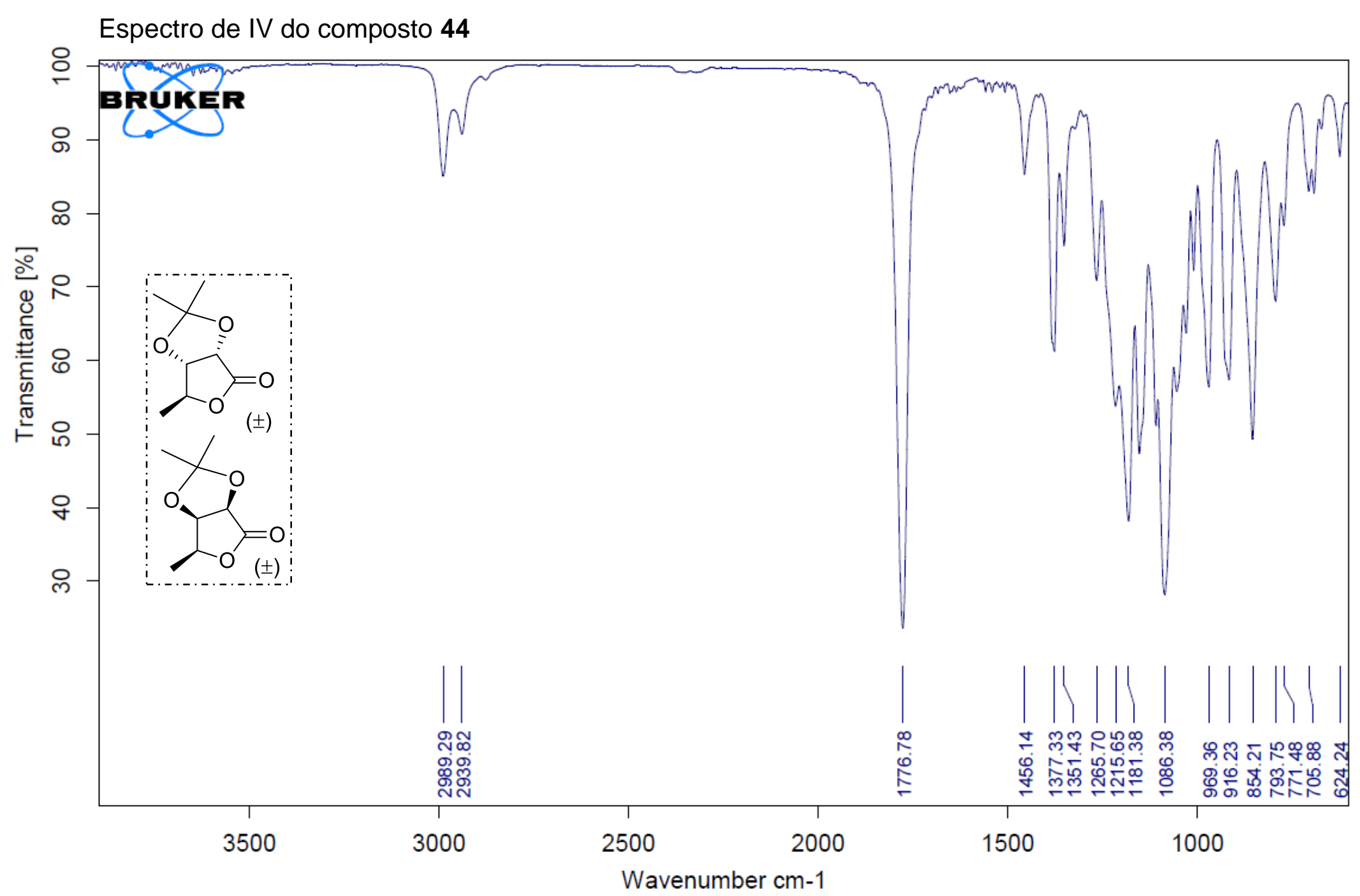




\section{Anexos}

$\mathrm{RMN}$ de ${ }^{1} \mathrm{H}$ de 45a. Mistura diastereoisomérica
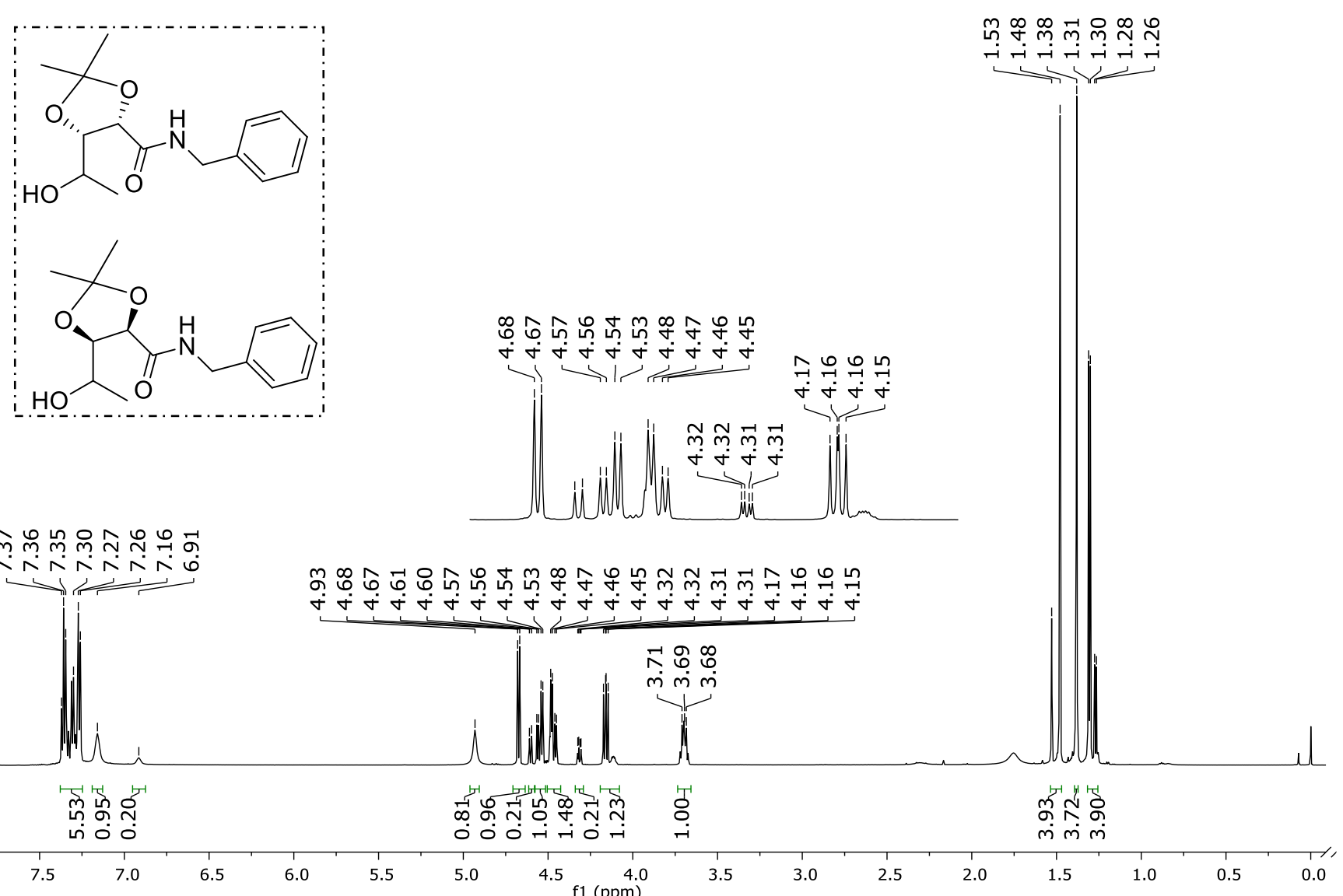


\section{Anexos}

$\mathrm{RMN}$ de ${ }^{13} \mathrm{C}$ de 45a. Mistura diastereoisomérica

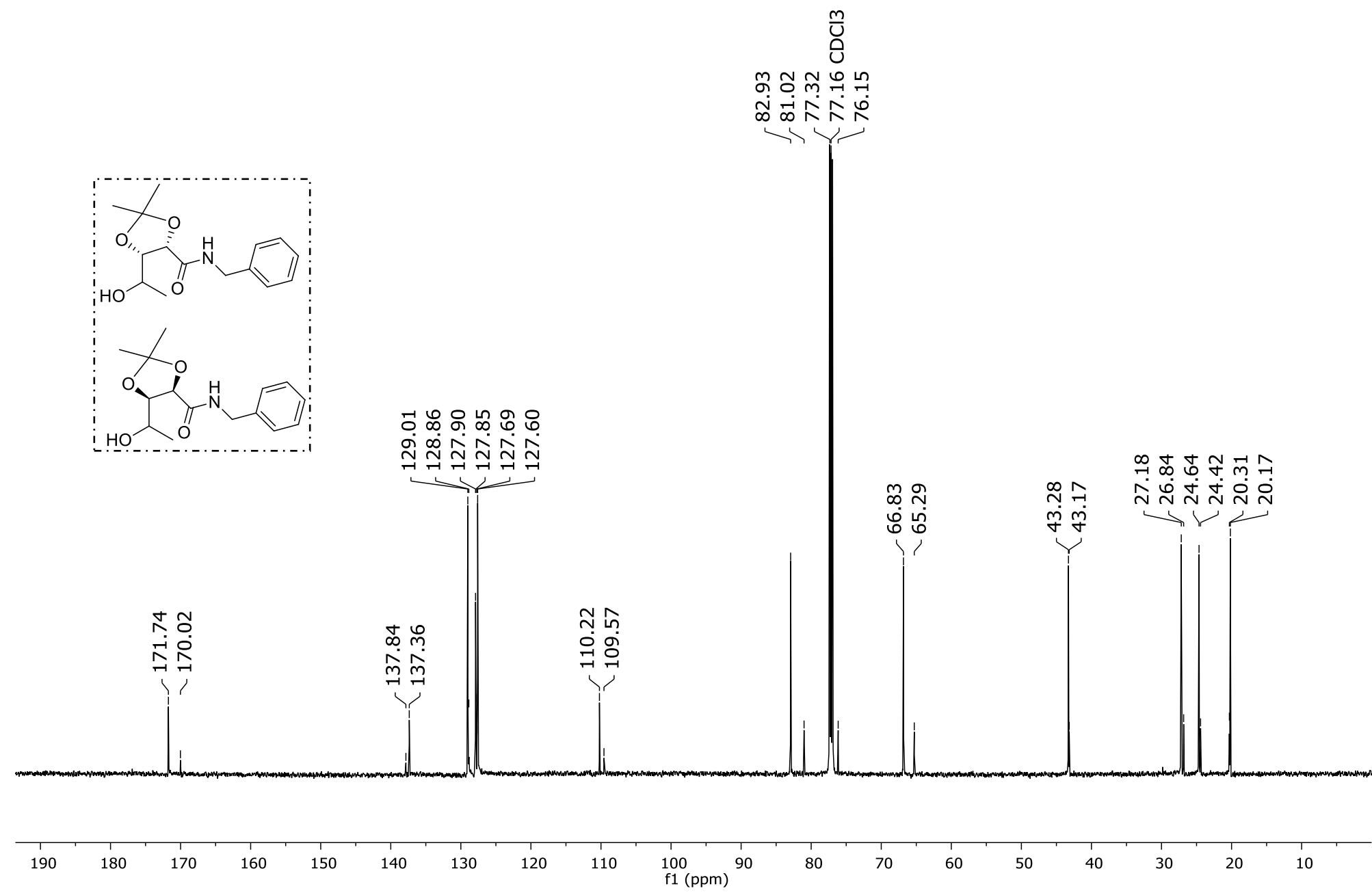




\section{Anexos}

Análise por CG-EM do bruto reacional de 45a. Mistura diastereoisomérica
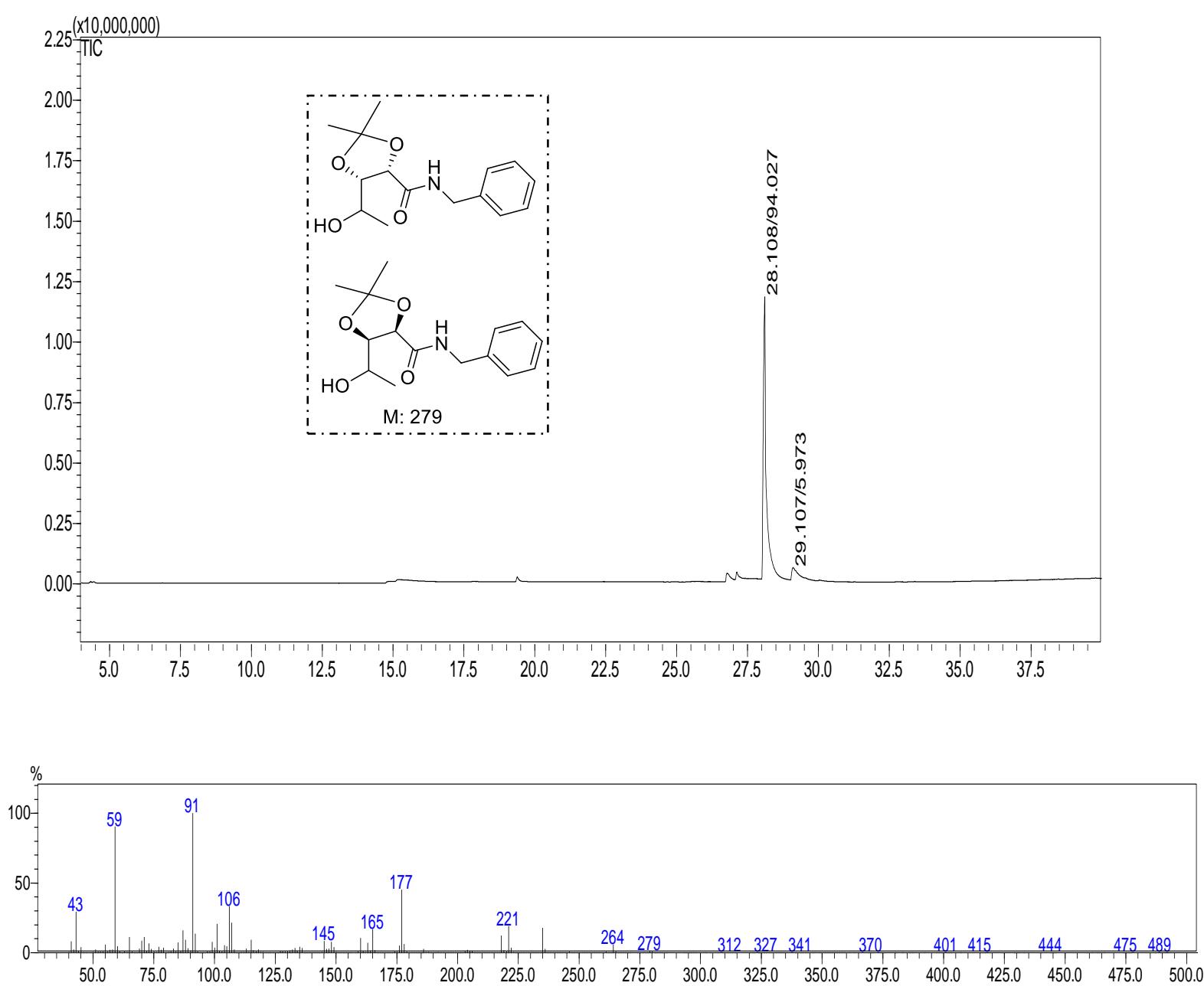
Anexos

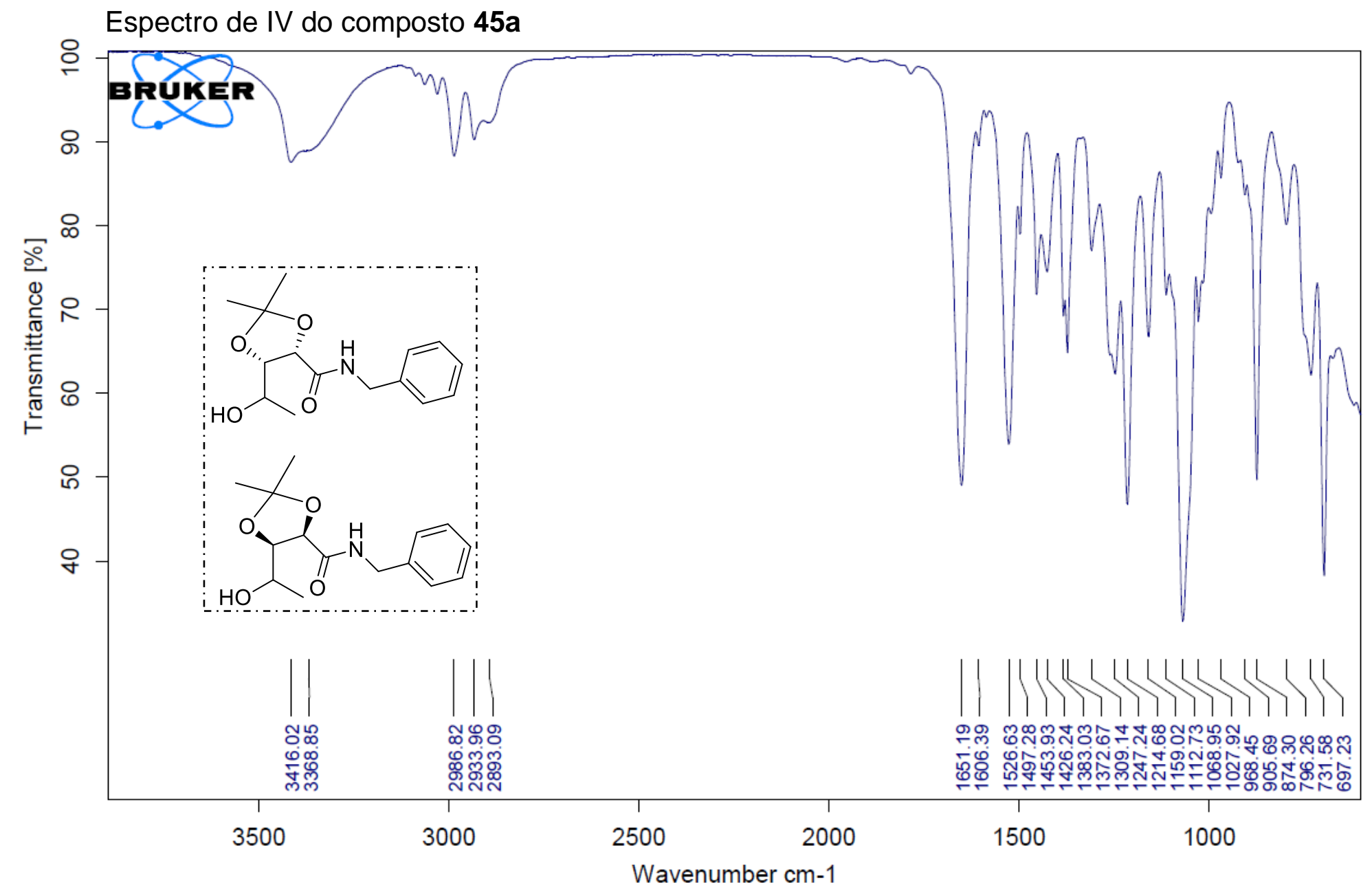




\section{Anexos}

RMN de ${ }^{1} \mathrm{H}$ de $45 b$. Bruto reacional. Mistura diastereoisomérica

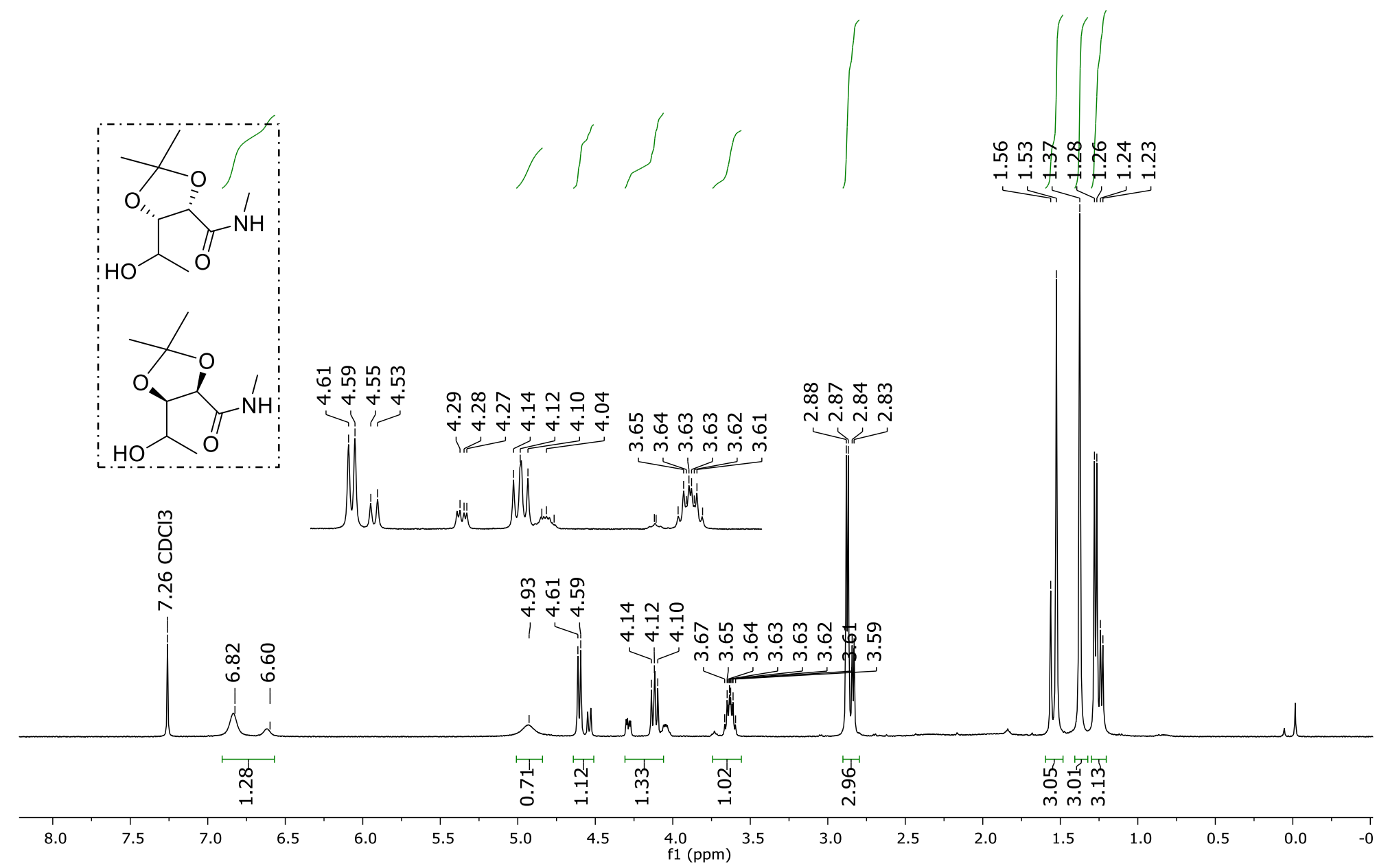




\section{Anexos}

RMN de ${ }^{13} \mathrm{C}$ de $45 b$. Bruto reacional. Mistura diastereoisomérica

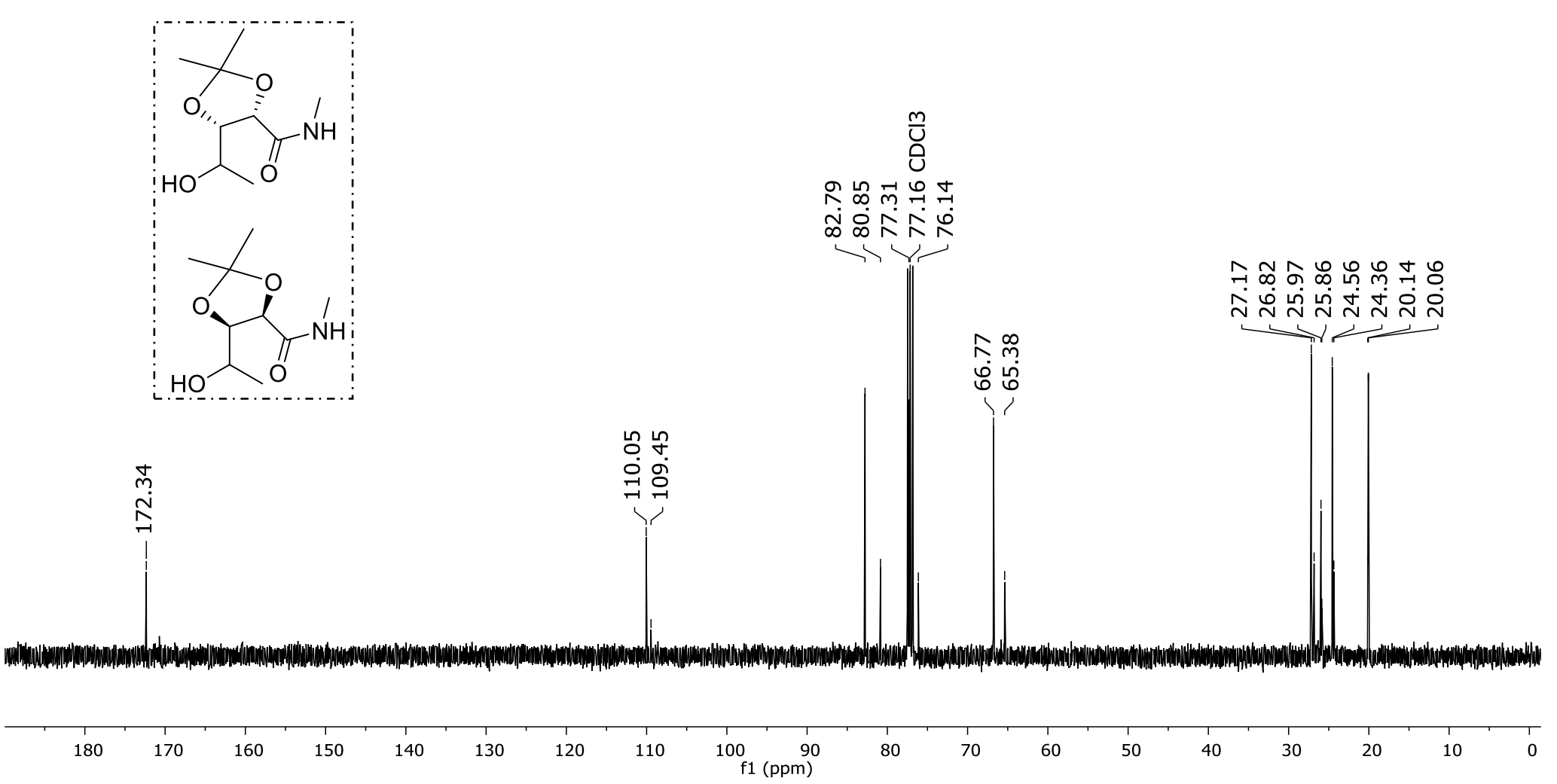




\section{Anexos}

Análise por CG-EM do bruto reacional de 45b. Mistura diastereoisomérica
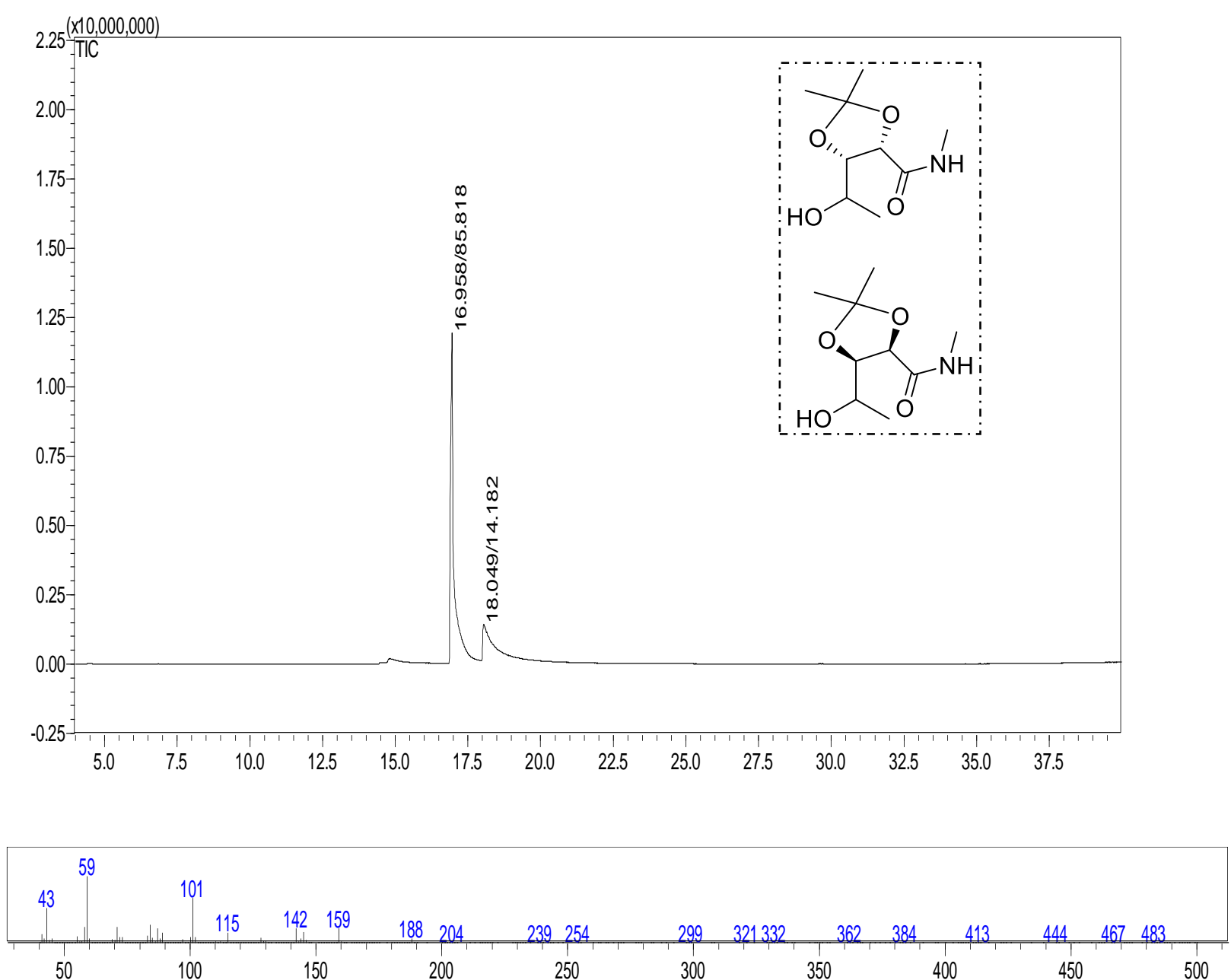
Anexos

Espectro de IV do composto 45b

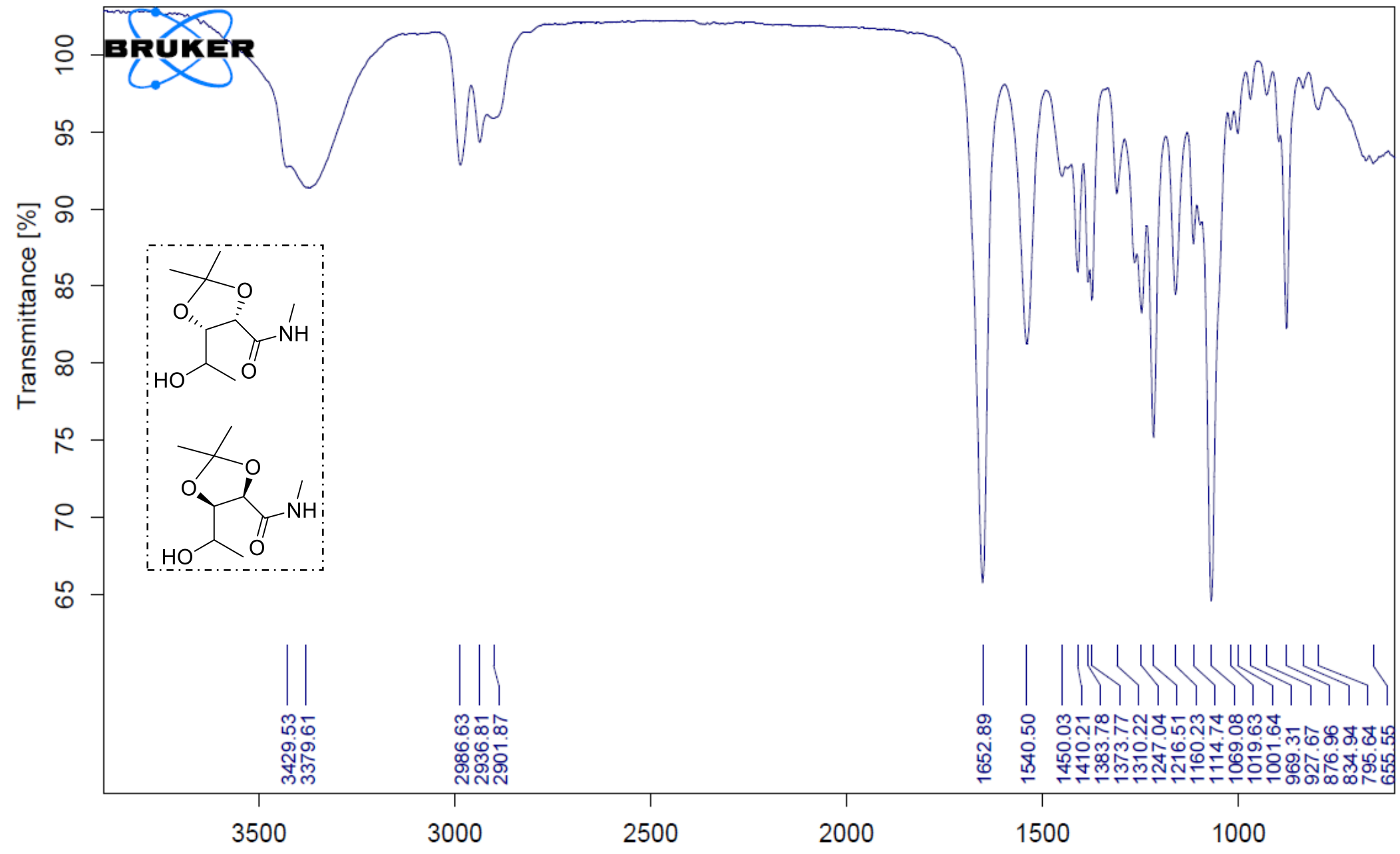




\section{Anexos}

RMN de ${ }^{1} \mathrm{H}$ de $45 \mathrm{c}$. Bruto reacional. Mistura diastereoisomérica

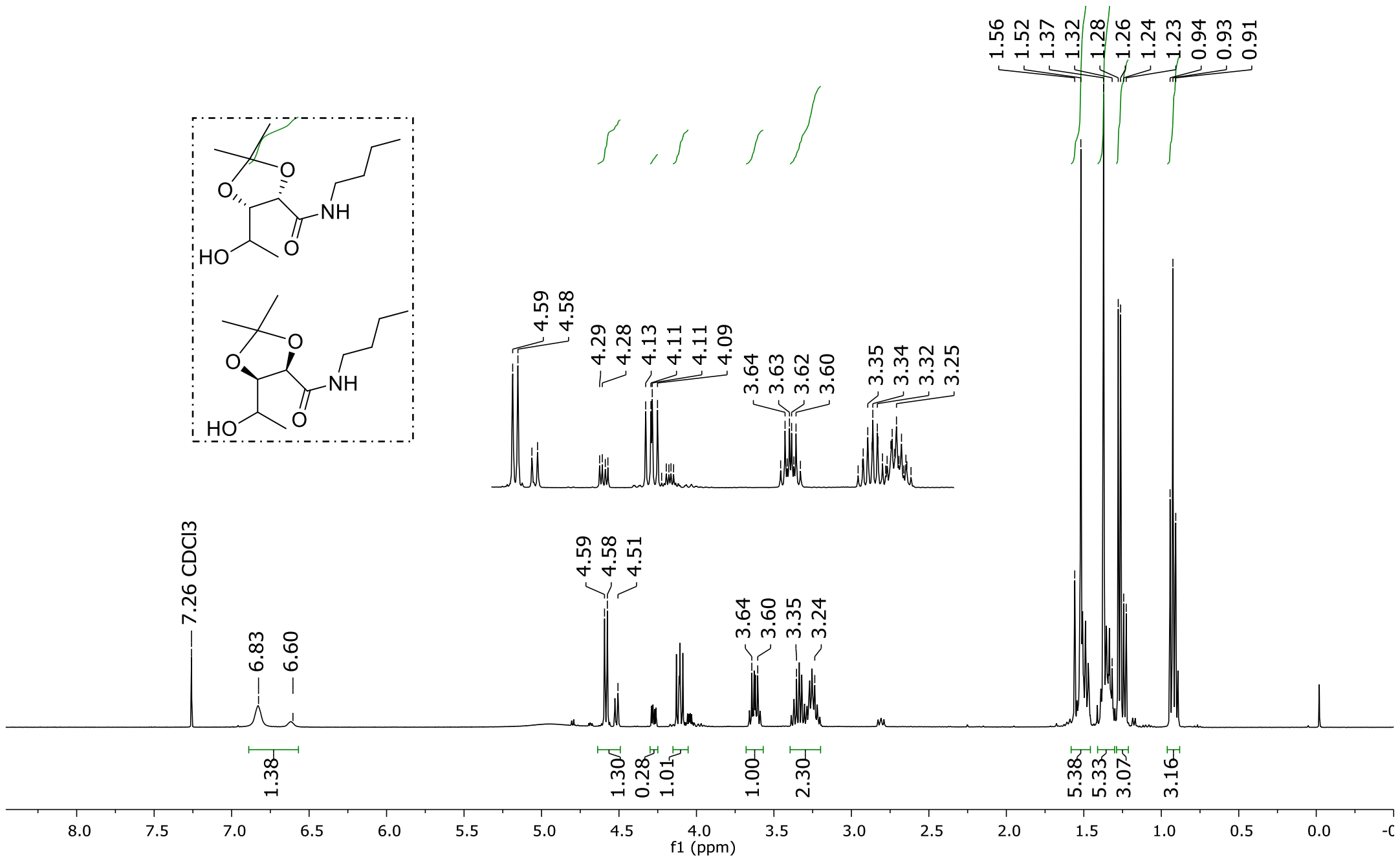




\section{Anexos}

$\mathrm{RMN}$ de ${ }^{13} \mathrm{C}$ de 45c. Bruto reacional. Mistura diastereoisomérica

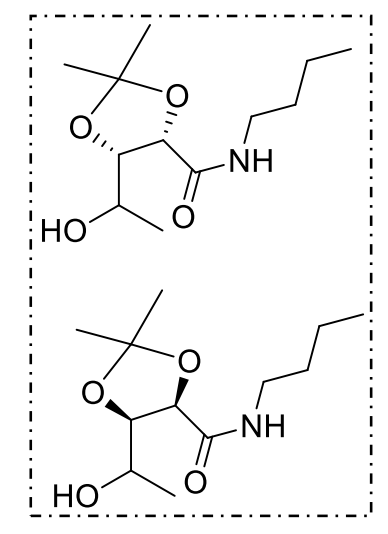

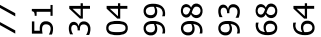

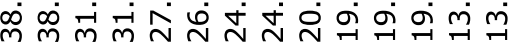

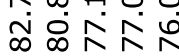
$\vec{m}$ ச่

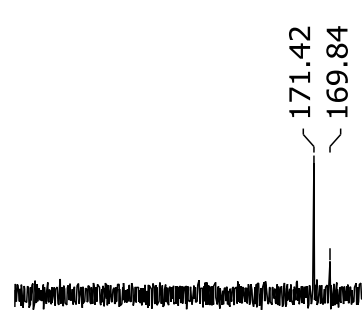

\&ุ․ำ

รㅇํㅇ

ㅇํㅇ
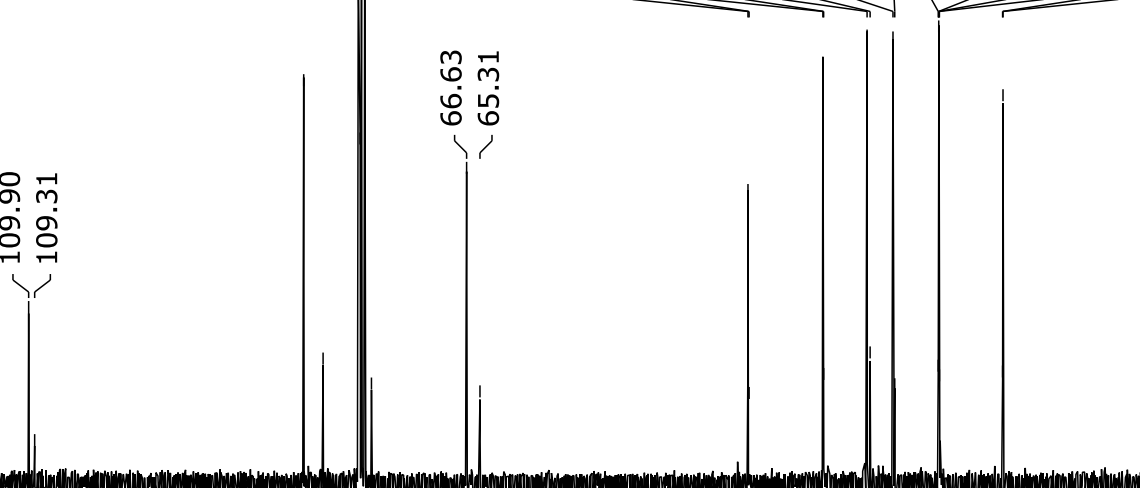

200

90

$180 \quad 170$

160

50

120

100
f1 $(\mathrm{ppm})$

90

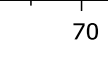

$60 \quad 50 \quad 40$

30

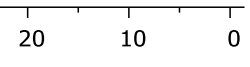


Anexos

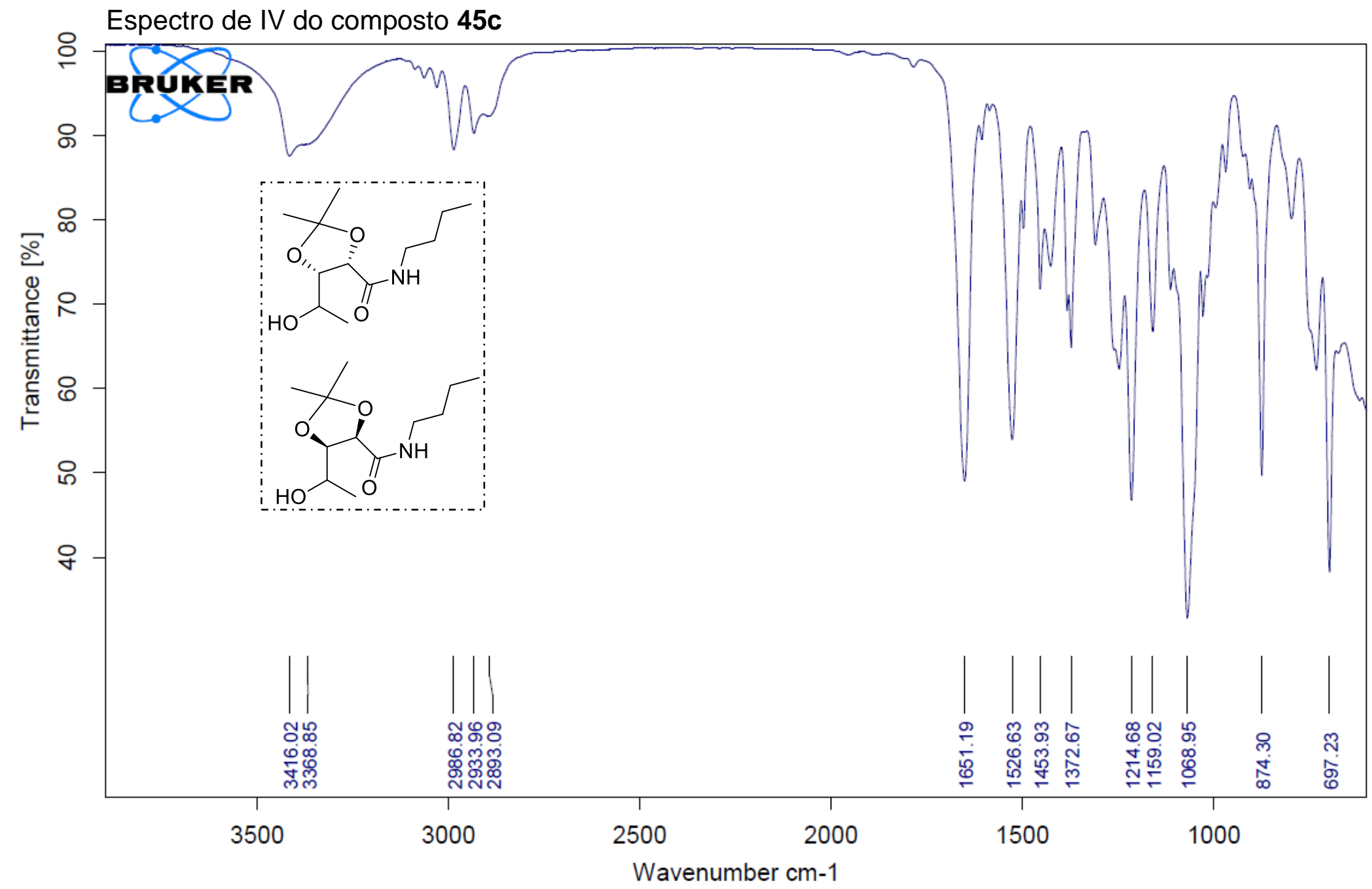




\section{Anexos}

RMN de ${ }^{1} \mathrm{H}$ de $45 \mathrm{~d}$. Bruto reacional. Mistura diastereoisomérica

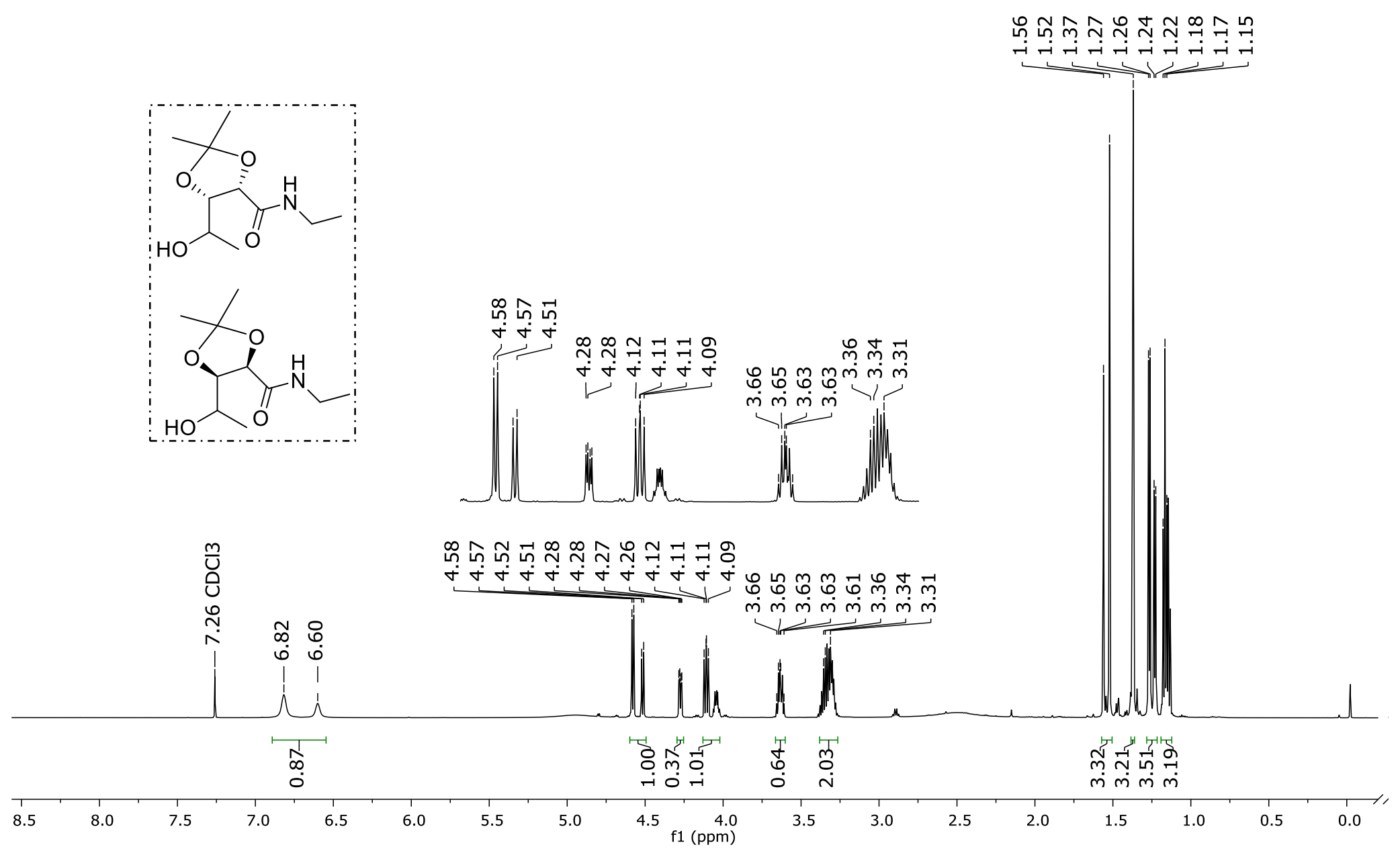




\section{Anexos}

RMN de ${ }^{13} \mathrm{C}$ de 45d. Bruto reacional. Mistura diastereoisomérica

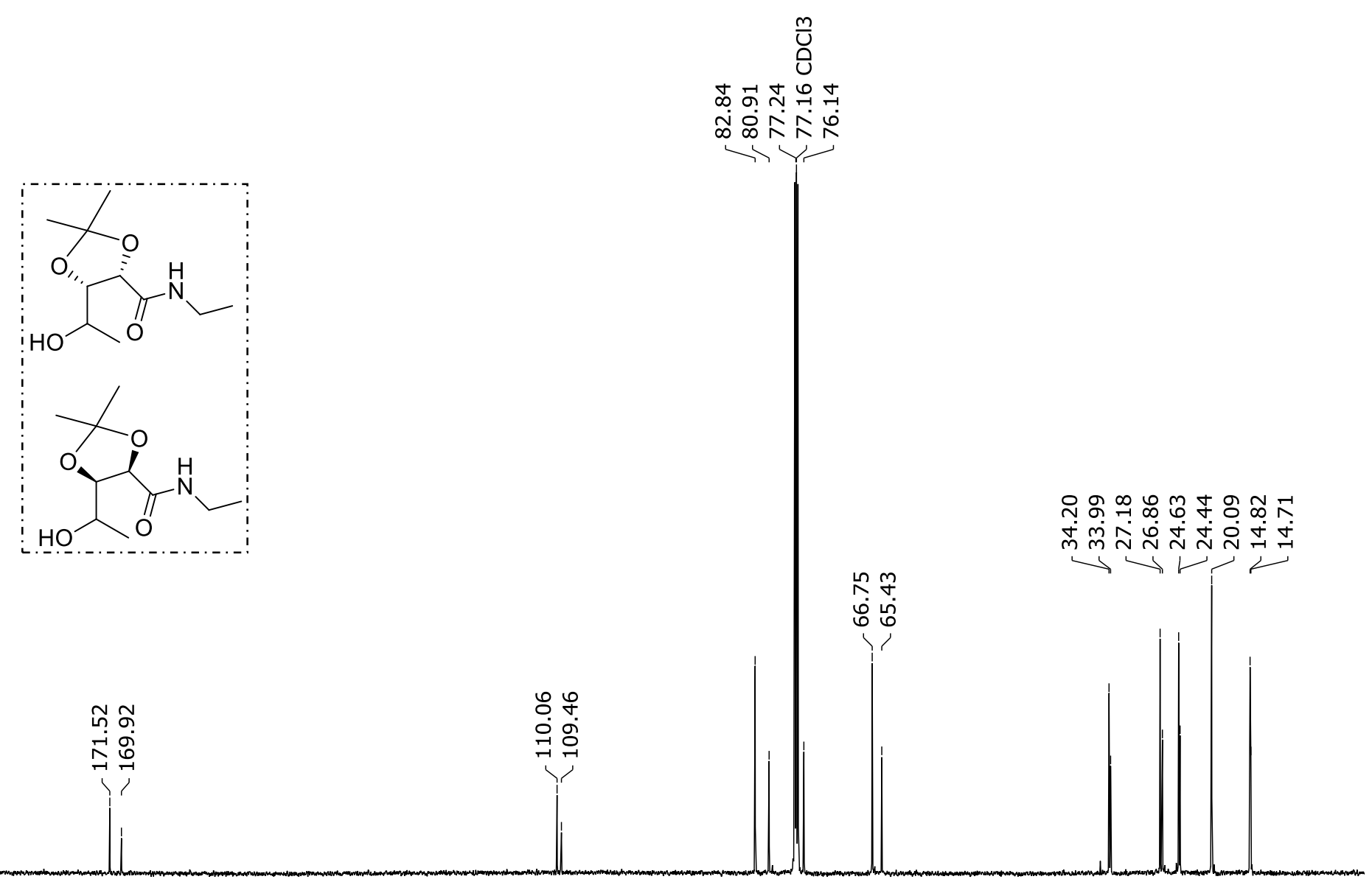

200

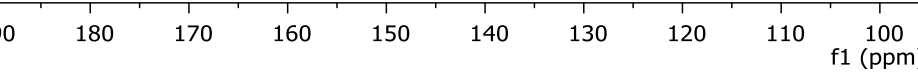

) 90

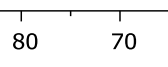

60
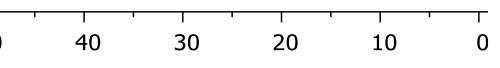


\section{Anexos}

\section{Análise por CG-EM do bruto reacional de 45d. Mistura diastereoisomérica}
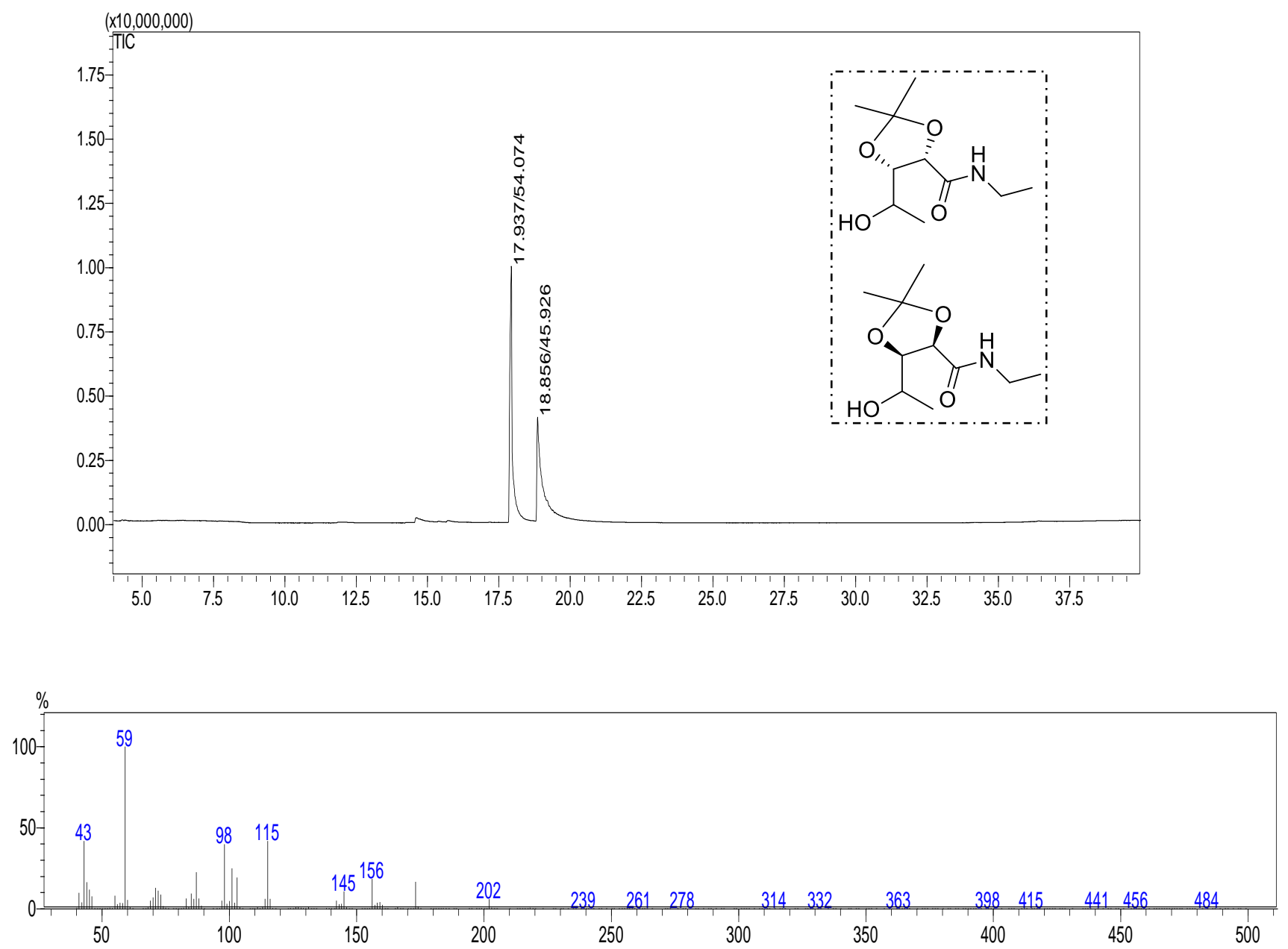


\section{Anexos}

RMN de ${ }^{1} \mathrm{H}$ de 45e. Bruto reacional. Mistura diastereoisomérica
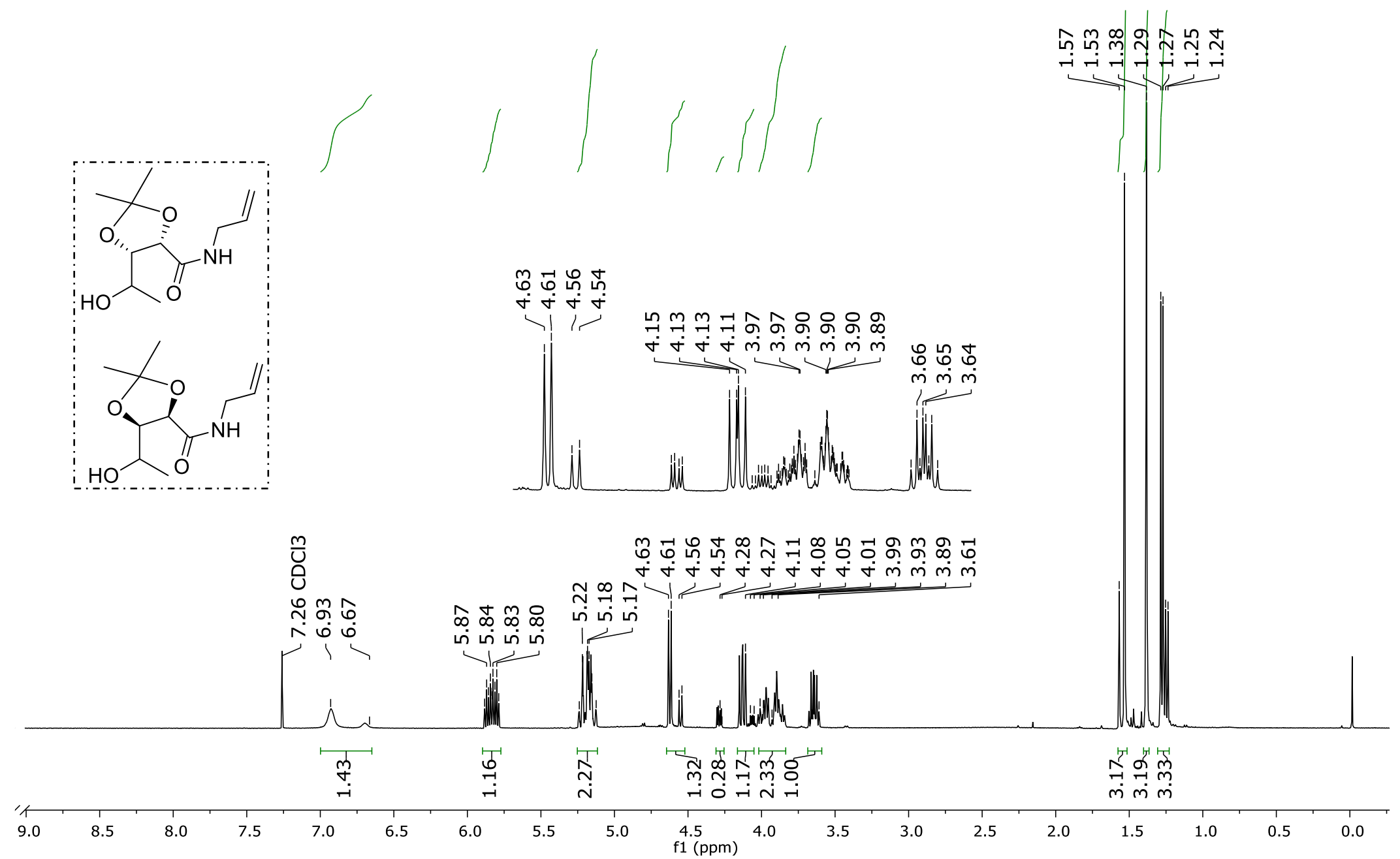


\section{Anexos}

$\mathrm{RMN}$ de ${ }^{13} \mathrm{C}$ de $45 \mathrm{e}$. Bruto reacional. Mistura diastereoisomérica

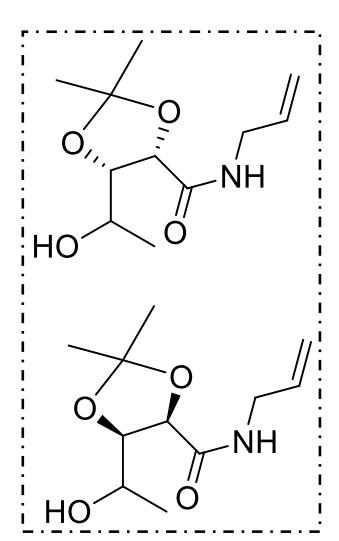

$$
\begin{aligned}
& \frac{m}{\mathrm{v}}
\end{aligned}
$$

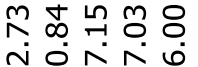

$\underset{6}{\sim} \stackrel{\infty}{\circ}$

ชั่

웅ํㅜㅇํㅇㅇㅛ

눅 웍

6 ก

$\stackrel{m}{\sim} \underset{\sim}{m}$

तो

고은
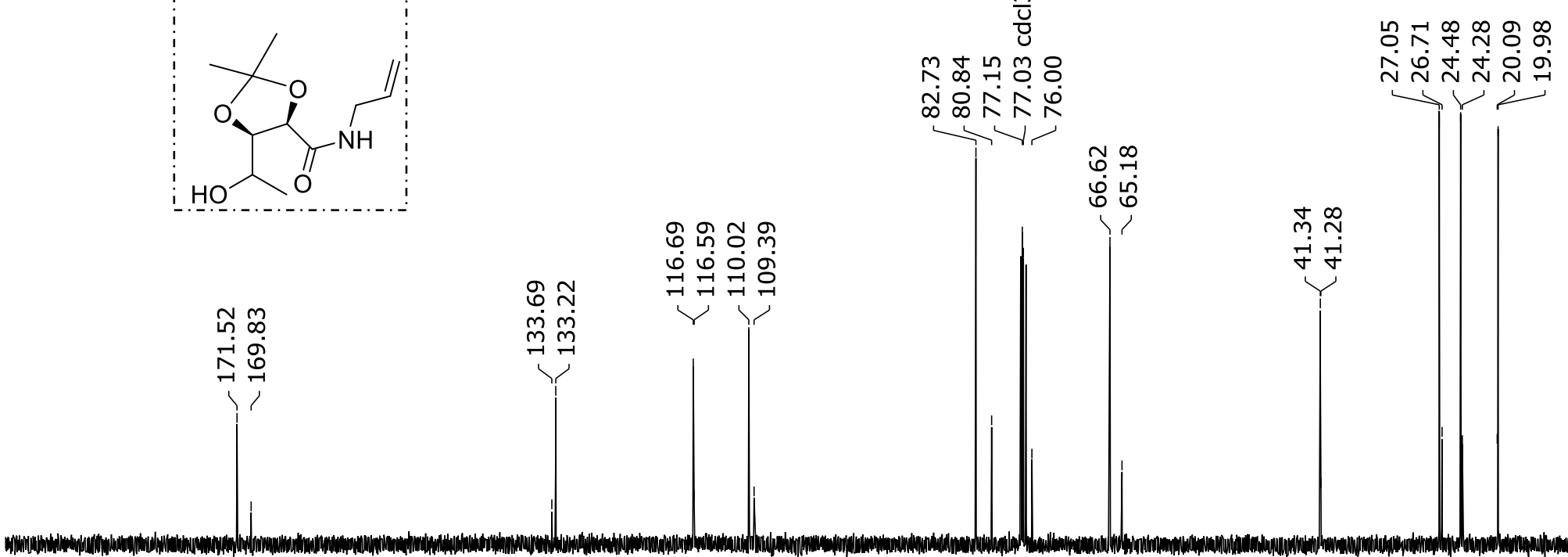

ஸे

$\vec{\gamma} \vec{\gamma}$
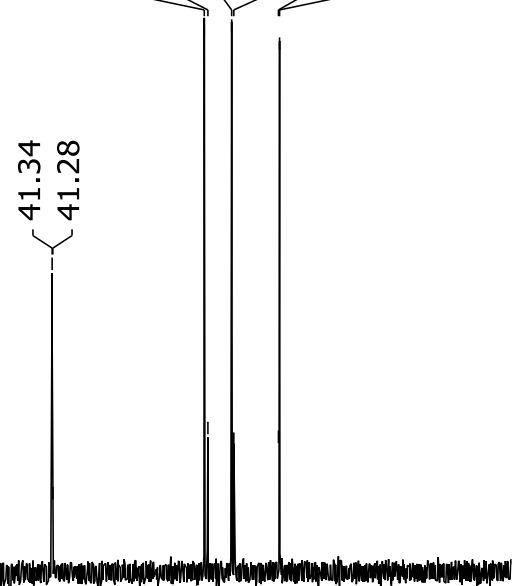


\section{Anexos}

Análise por CG-EM do bruto reacional de 45e. Mistura diastereoisomérica
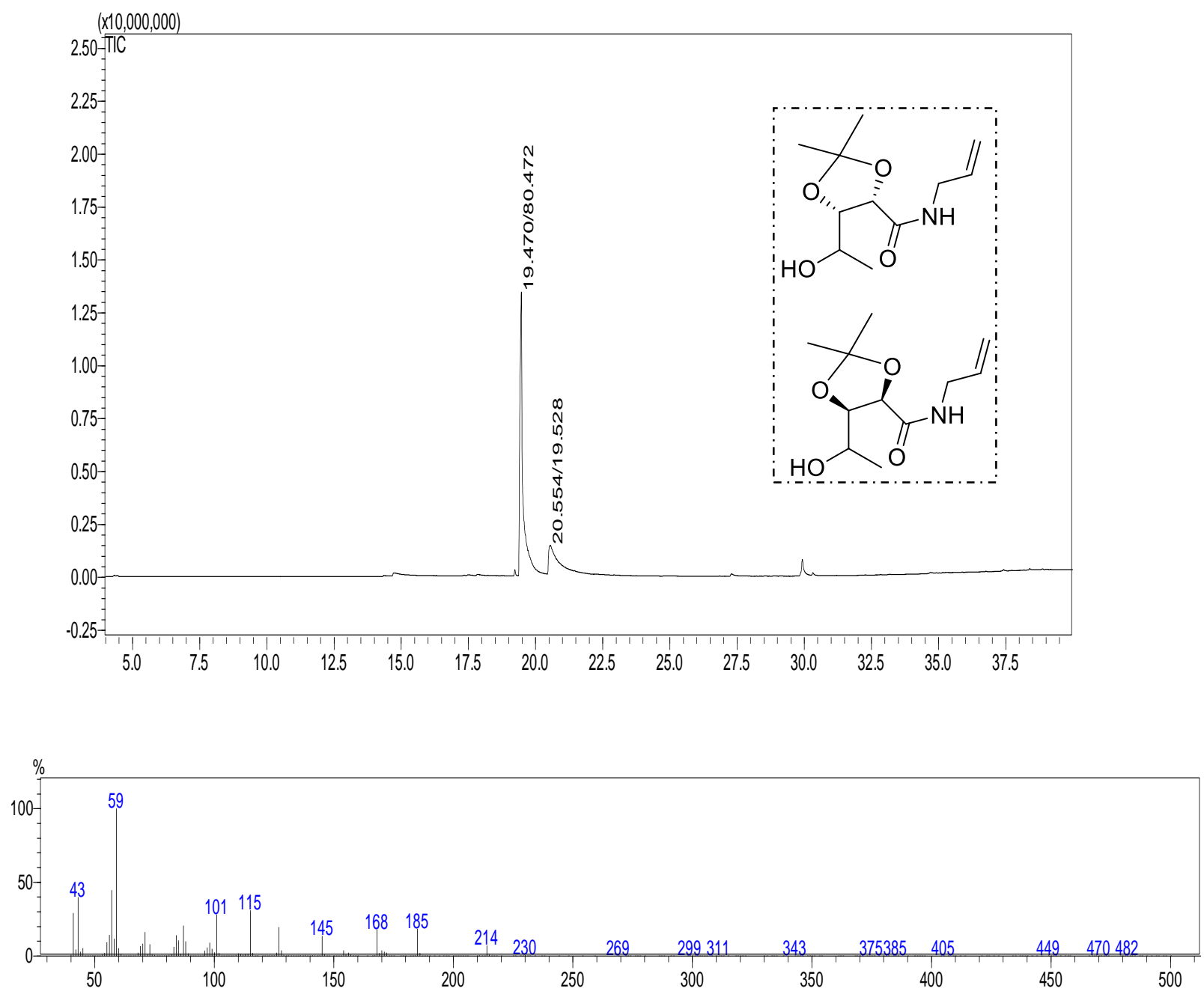
Anexos

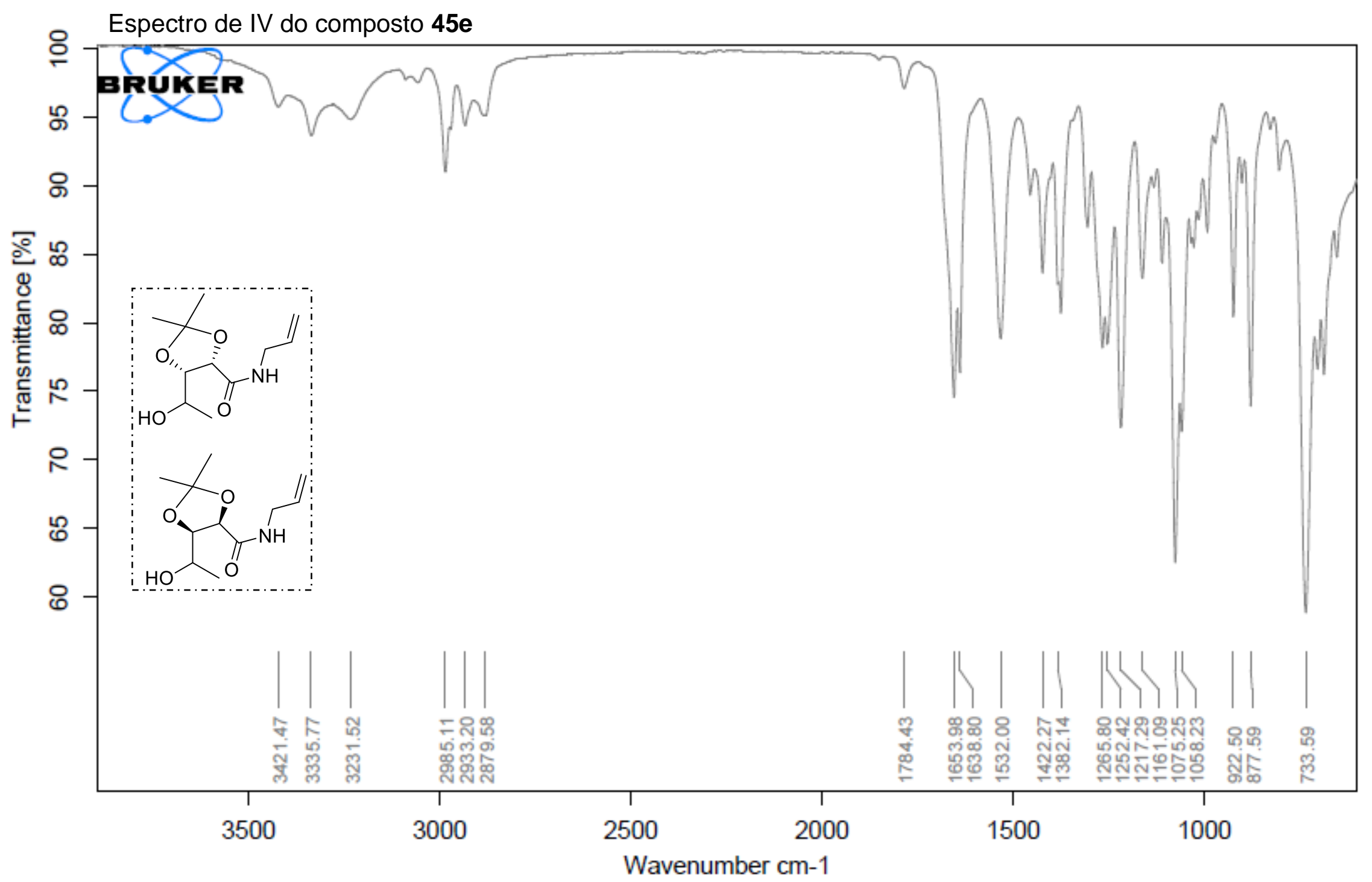




\section{Anexos}

$\mathrm{RMN}$ de ${ }^{1} \mathrm{H}$ de 45f. Mistura diastereoisomérica

の

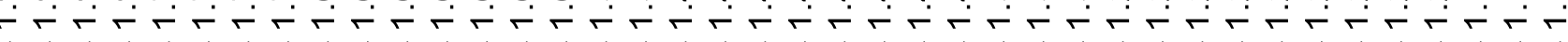
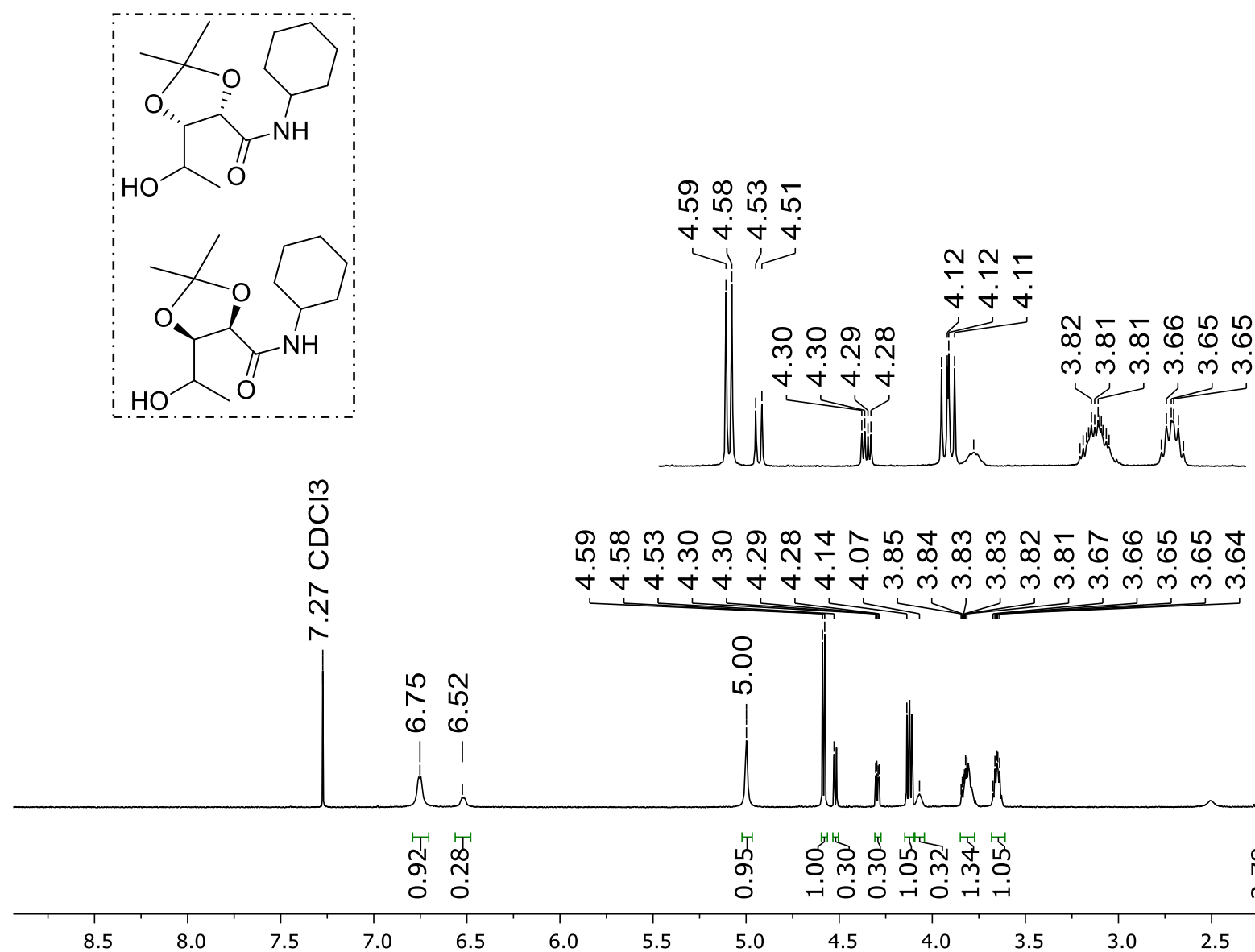

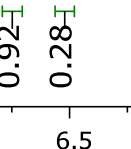

గ
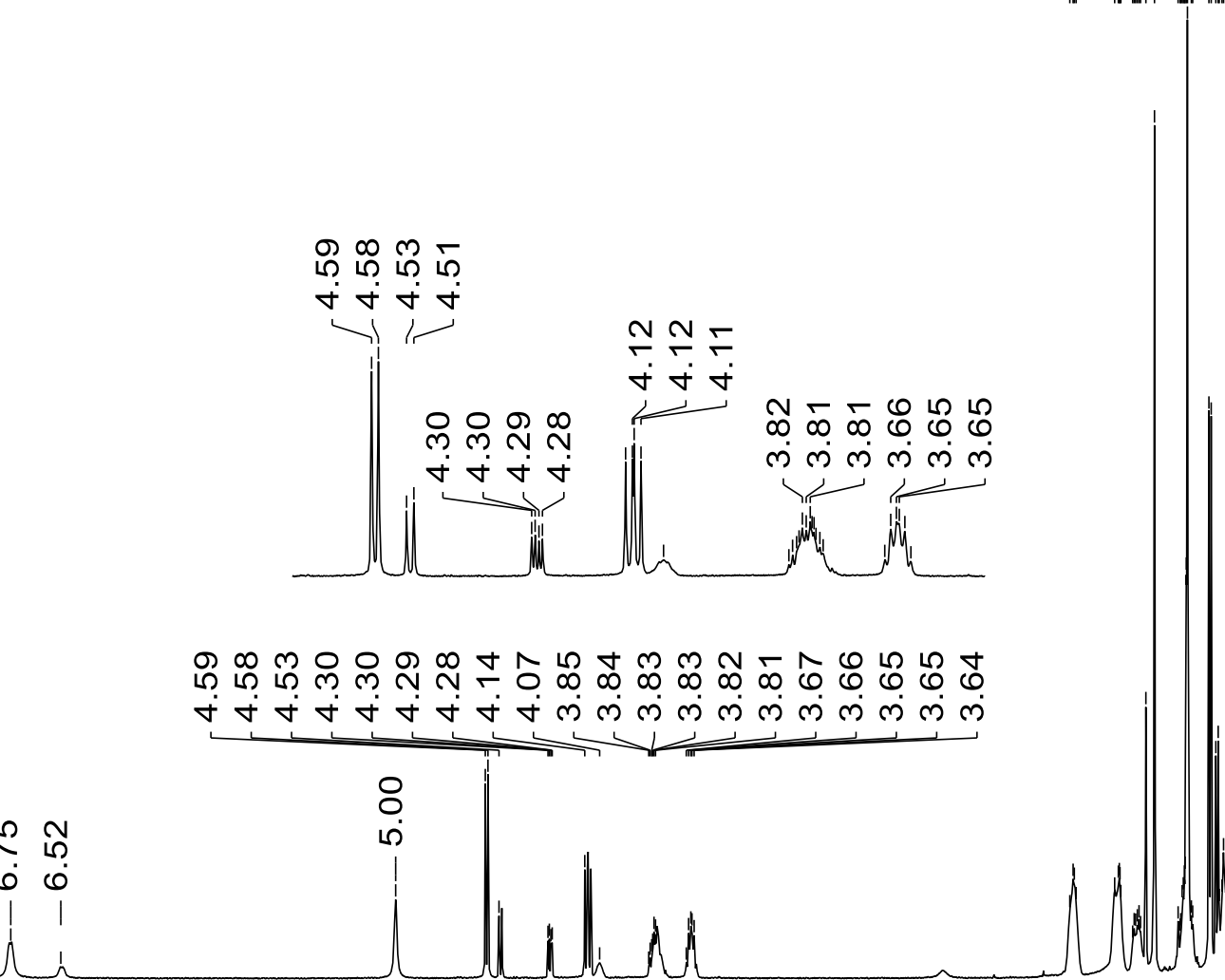

$8.0 \quad 7.5$

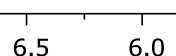

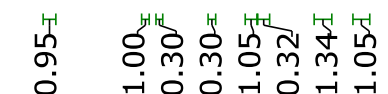

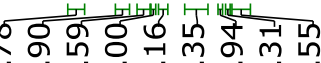
ง

$4.5 \quad 4.0$

$\begin{array}{llll}3.5 & 3.0 & 2.5 & 2.0\end{array}$

1.5 


\section{Anexos}

RMN de ${ }^{13} \mathrm{C}$ de $45 f$. Mistura diastereoisomérica

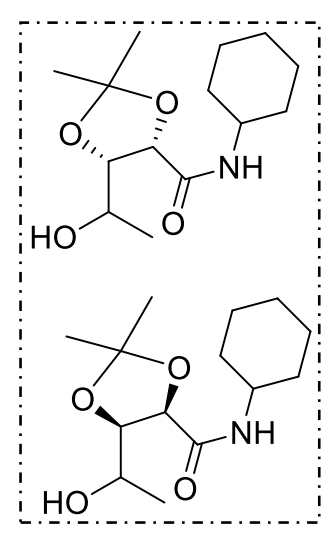

บ

นூํ요윰ำ

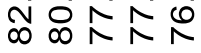

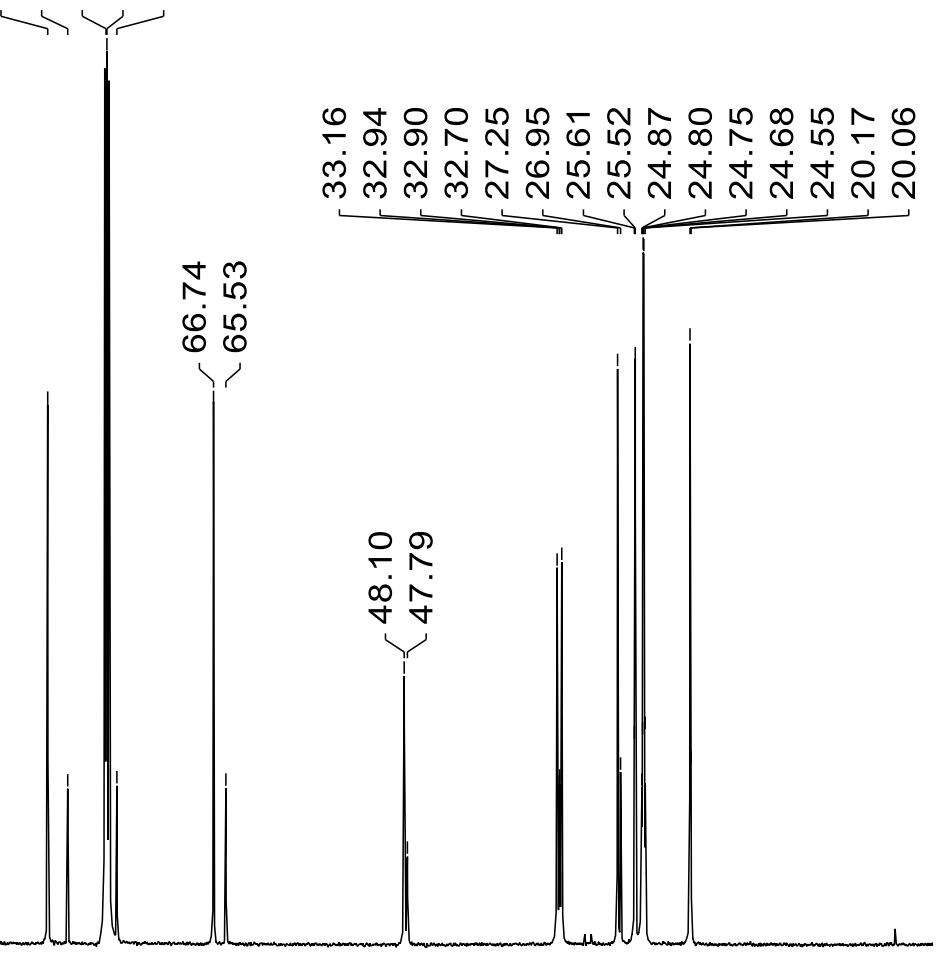

$190 \quad 180 \quad 170$

$\hat{\circ}$

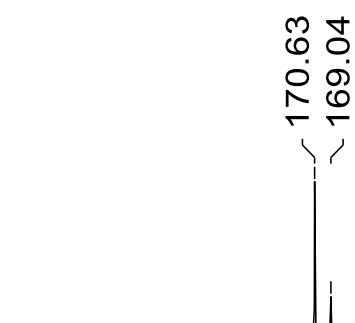

을 웅

10

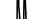




\section{Anexos}

Análise por CG-EM de 45f. Mistura diastereoisomérica
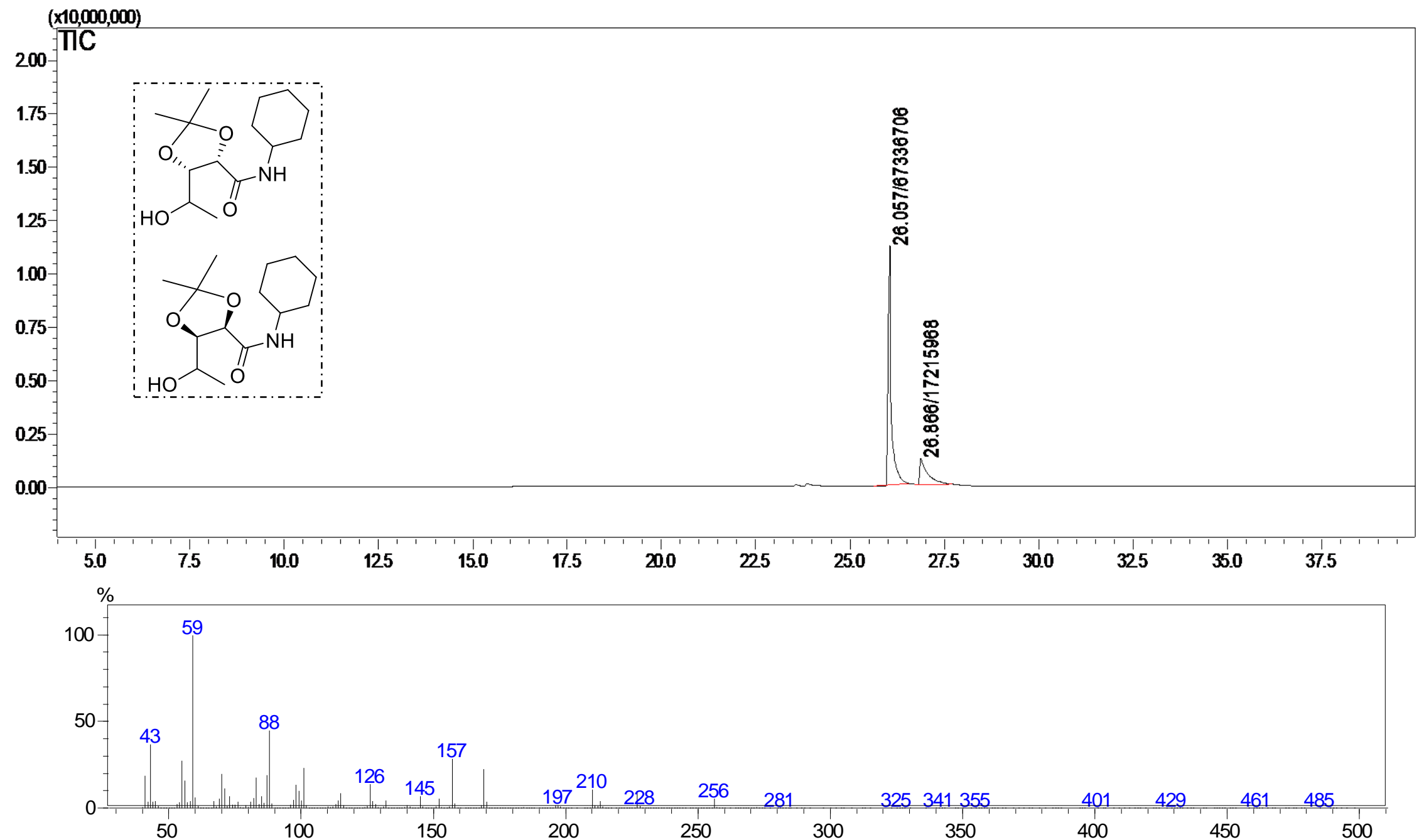
$\underline{\text { Anexos }}$

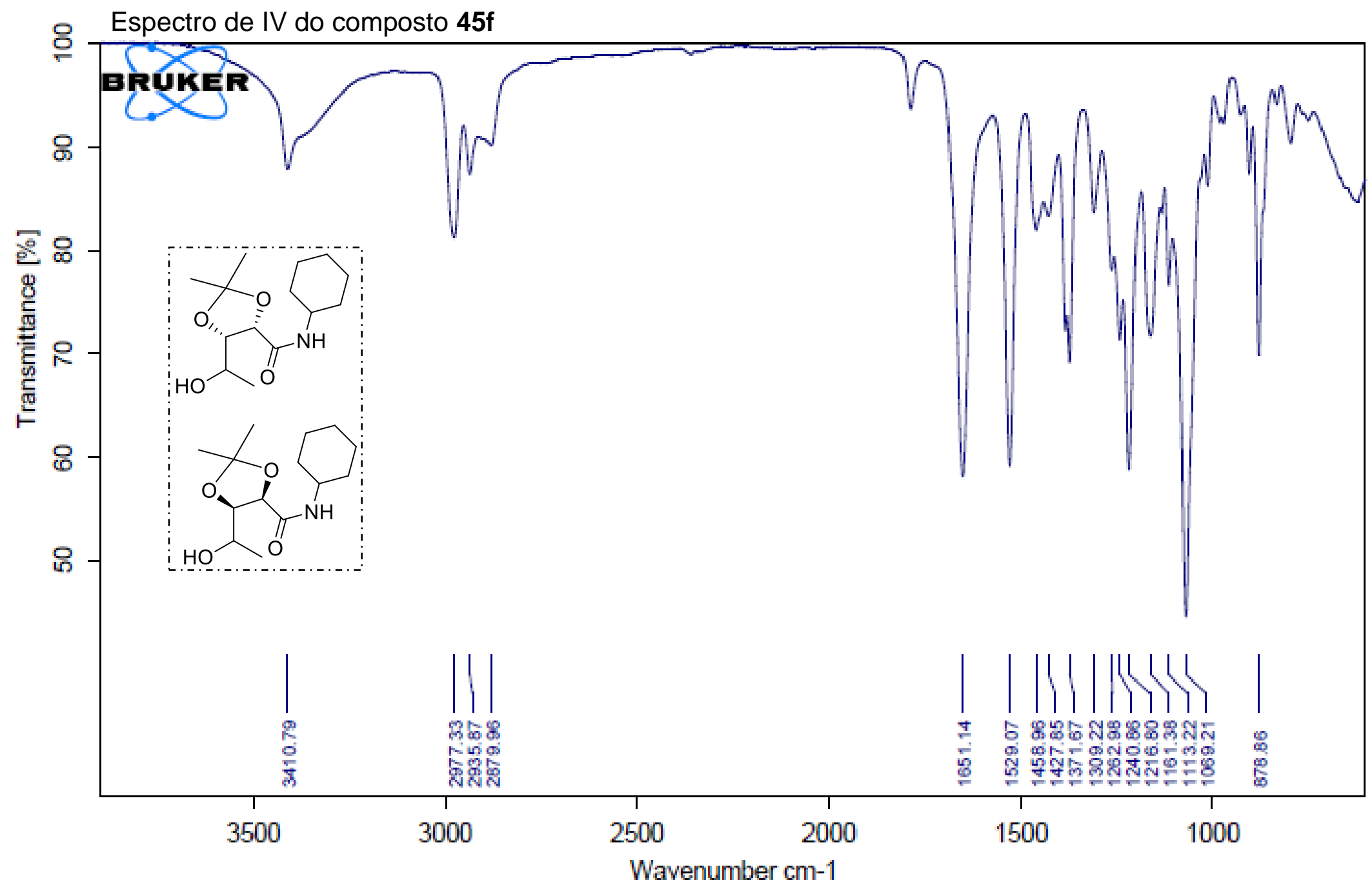




\section{Anexos}

RMN de ${ }^{1} \mathrm{H}$ de $\mathbf{4 5 g}$. Apenas 1 diastereoisômero
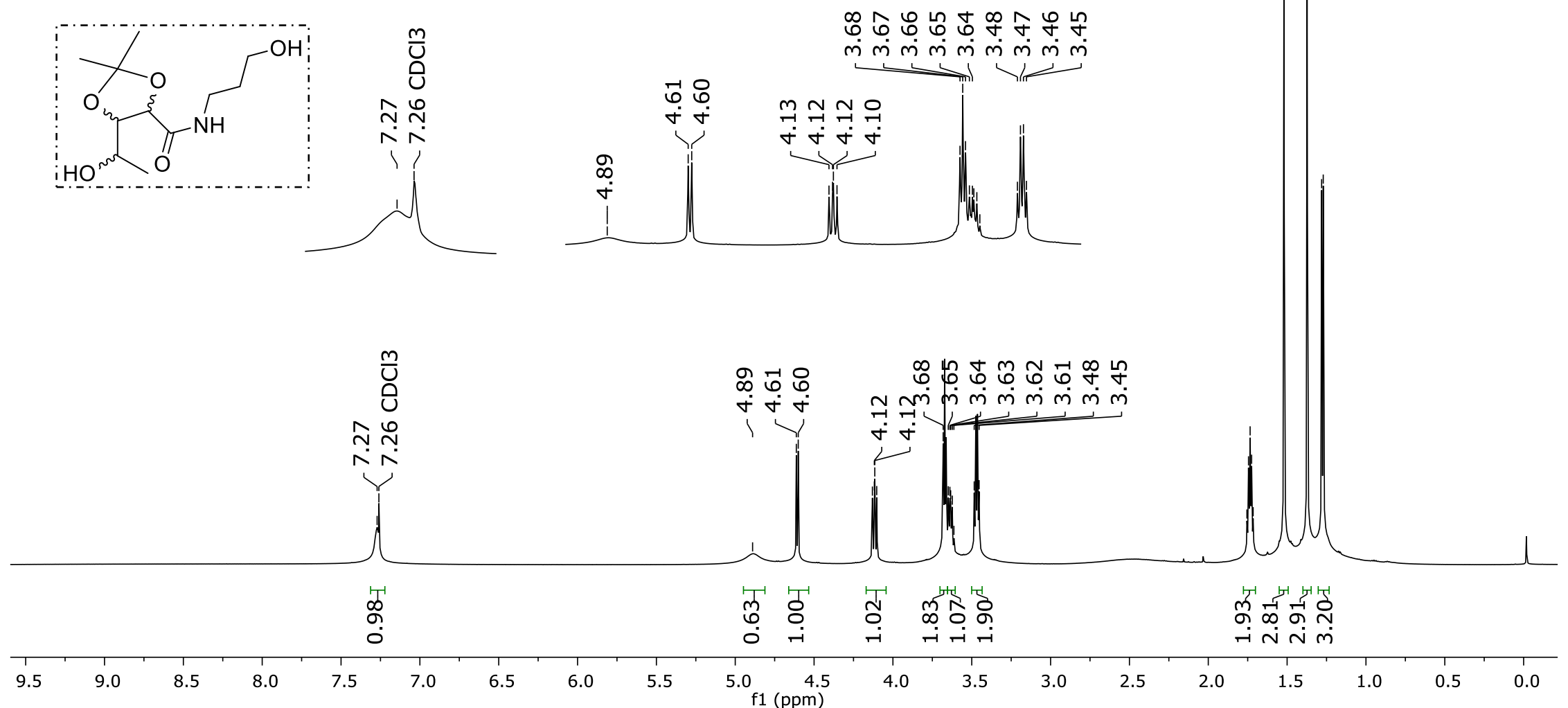


\section{Anexos}

RMN de ${ }^{13} \mathrm{C}$ de $\mathbf{4 5 g}$. Apenas 1 diastereoisômero

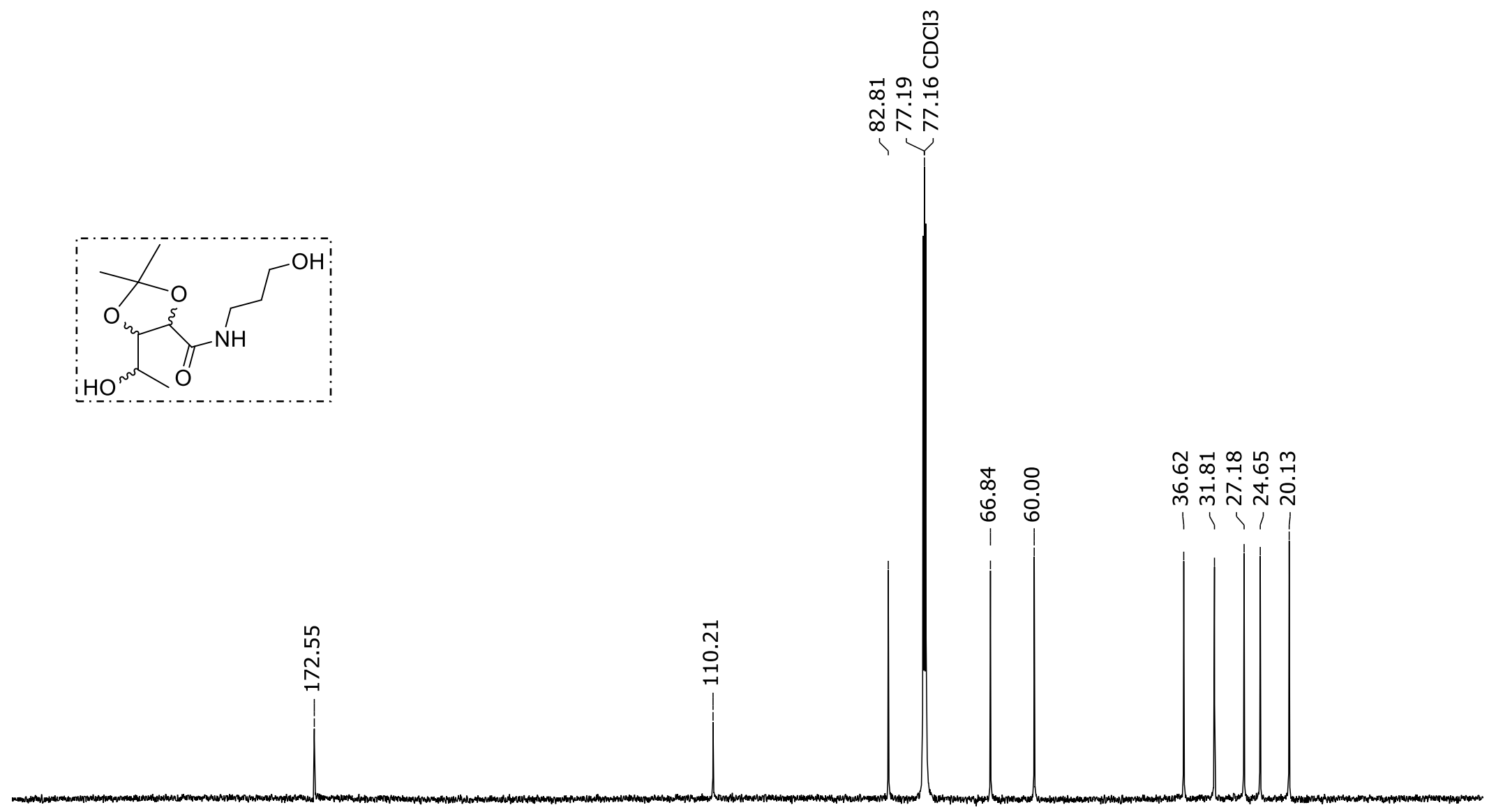

$\begin{array}{rllllllllll}210 & 200 & 190 & 180 & 170 & 160 & 150 & 140 & 130 & 120 & \begin{array}{c}110 \\ \mathrm{f} 1(\mathrm{ppm})\end{array}\end{array}$ 


\section{Anexos}

\section{Análise por CG-EM de $\mathbf{4 5 g}$. Apenas 1 diastereoisômero}
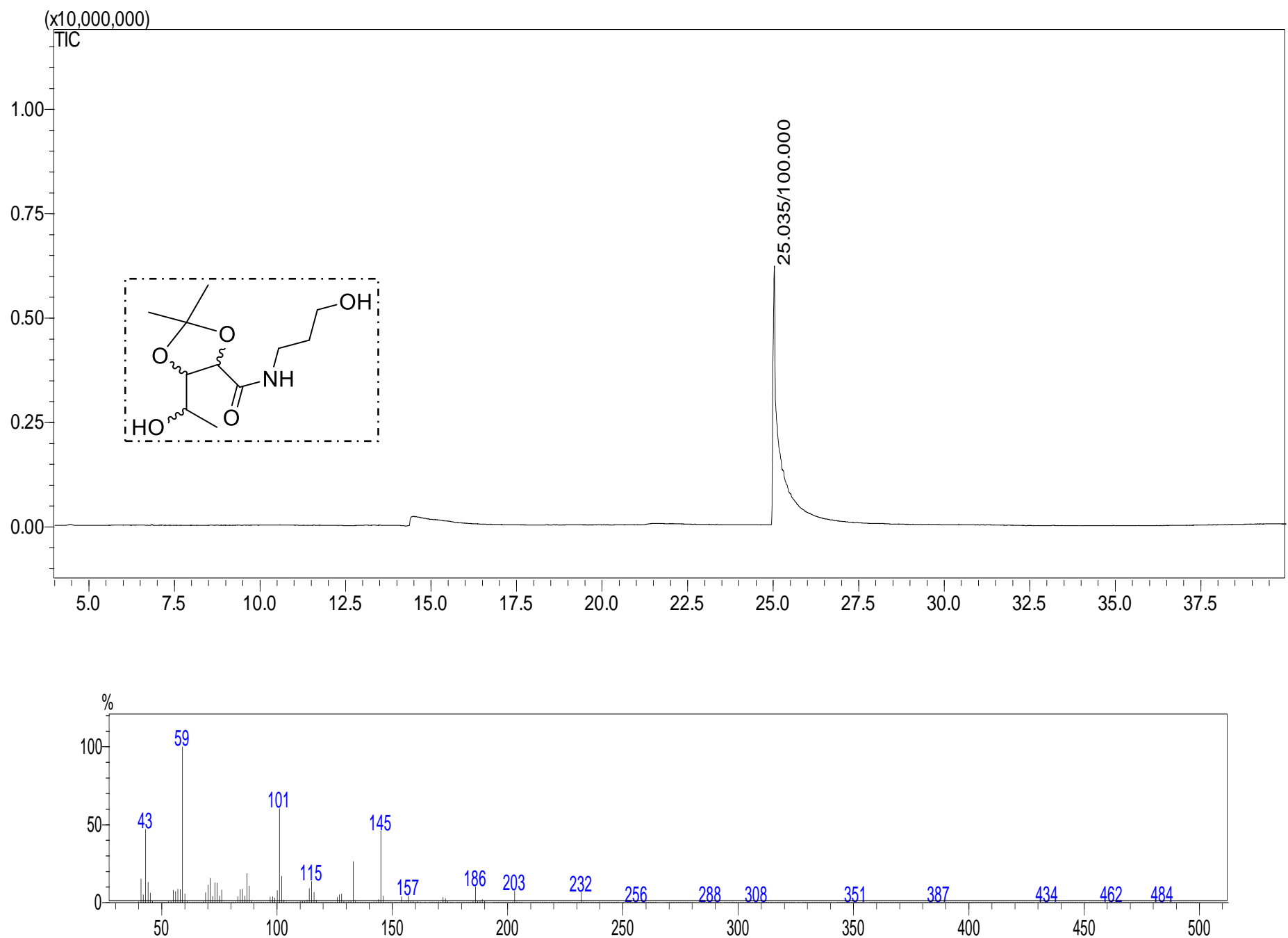
Anexos

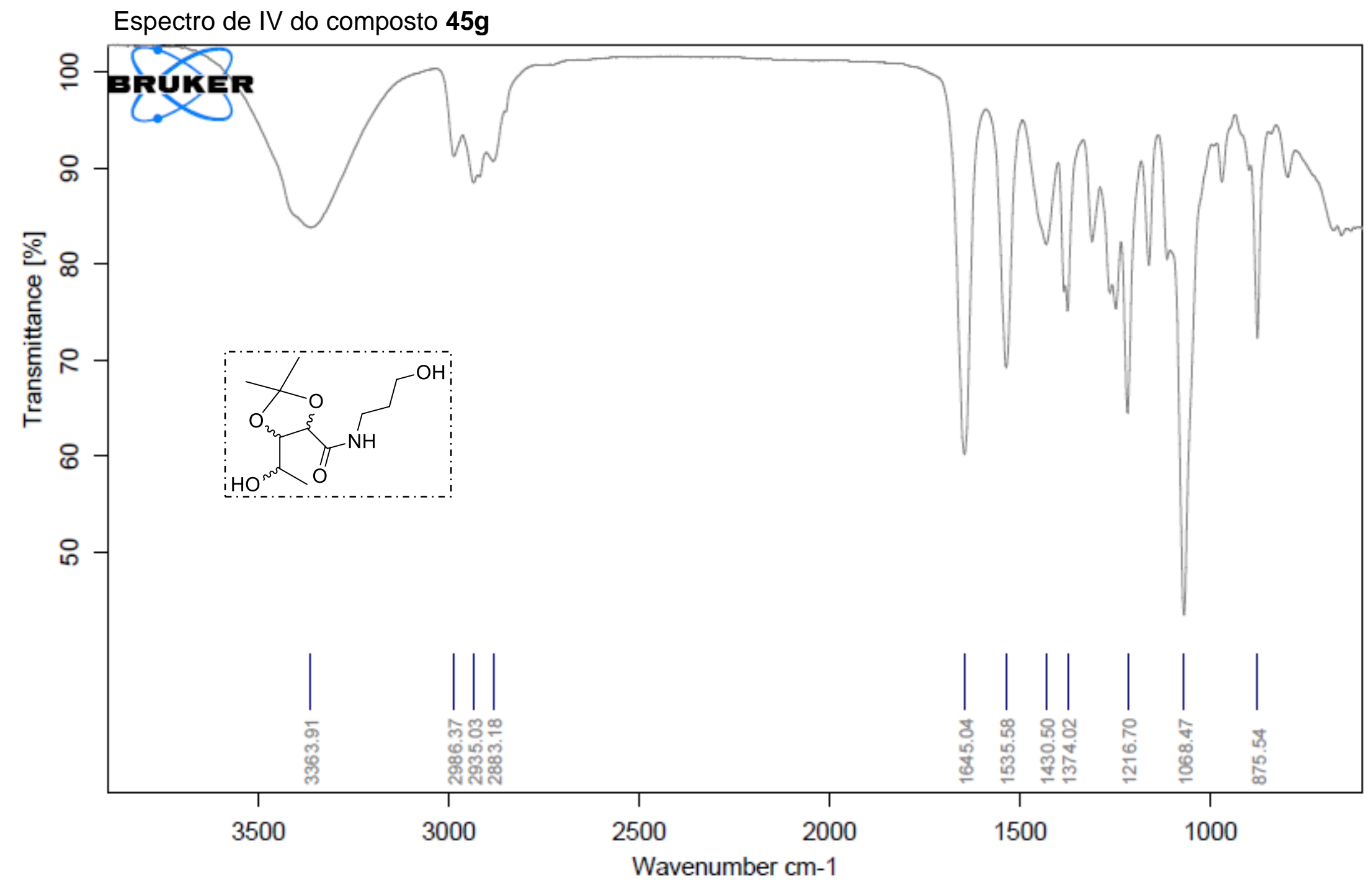




\section{Anexos}

RMN de ${ }^{1} \mathrm{H}$ de 45h. Apenas 1 diastereoisômero. Diastereoisômero 1

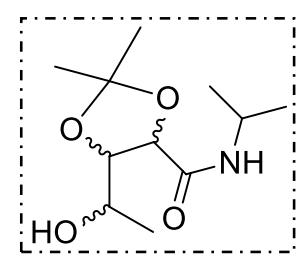

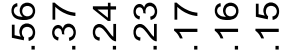

$$
\begin{aligned}
& \stackrel{-r}{-}-\dot{r}
\end{aligned}
$$

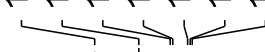

H.

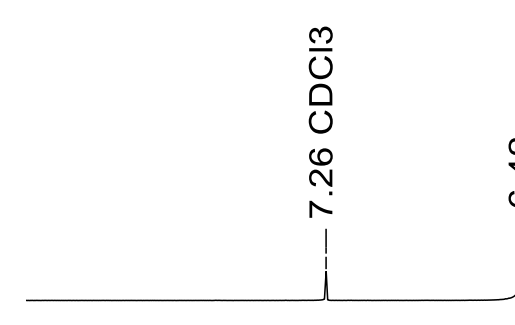

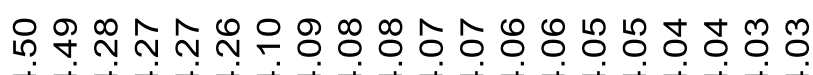

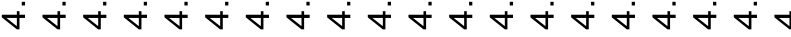
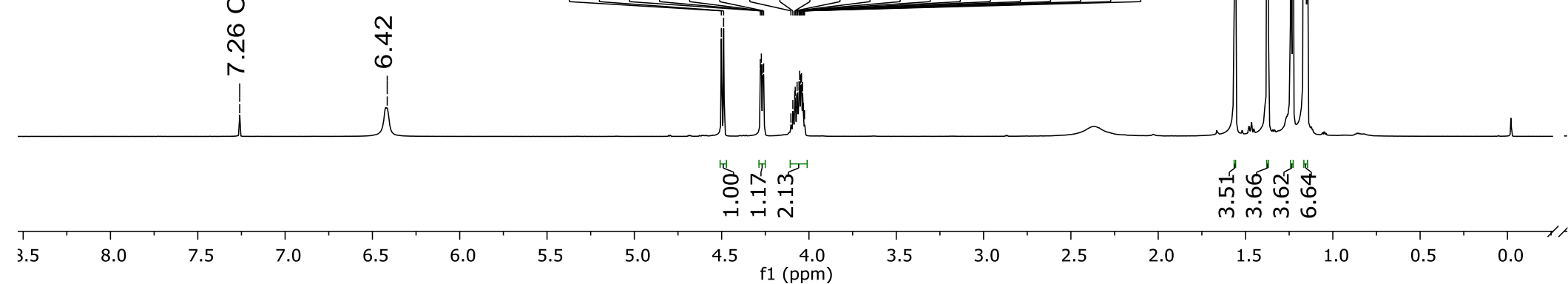


\section{Anexos}

RMN de ${ }^{13} \mathrm{C}$ de 45h. Apenas 1 diastereoisômero. Diastereoisômero 1

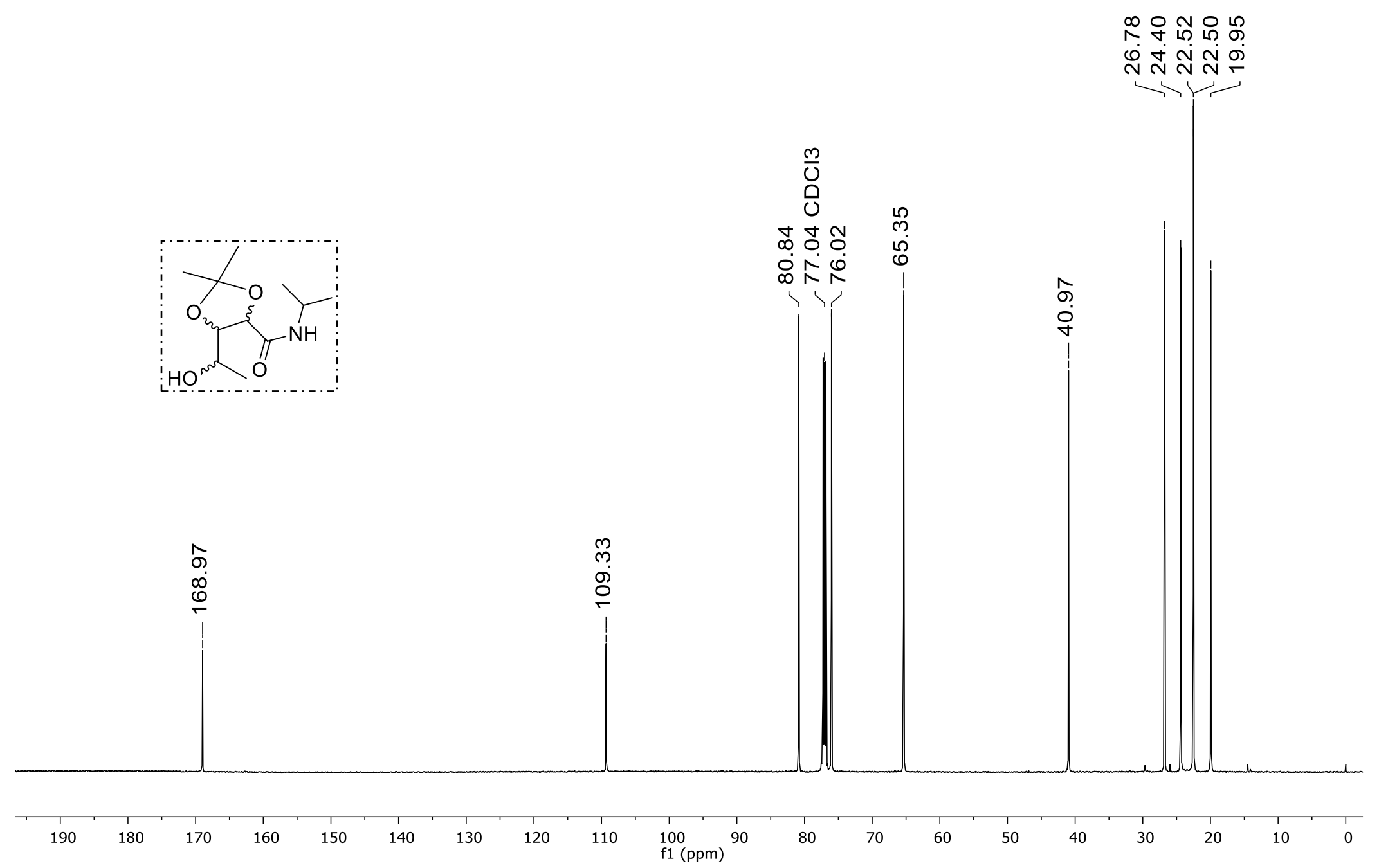




\section{Anexos}

RMN de ${ }^{1} \mathrm{H}$ de $45 \mathrm{~h}$. Apenas 1 diastereoisômero. Diastereoisômero 2

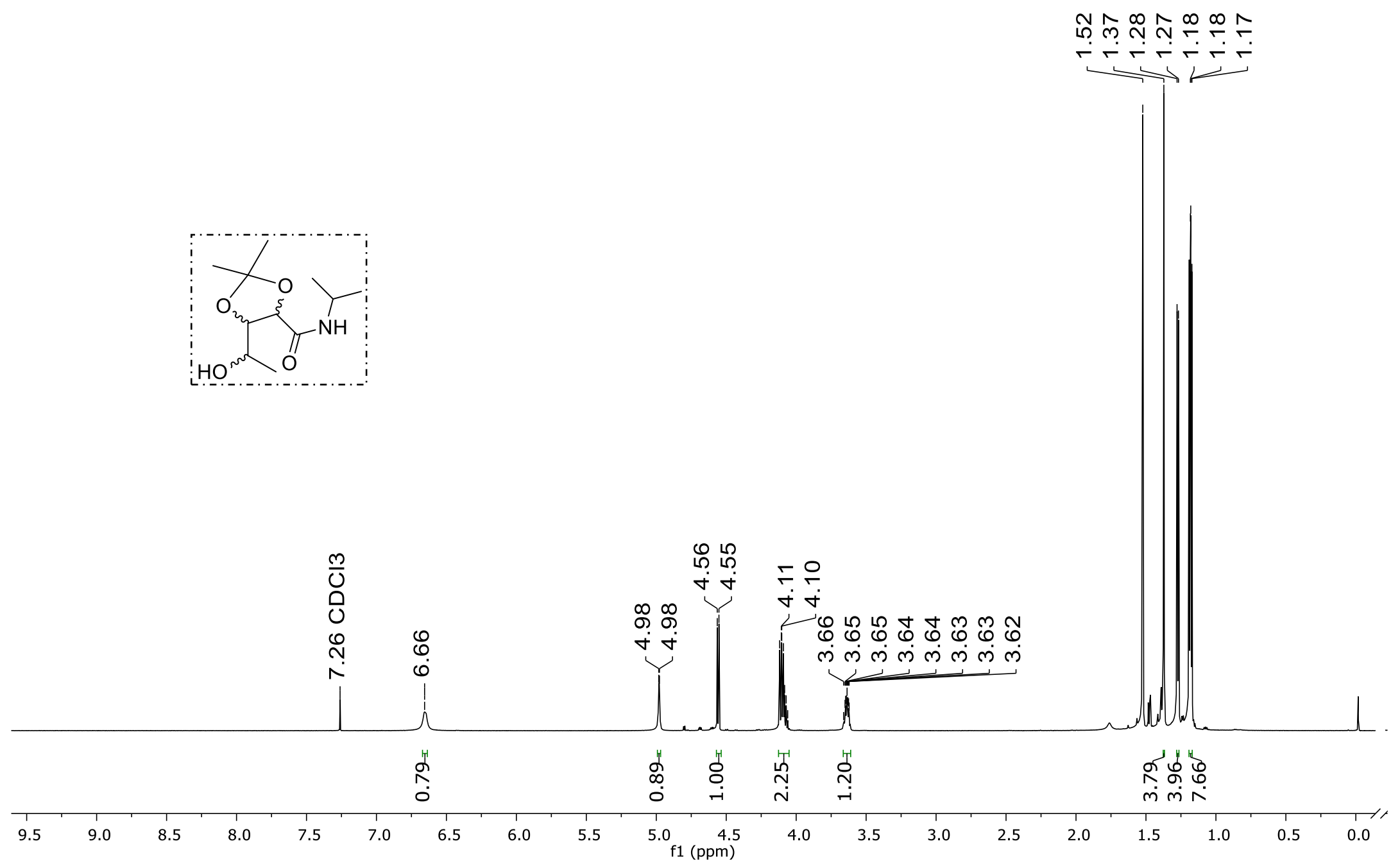




\section{Anexos}

RMN de ${ }^{13} \mathrm{C}$ de 45h. Apenas 1 diastereoisômero. Diastereoisômero 2

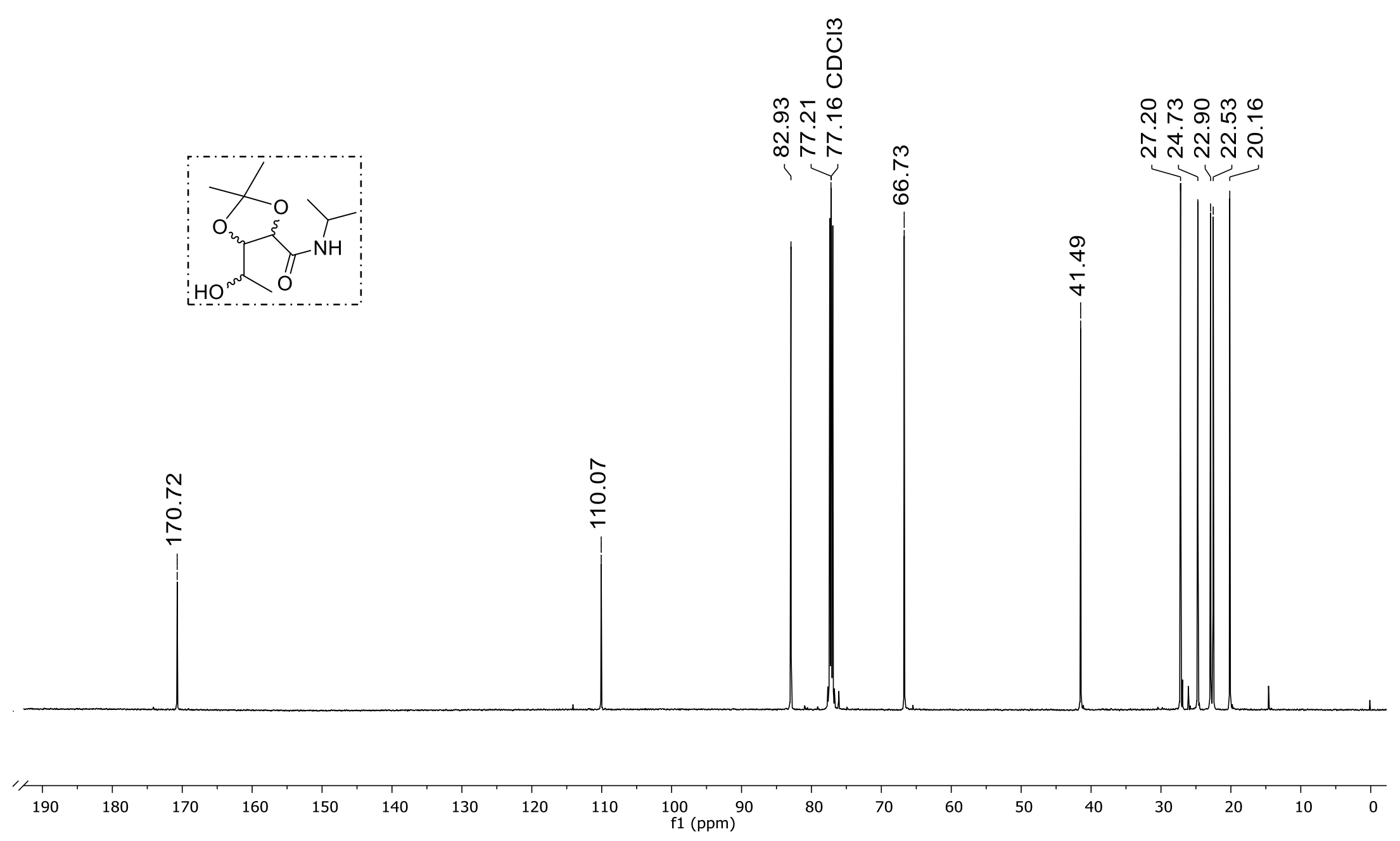


Análise por CG-EM de 45h. Apenas 1 diastereoisômero. Diastereoisômero 1
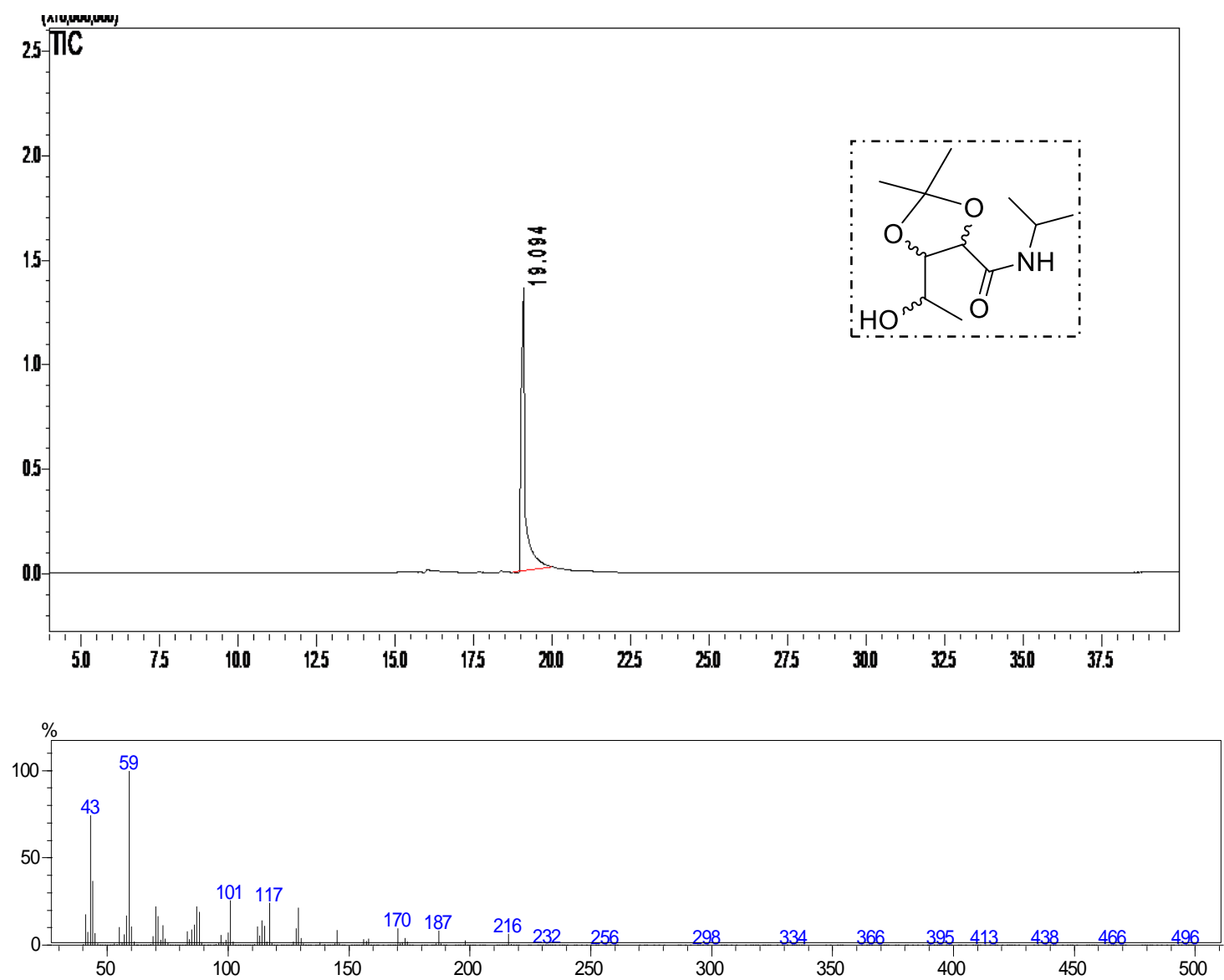

Análise por CG-EM de 45h. Apenas 1 diastereoisômero. Diastereoisômero 2
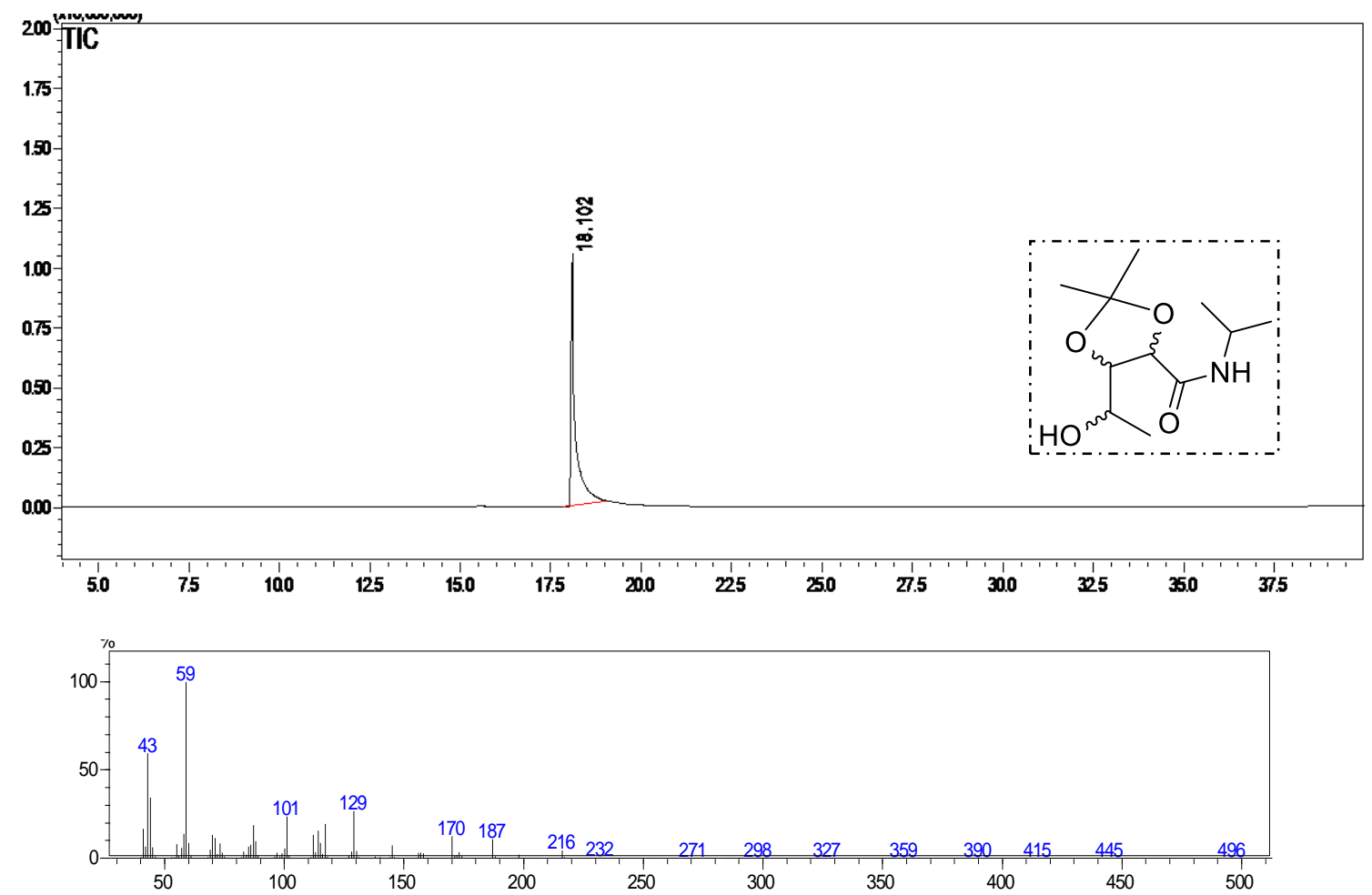
Anexos

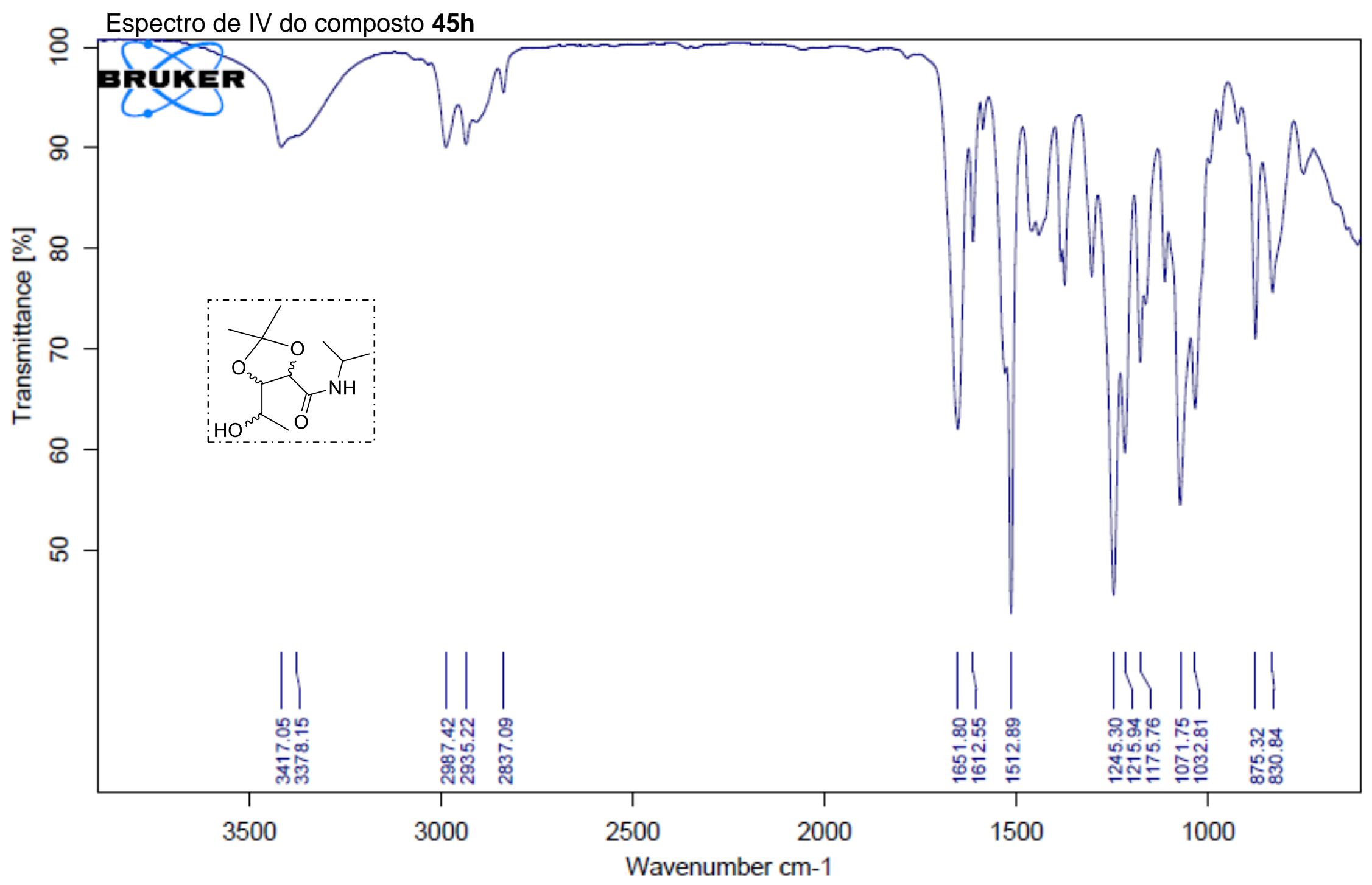




\section{Anexos}

$\mathrm{RMN}$ de ${ }^{1} \mathrm{H}$ de 45i. Apenas 1 diastereoisômero.
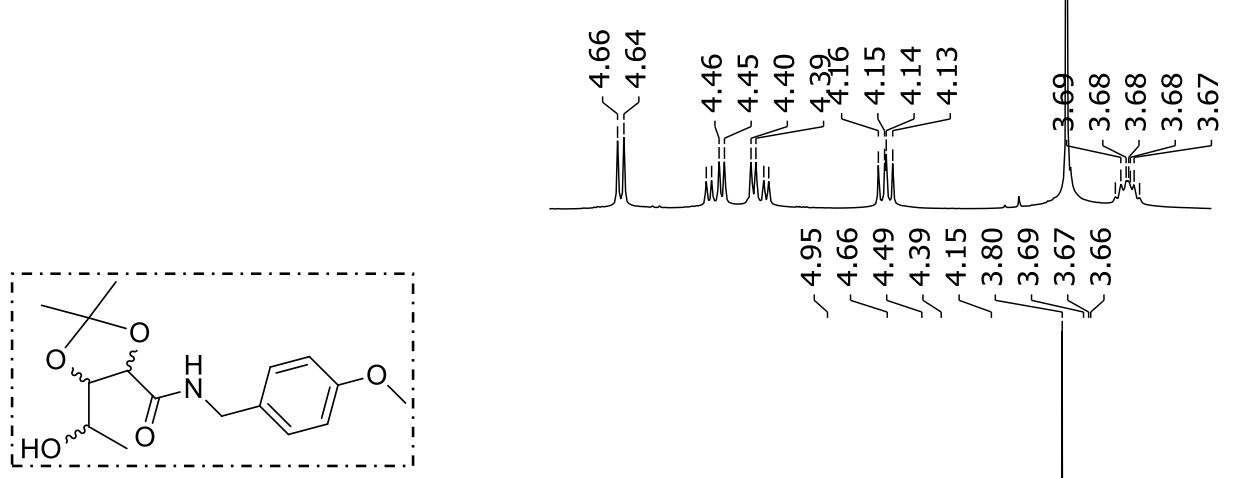

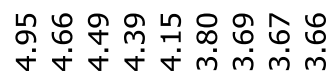

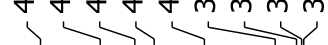

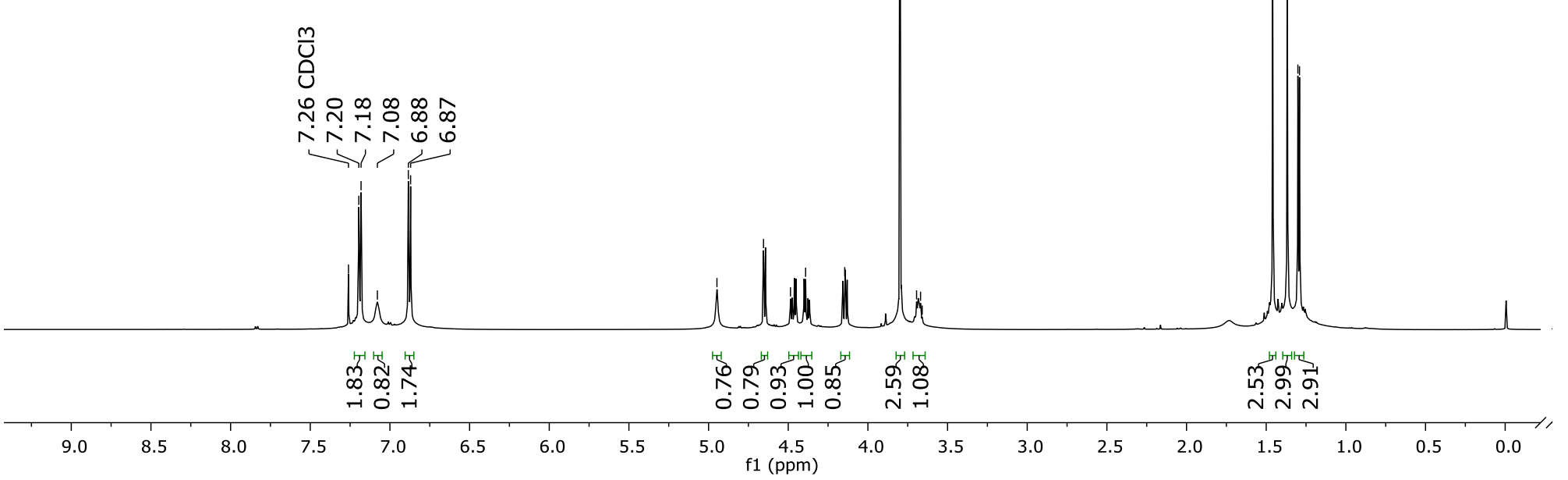




\section{Anexos}

$\mathrm{RMN}$ de ${ }^{13} \mathrm{C}$ de $45 \mathrm{i}$. Apenas 1 diastereoisômero.

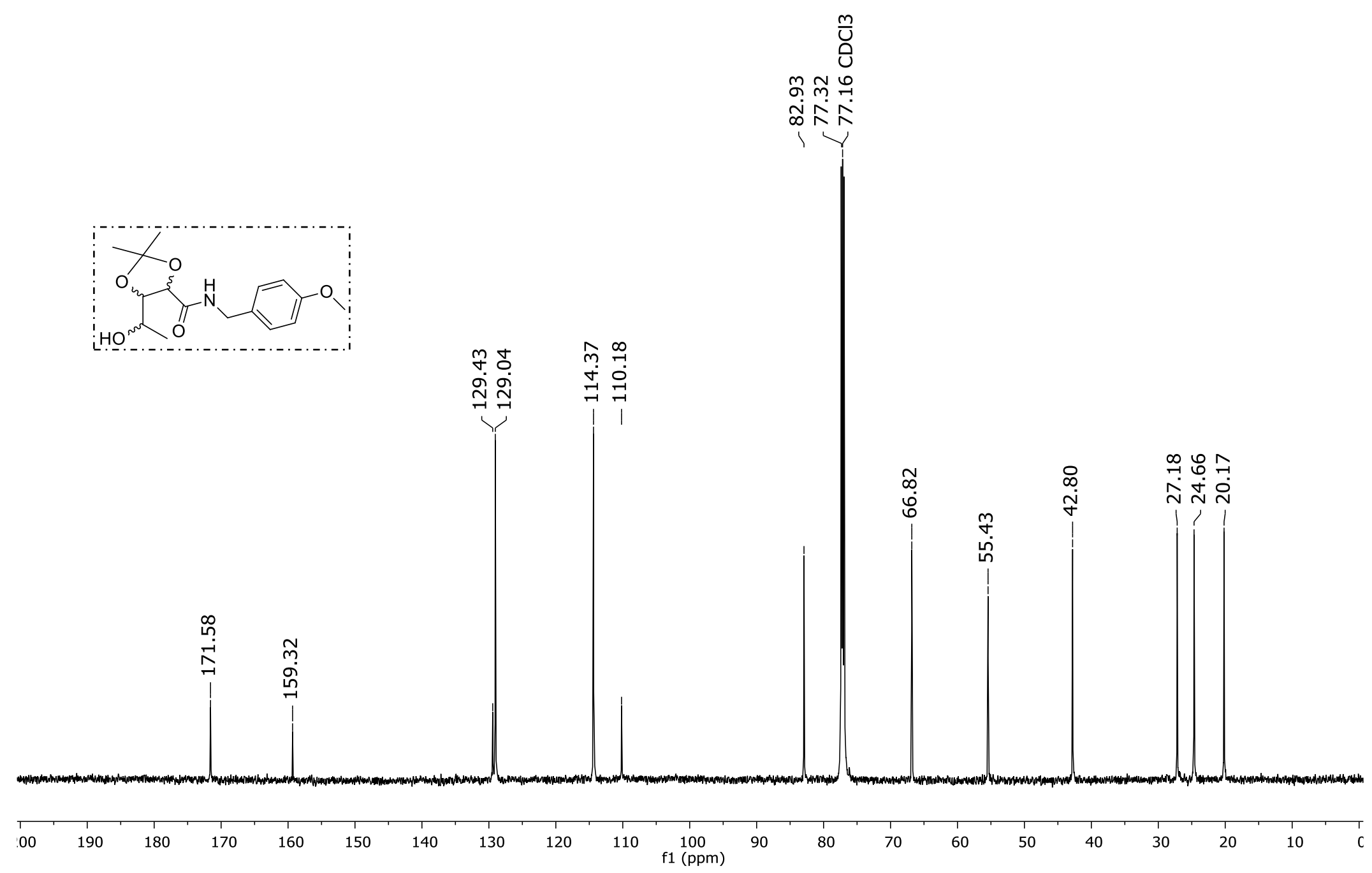




\section{Anexos}

Análise por CG-EM do bruto reacional de 45i. Apenas 1 diastereoisômero.
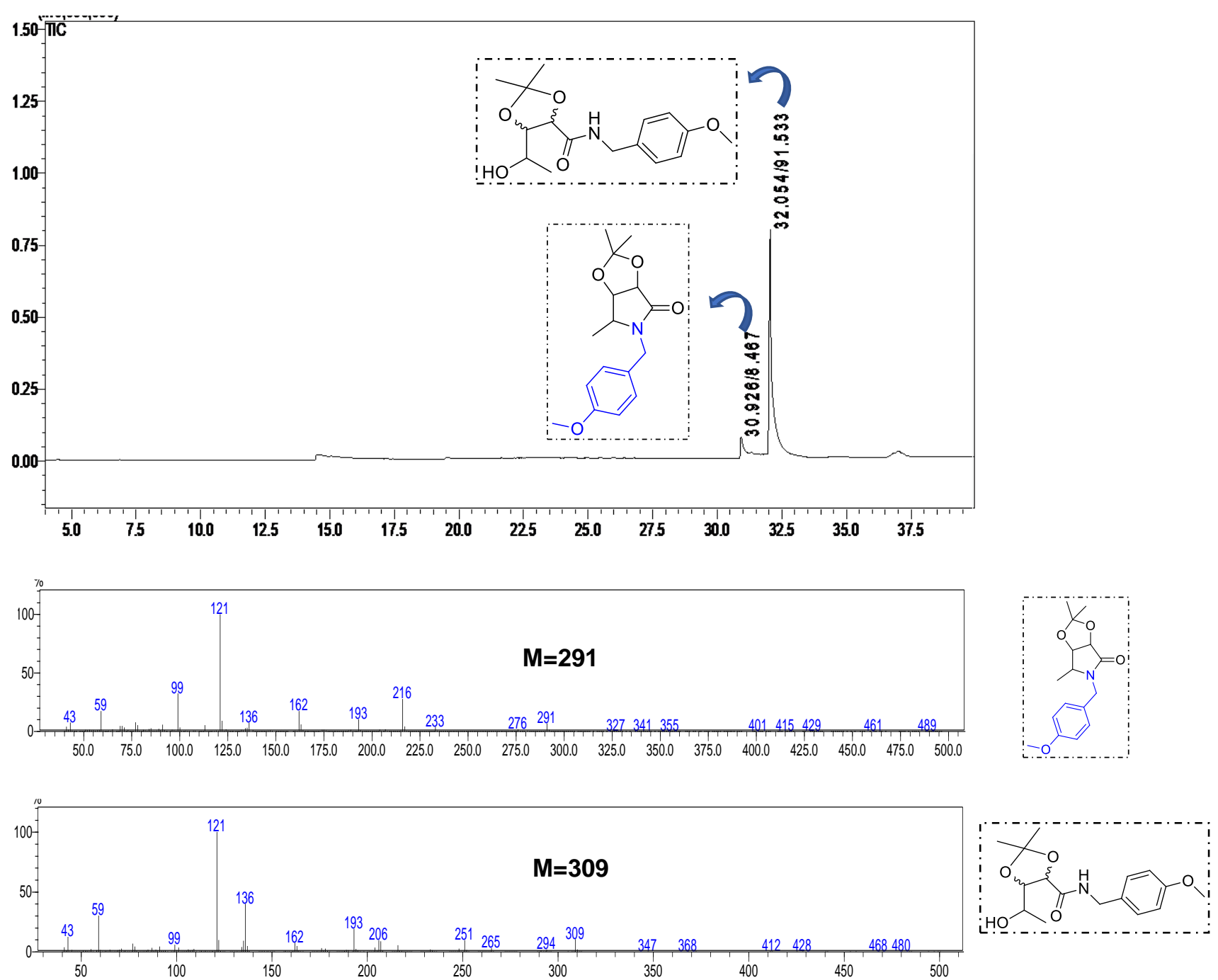
Anexos

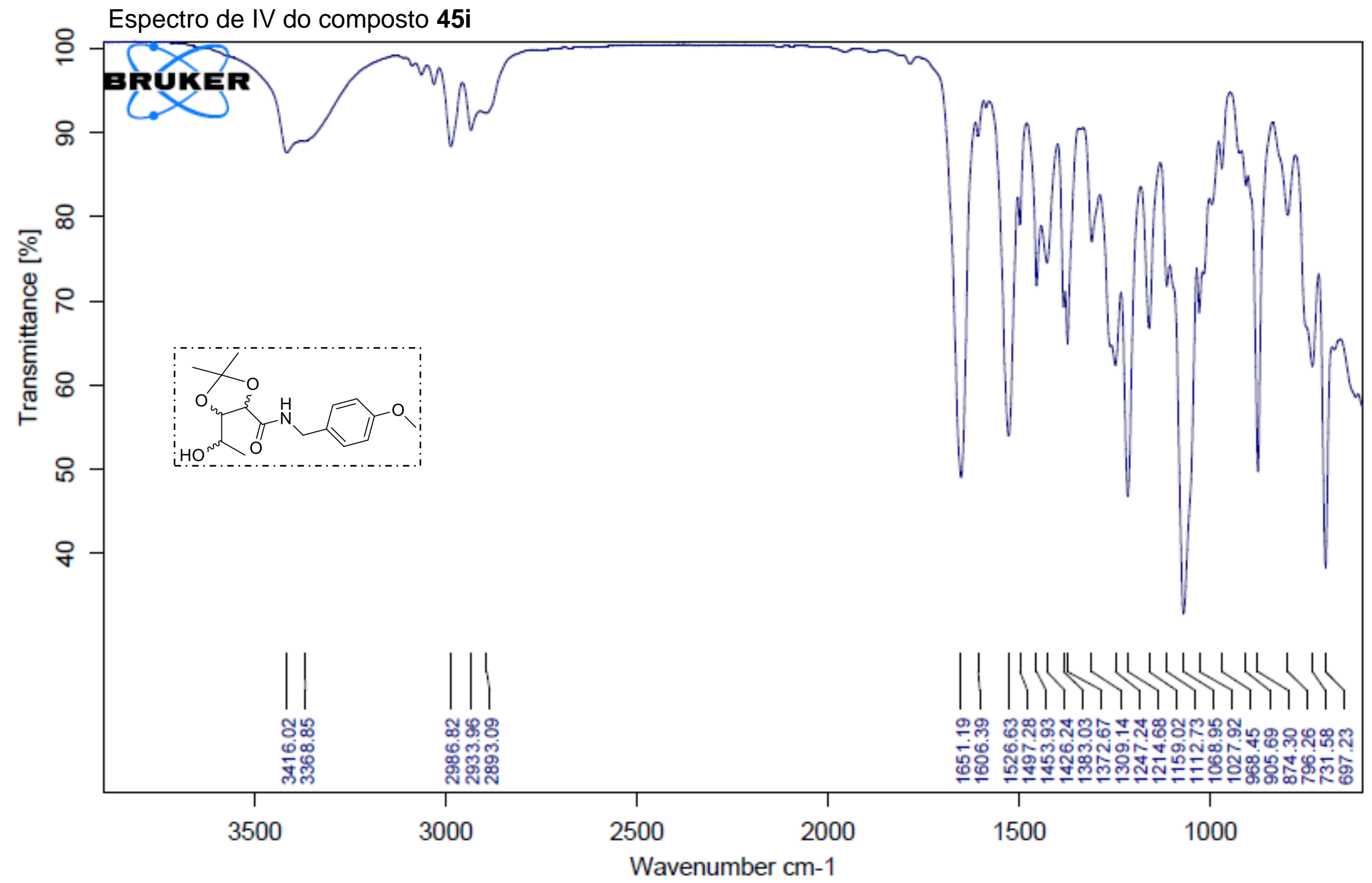




\section{Anexos}

RMN de ${ }^{1} \mathrm{H}$ de 45j. Apenas 1 diastereoisômero. Diastereoisômero 1

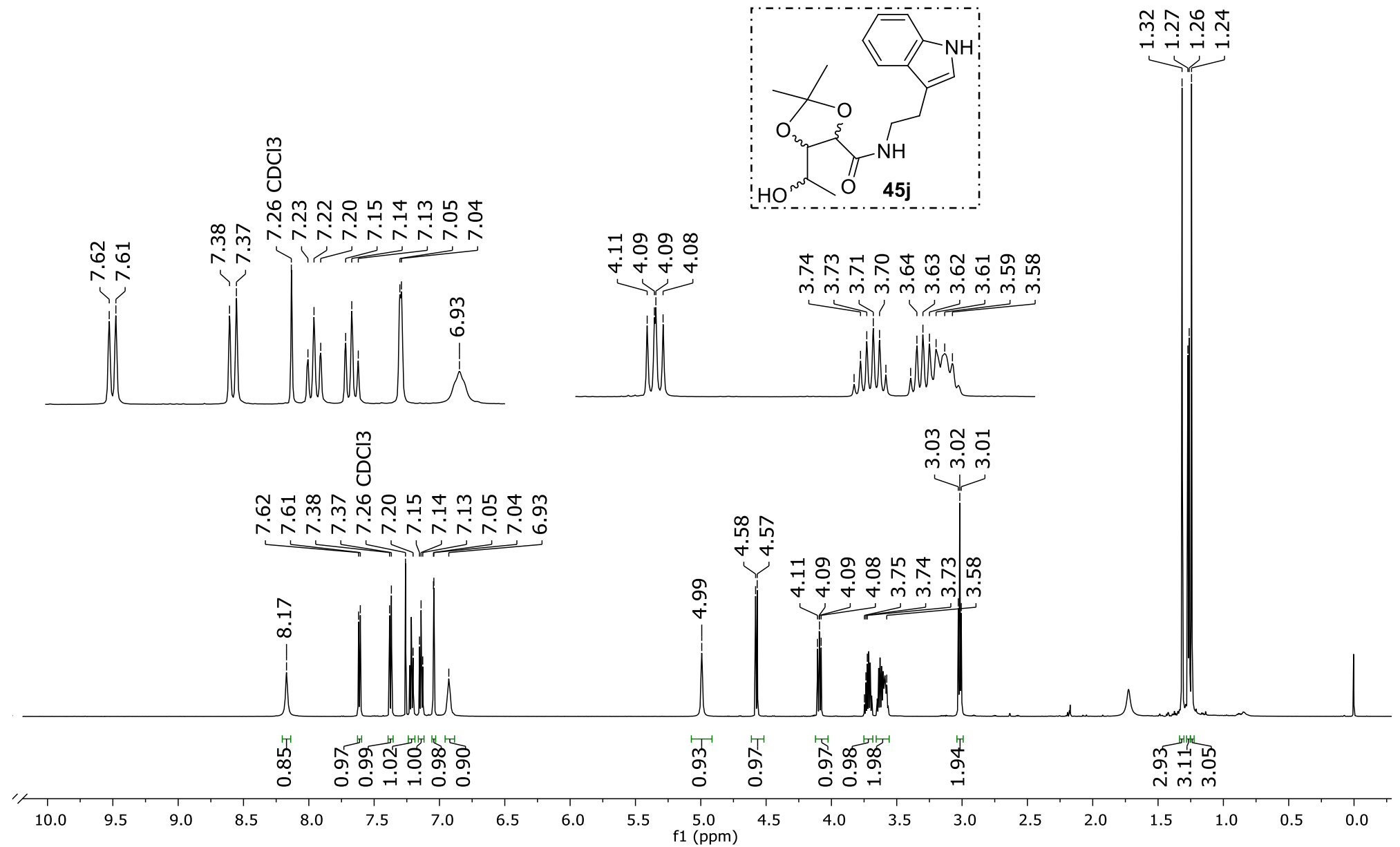




\section{Anexos}

RMN de ${ }^{13} \mathrm{C}$ de 45j. Apenas 1 diastereoisômero. Diastereoisômero 1

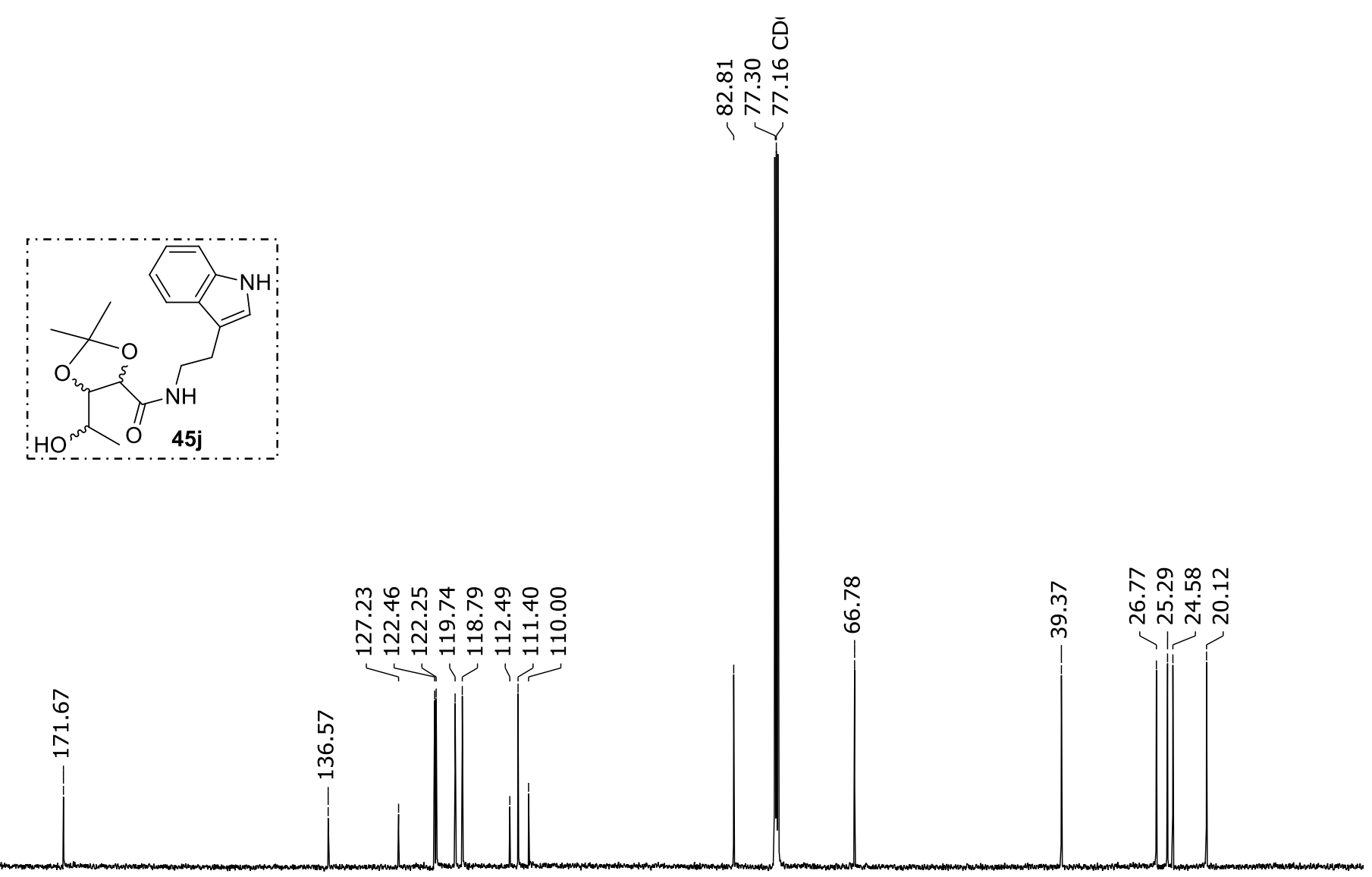

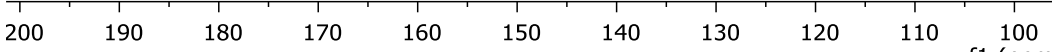
f1 (ppm) 


\section{Anexos}

RMN de ${ }^{1} \mathrm{H}$ de 45j. Apenas 1 diastereoisômero. Diastereoisômero 2

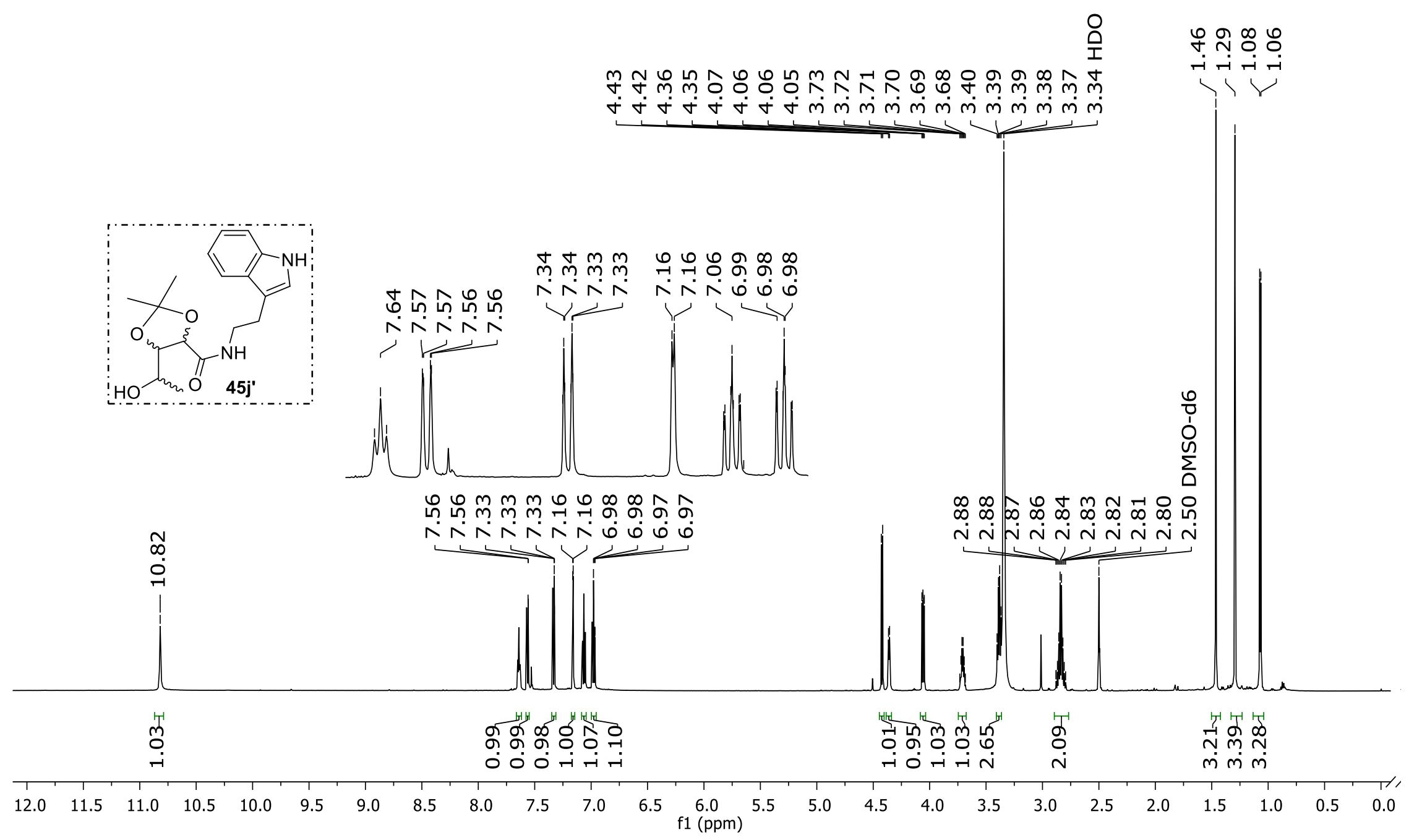




\section{Anexos}

RMN de ${ }^{13} \mathrm{C}$ de 45j. Apenas 1 diastereoisômero. Diastereoisômero 2

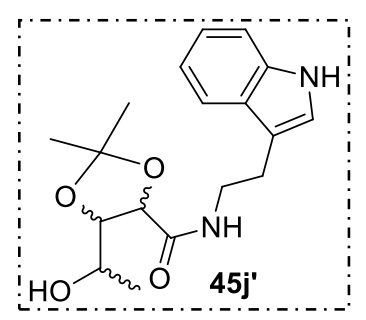

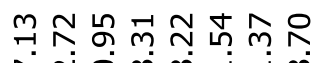

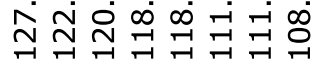

के

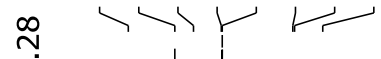

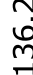

i.

กุ๊ิ

ㄴํㄴ

兽

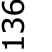

$00 \quad 190$

180

170

160

150

140

$130 \quad 120$

110

100

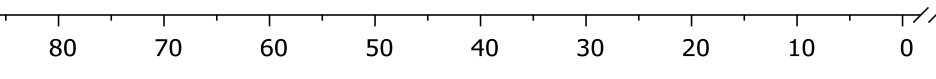


Anexos

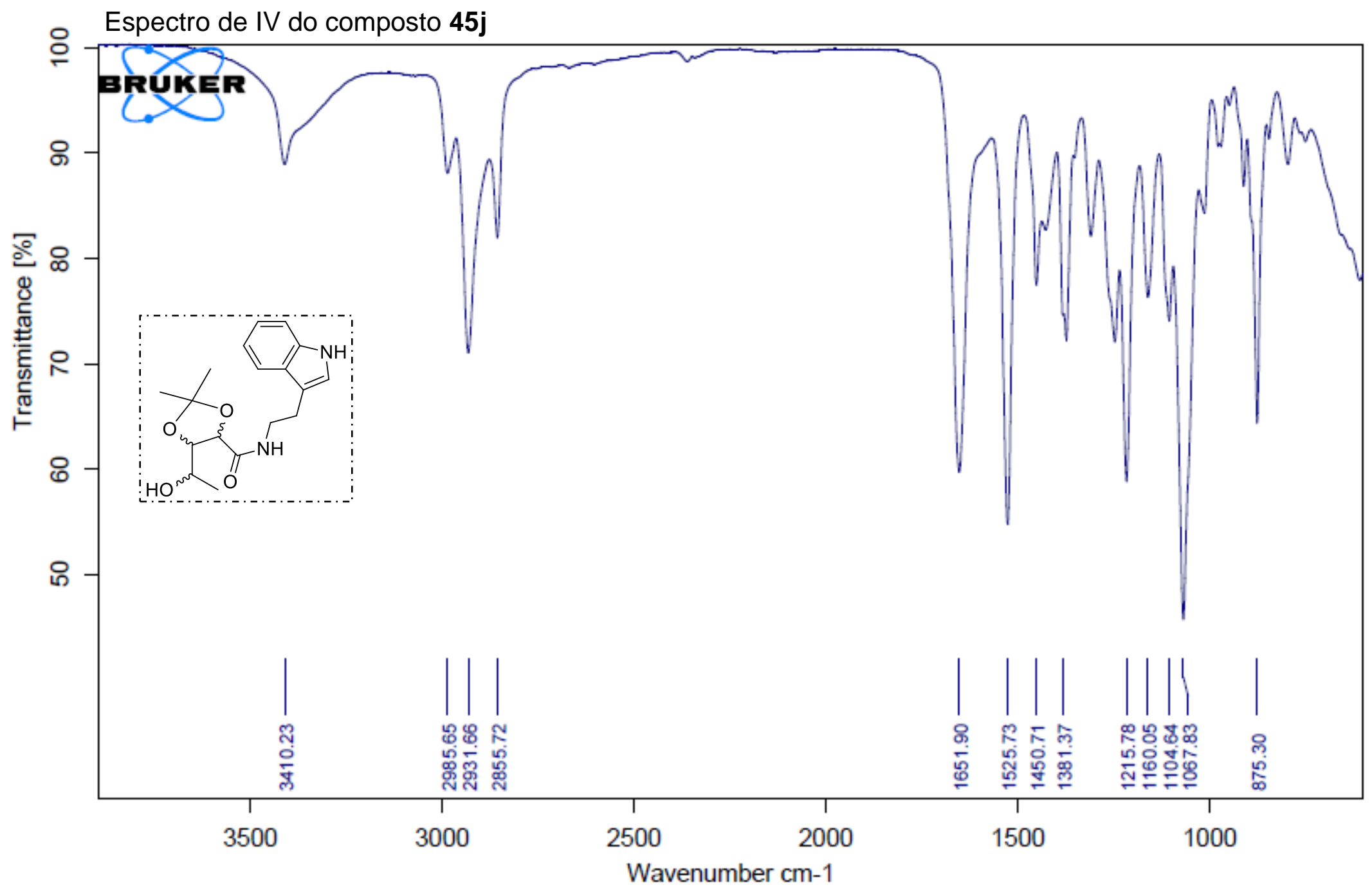


Anexos

Burtoloso_Camila_TH120.10.fid
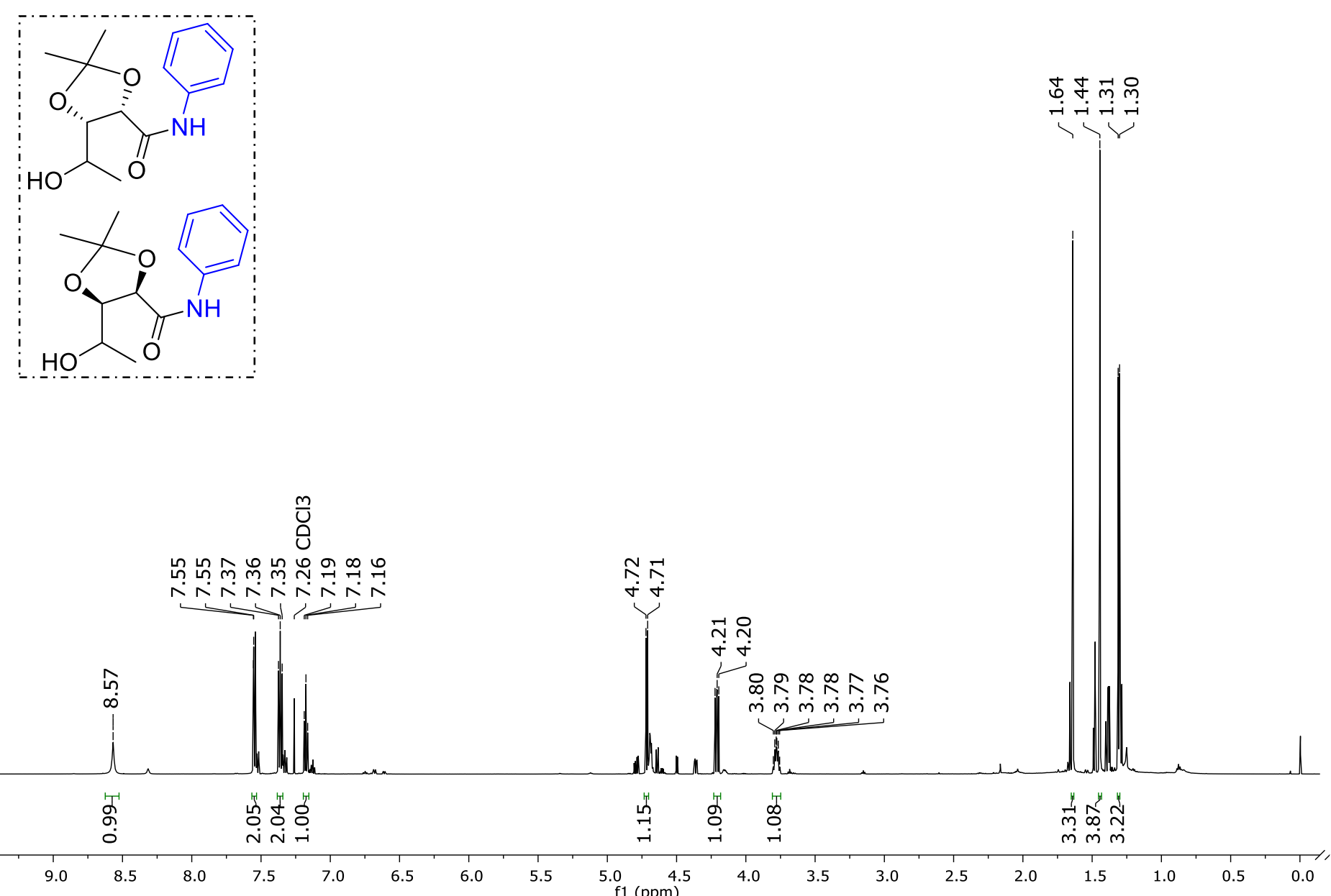


$$
\text { 湮: }
$$




\section{RMN de ${ }^{1} \mathrm{H}$ de $46 \mathrm{~b}$. Mistura diastereoisomérica}

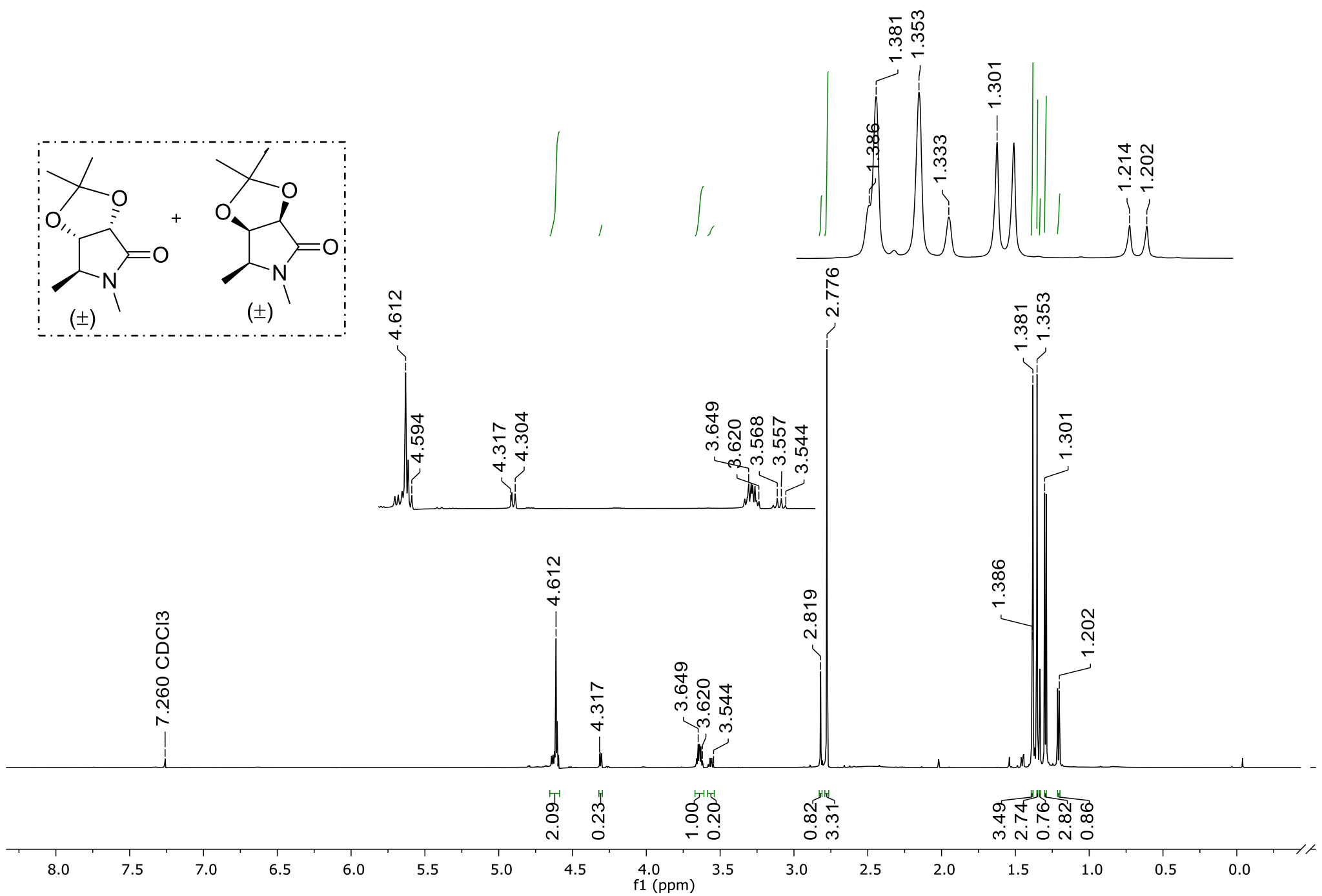




\section{Anexos}

\section{$\mathrm{RMN}$ de ${ }^{13} \mathrm{C}$ de $46 \mathrm{~b}$. Mistura diastereoisomérica}
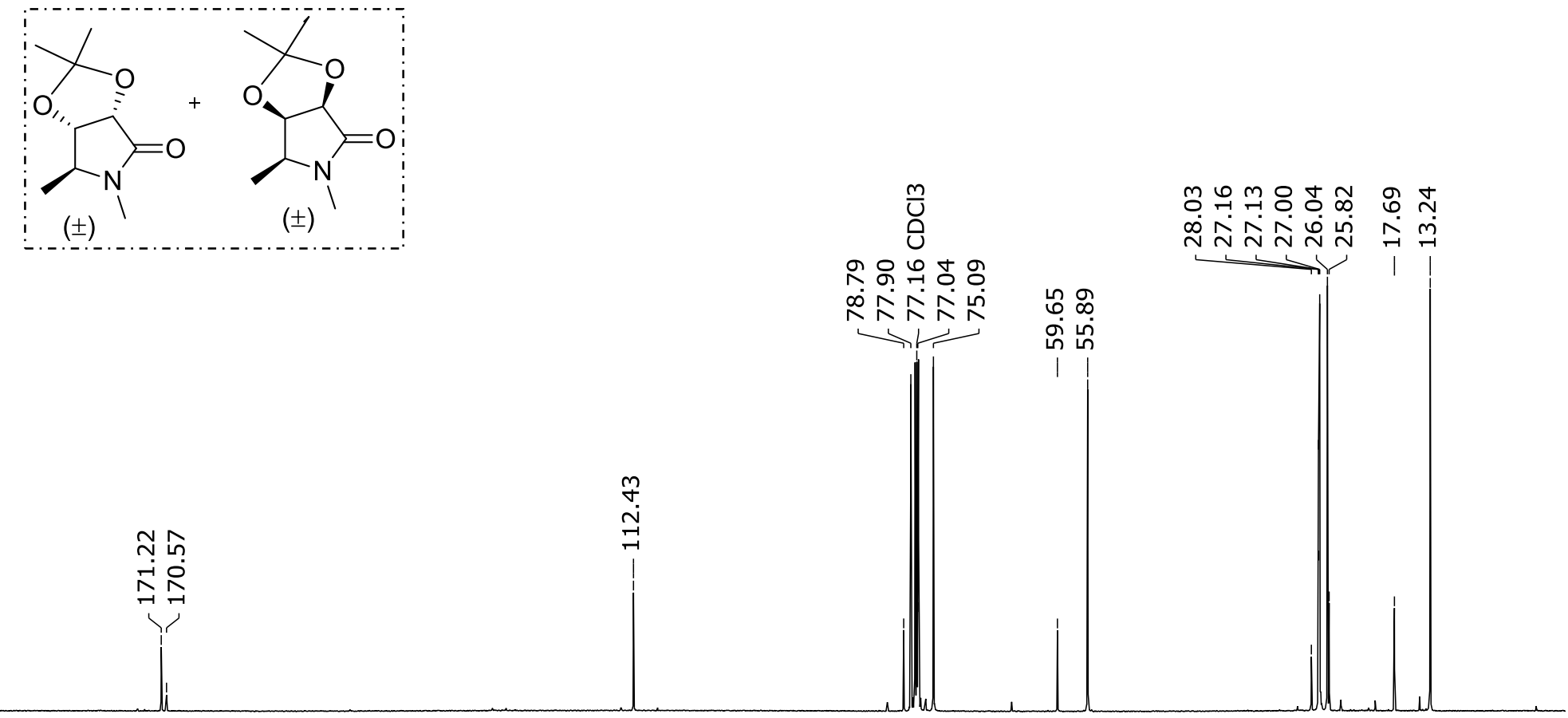

200

$190 \quad 180$

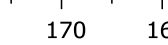

$60 \quad 150$

$140 \quad 130 \quad 120$

$110 \quad 100$ 100
$\mathrm{f} 1(\mathrm{ppm})$

80

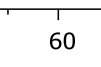

$50 \quad 40$

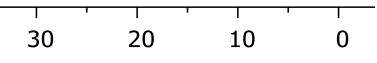




\section{Anexos}

Análise por CG-EM de 46b. Mistura dos diastereoisômeros.
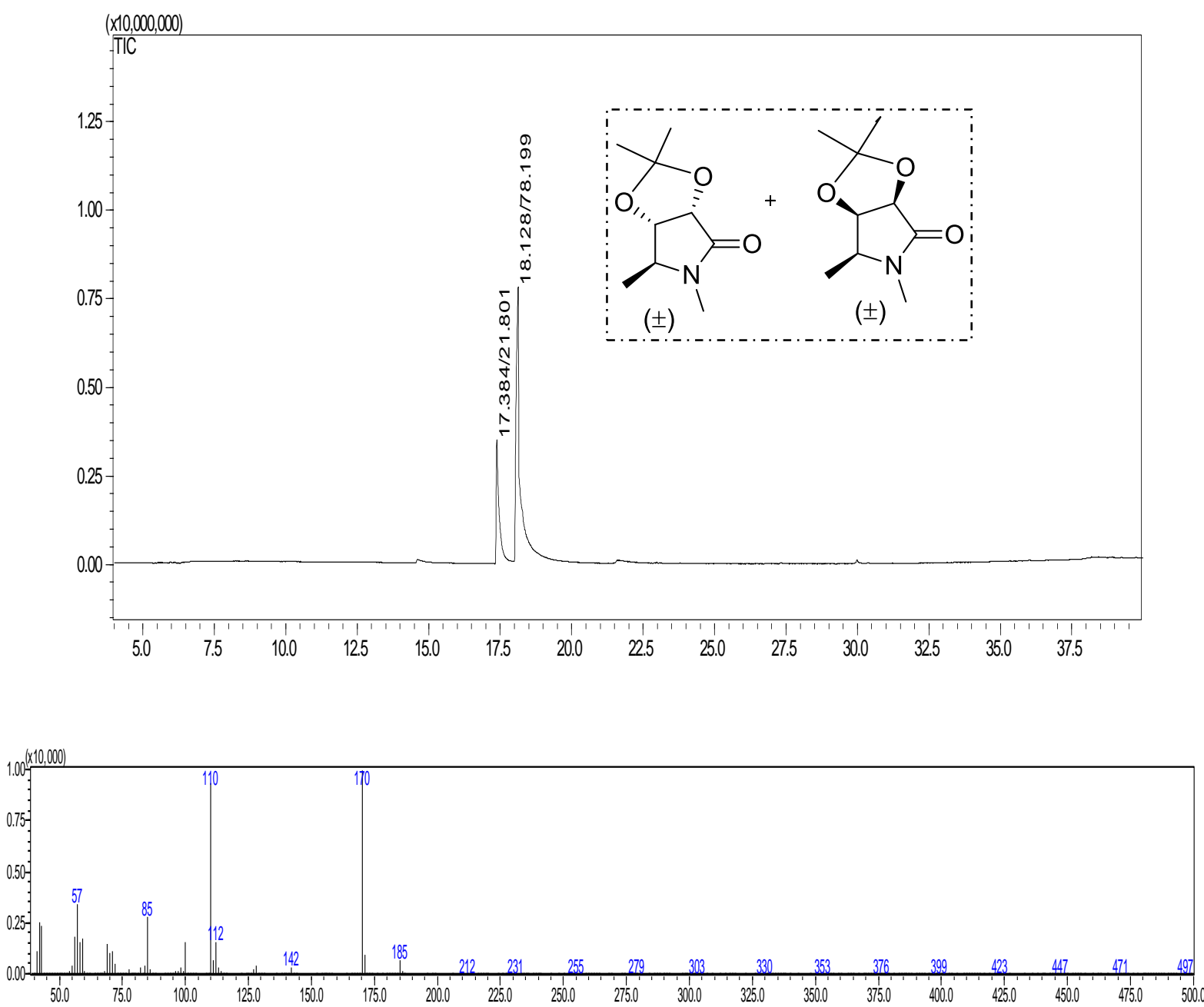
Anexos

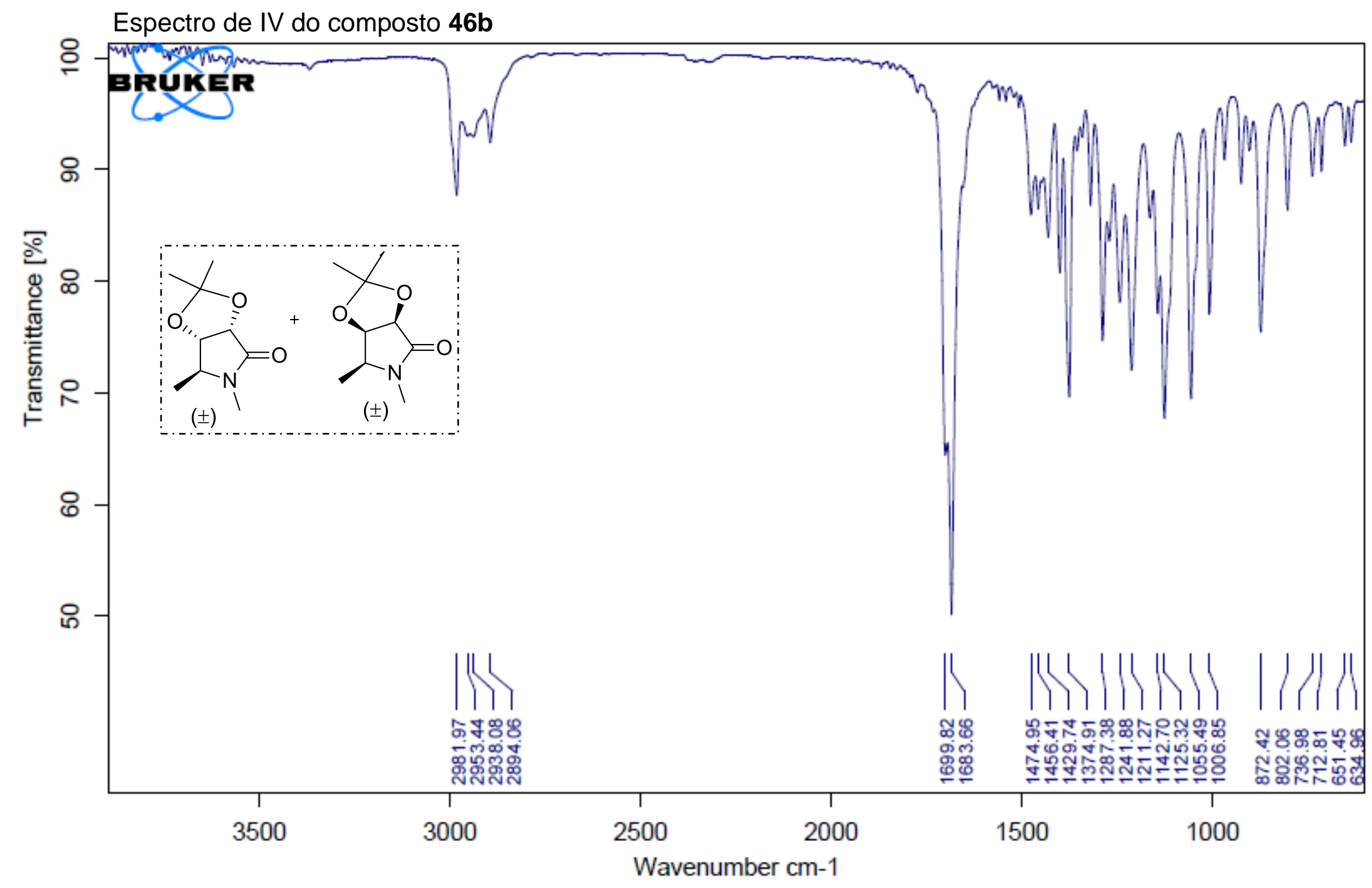




\section{Anexos}

RMN de ${ }^{1} \mathrm{H}$ de 46b. Apenas 1 diastereoisômero.

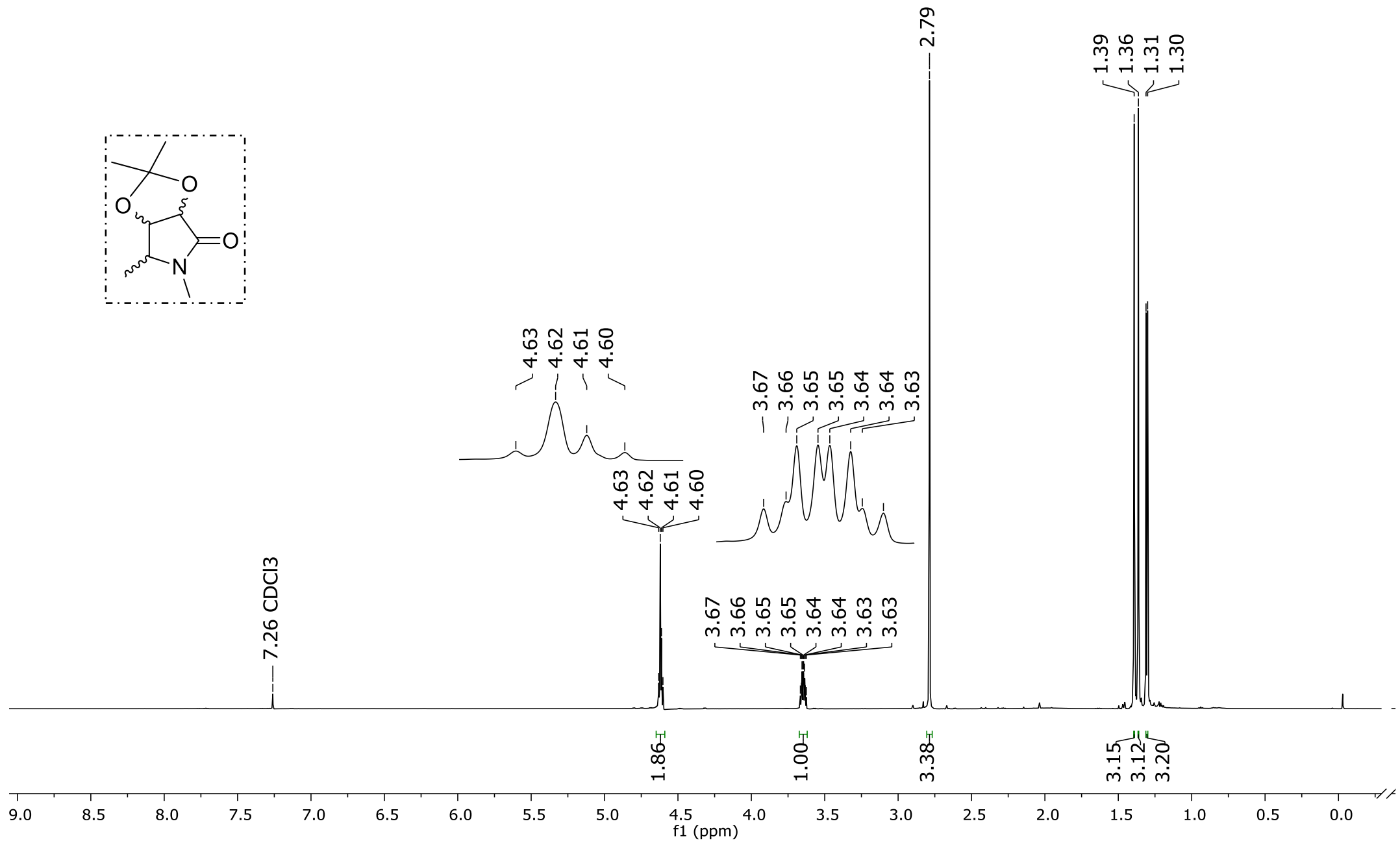




\section{Anexos}

RMN de ${ }^{13} \mathrm{C}$ de $46 \mathrm{~b}$. Apenas 1 diastereoisômero.

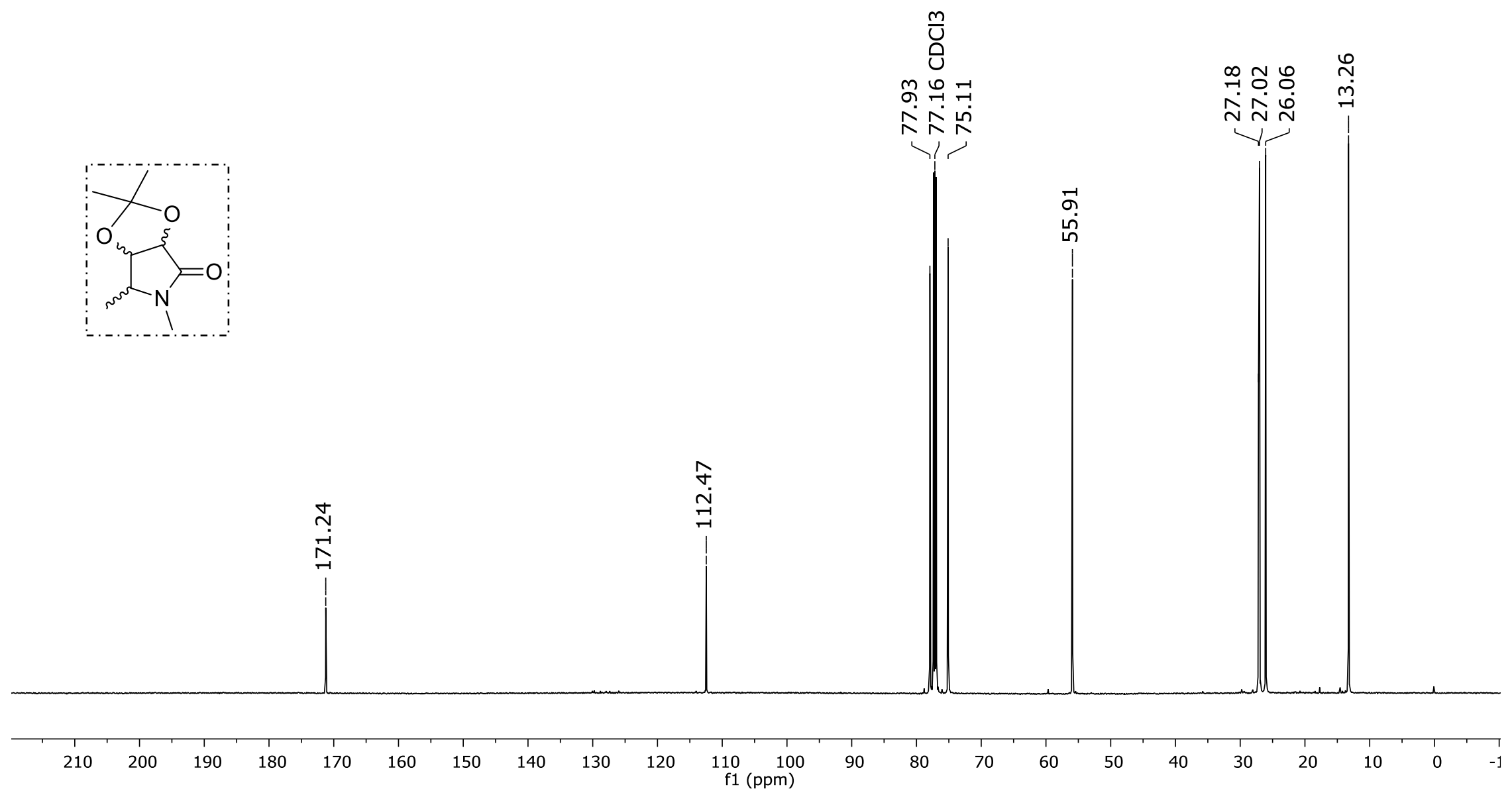




\section{Anexos}

Análise por CG-EM de 46b. Apenas 1 diastereoisômero.
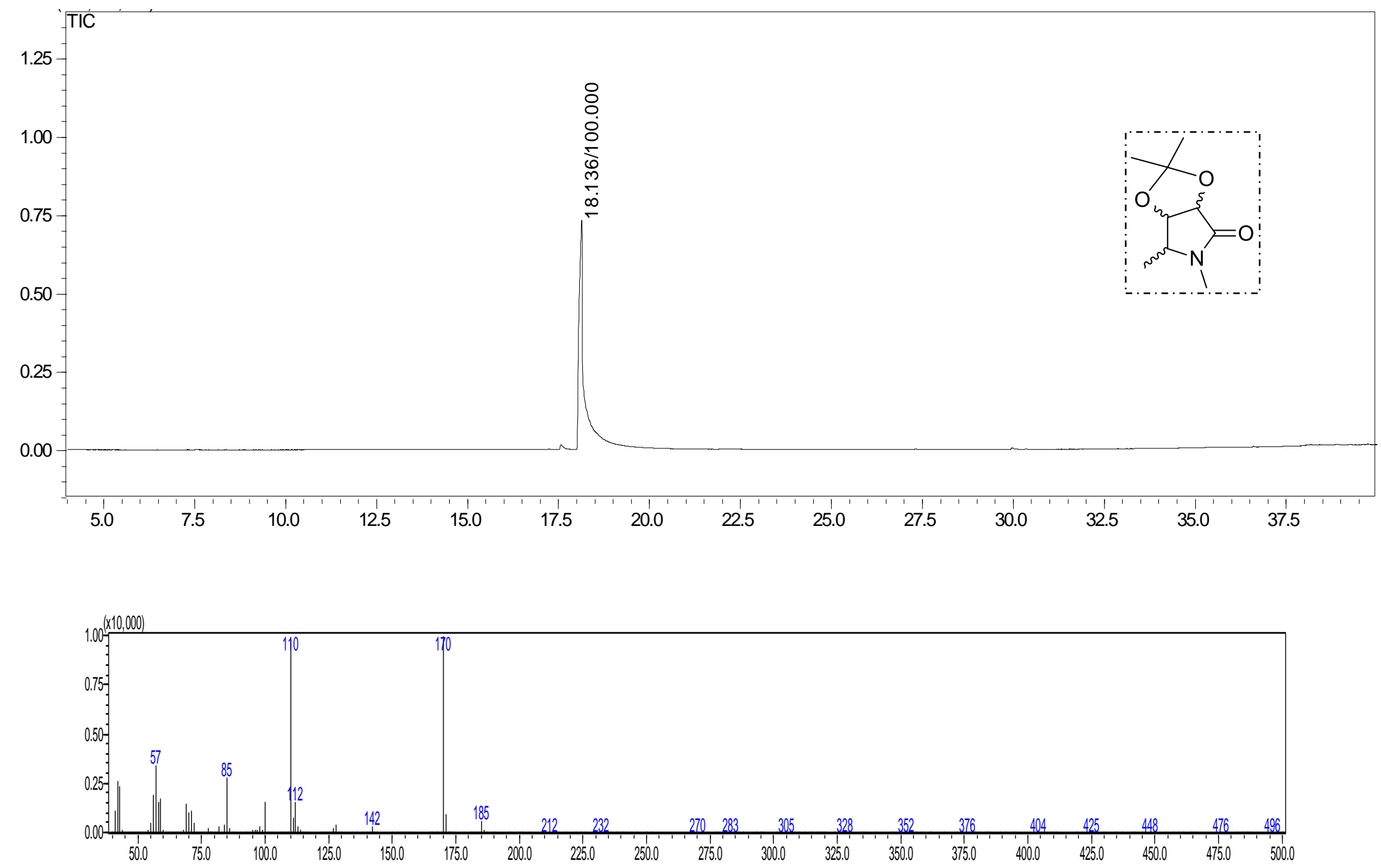


\section{Anexos}

RMN de ${ }^{1} \mathrm{H}$ de 46c. Mistura diastereoisomérica

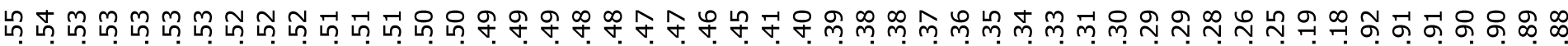

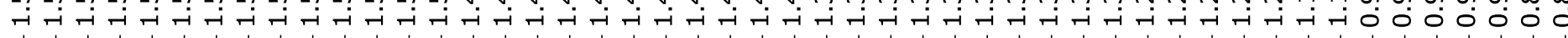
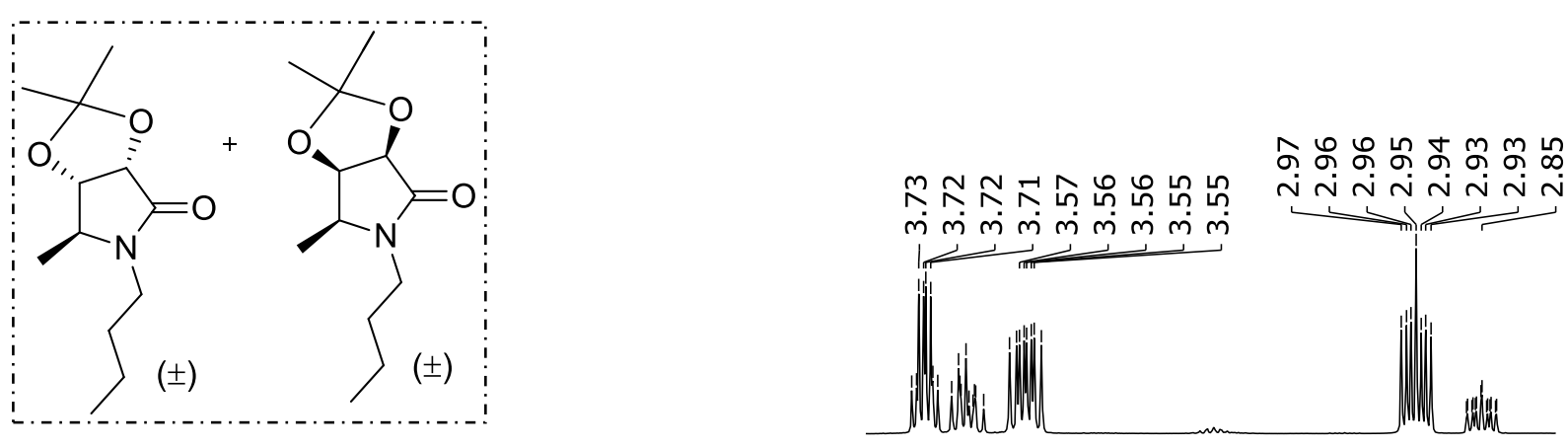

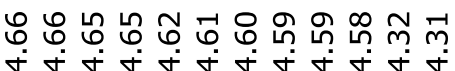

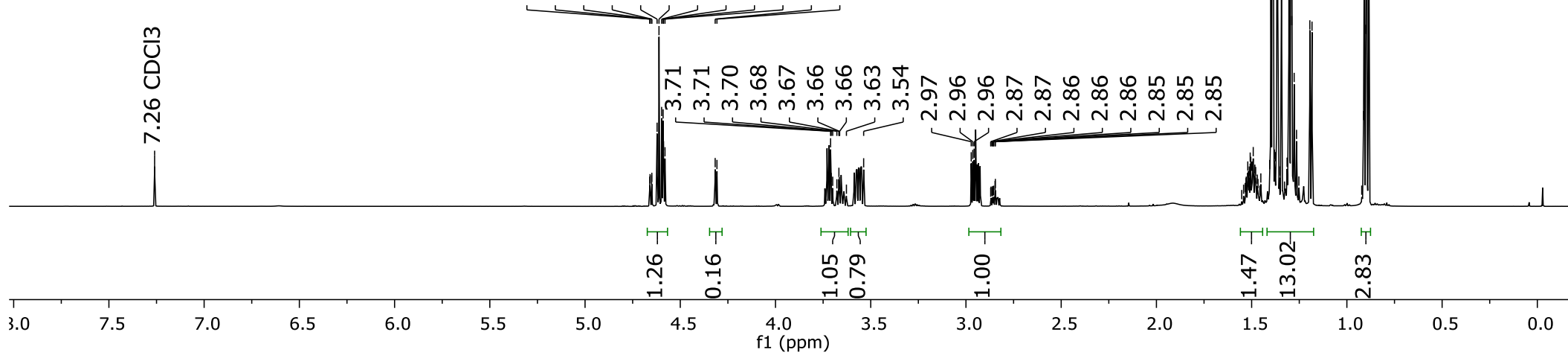




\section{Anexos}

$\mathrm{RMN}$ de ${ }^{13} \mathrm{C}$ de 46c. Mistura diastereoisomérica

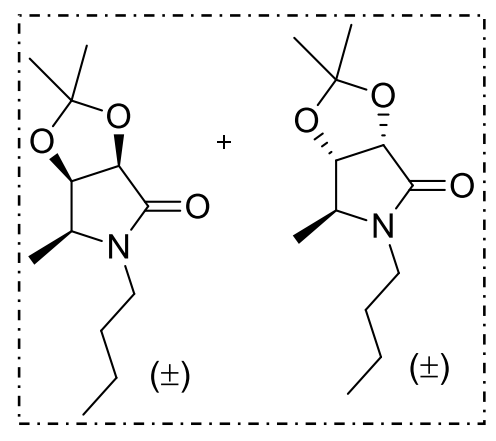

บั

ดำำ눈

市卡卡

กm $m$.

$\rightarrow$

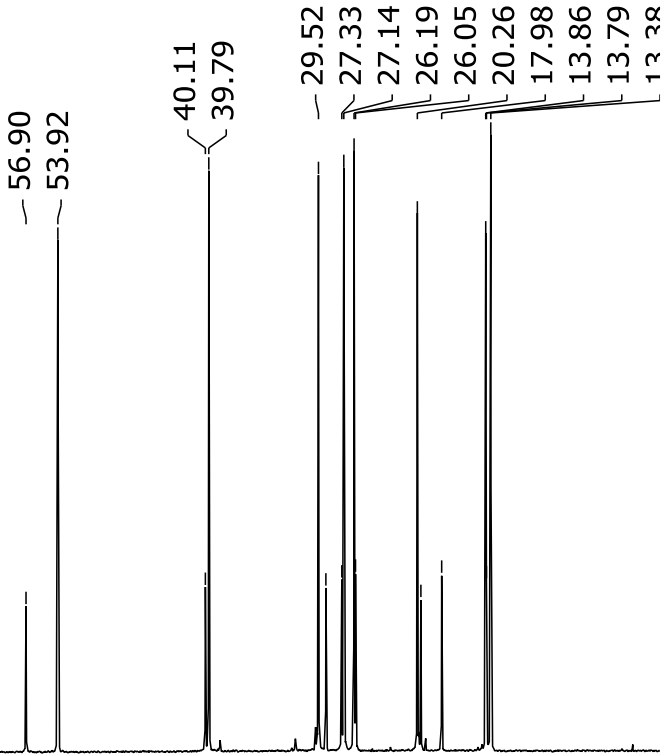

190

$170 \quad 160$

150

140

130

$20 \quad 110$

10090

80

70

60

50

40

$30 \quad 20$

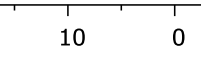


$\underline{\text { Anexos }}$

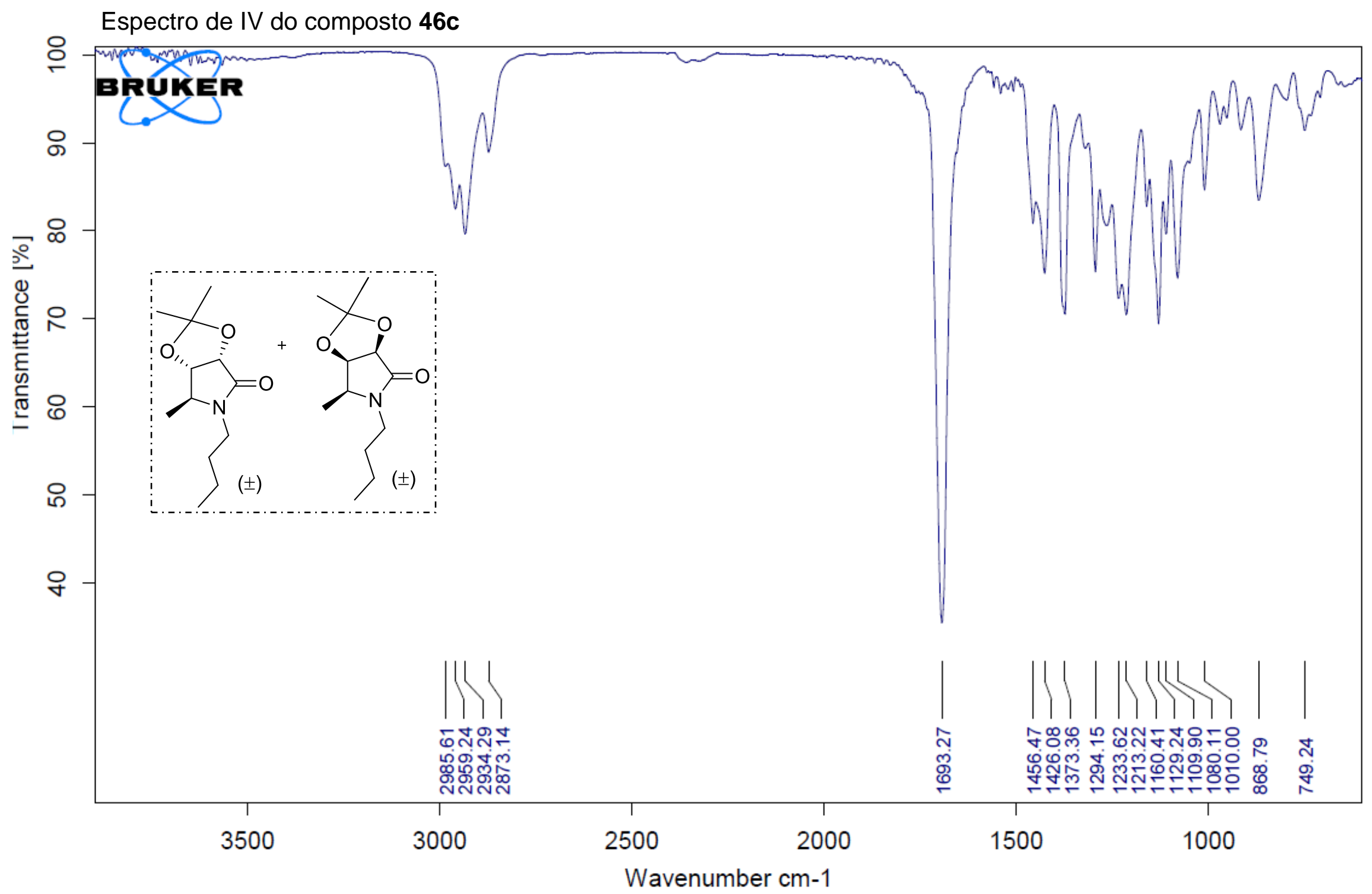




\section{Anexos}

Análise por CG-EM de 46c. Mistura dos diastereoisômeros.
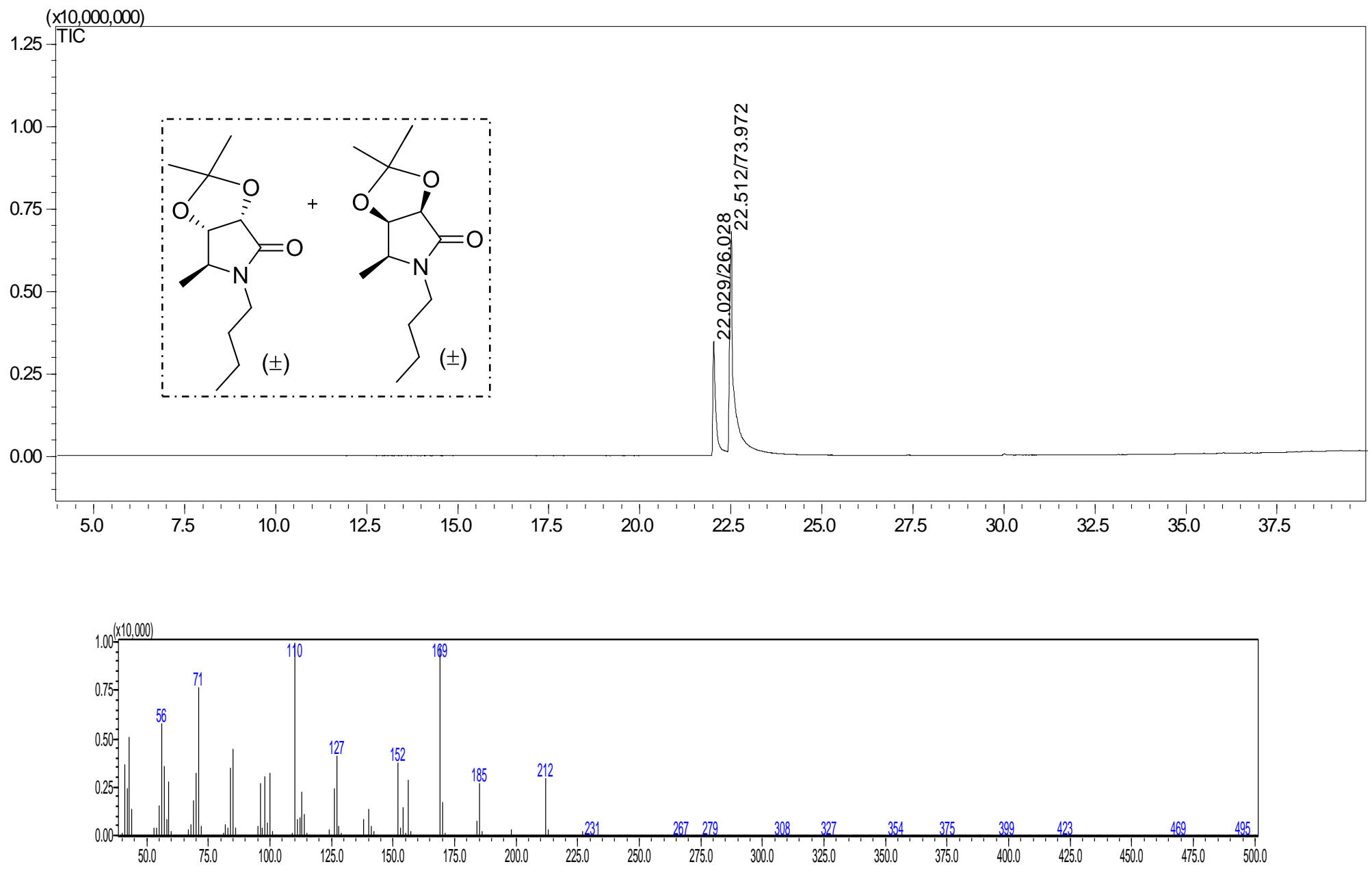